



NINETEENTH-CENTURY ENGLISH CERAMIC ART 




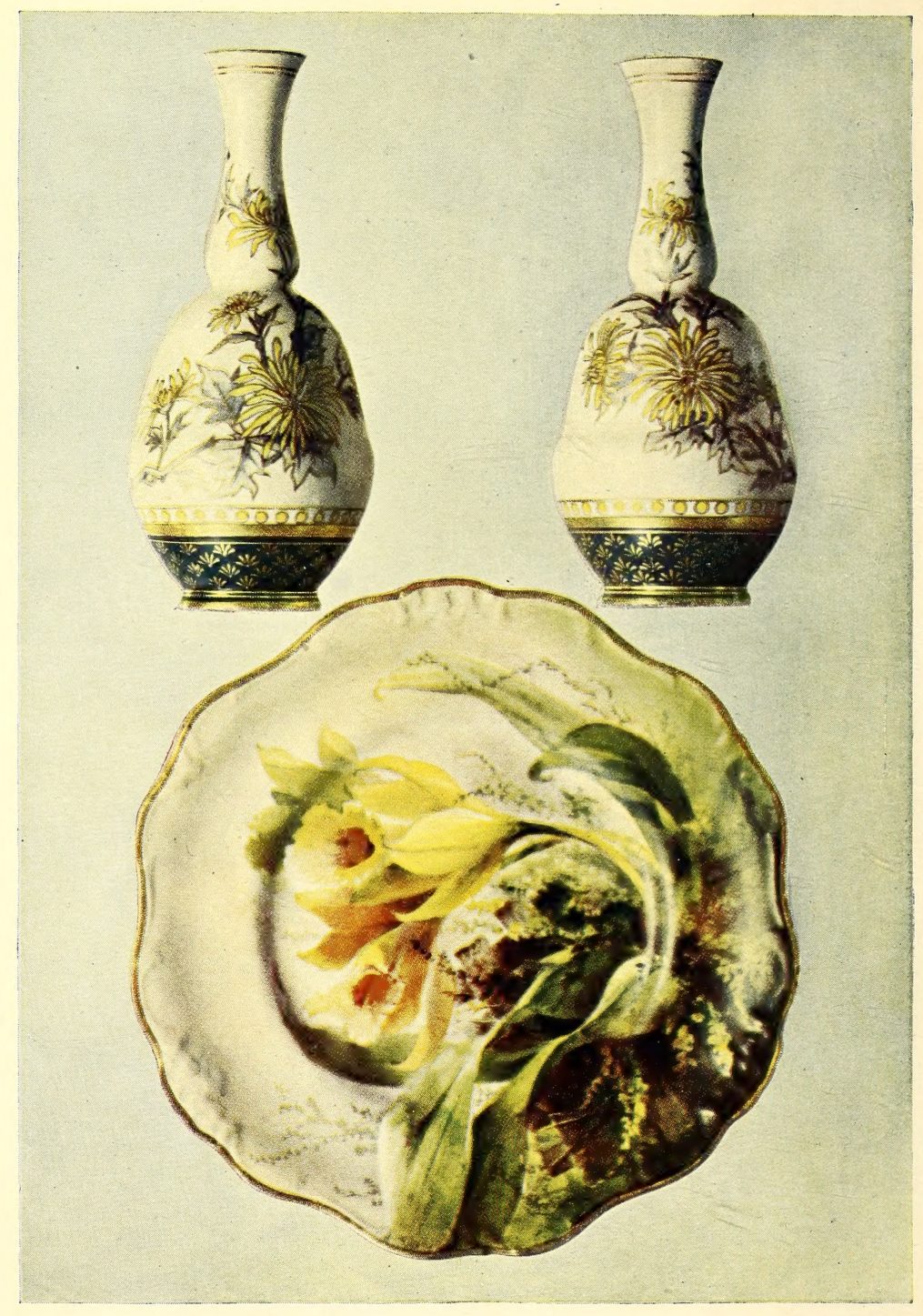

TWO "CARRARA" WARE VASES MADE BY DOULTON AT LAMBETH. AN "ORCHID" PLATE MADE BY DOULTON AT BURSLEM AND PAINTED BY DAVID DEWSBERRY.

[Frontispiece. 
BY

\section{J. F. BLACKER}

AUTHOR OF

"THE A B C OF COLLECTING OLD ENGLISH POTTERY"

"THE A B C OF COLLECTING OLD ENGLISH CHINA"

"THE A B C OF JAPANESE ART," ETC. ETC. etc.

With over 1,200 Examples Illustrated in Half-tone and Line

\section{LONDON}

STANLEY PAUL \& CO

31 ESSEX STREET W.C. 
PRINTED BY

HAZEL, WATSON AND VINEY, LD. LONDON AND AYLESBURY.

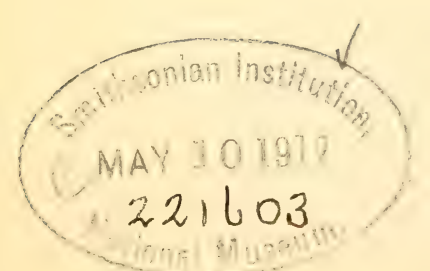




\section{ONTENTS}

CHAP.

I. INTRODUCTION : THE EXHIBITION OF I85 I AND BEFORE. II

II. THE STAFFORDSHIRE POTTERIES AND CORNWALL • . 3I

III. THE MASter potters AT tUnStAll : ADAMS • 49

IV. THE MASTER POTTERS AT STOKE-UPON-TRENT: COPELAND AND SONS, LATE SPODE $\cdot \quad \cdot \quad \cdot \quad \cdot 64$

V. THE MASTER POTTERS AT STOKE-UPON-TRENT : MINTONS 96

VI. THE MASTER POTTERS AT ETRURIA : WEDGWOODS - I2I

VII. SOME POTTERS AT BURSLEM : T. AND R. BOOTE, CORK AND EDGE, MAYER, PRATT, THE HILL-TOP POTTERY, ENOCH WOOD, AND OTHERS . . . . . I54

VIII. OTHER POTTERS AT COBRIDGE AND FENTON : CLEWS AND BROWNFIELD, FURNIVALS LTD., H. ALCOCK AND CO., ETC., AT COBRIDGE ; GREEN BROTHERS AND CROWN STAFFORDSHIRE; F. BEARDMORE AND CO., AT FENTON . . . . . . . . . . I74

IX. IN THE POTTERIES AT HANLEY : ASHWORTH AND MASON'S IRONSTONE CHINA; CAULDON PLACE, RIDGWAY AND BROWN-WESTHEAD, MOORE AND CO.; OLD HALL AND THE MEIGHS . . . $\quad$ I 89

X. LONGPORT AND LONGTON POTTERS: DAVENPORT. BARLOW, MOORE BROTHERS (NOW BERNARD MOORE), ETC. . . . . . . .

XI. MORE POTTERS AT STOKE-UPON-TRENT AND TUNSTALL: GOSS, GEORGE JONES AND SONS ; POOLE, STANWAY AND WOOD, ETC., AT STOKE-UPON-TRENT: BOOTHS ; MEAKIN, ETC., AT TUNSTALL . . 232 
CHAP.

XII. WORCESTER: FLIGHT AND BARR. CHAMBERLAIN. GRAINGER. HADLEY . . . . . 246

XIII. DERBY AND DISTRICT: DERBYCHINA. DENBY. BRAMPTON. PINXTON : COKE AND BILLINGSLEY. SWADLINCOTE: AULT. SHARPE BROTHERS AND CO. WOODVILLE : TOOTH, ETC. . . . . .

XIV. COALPORT AND DISTRICT. COALPORT : THE ROSES AND AFTER. JACKFIELD : MAW AND CO. MADELEY : RANDALL • • $\quad$ • $\quad$ •

XV. SOUTH ENGLAND POTTERIES. LAMBETH : ROYAL DOULTON, AND AT BURSLEM. STIFF AND SONS. FULHAM : DE MORGAN. SOUTHALL: MARTIN. BLACKFRIARS ROAD, LONDON : BLANCHARD, ETC.; SUSSEX RUSTIC WARE: MITCHELL . . .

XVI. NEWCASTLE, SUNDERLAND, AND DISTRICT. NEWCASTLE: MALING AND SONS. LUSTRE WARE, ETC., AND THE MAKERS; LINTHORPE ART POTTERY 。

XVII. LEEDS DISTRICT AND LIVERPOOL DISTRICT. LEEDS WARE. BURMANTOFTS. CASTLEFORD : DUNDERDALE. SWINTON : DON POTTERY AND BRAMELD (ROCKINGHAM) LIVERPOOL: HERCULANEUM. BIRKENHEAD : RATHBON

XVIII. POTTERIES IN THE WEST OF ENGLAND. BRISTOL: FIFIELD. DEVON : WATCOMBE AND ALLER VALE. BARNSTAPLE (BARUM): BRANNAM. FREMINGTON : FISHLEY. SOMERSET, CLEVEDON : ELTON .

XIX. WELSH, SCOTTISH, AND IRISH POTTERIES. WALES : SWANSEA-DILLWYN. NANTGARW: BILLINGSLEY. SCOTLAND: GLASGOW-J. AND M. P. BELL AND CO. HEATHFIELD-FERGUSON, MILLER AND CO. GRANGEMOUTH, ETC. IRELAND : BELLEEK

XX. ESSENTIALS TO THE POTTER'S ART. MATERIALS : CLAYS, GLAZES, DECORATION, ETC. • • . 482

XXI. A FEW LetTERS FROM MODERN POTTERS . . . 504 XXII. NOTES ON LOWESTOFT AND HEDINGHAM, ETC. CONCLUSION

INDEX . . . . . . . . 527 


\section{LIST OF HALF-TONE ILLUSTRATIONS}

Doulton.--Lambeth, and Burslem - . Coloured Frontispiece

Modern Worcester. The Peacock Vase, Finely Painted AND GILT

MODERN WORCESTER OF UNCOMMON Form AND BEAUTY • I 3

Modern Worcester. Painted Work . . . . . 21

MODERN WORCESTer. SHAKESPEARE'S “Midsummer-Night's DREAM" . . . . . . . . . . 25

adams Jasper Ware Vase, i796-i803 Period. In the British MUSEUM

Adams Jasper Vase with Blue Ground and Decoration in White Relief, "Luna Driving upon a Cloud," i 896; And Adams Jasper Ware Vase, i796-I803, White Relief on BLUE GROUND

Adams Dish, "A View of St. George's Chapel," I820; AND Adams Dish, Blue Printed, "A View of Denton Park, YORKSHIRE" .

adams Blue-Printed Dish, " Niagara Falls," i840; and Adams Blue-Printed Dish, "A View of Old Regent STREet," i 820

adams Plaque with Underglaze Colouring, i8i 8 ; and Adams Plate, Blue Printed, Columbus Design, i 830 onwards

Adams Plate, Painted; a Plate, Pale-Blue Printed, with Seaweed Design, i $790-1805$; and a Blue-Printed Plate, "Mitchell and Freeman's Warehouse, Chatham Street,

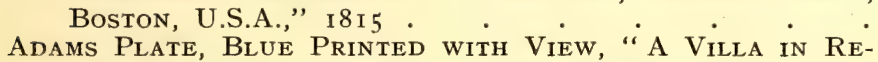
gent's Park"; ANd a Plate, Cupid Design, i 830 . 57

Spode. “La Pensierosa," after G. S. Newton, R.A., d. I835 65

Spode Vases of Fine Quality . . . . . .

Copeland Vase, Goldsmith Shape, Painted with ChrysanTHEMUMS

Parian Figures : Egeria, L'Allemgro, Maidenhood, Bédrice

Modern Copeland China

Modern Copeland, Richly Decorated : $:{ }^{\circ}$.

M. L. Solon's PÂte-sur-Pâte. "The Vintage." A Beautiful

VASE Solon's Pâte-sur-Pâte. Be bautiful “Minton" ivases

M. L. Solon's Pâte-sur-Pâte. Beautiful "Minton" Vases
Minton's Reproduction of the Famous St. Porchaire Ware

BeaUtiful MODERN WEDGWOOD. PORTIAND VASE

MODERN WEDGwOOD VASES IN JASPER WARE

MODERN WedgWOOD. JASPER VASES . . $. \quad \cdot \quad . \quad$ I 29

Modern Wedgwood. Jasper Plagues with Various ColQURED GROUNDS . 
Modern Wedgwood. Jasper Plaques in White on DifFerent Coloured Grounds. Stubbs' Horses in Jasper WARE

Perforated Cream Ware Compotiers and Chestinut Bowi AND COVER, AND OTHER MODERN WEDGWOOD WARE OF Fine QuALITY

MODERN WEDGWOOD.

Modern Wedgwood. Victoria Ware and China

A Puzzle Jug and a Mask Jug. Staffordshire

Wellington Jugs. StafFordshire

Rare Staffordshire Figures. The Mansion House Dwarfs, and a Rare Staffordshire Cow of Exceptional Size

English Powder Blue Vases, i760-70. Crown StaffordSHIRE

Chinese Famille Rose Vases, I730-60; and Chinese Famille VERTE VASEs, I670. Crown Staffordshire . . . I I

Beardmore's Sutherland ARt Ware . . . . . . I83

Beardmore's Basaltine and Athenian Art Ware • . I87

AsHWorth's Mason's Ironstone ChINA Jugs AND Bowls . IgI

Ashworth's Mason's Ironstone China Plates . . . 195

AshWorth's Mason's Ironstone China VAses, etc . . 199

EARly I9th-Century Toby Jugs, including "The SnuffTAKER"

Late Staffordshire Figures

DAVENPORT COMPOTIER, SHOWING THE TOP

Bernard Moore's Flambé Porcelain .

SAMPSON SMITH'S COTTAGE FIGURES.

SMIT'S COTTAGE FIGURES. STAFFORDSHIRE . 229

BOOTH'S Silicon CHINA

Booth's Scale Blue . . . . . . . . . . . 24 I

The Royal Works AT WORCESTER IN I9OO; AND BEFORE . 247

Worcester. Transfer-Printed, about i756; Scale Blue, ABOUT I768, I783 TO I840, I786 TO I85I . . . $25 \mathrm{I}$

Worcester VAses. Flight, Barr aNd Barr . . . 255

Worcester VASE. Flight, Barr and Barr . . . 26 I

Modern Worcester. China in Italian Style; China in Japanese Style; Faience; and Jewelled China.

Modern Worcester. Hadley's. Royal Porcelain Company

Modern Worcester Vase, c. 1850 . Subject, "The Battle of HASTINGS",

Modern Worcester. Pierced Vase by OWen . . .

Vase and Cover. Modern Worcester. Pierced Work by

Derby Vases and Two Jugs. ON the right, the Rodney

Jug Mugs

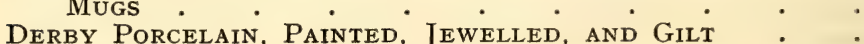

DERBY VASE

Royal Crown Derby. Modern.

Typical Derby Designs and Shapes; and Willow Pattern Dishes .

Pinxton Vase

Ault FAiEnCE

TOOTH'S Bretby ART Ware 


\section{LIST OF HALF-TONE ILLUSTRATIONS}

Coalport Vases .

Doulton. Plagues by George Tinworth." "King Herod WAS EXCEEDING Sorry." Hagar and Ishmael are Cast Out. Judas Casteth Down the Pieces of Silver.

Doulton Ware and Glazed Faience. Four Pieces by Mr. M. V. Marshall, and one with Flowers by Miss F. Lewis

Doulton Vases, Burslem. Two Views of the Nelson and THE DRAKE VASES

Tiles. Doulton Faience Glazed. The Four Evangelists

Mitcheli's Sussex Rustic Ware

Sunderland Lustre Ware. A Frog Mug (From Miss Edith Feilden's Collection); Typical Sunderland Ware . .

Sunderland Jug Marked “Dixon, Austin \& Co., SunderLAND"; SUNDERLANd Lustre Jug (MASONIC). • . 397

Dixon's SUNDERland Ware . . . . . . $40 \mathrm{I}$

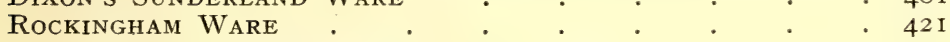

Typical Rockingham Vases : . 425

Della Robbia Ware executed by Miss E. M. Rope; Della Robbia Ware made by the Della Robbia Pottery

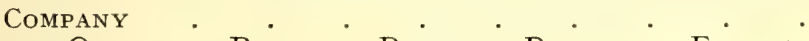

Painted Ornament, Bristol. Probably Painted by Fifield ; Moulded Ornament, Davenport . . . . . 433

WATcombe WARE . . . . . . . . . . 437

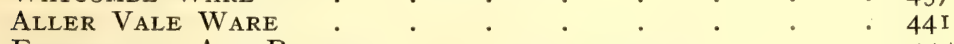

Fremington Art Pottery ..$\quad$. $\quad . \quad$. . $\quad . \quad 445$

Swansea Tea-Ware (Lent by Mr. George Stoner). . . 449

Swansea Vase. . . . . . . . 453

Swansea Cup and Saucer. Plate also Nantgarw Pattern. 457

Swansea Specimens . . . . . . . . . . . $46 \mathrm{I}$

Nantgarw Plates (Lent by Mr. George Stoner) : $\quad \therefore 465$

Cochran and Fleming's Wares . . . . . . 469

Early 19th-Century Wares. Castleford, White; StafFordshire, Black; Silver Lustre; Transfer-Printed Worcester and Spode; and LeEds and Bristol Painted (From A. M. Broadley's Collection) . . . . . 48

Staffordshire Toby Jugs and Figures $: \cdot v^{*} \cdot 489$

Transfer-Print, “Diabolo"; Transfer-Print, Shipping WITH Flower Border. StAFFordShire

Memorial Ware. Plate and Cup : Death of Queen Caroline. Saucer: Death of Princess Charlotte. Mug: Queen Caroline. Toy Plate: Marriage of Queen Victoria and Prince Albert. Jug: Wellington. Plate: William IV. Plate: Queen Victoria at her Accession. Plaque : George IV. Jug: First Locomotive Engine (From Miss Edith Feilden's Collection) . .0 .50 .501

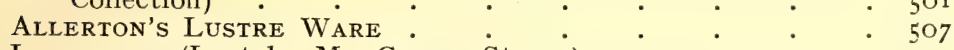

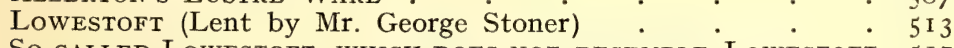

So-CAlled Lowestoft, Which DOES NOT Resemble Lowestoft $5 \mathrm{I} 7$

Lowestoft. The Mug and Covered Vase are Doubtful. 52 I 


\section{BY WAY OF FOREWORD}

TO THOSE WHO HAVE ASSISTED ME BY FORWARDING MATERIAL FOR THIS WORK-MARKS, BLOCKS, PHOTOGRAPHS, AND INFORMATION-MY GRATITUDE IS DUE, AND MY HEARTIEST THANKS ARE HEREBY TENDERED TO THEM. WITHOUT THEIR HELP IT WOULD NOT HAVE BEEN POSSIBLE TO PRODUCE THE BOOK, WHICH IS WHAT IT IS BECAUSE OF THEIR CO-OPERATION, AS IT IS NOT WHAT IT COULD HAVE BEEN HAD OTHERS RESPONDED IN LIKE MANNER. HOWEVER, OMISSIONS AND FAULTS SUCH AS EXIST ARE REMEDIABLE; HENCE I HAVE NO HESITATION IN INVITING ADDITIONAL CONTRIBUTIONS FROM MANUFACTURERS AND OTHERS WITH A VIEW TO A NEW EDITION WHEN THIS IS EXHAUSTED.

IN THE SEVERAL CHAPTERS, DUE ACKNOWLEDGMENT IS MADE OF THE SERVICES OF INDIVIDUAL HELPERS WHO HAVE SUPPLIED MATTER OR ILLUSTRATIONS. OTHERS DESIRE TO REMAIN INCOGNITO, WHOSE WISHES MUST BE RESPECTED IF REGRETTED. LASTLY, ESPECIAL THANKS MUST BE GIVEN TO MR. HARRY GREEN, WHO MOST KINDLY READ THE PROOFS, AND RETURNED THEM WITH REMARKS PLEASING TO AN AUTHOR, AND ONE WHICH MAY BE PASSED ON TO MY READERS: “THE LISTS OF POTTERS WILL BE DRY READING; MOST PEOPLE WILL SKIP THEM." DO, AN IF YOU WILL. AS A RECORD THEY REMAIN, AND TO MANY WHOSE NAMES APPEAR IN THEM THE INVITATION SET OUT ABOVE IS EXTENDED.

J. F. BLACKER. 


\title{
Nineteenth-Century English Ceramic Art
}

\author{
CHAPTER I \\ INTRODUCTION : THE EXHIBITION OF I85I \\ AND BEFORE
}

THERE are many books on English pottery and porcelain which treat of old ceramic art, but there are very few which deal with the later work of the nineteenth century, which show the special wares of the Victorian period and those of our own times, and which record the development of potteries whose oldest products are modern. Hence this book, which is an endeavour to do some justice to the descendants of the eighteenth-century potters, will at the same time recognise the talents of men who have moved along on independent lines, working out ideas which are characteristic of their wares.

The tenacity of certain of the old potteries is no less astonishing than the spasmodic brilliancy of some later ones whose careers have ended, though they have left imperishable records of skilled labour, abundant evidences of artistic work which one day will become valuable. The Wedgwoods, the Adams, the Mintons, are types of such old potteries; whilst amongst the modern work which has passed away it will be sufficient here to mention Hadley's faience, now made by the Worcester Royal Porcelain Company, and the Linthorpe Art Pottery, both of which possessed the highest artistic excellence. As will be seen in the account of Lin- 
thorpe, Mr. Henry Tooth was largely responsible for the progress there made, and the Bretby Art Pottery of Tooth \& Co., at Woodville, near Burton-on-Trent, is still flourishing.

During the time in which the material for this book was collected many firms have ceased to exist, yet here again the process of absorption has in a measure saved some, just as George Grainger \& Co., whose factory was established in Worcester in I80I, have now no separate being; they have been merged into the Worcester Royal Porcelain Company.

If we were dealing with politics, and not pottery, we might be tempted to inquire the cause of so many failures, but, confined to history, we can only record them. Yet the progressive improvements in the manufacture have only occasionally lagged, the tendency has ever been towards perfection. Even the production of fine pieces rivalling old Worcester, Chelsea, and the like, has been successfully attempted, though such work has ceased to be the aim of the manufacturer who has concerned himself more in raising the general level of excellence. Such firms as Minton and Doulton have done much to educate the public. They have produced wonderful wares resembling no others; the pattesur-pâte of Solon is as distinctive of Minton as George Tinworth's terra-cotta is of Doulton.

Scientific research and experiment have yielded results gratifying to the makers, appreciated by the people who, however, have only a slight idea of the thousands of trials and the years of study and labour which precede success. It was so with Josiah Wedgwood, and if his "trials " were numerous before he produced jasper ware, scarcely less are those undertaken by modern potters in endeavours to discover the secrets of the past, to reproduce rare enamel colours which should vie with the Chinese famille rose and powder blue. Yet recently, indefatigable industry allied with high intelligence has accomplished this and more; the potter has led the public taste to a better standard of art notable for its simplicity and beauty. Its modernity time will cure.

The early productions of the nineteenth century have already entered the realm of antiquity; old china and old 


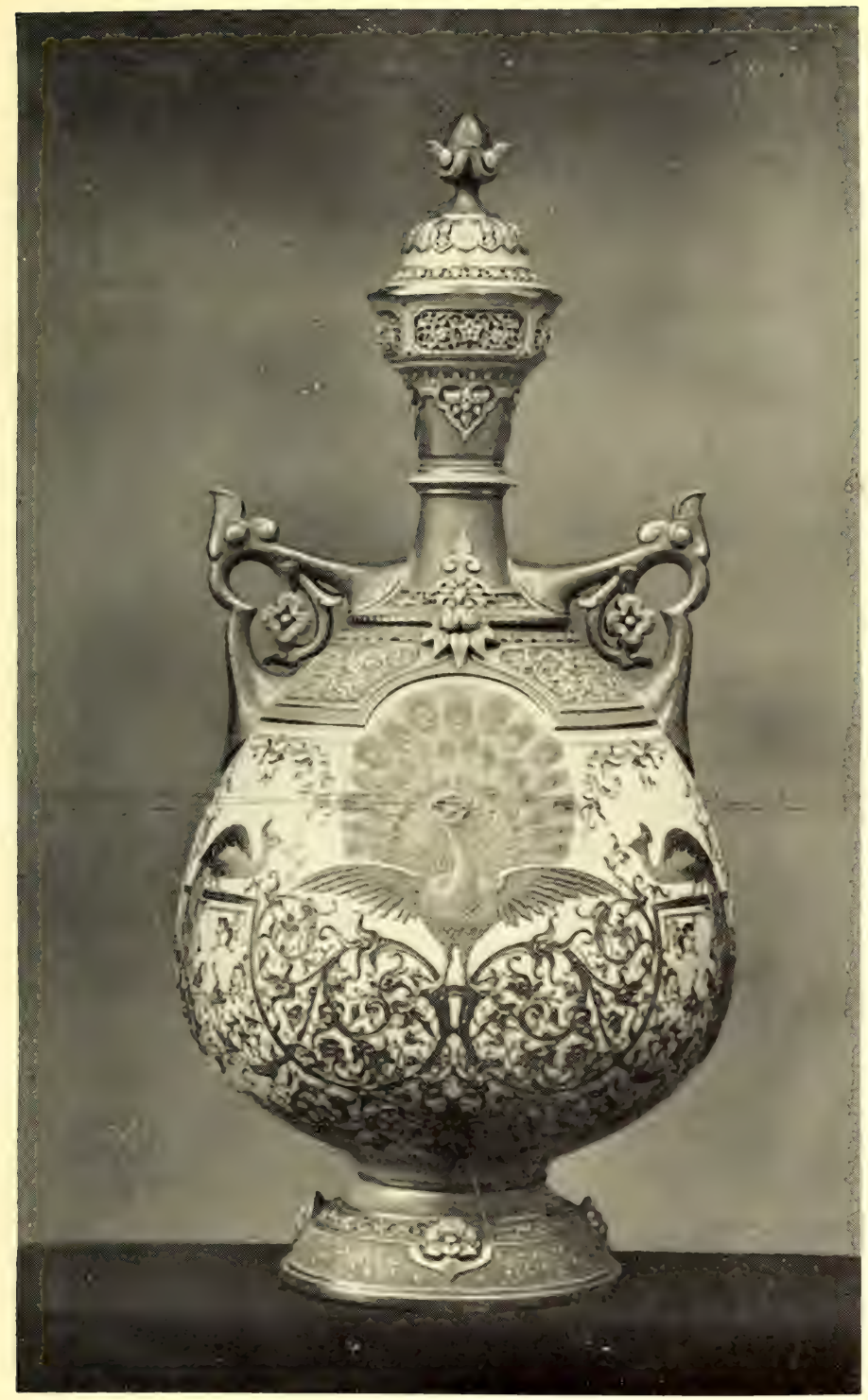

MODERN WORCESTER. THE PEACOCK VASE, FINELY PAINTED AND GILT. 

pottery are moving on to the Victorian period, which will receive much more attention as the years pass by. As much of this book will deal with the potters of that period it is not necessary to refer at length to it here. I only need emphasise the point that collectors should not despise the potter's art of the nineteenth century.

Naturally, and for all collectors, the finest examples of earlier work have the greatest attraction, but they have increased in value so enormously that unlimited means are necessary for their acquisition. Even ordinary old pieces are by no means cheap. And then comes the work of the imitator, forger, reproducer-call him what you will.

$\mathrm{He}$ is so clever that his best efforts may almost mislead the expert. He is often so expensive that his prices are almost equal to those paid for the genuine specimens which he copies. The price is fixed at a high figure to make the attraction more complete. Hence suspicion and distrust have been aroused, so that it requires the reputation of a dealer beyond reproach to remove them and to establish the confidence of the buyer, who feels safe when he knows that he can recover his money if need be. Bad imitations should deceive nobody. Unfortunately, they do, because people are careless.

Then apart from imitators who are deceivers, there is another class, in quite another category. He in that class says in effect, "I am a modern potter, but I believe many people who are unable to possess fine old treasures would buy good copies, therefore I make them, and you will find my own mark on the base." The proposition is quite sound, and I know that such pieces of modern make are on sale at some of the best establishments in London. They are what they profess to be ; nobody is deceived. Indeed, such copies will themselves in time become valuable, because their production is not unlinited, and their cost depends upon the character of the decoration, which is often elaborate.

Interest in the nineteenth-century pottery and porcelain is mainly focussed upon two exhibitions held in London in $185 \mathrm{I}$ and 1862 . With praiseworthy enterprise the $A v t$ 
Journal published illustrated catalogues, and from them many of the illustrations of this book are taken, and the criticisms then passed are quoted. I believe these will be of great service to collectors. The multiplicity or scarcity of examples from the various exhibitors is of itself some indication of the estimation in which their goods were held at the time of the exhibition. Other firms existed, as I shall show, but apparently they were not then enterprising. In I85I Messrs. Doulton and Watt of Lambeth gave evidence of the spirit which has always distinguished the firm. They had not existed long, yet they exhibited the white terra-cotta vases and the chimney-pots which are shown in the chapter on Doulton. Truly did the critic remark they " may be regarded as a prelude to further success." Most of my readers would place Doulton ware much earlier, yet really it was later than I85I ; some jugs and ornamental forms of vases being first produced for the Paris Exhibition of 1867 . Since then Doulton ware has traversed the world.

By the kindness of many of the proprietors of existing factories I have been furnished with information for publication, which I value very much. My acknowledgments are duly made; still, in repeating them elsewhere, I am but feebly expressing my sense of obligation for many kindnesses. When, in the future, the ceramic art of the nineteenth century becomes the prize of the collector, his interest will be centred upon objects like those which were exhibited in London in I85I and I862; the later products will age in their turn.

I cannot do better than continue this introduction with an extract from an essay on ornamental art which won the prize of one hundred guineas offered by the proprietors of the Art Journal in I85I for "An Essay on the best mode of rendering the Exhibition practically useful to the British Manufacturer."

The writer, Mr. R. N. Wornum, in dealing with pottery and porcelain, wrote as follows, and, though I have quoted all he said about ceramic art, it will not be too much, in view of the illustrations to which I have referred. 


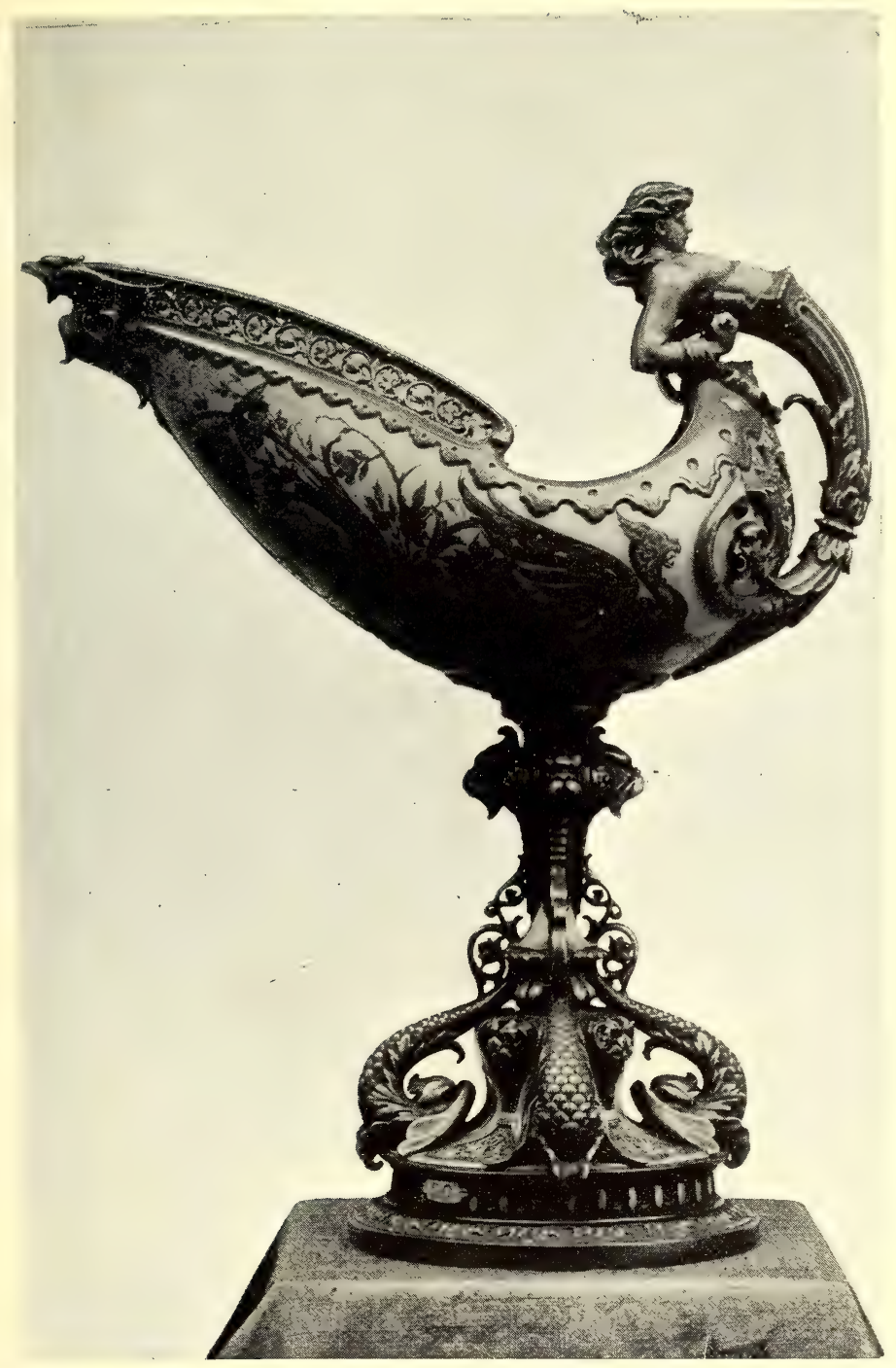

MODERN WORCESTER OF UNCOMMON FORM AND BEAUTY, 



\section{INTRODUCTION : THE EXHIBITION OF I85I 19}

"In this department of industry, more especially in the province of uses, the contributions of British manufacturers show an immense improvement in design upon the ordinary standards of former years; the very long unrivalled preeminence of the Messrs. Wedgwood in classical taste only proves how difficult it was to impress the mass of the master potters with even the belief in the real existence of such a quality as Taste. The material prosperity, however, of those who have taken the lead in cultivating this tardily acknowledged essential element of manufacture must establish now and for ages the absolute necessity for its cultivation as one indispensable foundation of success.

"To limit fine taste or design to such works as the more magnificent productions of Sèvres, which from practice we may assume to have been a rule, is a now admitted folly, which individual pecuniary interest, if no higher motive, is likely effectually to correct for the future. If in expensive productions the relative high price may be said to secure a return for the extra outlay consequent on employing higher talent, the same cause restricts the manufacture; and where the same high talent is employed over the low-priced article the remuneration is secured by the increased attractiveness and consequent greater demand. This was formerly discredited, but the general movement of late years in this direction, encouraged by the increased facilities of education offered by the Schools of Design, has proved its practical reality; and we can but hope that nothing will deter our manufacturers from pursuing this enlightened course.

"Form is the great element of pottery, porcelain, and glass, as applied to domestic uses, and should command the first consideration; a vessel, even should it have no other attraction than an agreeable shape, or, in other words, be wholly without decoration, may still be a beautiful and delightful object to the cultivated eye, and will itself eventually educate the uncultivated. Shape is the element of beauty ; decoration may enhance it, if judiciously applied, and may do much towards destroying it if had recourse to in too great proportion; but it is this, more or less, which tests the quality of taste. We cannot illustrate better what we mean than by referring to the stall of Messrs. Wedgwood, where we find only exquisite shapes just sufficiently decorated to enhance their effect. Though the designs of Flaxman for the most part, these are the revival of an old taste, or rather 
the utmost development of taste, after an uninterrupted education of many centuries; no parallel opportunity has ever offered itself to Christian Europe ; mere symbolism and religious dissensions have rendered it hitherto impossible. In comparing, therefore, the modern with the old, we compare the crude and unfinished productions of a divided attention, constantly interrupted by one whimsy or another wholly irrelative to the purpose, with the last and crowning efforts of the most cultivated people of the ancient world, after the successive and undivided attention of whole generations of educated designers in the attainment of beauty.

" Repudiate the idea of copying as we will, all our vagaries end in a recurrence to Greek shapes. All the most beautiful forms in the Exhibition, whether in silver, in bronze, in earthenware, or in glass, are Greek shapes ; it is true, often disfigured by the accessory decorations of the modern styles, but still Greek in their essential form.

"In adopting Greek shapes we are not restricted to either Greek materials or Greek colours, nor are we limited to their details; but if their principles are true, we can but work upon them, and whatever variations we adopt there is sure to be a beautiful effect in the arrangement. If reproductions in the Greek taste have hitherto had a general monotony of effect, it is because the materials themselves have been imitated, rather than the taste of form and decoration; let the materials and colours be properly varied, and all that sameness of effect which too often characterises these reproductions will disappear; this is sufficiently evident by a mere reference to silver, bronze, or glass, where the shape is the same, but where the idea of mere imitation or monotonous repetition never occurs.

"Though the Sèvres porcelain takes the lead in point of pretensions, it is not superior in taste, and is certainly inferior in matters of utility, to the specimens of Alderman Copeland, of Stoke-upon-Trent. We have in this stall much of that variation of classical models which appears to us to constitute the true use of these ancient remains, and the best evidence of a refined taste. There is besides on this stall much handsome porcelain of modern design, rich in decoration, without being gaudy; and in several styles, all well expressed, as the Indian, Moorish, Cinquecento, and the Louis Quatorze, and Louis Quinze; but the Greek justly prevails over all the others. 

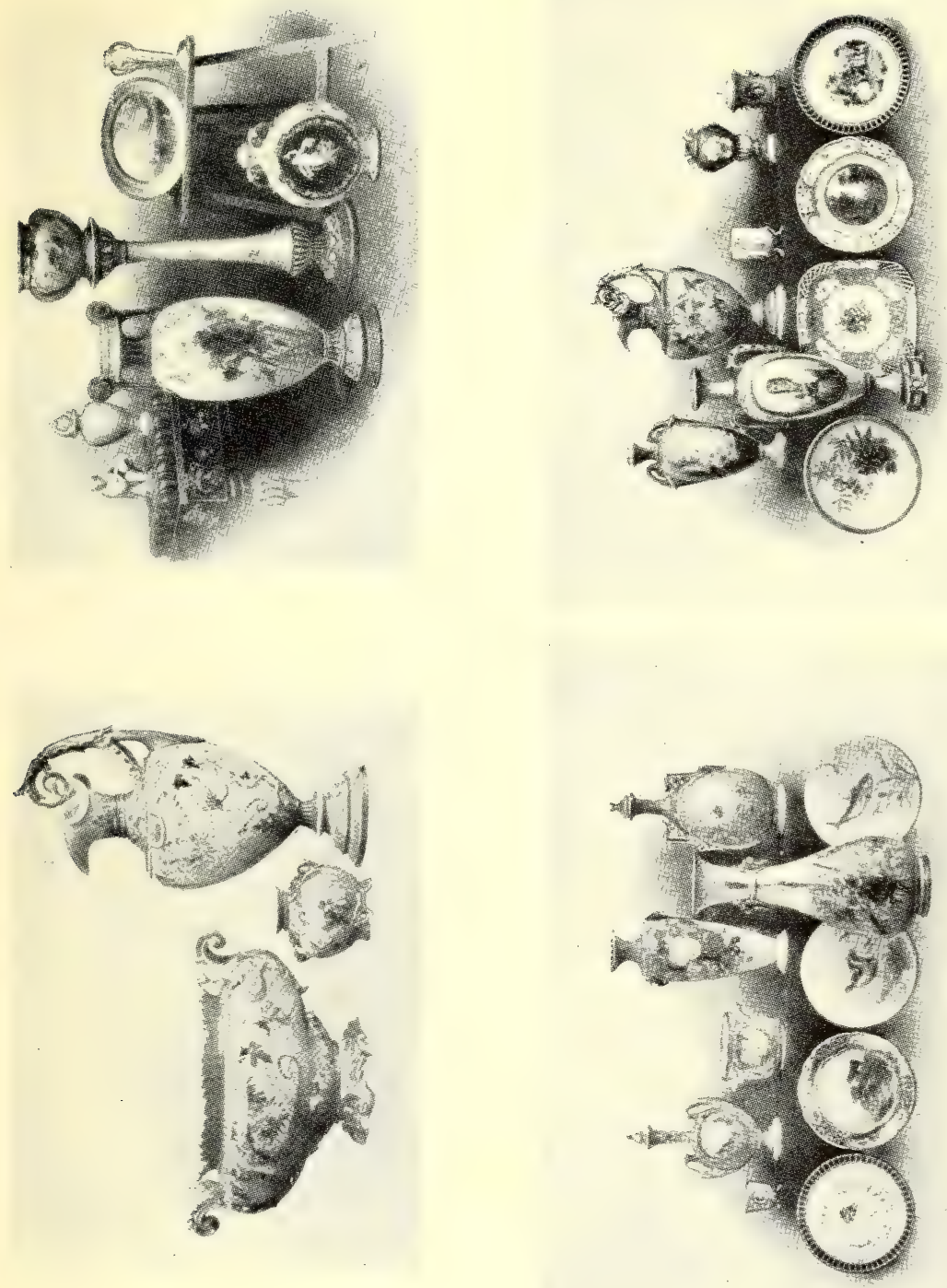

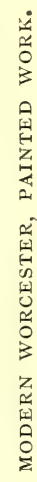





\section{INTRODUCTION : THE EXHIBITION OF I85I 23}

"Minton \& Co., also, of the Staffordshire Potteries, make likewise a magnificent display, especially in a dessert-service in Parian and porcelain mixed, in turquoise, white and gold, purchased by Her Majesty. The designs comprise many statuettes of an allegorical character, but in the ornamental details the Louis Quinze has been allowed too conspicuous a part ; the centre piece, a wine-cooler, is a good example of general skilfulness of treatment of relief, and of that class of design of which the ornamental details illustrate the uses, or ideas and customs, associated with the object of the design. On this stall is a beautiful Cinquecento ewer and basin, in Parian, which is one of the most tasteful specimens of this class of design in the Exhibition ; and in much the same style is a magnificent mantelpiece of exquisite design, but of more ordinary Renaissance character : many of its details, however, are admirable, as the scrolls and centre of the frieze; and the general style of the terminal plaisters, a nymph and faun so adapted, is perfect in character, except that the lintel or architrave is made to rest on the flowers which these figures carry in baskets on their heads, which, though not without a precedent, is an outrageous idea; the wreath round the heads of the figures would have made a better capital, and would have obviated this anomaly.

"This firm exhibits also a pair of magnificent vases, of which the handles, in metal, are extremely beautiful; a ram's head, scrolls, cornucopia, and infant boys, ingeniously grouped into a convenient and ornamental handle-shape; and there are also some clever imitations in Parian of the delicate trifles of old Dresden china, in flowers and fancy figures, of the school of Watteau. The colours generally, and the ordinary services of this firm, are extremely good ; and its encaustic titles are a very important contribution towards the general cultivation of Taste.

"The Louis Quinze is still the prevailing style in porcelain, as in many other manufactures; and, generally speaking, profusion of ornament is the rule. Much beautiful work, however, rich and simple, is exhibited by Ridgway \& Co., whose conservatory fountains and stair-rails are very agreeable novelties: also by Alcock \& Co., Burslem; Messrs. Boote, of Burslem; Meigh and Sons, of Hanley; Dimmock, of Shelton; Rose \& Co., of Coalbrookdale; Bell \& Co., of Glasgow; and Grainger \& Co., of Worcester, who con- 


\section{I9TH-CENTURY ENGLISH CERAMIC ART}

tribute in their semi-porcelain some minor works in excellent taste.

"The famed Dresden porcelain seems to exhibit the atrophy which not seldom is induced by a just consciousness of superiority at one time, ending in an assumed incontestable pre-eminence for all time: thus, while other fabrics have steadily progressed, that of Meissen has unconsciously remained stationary, and its specimens are in the Exhibition merely to astonish us how it ever attained its former notoriety.

"There is, indeed, very little in German pottery or porcelain to attract attention. The Berlin specimens take the highest position ; the Austrian is of a very ordinary character, and the beer-mugs of Neureuther, of Munich porcelain, or the terra-cottas of E. March, of Charlottenburg, or the stonechina of Villeroy and Boch, are among the most prominent German efforts in this class of industry."

The following chapters commence with the Staffordshire Potteries and continue in a rough order of importance. Starting with Adams, Copeland, Minton, and Wedgwood, some of the potters other than these will be found under Burslem, Cobridge, Fenton, Hanley, Longport, Longton, Stoke-upon-Trent, and Tunstall, the area shown in a sketchmap, now mainly included in the county borough of Stokeupon-Trent recently formed.

Many potters who, during the nineteenth century, simply made general earthenware or jet (black) and Rockingham (brown) ware are not noticed unless some distinguishing feature marks their productions. So the makers of ordinary tiles, and, with just a few exceptions, the manufacturers of terra-cotta, have but little space, though in some instances their work is of high merit. The limitations of space prevent more than short reference to the tiles which have been brought to such a high degree of excellence. I mention these points so that my readers may know what to expect in the chapters which follow, which will only deal with such eighteenth-century history as is essential. For instance, though Josiah Wedgwood died in I795, no description of nineteenth-century pottery could omit recognition of his great work, which has been so ably continued by his descen- 


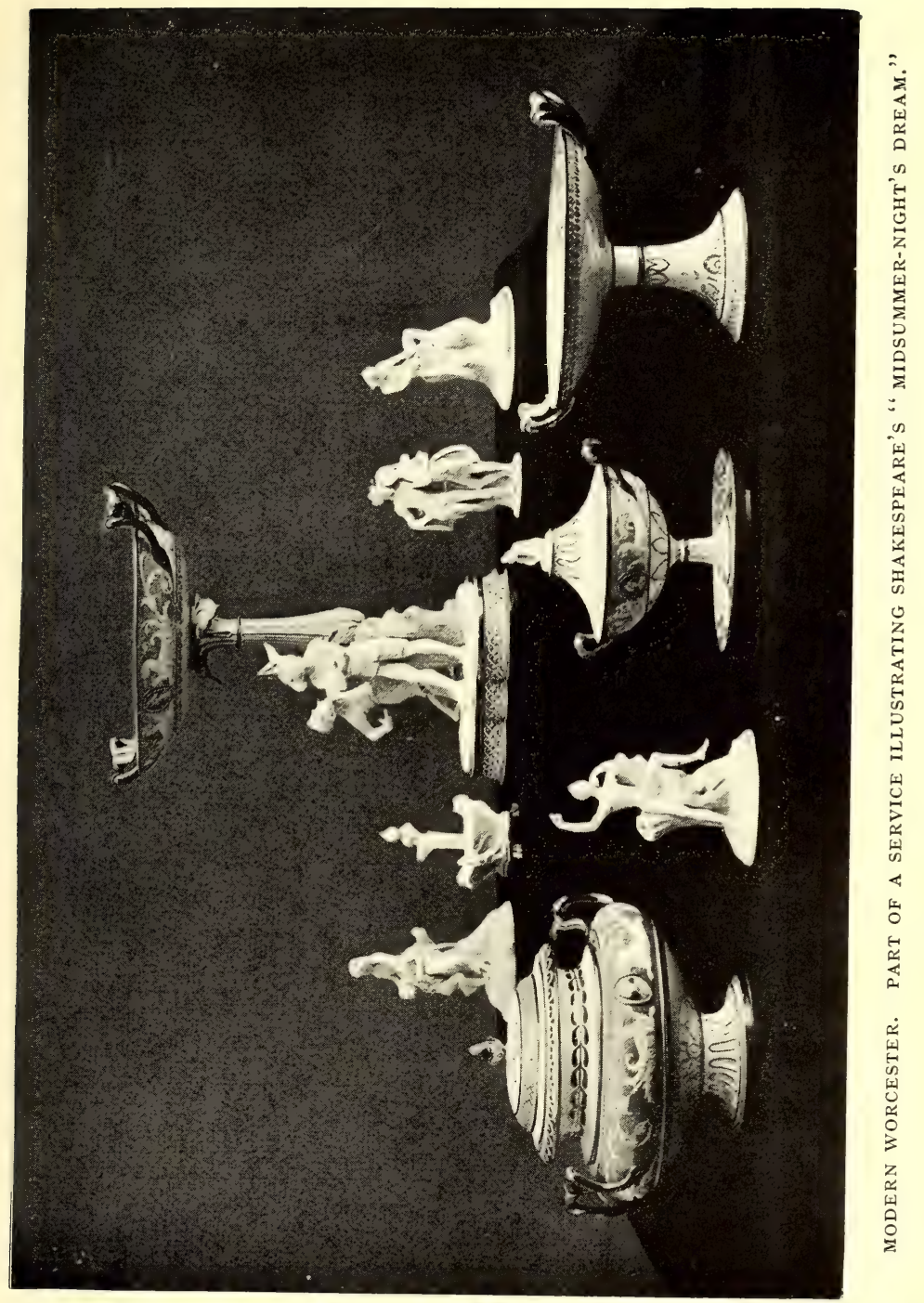



dants. Some other men in potteries beside Etruria have carried on, through the last century, the work which was started by their ancestors, without a break in the continuity of the productions. And lastly, some potteries, after a short and brilliant career, have ceased to be ; they were founded and closed wholly in the nineteenth century. A few of them, like Swansea and Nantgarw, have long since furnished treasures to the collector, whose delight in their beauty is only modified by their exceedingly high cost. It appears only to be a question of time before the productions of the Victorian period will be purchased just as eagerly.

References will be found regarding those wares which were made by many potters, the common wares (of which illustrations are given) which had but little interest when they were made, because of their wide distribution. Time and the elimination by breakages of much of these wares have conferred something of distinction, something of value, upon the specimens which remain. And this applies to figures such as Staffordshire, Leeds, Swansea, Sunderland, and other coloured and glazed figures, which were made by many potters in the nineteenth century and signed by few. Shaw, in I829, stated that at Hanley there were "some small works principally employed in making china toys," but he does not give the potters' names because they were unimportant. Amongst the names which are best-known after 1800 are Enoch Wood, and Wood and Caldwell ; Walton (I790-I839); Ralph Salt (I8I2-I840); Ralph Hall (early nineteenth century); Barker, Sutton, and Till (c. I832-50); and what have been termed the Leeds, Liverpool, Swansea, and Sunderland schools, with the factory mark or maker's name. Then again, lustre ware was also widely distributed. It was quite a common form of decoration for pottery, and Bristol, Swansea, Leeds, Sunderland, and Staffordshire works made large quantities of it. Such wares have been treated with scant respect until recent years, during which collectors have given them considerable attention. But quoting from a Staffordshire newspaper-" Of recent years the firm have obtained a good foothold in the 
antique-shops of the world"-we can see where a danger lies: modern firms continue to produce the wares which their predecessors made early in the nineteenth century.

The export trade from the Potteries to the Continent was seriously affected by the Berlin Decrees of Napoleon, issued from that city in I806, after the defeat of Prussia and Saxony, with the avowed object of damaging the trade in British goods, which were declared contraband, and Britain's ports were said to be blockaded. The blockade counted for little, but many manufacturers of earthenware, whose chief markets were on the Continent, suffered severely, and gave up business before the advent of the Long Peace which followed the victory of Waterloo and the Congress of Vienna in I8I5. Then, in 1826 and 1827 , trade generally was in a bad state, potters, like other traders, were in commercial difficulties, and men like Brameld, of Rockingham fame, only survived with the assistance of others; in his case Earl Fitzwilliam, his landlord, generously came to his relief. To mark this, the well-known griffin crest was adopted as the Rockingham mark; but even with this help, the manufactures of earthenware and china were both discontinued in I842. Amongst other potters whose names disappear from these causes or from death in the first half of the nineteenth century were many who were well-known. I mention Enoch Wood and Sons, I846; Wilson, I820; Warburton, I828; Walton, I839; W. Stevenson, about I828; Steel, I824; Rogers, I829; Phillips, I830 ; and Baddeley, who marked his wares EASTWOOD, as a few amongst many. With the London Exhibitions of 185 I and 1862 came better conditions, and in spite of the severe competition of other countries, when last century ended, the fine qualities of the ordinary earthenware and china and the undeniable beauty of the more costly productions had won their way by sheer merit into all the markets of the civilised world. 


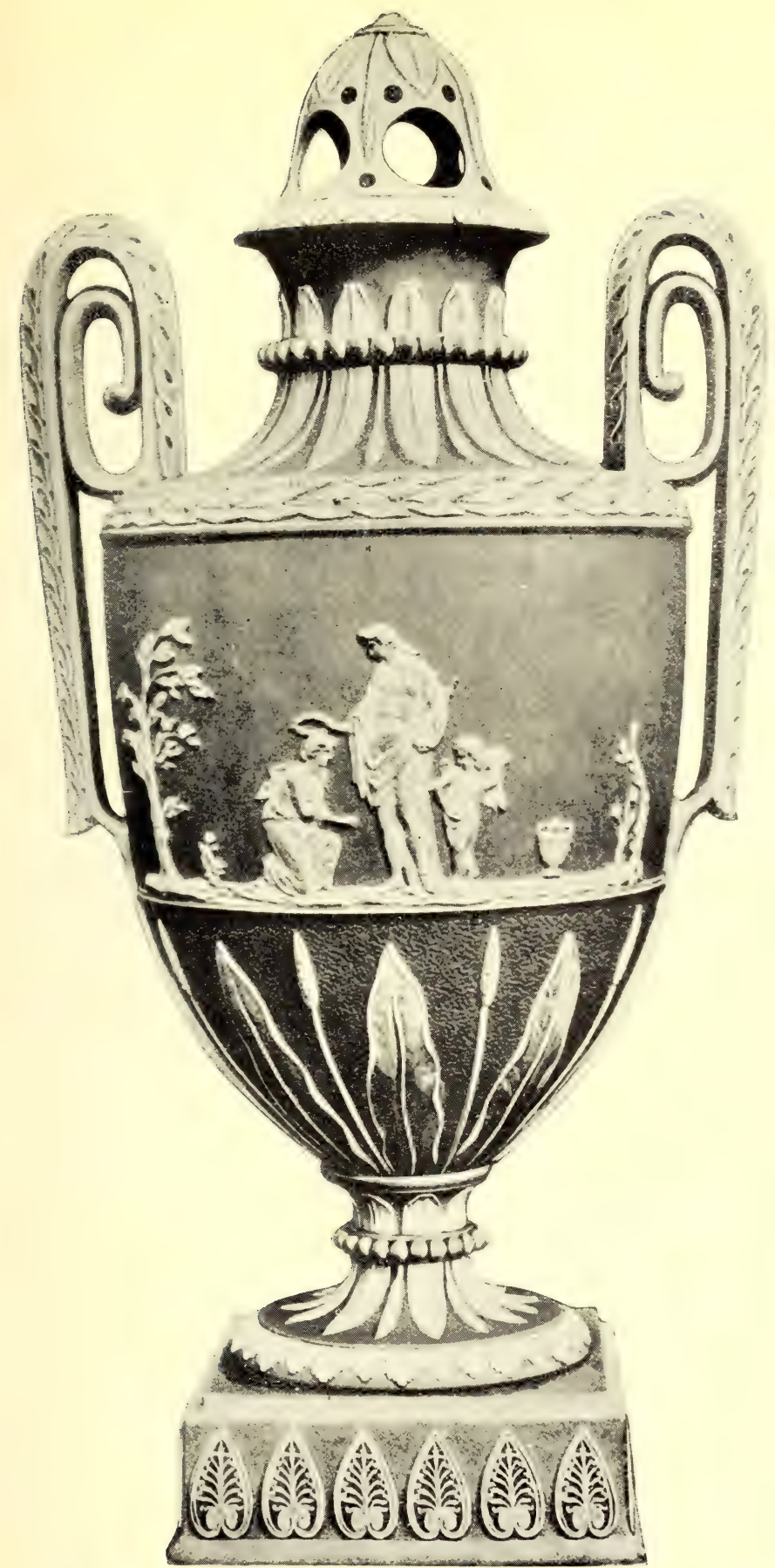

ADAMS JASPER WARE VASE, I796-I8O3 PERIOD. IN THE BRITISH MUSEUM. 



\section{CHAPTER II}

\section{THE STAFFORDSHIRE POTTERIES AND CORNWALL}

FROM very early times pottery was made in Staffordshire, but till towards the close of the seventeenth century it consisted of the local clay, sometimes decorated with clay or slip of a different tint, and lead glazed by dusting lead-ore on the clay vessel before firing. Then followed the saltglaze process in I680. The brothers Elers, in I688, made red and black ware; their processes were continued by Astbury and Twyford about the time when the tin glaze was discovered. The work of Wedgwood and others marked the eighteenth century, and the Potteries grew.

Dr. Shaw, writing in I829, describes the district known as "the Potteries" as being then about ten miles long, and varying in breadth from three to five miles. He estimated that about 50,000 persons were then employed in the Potteries, in the parishes of Stoke, Burslem, and Wolstanton, including operatives, colliers, and persons engaged on the canal bringing raw materials or carrying away manufactured articles. Eight years afterwards the same writer estimated that 30,000 persons were employed at Stoke-upon-Trent in connection with the various earthenware and porcelain works. Mr. Arnoux, in 1852, considered that the number of persons more or less engaged in the 133 factories of the Potteries was about 60,000 .

The Staffordshire Potteries still continue to afford the great mass of earthenware manufactured in this country, at the same time contributing a large portion of the porcelain produced. In I852 Mr. Arnoux estimated the yearly value 


\section{I9TH-CENTURY ENGLISH CERAMIC ART}

of English pottery manufactured at $£ 2,000,000$; and at that time $84,000,000$ pieces, of the value of $£_{1}, 220,000$, were exported.

In 1907 the value of the gross output of the china and earthenware factories in the United Kingdom was $£ 7,534,000$, of which the materials used cost $£_{2}, 854,000$. The net output, after deducting the cost of the materials and $£ 84,000$ for work given out to other firms, was $£ 4,596,000$. The number of persons employed was 67,870 , and 63,287 were at work in brick and fire-clay works.

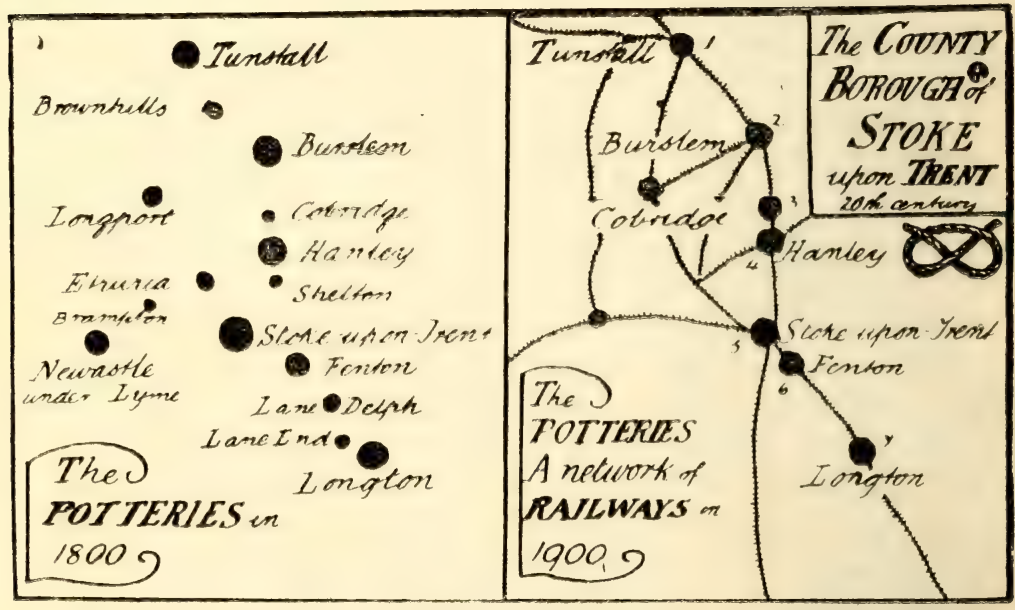

The chief mineral substances employed in the Staffordshire Potteries are kaolin or china-clay, from Cornwall and Devon ; porcelain-granite or china-stone from the same counties; natural clay from Dorset (Poole clay) ; flints from the chalk districts; and felspar from Norway and other places.

In I8I6 the Staffordshire manufacturers assembled to celebrate the fiftieth anniversary of the opening of the canal between the Trent and the Mersey, a work of the greatest importance to them. A museum was then inaugurated, illustrative of the progress of Staffordshire pottery, and some well-known old works which had been closed for many years were searched for specimens. Even so early 


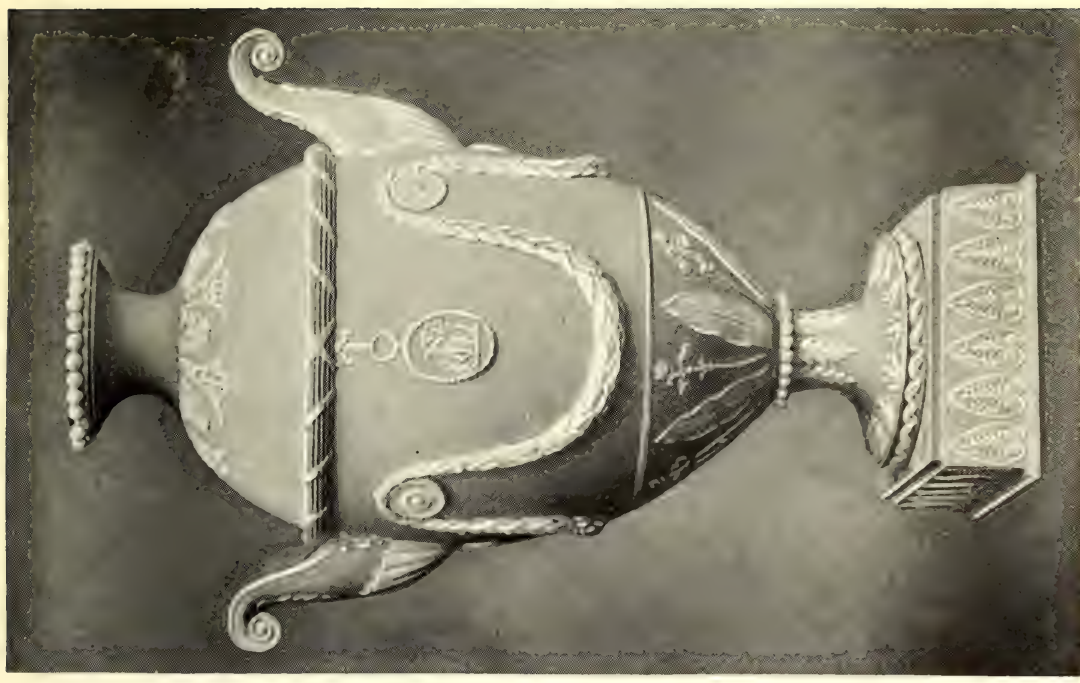

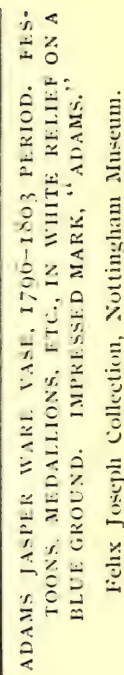

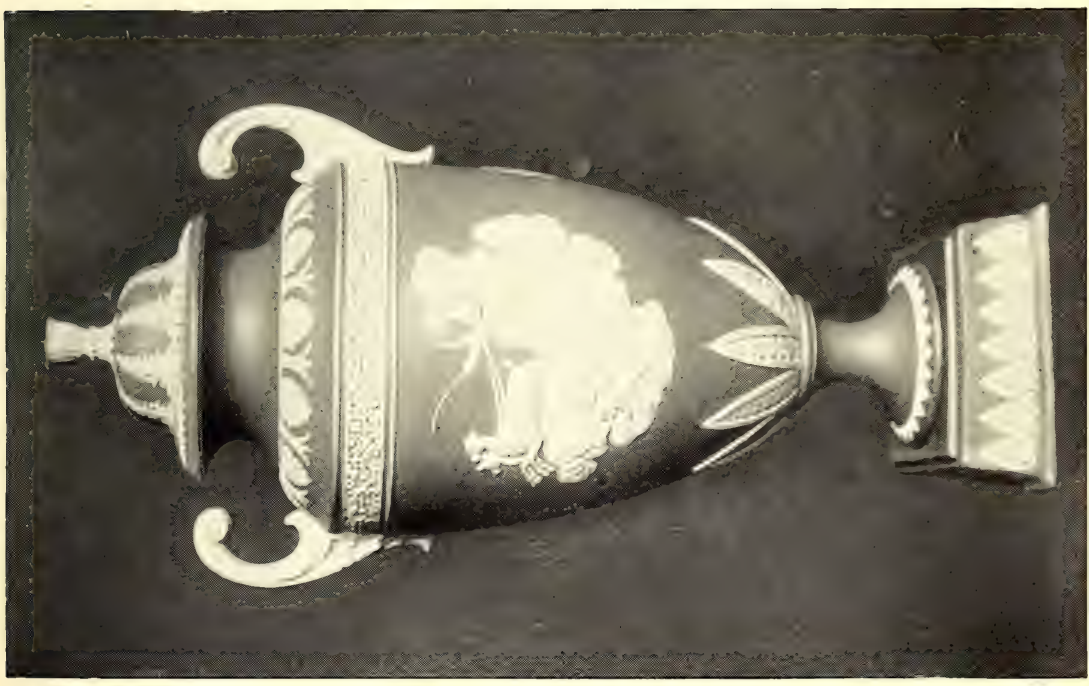

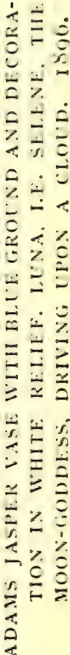



in the nineteenth century the interest in collecting pottery was manifested, and though it has been mainly concentrated upon the products of the eighteenth century, the inability of that period to meet the demands of collectors, and the natural effect of the lapse of time have opened a new field, which covers the first half of the nineteenth century; and signs are not lacking that even later Victorian china and earthenware will receive much closer attention. I need only cite the Lessore vases of Minton and specially of Wedgwood, the Solon vases, etc., also of Minton, the Coalport vases decorated by Cook, Hartshorne, and Randall, and the work of the last at Madeley.

Following the Great Western main line from Plymouth to Penzance, four or five miles beyond Par Junction is St. Austell, whose comparative prosperity is due to the chinaclay and china-rock trade of which it is the centre. The stranger visiting this town will be struck by the traces of this white material, which may be mistaken for flour or chalk, the streams around are often milky-white. The china-rock is referred to elsewhere, but from a Cornish guide-book I extract the following:

"China-clay or soft growan is a species of moist granite; that is, the rock once so firm and tenacious has been reduced by the decomposition of the felspar into a soft adhesive substance not unlike mortar, which, purified from mica, schorl, or quartz, proves well adapted for the manufacture of the best kinds of pottery. It is identical with the Chinese kaolin or porcelain clay. When this growan is of considerable adhesiveness, and, from its containing a larger proportion of quartz, resembles the Chinese petuntze, it can be excavated in large blocks or slabs, and exported as china-stone; but the clay or kaolin requires a more careful treatment. This is piled in stopes or layers, upon an inclined plane, and a stream of water is then directed over it, which carries with it the finer and purer portions, and deposits them in a large reservoir, while the coarser residium is caught in pits, catchpits, or catch-pools, placed at intervals, a process which may be compared to refining syrup out of molasses. From the reservoir all the water is drawn off and the clay removed 
to pans, where it is passed under the influence of a drying machine, thoroughly relieved of moisture, properly packed in barrels, and removed to the seaside for shipment."

The small sketch-map shows the district where much of the china-clay and Cornwall stone are obtained. At St. Austell many of the companies have their headquarters, and they ship most of their produce from Charlestown, though

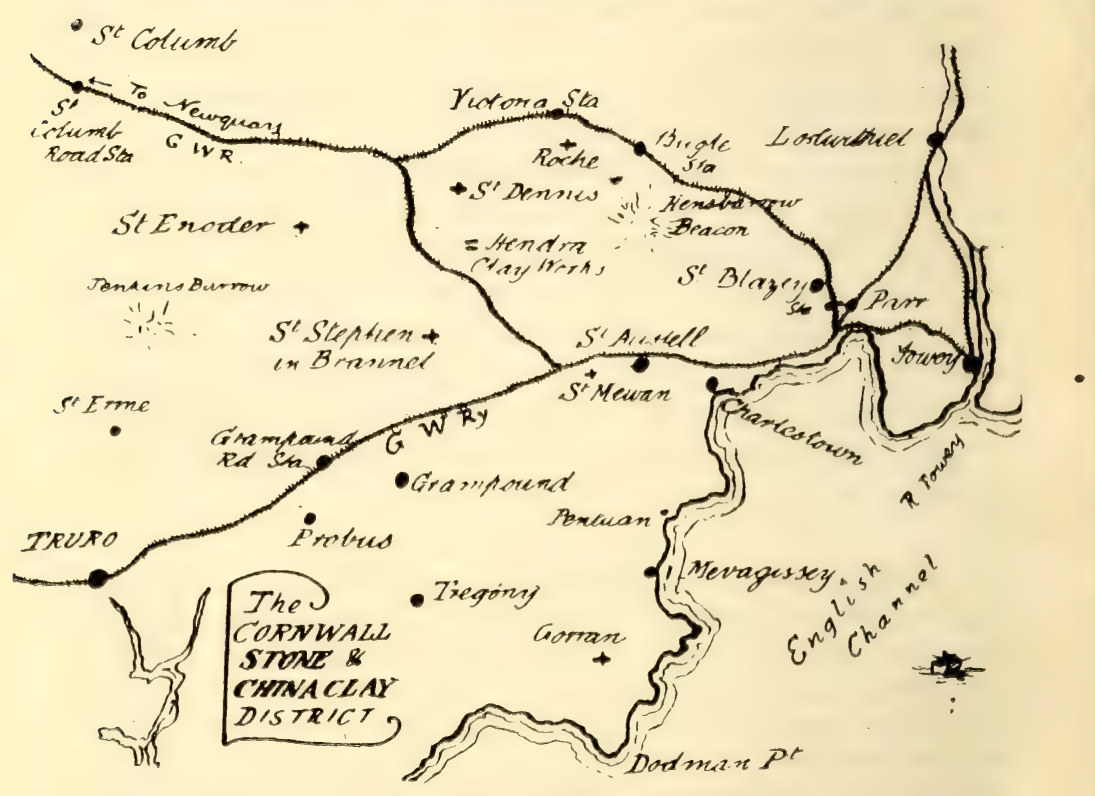

some use Fowey as their port. But around Bugle on the north, St. Enoder on the west, and Grampound on the south, and enclosed in the district between them, are many chinaclay works with which the scenery is scarred and crested.

There is a local tradition that Cookworthy first discovered china-stone in the tower of the stately church of St. Columb, which is built of stone from St. Stephens in Brannel. From his discoveries of stone and clay the great potting trade of England has received more benefit than from any others. Champion of Bristol, who bought Cookworthy's patent, was 


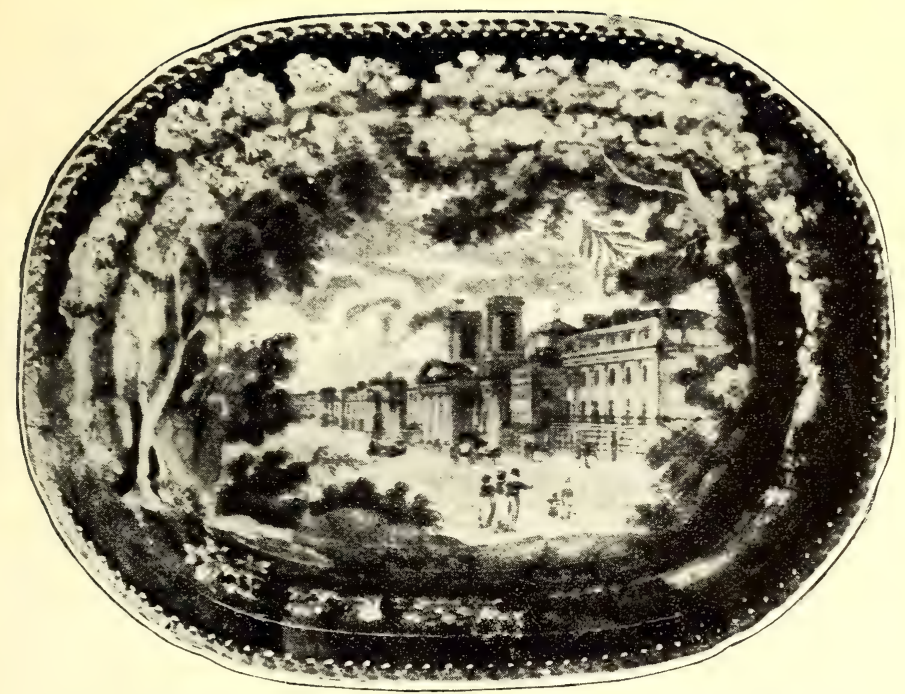

ADAMS DISH, BLUE PRINTED, "A VIEW OF ST. GEORGE'S CHAPEL, REGENT STREET," I 820 .

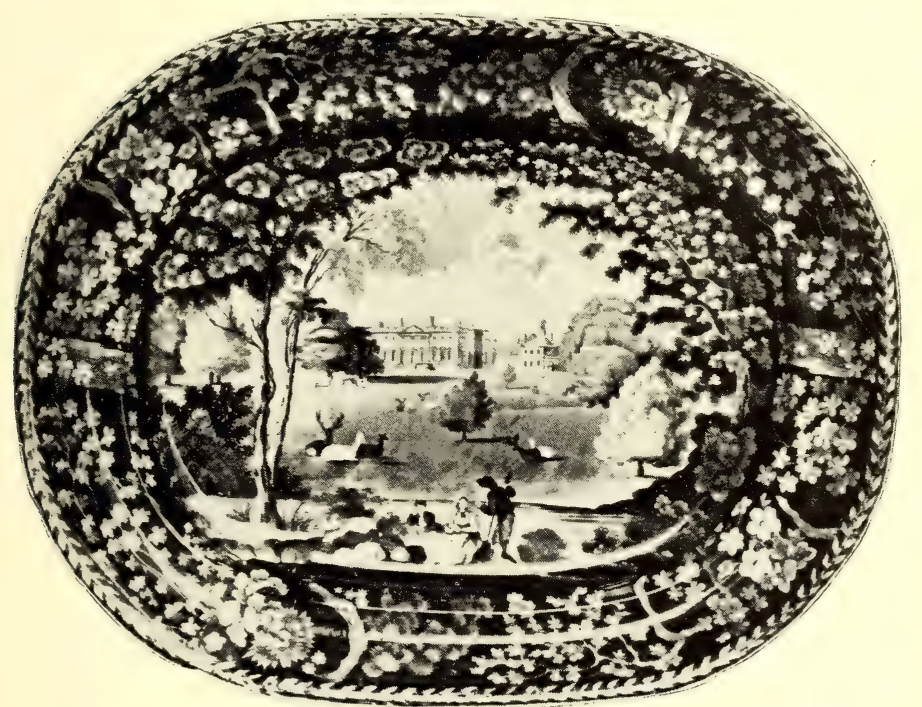

ADAMS DISH, BLUE PRINTED, “A VIEW OF DENTON PARK, YORKSHIRE." 

successful in his application for its extension for another fourteen years, making altogether twenty-eight years from the date, I768, when it was first granted; but the opposition of Wedgwood and other Staffordshire potters secured for them a great privilege, throwing open the use of these raw materials, except for the manufacture of porcelain. The potters confessed that, though their wares were equal, if not superior, to those of any other country, yet the body stood in need of great improvement, both in colour and texture. Hence, these materials becoming accessible, experiments resulted in such successes as those of Wedgwood, whose fine white terra-cotta of $\mathrm{I} 774$ became the white porcelain bisque of the jasper in I787, and those of Spode, to whom must be given the credit of using the china-stone with bone in $\mathrm{I} 800$ to produce that porcelain which, through the nineteenth century, was, in the main standardised, so that all distinctions of hard and soft paste disappear, with the exceptions of Nantgarw, Swansea, and Madeley, which for a short

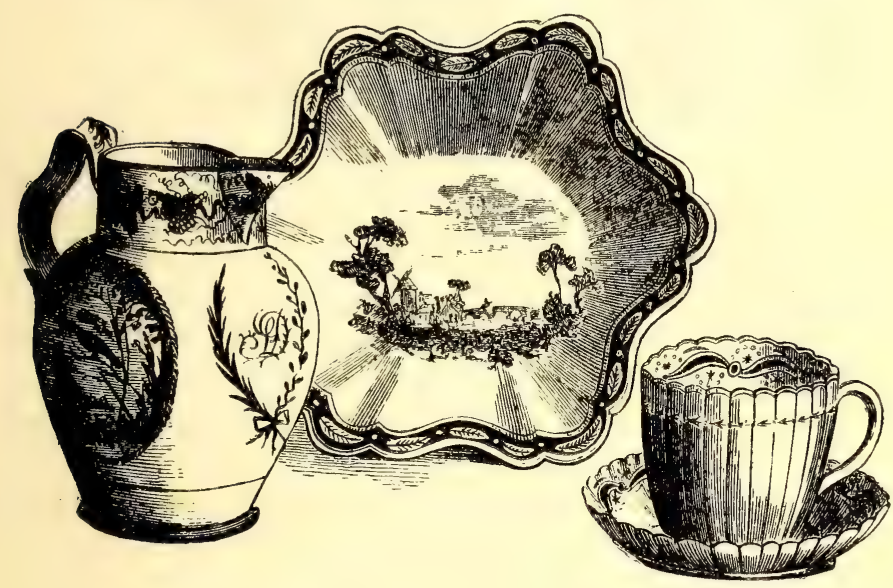

NEW HALL CHINA.

time produced a beautiful soft paste, and New Hall, which also for a short time made a hard-paste china far inferior to that of Bristol. It is certain that after a few years the 
New Hall productions were limited to artificial porcelain of poor quality. The works closed in I825.

A short consideration of the history of the nineteenthcentury soft paste shows that Billingsley was the person mainly concerned in its manufacture. Coke failed to produce it when Billingsley left him. Flight, at Worcester, in I8II, made the Regent body when Billingsley was employed by him, but it was found too costly. Dillwyn, at Swansea, gave up making Billingsley's porcelain in $\mathrm{I} 8 \mathrm{I} 7$ when he left, for Flight had assured him that it could not be profitably produced. Billingsley himself, at Nantgarw, I8I7-20

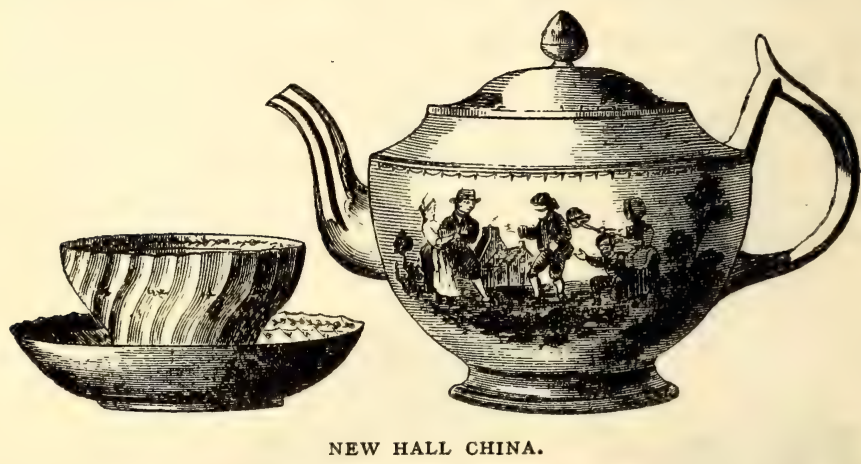

spent thousands of pounds, which his admirers lent him, and failed ; and finally Rose, at Coalport, when in the latter year he engaged Billingsley, very quickly decided that it was of no use to him. Meanwhile, in Staffordshire the manufacture of china increased. Mintons took a foremost place amongst the makers, whilst Copelands maintained theirs as successors of Josiah Spode the second, who died in I827. Curiously enough, Wedgwoods, in the time of Byerley, about I808, commenced to manufacture china, but gave it up after nine or ten years. In 1878 it was revived, and has continued up to the present day. The two features of English porcelains are whiteness and translucency, and in these they are superior to those produced by any other country, and far superior in durability. 


\section{STAFFORDSHIRE POTTERIES AND CORNWALL 4I}

In the earthenware the introduction of china-clay and china-stone has resulted in the disappearance of the once popular cream-coloured ware for general use. A white body and a fine glaze combined with much that is excellent in decoration give immense popularity to this earthenware and to the stoneware, and no less satisfaction to the potters themselves, who had long searched for a white ware which should displace the cream ware. Wedgwood's cream ware is perfection, but other potters, attempting to whiten cream ware by adding a little cobalt, secured a yellow leadglazed ware with a greenish tinge. Only at the beginning of the nineteenth century, under the circumstances mentioned, after Champion's patent had expired in I796, were these difficulties overcome, and in stone china the advent of Mason's ironstone china marked an epoch. White granite or ironstone china of good, sound, and durable quality forms one of the most important branches of the earthenware manufacture. It may be noted that Miles Mason, the father of G. M. and C. J. Mason, was a maker of earthenware blueprinted, which he marked with his name, but he had nothing to do with C. J. Mason \& Co., of Lane Delph works, who established the Fenton Pottery in 1825 for the purpose of securing greater facilities for the production of Patent Ironstone China, of which they had an exclusive sale, whilst the patent lasted, but afterwards white granite became a common product; even during Mason's time Hicks, Meigh, and Johnson produced a very good ironstone china.

Modern trade advertisements of ironstone china and porcelain granite are issued by firms who also make general earthenware. Ashworths still make Mason's Ironstone China, though Mason gave up in I85I; Royal Ironstone China, Warranted Ironstone China, are some of the names which are used with the maker's name as a mark, with Royal Semiporcelain or Semi-china-it may be with the same maker's name. These variations indicate certain improvements in the earthenware, and from the following chapters some idea of the vastness of the manufacture may be gathered with some conception of the skill, knowledge, and enterprise of those 
who have spent much time and money in making improvements, and in designing new forms and decorations to attract the world that buys. Cornwall stone made them possible.

Enoch Wood wrote a memorandum which shows how the potters in Staffordshire availed themselves of the permission to use the china-stone which was granted when they opposed the extension of Champion's patent. The memorandum was stuck upon a Wedgwood creamware dish, and reads as follows :

"The dish was made at Etruria by Messrs. Wedgwood and Bentley, the first year after Messrs. Wedgwood and Bentley removed from Burslem to Etruria. Richard Lawton served his apprenticeship at turning with them, and has had it in his house more than fifty years. It is my brother William's modelling. It was turned on a hand lathe, as plates were at that date. I preserve this to show the quality of common cream ware before the introduction of growan or Cornwall stone. This body is formed of flint and clay only, the same as used for salt-glazed ware at that time, and flint and lead (glaze) only instead of a salt-glaze, and it is fired in the usual and accustomed way and manner as usual for glazed teapots, tortoise-shell, mottled, and agate and cauliflower, etc. Also sand from the Mole Cop and Baddley Edge was used either in the body or glaze. N.B.-Before flint was introduced they used a certain proportion of slip for the body in the glaze to prevent crazing, and to make it bear a stronger fire in the glaze oven. I was the first person that made use of bone in earthenware when in my apprenticeship at Mr. Palmer's at Hanley Green."

This was dated Burslem, Sept. 26th, 1826 , and it is quoted by $\operatorname{Sir} \mathrm{A}$. H. Church. Too much praise can scarcely be awarded to those potters who utilised the Cornwall stone and china-clay so fully to their own and the public advantage, for the paste and glaze, a lead glaze, of the earthenware became the best in the world and, like the china early in the nineteenth century, it was technically perfect.

This perfection was not limited to the products of the eighteenth and early nineteenth centuries; it is well to remember that the later work can scarcely be distinguished 


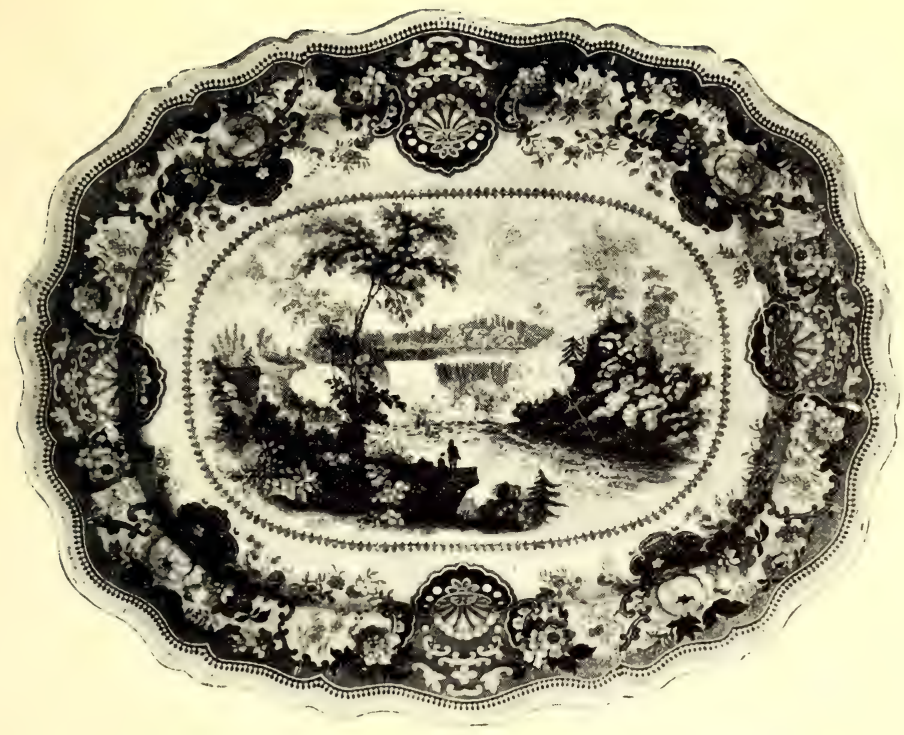

ADAMS BLUE-PRINTED DISH, "NIAGARA FALLS," I 840.

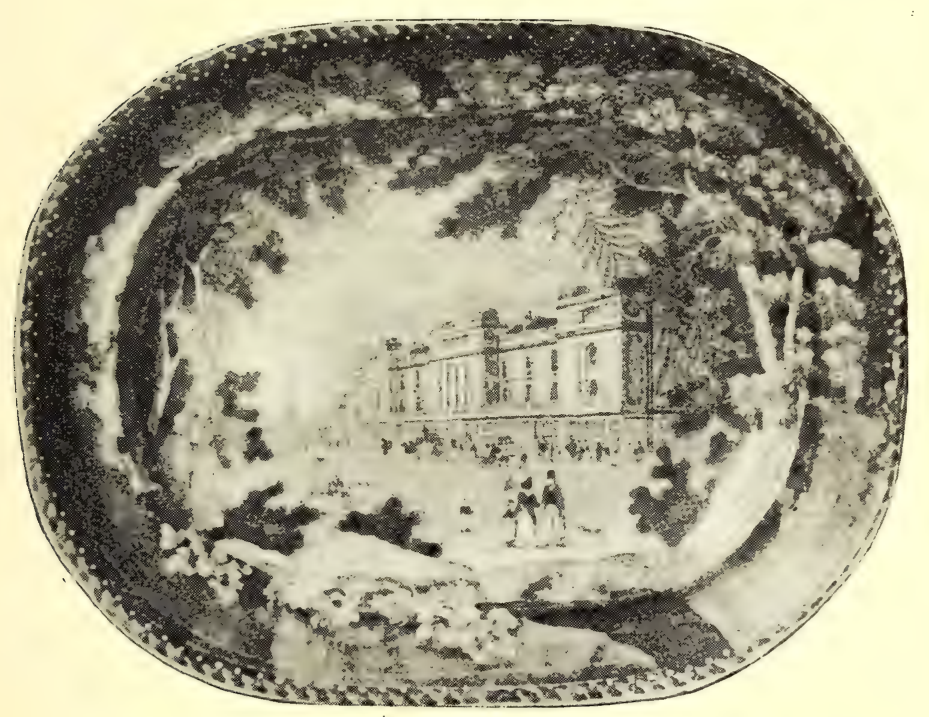

ADAMS BLUE-PRINTED DISH, "A VIEW OF OLD REGENT STREET FROM PICCADILLY CIRCUS," I 820. 

from the old, when the mark is constant, when the design is the same, and the body made from the same recipe. Where no marks at all have been in regular use, the difficulty is not diminished. There may be slight differences in the tint of the ware, in the finish or in the treatment, but it requires the ability and experience which result from constant handling and comparison to classify the old as different from the modern. This does not depreciate the skill of the old master potters, but it enhances the reputation of the modern ones, in some cases the direct descendants of the men who made the Potteries, who clung with dogged persistency to that district now so populous, and who drew from far-off Cornwall the materials, china-stone and china-clay, which were necessary for their manufacture. We can picture Mr. Minton's journeys to Cornwall, each of which from I798 onwards cost him thirty pounds, in those days when travelling was so difficult. We can imagine the loneliness of the wild country where the Hendra Company had its clay works and which he originated and developed. We can see in the sketch-map the Cornwall stone and china-clay district, with the Hendra works about three miles from St. Austell. But we scarcely realise that the early supplies to the Staffordshire potteries were carted over wretched roads to Charlestown, after being raised, worked, and casked ; were carried by ship to Liverpool, and then by canal to the Potteries, where clay was sold at $£^{6}$ I5s. per ton. A hundred years later the price, delivered in the Potteries, was $f_{2} 2$ Ios. The china-clay workings are still active in the land of "Tre, Pol, and Pen," one of the few existing industries which have survived, because all through the years there has been a steady demand for clay and stone from the manufacturers in England, and in Staffordshire especially.

In a chapter on some essentials to the potter's art it will be seen that materials other than Cornwall stone and chinaclay are necessary in the manufacture of earthenware, stone. ware, and porcelain, in which the bodies vary from an opaque, porous, and soft ware to a hard, translucid china, with stoneware forming a link between them. But the nineteenth 
century produced but little of the green-glazed buff ware, and little of deft ware and slip ware ; moreover, the tortoiseshell, agate, marbled, and combed wares had disappeared, followed by the salt-glazed white stoneware. The brown-glazed red or drab ware (salt-glazed), the white and cream-coloured earthenwares (lead-glazed), Rockingham, and jet ware became prominent as the staple productions of many factories which only made ordinary earthen and stone ware. Where firms have existed for a long time, their history is related as far as is necessary, and the old products of their potteries are described and criticised if that is found advisable.

I conclude this chapter with an extract from Sir C. H. Williams' poem "Isabella," in which he describes the visit of a Staffordshire admirer to Lady Isabella Montague :

" "To please the noble Dame, the courtly Squire Produced a Teapot made in Staffordshire.'

So Venus look'd and with such longing eyes, When Paris first produced the golden prize.

' Such works as this (she cries) can England do ? It equals Dresden, and excels St. Cloud.'

All modern China now shall hide its head, And e'en Chantilly must give o'er her trade For lace, let Flanders bear away the bell In finest linen, let the Dutch excel :

For prettiest stuffs let Ireland first be named; And for the best fancied silks let France be famed. Do thou, thrice happy England, still prepare Thy Clay, and build thy fame on Earthenware." 


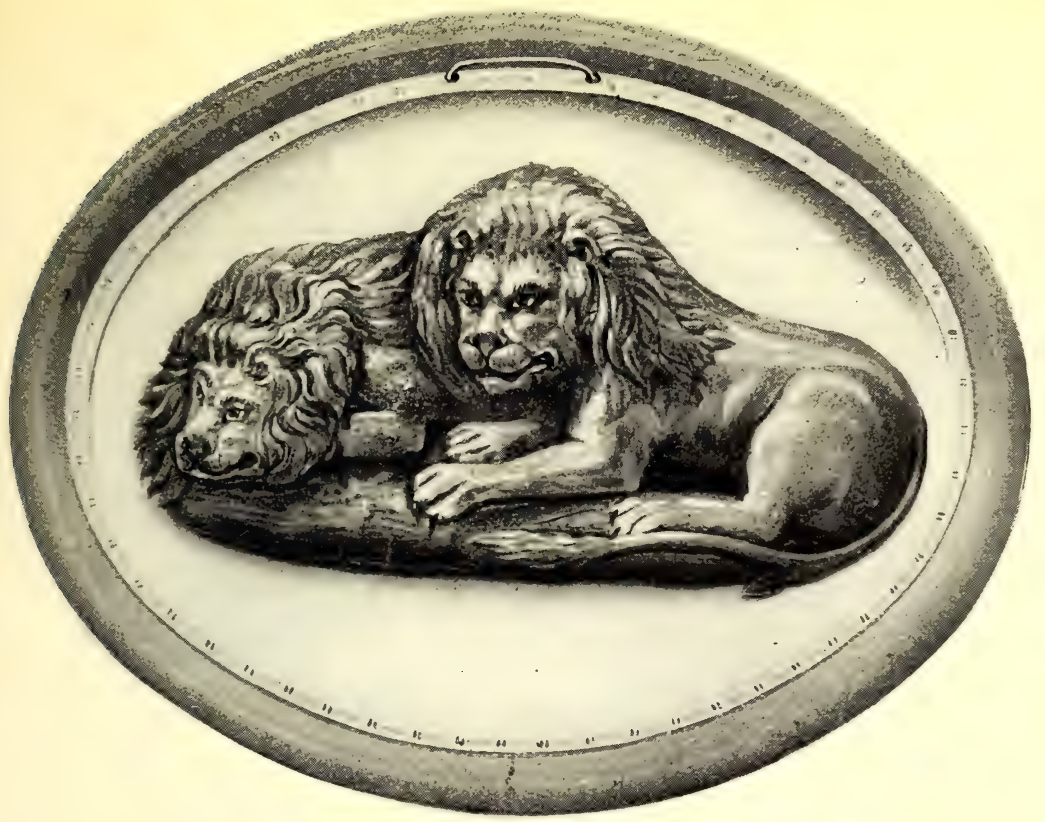

ADAMS PLAQUE WITH UNDERGLAZE COLOURING, I 8 I 8 .

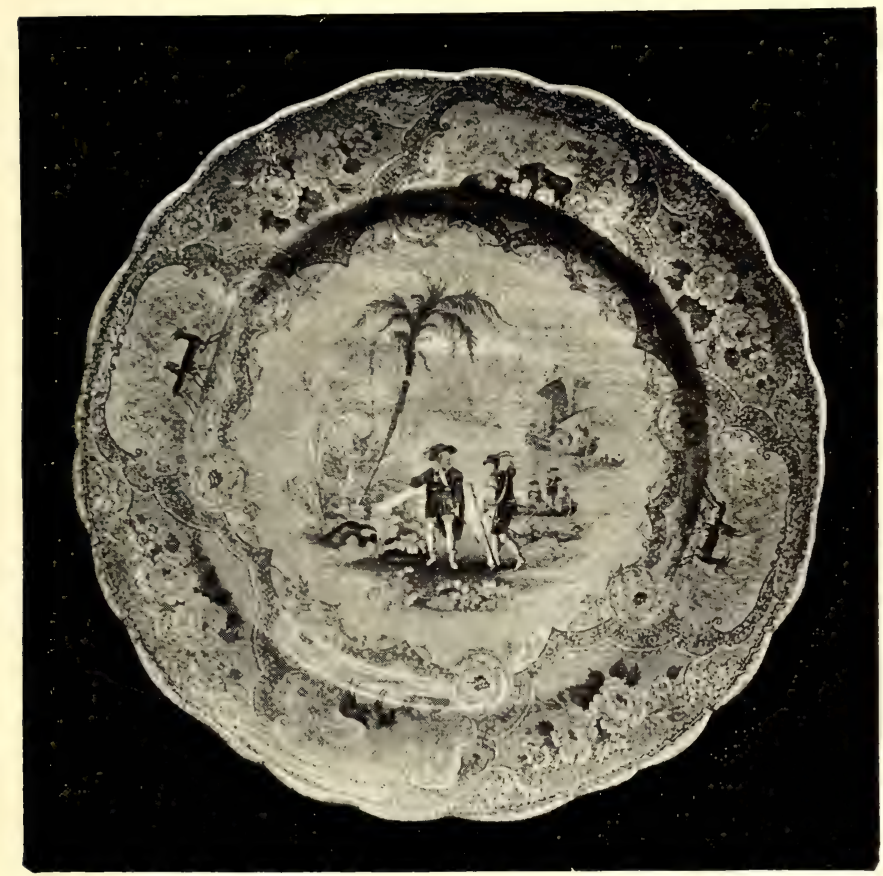

ADAMS Plate, BLUE PRINTED, COLUMBUS DESIGN. ONE OF MANY ILLUSTRATIONS FROM " PENN'S TREATY WITH THE INDIANS." IN VARIOUS COLOURS THESE PLATES, ETC., WERE MADE FROM I 830 ONWARDS FOR THE UNITED STATES OF AMERICA. 



\section{CHAPTER III}

\section{THE MASTER POTTERS AT TUNSTALL}

\section{Adams}

ONE of the most historical factories in Staffordshire and one of the most admirable of the Tunstall potteries is that of William Adams \& Co., Greenfield and Greengates Factories. Founded in 1657 , it has continued its career with a record extending over two centuries and a half, during which time one name at least has become immortal, the William Adams who died in I805. Of him an American writer has well said :

"Múch might be written about his famous pieces and the collections which now treasure them. Sufficient be it to say that William Adams indelibly impressed his name upon the history of pottery-making and left a reputation that will always testify to his industry, talent, and individuality. $\mathrm{He}$ died in I805, at the age of sixty. The history of the family of Adams, a most remarkable one, and the high reputation of the firm of William Adams \& Co. undoubtedly entitle their wares to a place in any collection."

Much confusion has arisen in consequence of the existence at the close of the eighteenth century and the beginning of the nineteenth, of three potters of the same name-three master potters. What are the facts ?

One William Adams, born I772, was a master potter at Stoke-upon-Trent, where he died in I829. Another William Adams, born I750, carried on the works at Brick House, Burslem, and also at Cobridge, and died in I830. The other William Adams was a master potter at Tunstall, dying, as we have stated, in I805. They were cousins, and their ancestors may be regarded as amongst the founders of the 
Potteries; the Brick House works of John Adams existed in the second half of the eighteenth century, being founded by him in 1657 , and from the William Adams who died in I6I7 the present head of the firm, Mr. William Adams, is ninth in direct descent. In the three families which were living about I 800 we have noted the three heads, each of whom was William Adams. William appears as the favourite, one might almost say, the traditional name of the eldest son in each family; one exception will be stated.

In I829, according to Shaw, the manufacturers at Stokeupon-Trent were Spode, Minton, H. and R. Daniel, Adams (in whose factory was set up the first steam-engine for grinding flints), Thomas Mayer, Boyle and Son, and Ward and Forrester. We will first trace that branch of the Adams family which Shaw states was the first to introduce copper-plate printing into the Staffordshire Potteries; that was the William Adams of Brick House, Burslem, and of Cobridge, whose successes were carried on by his kinsman, the William Adams of Stoke and Tunstall, and by Baddeleys of Shelton, Spode, Mintons, Enoch Wood, Ridgway, and others. The Stoke firm became WILLIAM ADAMS \& SON, for the eldest son William was made a partner in I8I9 when he became of age, and ten years later SONS was substituted to mark the entry of Edward, Lewis, and Thomas into the business, which was extended to five separate works at Stoke and one at Tunstall (Greenfield), where vast quantities of high-class earthenware, Parian statuary, and china were made, and not only supplied to the home market, but distributed all over the world, as it is now. Every country that uses crockery buys the Adams productions which are described later.

The recent formation of the pottery towns of Tunstall, Burslem, Cobridge, Hanley, Stoke, Fenton, and Longton into the county borough of Stoke-upon-Trent recalls the fact that Lewis Adams (I805-I850) was the first Chief Bailiff of that town in $1840-2$, a position corresponding to that of Mayor.

In I863, and on the death of Edward and Thomas Adams the remaining partners, the Stoke works were given up, the mak- 


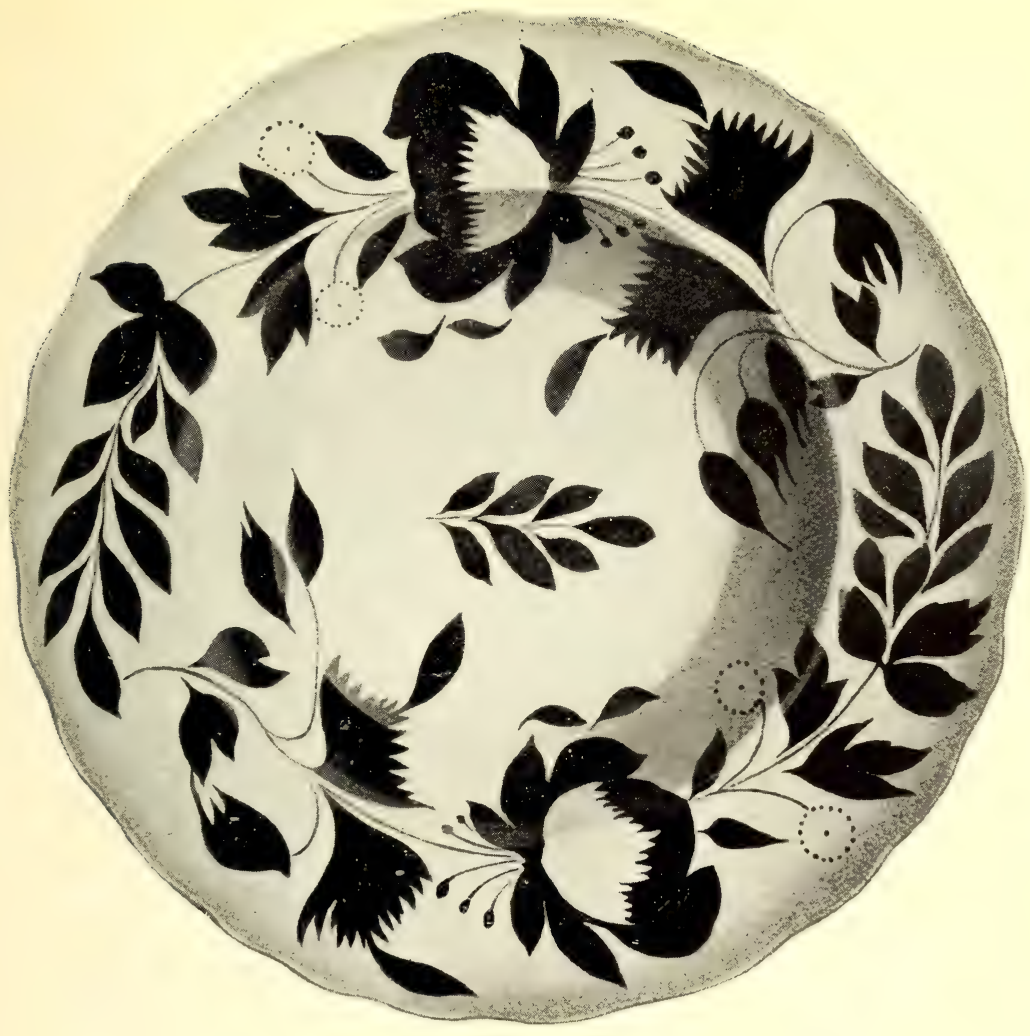

ADAMS PLATE, PAINTED.

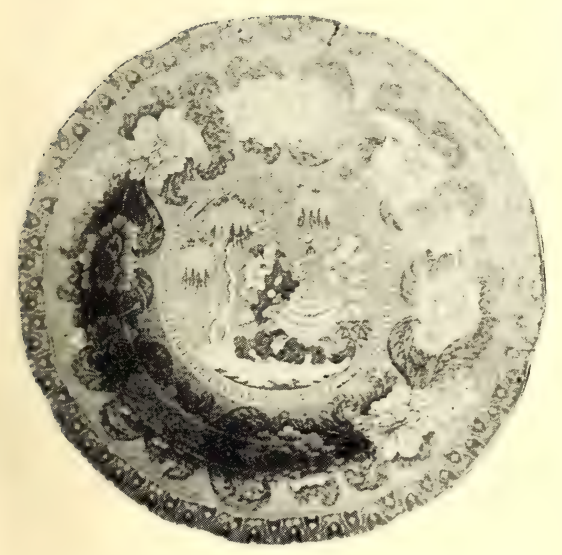

ADAMS PLATE, PALE-BLUE PRINTED, WITH SEAWEED DESIGN, I790-I805.

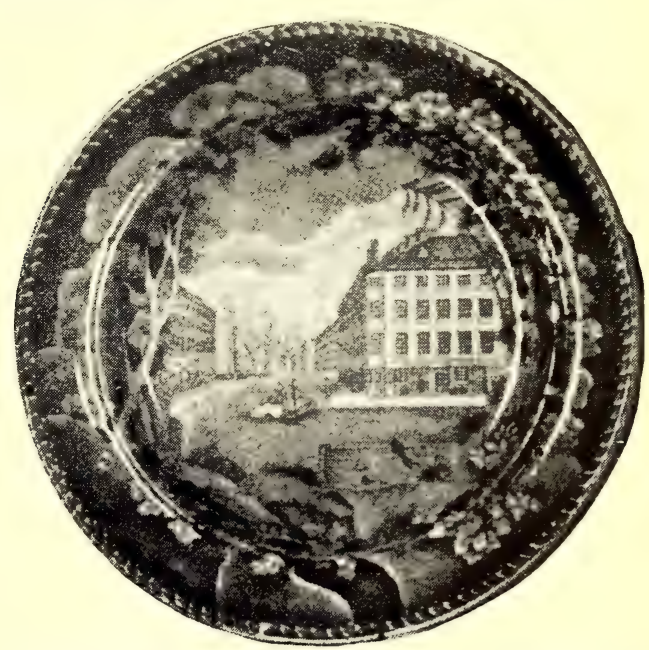

ADAMS BLUE-PRINTED PLATE, “ MITCHELL AND FREEMAN'S WAREHOUSE, CHATHAM STREET, BOSTON, U.S.A.," I 8 I 5 . 

ing of china relinquished, and the whole business transferred to the Greenfield and Greengates factories at Tunstall, where the master potter, the famous William Adams, lived till I805. He used the title ADAMS \& CO from I780 to I797, and ADAMS afterwards. This latter mark was continued upon the blue-printed ware, the cream-coloured ware, and the stoneware, as well as upon the jasper, which was of two kinds, solid and dip or surface-coloured. Shaw says that Benjamin Adams (who broke the continuity of the Williams) was successful in the manufacture of jasper about I80o, but we find that the manufacture ended in 1805 when the great potter's eldest son and partner, a young man of twenty-seven, died in the same year as his father, leaving Benjamin, a young man of eighteen, to carry on the business with the aid of his managers; but he did not make jasper, so that Shaw and Jewitt are both mistaken-their information is incorrect on this point. Adams jaspers were revived, as we shall see, towards the close of the ninteeenth century by the present generation of the Adams family-the Stoke branch-which is really the eldest line.

It was during the years $1863-5$, when the transfer of the Stoke business to Tunstall was accomplished, that the two sons of the head of the firm were made partners, the elder of whom, William Adams, was the moving spirit and principal until his death in I905, when he left another William Adams as his successor, the ninth in direct descent from William Adams of $\mathrm{I} 6 \mathrm{I} 7$, as a master potter, and his youngest brother, Percy W. L. Adams, is associated with him in the firm of WILLIAM ADAMS \& CO., which manufactures at the present time high-class semi-porcelain richly enamelled with Chinese decorations, ironstone china well named for its durability, and other grades of earthenware made upon scientific and modern lines, bearing simpler decoration, designed for common use. But much more than this is carried to a high state of excellence. I refer to those specialities, the reproductions of Adams jasper and of Adams blue-printed ware, the fine old styles which collectors love so much and buy with avidity. 
William Adams (I745-I805) the old master, contemporary and friend of Josiah Wedgwood, competed with him on business lines which provoked no apparent discord. Both of them made jasper ware, and the original Adams jasper was a product which held its own because of its intrinsic merits, which have been fully recognised by many writers whose capacity is unquestionable. The present firm specialises in reproductions of this artistic old work, and the modern bas-reliefs, classical figures, trophies, and the like are charming in purest white jasper upon various coloured grounds-dark blue, black, sage-green, or other colours. After the death of William Adams in I805, as we have seen, the continuous manufacture of jasper ceased, and about twenty years ago it was revived at the original factory, produced from the original recipes, and made exactly in the old way, and it is worthy of remark that the designs used by the old potters only resembled each other when similar casts, etc., were purchased from designers not specially employed at any factory. Palmer and Neale and Voyez were unscrupulous imitators of Wedgwood, but Turner was not, and certainly Adams jasper was original. I do not think that Flaxman's designs can be traced upon Adams ware, which to-day is finely modelled by first-class artists. The Egyptian black ware or basaltes, the Grecian red, the Etruscan ware, and the fine vitreous stoneware at present made are worthy of all commendation, which may be fairly extended to the Royal ivory. This beautiful ivory body in vases, rose-bowls, and many other forms is decorated with old English or Chinese ornament in enamel colours, or with those delightful blue prints which are so valued upon the old ware. These were first introduced into Stoke-upon-Trent and Tunstall in the last half of the eighteenth century by the two cousins William Adams.

In the nineteenth century, about $18 \mathrm{IO}-40$, quite a number of views were produced, some of which depicted American scenes, such as The Falls of Niagara ; New York ; Shannondale Springs, Virginia; West Point Military Schools, N.Y. ; Mitchell and Freeman's Warehouse, Chatham Street, Boston ; 

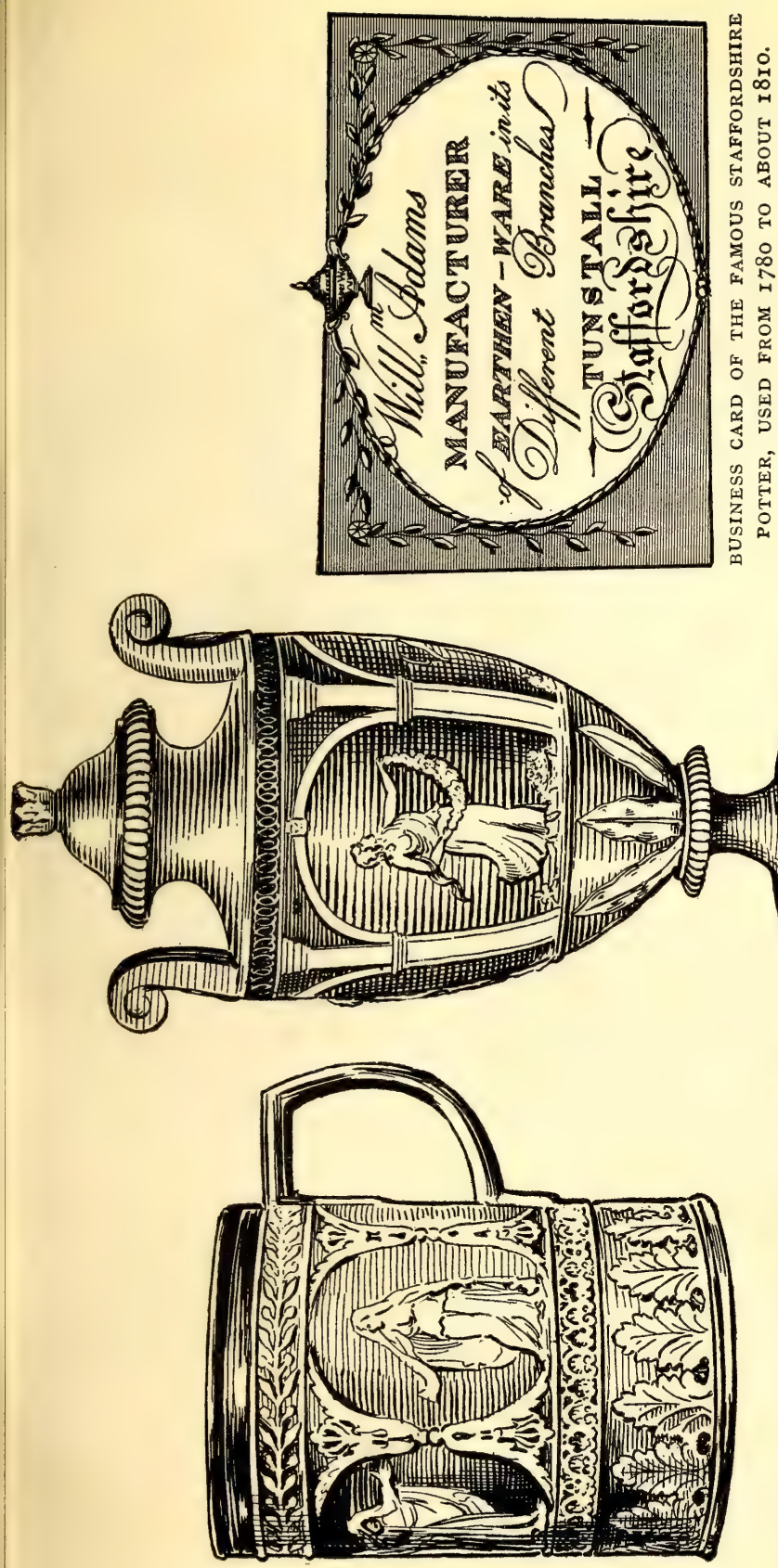

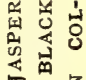

보웅

结

这告。

可

4 बं

岳 用告

员贾的

공

方옹

z

बू के

$\stackrel{4}{>}$

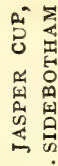

幽

空

3

穴

z

兒岁

究苗

คิ

氙

骂安

긴

红出

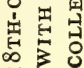



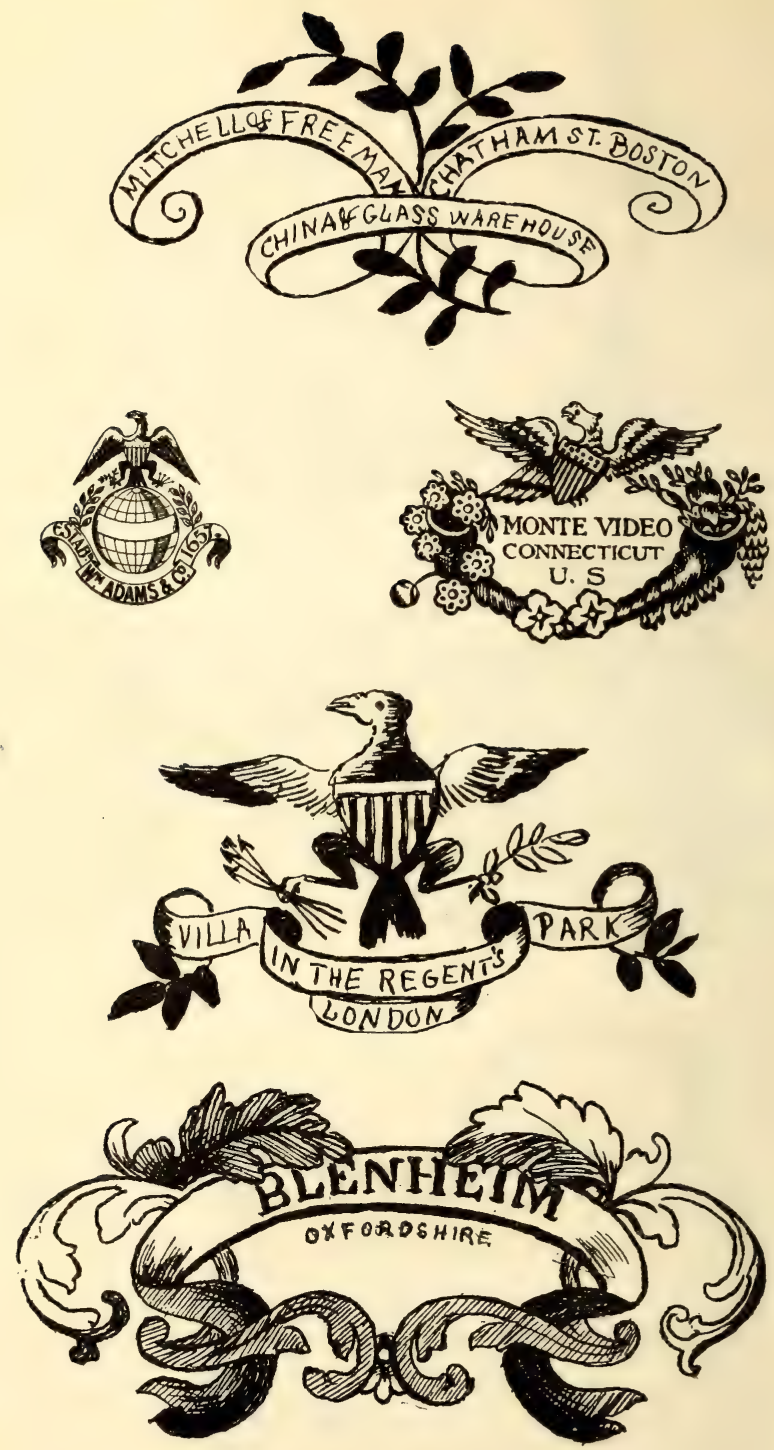

ADAMS' MARKS ON BLUE-PRINTED WARE MADE LARGELY FOR THE UNITED STATES OF AMERICA. FACSIMILES. 


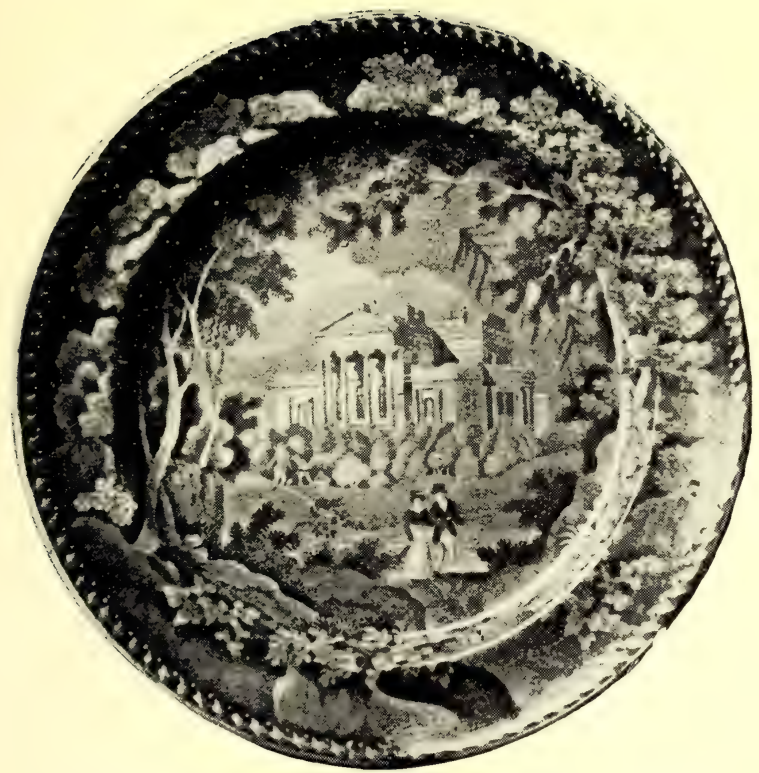

ADAMS PLATE, BLUE PRINTED, WITH VIEW, " A VILLA IN REGENT'S PARK," AND WITH FOLIAGE BORDER USED FOR MANY OTHER LONDON SCENES. PART OF A DINNER SERVICE MADE IN I82O.

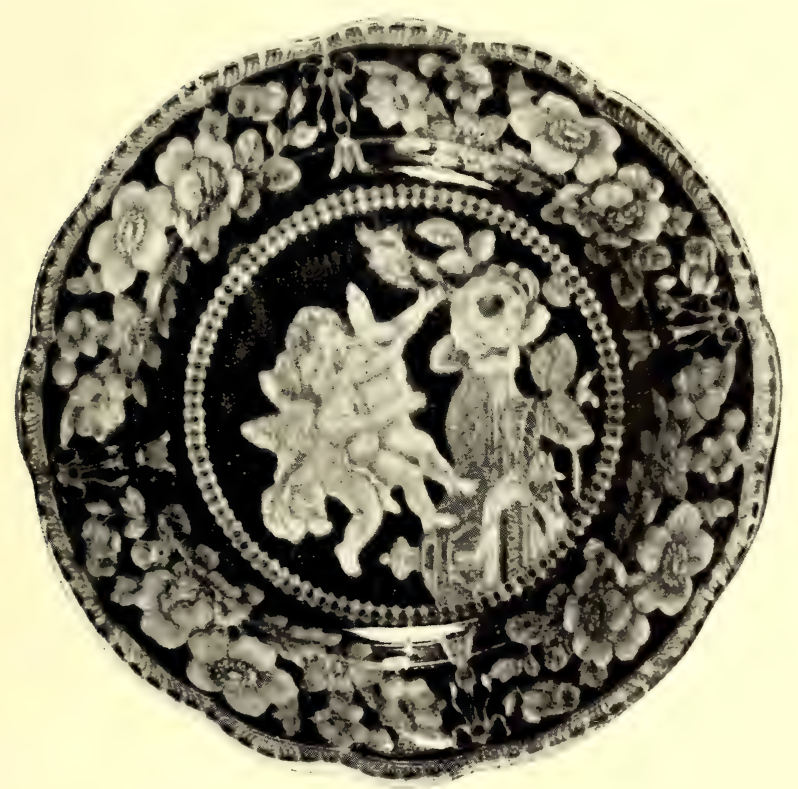

ADAMS PLATE, CUPID DESIGN, I830. 

and others, including the Columbus design made in various colours for the United States of America, where Adams ware has long been eagerly collected. A short time since, a well-known English collector wrote to ask me whether I knew where any good old Adams dishes with English views could be purchased. I replied that those persons whom I knew who possessed such pieces were themselves seeking for more-partly for the pleasure which they derived from the decorated dish as such; partly, too, for such subjects as "A Villa in Regent's Park," "St. Paul's School, London," "St. George's Chapel, Regent Street," "Denton Park, Yorkshire," and the like, some of which are shown in the illustrations with others of the beautiful jasper ware, etc. The Adams blue is particularly fine; we shall return to it.

Not only is the firm still making jasper ware by the same processes of handiwork, not only does it reproduce those blue-printed scenes from the engraved copper-plates, but it has adopted new subjects which can be scarcely less attractive- " Dr. Syntax's Tour" and a series of beautifully coloured and enamelled-by-hand pictures from the works of Dickens, amongst others. These are all on earthenware, for porcelain has not been made since the closing of the Stoke works, nor, in fact, since I863, when Close \& Co. took over a small part of that manufacture.

How attractive it is to consider that the present proprietors are the lineal descendants of potters who lived at Burslem in the early years of the sixteenth century, and whose ancestors can be traced much farther back than that! How pleasant it is for the ordinary buyer to know that at a reasonable price he can obtain for his own enjoyment reproductions of the Adams ware used by his great-grandparents, which compare favourably with the best of any made by any others in the eighteenth century, which are with them exhibited in the museums of England and America, and which have had an uninterrupted success from the date of their first appearance.

Here may be a fitting place to take a retrospective glance at the early history of the potters of the eighteenth century, 
when the Adams were working side by side with Whieldon, Whitehead, and Josiah Wedgwood. Fine cream-coloured ware and black basaltes were made before this by Warburton, father of Jacob Warburton, by Enoch Booth, and others. Booth and Twyford made basaltes chiefly, and an earlier Adams was engaged upon the same work, whilst the Elers, though doing the same, gave most of their attention to red ware with applied ornament. Even this was not new, it was only refined, for ornament in relief applied by pitcher or metal dies had long been in vogue. Some of the early ware is somewhat crude, though picturesque and original, as may be seen upon unmarked pieces ascribed to Astbury, Ralph Shaw, and Whieldon, but also made by the Warburtons, Booth, Whitehead, Adams, and others. It would have been impossible for any one firm like Whieldon's to have produced the quantity of old pieces with which to-day he is credited, although he was a manufacturer with a large business, who died, two years before the dawn of the nineteenth century, a wealthy man. During his time many potters, amongst them those I have named, took their part in the general progress, and though the name Whieldon may conveniently indicate the ware, it blots out all memorial of the men who were his compeers.

Again, salt-glazing was practised towards the close of the seventeenth, and early in the eighteenth, century. Nearly all the potters made salt-glaze ware, though they were familiar with the lead glaze on brown ware which indeed had been known for a long time, for Dr. Plot mentions its use as far back as I688. It was the improvement of the body which led to the disappearance of the salt glaze, for when the lead glaze upon cream ware demonstrated its durability, enamelled salt-glazed ware, though quaint and beautiful, yielded to another method of decoration-transferprinting became the popular mode. Mayer, in his "History of the Art of Potting in Liverpool," says: "The art of transfer-printing has helped to make English pottery famous throughout the civilised world, and has done much towards making its production one of the greatest staple manufactures 


$$
\begin{aligned}
& \text { Nivision of Ethnology } \\
& \text { S. National Museum }
\end{aligned}
$$

\section{THE MASTER POTTERS AT TUNSTALL 6I}

of the country." This brings me back to Tunstall and to Stoke, to that William Adams who, in 1787 , introduced into Tunstall blue-printing, and to his cousin William Adams, who was the first, in $\mathbf{I 7 7 5}$, to attempt copper-plate printing in Staffordshire. It had been practised at Battersea, Liverpool, and Worcester earlier, but the printing in blue was essentially a Staffordshire process which has been by the Adams firm continued, in that delightful cobalt blue, which, though employed at Caughley, Leeds, and Swansea, and in Staffordshire by John Turner, Josiah Spode, Enoch Wood, Thomas Minton, and others, in the nineteenth century, possesses a distinction entirely unique in its soft delicacy and mellow rich harmonious tones. The continuity of the firm has attracted the attention of the poetaster, who wrote :

"As Adam's was the first of forms Created from the clay,

So Adams make remains the first Of Potters of to-day;

But happier is the namesake far, No fall doth make it grieve,

Unlike the first, this Adams day Hath never known an Eve." 
List of the more important marks used by the ADAMS firm, Tunstall, Stoke-upon-Trent, since 1770.

Adans \& Co $\quad\left\{\begin{array}{l}\text { For Cream Ware } \\ \text { Plain and.Enamelled, 1770-1790 }\end{array}\right.$

ADAMS \& Co $\quad\left\{\begin{array}{c}\text { Eariser mark used for the Solıd Jaspers } 1780 \text { to } \\ \text { probably as late as } 1790\end{array}\right.$ ADAMS $\left\{\begin{array}{l}\text { Mark used for Printed ware, Fine Stone ware, } \\ \text { and Jaspers, both surface colour, and solid } \\ \text { Jasper, } 1787 \text { to about } 1810 .\end{array}\right.$

W. ADAMS \& Co. Jaspers, very occasionally

The above marks are not now employed

ADAMS

ESTBD $\quad 1657$

TUNSTALL

ENGLAND

ADAMS, TUNSTALL

$$
\left\{\begin{array}{c}
\text { Used for Jaspers, Egyptian Black, (Basaltes) } \\
\text { and Grecian Red. } \\
\text { (Still used) }
\end{array}\right.
$$

Still used for a variety of productions.

\section{ADAMS}

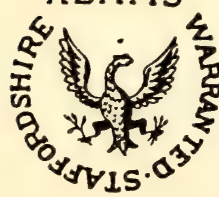

S Used for the Deep Blue Printed Ware,

All above marks are impressed in the paste upon the base of specimens.

W. AD.AMS \& SONS
STOKE. UPON TRENT $\left\{\begin{array}{l}\text { Printed in Brown or Black; used from 1820- } \\ 1860 \text { for Porcelain, Semi-Porcelain, Iron- } \\ \text { stone Ware, etc. }\end{array}\right.$ (Not now used.) 


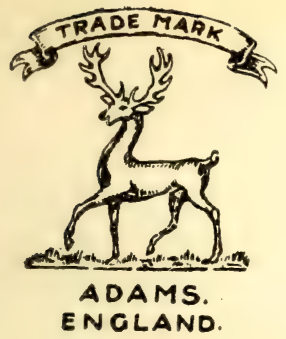

$\{$ Printed, still used for Plain and Persian Painted $\{$ Earthenware

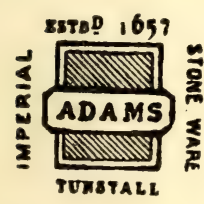

Printed, nıark stıll used for Imperial Stone Ware. also for Royal lvory, Ec

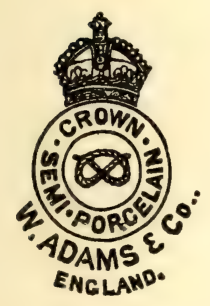

For Semi-Porcelaın, Table, etc. Wares.

W. A \& S . (detached or attached to various marks.)

W. A. E Co (detached or attached to various marks.)

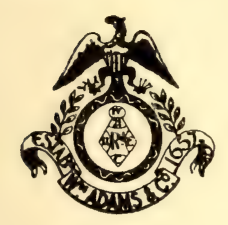

$$
1820-1860
$$

Sometimes used.

Royal Ironstone China, White Granite, Ec. 


\section{THE MASTER POTTERS AT STOKE-UPON-TRENT}

\section{Copeland and Sons, late Spode}

IN I80o the second Josiah Spode commenced to make porcelain at the works in Stoke where his father, who died in I797, had acquired a good name for the manufacture of pottery. So great indeed was its merit that a London warehouse was opened, where the son, his father's partner, assisted William Copeland, who travelled with the productions of the factory and managed the London business, which showed such expansion that the firm moved from Fore Street,

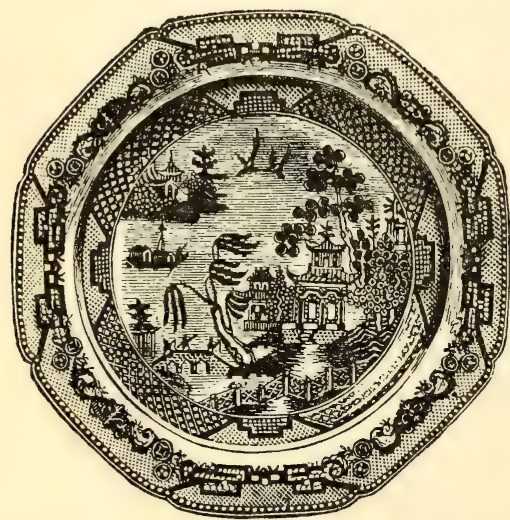

SPODE AND COPELAND'S WILLOW PATTERN.

Cripplegate, to an immense establishment in Portugal Street, Lincoln's Inn Fields, formerly a theatre. Before Josiah the second went home in I797 he made Copeland his partner, entrusting him with the sole charge of the London market, with its continental and other foreign trade.

Spode's application to his work was equalled by his success in the improvements he effected. Whether he introduced transferprinting, or whether it was practised from $I 784$ by his father, is not so much a matter of consequence as the adoption of a pleasing tint of light blue which distinguishes 


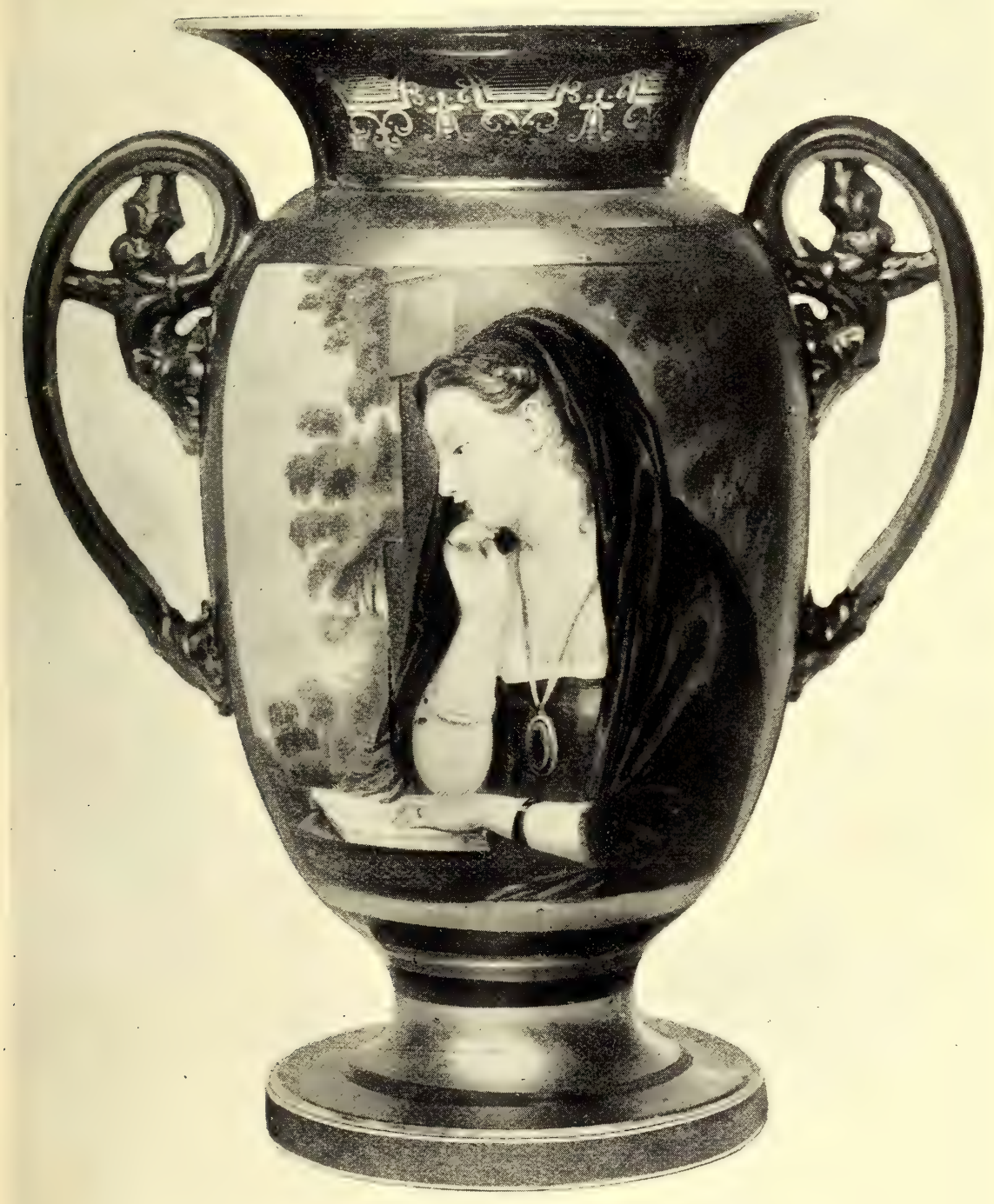

SPode. "LA PENSierosa," After G. S. NEWton, R.A., D. I 835 . Lent by Mr. George Stoner. 

Spode from other makers of the same ware. Early Spode earthenware plates marked "Spode \& Copeland," either impressed or printed, are amongst the objects which collectors covet. Some say that Spode was the first to introduce bone as a constituent of his porcelain. That may be doubted, but there is no doubt that he was the first to use felspar in its composition. Hence early Spode china possesses qualities of transparency and beauty which soon set the standard for all those factories which made porcelain.

Beautiful and original were the styles of decoration applied to this fine body, upon which reds and yellows, with a velvety dark-blue cobalt, richly decorated with gold, were displayed in Japanese patterns of uncommon merit. These may be seen in the cases of the museums to-day, or they may be admired upon the shelves of the collector, who does not forget that the present proprietors are per-

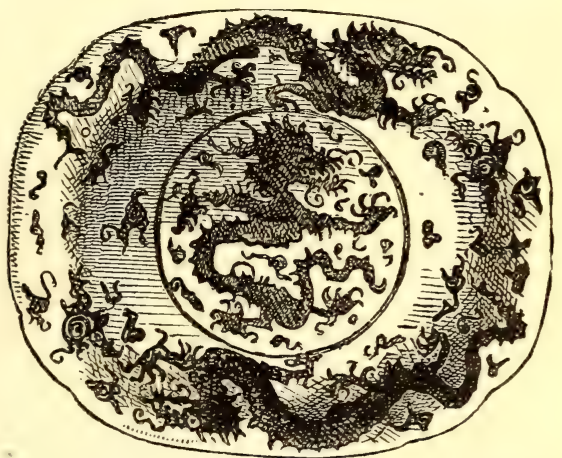

SPODE AND COPELAND'S DRAGON PATTERN.

fectly able to reproduce all the old designs from the original pattern books and moulds in their possession. Fortunately, guidance is secured by an excellent series of marks, most of which were printed or impressed upon the ware, though the early mark SPODE may be found pencilled on the glaze in colour, usually red.

Earthenware and china, both excellent, were followed by an opaque porcelain first made in I805. This stone or ironstone china had remarkable qualities of strength and beauty which made it exceedingly popular, not only in the houses of England, where complete services may still be found, but on the Continent, especially in France, where the softer faience of the country, which had already suffered by the introduction of Queen's ware, was nearly superseded by 
this ironstone. Jewitt remarks that the porcelain, the ironstone china, and the ordinary earthenware manufactured at this time were of the very highest character, in body, in glaze, and in decoration; indeed, in all three of these respects they rank with the best of the period.

Josiah Spode the second died in I827, one year after the decease of his partner, W. Copeland, whose son, W. T. Copeland, succeeded him in the firm. The work accomplished by Spode cannot be justly estimated without reference to his influence outside the Potteries, whereby the varying composition of the artificial soft pastes used in other districts was eventually relinquished in favour of a standard mixture of kaolin and felspar with bone-ash and other accessories. Rose introduced felspar at Coalport about I820; although Billingsley had brought with him the recipe for the wonderful Nantgarw porcelain, it was too expensive to manufacture at a profit. Derby existed till I848, and has only been reestablished since 1876 . Worcester trembled in the balance in I840. The differences between the pastes or bodies of the factories which finally accepted the ingredients which Spode adopted have ceased to be; there was for them no more "hard" or "soft" paste. I believe that potters and writers on pottery have scarcely done justice to Josiah Spode the second. If any one man is responsible for the concentrated china-making in the Staffordshire Potteries he is that man, for he it was who raised the art to its highest level of practical utility, and more than that, his finest productions compare, and not unfavourably, with the best that other factories have made.

His son, the third Josiah, died two years after his father, and the business was carried on, till I833, by his executors and by W. T. Copeland, an Alderman of the City of London, who, in that year, bought the whole concern from them. $\mathrm{He}$ shortly afterwards made his principal traveller, Thomas Garrett, his partner, and the firm became "Copeland and Garrett." In I835 Copeland became Lord Mayor of London, and twelve years later the partnership was dissolved with a corresponding change in the title to "W. T. Copeland, late 

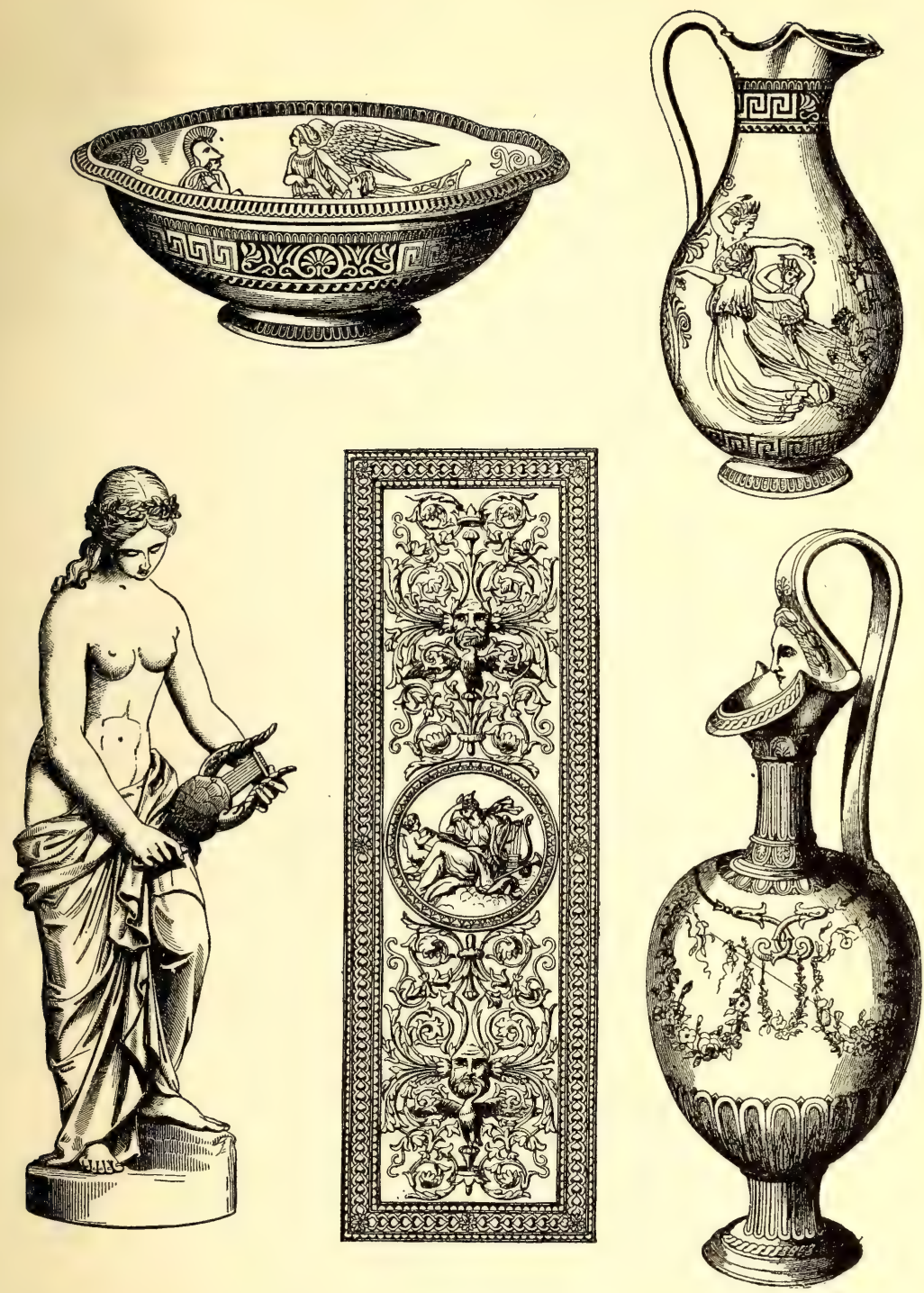

COPELAND'S EXHIBITS IN I $85 \mathrm{I}$. 
Spode." Twenty years passed, and in 1867 he took his four sons into the firm, and the style was further altered to its present form, "W. T. Copeland and Sons." One son only remains, R. P. Copeland, under whose skilful and energetic management, ably assisted by his eldest son, W. F. M. Copeland, the business has attained to its present distinguished position amongst the china-manufacturers of the world. It is true that the productions made during the period when Copeland was the presiding and good genius of the works are not old, but we are dealing with the nineteenth century, and no single factory has in those years-a hundred yearsmore worthily sustained its high reputation, more carefully and successfully advanced on right lines to satisfy an improved or altered taste, more admirably maintained art itself, or more efficiently defended this manufacture from attacks made by other nations.

The remarks in the Art Journal Illustrated Catalogue of the Exhibition in I85I deserve full quotation. They are as follows :

" The works of Mr. Alderman Copeland for the manufacture of porcelain and earthenware are at Stoke-upon-Trent-the principal town of the Staffordshire Potteries; his London establishment is in New Bond Street. The artist who presides over the works is Mr. Thomas Battam, whose taste, judgment, and experience have been largely exercised to secure for this manufactory the high reputation it enjoys, not only in England, but throughout Europe, in Asia, and in America. The list of the Alderman's productions comprises all classes of 'goods'-from the statuary porcelain figures and the elaborately decorated vase, to the commonest article of earthenware-manufactured for exportation by tens of thousands.

"The compartment allotted to Mr. Copeland in the Exhibition cannot fail to be universally attractive-not alone because of the grace and beauty of the articles shown, but as exhibiting our progress in a class of art upon which much of our commercial prosperity must depend. The collection will be studied carefully, and by foreigners especially, who will find much to admire, and much that will by no means suffer in 


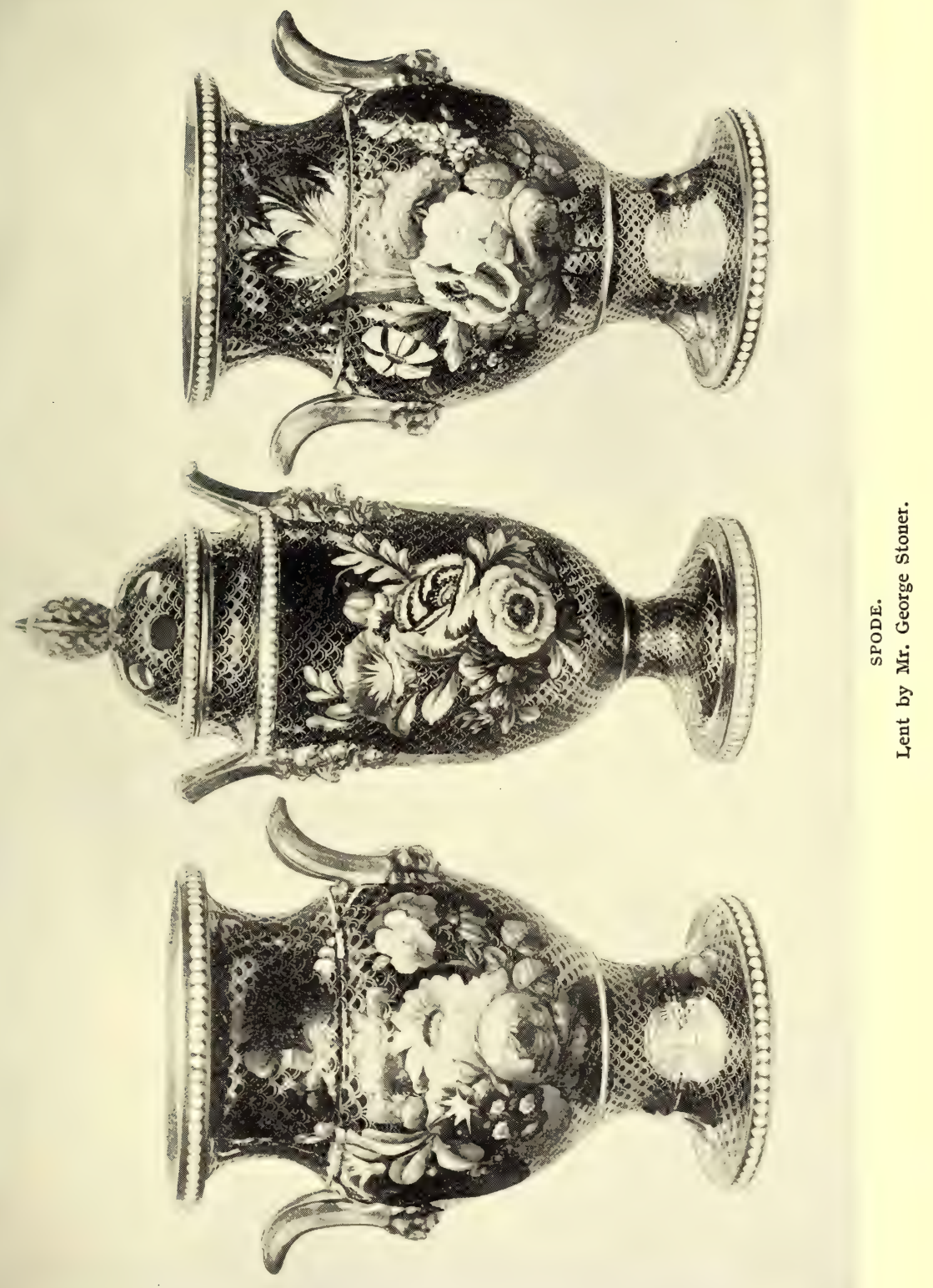




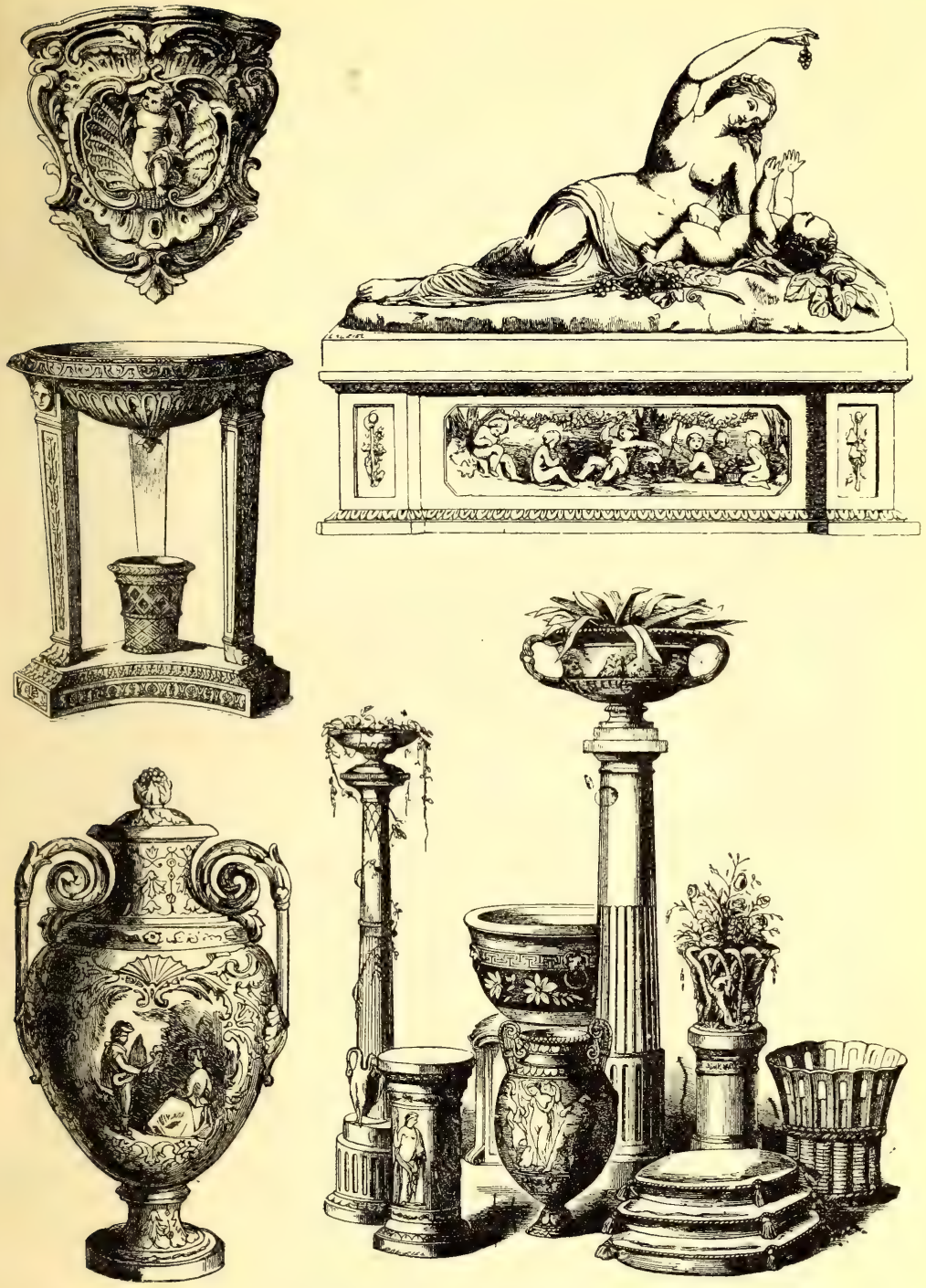

COPELAND'S EXHIBITS IN I 85 I. 


\section{I9TH-CENTURY ENGLISH CERAMIC ART}

comparison with the best productions of Dresden and Sèvres -always bearing in mind that at these Royal works objects are occasionally produced at national cost, such as those now to be found upon the stalls allotted to these famous factories; and that to expect private enterprise to enter into competition with them would be neither reasonable nor

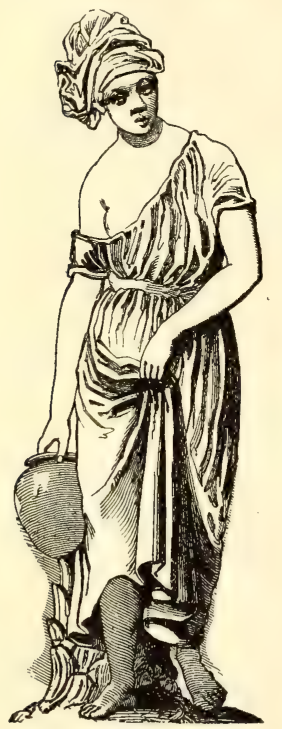

THE WATER-BEARER, BY CUMBERWORTH. COPELAND, I85I.

fair. At the same time it is only right to say that Mr. Copeland challenges a comparison between his productions and those of either Dresden or Sèvres-in so far as concerns articles made especially for trade-and that from such comparison he does not shrink as regards either the materials, ornamentation, or price.

"We have devoted to the works of Alderman Copeland a larger space than we shall be able to accord generally even to manufacturers of the first order ; but his works are very numerous and excellent, and although we assume to have selected the best, we have left unrepresented a mass of interesting and beautiful productions. For instance, out of forty statuettes in statuary porcelain we engrave but two-the 'Sappho' after Theed, and the 'Bacchus and Ino' after Foley ; setting aside the 'Sabrina' after Marshall, the 'Venus' after Gibson, and others of great merit and beauty formed in this valuable material. The tazza (with the doves) is a superb ornament, peculiarly adapted for general purposes of elegant decoration; it is executed in fine porcelain : the doves, from the celebrated doves of the Capitol, together with the festoons of flowers, and the embossment generally, are richly gilt. On the same page are a pine-stand, formed of the foliage of the pine, and a bracket called the ivy bracket. The ewer and basin are in the Greek style, with outlines after Flaxman. The statuette of Sappho is from the original by M. Theed-an artist of high ability, who has been for a long time resident in Rome. The figure is, we believe, the largest yet attempted in this style of Art-manufacture, being about thirty-four inches high. 


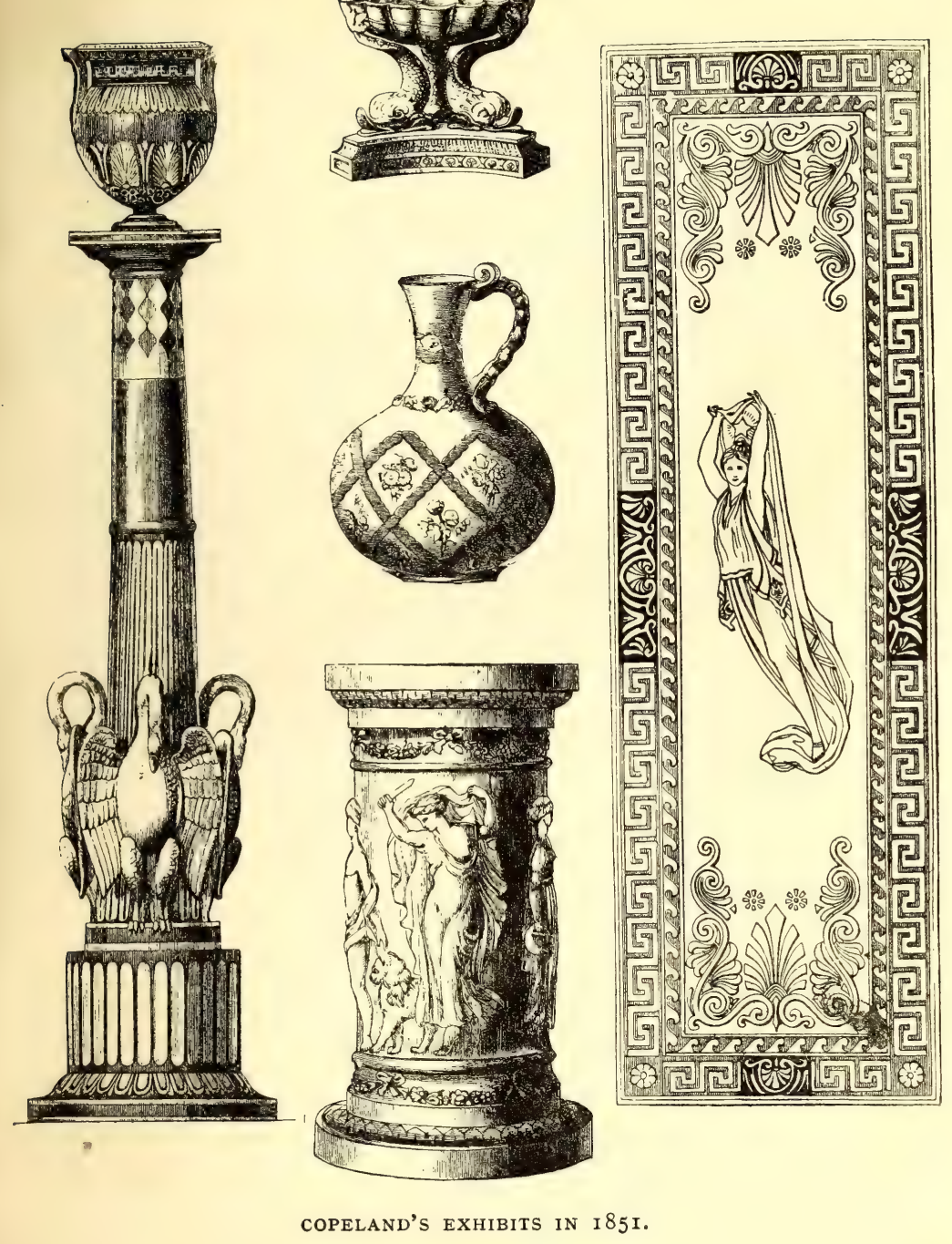


"The panel for a fireplace is one of a series of admirable designs in this class of manufacture, for which this house is so justly eminent; the foliated scroll panels and works are enamelled on a gold ground, the centre subjects in colours on black, and the outer borders enriched with chased and burnished gold, relieved with blue: the effect is extremely

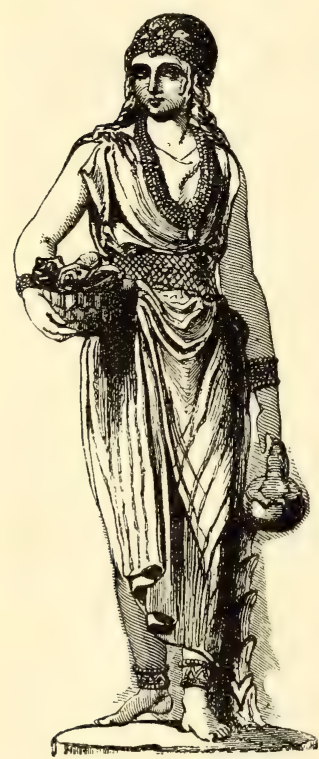

THE INDIAN FRUIT-GIRL, BY CUMBERWORTH. COPELAND, I85I.

rich and harmonious. The jug of Etruscan form is graceful in outline and ornamented with floriated decorations and antique enrichments. The Cupid bracket and tripod flower-stand are meritorious productions; the latter, with reference to its size and merit, we have not seen equalled in the beautiful material of which it is composed, viz. statuary porcelain; there is much classic elegance in this design, and the execution of its components is, in the highest degree, satisfactory. The vase (with figures) is of much beauty, and the 'Bacchus and Ino' of Foley, a very triumph of Art. The group of objects for the conservatory, consisting of vases, flower-pots, and pedestals for the same, require no explanation ; it is sufficient to point out their merits as elegant luxuries for the wealthy. One column is illustrated surmounted by a vase, both of blue and white porcelain, standing together about five feet high; the proportions have been well studied, and the base exhibits swans of considerable dimensions. A tazza in the Italian style, a kind of amphora or water-bottle of antique form and decoration, and a garden-seat ornamented with a bas-relief of classically designed figures, deserve attention ; so does another panel for a fireplace, simply but tastefully embellished with coloured designs: this application of the plastic arts to domestic architecture is now becoming very general in houses of a superior class.

"In all the examples here brought forward, there is undoubted evidence that the mind of the artist has been at work to accomplish the task of uniting beauty with utility, by a 


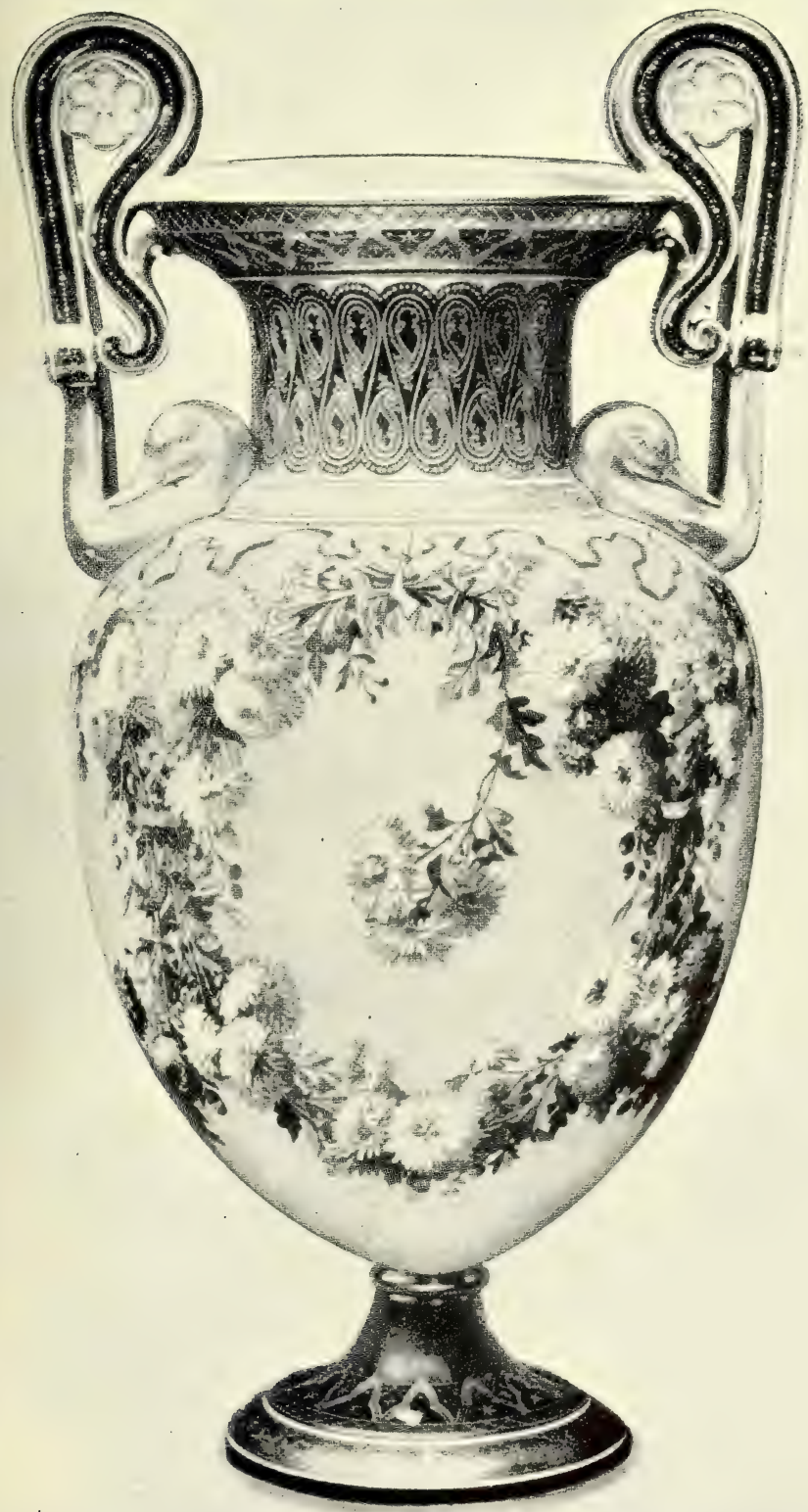

COPELAND VASE, GOLDSMITH SHAPE, PAINTED WITH CHRYSANTHEMUMS AND RICHLY JEWELLED AND GILT. MODERN. 


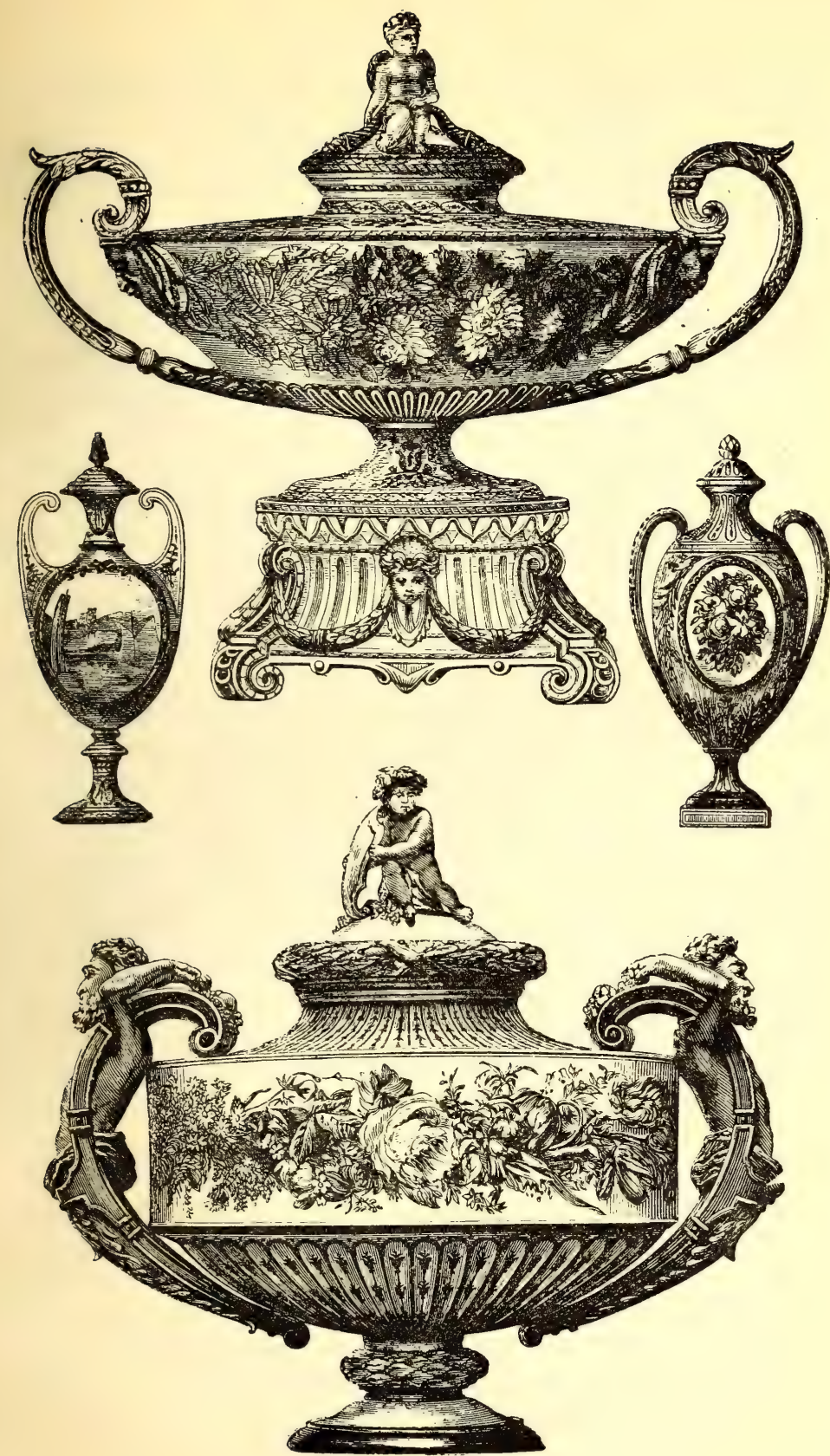

COPELAND'S VASES. 
skilful adaptation of what may be gathered from the past to the tastes and requirements of the present generation, however varied and exacting."

After such a full description of Copeland's productions we may pass on to the productions of the present firm. But, first, reference must be made to a magnificent dessert-service made in I866 for H.R.H. the Prince of Wales, being a commission given three years before his marriage. The service consisted of I98 pieces, all of which were different, though the decoration and style were preserved throughout. This was due to the exquisite painting of flowers, fruit, etc., by Hürten and others ; to the fine modelling by J. Durham, R.A., and by Miller and Halse; to the elaborate pierced decoration upon all the plates; and, generally, to the rich and harmonious effect of the service as a whole. The illustrations show the double plateau, with figures representing the four quarters of the globe, by Durham; one of the compotiers, and a covered cream-bowl. They give some idea of the beauty of this triumph of ceramic art.

Yet Copeland has never neglected the commoner forms of earthenware. One discovery of recent years was an ivory body termed an "ivory-tinted body" at first. An immense number of table and toilet services were executed in this ware, which was something like Wedgwood's Queen's ware in tone, only softer and more delicate. Notwithstanding its popularity it has been superseded by a body made in imitation of one introduced by Spode called "Spode Imperial." This is a beautiful white earthenware, having almost the appearance of china. The production of ordinary classes of goods is exceedingly great, not only in earthenware and stone, but in china.

Amongst the very finest coloured grounds produced by this firm are bleu-de-roi, such as that shown in the reproduction of the famous Mecklenburg service exhibited in I889; exquisite vases in rose-du-Barri and turquoise of a new tint, which was named cerulean blue; Sardinian green; and vermilion. There certainly appears to be no limit to the excellent 

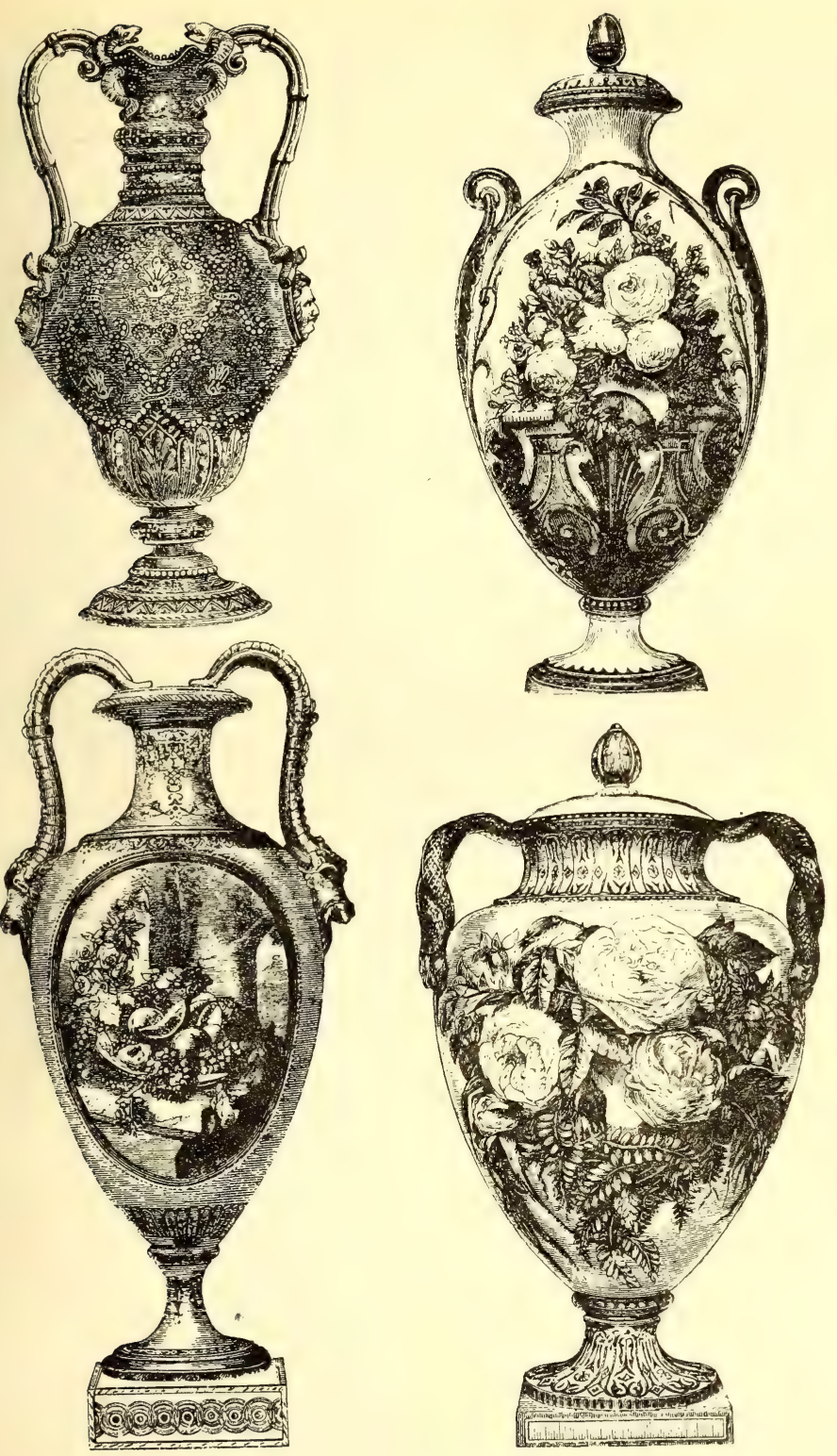

COPELAND'S VASES.

$8 I$ 
products which at the present day supply the market with porcelain in vases, tazzas, bottles, and other articles of many forms decorated in various styles, by painting, by altorelievo figures and flowers, by jewelling, enamelling, and gilding. It follows that these magnificent wares may be costly, but in a few words I may say that you can buy Copeland china in every style of art and on every scale of cost. The most sumptuous is the most expensive, but services and other pieces of a simple character, with severe yet tasteful decoration, may be purchased at quite reasonable rates.

In the coming years, when old Copeland china ware takes its place amongst the treasures of bygone times, collectors will want to know something about the artists who painted the decoration or modelled the figures. Hürten has been mentioned. He was one of the best flower-painters in Europe. His work on the service of I866 may be noted, and other examples of his flower-painting are given in the illustrations. Weaver was a bird-painter, one of the best of his time; some of his work is also shown. Besche, a figure and general painter of great power and excellence, and Abraham, also a figure-painter, appear in the recent works, with Abraham, junior, who painted figures too. Abraham the elder was at the head of the ornamenting department, in which many talented artists are still employed-enamellers, groundlayers, gilders, and painters.

We make one further reference to the Exhibition of I85I. That exhibition gave to Copeland's china a place in the ceramic world which has not only been retained at succeeding exhibitions in this and other countries, but it has acquired a world-wide reputation, unsurpassed by that of any other firm. The strongest determination is expressed by the present management not alone to maintain to the full that enviable reputation, but to add to it by ever-constant enterprise.

From I85I "Copeland" has been associated with all the leading exhibitions of the world, obtaining the highest awards, the last being at Paris in 1889 ; and it may not be out of place to record here a few extracts from the report 


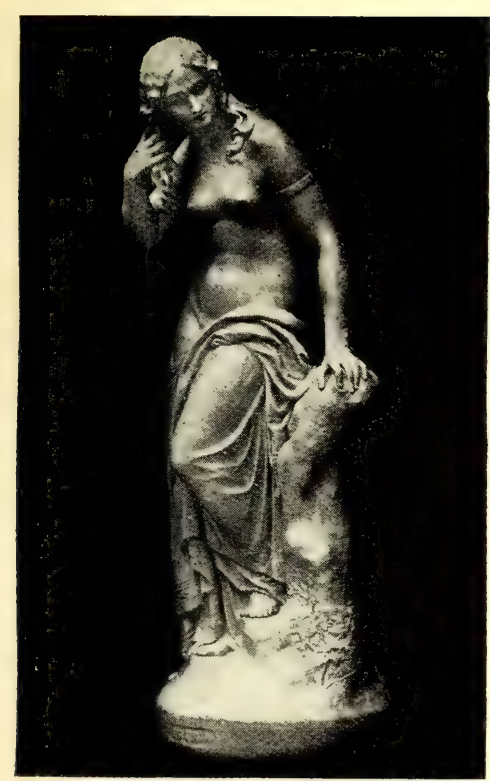

EGERIA.

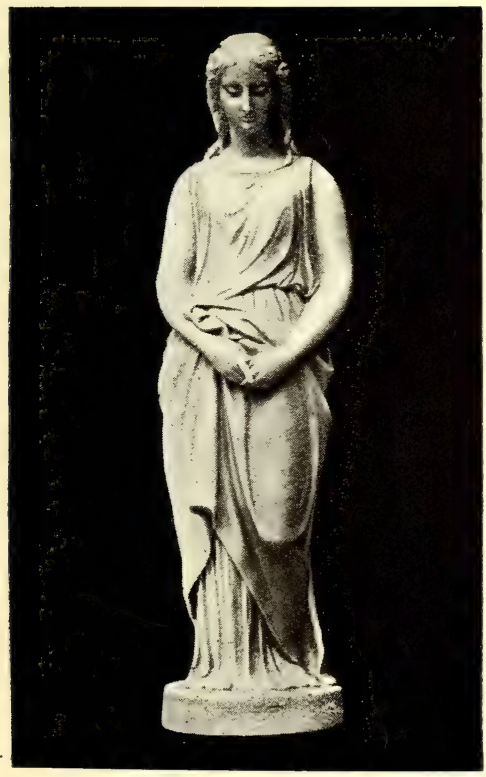

MAIDENHOOD.

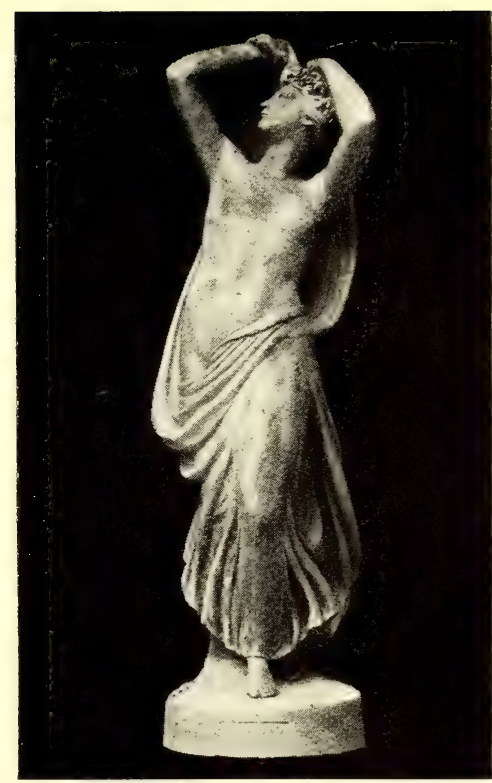

L'ALLEGRO.

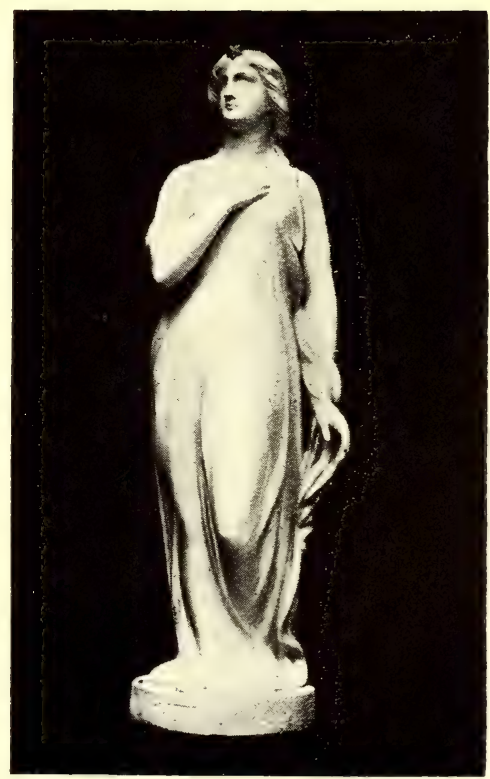

BEATRICE.

PARIAN FIGURES. MODERN COPELAND. 



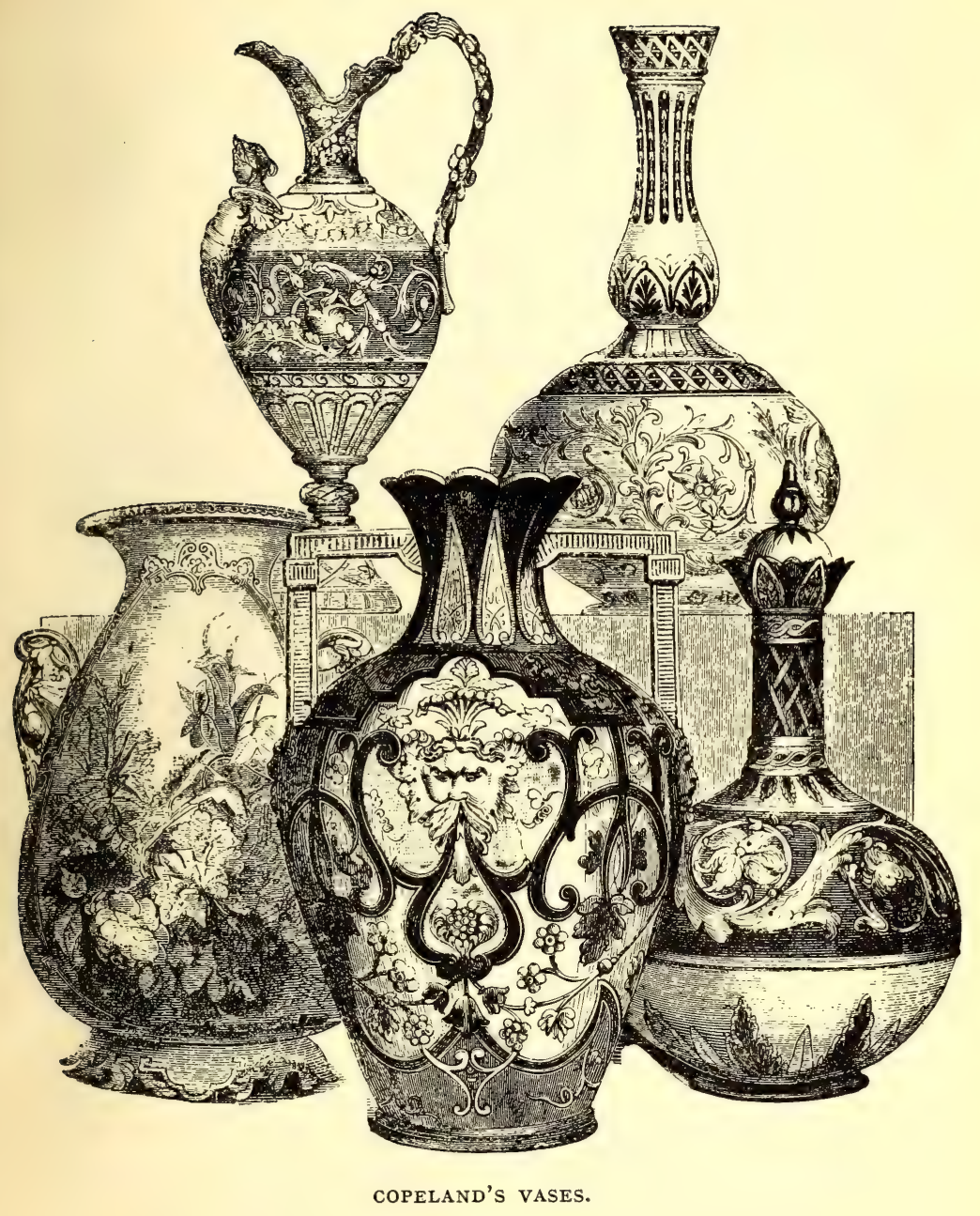


of the special representative of the Staffordshire Advertiser. He says :

"Messrs. Copeland's collection is in every respect-novelty, variety, technical skill, and artistic merit-worthy of their historic reputation. Of its kind, the most distinguished and novel among Messrs. Copeland's exhibits is a china dessertservice, entitled the 'Midsummer Night's Dream' Service. The centre-piece is composed of a sleeping figure of Titania, canopied over by the branches of a tree, and surrounded by foxglove and other wild flowers. There are eight tall comports, the dish in each instance being supported by a composition of a tree stem, covered with climbing or trailing plants, and a graceful fairy form. The comports are taller than usual, so that the artist had free play in modelling the figures. There are many low comports supported by elves and pixies. All the figures are pure white, and the flowers and other accessories are touched with delicate half-tones of colour. Each plate bears a named subject from the play. The purchaser of this service will often felicitate himself on the possession of an artistic treasure. We note next a reproduction of an old Chelsea dinner-service lent by the Grand Duchess of Mecklenburg-Strelitz. We were informed that the modelling alone cost $£ 400$. As a copy of a famous service it is admirable, whether regard be had to the paste, the glaze, the colours, or the artistic finish of the whole. The name of the founder of this firm is pleasantly recalled by two pairs of vases, one of classical and the other of Oriental form, decorated with various shades of blue, and enriched with gold, in a style much in vogue in the time of the late Mr. Spode.

"It is a sharp contrast to turn from these to a collection of slabs and plaques. We notice, first of all, two slabs, 40 in. by 20 in. painted, the one with roses and the other with chrysanthemums, and another pair, 24 in. by I 8 in., the subjects on which are azaleas and begonias. The surfaces of the slabs were 'roughened' before being put into the artist's hands; and, in the case of large works of this kind, when the subject is freely handled and the glaze is of the richest description, this has the effect of heightening the play of light and shade over the surface. In a still larger work-namely, a tile frieze, about I8 ft. long and $3 \mathrm{ft}$. deep-the artist has depicted with fine effect a large variety of tropical plants and foliage. This is unquestionably one 


\section{THE MASTER POTTERS AT STOKE-UPON-TRENT 87}

of the finest decorative works in the Exhibition. The next objects which demand attention are a pair of china vases of strongly marked Moorish character, in form and treatment. Both the bodies and the broad, flat handles are elaborately pierced, and the fretwork thus produced is lined out with gold and colour. The effect is sumptuous. Another pair of vases have chrysanthemums and roses depicted on an ivory ground, while the upper portions and the feet are grounded in Lincoln green enriched with gold. Still another

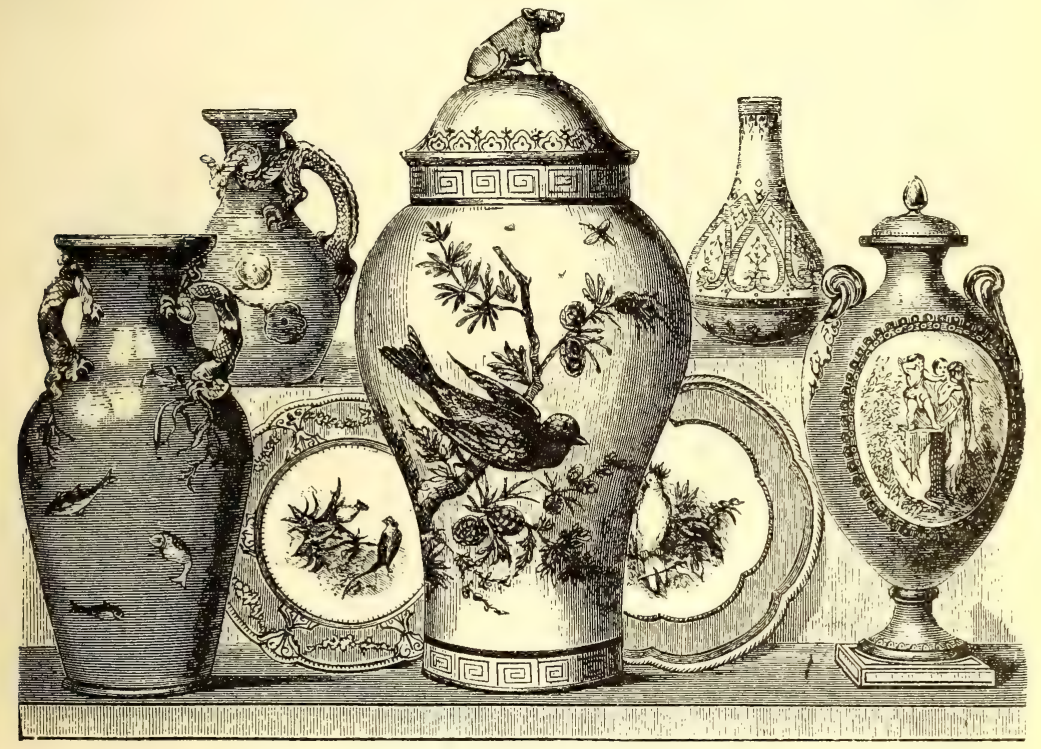

COPELAND'S VASES AND PLATES.

pair, of Oriental shape, are painted with fishes and seaweed. Two plates have subjects after Angelica Kauffman; im. mediately outside each picture is a band of turquoise blue, while the whole is enclosed in a richly painted and jewelled rim. These choice specimens are daintily disposed in velvetlined cases. On a pair of oviform vases are two figure subjects-a lady playing on a guitar, and another lady, for whose thoughts one might be induced to offer the customary penny were there any doubt as to the nature of her pleasant reflections.

"We also noticed, on the wall opposite this court, an oval 
panel with Cupids, after Boucher, and underneath which, ranged along the corridor, were some very fine specimens of celadon and white pillars, orange pans, Indian jardinières, and a tripod, a real triumph of pottery.

"We have to mention, in addition, two Parian figures, the sole representatives of a branch of the potter's art to which this firm formerly devoted much attention; for statuary porcelain, this bisque has excellences not possessed by any other ceramic medium, and its employment should not be permitted to die out. The few articles which we have selected for mention do not constitute a twentieth part of Messrs. Copeland's exhibits ; there is also a dessert-service, painted with English flowers and surmounted by a rim grounded in cobalt blue. And, lastly, there is a large vase of the double-gourd shape, which is literally encrusted all over with jewelled work resting upon a ground of gold and colour. Messrs. Copeland have long been celebrated for their jewelled work, and this vase may be considered as their masterpiece."

It is not often that a novelist tells the simple story of a manufacture, the making of plate; but Charles Dickens, who visited Copeland's Pottery Works in I852, and saw all the processes of its making, wrote a charming description of them in Household Words, under the title of "A Plated Article."

Copeland's made plain and painted and enamelled tiles of singular beauty which called forth the unstinted praise of Jewitt, who describes them as masterpieces of art, as well as of manipulative skill. He goes into rapture over an internal decoration of a mansion in Glasgow which Copeland had treated with all the resources of his works, friezes painted by R. J. Abraham, son of the Art Director, and by Mr. Besche, a skilful artist, whose works were in high repute, and he concludes a long and highly appreciative article published in the Art Journal in I875, thus :

"Messrs. Copeland are renowned for the excellence of their work, and for the true artistic feeling and skill which characterise everything that passes from their hands, and their present production will, if that be possible, add to their celebrity." "Copeland's tiles in endless variety for every 

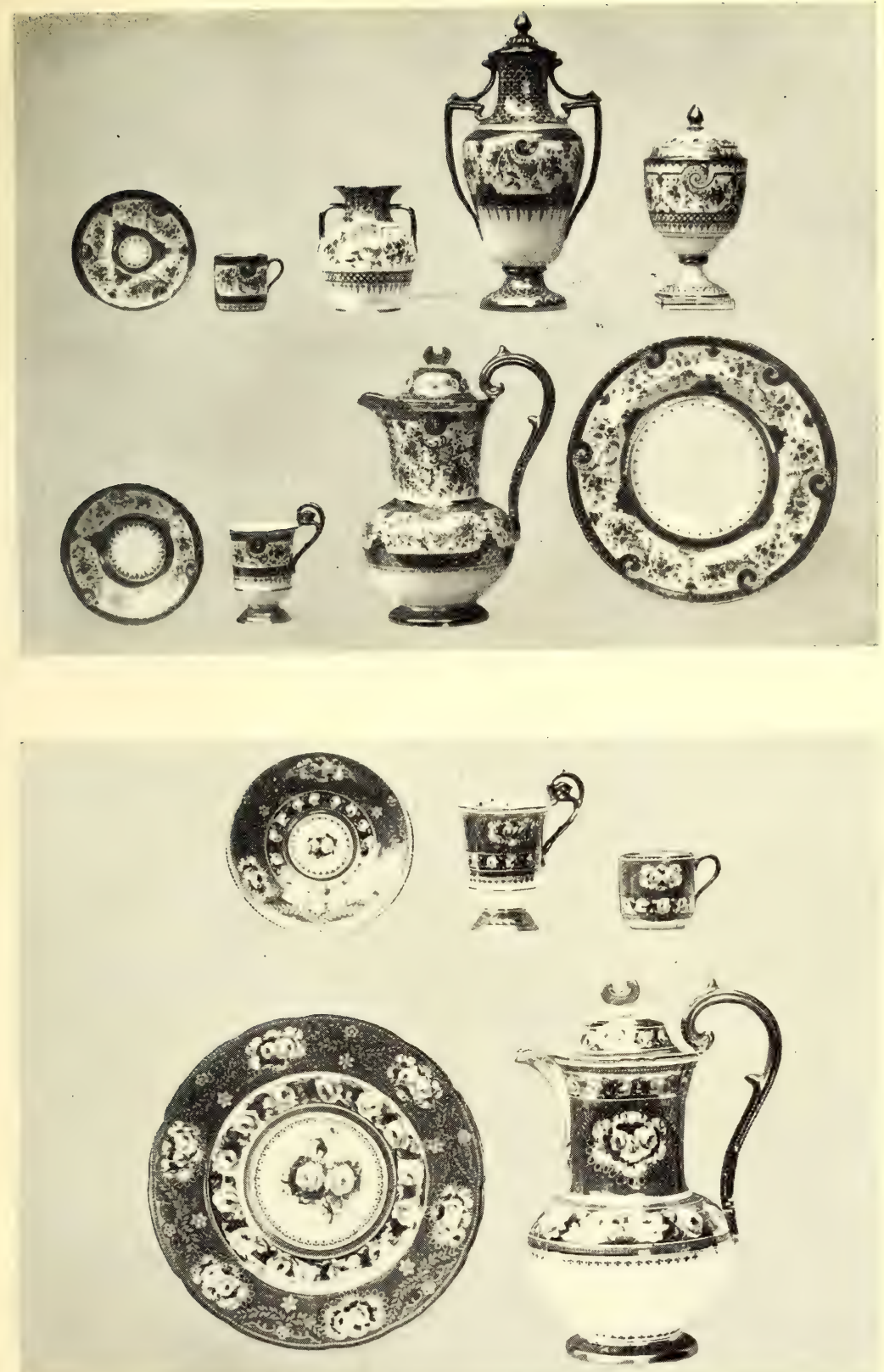

MODERN COPELAND CHINA. 



\section{THE MASTER POTTERS AT STOKE-UPON-TRENT 9I}

purpose are amongst the most striking and attractive novelties in this kind of mural decoration," he wrote in his book in 1878 .

With this I must pass from the tiles to the productions of the firm which are advertised in I900-in fact, the adver-

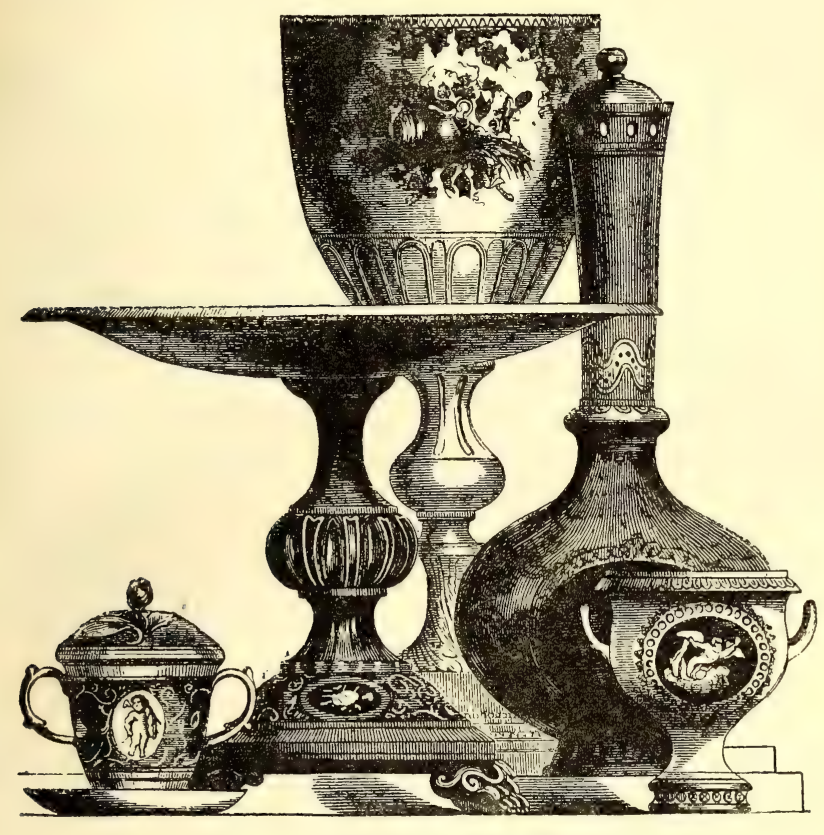

COPELAND'S CHINA.

tisement itself, though displayed, can be put into a short paragraph :

"Copeland's china and earthenware, non-crazing. W. T. Copeland \& Sons, late Spode \& Copeland, manufacturers of non-crazing ceramic wares, china, stone china, statuary earthenware. 'Spode Imperial,' the most perfect earthenware in the world. Spode.-The original models, pattern books, etc., are still employed by us in the production of the highly esteemed Spode ware, in the unequalled bodies of that eminent potter. Spode Japans, the finest in the world for decorative purposes and domestic use. The 'civic 
plate' expressly modelled for use at the Mansion House, the original invention to prevent surface chipping for hotels, etc. China and earthenware of every description."

The awards from no less than ten exhibitions, including the Grand Prix at Paris in I889, are noted.

Perhaps the most interesting events in the history of the furm have been the Royal visits, such as that of Queen Charlotte to Portugal Street, Lincoln's Inn Fields-the London warehouse-in I8I7, when the newly invented stone china was exhibited to the Queen and the Princess Elizabeth by Mr. Spode, after Mr. Copeland had conducted them over the different departments. We can quite understand that the visitors were highly gratified with their visit. Eighty years later the Princess of Wales (Queen Alexandra) visited the works at Stoke-upon-Trent, where she saw Brough, a painter of the Sèvres School, at work; and, in the showrooms, the party admired the rose-du-Barri and the feuille-dechoux grounds and the multitude of dainty articles displayed for the inspection of the distinguished visitors, the Princess accepting a pair of Sèvres plates and an invalid tea-set as souvenirs.

Still another Royal visit, from the Duke and Duchess of York (now King and Queen), honoured the famous pottery in I9oo. The processes of manufacture were shown to the Royal party from Trentham, who then proceeded to the showrooms, where they saw the vases known as Cavendish, Goldsmith, Ibex, Salford, Cecil, and other shapes, as well as the stone china with the "Temple" and "Tower" patterns, amidst a rich display of dinner, dessert, tea, etc., services. Mr. R. P. Copeland and his son, Mr. W. F. M. Copeland, received the thanks of the Duke and Duchess on their departure.

Such incidents as these are not only historical, they are inspiring, and the whole ceramic art of the country benefits thereby. Copelands have deserved all the honours they have won by their splendid work, which has always been devoted to the elevation of that art, to its advance at the head of the products of the world. 

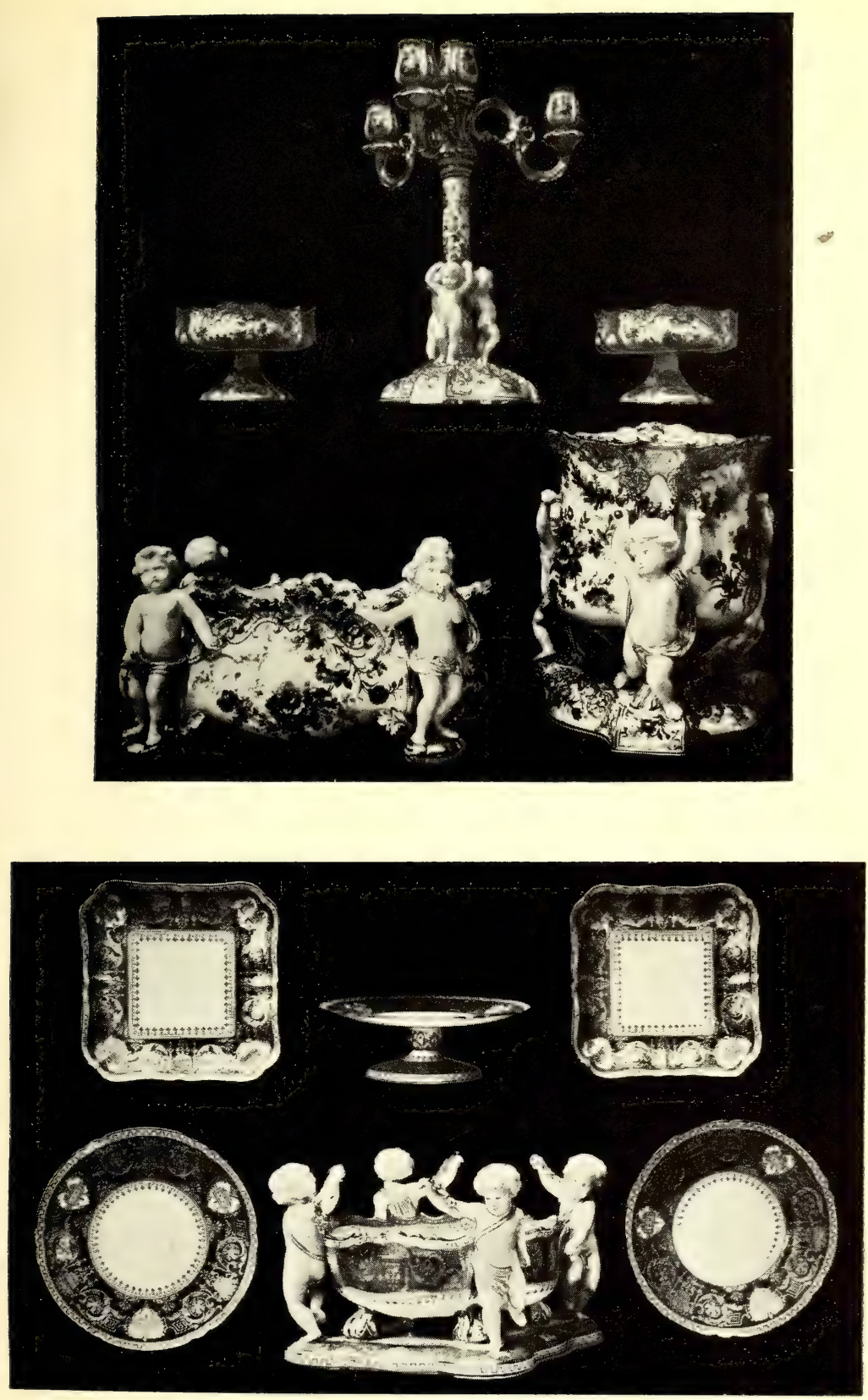

MODERN COPELAND, RICHLY DECORATED. 



\section{SPODE AND COPELAND'S MARKS.}

SPODE

Sometimes impressed in the body, and at others pencilled on the glaze; also SPODE in larger capital letters.

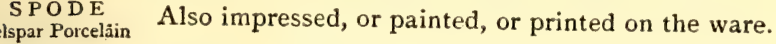

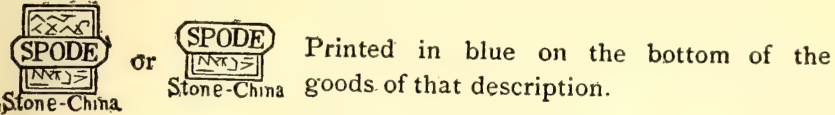

These, with immaterial variations in detail, were all printed on the ware.

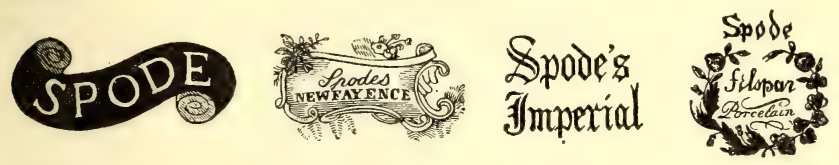

SPODE, SON

$\&$ COPELAND

or SPODE \& COPELAND, both impressed and printed.
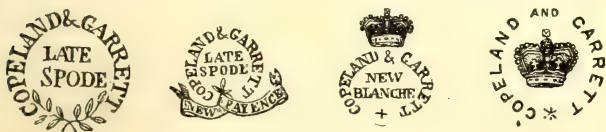

COPELAND

\& GARRETT

C \& G

with the name of

the pattern.

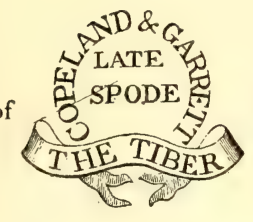

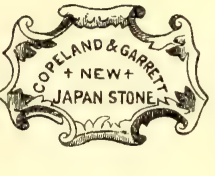

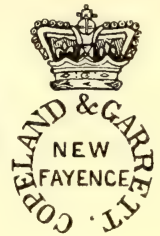

All the above printed on the ware.

Copeland
Late Spode. Copelandlaie Spode COPELAND late SPODE. COPELAND
LATE SPODE

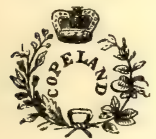

\section{COPELAND \\ COPELAND}

PATENT JASPER

\section{Copeland \\ Copeland}

Stone China
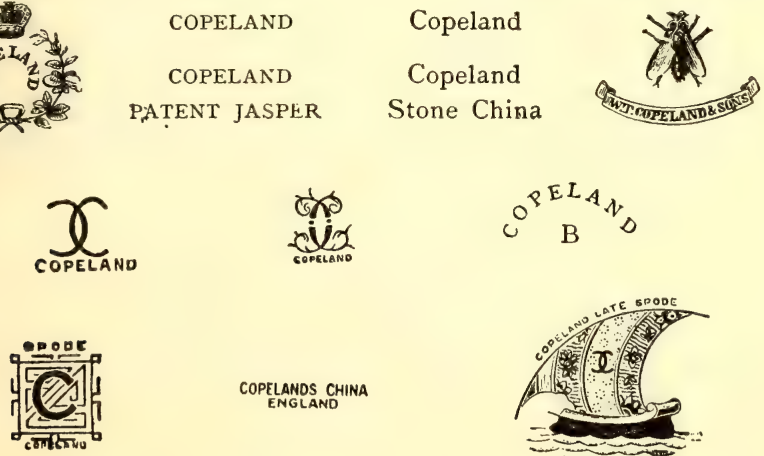

COPELANDS CHINA
ENGLAND

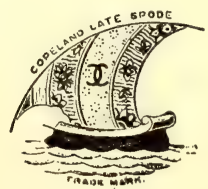




\section{CHAPTER V}

\section{THE MASTER POTTERS AT STOKE-UPON-TRENT}

\section{Mintons}

NEAR the commencement of the nineteenth century, to be exact, in May I796, Minton's works began at Stoke-uponTrent, and in I80o the business done amounted to nearly $£ 2,000$ in London alone, where Arthur Minton devoted himself to the sale of the goods produced by his brother Thomas, who was associated with Wedgwood, Adams, Hollins, and others in the Hendra Company, formed in I80o to work china clay and stone, as well as other minerals at Hendra and Treloar Commons in Cornwall.

Thomas Minton had acquired these properties for a small sum about a year before, so that as soon as the company was formed, material was forwarded to the Potteries, but the cost of carriage and the expenses of raising, working, and casking the clay were heavy; no less than $£ 6$ I5s. per ton was the price on delivery-nearly three times its present price. It is not surprising to find that after twenty years of difficulties these sources of supply were abandoned in favour of others, probably those which had supplied Champion of Bristol till I78I, when he sold his patent for true porcelain to a company of six Staffordshire potters, who originated the New Hall works at Shelton. Hollins and Warburton were interested in the Hendra Company. Now, New Hall discontinued hard-paste porcelain about $\mathrm{I} 8 \mathrm{I} 2$, and it was sold off in I825, when the manufacture there entirely ceased. I mention this to point out that the sources which had supplied Plymouth, Bristol, and New Hall became available for the Staffordshire potters. 

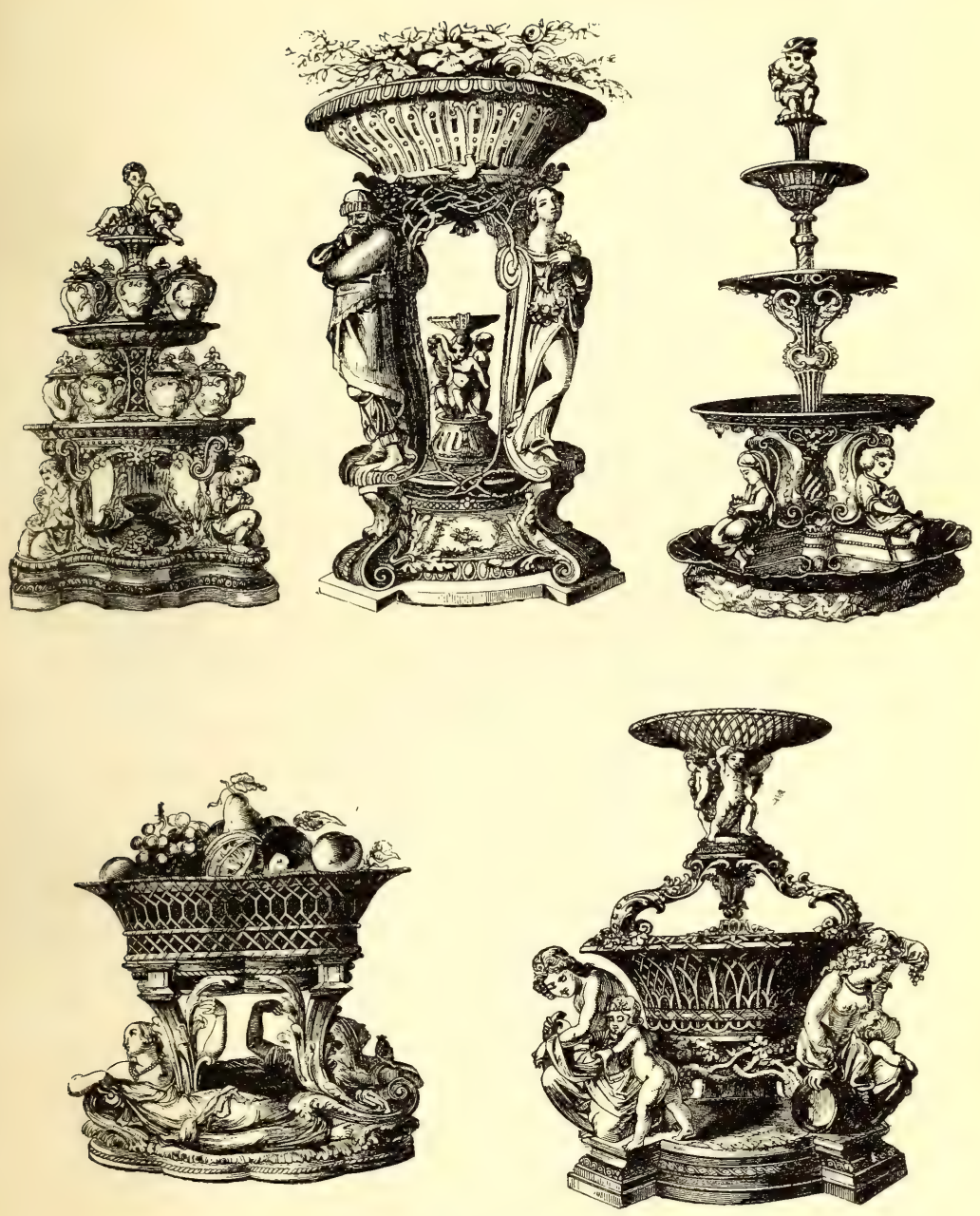

MINTON'S EXHIBITS IN I85I. 


\section{I9TH-CENTURY ENGLISH CERAMIC ART}

Minton's work at Stoke from the beginning met with success. I differ most distinctly from the opinion expressed by the authorities that the early wares of the great Staffordshire factories were artistically of little account. It may be that at Derby, Coalport, and elsewhere patterns were produced which were copied on the Staffordshire wares with little variation, though that is far too sweeping. The Japan patterns were the most satisfactory, we are told; that, again, is open to argument. I agree that the Japan patterns were well done, but there were others not of Derby nor of Worcester, but of Staffordshire, and early nineteenth-century too.

Thomas Minton was an engraver, whose early efforts were aided by Poulson, an experienced potter, and by John Turner, who became the practical potter after Poulson's death in I808, the same year that Herbert Minton, the second son of Thomas, only a boy of sixteen, entered upon his career of traveller and salesman for his father, or rather for the firm which was "Minton and Poulson" for a short time, and then "Minton, Poulson, and Pownall," again for a short time. Pownall supplied some capital and was a sleeping partner. A new title, "Thomas Minton and Sons," marked the entrance of two sons into the business, Thomas and Herbert ; but the former wished to study for the Church, and in I82I, after four years' partnership, he left the work to his father and his brother Herbert, who, from 1828 to 1836 , gave his energies to the business, though, for some reason, there was no partnership during those eight years. In I836 Thomas Minton, the potwork owner, died, and Herbert, having resumed the management shortly afterwards, took John Boyle as a partner, but he left in I84I to join the Wedgwood firm. Other changes followed, for, in I845, Hollins, a nephew of Mrs. Minton, became a partner in "Herbert Minton \& Co. " ; Colin Minton Campbell, a nephew of Mr. Minton, joined the management four years later. When Herbert Minton died, in 1858 , the other two partners continued the firm which is known all the world over as "Mintons."

The early productions of these works were common to 


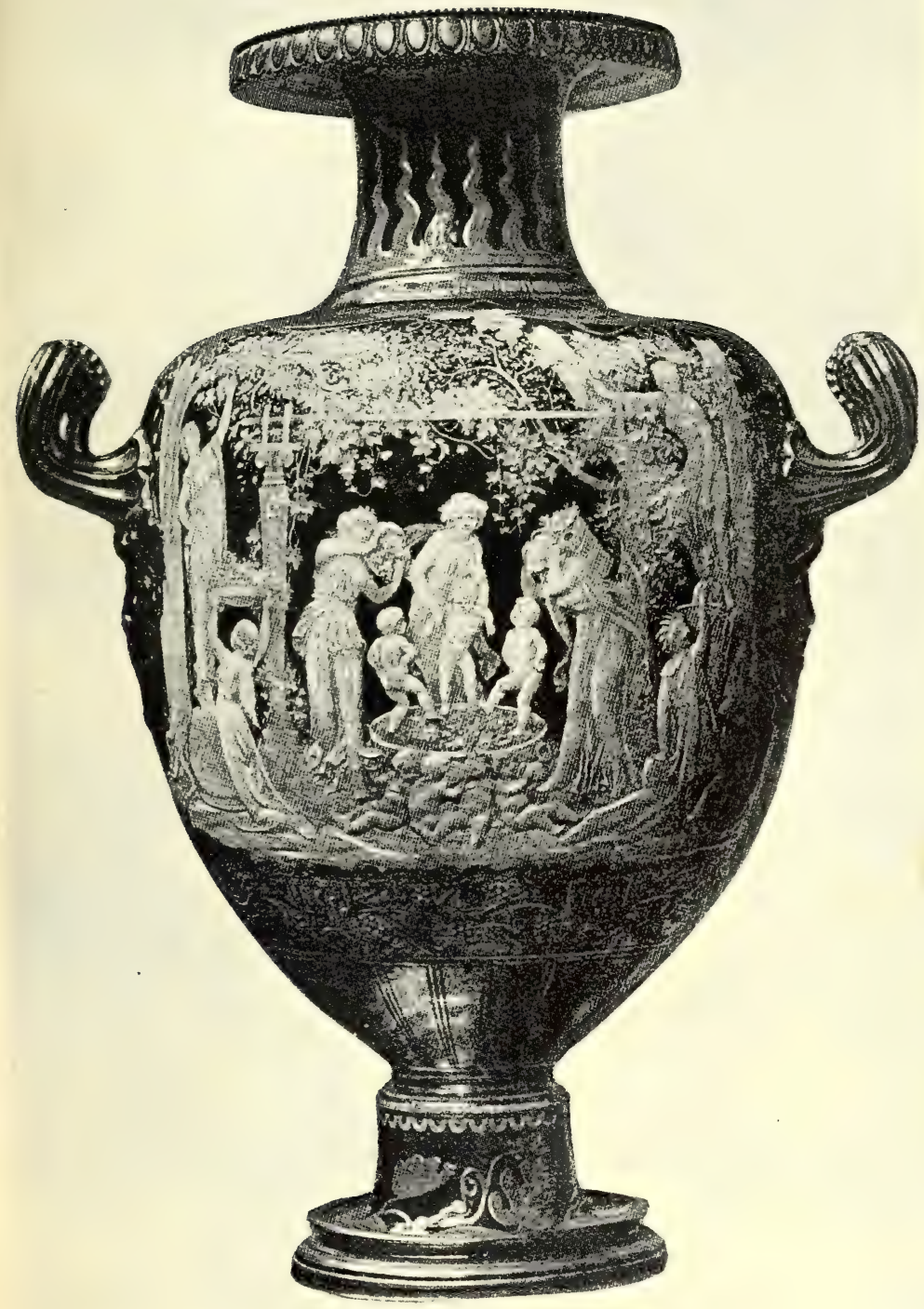

M. L. SOlon's PÂTE-SUR-PÂte. "THE Vintage." A BeAutiful VASE. MINTON. 


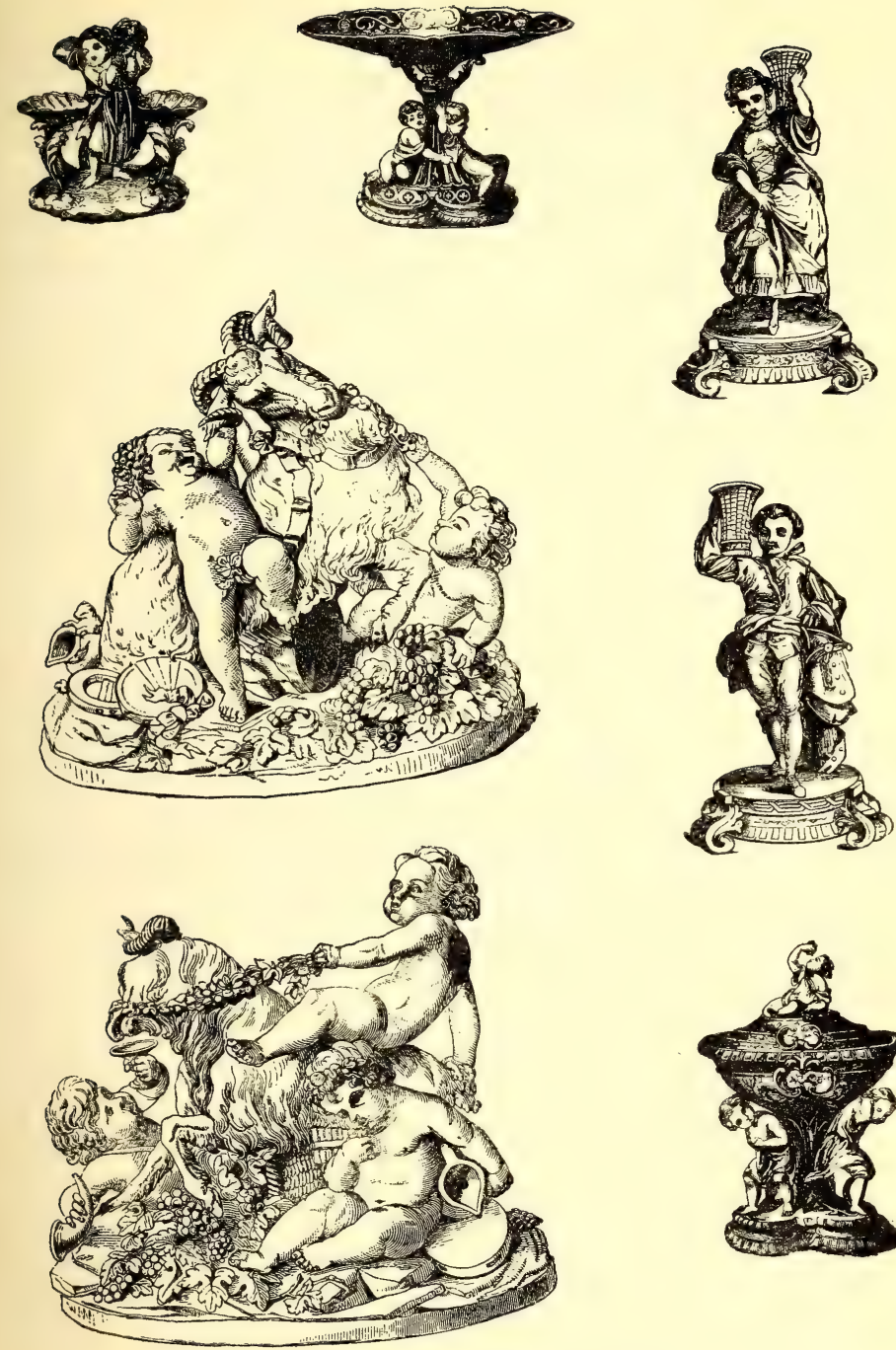

MINTON'S EXHIBITS IN I85I. 


\section{IO2 I9TH-CENTURY ENGLISH CERAMIC ART}

all of the existing factories. They were earthenwares, white or cream-coloured, decorated with transfer-printing. At the beginning of the nineteenth century semi-transparent porcelain was made, which continued from I798 to I8II ; then earthenware gave employment to the workers for ten years when, first, semi-transparent china was resumed, and this was soon followed by the introduction of porcelain, in which the firm has reached the highest standard, not only in the potting but in the decoration.

Amongst the skilled decorators employed as early as 1825 were Steele, Bancroft, and Hancock, flower and fruit painters, who left Derby when the decline of that factory had begun under the administration of Thomas Bloor. They had full scope for their talents at Stoke, though from I837 to I847 John Simpson was the principal enamel-painter of the highestclass decorations, especially figures, and another artist, also an enamel-painter, Samuel Bourne, had, in I828, been engaged as chief designer and artist. A glance at these few sentences indicates very clearly the rapid progress which had been made and the intention of the managers in those days - they meant to go forward. The new members of the firm were content with the appointment in I849 of Monsieur Arnoux, and it was arranged that he should carry out a patent which had been acquired by Minton in I 839 in conjunction with Dr. Turner. This introduces an element which forms a departure from the English bone porcelain which was generally made by the English factories of the nineteenth century, having a body or paste of bone-ash, china-stone, and china-clay; and a glaze of china stone and clay with boracic acid, alkalies, and lead-oxide. This body was first fired to "biscuit" and the glaze subsequently at a lower temperature. Minton made "hard paste." His improved porcelain was made from kaolin or china-clay converted into cream and passed through sieves, Dorset or similar clay treated in like manner, and pure felspar-all in certain proportions and mixed with great care. In I849 this hardpaste porcelain for chemical uses was brought to such excellence that it was said to be better than Meissen or Berlin. 

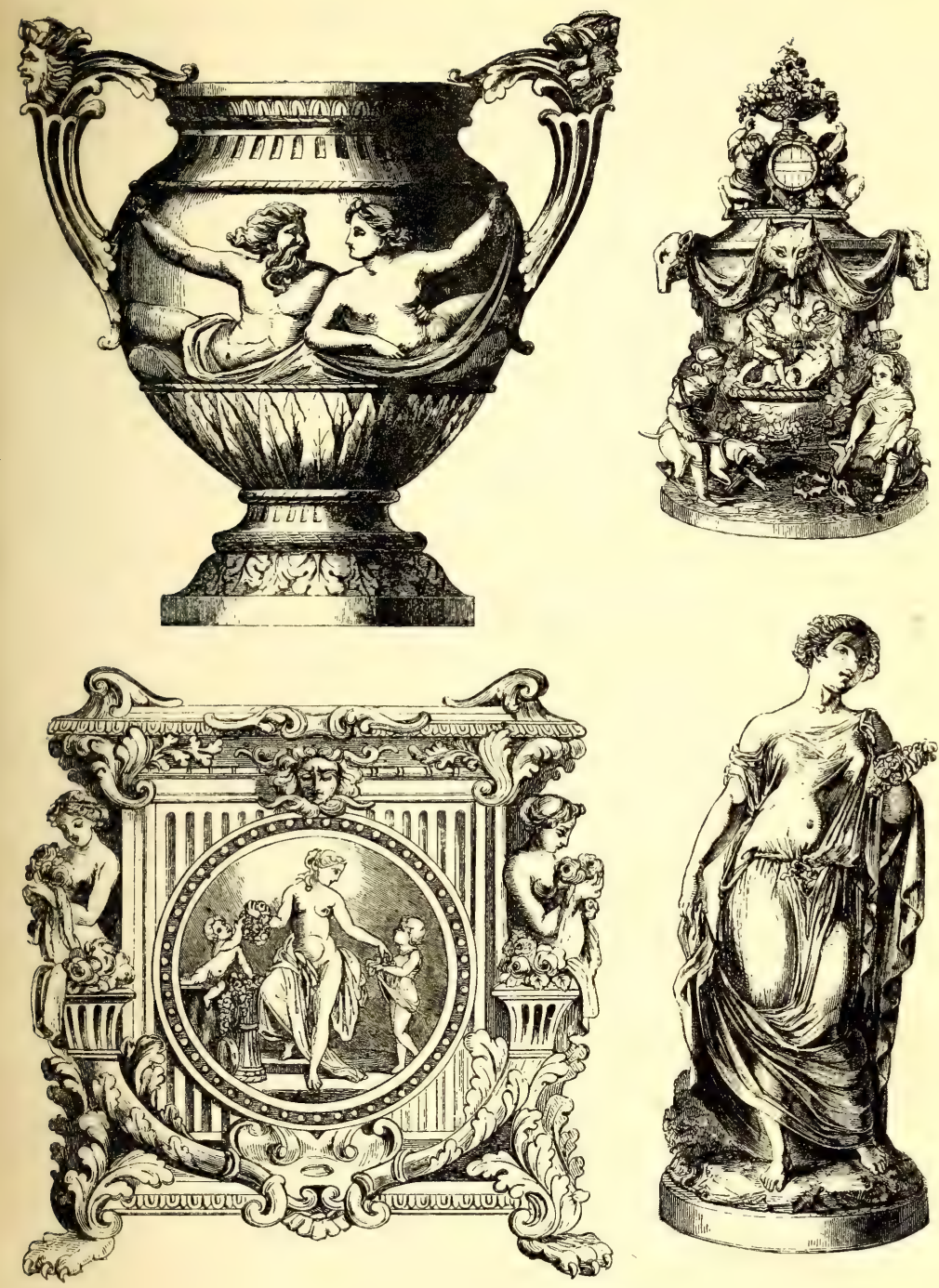

MINTON'S EXHIBITS IN I85I. 


\section{I04 I9TH-CENTURY ENGLISH CERAMIC ART}

The various risks attending its manufacture were such that in a short time it was abandoned, leaving M. Arnoux free to devote his talents to the artistic decoration of the ware, to do his share in upholding the distinguished position which the firm gained in $185 \mathrm{I}$. We turn to the catalogue and quote the opinions of the expert then :

"The porcelain manufactory of Messrs. Herbert Minton \& Co. is at Stoke-upon-Trent, the principal town of the famous district known as the 'Staffordshire Potteries.' The establishment has long been eminent for the production of admirable works. The head of the firm is a gentleman of accomplished mind, and of refined taste, and his large resources have been made available to obtain good models and valuable assistance, wherever they could be found, in all parts of Europe. His collection at the Exhibition consists of an extensive variety of objects, all of which are of the highest merit; it is not too much to say that the corner of the gallery in which they are placed has been a point of attraction to visitors, and that here, at all events, foreigners have been enlightened as to the capabilities of British producers to encounter competition with the whole world. We engrave several of Messrs. Minton \& Co.'s productions, commencing with the dessert-service purchased by Her Majesty. The service, which is entirely original in the models, arrangement, and decoration, is one of exceeding beauty, designed with pure artistic skill, and exhibiting, in manipulation and finish, a degree of refinement that has rarely, if ever, been surpassed in modern art. The subjects have been elaborately treated; it would seem as if the utmost amount of labour had been expended upon them-yet nowhere do they seem crowded or overladen ; a result which arises, no doubt, mainly from the delicacy of the material, the figures and ornamentation being of Parian slightly gilt, and the baskets of richly decorated porcelaina very novel combination."

The illustrations show several examples from this service -a jelly or cream stand, a three-tier plateau, a flower-stand, a trefoil fruit-basket, an oval fruit-basket with a salt-cellar, a small plateau or fruit-dish, and a covered cream-bowl, and a wine-cooler which forms the centre piece. 

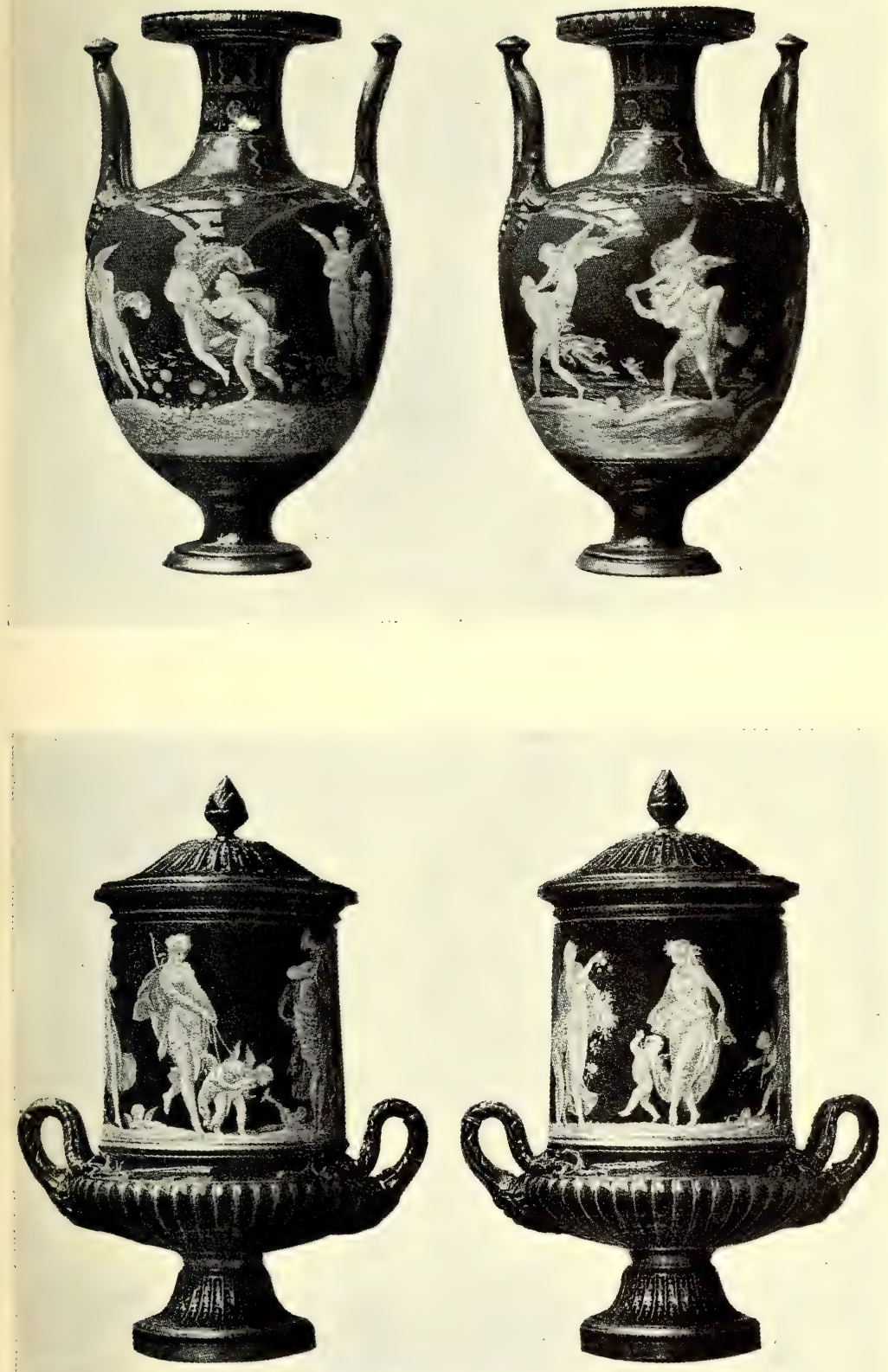

M. L. SOLON'S PÂte-SUR-PÀte. BEAUtiful Minton VASES. 

"The two groups of children sporting with goats are in Parian-that exquisite material in which England remains unrivalled, and which is second only to marble. They are original designs, executed in the style and spirit of the last century, and it is not too much to say that the delicacy of the modelling, and the grace and truthfulness of the attitudes have been seldom equalled. The two small figures are elegantly formed; they are in gilt Parian with the stands in porcelain tastefully decorated, and serve as candlesticks. They are original designs in the style and costume of Louis Quinze. The very large vase for plants designed expressly for Messrs. Minton \& Co. by the Baron Marochetti, and the rectangular vase, are in terra-cotta. The figure is one of the admirable statuettes in Parian exhibited by this house. Of these, Messrs. Minton \& Co. have produced many from original sources-some after eminent foreign sculptors, but chiefly from the leading artists of our own school. In the whole collection we find abundant evidence of that matured judgment and refined taste by which the manufacturers of Great Britain have been, of late years, elevated, and which, in the present Exhibition, have so largely contributed to uphold, and will extend, our national repute."

The award of great merit to this firm was one, the first, of many such honours which have been deservedly won in exhibitions at home and abroad. When we mark how keen was the desire on the part of the management to secure the services of distinguished artists, we are bound to acknowledge their enterprise and to admire its results. M. Arnoux was the first of the Frenchmen engaged, but he was followed by M. Emile Jeannest, a sculptor, who, in I854, went to Elkington's; by M. Carrier de Belleuse, who succeeded M. Jeannest, and after some years returned to Paris to serve upon the commission of the Sèvres manufactory; by M. Protât, who sculptured some of the statues at the India Office, afterwards returning to France; and by that wonderful designer, painter, and expert, M.L. Solon (Milès), whose masterpieces in pâte-sur-pâte will remain on a pedestal apart, painted with finest clays, laid on the finest bodies with coloured grounds. He signed his works in various ways; but really no signature is necessary-they are unattainable by any 


\section{IO8 I9TH-CENTURY ENGLISH CERAMIC ART}

except a master hand guided by a master mind. They are worth large sums, though of course they are quite modern. In time to come, the hundreds of pounds which are now paid for a pair of fine vases will scarcely buy small ones, and the plaques which have sold for forty or fifty pounds will rise to prices undreamed of now. They were not moulded, they cannot be repeated, they are unique pâte-sur-pâte, signed "Solon " or "Miles" or "M. L. S." interlaced ; and "Miles," a name that contained the three initials of M. L. Solon, was also used by him in France before he left Sèvres, at the time when the Franco-Prussian war, in 1870 , brought the invaders to the gates of Paris. Then he came to England and to Mintons'. In a beautifully illustrated book, which the firm kindly sent me, Solon gives a short account of his life as an artist, and his work, Pâte-sur-Pâte (body upon body), which name he adopted, although at the Sèvres manufactory it was known as pâte rapportée and pate d'application, which is the term now in use.

Some excerpts in the writer's own words convey the very best information :

"It may not be inopportune if I point out the differences existing between this process and a few others which may be thought akin to it in their results. The Wedgwood jasper ware, for instance, although offering likewise white reliefs upon coloured ground, is, as the reader is no doubt well aware, produced by mechanical means. Each part of a given model is pressed separately in a plaster mould and subsequently stuck on the even surface of the piece to be decorated. It may be multiplied to an unlimited number of copies; a careful workman is equal to the task. A pâte-sur-páte basrelief, on the contrary, is always an original--a repetition of it could only be made by the artist who has executed the first one. In the Limoges enamels, sometimes mentioned as presenting some analogy, the difference is still better marked, for, in this case, effect is not obtained by gradation of reliefs, but rather of lights and shades. The dark tint of the ground is taken advantage of to form the shadows, and the white enamel comes into play, just as white chalk intervenes in an effective drawing on tinted paper.

"Pâte-sur-pâte decoration may be executed upon any 
semi-vitrifiable body, but the material used for the applied parts must always be of the same nature as the mass of which the piece itself is formed. The hard porcelain paste is, for density and fineness of substance, superior to any other; it is the one employed in France and Germany. But, as few metallic oxides can stand the high degree of heat to which it has to be submitted, the scale of available colours is consequently very limited. With the body in use at Messrs. Minton's, on the contrary, a great variety of colours can be obtained. It is a sort of Parian (felspathic china); the elements entering into its composition are the same as those used for hard porcelain, but mixed in different proportions. Most complicated kinds of forms car be produced in that body; the biscuit is at first thoroughly fired, and during this operation the pieces can be properly supported in all their weak points; the glazing is subsequently proceeded with at a much lower temperature. It is not so with hard porcelain: the highest degree of heat has to be reached to bring the glaze into fusion; supports cannot be used, as they would stick to the piece, and therefore only a certain class of shapes can be attempted.

"The regular English china body, so well adapted to surface painting, may also be employed, but as most of the oxides which may be safely used with the Parian are attacked by the phosphate of lime contained in the china body, this latter gives only unsatisfactory results."

After showing that the idea of this new style of decoration came, not from Wedgwood jasper ware, but from a Chinese celadon vase with white flowers in the Ceramic Museum at Sèvres, M. Solon proceeds with an account of the early experiments, which we will leave in favour of a description of his mode of working, which he commends for its simplicity. It

" may induce artists and amateurs to give it a trial. A vase or a plaque of unbaked clay can easily be obtained from a china-manufacturer. By passing it through a muffle kiln it becomes hard enough to be handled with facility. The contraction it will undergo in the firing will be about oneseventh of its original size ; the clay employed upon it therefore also must be unbaked clay to allow of its following the 
general contraction of the whole piece. Either the vase or plaque is made throughout of coloured clay (solid) or the coloured clay is merely laid as a ground (dip) upon the surface of white clay; this is the safest way to obtain a very dark tint. To ensure success an important precaution has to be taken when proceeding with the work. The clay, diluted with water to the consistence of a batter, or, as it is called, made into 'slip,' is laid on by thin washes with a paint-brush, one wash being followed by another, till the required thickness is obtained. If due care is taken never to apply a fresh coat until the preceding one is perfectly dry, the work will never crack or peel off. This is the only technical rule absolutely necessary to observe. All else that remains depends more on the artistic feeling of the operator than on professional secrets."

From this account of pâte-sur-pâte decoration the mind of the collector will revert to the early slip ware, in which white or light-coloured clay was dropped upon the dark reddish or reddish-brown tygs, posset-pots, and dishes, especially in what is known as Wrotham and Toft ware, which dates from the seventeenth century. M. Solon glorified the process and brought to bear upon his creations a wealth of imagination and a power of execution which will do much to baffle the copyist, especially when his work is combined with the body of felspathic china, the Parian which made his paintings so effective. This smooth-feeling body is Mintons.

The improvements patented by Mintons have had great influence in improving the manufacture. I might spend much space in describing the efforts of Herbert Minton to manufacture "ornamental tiles," "ornamental bricks and quarries for floor pavements and other purposes," but such objects, though of great interest, can only receive passing notice. For a long time the tile department was in difficulties, though Minton bought the patent rights and moulds of Samuel Wright of Shelton about I845, which step he never regretted. The immense production of tiles began in a single room where only three men were at first employed. The right spirit was shown when Boyle suggested to Minton, 


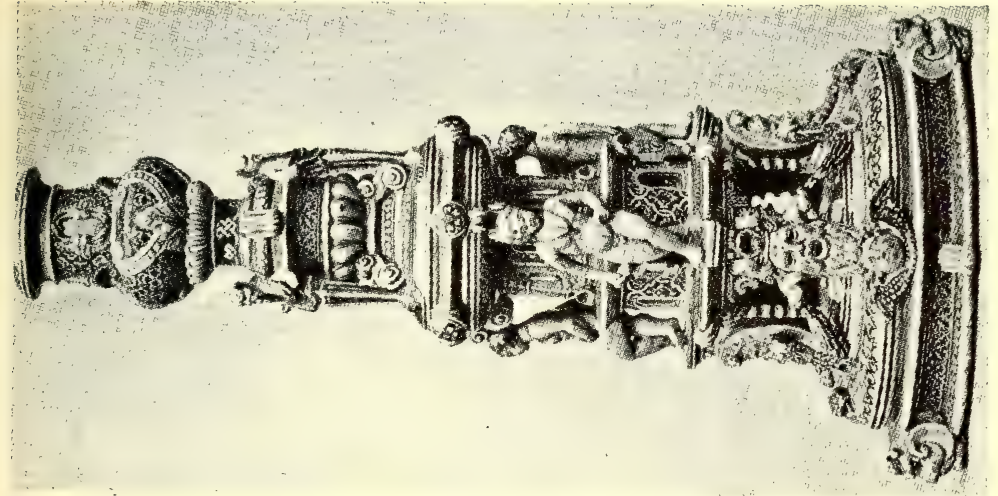

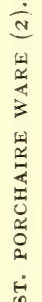

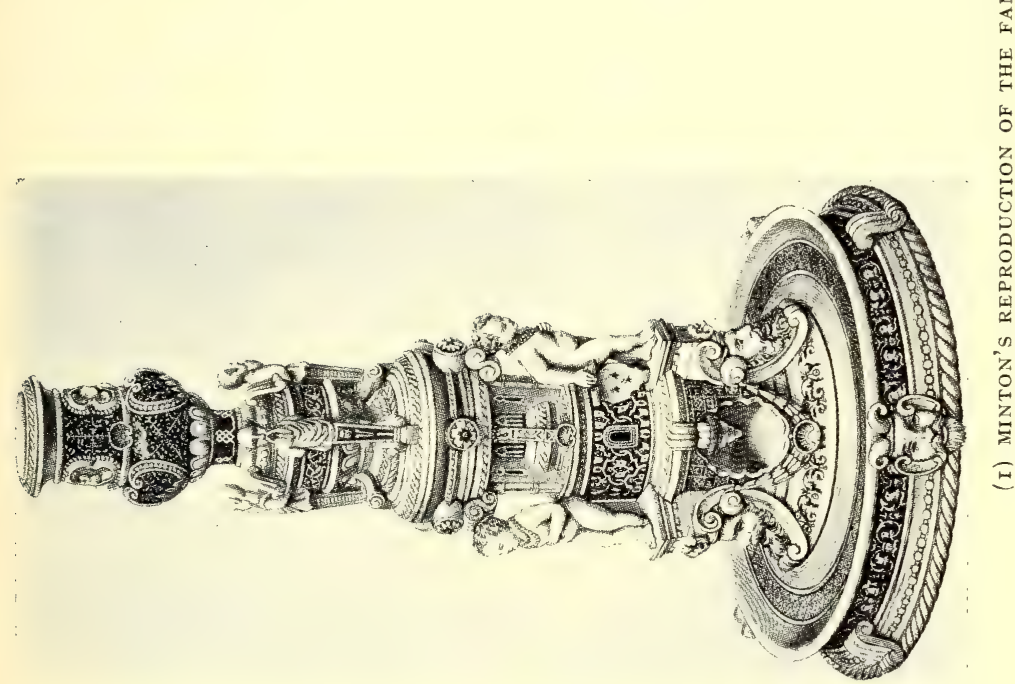



his partner, that the tile department ought to be abandoned. "Say no more on the subject, Mr. Boyle," was the reply. "I will make these tiles, if they cost me a guinea each." $\mathrm{He}$ did spend many thousands of pounds in perfecting the manufacture which is now carried on by the firm of Minton, Hollins \& Co. at the Patent Tile Works, Stoke-upon-Trent. And it may be fairly conceded that in the manufacture of encaustic and other tiles the entire modern trade is under deep obligations to the pioneer whose determination was so strong.

Other modern productions must receive some slight notice, though some day Mintons will have their own historian, who will describe at length the introduction of majolica in 1850 , and of Della Robbia and Palissy wares in I85I, who will tell of the wonderful button-presses which produced in 1846 no less than 50,500 gross, great gross of buttons, and afterwards ceased to make them. He will have access to all the records surrounding the persons engaged in a great everexpanding concern, and he will produce a book which will rank with Binns on Worcester, Haslem on Derby, and Owen on Bristol.

Herbert Minton was never daunted by difficulties. He had the faculty of grasping clearly the ultimate result of inventions which were offered to him, and he had the dogged persistence which overcame such difficulties after innumerable disappointments. I have said something about this in the few words on tiles, but another instance equally characteristic was displayed when he joined Collins and Reynolds in their endeavours to substitute for transfer-printing in colours a method of taking impressions from the flat surface of metal or stone instead of from engraved lines. Months and years were passed in experimenting, then the last obstacles were removed, and the process established as an additional means of mechanical decoration, which was especially suitable for flat surfaces, such as tiles and wall decoration. In the trade advertisements evidence is given of all usable ornament ; "embossed tile, glass and crockery lithographs, ceramic transfers, every description of wood and copper engraving," are offered, as we might expect, as well as "stilts, spurs, and 


\section{II4 I9TH-CENTURY ENGLISH CERAMIC ART}

thimbles, and every requisite for firing tiles and pottery." These and other means which affect cheap production are available because men like Herbert Minton were not afraid to spend money in experiments.

It would be far too great a task to treat in detail the china, the stoneware, and the pottery which Mintons are making now, so vast is the concern, so varied the material and the decoration. From the simplest forms in white to the richest enamelled and gilt ornament, all alike are marked by the finest qualities. If this applies to objects for use in the house, how much more fully does it apply to objects for ornament, upon which these specialists have exhausted the realm of design, upon which they have expended all that taste and skill can furnish, in a whole-hearted devotion to traditions of the past, mingled with, I do not know, what aspirations for the future!

The great reputation of Mintons for productions so varied has been attained by a never-ceasing search for the best men. I have mentioned some-MM. Arnoux, Jeannest, Carrier de Belleuse, Protat, and Solon; Lessore, too, before he went to Wedgwood's. Then, amongst the other painters, Boullemier, Jahn, Müssil, Pilsbury, and Allen stand prominent. With such artists came the originality which has distinguished the firm, and which has received universal admiration and particular recognition at the many exhibitions where, at home and abroad, Mintons' stall has always proved a great attraction and an instant success. In Igoo the advertisement reads :

" Mintons Limited, potters by special appointment to Her Majesty, manufacturers of china, earthenware, majolica, and tiles. Manufactory-Stoke-upon-Trent. London warehouse-25, Farringdon Avenue, E.C."'

Here is no mention of gold medals, etc., awarded; no attention is called to the production of first-class ceramic art-only a plain and simple statement that Mintons are potters. Yet, in the nineteenth century, no firm excelled this in making china which was not only a triumph of execu- 
tion in its high qualities, but, in producing such quantities of really fine goods, it was also a triumph of efficiency, which in this department of British trade has gone far to maintain the national reputation for superiority of manufacture. When any firm adopts and maintains the highest standard in its productions, its credit therefrom becomes a national asset, and Mintons' famous name has won its way to worldwide recognition because, from the most simple and cheap ware to the most elaborate and costly porcelain, one test has been applied-that of excellence. Nothing less has satisfied the proprietors, and the public fully appreciates the position.

The marks used by Minton were many ; usually the name MINTON was impressed upon the ware, or MINTON \& BOYLE, MINTON \& CO., and others given below, mostly printed. There are two others which may puzzle some in the absence of the name of the firm. "B.B" with "New Stone" is one ; "B.B" indicates " best body," and refers to the paste. The other is "AMHERST. JAPAN No. 62 Stone China"; this, used from about I823, simply names the pattern.

\section{MINTON'S MARKS.}
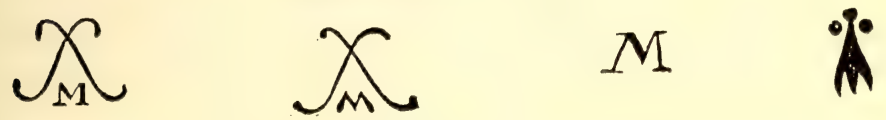

Sometimes the words "FELSPAR CHINA," "NEW STONE or "SEMI CHINA" occur.
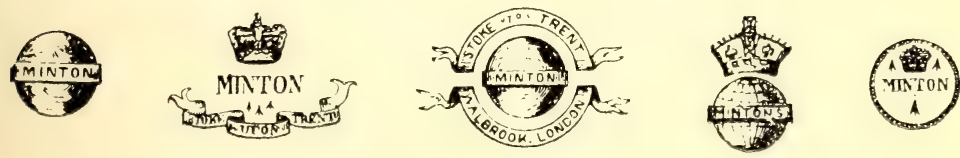

M.\& CO. M.\& B, H.M.\&CO.

\section{Minton, Hollins \& Co.-Tiles}

The firm of Minton, Hollins \& Co., at the Patent Tile Works, manufactures tiles for pavements, wall-linings, hearths, fireplaces, and for other purposes, in marvellous designs, and 
in a variety of forms, such as glazed and unglazed encaustic tiles in many colours and varied combinations, majolica and enamelled tiles in bold relief and richly coloured, or flat with printed or painted decoration, and so on, including many tesseræ for geometrical or tessellated pavements of beautiful patterns.

Although Herbert Minton conceived the idea of making encaustic tiles in 1828 , which resulted in many experiments, it was not until 1840 that the tile department was established. In August I845 Hollins joined the general business, when tile-making became a separate concern under the title of Minton, Hollins \& Co. Next year, Wright, a son of the patentee, became a partner in Minton, Hollins, and Wright. In 1868 the partnership ceased, and M. D. Hollins remained as the chief of the firm, which reverted to the former name, Minton, Hollins \& Co.

Particulars of the manufacture are given under "Mintons," and the only further statements that I need make concern the extraordinary success which has attended the manufacture. Not only has that been recognised by Royal appointments, but no less than ten first-class medals have been awarded: London I85I, Paris I853, London I862, Paris I867, Moscow I872, Vienna I873, Philadelphia 1876 , Paris 1878 , Melbourne I88I, and Calcutta I884. This world-wide record reflects the estimation, the high appreciation, in which the productions of this enterprising and successful firm are held, and it would be scarcely too much to say that the tiles, for durability of material and superiority of design, are unequalled. The foresight and determination of Herbert Minton have been fully vindicated. The marks are the name or initials M., H. \& Co. placed on the back of the tiles. The illustration gives an idea of some of the work.

\section{The Campbell Company.-Tiles}

In 1868 , when Hollins remained as sole proprietor of the tile works of Minton, Hollins \& Co., a company took over the interests of R. Minton Taylor, who had at that time acted 


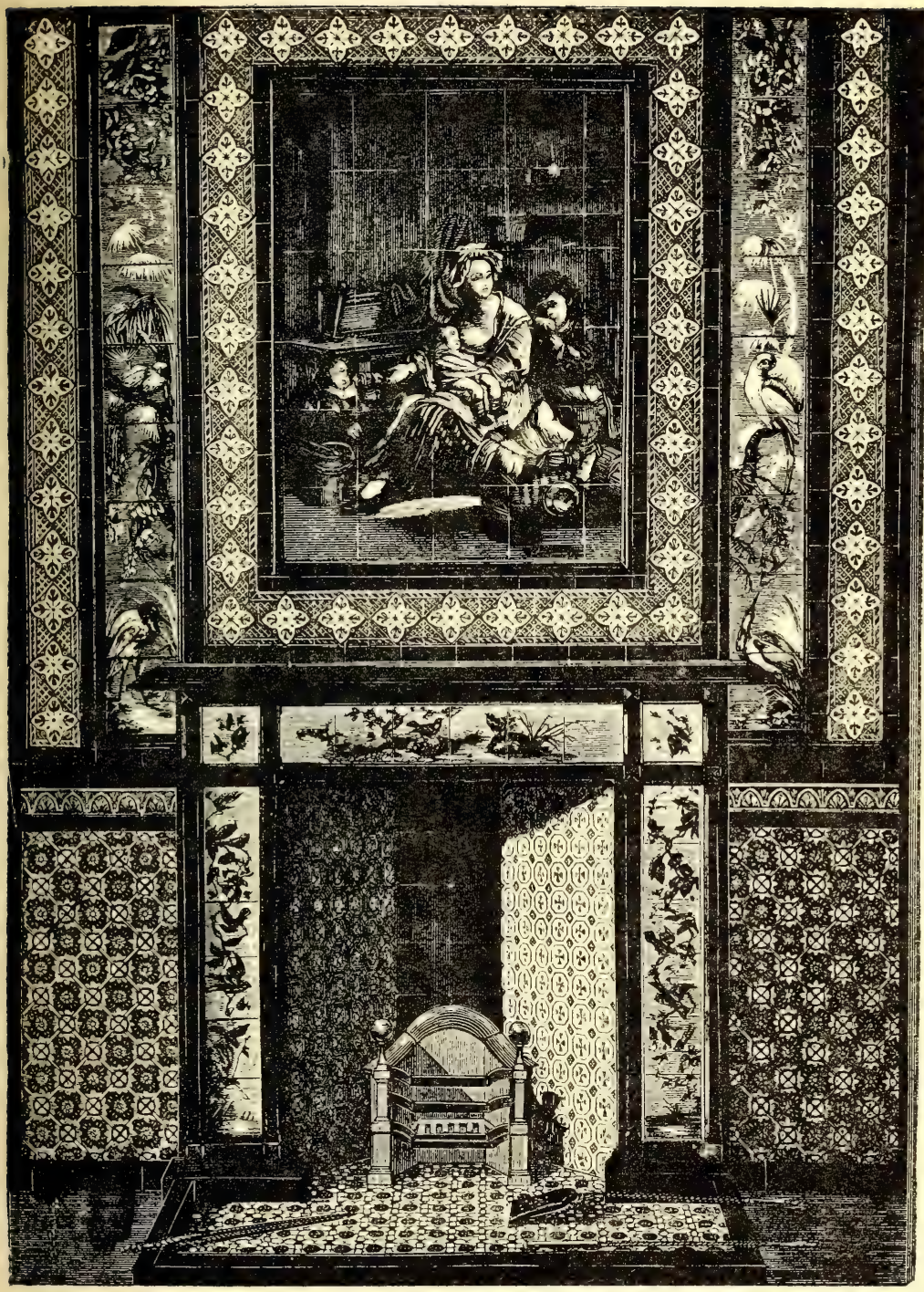

TILES. MINTON, HOLLINS \& co.'s EXHIBIT, PHILADELPHIA EXHIBITION, I876 
on the management. A new factory was constructed in 1876 at Stoke, where encaustic, mosaic, geometrical, and majolica tiles were produced in many varieties, embodying designs which ranged over a wide field of conventional and classical subjects, very much after the styles which brought distinction to the neighbouring pottery.

Here again the encaustic tiles, usually red or buff, are manufactured in all colours, and in many combinations, which reflect credit upon the workmen, as the designs do upon the artists. So, too, the geometrical tiles in great variety rival those which other factories make, being specially noted for the accuracy of their dimensions, a point of vital importance.

Then the tiles not meant for pavements or floors or any such use, but for walls, ceilings, friezes, flower-boxes, and fireplaces, are distinguished by their excellence. Finely modelled, often in high relief, harmoniously and richly coloured, they reveal the best qualities of such ornament in which arabesques and other conventional forms are scarcely less praiseworthy than those designed from nature. Minton Taylor's studies of trees, birds, and flowers show much power ; he has appreciated the full value of nature-study in this relation to tiles.

Other work is the making of tessellated pavements, which need not be dealt with here, except to remark that the chief designers were E. W. Pugin, J. Gibbs, J. Seddon, and Dr. Dresser, who had much to do with the founding of the Linthorpe pottery, which see. The proprietor of the factory, Colin Minton Campbell, is the head of Mintons; and Minton Taylor is the manager. The mark, which was the initials of the words, Robert Minton Taylor, Fenton Tile Works, has been succeeded by the name of the company encircling the points of the compass-NEWS. 


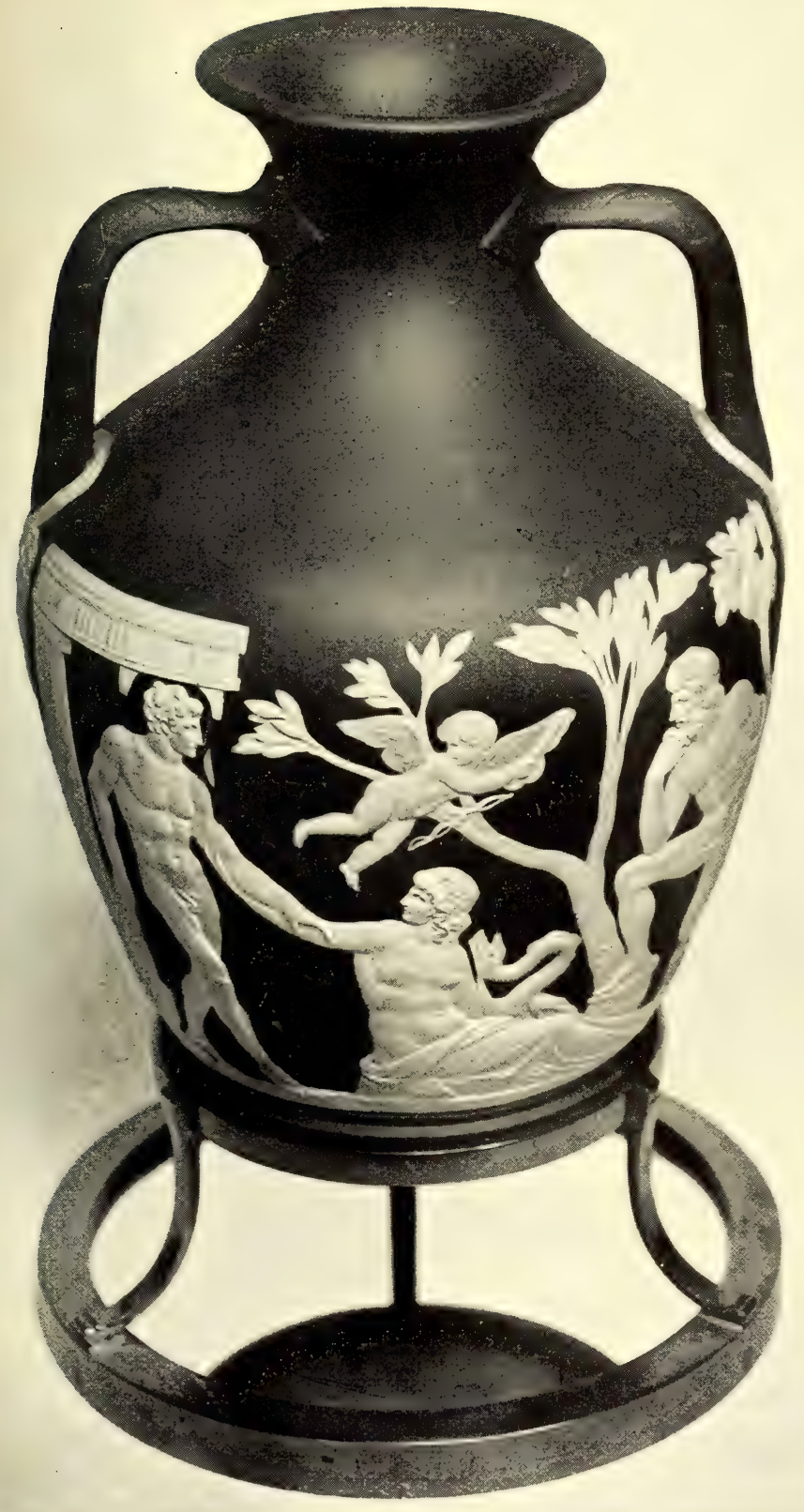

BEAUTIFUl MODERN WEDGWOOD. PORTLAND VASE. 



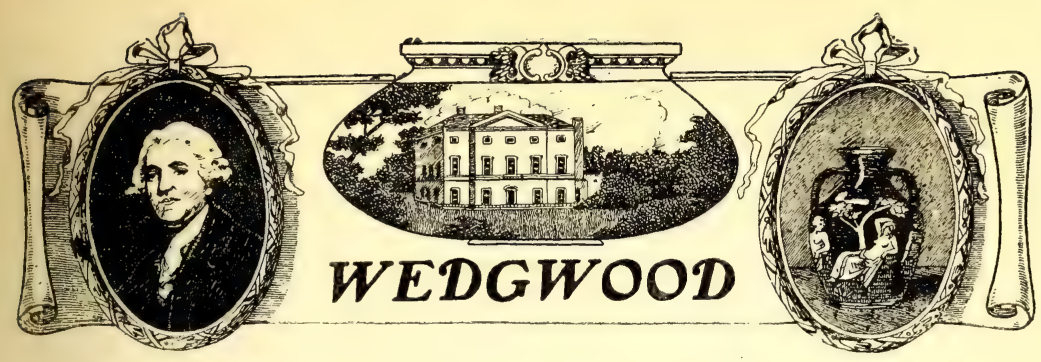

CHAPTER VI

\section{THE MASTER POTTERS AT ETRURIA}

\section{Wedgwoods}

ENGLAND's greatest potter, Josiah Wedgwood, passed away in I795, just before the beginning of the nineteenth century. Five years before his death he took as partners his three sons, John, Josiah, and Thomas, and his nephew, Thomas Byerley. Byerley's experience and skill were of the greatest value to the management until his death in 18 Io. He introduced the manufacture of china, which was discontinued in about ten years, so that it is rare. In body-texture, in colour, in glaze and decoration, it was extremely good, and its value is increasing.

The second Josiah Wedgwood carried on the business from I8Io to I823 when his eldest son, the third Josiah, became a partner, and Francis, another son, was admitted to the same privilege in 1827 . The works were continued on the old lines-the buildings even now are unchanged in the jasper department, the processes for making it are the same, and in many cases, the workmen are the descendants of the men who helped Josiah, the master potter.

Then, in I84I, the father retired, and next year his son Josiah followed him, so that from I 842 to I870 Francis Wedgwood represented the family, being associated with other partners, John Boyle I843-5, and Robert Brown 1846-59. Though the marks upon the ware were confined 


\section{I22 I9TH-CENTURY ENGLISH CERAMIC ART}

to WEDGWOOD, with the one exception of the WEDGWOOD AND Bentley stamps, which were in use from I 768 to I 780 , the title of the firm changed with its varying constitution.

Thus it was that Etruria-the celebrated establishment founded by Josiah Wedgwood, and where the knowledge and the classic taste and genius of Flaxman, combined with his own ability, gave a world-wide reputation to the firmwas represented amongst the exhibitors in $185 \mathrm{I}$ by Wedgwood and Brown.

The illustrated catalogue says they

" have reproduced some of the best articles originally designed or executed by its famous founder. There are still many designs of high quality which have not yet been worked out, and we may instance the group of the Infant Hercules strangling the Serpents, said to be the work of Flaxman, and now first made for the Exhibition in Hyde Park. The Venus which we engrave is also produced for the first time, on the same occasion, as well as the Cupid. The entire series of works displayed by the present firm are of the classic form and style of decoration, so well-known to connoisseurs; the ground of each article being of a lavender tint ; the figures and ornaments, in pure white clay in relief upon the surface, have the delicate and beautiful shades of the tint faintly appearing through the more delicate parts. Many of these vases are of large size, and some have figures directly copied from the antique; others being designed in strict accordance with those upon the Greek and Roman gems. Indeed, the Wedgwood imitations of these rare and costly articles have always been highly prized. There is much simplicity in the general character of the floral and other ornament which decorate the surface of these choice works; and we rejoice to see this eminent house again prepared to assert its position among the principal Art-manufacturers of the present day; attesting to the deserved character obtained for the establishment by the famous Josiah Wedgwood. These works are all carefully and beautifully executed, and deserve the high praise they will command ; and the re-awakened attention which will be insured to one of the most famed and tasteful of English establishments, in connection with plastic art."

I can only add that the opinions thus set out are worthy 

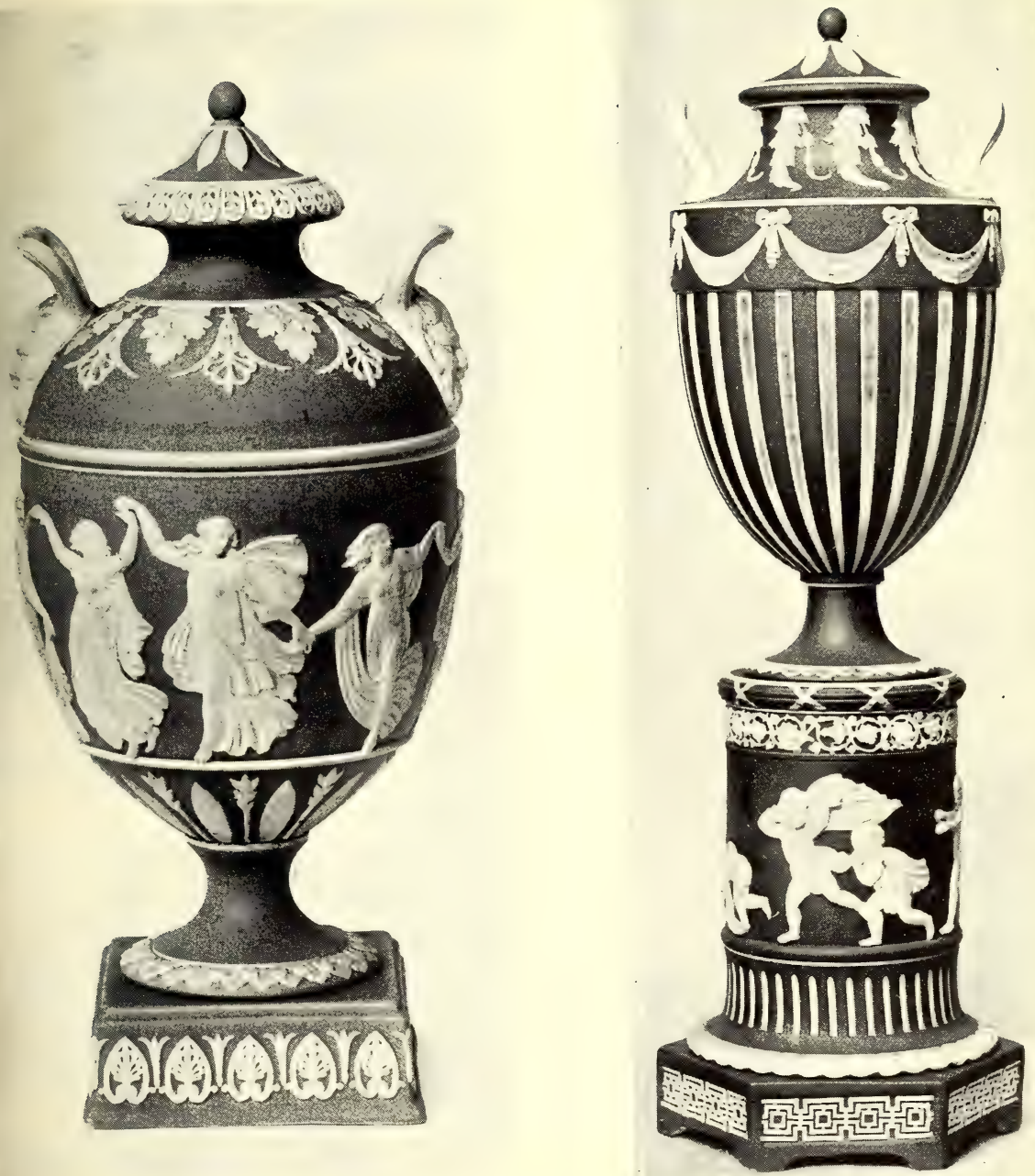

MODERN WEDGWOOD VASES. 


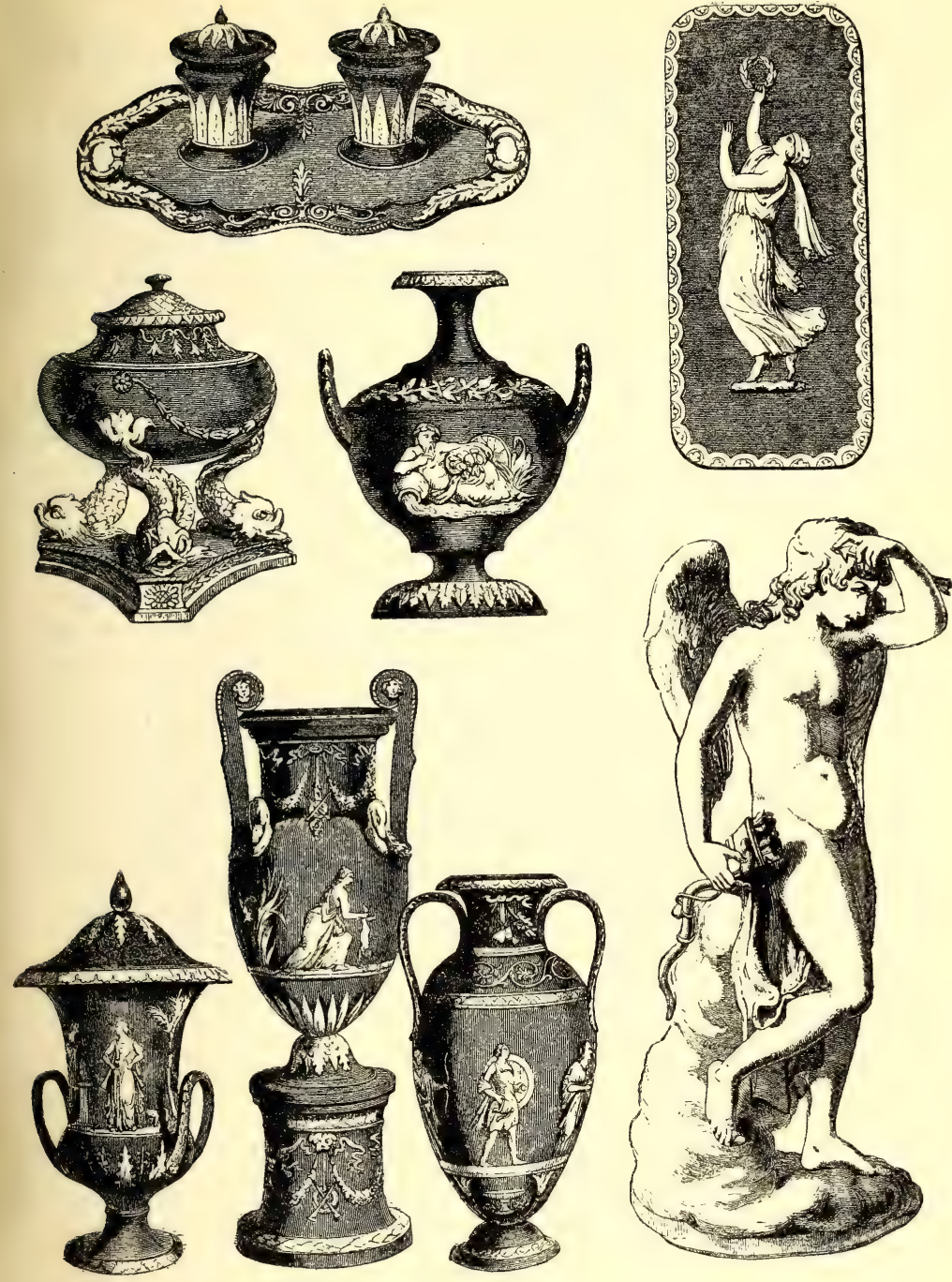

WEDGWOOD'S EXHIBITS IN I85I. 


\section{I26 I9TH-CENTURY ENGLISH CERAMIC ART}

of careful consideration by those who love old Wedgwood ware, and are unable to buy it owing to its cost.

That notable French collector and author, Monsieur A. Jacquemart, has left on record a short account of Wedgwood in his work, Les Merveilles de la Ceramique, which I quote, as it sets out in a compressed form the chief products made by Wedgwood and by his successors in the nineteenth century. The manufacture of the various classes of goods has never ceased at Etruria, which we place in Hanley rather than Burslem, as M. Jacquemart does.

"De I759 à I770, cette ville devint le centre de la plus brillante usine de l'Angleterre, celle de Josiah Wedgwood; les produits de cet illustre inventeur sont très-difficiles à classer ; tous sont dérivés de l'earthen ware ; mais la pureté de leur pâte, l'adjonction du kaolin dans certaines variétés les rapproche tellement de la porcelaine tendre, qu'on pourrait y classer beaucoup de ces petits chefs-d'œuvre. On connaît les remarquables médaillons à fond noir sur lesquels se détachent des bustes et bas-reliefs d'un blanc translucide; on voit plus fréquemment encore les charmantes imitations antiques où les figures en biscuit blanc s'enlèvent sur un fond bleu doux; ces délicats ouvrages, appelés queen's ware parce que la reine s'était faite la protectrice du fabricant, se distinguent cependant en espèces que le fondateur de l'usine désigne ainsi: porphyre; basalte ou biscuit de porcelaine noir; biscuit de porcelaine blanc; jaspe à reliefs blancs : biscuit couleur de bambou; biscuit de porcelaine propre aux appareils chimiques. La vogue de ces élégants travaux donna bientôt à l'établissement un développement considérable.

“En I770, un village entier, appelé Etruria, fut fondé pour contenir la fabrique et ses employés; le célèbre Flaxman composait les sujets et modelait les plus importants ouvrages. $\mathrm{Du}$ reste, les poteries de Wedgwood devinrent le type des fabrications générales, et à côté des objets inscrits en creux du nom de l'inventeur, on trouve une foule d'imitations dont les auteurs sont à peine connus."

Cream-colour ware may be ascribed to I762; it became Queen's ware two years later, when a complete dinner-service 

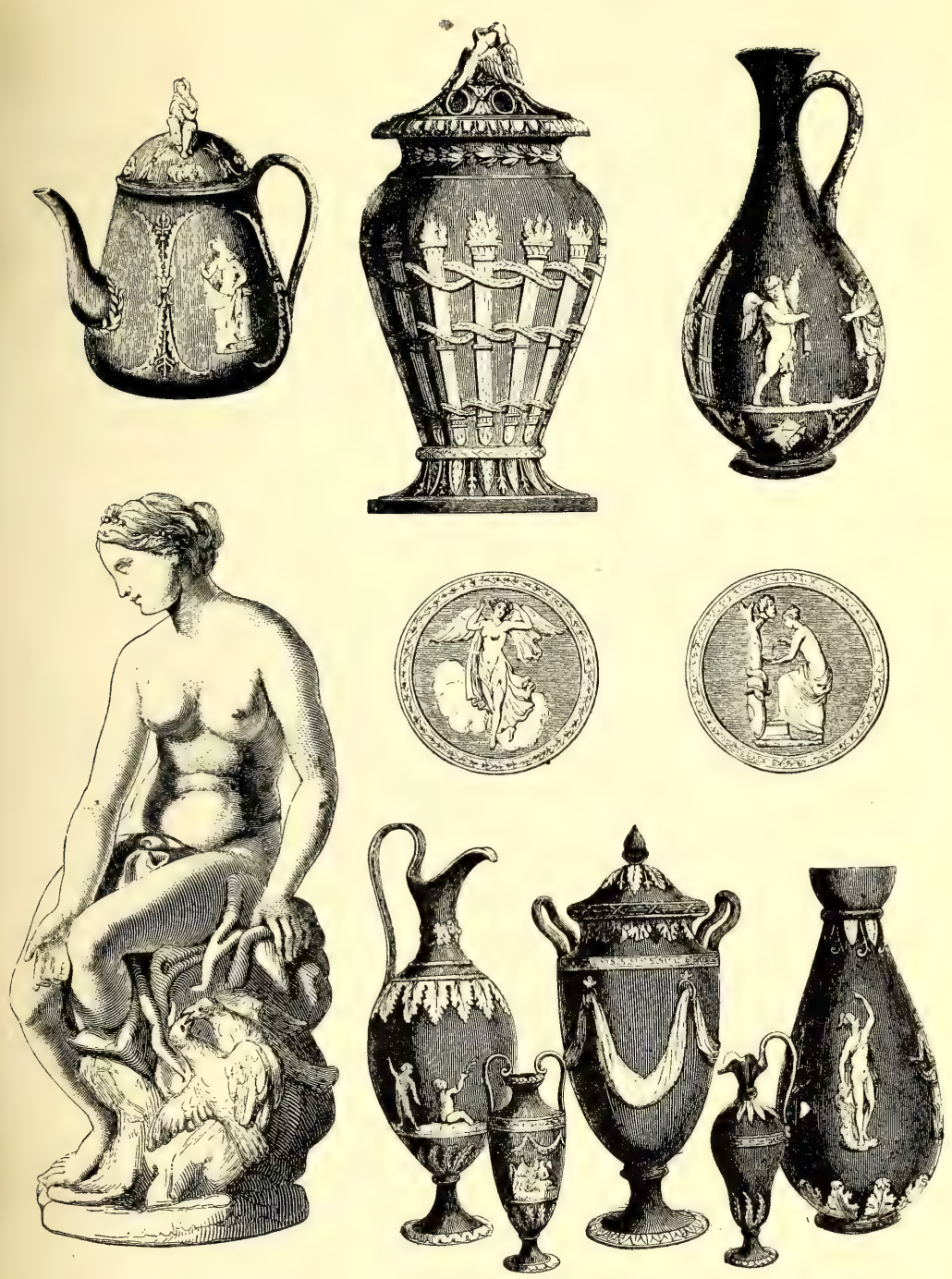

WEDGWOOD'S EXHIBITS IN I85 I. 


\section{I28 I9TH-CENTURY ENGLISH CERAMIC ART}

was made for Queen Charlotte, who appointed Wedgwood "potter to the Queen." Basaltes ware was improved in I762, and in I773 the potter described it as

"a fine, black porcelain, having nearly the same properties as the basaltes, resisting the attack of acids, being a touchstone to copper, silver, and gold, and equal in hardness to agate."

Notwithstanding these fine qualities, the black basaltes has never received that homage from the collector which it deserves, though its modelling often marks the highest level of excellence. Even the best period, I768-80, is but moderately valued, but, though the absence of colour will always militate against such success as has followed the jasper ware, I think the day of black basaltes will come. Certainly the Etruscan painted vases, which are mostly in the basaltes, are more decorative because of the painting effected in encaustic colours. The variegated or crystalline ware presents many points of interest. Some of the best pieces might be mistaken for actual hard stones cut by the lapidary, so truly does the veining imitate nature in serpentine, agate, verde antique, green jasper, grey granite, and red porphyry. The brilliant polish or glaze adds greatly to the beauty of this ware, in which two processes were employed. The first was an application of colours to the surface of Queen's ware, the cream colour being hidden by them; the second carried the colouring in the solid clay, which was veined in the mixing, not an intricate process. Really fine specimens of solid agate, etc., are regarded with the high favour of collectors.

With clays from Dorset, Devon, and Cornwall, with chinarock or growan-stone and flint, and later with the addition of baryta, were produced "the fine white terra-cotta of great beauty and delicacy," and even better, "the fine white artificial jasper," "possessing the general qualities of the basaltes, and capable of receiving through its whole substance such colours which no other body, ancient or modern, has been known to do." This was the origin of the famous 


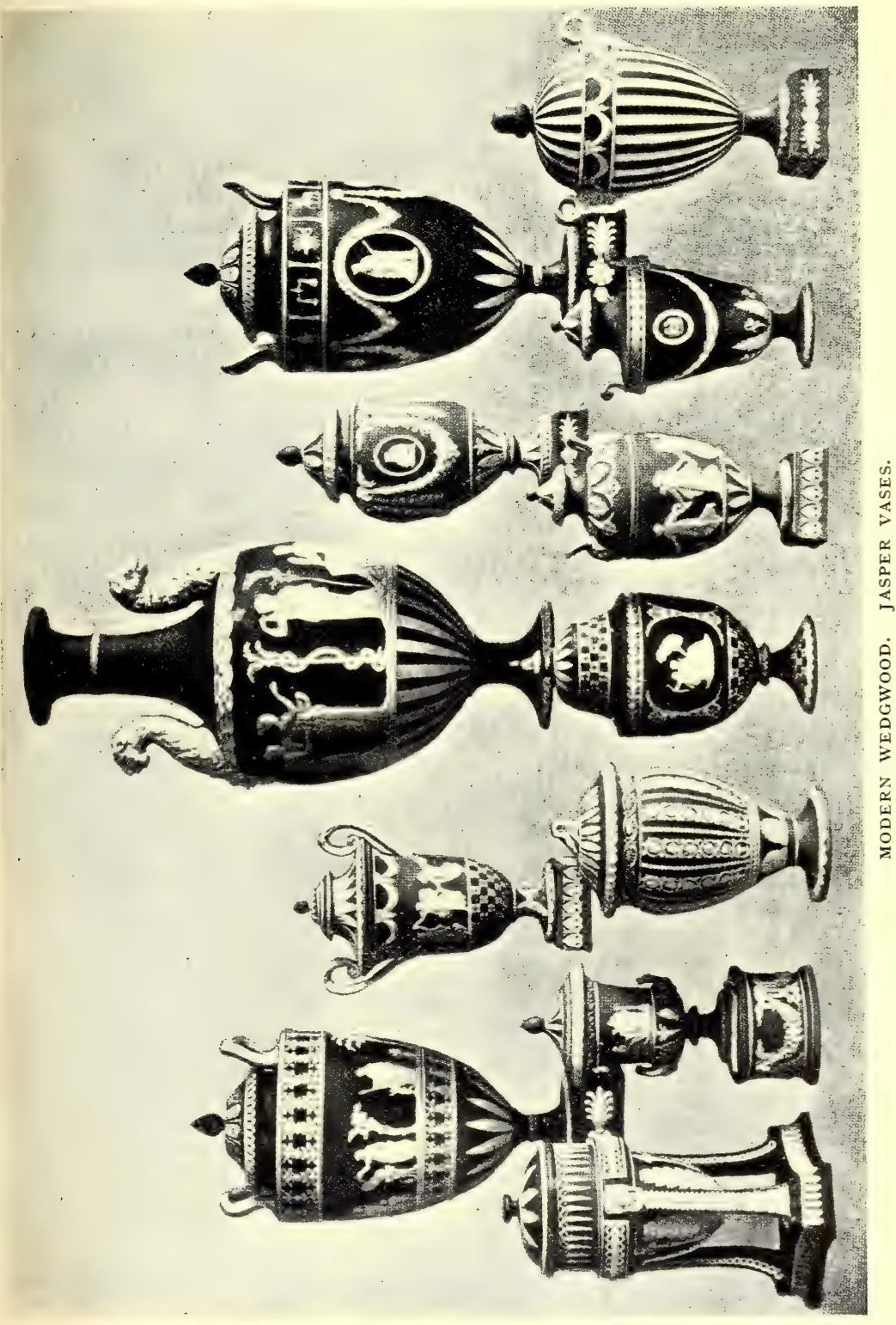



jasper ware, which was peculiarly fit for cameos, portraits, and all subjects in bas-relief, as the ground could be made of any colour throughout in solid jasper, whilst the raised figures were in pure white. As a matter of fact, solid jasper is almost entirely blue. The jasper dip was a surface colouring, produced by a wash containing cobalt or other metallic oxides, which gave blue of various shades, and black, lilac or lavender, olive-green, pink, and sage-green.

Though these were invented in the eighteenth century, their use has never ceased, but examples with a yellow ground are rare, and we have noted that the exhibits in $185 \mathrm{I}$ had the lavender or lilac ground. In the high reliefs of portraitmedallions, plaques, and tablets, the waxen body is mostly used, that for the gems being the semi-opaque body, which, from the extremely low relief, showed up the field of colour. Sometimes a white jasper body has a wash or dip of colour in front which differs from the blue at the back, sometimes a blue jasper dip is applied over solid blue jasper, and sometimes, too, the ornament applied to a jasper-dip vase may be in solid coloured jasper. When the figures and other reliefs in white are applied to a coloured ground, very often the colour shows through the thinner parts of the white decoration. In all of the finest jasper ware the uniform smoothness of the surface, and the clearness and sharpness of the raised ornament are accompanied by a perfect uniformity in the paste or body, the whole result being of the highest excellence, exquisite in delicacy and finish.

Red ware, or rosso antico, is still made of clay obtained locally, but the portrait-medallions and bas-reliefs made from it have not been successful ; even when black was applied in ornamentation of the red, the results were not satisfactory, but when the colours were reversed, articles of great beauty were made, which now are valued by collectors. Canecolour ware, or what Jacquemart terms biscuit couleur de bambou, became very popular, and in its various tints is very attractive, though it was used almost entirely for teaservices and other articles.

Jewitt properly remarked with regard to Wedgwood ware 


\section{I32 I9TH-CENTURY ENGLISH CERAMIC ART}

and its success that the present-day art productions of attractive and showy character are so extensively made, and so readily purchased at a low rate, that the quiet, unobtrusive, but truly lovely bas-reliefs originated by Wedgwood only command a limited sale, and even then at such prices as will not admit of the same scrupulous attention being paid to their production as in the earlier days. There can be little doubt that before the advent of the present proprietors some slackness had crept into the works, so that the productions failed to reach the high standard of all-round superiority which had so long distinguished Etruria, although the power to accomplish the very finest designs has never left that home of ceramic art. The Portland vase, for instance, was reproduced in 1877 regardless of expense, in exact imitation, both in form and colour, of the first copies.

The firm continues to produce jasper, basaltes, red, creamcoloured, and all the other wares for which the factory is famous. Even now there are rivals who have survived from the eighteenth century-rivals or imitators, which ? The question is not quite so easy to answer as it looks, but Wedgwoods have preserved an unbroken record of continuous production where others have lapsed and followed the lapses by revivals. That continuous stream of chaste and truly beautiful jasper ware in vases, plaques, medallions, etc., has been accompanied by developments which have introduced many new and beautiful designs and combinations. With dark or light blue grounds, and others in pink and sagegreen, the raised figures and ornaments have still maintained their superiority. Was it in $I 777$ or $I 785$ that the jasper dip was discovered? We know that it displaced the solid jasper until about $185^{8}$, when it was used again. But let us follow the special feature of the nineteenth century, the new departures-the majolica first. The true Italian majolica, and Minton's reproductions of it, appear to have been made of a somewhat coarse cane-coloured clay, decorated with opaque enamel colours; but the Wedgwoods, who commenced the manufacture in I860, applied transparent coloured glazes to a white body, and by these means secured 

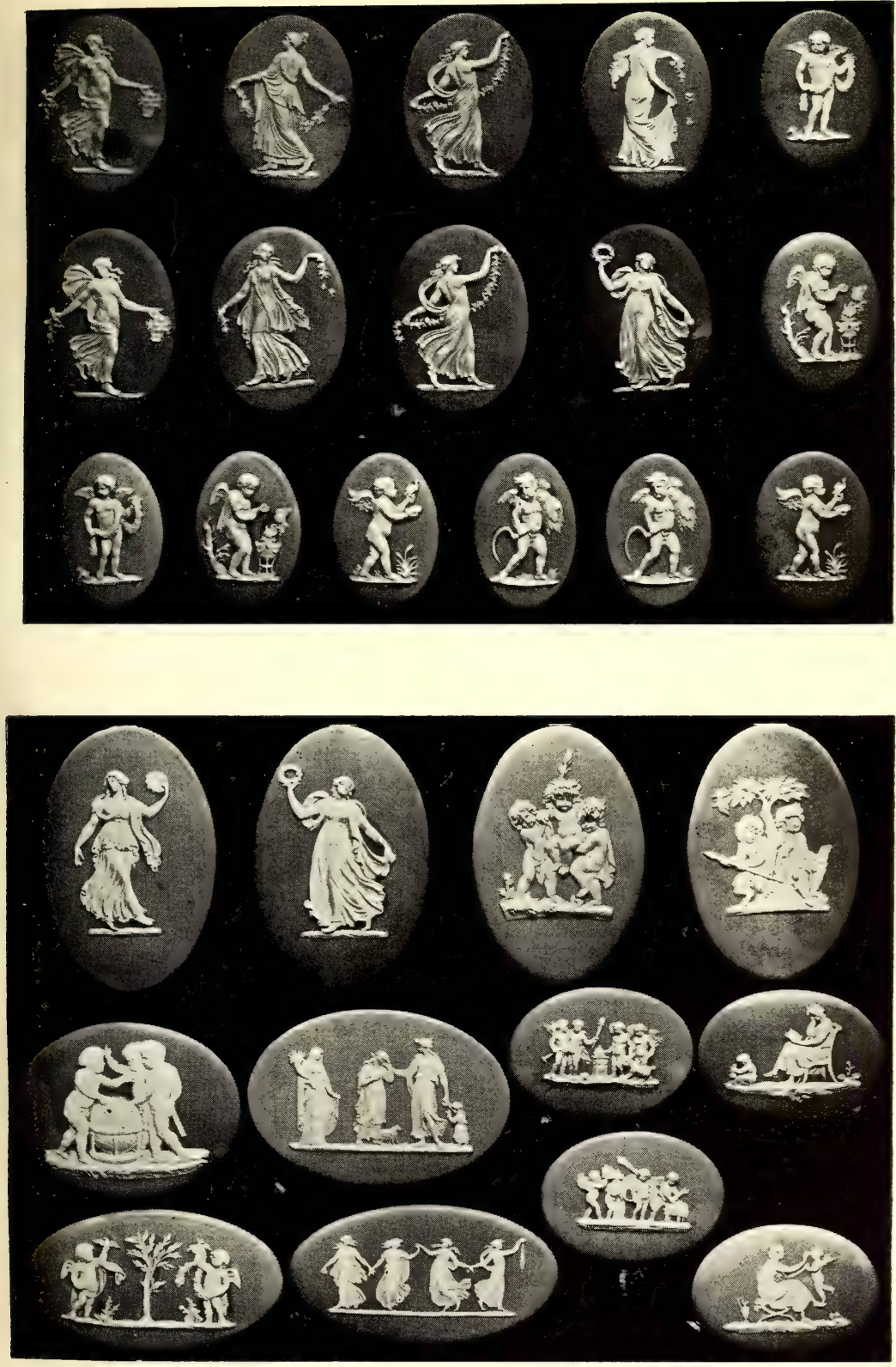

MODERN WEDGWOOD. JASPER PLAQUES WITH VARIOUS COLOURED GROUNDS. 



\section{I36 I9TH-CENTURY ENGLISH CERAMIC ART}

work of such potters and such artists cannot remain for ever despised.

Few people remember that Wedgwoods made inlaid ware in the nineteenth century. I have before me a tobacco-jar of black basaltes inlaid with Greek-key and other patterns in a rich yellow clay, glazed inside and marked FAO I43 over WEDGWOOD. The letter $\mathrm{O}$ may indicate $\mathrm{I} 860$ or I886. In any case it is modern, striking in its novelty, pleasing in its simplicity, eminently suitable for its purpose, resembling remotely the faience of Oiron or St. Porchaire, so often termed Henry Deux ware, in being inlaid. In both a pattern was impressed in the wet clay which was filled with another coloured clay. Then the surface was either turned or scraped level, so as to reveal the inlaid design upon the body of the piece.

In addition to cream-coloured ware-the Queen's warewhich has never been neglected by the Wedgwoods, there was a PEARL ware with the word impressed. This was much whiter than the cream-colour, in fact it may be noted as the precursor of the ordinary white ware of the present day. Yet the fine qualities of the Queen's ware maintain its position-light and pleasant to the touch, true in the potting, faultless in glaze; services and every variety of useful articles are made in it, as well as in the pearl body, of great hardness and durability, either plain white, printed, or otherwise decorated. Under the third Josiah, I823-42, the process of transfer-printing in blue and black was most successful, owing to his discovery of a special glaze which was eminently suited to that process, giving rich, soft, flowing effects which have not been obtained elsewhere.

Of course, after what has been said about the repetition of blocks from early times, the forms designed by John Flaxman, William Hackwood, Dalmazzoni, Davaere, Pacetti, Joachim Smith, Aaron Steel, Henry Webber, Lady Templeton, and John Coward are not uncommon in nineteenth-century Wedgwood ware, though much of the work of the other artists is ascribed to Flaxman, almost as a tradition. Yet, later than all these, other modellers were engaged, notably 


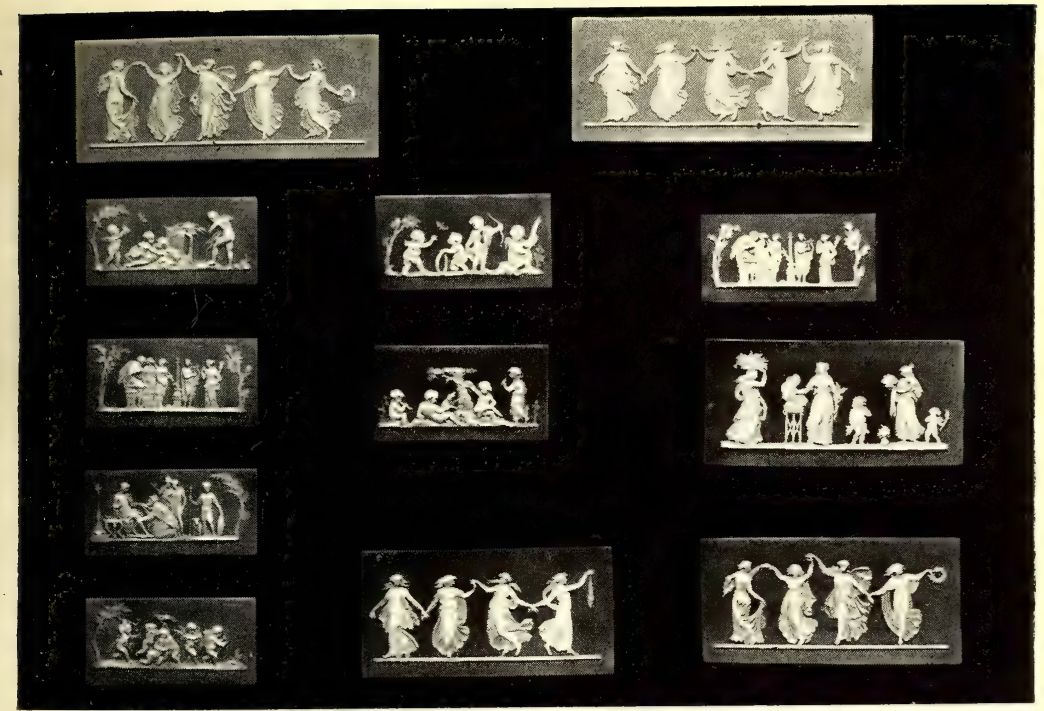

MODERN WEDGWOOD. JASPER PLAQUES IN WHITE ON DIFFERENT COLOURED GROUNDS.

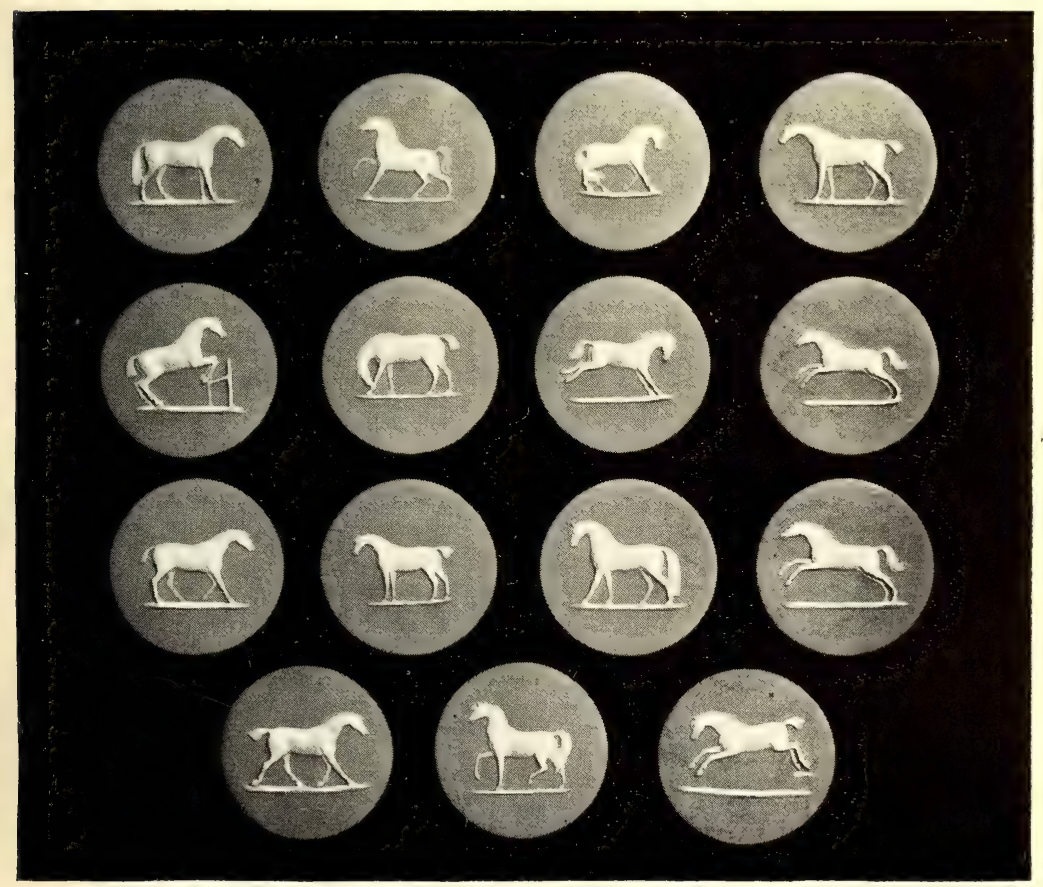

MODERN WEDGWOOD. STUBBS' HORSES IN JASPER WARE. 

Charles Toft, who was, about I870, one of the chief figuremodellers at Elkington's. He designed many of the pieces exhibited at Paris in 1878 by Wedgwood. Before his time, however, another and more celebrated artist had lived and worked at Etruria, and when the climate affected him injuriously he went back to France, where he still painted for the Wedgwoods. This was M. Emile Lessore of worldwide fame. At Sèvres first, in I85I, he turned his attention to china-painting, being one of the first to use the freedom of the artist's brush in ceramic decoration,

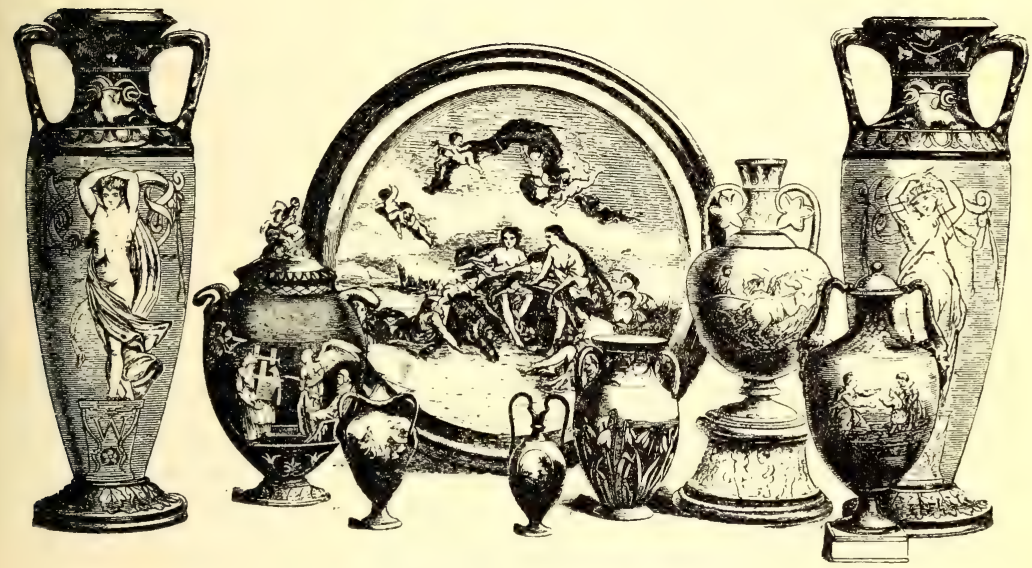

WEDGWOOD WARE. THE EUROPA PLATE, ETC., PAINTED BY LESSORE.

whereas before his time, with but few exceptions, painting on china was the stippled work of the miniaturist. His new style caused dissension at Sèvres, so he came to England in 1858, and was employed at Mintons' for some short time, migrating then to Etruria, where he obtained the success he so well deserved, for in London in I862, Paris I867, and Vienna I873, medals were awarded to him. When he went back to France he painted pieces which were sent to Etruria; during the siege of Paris some of his best works were concealed in the cellars of his cottage, and afterwards forwarded as before. When he died, in 1876 , the world 


\section{I40 I9TH-CENTURY ENGLISH CERAMIC ART}

lost a master of subdued and delicate colouring and artistic design, whose place was indeed hard to fill.

Still the work went on, another artist from Mintons', Thomas Allen, a noted figure-painter, was appointed, and some of his work in colours applied on the biscuit and fired with the glaze at a high temperature was appreciated at the Paris Exhibition in 1878 , with that of Charles Toft before mentioned.

During recent years many potters have adopted colour processes, for decorating ware, founded upon photography, and in these the firm of to-day was foremost, as it is in every movement tending to advance the position of a great and valuable industry, an important part of national commerce.

No doubt you have noted one characteristic of the whole of the I85I ware-the ground colour is lavender, and the shades of lavender tint the thinnest parts of the cameo ornament, which, at the works, is applied by the ornamenter upon the coloured background. To do this without in any way blurring the sharpness of the design as it leaves the mould implies a dexterity only acquired by years of practice. The working-moulds have a natural tendency to wear away, thus destroying the sharpness of the cameo ornament. They have to be renewed from block moulds. The original designs by Flaxman, Hackwood, Webber, and others, were modelled in wax, and the block moulds are made from these. Hence much care is necessary to preserve the block moulds whilst remembering, above all, the sharpness and clearness of outline which alone confer distinction upon the work, which might easily be spoilt if the ornamenter neglected to apply his clays in right order, for the shrinkage of the ornament must correspond with that of the background, both in the drying and the firing.

The points which mark excellence, in the eyes of the collector, on jasper plaques, vases, etc., are the smoothness and colour of the background, the sharpness and translucency of the ornament, and the under-cutting, which is often distinctive of the finest specimens, in which certain parts which could only be moulded flat are relieved by cutting whilst the clay is soft, 
Sir A. H. Church's criticism on Wedgwood and Wedgwood ware is so masterly that I venture to submit it for the consideration of my readers, who may not agree with the whole of his conclusions, though some of them can scarcely be denied by the most ardent admirer of the ware :

"There is a notable difference between theproductions of Josiah Wedgwood and those of his predecessors. Hitherto the potter's art in England had been essentially English. True, it had received from time to time foreign elements, yet it had assimilated them. But no previous potter ever worked upon so large a scale, nor so completely modified the style and the materials of the art. Henceforth Wedgwood's improvements and Wedgwood's patterns and designs were copied far and wide. His improvements in the potting or fashioning of his wares, and in their body or paste, were very great and perfectly legitimate. So much as this cannot be said of the artistic value of his work. Accepting, and even encouraging, the prevailing fashion of his day, Wedgwood adopted the rather shallow conceptions of classic art then in vogue.

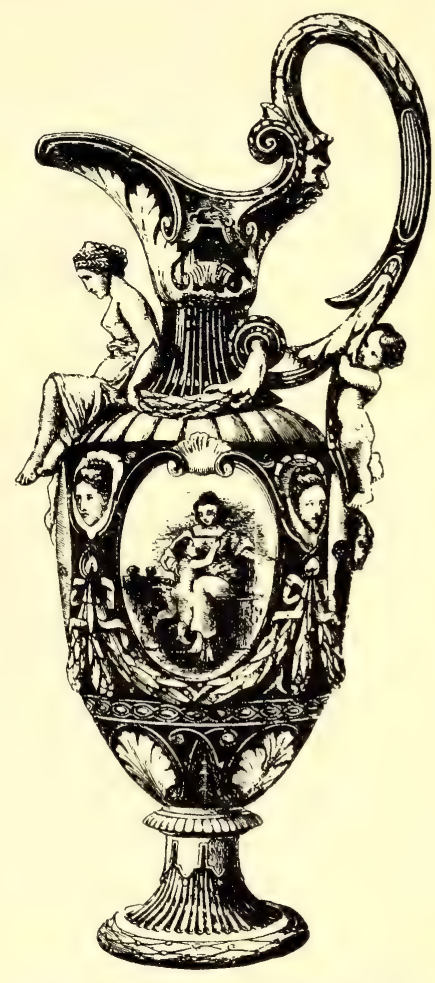

WEDGWOOD WARE. EWER PAINTED BY LESSORE, MODELLED BY PROT $\hat{\Lambda}$ T.

Classic forms stimulated and satisfied his efforts towards mechanical perfection: classic finish he tried to render by means of those fine pastes which he was ever elaborating.

"But no amateur of antique gems would accept Wedgwood's copies as adequate translations of the originals. The lens reveals the roughness of grain, the lumpiness of surface, and the faults of contour in the one, while it serves but to bring out the beauty of the other. Even the Barberini vase, 


\section{I42 I9TH-CENTURY ENGLISH CERAMIC ART}

a masterpiece of potting, of material, of firing, and of every excellence of workmanship, is but a copy after all. Its shape is inelegant, and the story which its ornament was meant to tell, ill understood. What labour, what skill, given to work incapable of naturalisation! But to the portraits of contemporary celebrities which Wedgwood produced in jasper and basaltes wares, to his works after Flaxman, and to a great deal of his ' useful' ware, must be accorded the very highest praise.

"In a word, Wedgwood was a great potter, but not a great artist. In the former capacity he influenced favourably the whole subsequent course of English ceramic industry; less happy in their results have been his fondness for the antique, and his lack of originality. The 'taking' delicacy and finish of his wares induced a number of imitators to copy his copies. Perfection of material and workmanship displaced the old native picturesqueness, vigour was sacrificed to finish, originality to elegance. But it would be most unfair to the memory of Wedgwood if too much stress were laid upon this critical view of his methods and style.

"The improvements which he effected in the ceramic industry of the country were too substantial to be seriously compromised by the want of spontaneity in the artistic character of much of his choicer ornamental ware. Indeed, the latter formed in reality but a small proportion of the array of different productions which emanated from the works of Josiah Wedgwood. His 'useful' and ' table'. ware it was that made his fortune and influenced the whole subsequent manufacture of pottery in England. No earthenware, native or foreign, combined so many technical perfections. Well-ground clays and flint formed the body. The 'potting' was so good that every part and piece was in complete correspondence with every other, while no more material was used than was necessary to secure solidity. Plate rested perfectly on plate, lids fitted perfectly to kettles, basons, and tea-pots. The colours of the wares were refined and uniform, the firing complete, the glaze thin. And the forms of the 'useful' ware showed an exact adaptation to their uses. The spouts and lips of milk-ewers and jugs and tea-pots permitted of their contents being poured out with neatness; the handles could be held; the lids did not fall off.

"Wedgwood does not appear to have manufactured porcelain of any of the recognised varieties. But about the year 


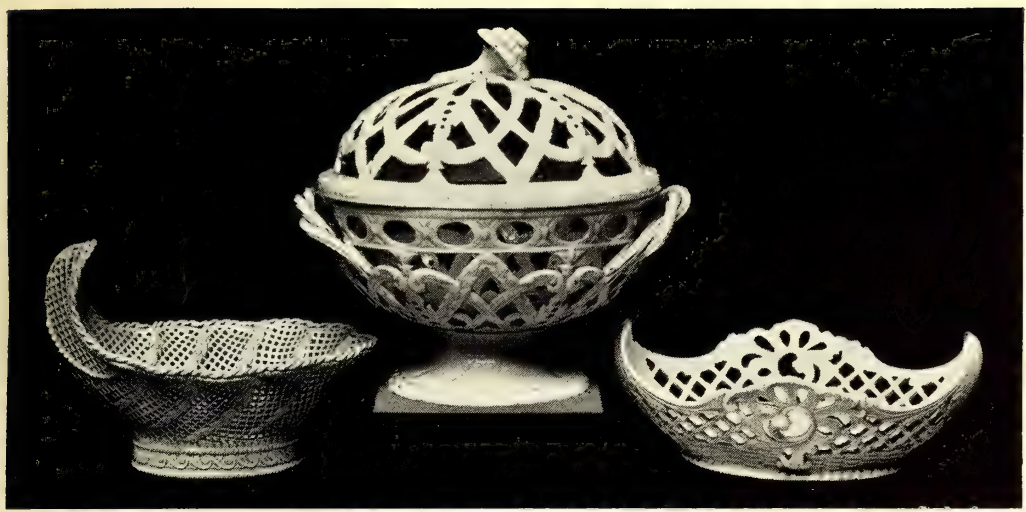

PERFORATED CREAM WARE COMPOTIFRS AND CHESTNUT BOWL AND COVER. MODERN WEDGWOOD.
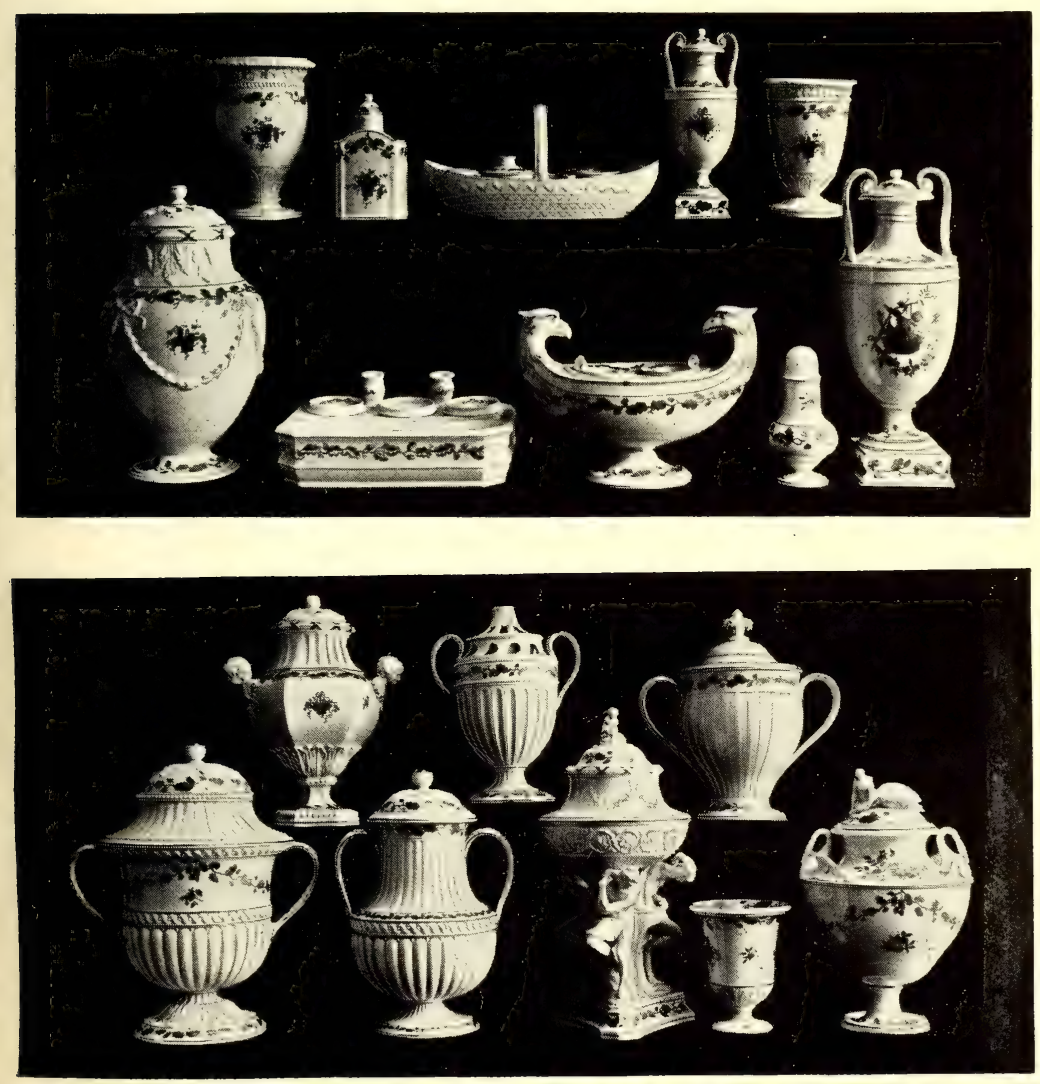

MODERN WEDGWOOD WARE OF FINE QUALITY. 

I805, ten years after Wedgwood's death, his nephew, Thomas Byerley, made a fine true porcelain: it was produced in small quantities for about eight or ten years, and is now but rarely met with. Unfortunately, its style of decoration and the forms it was made to assume do not, in most cases, exhibit a refined taste. The best specimens we have seen were comprised in a richly painted complete dessert-service, enamelled with conventional floral designs and richly gilt. Examples of Wedgwood porcelain with painted landscapes, naturalistic flowers, or embossed designs in low relief without colour, will be found."

Whilst remembering that the old forms designed by Flaxman are still produced, just as they have been throughout the nineteenth century, we must not forget that fine ordinary ware has also received great care and attention. The pearl body represents a high standard, not alone of whiteness, but of durability, and, like all ware of its kind, may be plain or highly decorated. Rockingham ware, too, in tea-pots, coffee-pots, and services, has had remarkable success. The cups are distinguished from others of that ware by being white in the inside. Red ware, porous ware, and, above all, the modern cream ware, have enjoyed much public patronage. The vine pattern, the thistle and scale, and many others found in to-day's pattern-books, such as the strawberry, the lag-and-feather, and the convolvulus, have just as many admirers as they had when they first appeared on the cream ware, which Wedgwoods make in a style superior to that of any other firm, a fact which was recognised when the firm was selected to produce a table service for President Roosevelt of over I,200 pieces.

As we might expect, blue-printing was introduced into Etruria at a very early period. We know that Josiah Wedgwood sent much ware to Liverpool for transfer-printed decoration before he set up his own machinery, but amongst the most charming blue-printed earthenware that of the third Josiah takes a high place, for he devoted himself to its improvement. A special glaze, combined with a rich, soft colour, rewarded his efforts, and before me is a willow-pattern 


\section{I46 I9TH-CENTURY ENGLISH CERAMIC ART}

plate which embodies all that is best in this style of decoration. It is marked with WEDGWOoD, and FF impressed with $\mathrm{O}$ in blue, printed. This ware, from $\mathrm{I} 820$ onwards, was very popular, and, of course, many other potters made similar ware. Some of them introduce a little volatilising salt into the sagger in which the ware is fired, to secure a blue known as a "flow" blue.

A few remarks have been made about Wedgwood china which was manufactured for a few years early in the nineteenth century, and then discontinued. The mark at that period, WEDGWOOD, was printed in red or blue. One of the most recent developments has been the revival of china ware, which, beginning in 1878 , has continued to the present day.

The productions of the firm, through all changes of proprietors, are divided into two classes-useful and ornamental. The former now comprises services of every kind in fine earthenware and in china, which for whiteness and transparency of body equals any other manufactured. Additional patterns are frequently added, whilst the old designs are not forgotten. In the "ornamental" section, the vases, medallions, and other articles are reproduced, with the addition of many more. As I shall show presently, the firm has not been content to stand still in mute admiration of the laurels gathered by its great founder, but during the nineteenth century it has been progressive and enterprising, so that at no time has it been more active than when that century closed.

When we speak of special objects like the Barberini or Portland vase, the original of which is now in the Gem Room at the British Museum, restored from the fragments into which it was smashed in I845, we must remember that the twenty-four copies which were sold at $f 50$ each were only a very small proportion of the total number made during the century under consideration. In fact, in making comparisons between the work of the great Josiah and his successors, whilst yielding the palm to the charm of his super-excellence in the unsurpassable design and execution of his masterpieces, the Wedgwood jasper and other ornamental ware to-day is as far above its imitations as the products of the great potter 


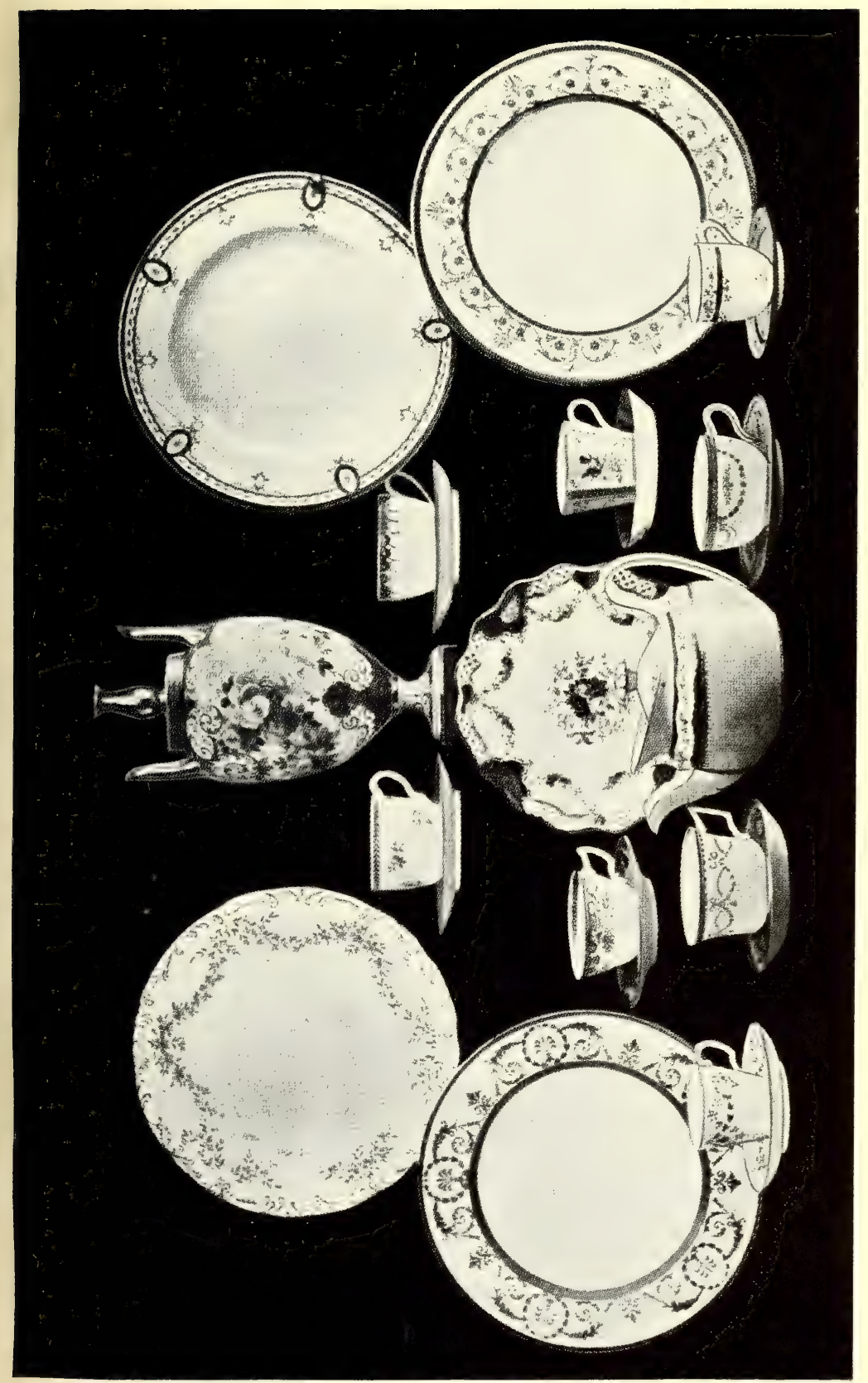

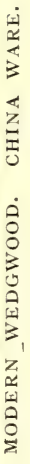



were above those of his imitators. What was true when Jewitt wrote in 1878 applies with equal force at the present time; but before considering that, we will refer to an event which happened at Etruria in the autumn of 1905, when two battered crates, which had been for years neglected, if not forgotten, were dragged to the light of day, revealing a wealth of trial pieces which dated from the time of the old master potter-the trial pieces from his own hands, his life work. Then careful search was instituted through the old premises, and in out-of-the-way cupboards and dark corners were found original wax models by Flaxman and other artists, with patterns and old pieces of ware-surprising specimens of old Wedgwood. Now they are exhibited in the Museum, which should be visited by every student of ceramic art, and specially by every admirer of Wedgwood ware. The Victoria and Albert and the British Museums, and some provincial museums, notably Nottingham, furnish further features for close study.

But the most careful student will suffer from the absence of data on certain points-the marks, for instance. Bearing in mind that the WeDGWOOD AND BentLey (I768-80) mark is found only upon jasper and crystalline agate or imitation stone vases, upon plaques, medallions, and portraits of the same period, and that it is seldom or never found upon blue and white jasper vases, nor upon examples of green, pink, lilac, or cane-colour, the only name used is WEDGWOoD. ETRURIA was added about I840, but soon disused. It is evident that WEDGWOOD, being used now exactly as it was in the eighteenth century, is no evidence as to the period of manufacture; and Miss Meteyard has pointed out that whenever three capital letters are found together upon a piece it is modern, certainly not older than 1845 , which leaves us with no guide except the superior quality of the old work. The same blocks were and are used, the same methods adopted, the same kinds of goods made, the same mixtures for bodies and glazes manufactured; but no record has been discovered which tells us what certain letters, flowers, figures, and numbers mean - whether they are workmen's marks or 
pericd marks. It is true that T.T.B.O indicates the tiptop of biscuit oven, T.B.O the top of biscuit oven, and M.B.O the middle. These were directions as to firing-they were instructions to the fireman, showing him where to place the saggers containing the green or unburnt ware so as to obtain the best results; but they have no evidence for the collector as to age.

It remains, therefore, a task for the expert to determine the age of the products of the eighteenth and nineteenth centuries, with the exceptions I have given. In I907 a mark making the date quite plain was adopted. The first mark is a figure 3, which indicates the third cycle of marks, then follows a capital letter showing the workman's mark, and another capital for the year mark, which for Igog is L, I9Io M, I9II N. Assuming that the alphabet has been used to M three times in three cycles, the letter A would have been used first in 1846 , then again in 1872 , and for the third time in I898. Though this may be absolutely correct, the answer is not given to the question, What is the age of this piece of Wedgwood having the mark of the three capital letters ? We know it is modern; but how modern? The mark-the vase with WEDGWOOD below-was first adopted in 1879 , and the word ENGLAND was added in I89r, to meet the requirements of the American Customs that imported goods should show where they were made.

The cream-coloured ware, famous as Queen's ware, is still made at the Etruria works. Just a short time since, the enterprise of the present proprietors, Messrs. Cecil and Francis H. Wedgwood, gave many interested spectators an opportunity of examining several fine specimens of the celebrated service which was made for the Empress Catherine of Russia. This service of 952 pieces cost $£ 3,000$, and the decoration, of landscapes from English sources, was very remarkable, for much of the cream ware, which was the largest product of most of the potters, was plain, without any decoration at all, and painting was far from common. In this service the enamel colours were delightfully soft and delicate. Upon the pale yellow body the scene, painted in brown-tinted 


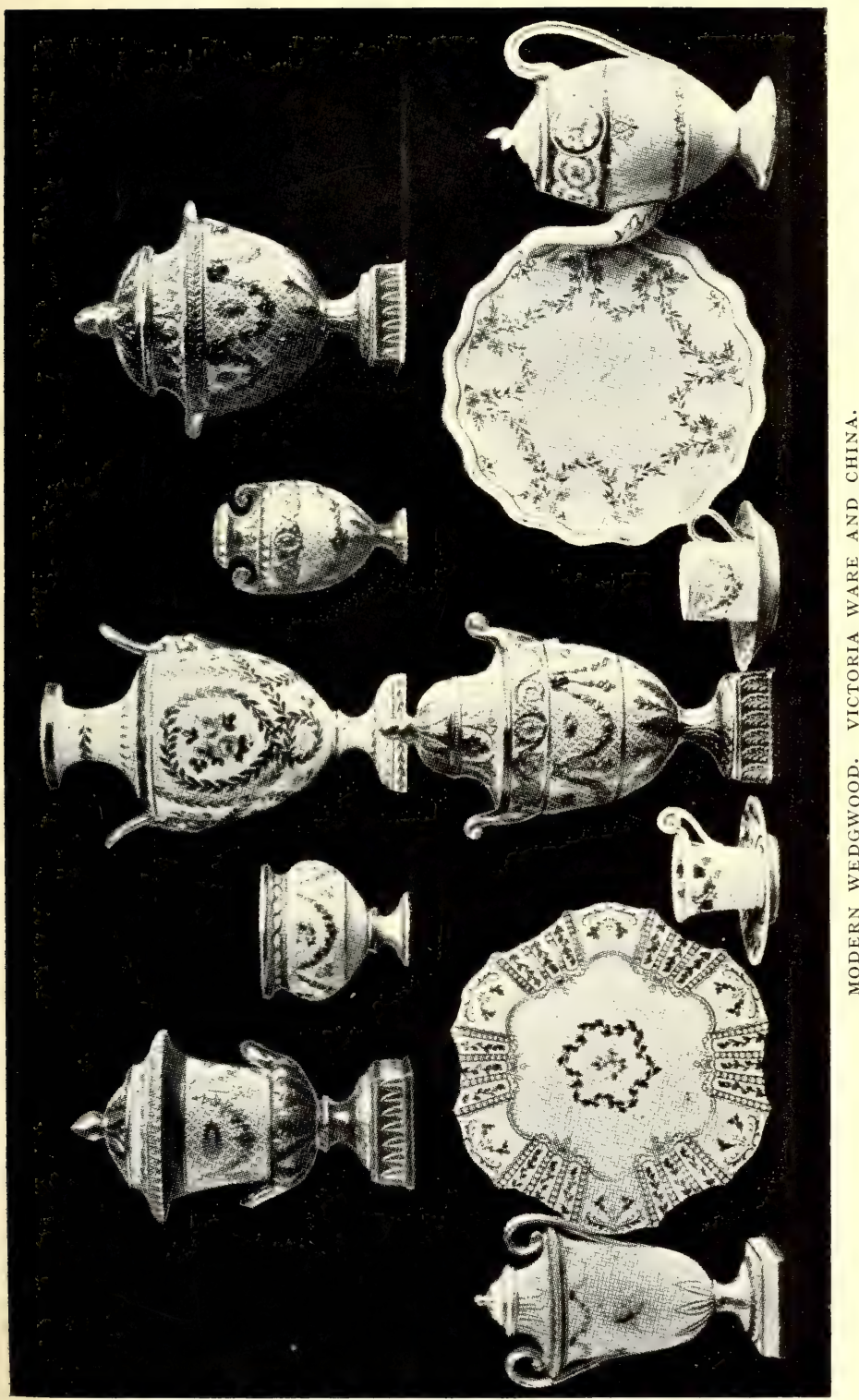



purple, was surrounded by a border of mauve flowers and green leaves supporting at the top, above each view, a green frog in a shield, indicating its destination, the palace of La Grenouillère, close by St. Petersburg.

I note this specially, because of the beauty of the old service, which was completed in I774, and because of the earnest, practical, and successful efforts which resulted in the permission from the Czar for some fine pieces of the service to be loaned to the Wedgwoods for exhibition in London, where they excited much attention and admiration, similar, no doubt, to the effects produced when, on their completion, they were on view in Greek Street, Soho, before being sent to Russia.

The illustrations, kindly furnished by the firm, will give my readers some idea of the beauty of modern Wedgwood, which, in its own world, stands alone, for the history of ceramic art records triumphant success extending over the whole period of its existence, and the present proprietors worthily maintain the splendid traditions of the past. 


\section{CHAPTER VII}

\section{SOME POTTERS AT BURSLEM}

\section{T. and R. Boote}

"THE mother of the Potteries" was the title given to Burslem, which, in the seventeenth century, was the largest pottery in the country, where for making different sorts of pots there were different sorts of clay, the best being found nearest the coal, all close to each other.

At the end of the eighteenth century the Waterloo Potteries made salt-glazed ware. About 1809 they belonged to Joseph Machin and Jacob Baggaley, passing later through other hands until they were acquired by Messrs. T. and R. Boote in I850. Before that, $R$. Boote had taken out a patent for "decoration" which consisted in producing coloured designs on grounds of different colours, as black on white or white on black. The criticism on the pieces exhibited in I85I states that the firm has

" attained considerable eminence as producers of earthenware of a fine order. We have engraved on this and the succeeding page several of their productions which have attracted great and deserved attention, having placed their names high on the list of our best manufacturers. The first, fourth, and fifth jugs are made by mosaic process, the patterns being let in, and giving the effect of bas-reliefs without being raised. The second jug is of Parian, with the bouquet in high relief; and the third, also of Parian of a fawn colour, with white figures of Gothic form. The two large vases, somewhat similar in form, are of drab-coloured Parian, the flowers and fruit, which are beautifully modelled in high relief, being white; the centre vase, of mosaic character, has a rich jet tint ; the pattern is of a deep mazarine blue, traced 


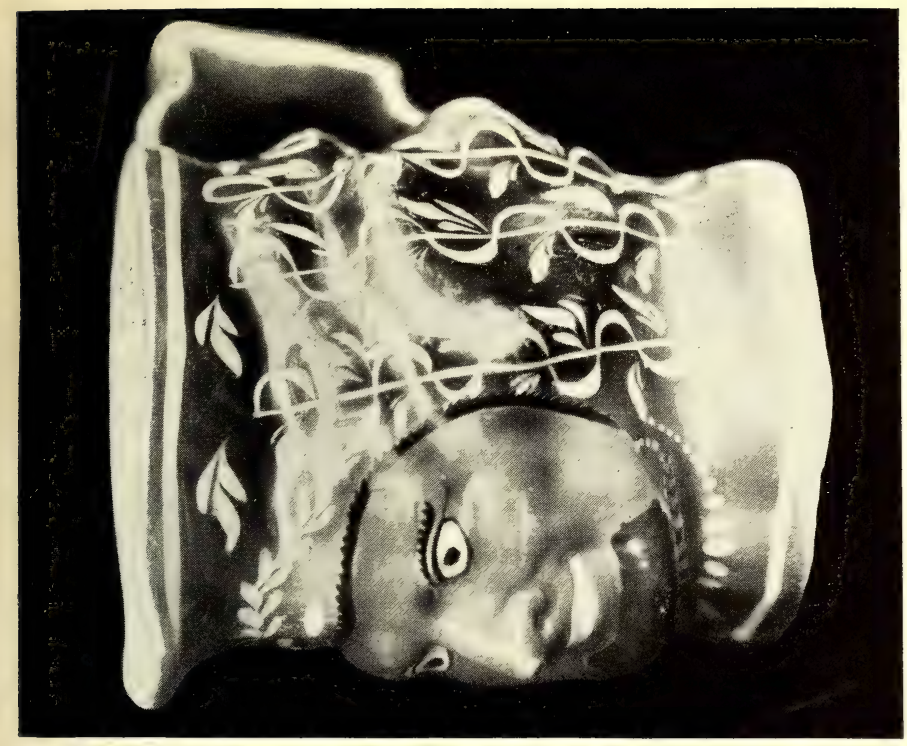

0
0
0
0
0
4
$\vdots$
4

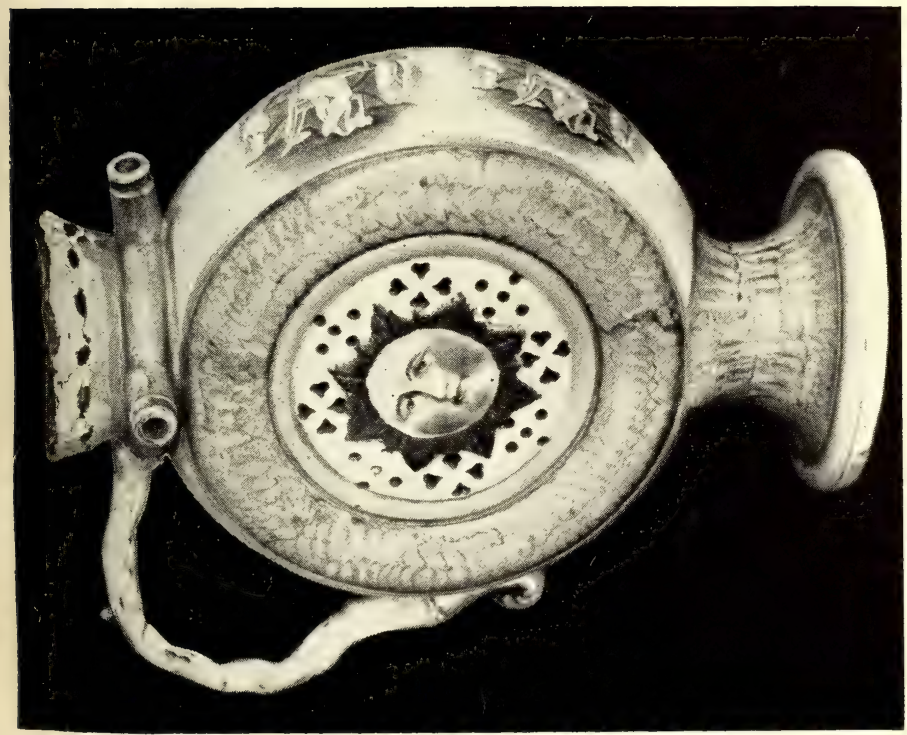

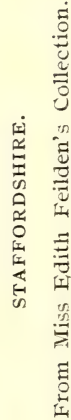



in gold. The flower-vase is in the Gothic style; stained glass is introduced on certain of the perforated parts."

This report is borne out by the illustrations, which depict pieces, with which many will be familiar, executed in Parian.

Parian ware has never secured that favour which the potters sought for it. Minton made beautiful Parian ware, so
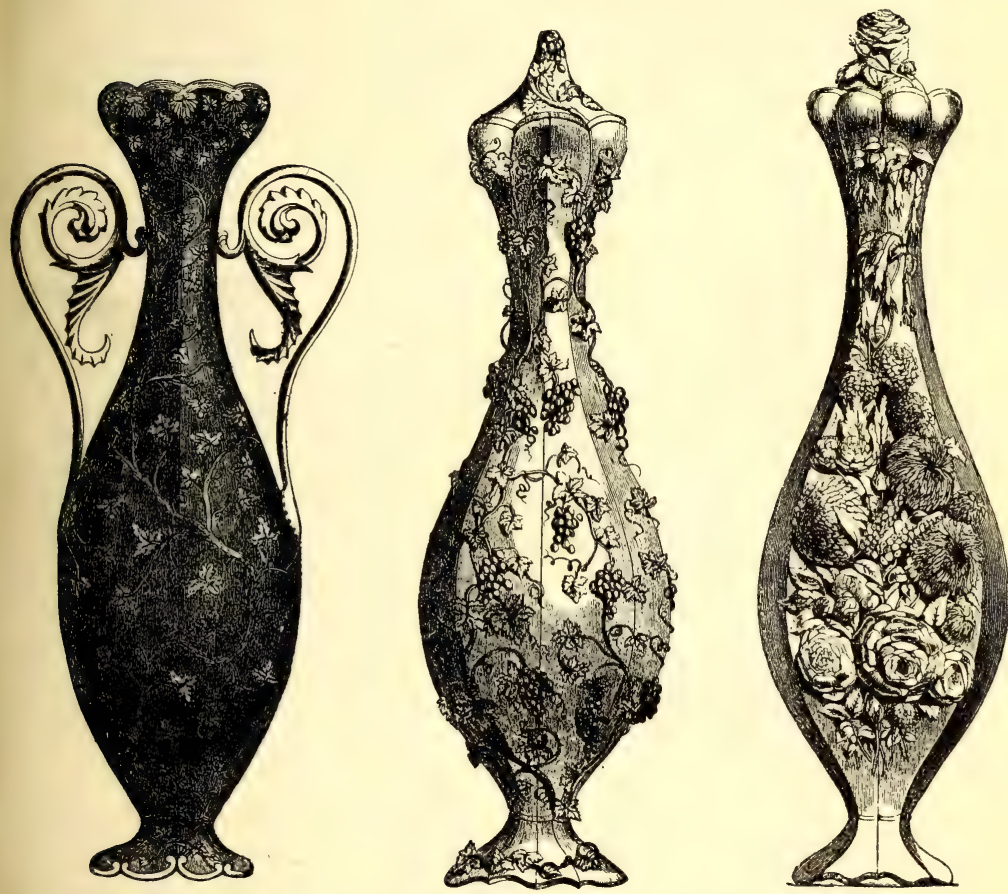

T. AND R. BOOTE'S EXHIBITS IN I85I.

did Copeland, and that of Messrs. Boote was almost of equal excellence, in vases, jugs, and other objects, including single figures and groups. Parian is very beautiful, its soft ivory tone is unrivalled, and no prophet is required to say that the time soon will come when it will be eagerly collected.

At these Waterloo Works other tints besides the ivory were made. Reference will be found to them in the criticism; 


\section{I58 I9TH-CENTURY ENGLISH CERAMIC ART}

but the buff ground with raised flowers in white, and other varieties, were discontinued, so that they will become difficult to acquire.

In addition to semi-porcelain and earthenware, the firm has for many years manufactured tiles, which at the Exhibition of 1862 were thus reported upon by the jurors :

"The tiles are deserving of high commendation; the designs are well selected, the equality of the surface evidences great efficiency. Messrs. T. and R. Boote claim some originality in their process, to which this perfection is not only attributable, but obtained at a much less cost."
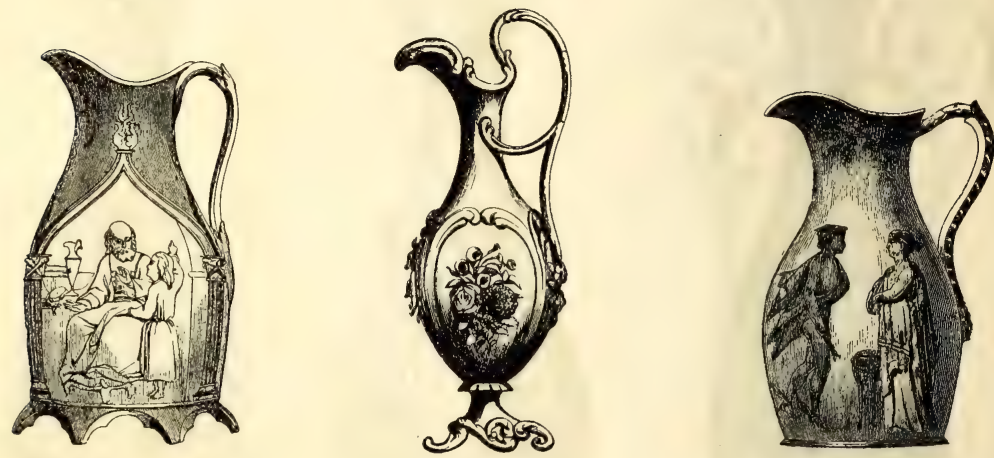

T. AND R. BOOTE'S EXHIBITS IN I85I.

They were patentees of this process for inlaying encaustic tiles.

The marks used were T \& R B impressed, or T. \& R. Boote printed in black under the Royal Arms, or under a couched greyhound between two laurel-wreaths. There are other emblems, such as a liner at full speed, and a shield surmounted by a crown, but T. \& R. Boote appears below, as it does in raised letters on the tiles.

\section{Cork and Edge}

About I8Io the Newport Pottery passed into the hands of John Davenport, from whom Cork and Edge acquired it. The present firm, Edge, Malkin \& Co., occupies the premises 

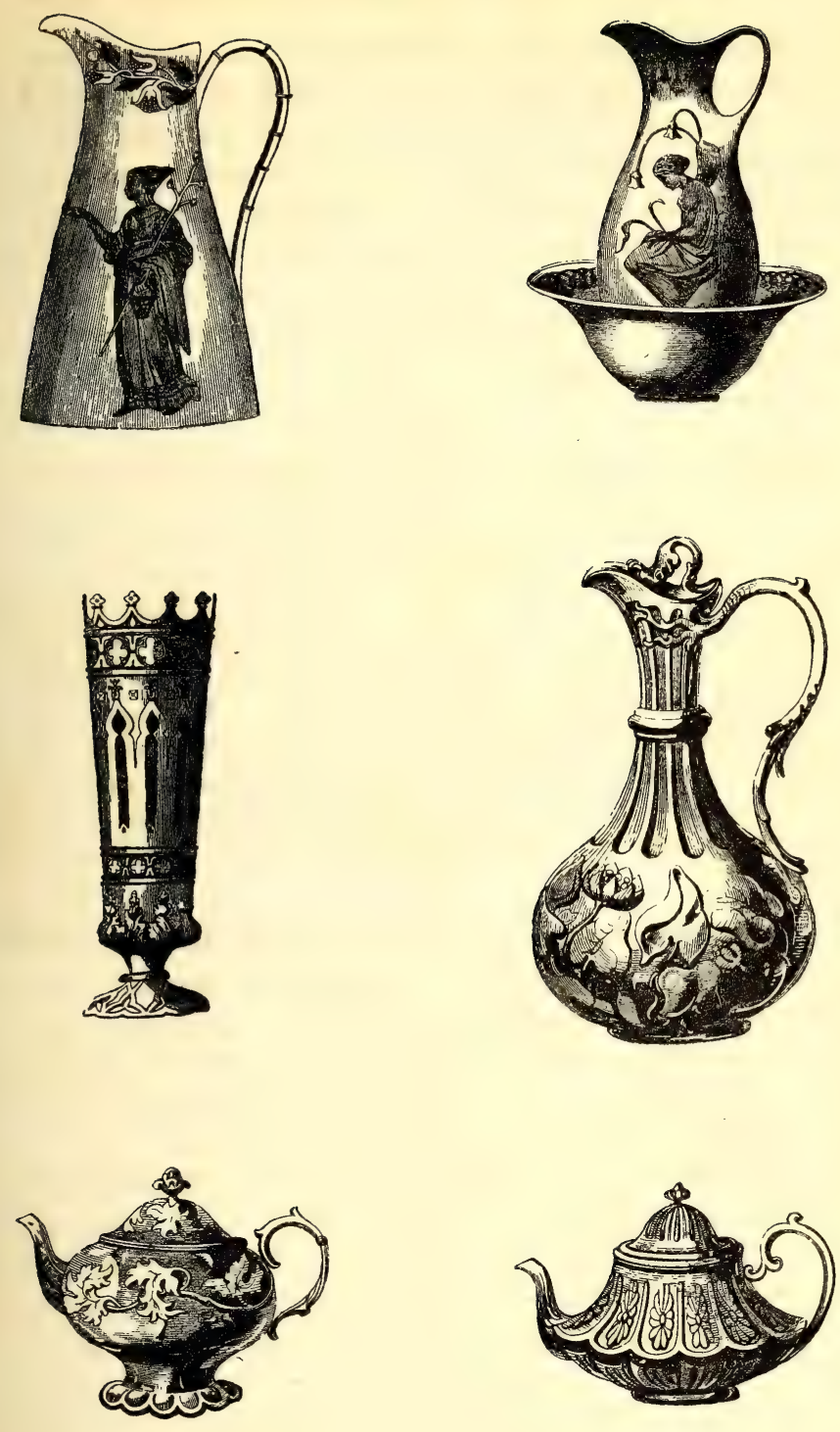

CORK AND EDGE'S EXHIBITS IN I85 I. 
in Newport Lane, and manufactures ironstone china and earthenware. The latter only was made by Cork and Edge, who in I85I exhibited ordinary articles of domestic use, which from their ornament have already received some attention from collectors attracted by the patterns inlaid in different colours upon the body of tea-pots such as those engraved. They were sold quite cheaply, they are valued for their peculiar grace in design, even when in simple brown ware, as in the first example.

They were praised by the critic, who said :

" A patented branch of their business is devoted to the ornamentation of similar articles by inlaying clays of various tints, thus producing an indestructible colouring for the leaves and other ornaments, such as appear upon the second specimen of their works. The water-jug, which completes our selection of articles from this establishment, is a tasteful arrangement of forms; the water-lily being introduced in the base of the jug with very good effect. It must be borne in mind that all these articles are constructed only for the cheapest market ; and we give them as instances of improvement in such branches of our national industry as were, but a few years ago, as must be acknowledged, most inartistic in taste."

The concluding remark is perfectly true, but the cause of failure in art is largely due to the lack of support which in troublous times cannot be afforded to anything but the plainly necessary, which may be transposed as necessarily plain. The early years of the nineteenth century in England saw an infirm King at home and wars abroad.

Daniel Edge appears in Ward's list of the Burslem potters as having pot-works at Waterloo Road, and Cork was a partner with Condliffe at Queen Street. Success came to them in the Newport Pottery-to them amongst a few whose names are given. Burslem was long the centre of potting, being, in the seventeenth century, the home of the Wedgwoods. Shaw, in I829, mentions the various factories held by Enoch Wood and Sons, and amongst others, Machin \& Co., T. and B. Godwin, T. Heath, J. Cormie, J. Hall and Sons, and J. R. Marsh as the chief potters or owners. 


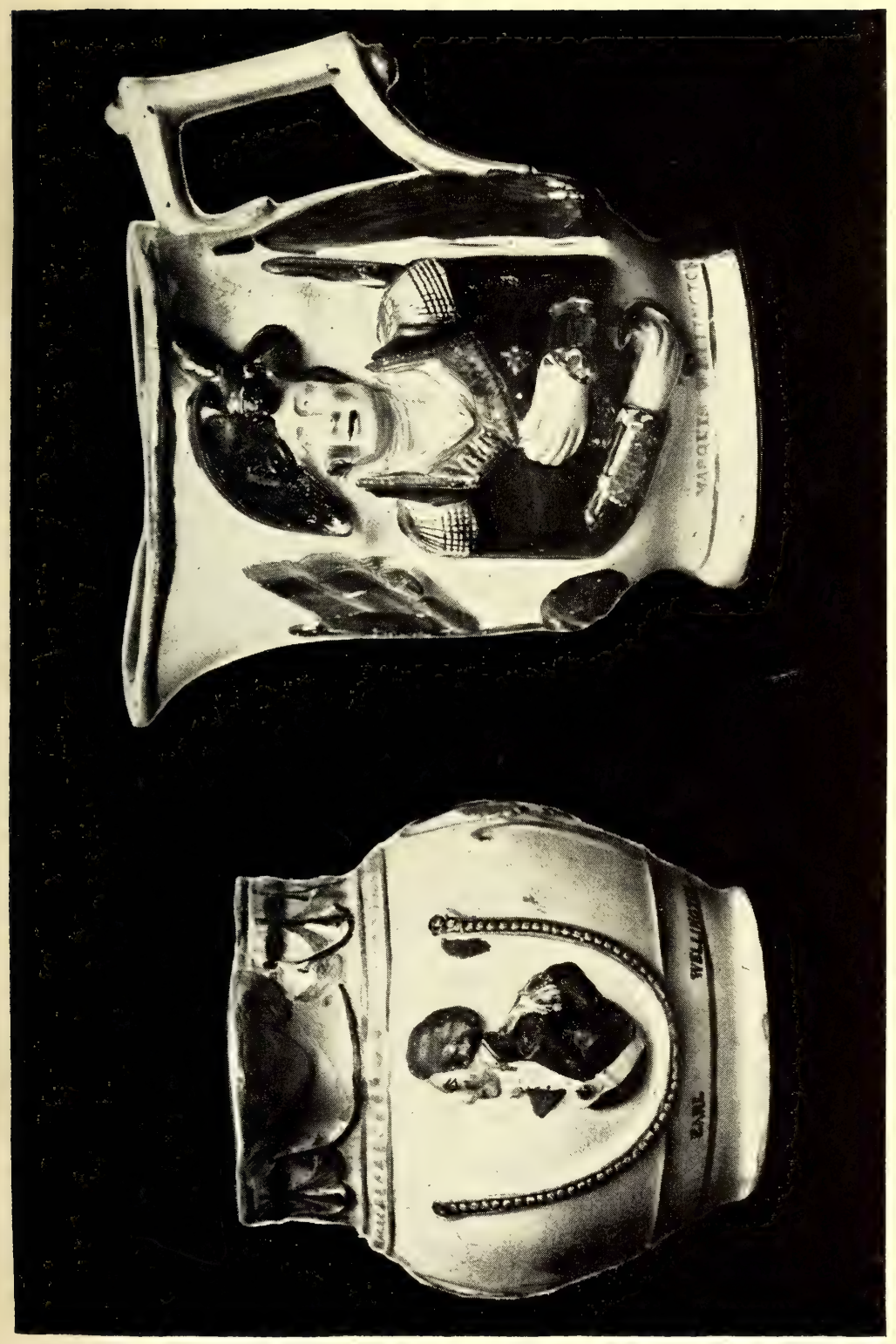



Ward's list, in I843, repeats Enoch Wood and Sons, Machin $\&$ Co. becomes Machin and Potts, Thomas Godwin reappears, but the others have gone. The other names are Samuel Alcock \& Co., Hill Top ; Mellor, Venables \& Co., Hole House ; John Wedgwood, Hadderidge; Barker, Sutton and Till, Liverpool Road; Peter Hopkin, Market Place; William Pointon, Green Head; Joseph Hawley, Waterloo Road; Maddock and Seddon, Newcastle Street; James Vernon \& Co., High Street; James and Thomas Edwards, Kiln Croft ; Nehemiah Massey, Bournes Bank; Ann Holland, Hill Top ; and Jones and Bell, Bell Works.

Why do I use a list like this ? Just to show that eight years later, when the Exhibition was held, only four of the Burslem potters were represented-Boote, Cork and Edge, Mayers, and Pratt. The state of Burslem was decidedly poor from the business point of view, many of the works were not occupied. The opening of Etruria by Josiah Wedgwood shifted from Burslem to Hanley the tide of success; the Churchyard Works were still unoccupied in I843, with the Big House Works, which he had vainly proposed to purchase from his relatives. Burslem will ever be associated with his early successes, with the bride who was worthy of him. For the Royal Doulton Potteries, Burslem, see Doulton.

\section{Mayer}

The firm of T., J., and J. Mayer, of the Dale Hall Works, Burslem, were exhibitors in I85I; among numerous other contributions were the tea-urns, vases, and jug shown in the illustrations.

"We are so accustomed to see the first-named objects manufactured in metal, that any of a ceramic substance must be regarded as a novelty; they are, however, made of a highly vitrified stone ware, that will resist the action of extreme variations of temperature, and are consequently well adapted to their purposes."

So much for the critic. 


\section{I64 I9TH-CENTURY ENGLISH CERAMIC ART}

Mr. Joseph Stubbs founded the factory in I790, so that nearly all of its products pertain to the nineteenth century. $\mathrm{He}$ manufactured earthenware with such success that he retired in I836, when T., J., and J. Mayer-Thomas, John, and Joshua-succeeded him, and introduced many artistic productions, the results of study and application. Amongst them may be noted polychromatic printing, Parian with an
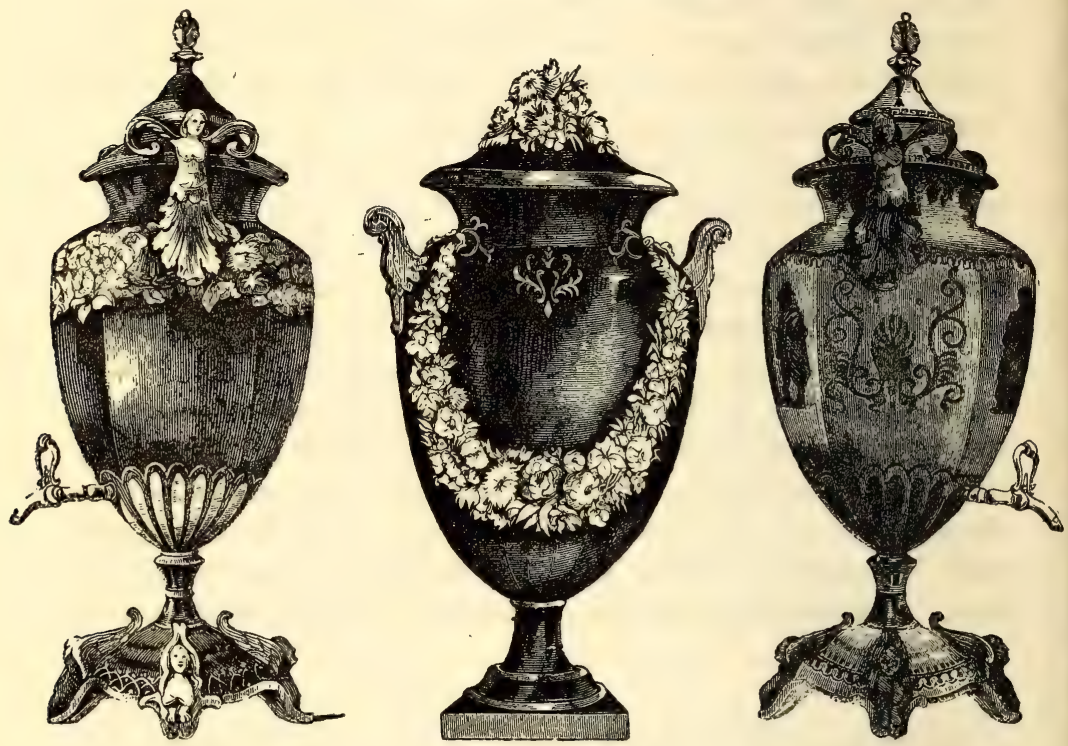

T., J., AND J. MAYER'S EXHIBITS IN I85I.

improved body, cane ware like the jug with oak pattern, which is here engraved.

These objects, especially the tea-urns mentioned above, were largely produced by the successors of the Mayers, for the firm underwent several changes after the premature death of Joshua through overwork. T., J., AND J. MAYER, or MAYer Bros., became Mayer Bros. and Elliott, then Liddle, Elliott \& Co., and Bates, Elliott \& Co., followed by Bates, Walker \& Co., who introduced a mark, a kneeling nude figure, holding a ewer before him on a slab, which bears the date 
I790. Another mark is the name of the firm upon an oval ribbon, with date of registration of the patent inside.

An immense variety of articles, useful and ornamental, were produced in all styles, from the plain white to complicated decorations, painted, enamelled, and gilt teaservices, and other useful and ornamental ware, earthenware of fine quality. The terra-cotta figures and groups have considerable distinction for both design and finish. The clay for this terra-cotta is found close at hand, and the body produced resembles Watcombe pottery. Subjects from the antique, such as "The Fighting Gladiator," "The

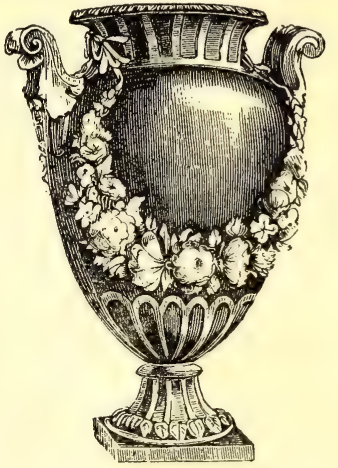

ONE OF T., J., AND J. MAYER'S EXHIBITS IN I85 $\mathrm{r}$. Young Apollo," and "The Bath," were varied by "The Seasons," "The Elements," and pieces by Beattie and others.

To the terra-cotta were applied various colours in slip, such as green, blue, and chocolate, forming a group known as Turner jasper ware, from the fact that many of Turner's original moulds were the property of the firm, which reproduced the forms in many ways, none of which equalled the work of Turner, the rival or imitator of Wedgwood. Some

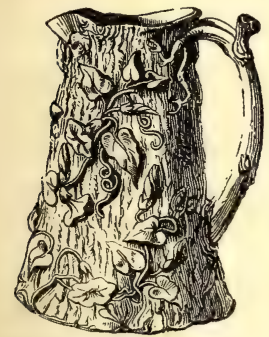

ONE OF T., J., AND J. MAYER'S EXHIBITS IN I85 I. say rival, others imitator; but Turner's work was original.

Polychromatic printing was brought to considerable success. The vases and other articles were transfer-printed whilst in the biscuit state, the coloured transfer being applied in a single operation, giving an effect which is in entire good taste-quite a contrast to many wares in which the decoration is transferred by means of a coloured print.

Dale Hall Works have had many proprietors. Some pieces may be found with B. G. \& W., others with J. G, for James 
Gildea, and still later with $\mathrm{K} \&$ Co B, for Keeling \& Co., Burslem. The mark adopted by Bates, Walker \& Co., of the kneeling figure with the ewer on a base, dated I790, has been retained.

\section{Pratt}

" The stand of Messrs. F. and R. Pratt, of Burslem, exhibits several excellent examples of earthenware, printed in a peculiar style, some of them after the pictures in the Vernon Gallery, and also a dessert-service with designs from the works of our best painters. We have selected, from their more miscellaneous contributions, some objects of a less deco-

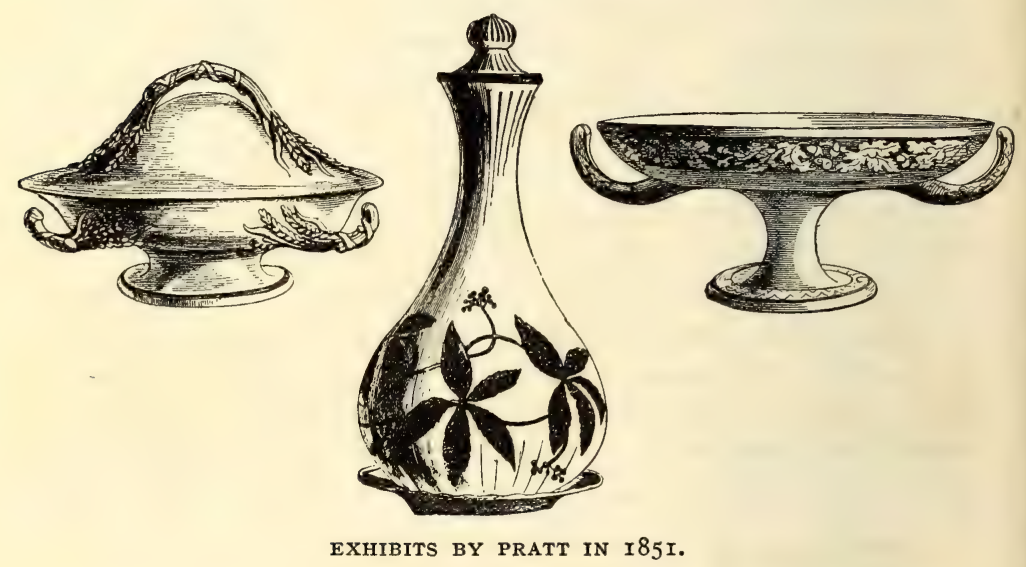

rative character, but, nevertheless, most excellent of their class. The forms Messrs. Pratt have adapted to objects of general use have been in some instances taken from the Etruscan, and exhibit, therefore, the good taste of the manufacturers in resorting for suggestions to the best sources."

This is the report in the catalogue on the earthenware. Another follows regarding a clock-case in terra-cotta, also illustrated :

"It is of large size, intended for the exterior of a building, for which its truly excellent design peculiarly adapts it. The 
figures, which have an antique character and are elegantly posed, are well modelled, and the entire composition is conceived in an artistic spirit."

Though Messrs. Pratt \& Co. are placed amongst the potters of Burslem, their works, the Fenton Potteries, are, as the name shows, in Fenton, where the firm has existed since the beginning of the nineteenth century. When Mason, the producer of the well-known Patent Ironstone China, gave up the Minerva Works in the same township, they passed for a time into the hands of Messrs. Pratt, who also bought the

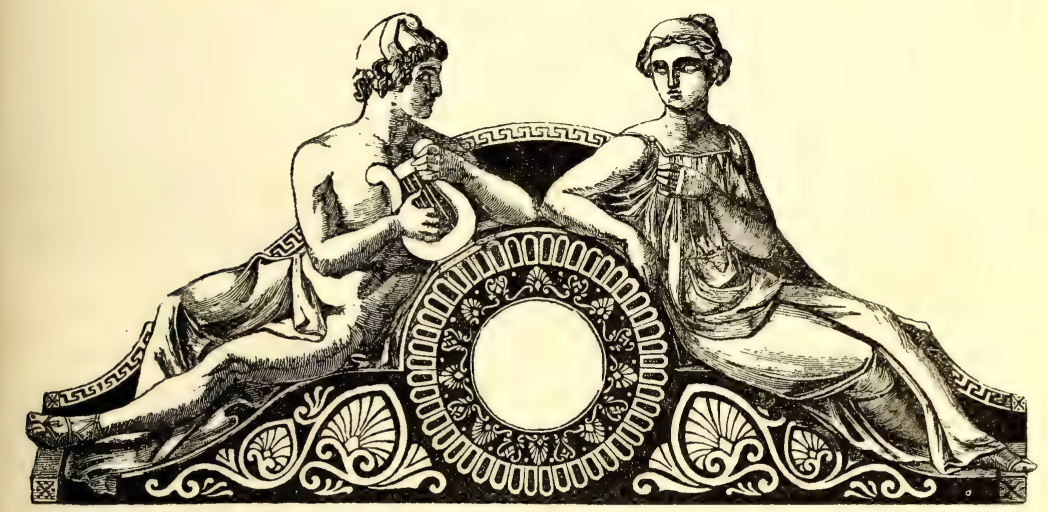

ONE OF PRATT'S EXHIBITS IN I85I.

Eagle Pottery at Castleford. The Minerva Works were acquired ultimately by Green, whose grandsons are amongst the most distinguished potters of the present day, and will be referred to again when I deal with the Fenton potters.

The Pratts also sold the Eagle Pottery, and devoting their attention to ordinary earthenware, they produced services which shared the repute of their ornamental articles. Underglaze colour-printing was a favourite method of decoration, but in none of these did they reach such eminence as in their terra-cotta, which was close-grained and somewhat vitreous, and artistically decorated in enamel colours in the Etruscan style. Two large vases, after being exhibited in $185 \mathrm{I}$, received the silver medal of the Society of Arts, and were bought by 
Prince Albert. The firm now continues the manufacture of terra-cotta and earthenware.

\section{The Hill-Top Pottery}

In I839 Samuel Alcock \& Co. rebuilt the pottery which once belonged to Ralph Wood, and absorbed the works of Riley, formerly John Taylor's, J. Robinson and Sons', and William Taylor's, which were all pulled down. Alcock, who marked his goods with the name of the firm, made fine china and earthenware until about I860, at which time the establishment and estate were bought by Sir James Duke and Nephews, who continued and improved the manufacture with such success as to receive distinction at the Exhibition of 1862 . The earthenware and china ranged from the plain white to the most superb styles of decoration. The Etruscan vases reproduced some of the finest antiques, and the other ornamental pieces were of superior quality.

Then, in I865, the estate was sold to Mr. Ford, and next year the Earthenware and Porcelain Company, under the management of $\mathrm{R}$. Daniel, once a noted potter at Burslem, Hanley, and Stoke, bought it, with a poor result, for in 1867 it was in liquidation, and once more came into the hands of Mr. Ford, who, however, the same year sold the china department to Alcock and Diggory, and the earthenware to Burgess and Leigh, by whom it is still (Igoo) carried on as Burgess and Leigh, Middleport and Hill Potteries. They manufacture ordinary and high-class wares in the usual services, as well as many ornamental articles. Their mark is the beehive, which was used by Alcock. This is on a stand, in front of which is a ribbon, on which the name of the pattern is printed, with $\mathrm{B} \& \mathrm{~L}$ below. The words Hill PotTery are placed above the bees and two branches of flowers. The mark of Sir James Duke and Nephews was the dexter hand, denoting a baronet.

\section{Enoch Wood}

The name of Wood holds a prominent position amongst the old master potters of the eighteenth century. Enoch Wood, 


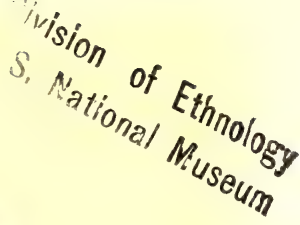
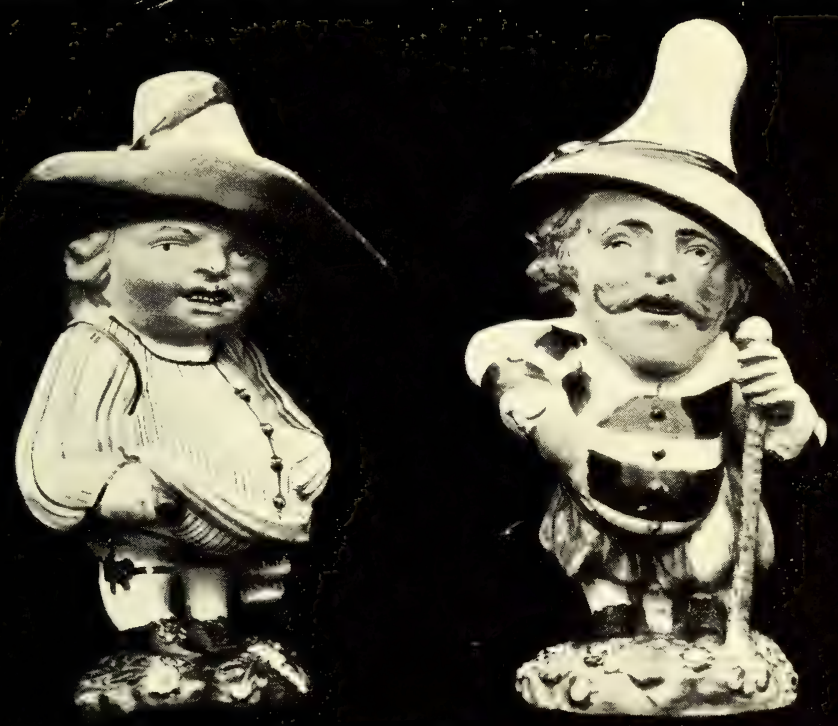

RARE STAFFORDSHIRE FIGURES. THE MANSION HOUSE DWARFS. ALSO MADE IN DERBY CHINA.

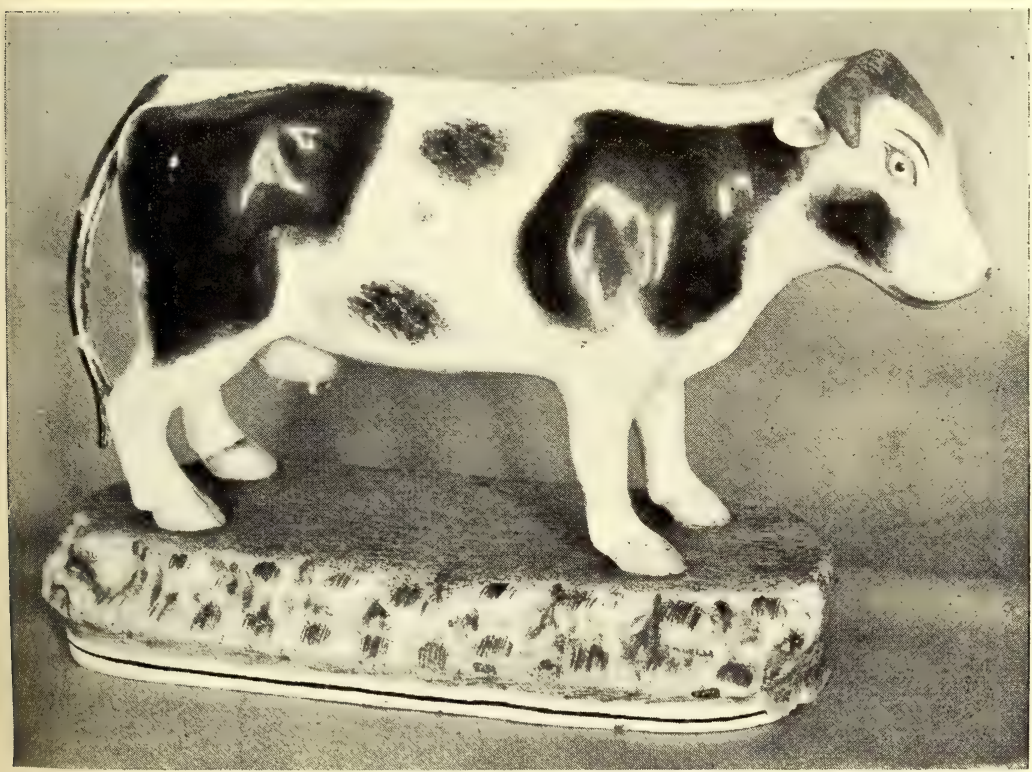

RARE STAFFORDSHIRE COW OF EXCEPTIONAL SIZE.

From Miss Edith Feilden's Collection.

I69 

sometimes called "the father of the Potteries," commenced business in I784. From I790 to I8I8 the firm was Wood and Caldwell, then from I820 to I846 Enoch Wood and Sons. The nineteenth-century potters of the old school faded away early in that period, and most of them had gone before I850. Enoch Wood manufactured cream ware, white glazed earthenware, figures, and busts. The ordinary ware, common to the pot-works, had nothing which calls for notice in his work, but as a modeller he ranks nearly equal to Ralph Wood and Wedgwood in the making of Staffordshire figures. Other potters who were engaged in similar figure-making included Voyez, Neale \& Co., Bott \& Co., Wilson, Lakin and Poole, Walton, Salt, and Dale. Most of these were the later makers, and the list gives in order their comparative merits.

A further note follows the account of Wood, whose name will ever be known for two things; his busts of Wesley and Whitefield is one, and his collection of pottery is the other. What a pity it was that at its death, when it was dispersed, many of the pieces were bought for the Dresden, rather than the British, Museum! It is true that some were acquired for the Museum of Practical Geology, and afterwards removed to South Kensington; but regrets are vain! The British Museum Guide contains these remarks: "An immense number of figures were made in Staffordshire earthenwares, though they are very scantily represented in this collection." The greater number of the nineteenth-century figures have but little value, and the absence generally of marks is confusing when one endeavours to identify the makers, who, by the way, produced many Toby jugs. E. WoOD or ENOCH WoOD, ENOCH Wood \& Co., Enoch Wood \& Sons, and Wood \& Caldwell are some of the marks which have been found impressed in the body of this Wood's ware. Wood was succeeded by Pinder, Bourne, and Hope, afterwards Pinder, Bourne \& Co., which became Doulton's, Burslem.-See Lambeth.

Shaw, in I829, mentions that besides the various factories held by Enoch Wood and Sons, there were about twenty-six other pot-works, the principal of which were Machin \& Co. ; T. and B. Godwin ; T. Heath ; J. Cormie ; J. Hall and Sons ; 
and J. R. Marsh. In I843, according to Ward's list, the potters at work were Enoch Wood and Sons ; Samuel Alcock \& Co., who occupied their pot-works at the Hill Top; Machin and Potts (formerly Machin and Baggaley), at the Waterloo Works; Mellor, Venables \& Co., Hole House; Thomas Godwin, Burslem Wharf; John Wedgwood, Hadderidge ; Barker, Sutton, and Till, Liverpool Road; Peter Hopkin, Market Place; William Pointon, Green Head ; Samuel Mayer \& Co., Waterloo Road; Joseph Hawley, Waterloo Road; Maddock and Seddon, Newcastle Street ; James Vernon \& Co., High Street; James and Thomas Edwards, Kiln Croft; Cork and Condliffe, Queen Street ; Nehemiah Massey, Bournes Bank; Ann Holland, Hill Top ; Daniel Edge, Waterloo Road ; Jones and Bell, Bell Works; and those not then occupied were the Churchyard Works (late J. and J. Jackson), the Big House Works (formerly Thos. Wedgwood), the Hamill Street Works (formerly Cartlidge and Beech), the Knowl Works (formerly Breeze's), and the Navigation Works (late John Walton's).

In I90o the list had grown considerably, and, leaving out the names of the factories, the following are the chief names of the firms: C. F. Bailey; J. Barber; T. and R. Boote (two factories); E. and J. Bourne; Burgess and Leigh; Davidson and Sons; Doulton \& Co., Ltd. (see Doulton); Dunn, Bennett \& Co. ; Edge, Malkin \& Co. ; Edwards Bros. ; W. Edwards and Sons; S. Ford \& Co. ; Ford and Sons; Gibson and Sons ; R. Hamersley and Son ; Hobson ; Hollinshead and Griffith ; W. Hulme ; Johnson McAlister Tile Co. ; S. Johnson; Keeling \& Co. ; W. Kent ; King and Barrett ; Macintyre \& Co.; J. Maddock and Sons; Malkin Tile Works Co. ; Marsden Tile Co. ; Mellor, Taylor \& Co. ; A. J. Mountford; E. Plant; Price Bros.; J. Sadler and Sons ; R. Sudlow and Sons; T. Till and Sons; Tilstone Bros.; Wade \& Co. ; J. and W. Wade \& Co. (tiles); Wilkinson Ltd. ; Wooldridge and Walley; Wood and Hulme; H. J. Wood; Wood and Barker; Wood and Son; W. Wood \& Co. Some firms-a few only-make china, nearly all manufacture earthenware. 
The productions of Enoch Wood may properly be followed by the names and the dates of the other potters who in his neighbourhood made figures of similar type. Wilson died in I820, Lakin and Poole ceased in I846, Walton died in I839, Salt in I864, Dale about I840. And at the same time I might note those potters who made the cream ware, and the white transfer-printed glazed ware, the black basaltes and the jasper ware, those whose names are sometimes found impressed or printed, but whose productions are not noticed elsewhere in this book. They were working in the first half of the nineteenth century, or during the next few years. Warburton ( Jacob ?) of Cobridge died I826; Steel of Burslem (I766-I824) made jasper ware; S. Hollins of Shelton (I774-I8I3) made a fine maroon stoneware; E. Mayer of Hanley (I770-I8I3) made black basalt, cream ware enamelled, etc. ; Birch of Hanley (lived in the first years of the nineteenth century) made jasper and black basalt; J. Lockett of Burslem (flourished about I802) made jasper and stoneware; John Aynsley of Lane End (lived at about the same time) made cream ware, etc.

Still another list of names, occurring on Staffordshire ware made in the early years of the nineteenth century, and used as marks upon the ware, includes: Bott \& Co. ; J. Clementson; Clews; Cookson \& Harding; Green ; Hackwood ; Harding ; Harley; Miles Mason, of Lane Delph; Mayer \& Newbold; Meir ; Mohr and Smith ; Moseley ; Phillips ; Riley ; Rogers; Sneyd; and Stevenson. From these lists it will be evident that during the time when the most noted potters were producing the wares with which their improvements were closely associated, many ordinary makers were making similar wares which did not embody those improvements, over a period of time of considerable length, which was terminated in many cases by a general slackness of business about I800, and again in 1826 and 1827 , which have been called "years of great commercial difficulties." 


\section{CHAPTER VIII}

\section{OTHER POTTERS AT COBRIDGE AND FENTON}

\section{Cobridge : Clews and Brownfield}

THE Cobridge works in the nineteenth century were erected in 1808 and closed in I8I9, then opened again by James Clews, whose mark was a crown over his name, till I829, when they were again closed. The ordinary white, blueprinted, and sponged earthenware was made in those early days. In 1836 other parties opened the works, including W. Brownfield, who became sole proprietor in I850, continuing so till I87I, when his son, W. E. Brownfield, joined the firm of W. Brownfield and Son. Some of the most successful imitations of Mason's ironstone china were produced in addition to the usual white, printed, enamelled, and gilt ware, though the speciality of the firm was stoneware, which was remarkably good in quality and in modelling. So good, indeed, was it that, at the Exhibitions in London, I862, and Paris, I867, a medal was awarded.

In $187 \mathrm{I}$ the manufacture of china was specially provided for by the erection of new buildings, and the services of tableware afterwards made were quite good in form and decoration. Some china vases, centre-pieces, and the like were especially commendable. Two finely painted ones with Ettylike subjects representing "Morning " and "Mid-day" have been referred to as among the highest achievements of modern art. The printed marks include $\mathrm{W} \& \mathrm{~B}, \mathrm{~W} \mathrm{~B}$, and $\mathrm{W} \mathrm{B} \& \mathrm{~S}$, with the addition of the name of the pattern, which is often so puzzling to those who own pieces so marked. The impressed marks are the well-known Staffordshire knot, which 

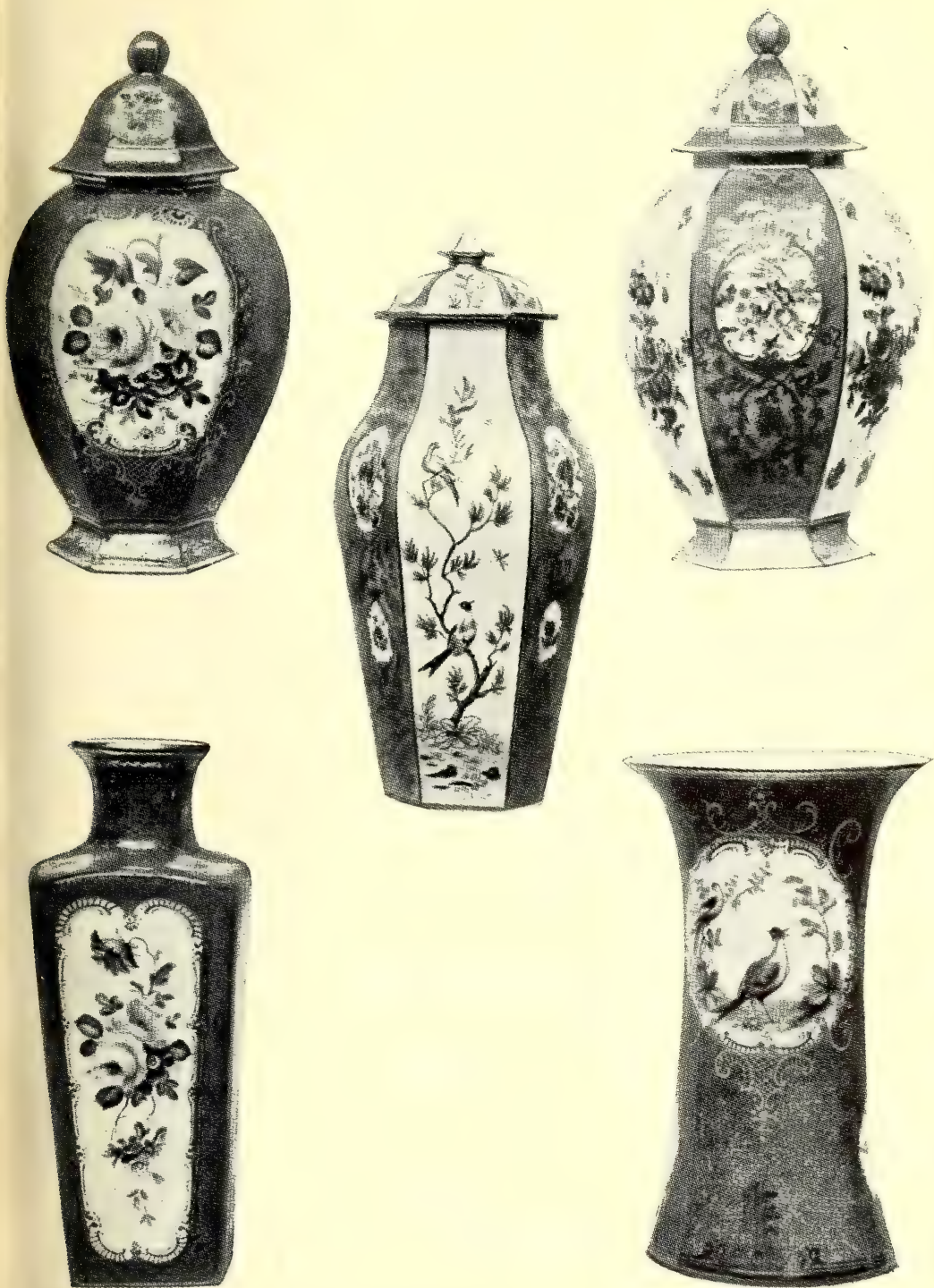

ENGLISH POWDER BLUE VASES, I760-70. BY THE CROWN STAFFORDSHIRE PORCELAIN COMPANY. 

so many potters use with their initials, which in this case are $\mathrm{W} \mathrm{B}$ and the name BRownfIELD. In $\mathrm{I} 876$ these works employed upwards of five hundred persons; their name still appears amongst the Cobridge works as Brownfield's Pottery, Ltd.

\section{Cobridge: Furnivals Ltd.}

This firm, originally T. Furnival and Sons, was established about the middle of the nineteenth century for the manufacture of white granite and vitrified ironstone and also decorated wares. These have various styles and qualities of decoration, amongst which embossed moulding was a special feature, the lines being so fine and delicate that when filled with glaze the surface remains perfectly flat and smooth. Another feature is the combination of transfer-printing with hand-painting, enamelling, and gilding, simply marked with the name FURNIVAL impressed upon the ware. Furnivals Ltd. are now manufacturers of all kinds of earthenware of good quality and design.

\section{Cobridge : H. Alcock \& Co., Waterloo Road Works}

H. Alcock \& Co. appear in Igoo as being the proprietors of the Waterloo Road Works, which were founded in 1820 by T. Hughes. The Alcocks appear as potters in the list of I843, and they seem to have taken over these works sometime after 1876, when Hughes, another Thomas, had succeeded Stephen Hughes \& Co. The goods he produced were the usual articles in granite or so-called ironstone china of good style and quality. Many smaller firms in the Potteries catered especially for the American markets, which demanded a strong, durable ware, and the same qualities made ironstone china popular at home; though such goods will never have much interest for the collector, it is necessary to survey the whole field of the manufactures of the nineteenth century, without placing any considerable stress upon what was the bulk of the work, the useful articles of everyday service for 


\section{I78 I9TH-CENTURY ENGLISH CERAMIC ART}

which there was a constant demand from Staffordshire, which produced them at comparatively low prices.

The potters at Cobridge in 1843 were Wood and Brownfield, John and George Alcock, Francis Dillon, Elijah Jones, Stephen Hughes \& Co., B. E. Godwin, J. M. Godwin and J. Godwin, John and Robert Godwin, G. and R. Leigh, and Coxon, Harding \& Co.

In Igoo we find the following: H. Alcock \& Co., Banner $\&$ Co., Brownfield's Pottery Ltd., Furnivals Ltd., Pidduck, Rushton \& Co., and the Porcelain Tile Co. amongst others.

\section{Fenton: Green Brothers. Crown Staffordshire}

The Minerva Works, Park Street, Fenton, now owned by a limited liability company under the title of the Crown Staffordshire Porcelain Co., were once the property of the famous maker of "Patent Ironstone China." Here Mason $\&$ Co. produced the ware which had such great success (see Mason's and the G. L. Ashworth and Brothers, who bought the patent, or rather their predecessor, Morley, did).

From about I830 Thomas Green was sole proprietor, until he died in I859, when his widow, Mrs. Margaret Green, under the style of "M. Green \& Co.," maintained the Minerva Works in the most efficient manner, being ably assisted by her sons, Messrs. T. A. and S. Green, who eventually acquired the business. The early productions of the firm included miniature ornaments and services, what we should term toy sets, in addition to the usual ware, and though, about 1876 , china services of the ordinary sizes were produced, having fine qualities, the toy sets were not discarded, and they are still popular. The great development in the later productions is as wonderful as it is praiseworthy. By long and careful experiment their chemists have discovered the exact shades of the marvellous enamels which the Chinese brought to perfection: the bright rose-colour which has never been produced successfully since 1800 , whilst the powder bluenot purple nor grey-the true powder blue, has been the despair of all manufacturers since I750. The powder blue 

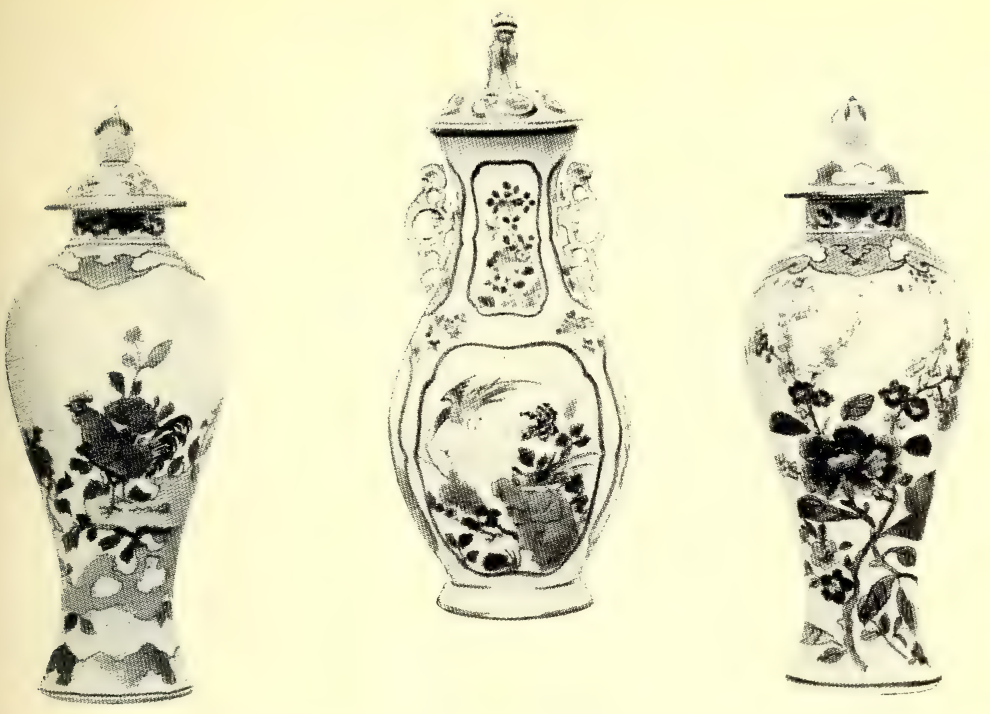

CHINESE FAMILLE ROSE VASES, I730-60.
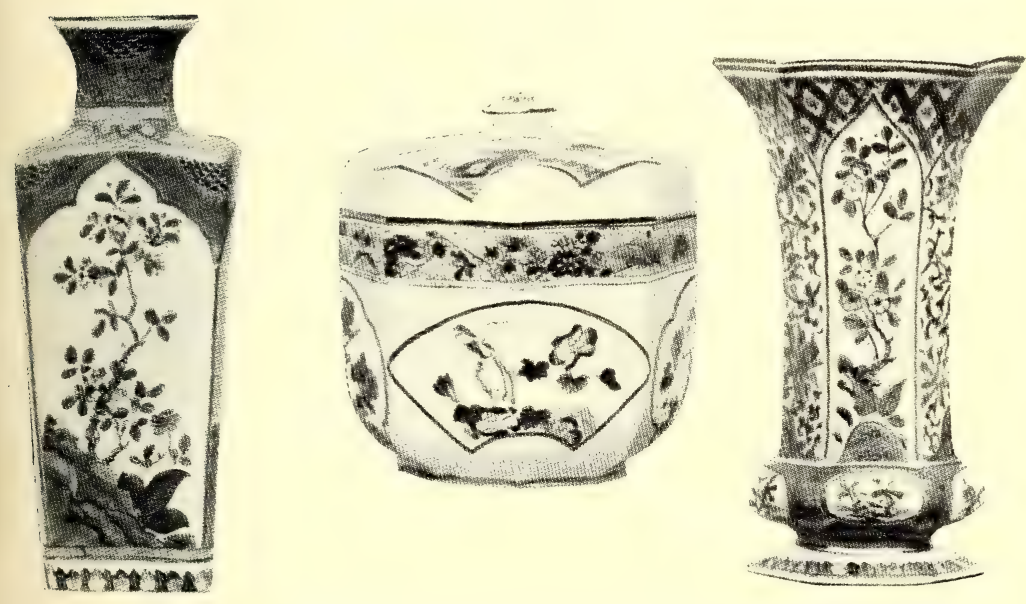

CHINESE FAMILLE VERTE VASES, I670. BY THE CROWN STAFFORDSHIRE PORCELAIN COMPANY. 



\section{OTHER POTTERS AT COBRIDGE AND FENTON I8I}

on the vases made by the Crown Staffordshire Porcelain Company is the result of some thousands of trials, extending over ten years, and is considered by connoisseurs to be most successful. Each piece, every vase, is, what it professes to be, a copy, which is marked either with a crown over "Staffs," or over "Staffordshire" surmounting two G's, one reversed, in a monogram. A little while ago I saw some of these reproductions at the London showrooms of Green Brothers,

49 Hatton Garden, and my opinion was that

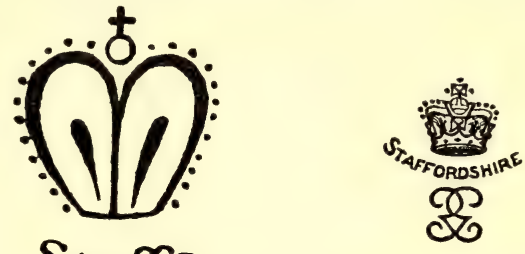
nothing of finer quality had ever been made in England, nothing with such an Oriental tone. The famille verte copied from the best period, I670, the famille rose from Keenlung's masterpieces, the powder blue which was at its best in England about I760-80-all these are wonderfully good copies. Then, not content with that, the firm copies old English work with equal success.

The flowers that Billingsley painted at Derby, Worcester, Nantgarw, Swansea, and Coalport will be dealt with elsewhere, as his work, though commencing with Duesbury in I774 at Derby, ended at Coalport in 1827 or $I 828$, so that a half, and the best, of his work was done in the nineteenth century. These flowers are amongst the schemes of decoration used by this company. With regard to the whole question of reproduction, I agree with the views as expressed in their booklet. Reproduction with a distinct intimation of the origin of copies, when there is no attempt to deceive, is not harmful, indeed, it is beneficial if undertaken with such a spirit as this quotation shows:

" it is with a feeling of reverence and respect for the great artists of the seventeenth and eighteenth centuries that we have attempted to follow up their ideas, which we confidently hope will meet with the appreciation of that large section of 


\section{I82 I9TH-CENTURY ENGLISH CERAMIC ART}

the art-loving public who wish to preserve in their homes the artistic feeling that seemed to come naturally in the eighteenth century."

The present title of the firm was adopted in I890. In I900 it was turned into a limited liability company, and was managed by two grandsons of the original Thomas Green, Messrs. H. and C. Green, and Mr. Mellor. The great development in the later productions is due to Mr. Mellor and a number of very clever artists whom he got together.

Another Thomas Green in I795 bought the Churchyard Works, Burslem, from John Wedgwood, brother of Josiah, and manufactured earthenware there till I8II, when the business passed from owner to owner, amongst others Bridgwood and Clarke, and in I874 W. E. Withinshaw; both firms marking their goods with their initials.

There exists at Church Gresley, near Burton-on-Trent, another firm having the name of Green-T. G. Green \& Co. -whose goods, mainly yellow ware, are marked with the initials T.G.G. \&. Co. Ltd. "in front of a church" both in a shield surmounted by a ribbon. The original works were established ten years before I800; later, W. Bourne made ironstone can-ware, which was successfully continued by his successors, of whom T. G. Green from I864 onwards was the most prominent.

\section{Fenton: F. Beardmore \& Co.}

This enterprising modern firm scarcely enters into the history of the nineteenth century, except indirectly, as the purchaser of the old shapes and patterns of older firms not now in existence. Such were Hulme and Christie, Christie and Beardmore, and Brownfield and Sons, though only a portion of the patterns and shapes of the last firm were bought. All of these are being reproduced to-day in a style and quality that are equal to anything then sent out, and in a variety of colours-flown neutral, flown green, flown blue, Berlin blue, chocolate, etc.

But the factory does not confine its attention to table and 



\section{OTHER POTTERS AT COBRIDGE AND FENTON I85}

toilet ware; it turns out first-grade goods in semi-porcelain and best ivory bodies, and two specialities in addition, for which special merit is claimed. For the first time, we are told, after patient study, research, and experiment, true examples of the art of the ancient Greeks are placed upon the market at popular prices. Basaltine is the name given to a series on the pieces of which is applied a beautiful dull black surface, the finest imaginable for the delicate and faultless lines of the Greek draughtsman. After various experiments, success has been achieved. No expense has been spared in designing shapes in harmony with these old Greek masterpieces-copies from the finest examples in the British Museum and the Continental galleries.

The Athenian art-ware is somewhat of a departure from Basaltine. By a judicious colouring of the drapery and figures, some good effects have been produced, in which the contrasts in colour, and the variety of shapes have much that is commendable. I must say that the catalogues furnished to me by the firm deserve a share in that commendation. They are well illustrated in colours, and quite a new feature is introduced by quotations from Ruskin, which deal with the art of the Greeks, such as :

"From all vain and mean decoration-all weak and monstrous error-the Greeks rescue the forms of man and beast, and sculpture them in the nakedness of their true flesh, and with the fire of their living soul."

"Distinctively, from other races, as I have shown you, this is the work of the Greek, to give health to what was diseased, and chastisement to what was untrue."

"It is one of the primal merits and decencies of Greek work that it was on the whole singularly small in scale, and wholly within reach of sight to its finest details."

"The Greeks have been the origin not only of all broad, mighty, and calm conception, but of all that is divided, delicate, and tremulous."

"Ruskin's Lectures on Art."

I cannot say whether such thoughts as are expressed by John Ruskin appeal with any degree of force to the buyers of such wares as have been described, but one can appreciate 


\section{I86 I9TH-CENTURY ENGLISH CERAMIC ART}

fully the departure from the stereotyped appeal found in many trades lists, by manufacturers of earthenware and china of all descriptions, suitable for home, colonial, American, and foreign markets. These classical designs are benefited by Ruskin's comments on Greek art; they form one of the specialities referred to. The other is not at all classical, but purely homely. It is called the "Bit of the Old Country" series, and, as its name implies, its decoration represents a country scene, where picturesque cottages stand under the shadow of giant elms, near the calm stream, upon which floats a red punt. The tones of colour are harmonious and striking. Here again, the firm is ready with a quotation, with which I must conclude. It is from George Gissing's Private Papers of Henry Ryecroft :

" Even during that strange time when hardships and passions held me captive far from any glimpse of the flowering earth, I could be moved, and moved deeply, by a picture of the simplest rustic scene. At rare moments, when a happy chance led me into the National Gallery, I used to stand long before such pictures as 'The Valley Farm,' 'The Cornfield,' 'Mousehold Heath.' In the murk confusion of my heart these visions of the world of peace and beauty from which I was excluded-to which, indeed, I hardly ever gave a thought-touched me to deep emotion. But it did not need -nor does it now-the magic of a master to awake that mood in me. Let me but come upon the poorest little woodcut, the cheapest 'process' illustration, representing a thatched cottage, a lane, a field, and I hear that music begin to murmur. It is a Passion-Heaven be thanked-that grows with my advancing years. The last thought of my brain as I lie dying will be that of sunshine upon an English meadow." 

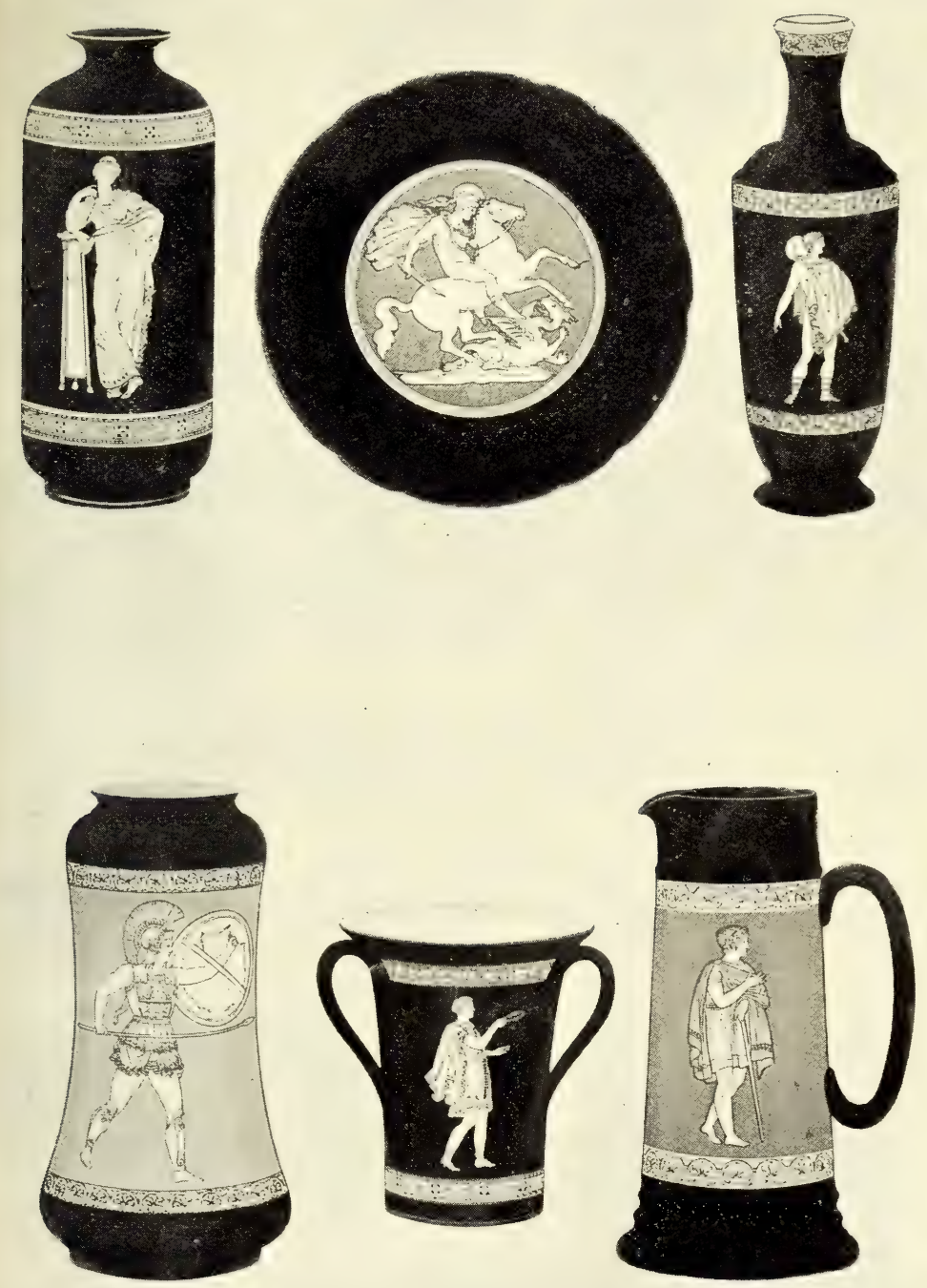

BEARDMORE'S BASALTINE AND ATHENIAN ART WARE. 



\section{CHAPTER IX}

\section{IN THE POTTERIES AT HANLEY}

\section{Mason's Ironstone China-Ashworth's}

THE ever-famous "Ironstone China" dates from the early years of the nineteenth century, the patent for its manufacture being taken out in I8I3 for "a process for the improvement of the manufacture of English porcelain," the specification being that "scoria, or slag of ironstone, pounded and ground in water, in certain proportions, with flint, Cornwall stone, and clay, and blue oxide of cobalt." Whether the scoria or slag of ironstone was actually responsible for the name "ironstone," or whether that name was the indication of the qualities of the ware-its hardness and strength-may be a matter for speculation; but there never was any doubt that these qualities and the decoration combined to give such popularity that has seldom been rivalled in this country. Our forebears took much delight in Mason's ware.

It was by no means a mere passing fancy, for, though Mason himself did not maintain his early success, those who have followed him in manufacturing ironstone china have had no cause for regret. The manufacture is now carried on by G. L. Ashworth and Bros., at Hanley, but the Daisy Bank Pottery of Wm. A. Adderley \& Co. at Longton appears in my list of the year I900, and it was at those works that Mason met success and failure.

The Broad Street Works at Hanley were the home of Mason's china after Mason failed, and in those works all of the shapes and decorations have been reproduced on ware which possesses the durability that has been its great feature. And still the trade flourishes, and through the home and foreign markets 
there comes a constant demand for immense quantities in all qualities, from the simplest in decoration to the most elaborate, in which colours and gilding are applied with finished skill. Ashworth's vases, the Indian vases of fine form, are worthy of a high place. No doubt collectors in the future will think so, but for the decoration of a modern home scarcely any will be found of better design or richer colour ; none will be equal in durability, which is, after all, a consideration worthy of the purchaser, who often buys cheap foreign goods because they are bright, even if they have no artistic qualities. It is not too much to say that English china and earthenware, such as are produced by the firm of Geo. L. Ashworth and Bros., have an immense superiority over the products of other countries. And they are much cheaper, because one service of ironstone china would outlive several of the fragile ones to which I have referred, and in the first cost there is not a great difference.

I have not dealt with the history at length, because the firm was kind enough to supply me with the information from the Art Journal, which follows from this point:

"The ware usually but erroneously known as 'Leek Pottery' (so called, but without any claim to the name, by Marryatt and Chaffers) is one of the highest developments of earthenware for decorative services, and is certainly at the same time one of the best, most beautiful, and durable of bodies. Of extreme hardness and solidity, and of faultless colour, it is capable of receiving the highest styles of decoration, and of becoming, in fact, equal to the finest china in richness of colouring and in artistic manipulation.

"The manufacture of this peculiar ware owes its origin to Mr. Charles James Mason, a potter of great skill and of commendable taste, who, after a long series of experiments, took out, in I8I3, a patent for the process, and carried on its manufacture for many years with great spirit and success.

"Mr. Mason was, it will be noticed, at this time (I8I3) of Lane Delph, near Stoke-upon-Trent, and here he carried on his manufactory. 'Lane Delph,' it ought to be stated, in the many changes which have been made in the names of 


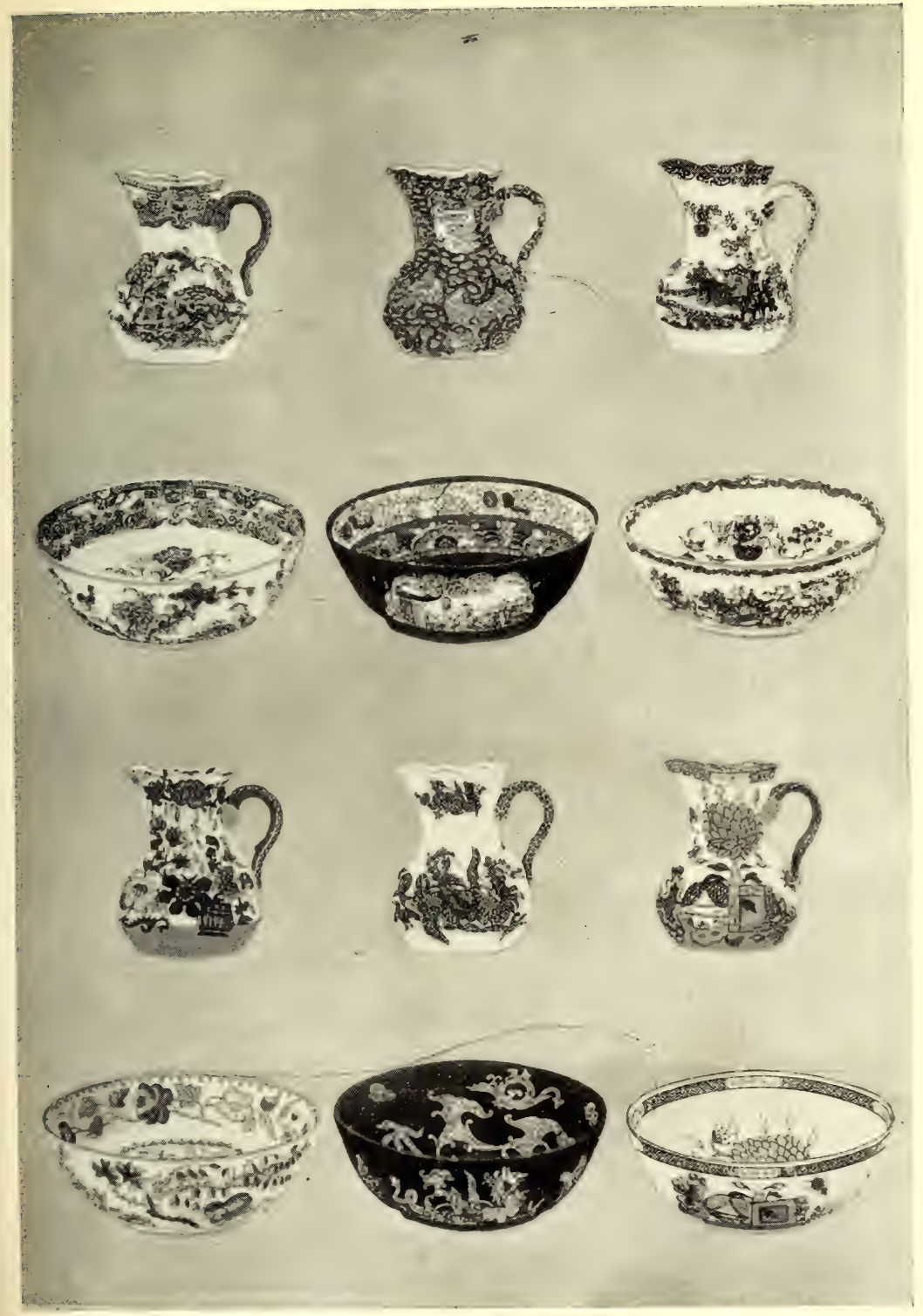

ASHWORTH'S MASON'S IRONSTONE CHINA JUGS AND BOWLS. 

places in the pottery district, is now synonymous with "Middle Fenton.' The manufacture was at this time carried on under the styles of 'G. M. and C. J. Mason,' and 'Charles James Mason \& Co.' The partners were Charles James Mason, the patentee of the Ironstone China, and his brother, George Miles Mason, who, in I832, unsuccessfully contested the then new district borough of Stoke-upon-Trent in the first election after it was constituted a borough ; his successful competitors being Josiah Wedgwood and John Davenport, both, like himself, manufacturers in the district. After a time Mr. George Mason retired from the concern, and it was then continued by the patentee alone. The concern, however, for want of capital and other causes, gradually dwindled down, until at length the moulds and copper-plates, etc., on which an immense amount of money had at one time or other been expended, got into various hands as securities for debts, and Mr. Mason thus became involved and crippled in his transactions. In I85I Mr. Francis Morley purchased the patent, the moulds, copper-plates, and entire business, from Mr. Mason, and, having got these matters together from the various parties who held them, removed the whole of his manufactory.

"Mr. Morley, whose connection with the Potteries commenced in I835, succeeded to the very old-established concern of Messrs. Hicks, Meigh, and Johnson, which he carried on for a time under the style of 'Messrs. Ridgway, Morley, Wear \& Co.' and afterwards by himself alone. This manufactory is one of the oldest in the Potteries. It was in existence in the early part of the last century (probably established about I720), and afterwards belonged to John Baddeley, an eminent potter, who died in I872. Here, it is said, printing in oil was first practised. Messrs. Hicks, Meigh, and Johnson were among the most successful manufacturers in the district, and produced, among other wares, a remarkably good quality of ironstone china. Besides this, they were large manufacturers of earthenware of the ordinary and finer kinds, and of china. They and their successor, Charles James Mason, were the only makers of ironstone china ; and when Mr. Morley, who purchased their business, became also, later on (in I85I-2) 


\section{I94 I9TH-CENTURY ENGLISH CERAMIC ART}

the owner of Mason's process and of his moulds, plates, etc., he became the only manufacturer of ironstone ware. Having united the two manufactories, he removed Mason's concern from Fenton to Shelton, and entered with great spirit into the production of goods on Mason's principle, increasing his trade very considerably, and, by close application and scrupulous care in the decorative department, established a lucrative business. In the first French Exhibition of I856 Mr. Morley exhibited some samples of his ironstone china, selected hastily from such of his general goods as happened to be in the warehouse, and for them was awarded the first-class medal.

"About nine years ago Mr. Francis Morley retired from the trade, and sold his entire business, moulds, plates, etc., to Messrs. Ashworth and Brothers, who continue the works.

"Messrs. Ashworth and Brothers continue, to the fullest extent, the manufacture of the 'Patent Ironstone China,' which they and their predecessor named the 'Real Ironstone China 'on their marks, and produce all Mason's best patterns in services, etc., made from his original moulds, which Morley carefully preserved and repaired.

"They also manufacture Meigh's ironstone, from the old moulds, etc., and make, besides these great features of their trade, every description of general earthenware in table, toilet, dessert, and other services, and in ornamental goods of the best quality. These they produce in immense quantities, both for home and foreign markets, about one-third of their whole productions being exported. The ordinary classes are principally exported to Russia, India, etc., and the more rich and costly to Havanna, Spain, and other countries. Sanitary wares are also produced, as well as insulators for our own and foreign governments. The 'Ironstone China,' from its extreme hardness and durability-indeed, it is not easy to break even a plate-is specially adapted, in its simpler styles of decoration, for services used by large steam-ship companies, hotels, clubs, colleges, and other places where hard usage has to be undergone ; while in its more elaborate and rich stylesand it is capable of the very highest degree of finish-it is eminently fitted for families of the highest ranks. It is much 


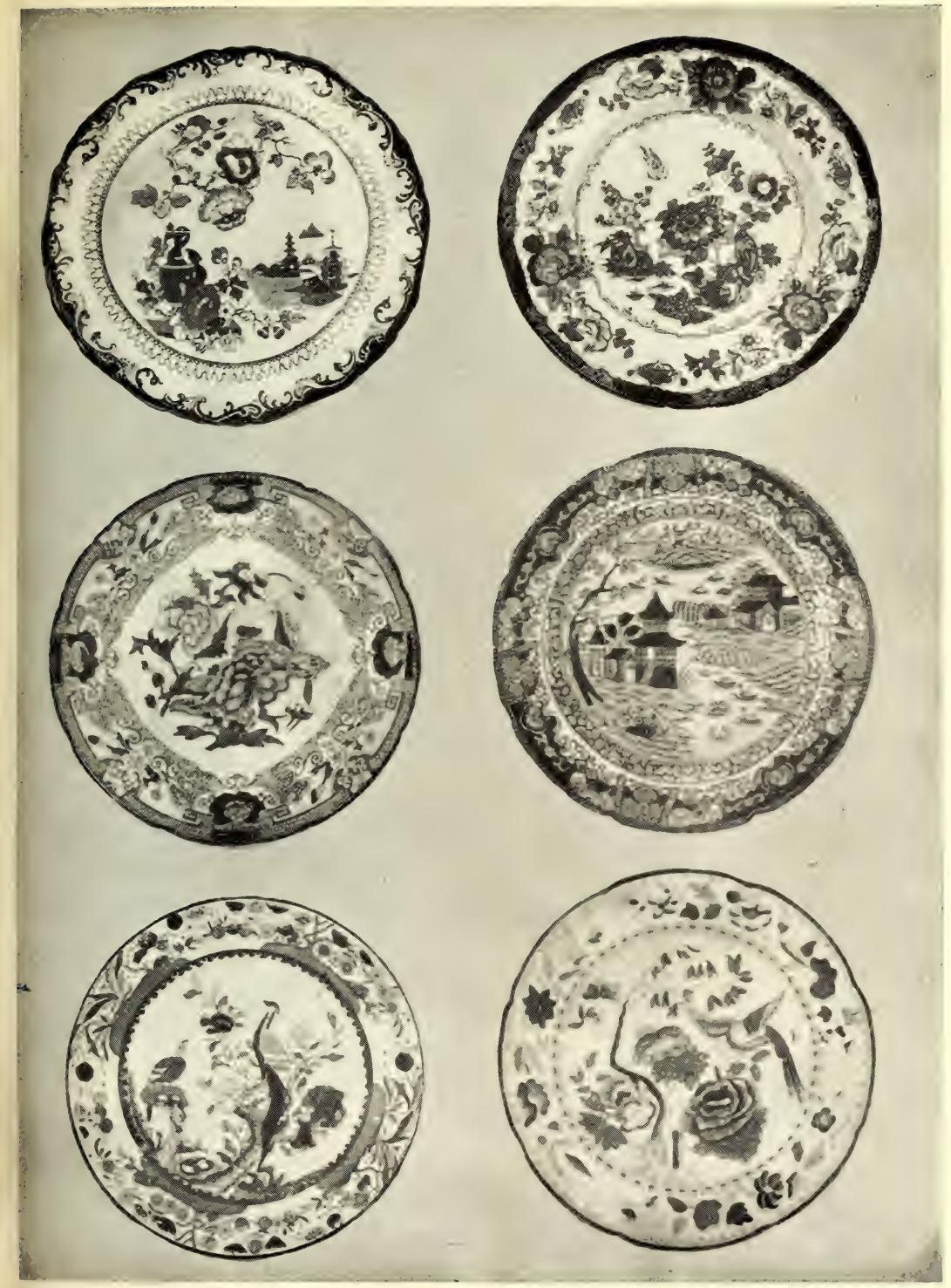

ASHWORTII'S MASON'S IRONSTONE CHINA PLATES. 

used in the houses of the nobility and higher classes. No climate affects this ware.

"The marks used by Mr. Mason were principally

\section{MASON'S \\ PATENT IRONSTONE CHINA}

with a crown printed in blue on the bottoms of the pieces, or

\section{MASON'S PATENT \\ IRONSTONE CHINA}

impressed in the body of the ware.

"After the patent passed out of Mason's hands into those of Morley \& Co., the mark was changed on more than one occasion. The principal one appears to be

\section{Real \\ IRONSTONE \\ CHINA}

impressed on the ware, and the Royal Arms, with supporters, crest, motto, etc., above the words

\section{IRONSTONE CHINA}

printed on the bottom of the goods. The mark of Messrs. Ashworth and Brothers for this peculiar ware is much the same as that of Mr. Morley.

SOME OF MASON'S MARK'S. FACSIMILES.

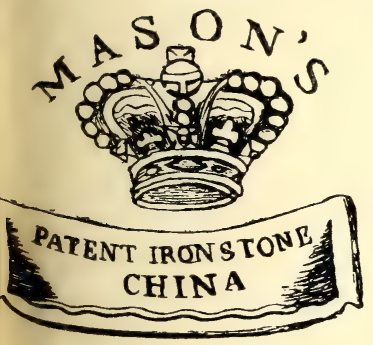

MASON'S PATENT IRONSTUNE CHINA

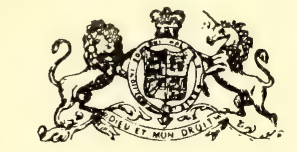

MASON'S PATENT

IRONSTONE CHINA.

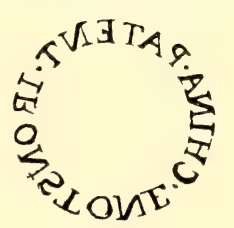

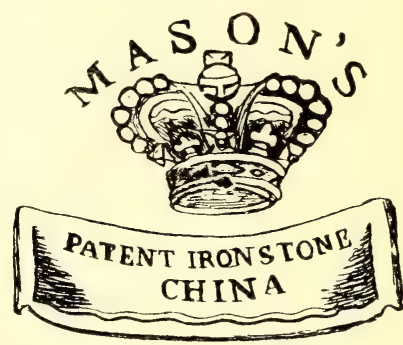

ASHWORTHS.

"The works of Messrs. Geo. L. Ashworth and Brothers, where the Ironstone China is now made, are at Hanley." 


\section{Cauldon Place}

When, in I802, Job Ridgway, father of the two famous potters John and William, built the works which have become a household name outside the pottery world, they became his partners in the firm of "Ridgway and Sons." After I8I4, when the father died, the brothers worked together for some years, being patentees of an improved tap or valve for drawing off liquors in I825, and appearing on Shaw's list of Hanley potters as "J. and W. Ridgway" in I829. Then, when another patent was obtained in I840, John Ridgway appears alone in applying for it, whilst for two others granted in the same year the applicants' names are "Ridgway and Wall." Though partners came and went " John Ridgway \& Co." continued as the title until I855, when the business passed into other hands and became "T. C. Brown-Westhead, Moore \& Co.," as it is at present.

Before that change happened Ridgway had received the most flattering recognition, in I85I, from the jury, who stated that the firm was one of the most important in the Staffordshire Potteries. A prize medal was awarded to the ware which was exhibited, for its excellent quality, for its simplicity and elegance in form and design, as a useful variety, which either in china or earthenware was comparatively inexpensive. Jewitt remarks that the productions of the manufactory are, and have uniformly been, the useful varieties of elegant forms where applicable, and of various styles of decoration. Table, tea, breakfast, and toilet services in fine earthenware, printed or otherwise decorated, and in china, in endless forms and patterns, are produced in immense quantities. Parian is also, to a small extent, produced. Before considering most particularly the productions of the present firm, the gratifying report written by the critic of the Art Journal in that year is next set out, and I can imagine that many persons studied his remarks on the

" contributions in porcelain and earthenware of Mr. John Ridgway, of Cauldon Place, Staffordshire Potteries. They exhibit examples of the useful rather than the ornamental; 

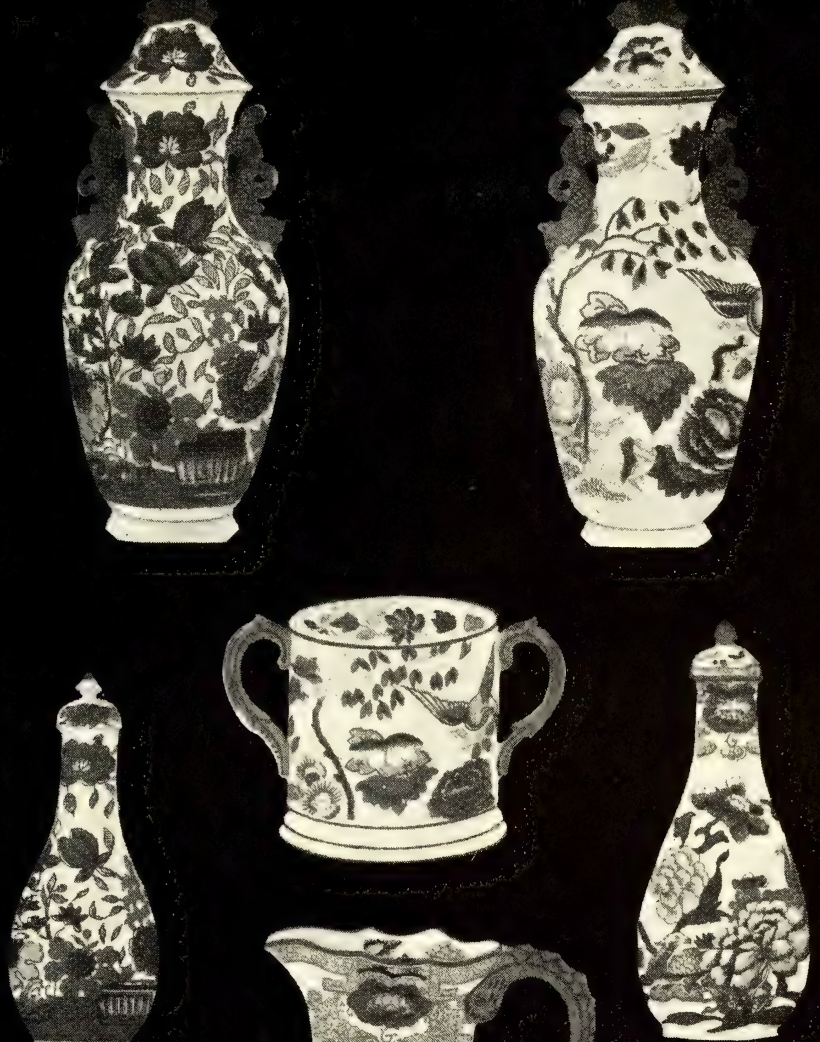

ASHWORTH'S MASON'S IRONSTONE CHINA. 

Mr. Ridgway's attention having been more especially directed to improvements in the forms and decoration of objects which are the wants of every day. The establishment of Mr. Ridgway is one of the largest, and among the best conducted, of the many factories of Staffordshire; and there is no manufacturer who has obtained higher reputation for the excellence of the materials employed. The works exhibited by him will demand consideration on this ground.

"We first engrave two of several 'Fountain' hand-basins
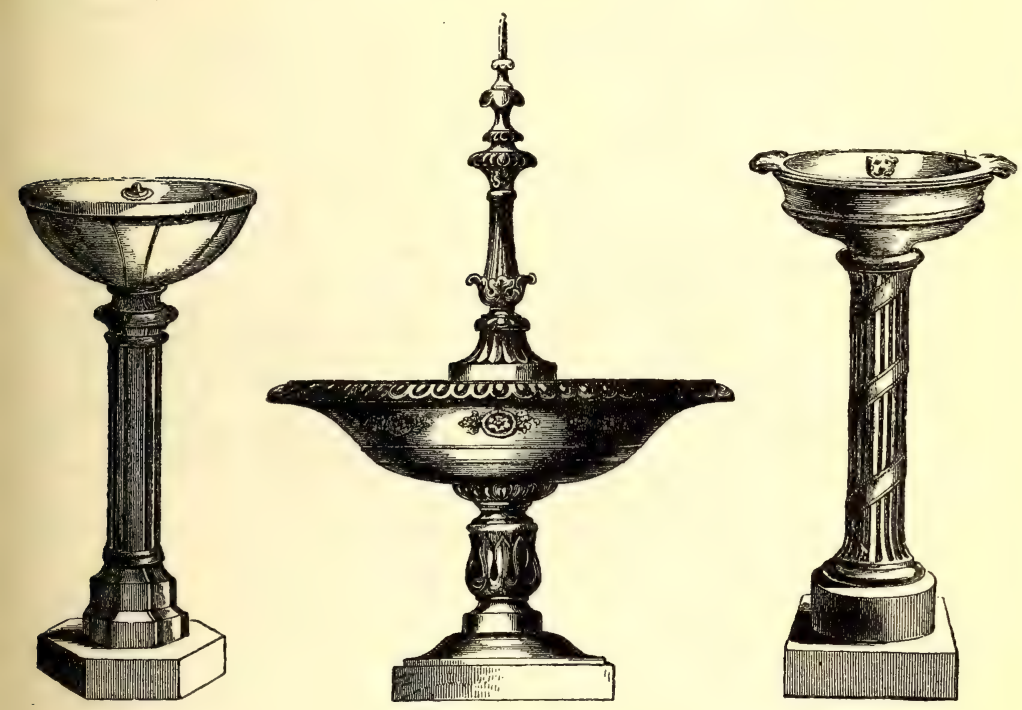

RIDGWAY'S EXHIBITS IN I85 I.

-objects which Mr. Ridgway devised in order to meet a suggestion of the Board of Health for a frequent and easy supply of pure water, and facilities for the rapid disposal of water that has been used. 'These vessels may be fixed by any plumber conversant with such work. They require neither wood nor brickwork about them, but simply to have the supply and discharge pipes attached, and to be screwed down to the floor.' But it will be perceived that although the usefulness of these articles has been the primary consideration, their elegance has also been properly cared for, and they are really graceful additions to the dressing-room, 
free of the trouble attendant on the use of the ordinary ewer and basin.

"Another novelty is a stair-rail, also made in earthenware, and susceptible of much that is ornamental in painting and gilding; there is a lightness and an elegance in this object, not without a peculiar value, when used appropriately, for terraces, etc.

"The large group delineates a graceful tea-service, remarkable for its simplicity. The amount of decoration is but small, but it is good of its kind, and as symmetry of contour has been chiefly considered, as well as that recommendable quality, economy, we cannot but think it has claims to atten-

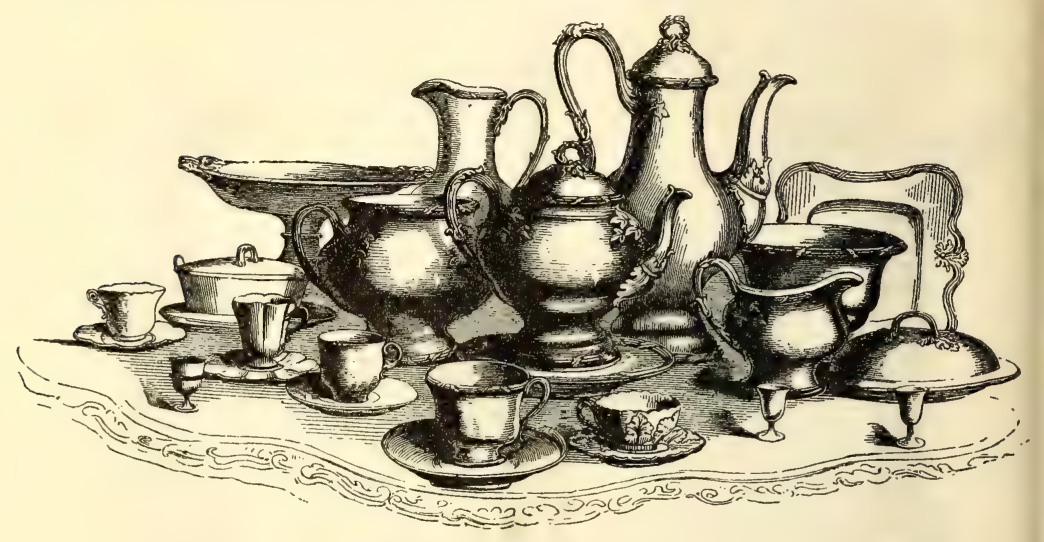

RIDGWAY'S EXHIBITS IN I $85 \mathrm{I}$.

tion on these heads. We must be understood, in some instances, to be doing what we trust the public may also do, when we award due merit to all manufacturers who endeavour to improve ordinary articles of domestic use, while they do not, at the same time, too greatly tax the buyer. There is as great a merit in this as in the production of articles of higher elaboration, produced, as they generally are, at prices which confine them exclusively to the rich. We have always fully appreciated the value of decorative Art, and, sometimes, had to deplore the want of a judicious acquaintance therewith in our manufactories; yet, while we are willing to bestow commendation, when deserved, on the ornamental articles which now meet the eye at every turn, and testify to the enlarged acquaintance of our mechanical designers with the 


\section{IN THE POTTERIES AT HANLEY}

leading principles of elegance, we are not the less prepared to give the meed of praise to the simple, the tasteful, and the economic works, which are to render pleasure as well as service to the humbler classes. We also frequently see, with satisfaction, a simple treatment adopted even for expensive works ; it is not elaboration of ornament which makes elegance or gives dignity to design, a fact with which all who have studied Classic Art are sufficiently familiar.

"The principal pieces of a dinner-service, which fill another
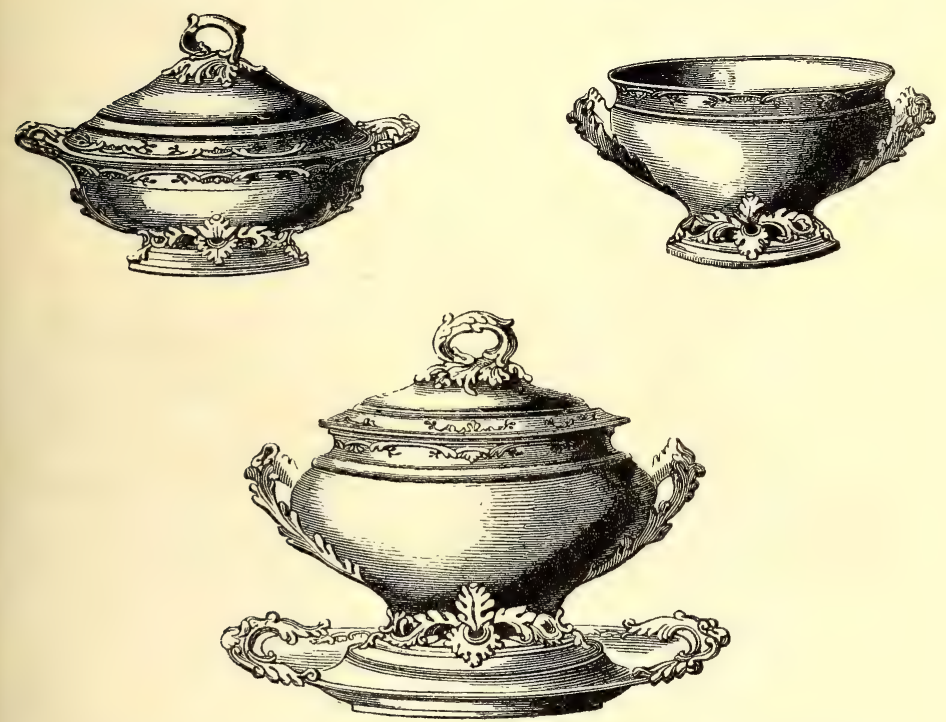

CAULDON PLACE EXHIBITS IN I85I-THEN RIDGWAY, NOW BROWNWESTHEAD, MOORE \& CO.

of our columns, are equally remarkable for the simplicity with which they are designed. The ornament upon them is of the most unpretending kind, and all the better for its unobtrusiveness. It consists entirely of a few simple scrolls and fanciful leaves, which form the handles or encircle the bases of the various articles upon which they are introduced. The general form of each article is well preserved and its elegance enhanced by the contrast afforded in the ornament thus sparingly introduced, and the result is exceedingly satisfactory. 
"The fountains are of a more ambitious character, and they may also be considered as novelties. The purity of well-glazed pottery gives it a peculiar applicability for such a purpose, and the happy manner in which its surface might be rendered agreeable to the eye, by the decoration so readily placed on it, should give it a claim to the attention of persons of taste. Flowers and foliage, or tints of varied hue, might give variety and beauty to such decorative adjuncts to the garden, of which none of the generally used materials are

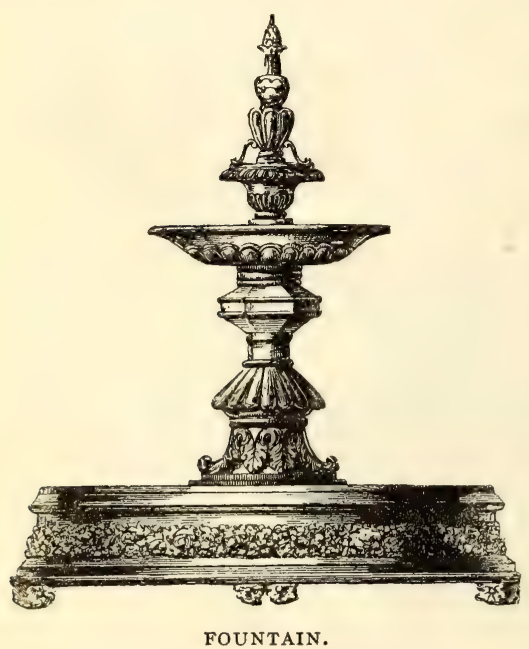
equally susceptible; and the 'coolness' of their appearance, a particularly acceptable quality in those seasons when gardens and fountains are especially agreeable, is also considerably enhanced, when formed of porcelain. The first fountain of the $t w o$ which we engrave is designed in the taste of the seventeenth century, and is, therefore, to be considered as a type of a peculiar style, which was sometimes introduced with good effect on old Delft ware, and occasionally appeared as a centre for the dinner-table. It is susceptible of bright masses of colour, the boldness of its surfaces, as well as their occasional angularity,-affording full scope for this. Our second example is more classic in its outline, and elegant in its proportion; floral ornament is sparingly introduced on its surface, and its general effect is that of chaste simplicity.

"It will at once be apparent that there is a decided "opening' for such a branch of pottery-manufacture; one that will much add to the reputation of the Staffordshire manufacturer if taste be properly directed; and one that will be welcomed in the present day, when so much is required and patronised by persons of refinement. We trust the ' fitness' of articles for the localities to which they are to be 

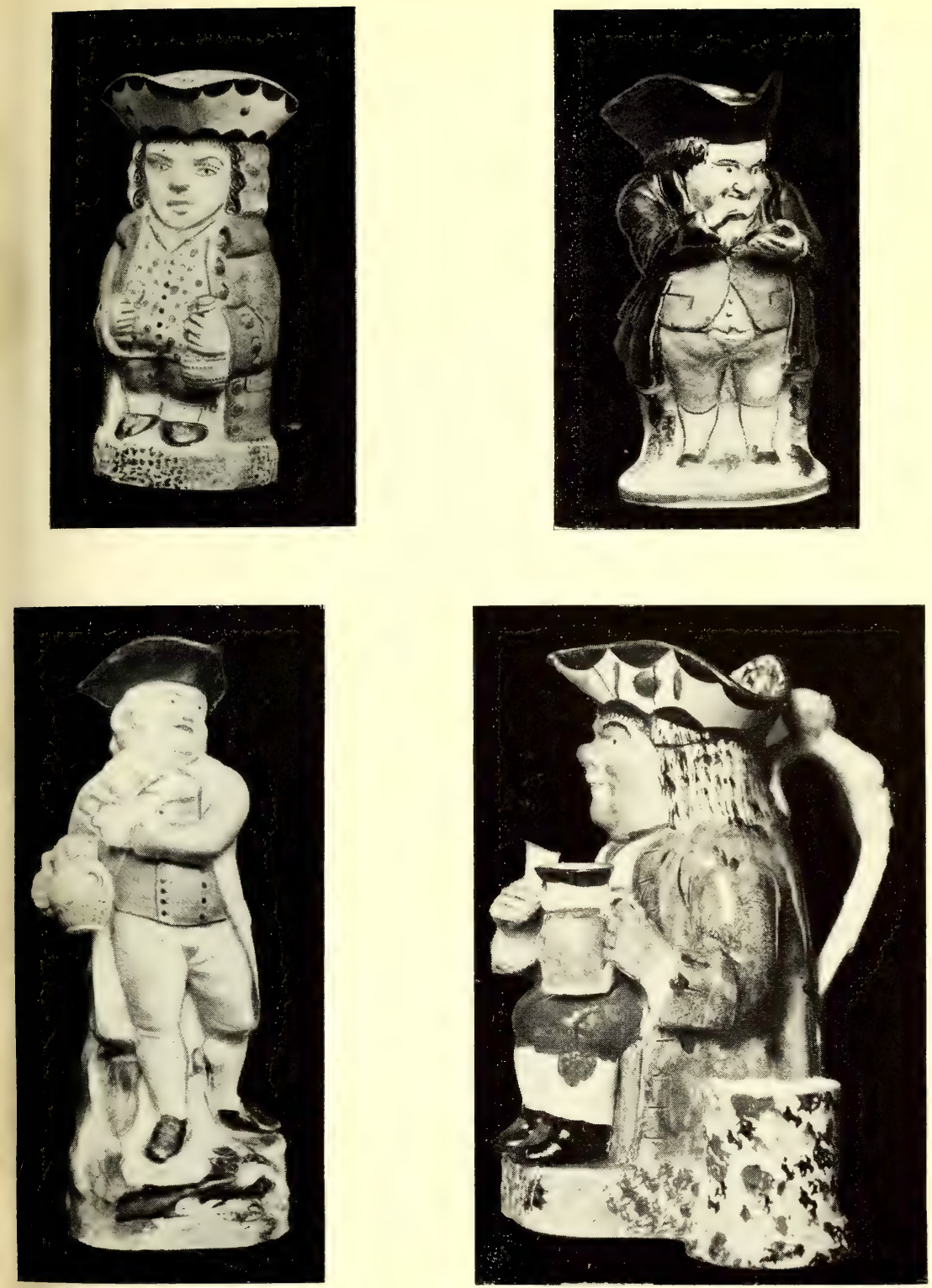

EARLY I9TH-CENTURY TOBY JUGS, INCLUDING “THE SNUFF-TAKER." 

devoted may be more carefully studied than has been our wont in years gone by; this object, which should be scrupulously considered and provided for by the manufacturer, would achieve entire success. Mr. Ridgway is an extensive as well as a valuable contributor to the Exhibition, as they who know his establishment might have expected."

This criticism is charged with good sense, and I think you will agree that Ridgway was worthy of it. To say that there will be little old Ridgway ware and china amongst future collections is to assume that fashion will never fail in its pursuit after fine specimens. That is probably true; useful articles stand in another class, and though there is fine old Ridgway it is not easy to get, owing to its scarcity.

Ridgway continued his connection with T. C. BrownWesthead, Moore \& Co. until I858, when he retired and left the actual management to $\mathrm{W}$. Moore, who had been his valued assistant. Then came the London Exhibition of I862, which brought another medal, and began what might almost be termed a series of successes for the china, earthenware, Parian, and majolica which form the main output. We can only refer to some special services and pieces. In I877 a magnificent dessert-service was made for the then Prince of Wales, beautifully painted with scenes from the huntingfields, every subject being different, just as in Copeland's service made for him in I866. Cauldon Place competed with Sèvres, Dresden, and other Continental manufactories, and succeeded in obtaining orders from the Russian royal family for richly decorated breakfast, tea, dinner, and dessert services. If the firm did nothing more, that effort was enough to stamp them with a high mark of distinction. A private enterprise defeated state-aided institutions; it seems impossible, yet it was done, and a reflection of it occurred when H.R.H. the Duchess of Edinburgh, herself a Russian princess, gave to Messrs. Brown-Westhead, Moore \& Co. a commission to manufacture a series of toilet-services from her own designs.

Amongst English firms this had a large collection exhibited at the Philadelphia Exhibition of 1876 , and some years later "Cauldon " china, earthenware, and sanitary ware (stoneware, 
etc.) vied with Copeland at Paris, where both firms were awarded the Grand Prix. This was in I889, and in 1893 Brown-Westhead, Moore \& Co. received the highest awards at Chicago. Their enterprise is shown in other directions too, for in addition to the show-rooms in London, there are two in Paris, one for sanitary ware, and others at Hamburg and Rotterdam. In summarising the productions of the firm it is not possible to present all that should appear, but the illustrations do not assist the description, which is far too short, but must suffice.

The goods produced at Cauldon Place embrace almost every description of ceramics. In earthenware all the usual table and toilet services, and useful and ornamental articles of every class are made. The quality is peculiarly good, hard, compact, and durable, and the patterns chaste and effective. They are produced in white and in every variety if printed, flown, enamelled, painted, and gilt patterns. In thina, which in body and glaze is of the highest quality and of peculiar durability, an immense variety of services and articles are produced, and all are equally good in point of artistic decoration; the ground colours, whether rose $d u$ Barry or otherwise, of a remarkable purity and evenness, and the gilding, both dead and burnished, of unusual solidity. The same remarks apply with equal force to the dessert ware, some of the patterns of which are of surpassing loveliness and give evidence of the highest and most successful cultivation of decorative art. One special design has an outer rim, so to speak-for the plate itself is perfect without it-formed of loops of ribbon standing out clear from the beaded edge of the plate. This simple but graceful arrangement imparts a lightness and elegance to the service which are quite refreshing. Another has the rim formed of rays of pellets with a pleasing and novel effect ; the tripod stands of the comports being, like the plates, exquisitely modelled and richly painted and gilt. Other patterns, notably one with a rich maroon ground and white bead edge, are, besides being exquisitely painted and gilt, enriched with jewelling. Vases of pure and severe taste in form, and displaying great skill and 

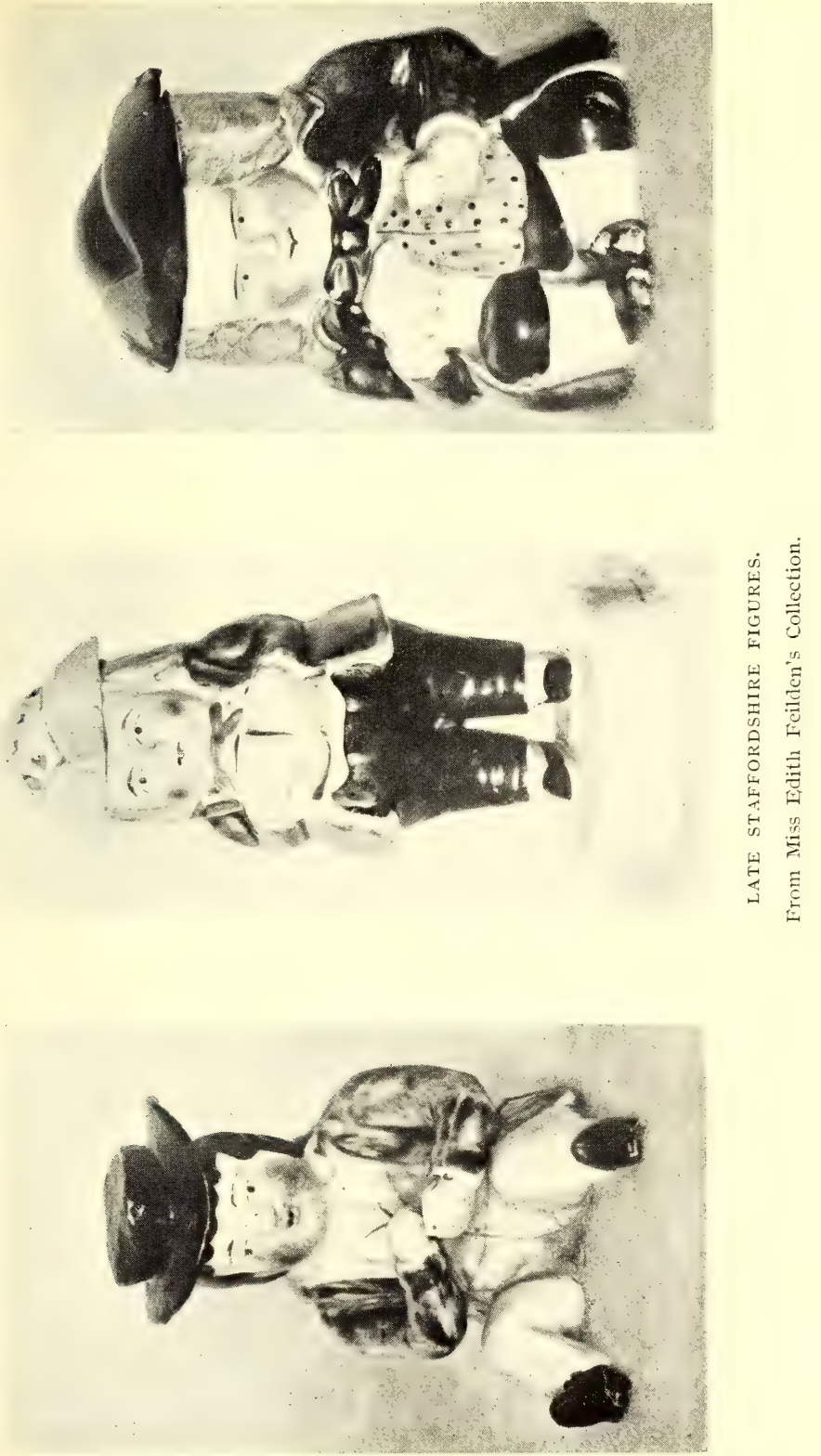

judgment in decoration, are also produced, as are likewise jugs of faultless excellence.

The marks used on old Cauldon were "I. Ridgway ;" "Ridgway \& Sons" ; “ J. W. R." in a shield; " John Ridgway \& Co., Cauldon Place, Potters to Her Majesty," with the Royal Arms and "By Royal Appointment." The present firm has several with the name in full or its initials " B W M" or "B W M \& Co," and "Cauldon, England." Occasionally a crown with the same names of origin is found to mark the fact that the proprietors were "Potters to Her Majesty."

\section{Old Hall and the Meighs}

Shaw, in 1829 , named the following potters of this Hanley district of the Potteries: E. Mayer and Son ; Job Meigh and Son (Old Hall) ; Dimmock \& Co. ; Toft and May ; J. Keeling ; W. Hackwood ; T. Taylor ; J. Glass ; J. and W. Ridgway ; Hicks, Meigh, and Johnson; H. Daniel and Sons; J. Yates; and Hollins, Warburton, Daniel \& Co. (New Hall). Some of these potters were the successors of those who worked in the same potworks from the early years of the eighteenth century, but the Old Hall factory was only established by Job Meigh in I770, and, until its acquisition by a limited company in I86r, Job had two successors, his son and grandson, both named Charles.

Their business was described as one of the largest in the district, and some particulars which have been recorded reveal extraordinary activity about I85I, when upwards of seven hundred hands were employed in the various departments in manufacturing eighty tons of clay into various articles by the use of two hundred and fifty tons, every week. The output must have been enormous.

At the Exhibition in that year medals were awarded to the firm, which received further similar recognition from the Society of Arts. The stoneware of that period is familiar to us. The illustrations in jugs, flower-pots, and the like give a good idea as to the style of decoration employed upon the stoneware, which had a body of fine quality, hard and remarkably durable. 


\section{$2 \mathrm{I} 2$ I9TH-CENTURY ENGLISH CERAMIC ART}

In Parian or statuary porcelain, vases, groups, busts, figures, and other ornamental pieces were made. The body of this ware was amongst the best of its class, and the modelling and finish of faultless excellence. The clock in Parian, one of the exhibits, shows a case of very elegant design, superior to any which I have seen in this material, and the vase with classical figures shares with the bacchanalian cup a distinction far beyond the ordinary. They deserved the good opinion of the critic who, at that time, wrote: "They are works of a right good order, and exhibit marked improvement in one of the most extensive and best-conducted of the factories of Staffordshire "; and Jewitt, writing in $I 878$, gave much credit to the Old Hall Earthenware Company, which succeeded the Meighs, and is now the Old Hall Porcelain Works, Hill Street.

The productions of these works include every variety of earthenware from the highly decorated to the ordinary blue, printed and plain white wares, with porcelain, in addition to productions such as those which have been described. Many of the patterns are of great artistic merit; all are chaste and effective. Perhaps the one design peculiar to this factory, or at least the one in which it excelled, was the convolvulus, coloured after nature, with sober yet rich gilding. The excellence of the painting and enamelling, the jewelling and the gilding, call for remark, especially in the fine dessertservices, the most costly varieties of which will bear comparison with those produced by other firms for the quality of the paste, the shape, and the artistic decoration. The transferprinting, too, is well done, being clear and bright, and in combination with hand-painting, has reached a high standard. In stoneware the jugs are specially good, and the black ware or jet is often pleasingly decorated with dead and burnished gilding and coloured enamelling.

SOME MEIGH MARKS.
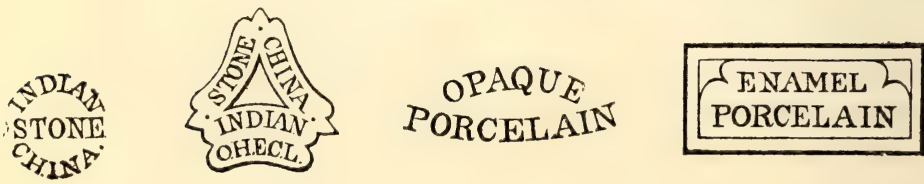

MEIGH. 

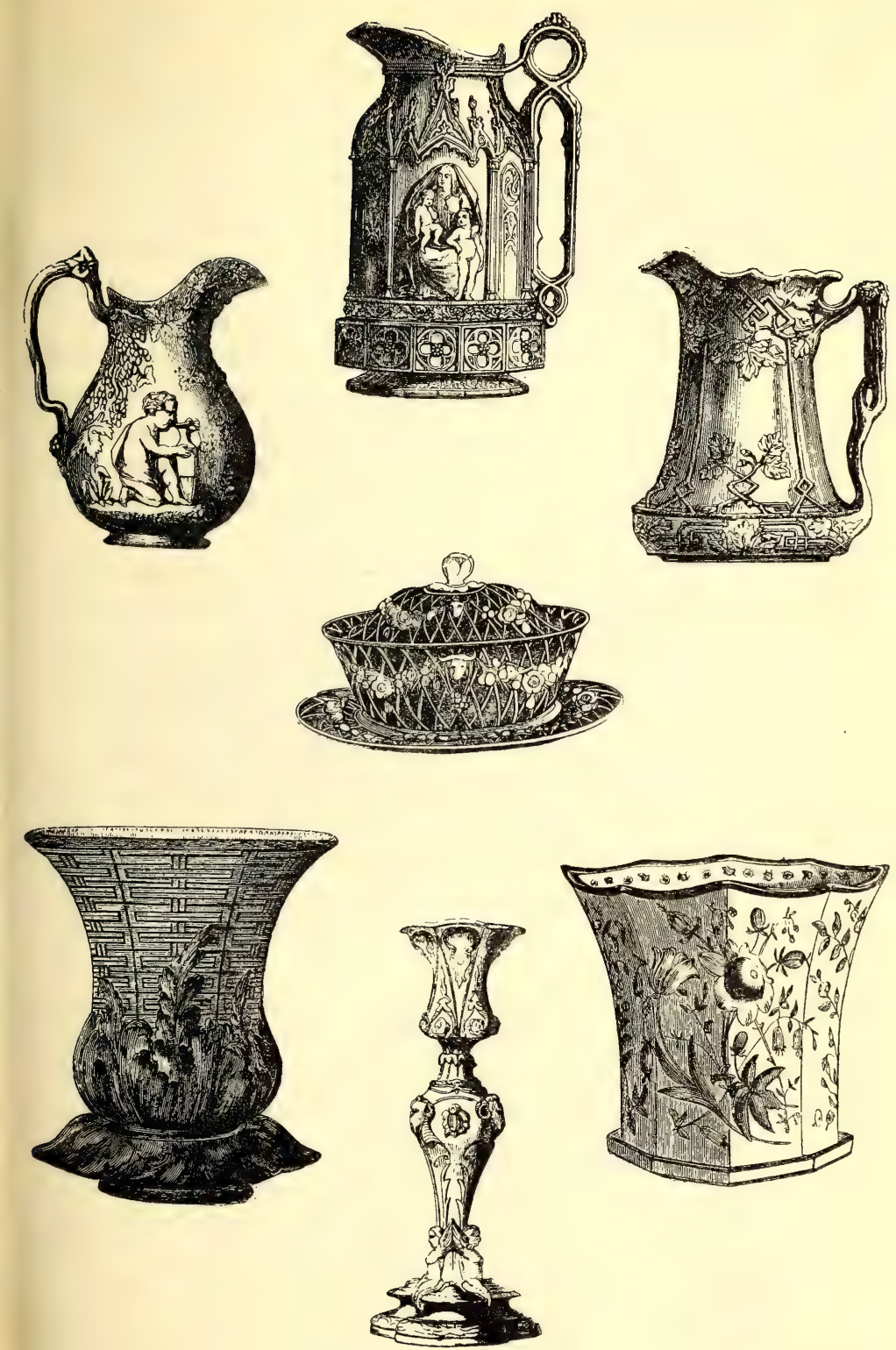

MEIGH'S EXHIBITS IN I85I. 
The works are very extensive and include mills for grinding all descriptions of materials used in the manufacture of earthenware and china. Some Staffordshire potters avail themselves of the supplies of ground flints and stone prepared by potters' merchants, who say that French boulder flints and West of England hard, purple, vitreous china-stone, when dry-ground, are much superior to those water-ground for clay-making, owing to the entire absence of chirt-runners and pavers in their grinding-mills. They claim that the dry, fine powder having from Io to I5 per cent. less water is cheaper and better fitted for fritting and for glaze and colour making, and that, not coming into contact with iron, it is entirely free from dirt and rust. The Old Hall works are capable of supplying a large demand.

Their markets abroad include the colonies, France, Germany, and the United States, which is the chief American buyer. It is well known that for years past choice examples of fictile ware, as well as high-class other kinds of articles of British handicraft, have found ready sale in America; but we were scarcely prepared to learn, during a recent visit to the Potteries, that the chief firms were paying altogether special attention to American orders; and that a few other firms, who make general goods of superior finish, but do not aim at the very highest class of work, were devoting themselves almost entirely to trade with that continent.

Some of the old-fashioned London dealers in china and glass, such as Phillips, Goode, Mortlock, Daniell, who mainly supply the nobility and gentry, have their own pick of artistic pottery from Staffordshire, and from Worcester, Derby, Coalport, and elsewhere; but the fact remains that America is at the present hour the purchaser of the most costly work, and, to a very large extent, of the better-class general pottery of English make. Noted manufacturers like Minton; Copeland; Wedgwood, Brown-Westhead, Moore \& Co. ; Doulton \& Co. (Burslem) ; Brownfield; Moore Bros., apart from their specially decorative pieces, are now busy catering for American requirements which differ somewhat from English in a few 

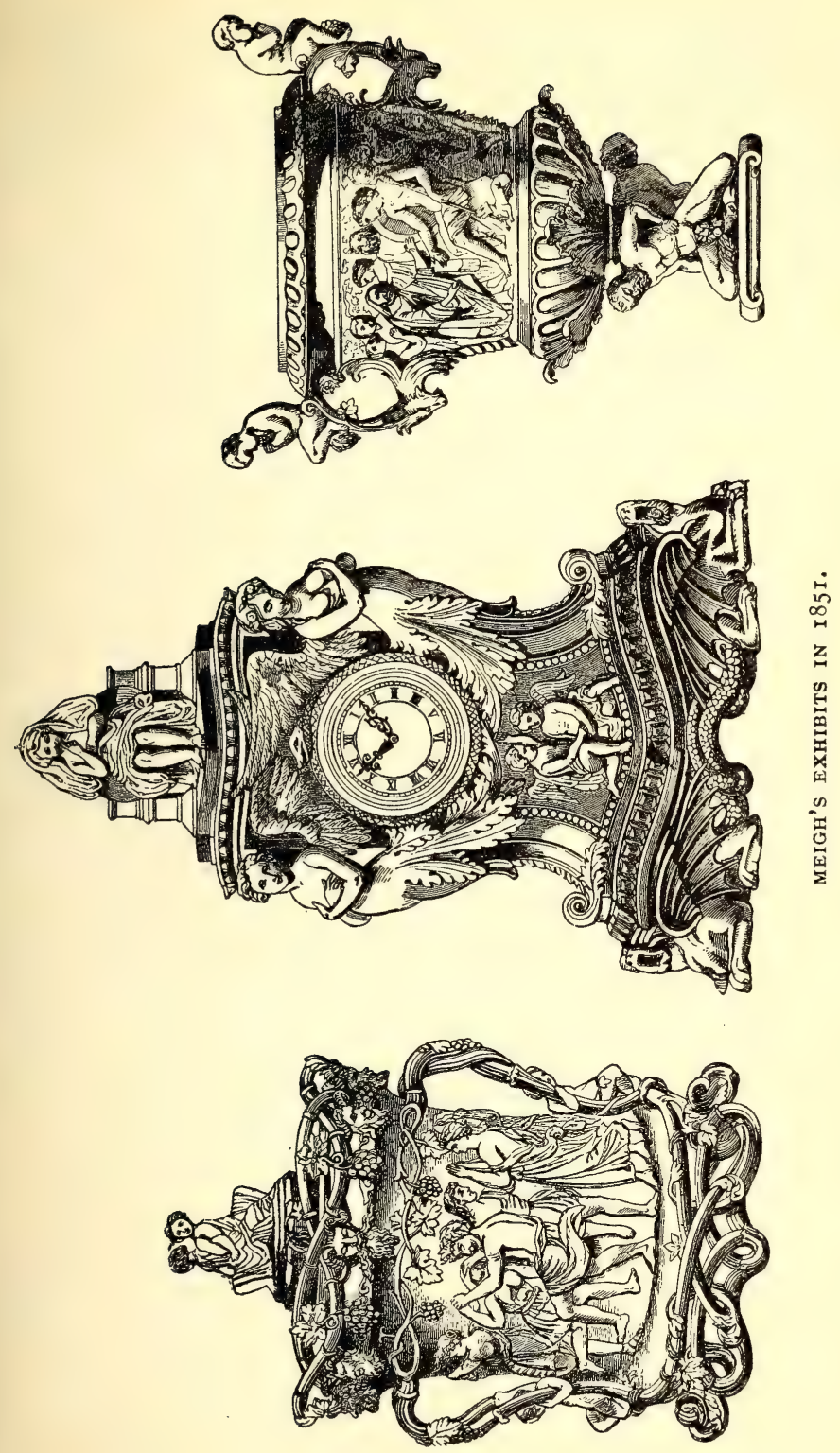
2 I6 I9TH-CENTURY ENGLISH CERAMIC ART

particulars. For instance, their dinner-services seldom include tureens and vegetable dishes of the same material, it being a recognised rule for these to be in silver, which costs little more, and, indeed, sometimes less, than richly decorated articles of the highest quality in porcelain. 


\section{CHAPTER $\mathrm{X}$}

\section{LONGPORT AND LONGTON POTTERS}

\section{Longport : Davenport}

THE manufactories at Longport, which in I793 came into the possession of John Davenport, ceased in I886, so that the bulk of the work was carried on in the nineteenth century, at the close of which, early Davenport china had already become of value to the collector, and fine examples are now much sought after. This was one of the works where glass-making was carried on side by side with earthenware at first, and later on with the addition of china. The earthenware made was that common to the Potteries-white, cream-coloured, and blue-printed, with open-rim work of the same kind which Adams, the Herculaneum works at Liverpool, and other makers produced. And as Davenport's early wares, blueprinted, were, like Adams', typical, I may say that this was the commonest of all forms of decoration, but certain firms were happier than others in the selection of their particular tint of cobalt blue, which, by transfer-printing, was applied to the biscuitware and then glazed. Besides Davenport and Adams and Close \& Co. (late William Adams and Sons), Wedgwood (second Josiah), Spode, Minton, Stubbs of Longport, Riley, Miles Mason, Enoch Wood and Sons, the Don and Middlesbrough potteries, all the potters of Shelton, are a few who freely employed this style of decoration, and many other factories like those of Leeds, Newcastle, and Sunderland, practised overglaze black printing through the nineteenth century or some part of it.

Davenport's manufactures were as popular as he was. 
In I832, two years after he retired from business, he was elected M.P. for the borough of Stoke-on-Trent, being one of the first two members who represented that town. Henry Davenport then carried on the business, which, on his death in I835, passed into the hands of his brother William, who greatly extended them. He died in 1869 , and was succeeded by his only son Henry, who in 1876 was fully sustaining the high character of the productions of the works, which, however, ceased about four years later.

It was John Davenport who in I806 welcomed the Prince of Wales, afterwards George IV., and his brother the Duke of Clarence, afterwards William IV., when they visited the works, and no doubt he superintended the order which came from the latter on his accession in I 830 for a superb service to be used at his coronation banquet. This service gave the most entire satisfaction, and on it for the first time Davenport added the crown above his name as his mark.

The special features of the firm's productions during its existence are seen in various pieces, such as vases and the like, where the handles, borders, rims, and feet are massively gilt, and where the raised ornamental flowers often enclose a slight landscape in colours. Derby and Coalport practised a like form of decoration, and when neither of the three factories marked the wares, as sometimes happened, an expert only can identify them, for the body, glaze and form were not peculiar to either. They were all of English bone-porcelain, which nearly all the factories used from the early years of the nineteenth century; with slight variations the constituents were: for the body, china stone and clay with bone-ash ; for the glaze, the same stone and clay with boracic acid, alkalies, and lead oxide. The colours employed by the Davenports were especially good, both in the painting and the coloured grounds.

The deep blue and rich shades of red and the other colours somewhat lavishly employed were generally combined with massive gilding, which on some pieces, however, though elaborate, is delicate. Perhaps the best word which would adequately describe some of the rich tea and other services is sumptuous, especially when the fine old Indian and Japan 


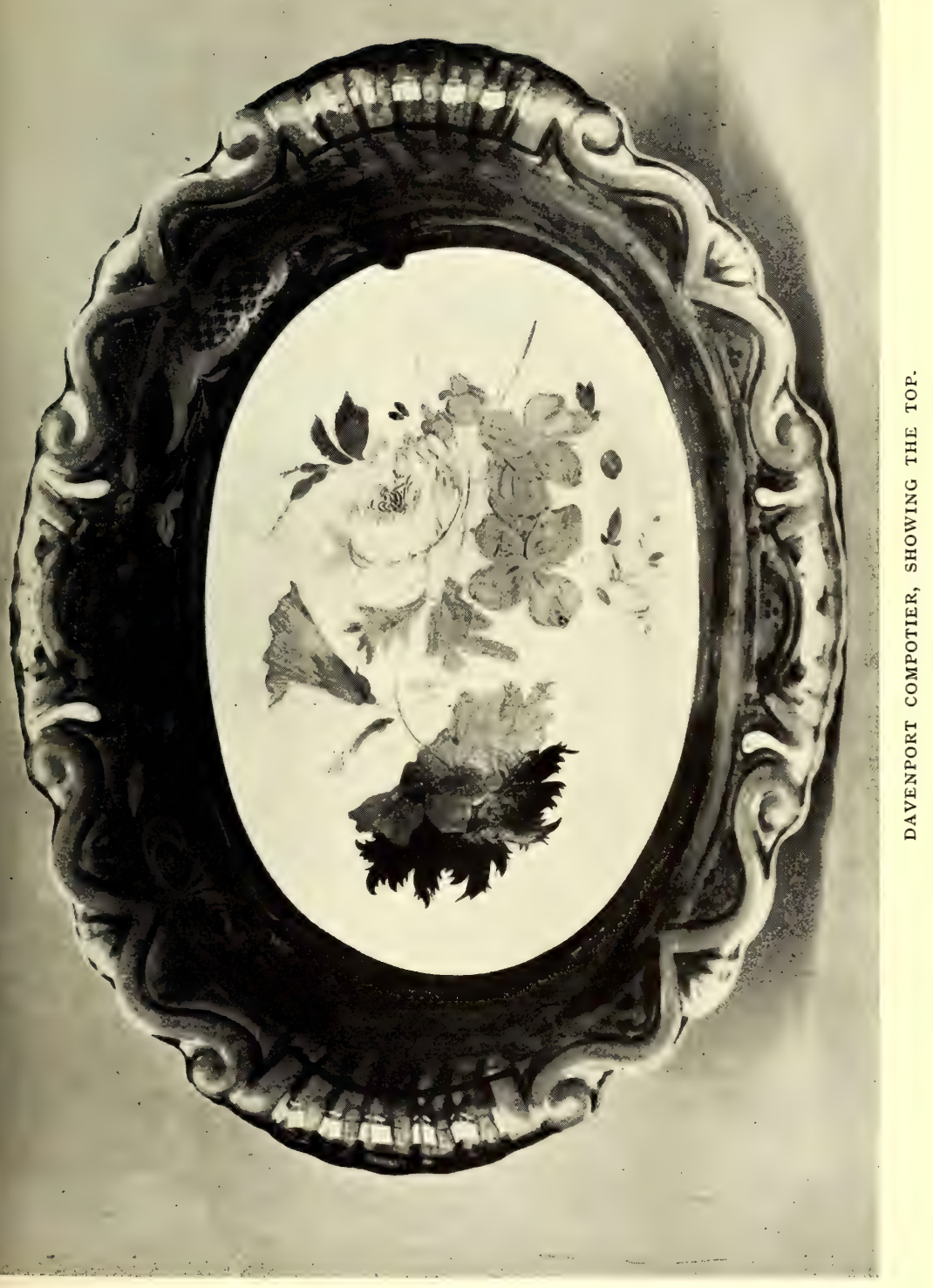



patterns were used, for which Spode and Derby were also noted. In the tea-services, which had often coloured grounds of rose $d u$ Barry or celadon, cups may be found with sunk panels, and with feet which were usually gilt. During the early years of the nineteenth century the wares, the china especially, suffered from a mediocrity of artistic decoration, from which may be excepted the better class of Japan patterns painted at Davenport's, Spode's, and Derby ; the highly esteemed Copeland and Minton china did not depend upon feeble imitations of earlier work as did those of many Staffordshire potters, and therefore stands in a class apart.

Davenport's stone china and earthenware were extremely varied in pattern and shape, and, above all, in decoration, from the plain to the most elaborately decorated. Like similar products from the other factories, these were technically excellent, and, amongst the many patterns which have been most popular, the willow pattern transfer-printed stands first, the blue being very pure.

The marks used were DAVENPORT or LONGPORT over an anchor, which was the factory mark, though the china-ware after I830 omitted it for the crown above the name. In the printed marks variations may occur such as DAvENPORTS \& Co. in a circular garter. The only other mark without either the name or the anchor is a small flower with six petals.
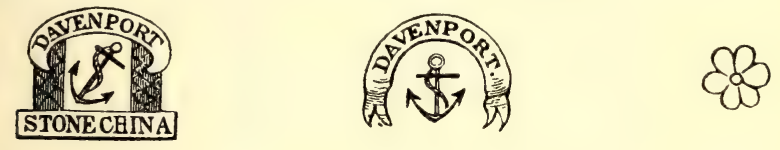

$\mathrm{D}^{\mathrm{aven}^{\mathrm{en}} \mathrm{p}_{\mathrm{rt}}}$

ㅇ․
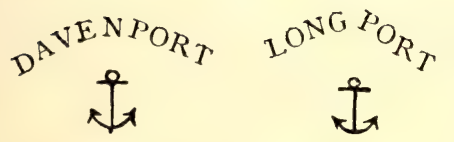

DAVENPORT

LONGPOR'1

DAVENPORT

LONGPORT STALFORDSHIRE

Amongst the Longport potters in Igoo were Capper and Wood, who made jet and Rockingham; W. and E. Corn, white granite, porcelaine-royal, and art pottery ; Gaskell and Grocott, door furniture ; Thos. Hughes and Son, white granite, semi- 
porcelain, and earthenware; and W. T. H. Smith \& Co., earthenware and tiles.

\section{Longton : Barlow}

Amongst the oldest works in Longton, those of Market Street were said to have been the first established by Cyples. The Cyples and Barker partnership followed, and later they were acquired by Thomas Barlow. For some time black basaltes and tinted bodies only were produced of a fine compact body. Lustre-ware was added to the manufacture, and marked with an impressed B. A great step forward followed in the introduction of china of the usual kinds for household use, until Barlow turned his attention with much success to decoration. In the Exhibition of $185 \mathrm{I}$ appeared the appended report :

"Cups and saucers are the needs of every household in all parts of the civilised world ; they are especially so in England. All our manufacturers produce them; but in one case at the Exhibition there was a collection of these objects only: they were the productions of Mr. Thomas Barlow, of Longton, and manifested much taste and artistic skill, being highly creditable to the manufacturer and the artists in his employ: the designs, both shapes and decorations, were by Mr. H. J. Kane, and the whole of the flower painting was by Mr. Thomas Simpson. The subjects were by no means exclusively floral ; they were frequently arabesque, sometimes had heraldic devices, and often were ornamented with raised gold. The dessert-plates (of which we give specimens) were principally of one pattern-an agreeable novelty - the centres being varied ; they were excellent Art-productions."

The same proprietor in 1876 was manufacturing earthenware of all the familiar kinds in Commerce Street, where the firm of T. W. Barlow and Son, in Igoo, still carried on the work. At that date the list of Longton potters included no less than ninety-five names.

\section{Longton: Moore Bros. now Bernard Moore}

These art-works at Longton produce some of the most lovely porcelain which this generation has ever seen, notable 

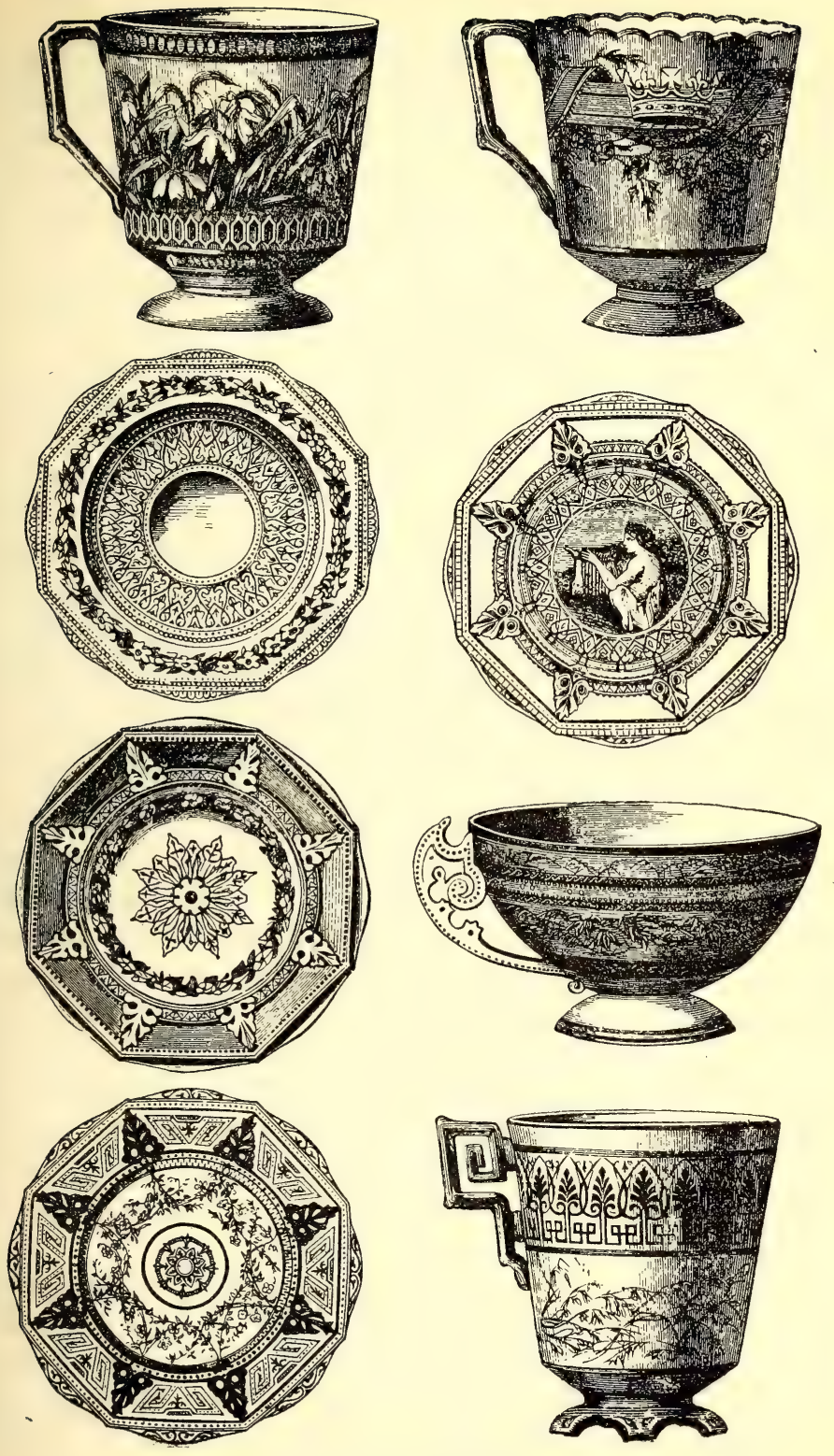

BARLOW'S EXHIBITS IN I85I.

223 


\section{I9TH-CENTURY ENGLISH CERAMIC ART}

above all for the extraordinary brilliance of the coloured glazes in which the Chinese, who have been for ages unrivalled, meet a worthy opponent, in which Bernard Moore fairly reveals himself as the master of porcelain enamels of wonderful quality, and in which he has placed this country at the head of the ceramic world.

The St. Mary's Works, where these wizard-like transmutations occur, were founded in I 830 and carried on until 1859 by Moore and Hamilton. Then Samuel Moore became the sole owner, and built new works which, in I870, had new owners; his sons, Bernard and Samuel, succeeded him as Moore Bros. The early productions included china services for household use, more or less decorated, but the output has been more and more that art porcelain so altogether admirable with famous enamel colours. In I876 Jewitt notes a camel teapot- "the Arab tying on the bale forming an excellent handle, and the neck and head of the animal a good spout-a well-conceived design, powerfully and cleverly modelled. Then, a group of two Cupids carrying a third, who bears a turquoise shell, massively gilt inside, is described with the remark that the Persian turquoise glaze made by the firm is remarkably clear and brilliant in colour, and not surpassed by other houses. And he goes on to say that, in enamelling, Messrs. Moore Bros. have made much progress, some of their designs in cloisonné enamel being highly effective, both in form of vessel and in arrangement of colour. Notable among these are pilgrim bottles, the rich and massive gilding of which throws out and relieves the enamelling in a very marked and effective manner. In china, and also in majolica, Japanese reproductions are made; in these the well-known Chinese ruby glaze has been cleverly imitated; it is rich and full in colour."

I could name many potters whose work in colours is very fine for pottery, but I know of one only who is in the same class with Bernard Moore in porcelain. The sang de liouf is a marvellous red, and the transmutation vases, where that colour is veined and splashed with others, resemble a beautiful veined red jasper, and that famous peach-blow, or should it 


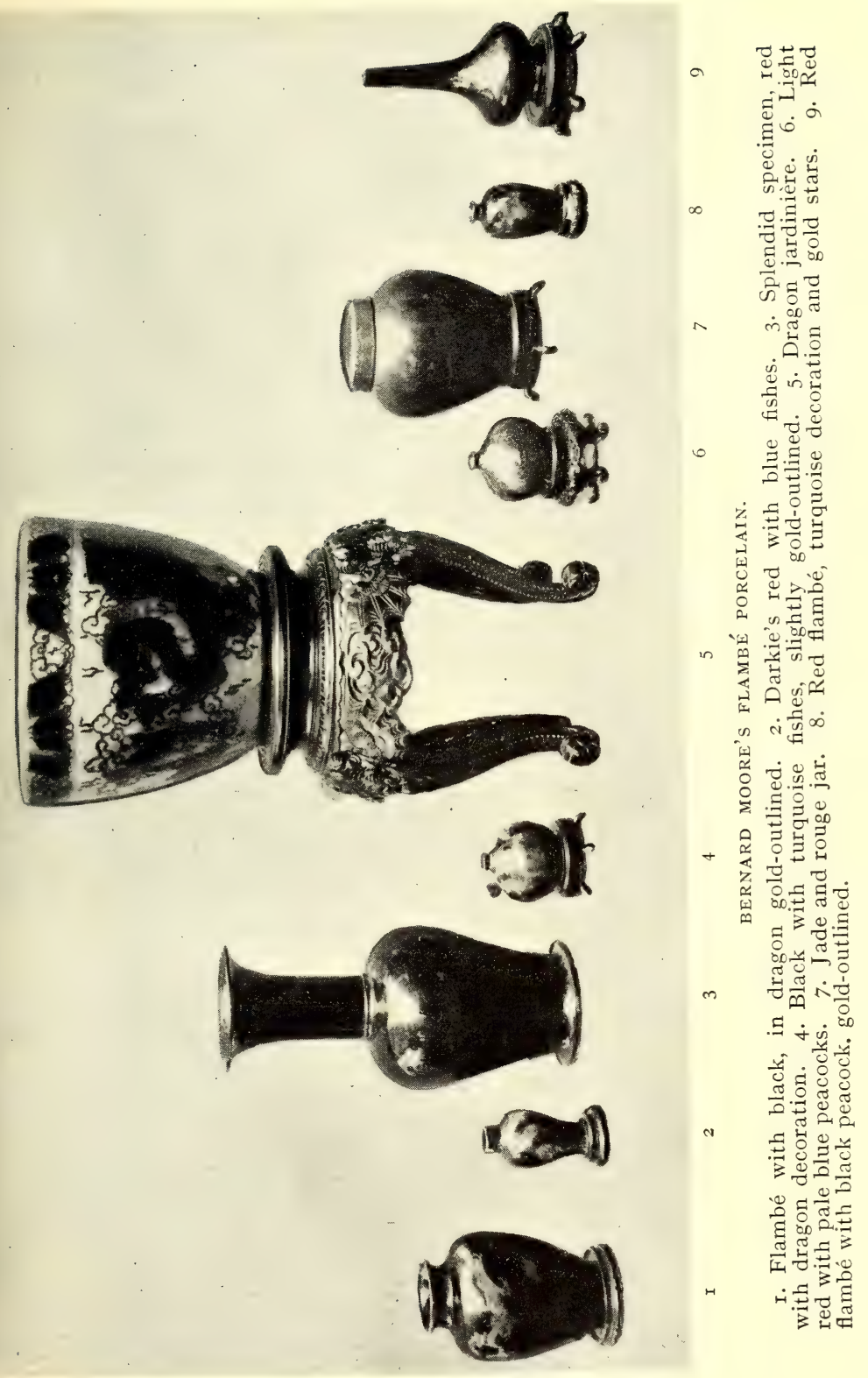



be peach-bloom? A small vase has realised $f^{10}$ ?ooo, that is for an old Chinese piece, and I saw two the other day which I valued at $£ 5$, 00o, but they actually cost $f^{\prime} I, 500$ more than that. Then Moore's haricot, rouge flambé, which is the veined red I have mentioned, and the whole range of splashed or transmutation glazes strike a collector with delight. In addition to these Chinese glazes the firm produces lustre and Hispano Moresque majolica and gold flambé, and what can I say more ? Nothing except that all Bernard Moore ware is collector's ware, which should be purchased and preserved in the same way that our ancestors preserved the treasures which have come down to us. Artistic china, in the nineteenth century, has realised prices which would have astounded the eighteenth-century makers, and history repeats itself.

Of these fine glazes, W. Burton, the expert and author, says :

"For some years a few European potters have discovered for themselves a method of producing effects equal to, and in some respects excelling, the old Chinese. Among the best of these the flambé glazes of Mr. Bernard Moore, of Longton - a most distinguished potter, and the first English potter whose researches enabled him to solve this problem-hold the highest place. His glazes are as perfect, their tones as varied, and in some cases their colours are more brilliant than any that have come from far Cathay. Owing to the difficulties of manufacture these pieces can never be produced in the same wholesale fashion as the more ordinary glaze of commerce. From the nature of the process, every piece is practically an individual specimen bearing on it the mark of the master, and worthy therefore of its place in the finest collections of ancient or modern pottery."

Many awards have been made to Mr. Bernard Moore's beautiful ware: Grand Prix, Sydney, I879; Grand Prix and Gold Medal, Melbourne, I880; Grand Prix, Chicago, I893; and others later.

The pottery is now at Wolfe Street, Stoke-upon-Trent.

The list of Longton potters in Igoo is a very long one (many of them make earthenware, in which cases I only give 
the name of the firm): William A. Adderley \& Co., china and earthenware; Chas. Allerton and Sons, china and earthenware; C. Amison, china; Arrowsmith \& Co., china and earthenware ; Edward Asbury \& Co., china ; H. Aynsley \& Co., opaque porcelain, etc. ; John Aynsley and Sons, china ; Barker Bros. ; Barkers and Kent, Ltd. ; T. W. Barlow and Son ; G. L. Bentley \& Co., Cyples' Old Pottery ; Beresford Bros., china, earthenware, etc. ; J. W. Beswick, earthenware and majolica; Blackhurst and Hulme, china ; Blair \& Co., china; Boulton \& Co., china ; Thomas Brain; Bridgett and Bates, china ; S. Bridgwood and Son, china and earthenware ; R. Bridgwood, china and earthenware; Britannia China Co., china ; British Anchor Pottery Co., Ltd.; John Bromley; F. Cartlidge \& Co., china; Cartwright and Edwards, china and earthenware; D. Chapman and Sons, china ; Colclough \& Co., majolica and art ware; Collingwood Bros., china; Thomas Cone ; J. H. Cope \& Co., china ; Dewes and Copestake, china and earthenware; Dresden Porcelain Co., china ; Eagle Pottery Co. ; Edensor Pottery Co. ; G. Edwards, china ; W. J. Edwards; Edwards and Brown, china; T. Forester and Sons, art pots, vases, etc.; J. Goodwin, Stoddard \& Co., china; Grove \& Co.; Hammersley \& Co., china; Hawley, Webberley \& Co. Thomas Heath, majolica, art ware, and earthenware; Hill \& Co., china; J. Holdcroft, majolica and earthenware; James Hollinson, china and earthenware; Holmes and Son; J. W. Holt, china and earthenware; A. J. Hull, china and earthenware ; W. Hudson china ; A. B. Jones and Sons, china and earthenware; Wm. Jones, china ; James Kent ; Thos. Lawrence ; Thos. Ledger ; J. Lockett \& Co. ; Longton Porcelain Co., china ; W. Lowe ; A. Machin \& Co., china and earthenware; Andrew Mackee, china and earthenware; McNeal \& Co.; J. H. Middleton, china ; Moore Bros., art porcelain; T. Morris, china ; Plant Bros.; R. H. and S. L. Plant, china ; R. Plant and Sons ; Thos. Poole, china and jet; G. Proctor \& Co., china ; Ratcliffe \& Co., Redfern and Drakeford, china; Robinson and Son, china ; Rowley and Newton, Ltd., china and earthenware; Royal Art Pottery Co., flower pots and vases; Sheaf 

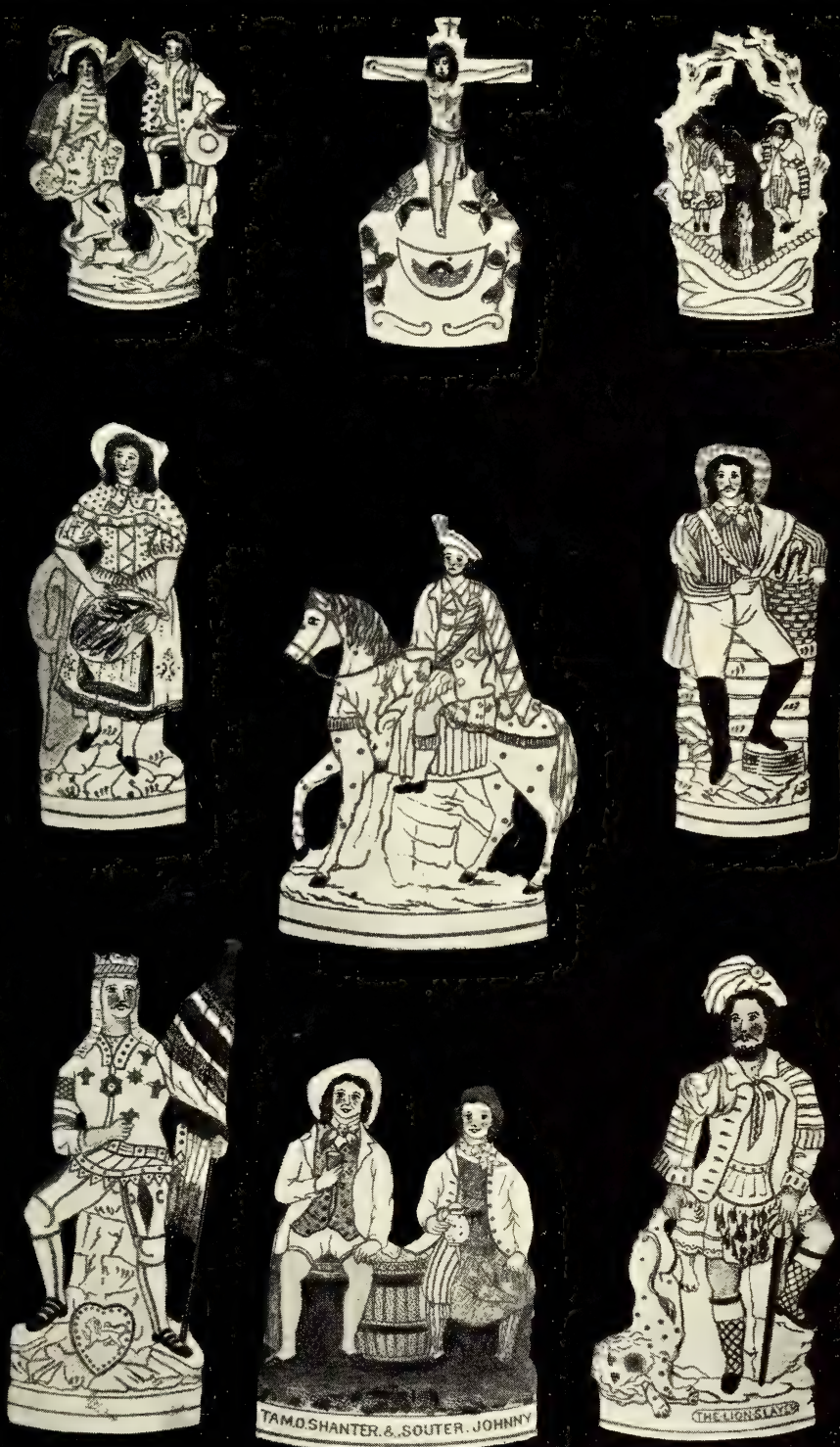

SAMPSON SMITH'S COTTAGE FIGURES. STAFFORDSHIRE. 



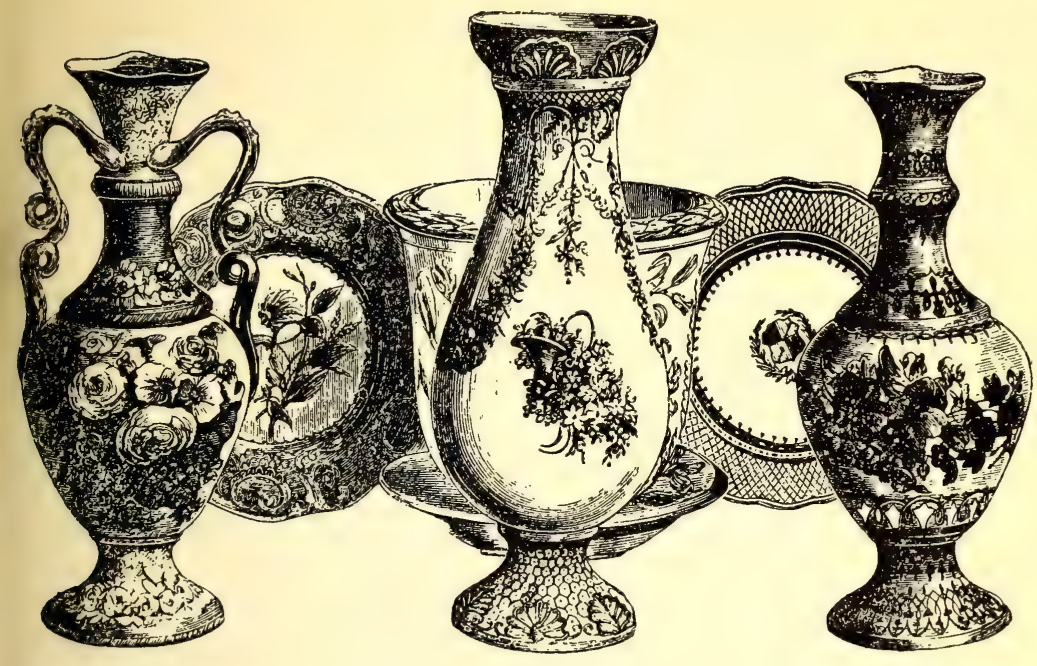

J. LOCKETT'S EXHIBIT IN I862.

Pottery Co., jet teapots; J. Shore \& Co., china ; Sampson Smith, china ; Stone China Co. ; John Tams; Taylor and Kent, china; R. Till and Bates; Joseph Unwin \& Co.; Wagstaff and Brunt, china and earthenware ; C. Waine, china ; T. Walters, china ; G. Warrilow \& Sons, china ; Wildblood, Heath and Sons, china ; T. Wild \& Co., china; Wileman \& Co., art porcelain ; H. M. Williamson and Sons, china ; J. B. Wood \& Co. ; etc. 


\section{CHAPTER XI}

\section{MORE POTTERS AT STOKE-UPON-TRENT AND TUNSTALL}

\section{Stoke-upon-Trent : Goss}

THE firm of W. H. Goss, of London Road, Stoke-upon-Trent, was founded in I858. Everybody knows Goss' armorial china-many persons have collections of it ; one of my lady friends has hundreds of pieces in all sorts of quaint shapes with the arms of towns which she has visited, or which have been sent to her by those who are interested in her collection. Other firms have taken up the manufacture of such miniature china, and from foreign countries come the cheap reproductions which feebly imitate the delicate ivory porcelain for which this firm is famous. Its soft, mellow body is far superior to that which is often sold as Goss' china, but the name $\mathrm{W}$. H. Goss is stamped on this ware though not always, and the bird mark, a falcon rising, is used on first-class goods, for it must not be forgotten that in addition to a world of miniature articles the firm has produced vases, tazzas, etc., of considerable size and great beauty, as well as a number of objects for personal wear, such as brooches, earrings, charms, and the like. The last are not only made in the patent ivory porcelain, but in biscuit resembling the Derby biscuit, with modelled flowers, though some of Goss' are tinted in natural colours.

Amongst the other productions of the London Road Works are Parian and terra-cotta. In Parian many busts were modelled by Gallimore, an artist of distinguished merit. Amongst them was a fine one of Llewellyn Jewitt, done in I875. No man has done more for English ceramic art than Jewitt, 


\section{MORE POTTERS AT STOKE AND TUNSTALL 233}

and every student of the subject must acknowledge, as I do, the many obligations we owe to his fine work published in I878. Another bust, that of S. C. Hall, the famous editor of the Art Journal, was also modelled by Gallimore, who came from the Irish factory at Belleek ; the only distinguished porcelain made in Ireland came from the same factory, which see.

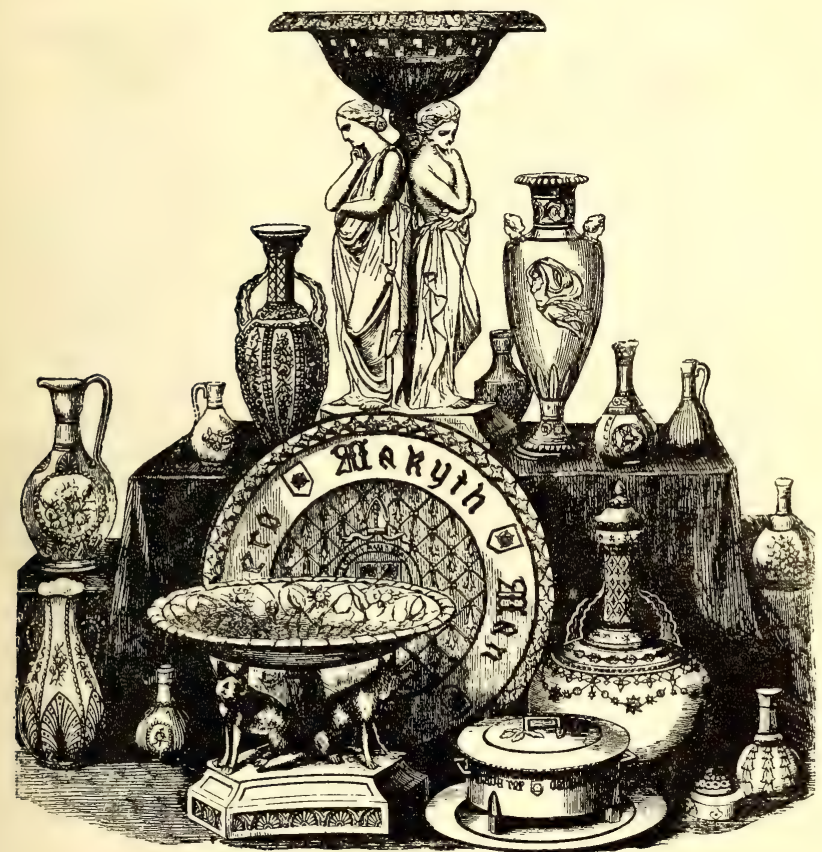

GOSS WARES, PARIAN, ETC.

Space fails, or the decorations of Goss' vases might be fully described-classical figures, landscapes, natural flowers, and conventional designs of much beauty; jewelled porcelain after, but superior to, that of Sèvres for the jewels which, in his ware, do not fall off, being inserted in a setting, a hollow prepared for them. As representing the work of the latter half of the nineteenth century, the ideas of the potter are worthy of record. A special feature of his terra-cotta is the 
use of the leaf as a motif in the decoraton, much of which is distinguished by an originality and personality seldom met with. In one sentence, the work of the firm of W. H. Goss is far above the average.

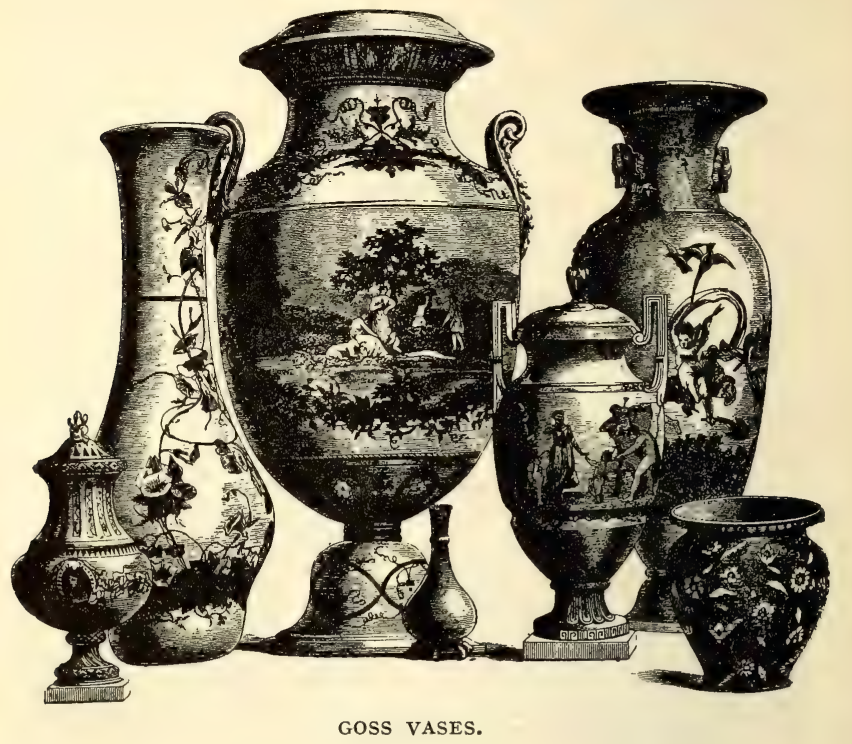

Stoke-upon-Trent: Jones, etc.

George Jones and Sons, Limited, appear amongst the Stoke potters in I900, as they did in I878. Established in I86I, the firm makes earthenware, white granite, and stoneware, and also majolica which deserves notice. For their exhibits at Paris in 1867 they received a medal, and further shows in London, I87I, and Vienna, I873, added to their reputation. In majolica, ornamental and useful articles of good form, carefully finished, are of considerable merit. The illustrations showing some of the pieces which were exhibited bear evidence to the attractiveness of the ware, the designs being effective and the modelling good. The mark used is a monogram of the letters G. J. 
MORE POTTERS AT STOKE AND TUNSTALL 235

Poole, Stanway, and Wood were the successors to many proprietors of the Anchor Works established in I859. About I875 the partners named, in addition to the manufacture of china, devoted much attention to Parian statuary, which was decorated with majolica colours, a process introduced by Turner, who had been a partner with Poole when, in I87I, the firm was Turner, Hassall, and Poole. Notable amongst the figures were a charming pair by Carrier de Belleuse"Night" and "Morning." Josiah Wood was a descendant of a long line of potters; his grandfather, Aaron Wood, was the son of that Aaron Wood whose brother, Enoch Wood, receives especial notice. The speciality of the firm, which does not appear as such in the Igoo list, was the delicate colouring and glazing of the draperies of the Parian figures and groups; the peculiar softness of the unglazed flesh gave an effect which was very charming. In the Igoo list appears a firm which has for many years devoted constant attention to Parian-Robinson and Leadbeater, who bought works at Glebe Street in I865. Now they are in Wolfe Street.

The manufacturers at Stoke, according to Shaw, in I829, were: Spode; Minton; H. and R. Daniel, who here only made porcelain, their earthenware works being at Shelton; Adams, in one part of whose works the first steam-engine for grinding flints was erected-see Adams; Boyle and Son, who made china and earthenware; Thomas Mayer of Cliff Bank, formerly D. Bird's, named " the flint-potter" because he found the exact proportions of flint and clay required to prevent cracking in the oven; and Ward and Forrester. In Ward's list, I843, Copeland had succeeded Spode; Mintons ; Adams and Sons, who at one time had five separate factories, four here and one at Tunstall (three had been Wolfe's, one the Bridge Works, and the other H. Booth's) - see Adams ; Boyle ; S. and G. Reade, and Lowndes and Hill.

In I90o, Boltons Ltd. ; L. A. Birks \& Co. ; Borgfeldt \& Co. ; Boulton and Floyd; J. W. Brough ; Brown-Westhead, Moore \& Co.-see Cauldon ; G. and T. Burton ; Campbell Tile Co.which see ; Carlton Pottery Co. ; W. T. Copeland and Sons-see Spode and Copeland ; Elton \& Co. ; Empire Porcelain Co.; 


\section{I9TH-CENTURY ENGLISH CERAMIC ART}

Fielding \& Co. ; W. H. Goss-see Goss ; Grimwade Ltd. ; S. Hancock and Sons ; Jones and Sons ; W. Kirkham ; J. F. Matthews ; Minton Ltd.-which see ; Minton, Hollins \& Co.which see; Myott, Son \& Co. ; Robinson and Leadbeater; Shorter and Boulton; T. A. Simpson \& Co. ; Jas. Smith ; Wiltshaw and Robinson; and F. Winkle \& Co. are amongst the firms mentioned, but since then some have gone away.

\section{Tunstall : Booths}

In the years preceding the close of the nineteenth century this firm conducted a series of experiments with the object of rediscovering the secret of the beautiful blue colour which characterised the earliest English china-that clear cold blue which has so much decorative value. At last, Charles Bowers, the present managing director of Booths Ltd., a very able

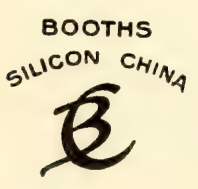

TRADE MARK

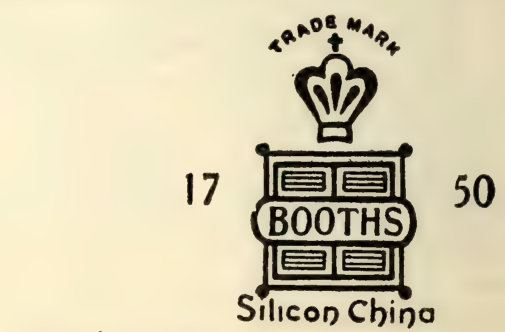

BOOTH'S MARKS.

chemist and potter, was successful, and the old blue is on the market again, marked with a monogram formed of his initials, C. B.

With the rediscovered blue a decision was made that it could be used most appropriately upon reproductions of the exact shapes that were in vogue when this colour was at its best, between I750 and I80o. The firm produces perforated baskets and plates in complete dessert-services of charming forms just like the old china, with its blue decoration; perforated flower-vases with lining for table decoration; tea ware including tea-pots and coffee-pots of several sizes; dinner ware and jugs, leaf-shaped dishes, antique flower-holders, teapoys, etc. These are all manufactured in Booth's Silicon 

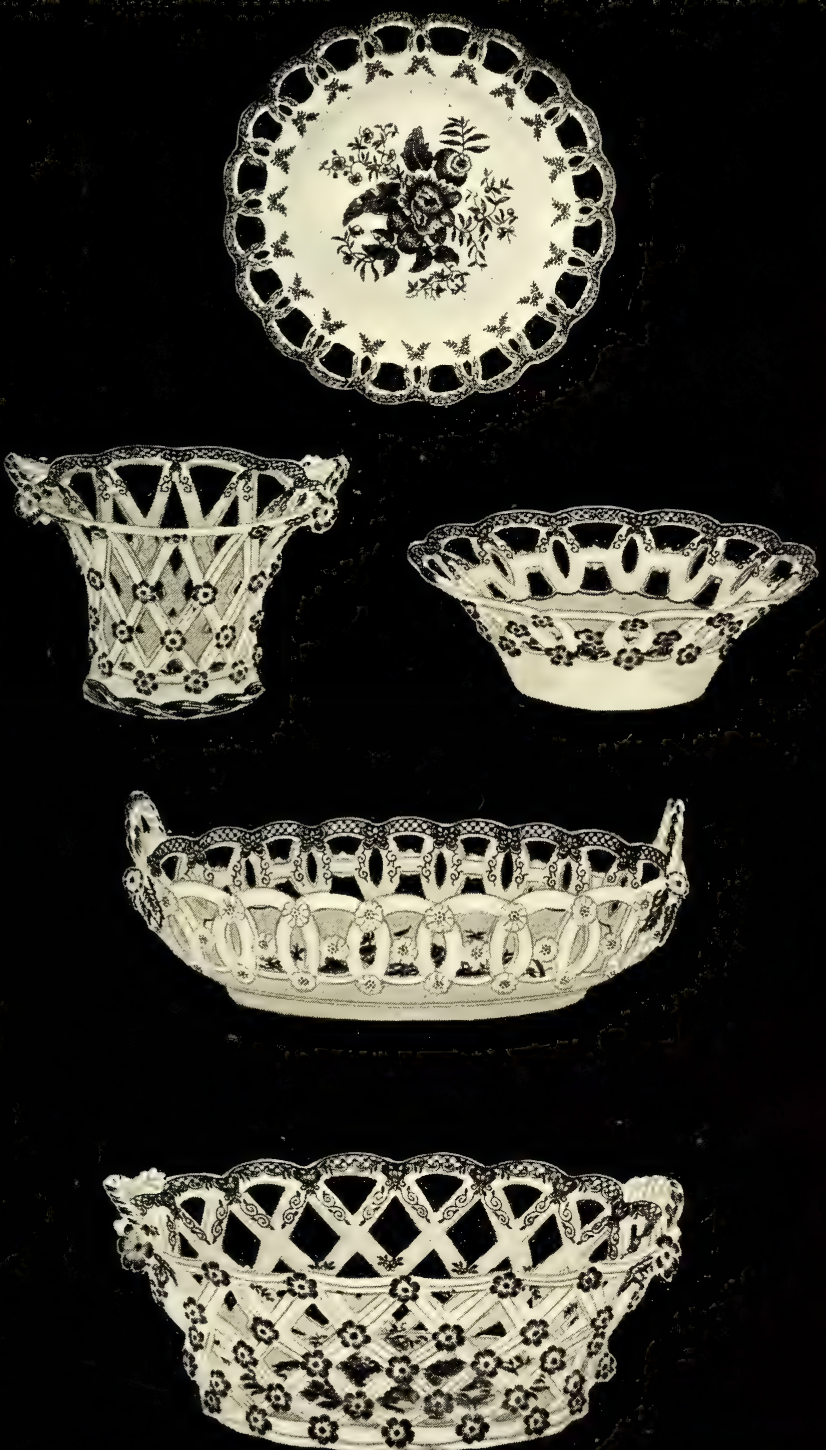

BOOTH'S SILICON CHINA. 

China, which, with the initials noticed, forms the trade mark. The old blue pattern is known as the "Peony."

In the rush to produce cheaply, hand labour has given place to machinery. The mark of the potter's thumb has yielded to a lavish display of cheap gold; the carefully printed plate to a lithograph that is produced in its thousands. It is to an art-loving public that Messrs. Booth will appeal, and they propose to return to the old methods of making the ware. The throwers and turners will be reinstated. The ware will be made by hand, with all the individuality of early work. The beautiful old shapes with their simple and wellconsidered lines, the prettily modelled little flower-work embellishing jugs and tea-pots-all that went to make the old pieces things of beauty will be preserved. The designs will be faithful reproductions of the old work, which was mostly founded upon Chinese designs that were in use in England about I750, or copies of Delft pieces that in their turn had been copied from the Chinese. The coloured work will be of the same type-bright rose peonies, quaint birds with brilliant plumage, and decorative schemes of colour.

Perforated baskets in several shapes and sizes were first manufactured at Bow, and afterwards at Chelsea, Worcester, and other factories which made porcelain, as well as by Adams and Davenport amongst the makers of earthenware. Such baskets make the most charming fruit-dishes; dessert-services can be made up with the different-shaped dishes and plates produced by Messrs. Booth, and the small baskets are most delightful either for ferns or for bon-bons. And, in addition to the hand-made articles, dinner-services that have all the beauty of the old work are sold at prices within the reach of every one. All hand-made productions are stamped with the C. B. monogram, and all other patterns with Booth's stamp and the date of the design, I750.

The following information has been specially communicated by Mr. Harry Green, one of the directors of Booths, and carries the history of the firm to date. In Igoo, as may be seen, plans were projected which were carried out successfully later. 
The business was founded by Mr. Thomas Booth between I850 and I86o, who had a small factory in Burslem, for the manufacture of earthenware, dinner, and toilet ware. At his death his son, Mr. T. G. Booth, removed to larger and more convenient works at the present address. The class of goods manufactured at that time was of a fairly cheap character.

About I885, tiles were introduced, and for ten years a very extensive trade was done, both in printed and majolica, principally for grates and hearths.

In 1898 the business was turned into a limited company, Mr. T. G. Booth being managing director. Considerable strides at that time were made in the quality and class of the goods sold. About I90o, after years of experimenting, the company produced a greatly improved quality of ware, which they called by the name "Silicon China." This enabled them to introduce an entirely higher class of decoration, which prior to that date had only been seen on the finest bone china, one of the most popular forms of decoration being the dark blue band with gilt lines. The improvement in the designs and quality continued, but it was not until the retirement of Mr. Booth, in I905, and the appointment of Mr. C. H. Bowers as general manager, that the most important discoveries and reproductions were introduced. The beautiful tone of the old blue that was used by the early manufacturers had become a lost art; it was rediscovered by Mr. Bowers, and used to reproduce some of the early patterns, such as the peony and blue sprig ware that was done upon early English china and earthenware. This ware was originally marked with his initials, "C.B." More ambitious reproductions were attempted, the most successful of them being the scale blue, painted with exotic birds, also several of the old Chelsea patterns in a beautiful sapphire blue. A speciality was made of reproducing in pottery, with all the individualities of the early work, the beautiful old shapes with their simple and well-considered lines, and prettily modelled flower work embellishing the jugs, teapots, and perforated baskets. A very large business is being 


$$
\text { "ision of }
$$
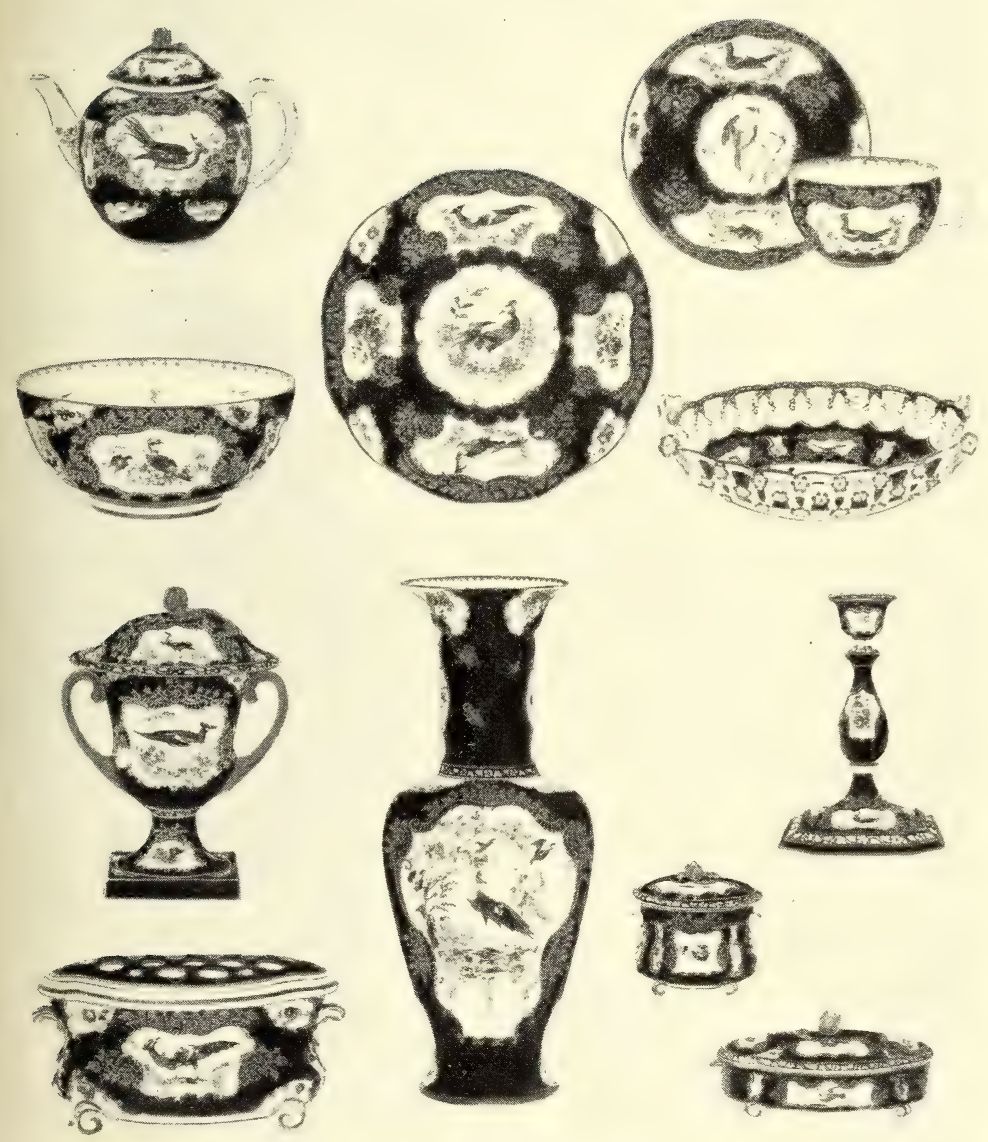

BOOTH'S SCALE BLUE. 

done in these reproductions both in America and on the Continent; and the firm obtained a diploma d'honneur at the Brussels Exhibition in IgIo for their exhibits, her Majesty the Queen purchasing several specimens. In addition to this fancy ware, the old blue is used for the decoration on dinner-sets and tea-services in the old Lowestoft and early English styles ; it is particularly useful as a groundwork for the quaint old coloured wares of the nineteenth century.

I owe Mr. H. Green many, many thanks for his valuable help, particularly for reading the proofs of this work. These I place on record here with gratitude too deep for words.

\section{Tunstall : Meakin}

The Royal Albert Works in 1876 were carried on by Alfred Meakin, who made the ordinary classes of earthenware goods, and I take this as an example of the evolution of an old industry from comparatively small beginnings, by ceaseless energy displayed within the years which followed the end of the nineteenth century, when the business was taken over by Steward Johnson, the eldest of three brothers, who managed the adjacent Royal Victoria Works as well, and whose family owns twelve or thirteen of the largest factories of household earthenware and semi-porcelain. Altogether thirteen biscuit and glost kilns are kept at work here, burning every week the objects which have been made from tons of ball clay, Cornish stone, china-clay, and flint.

Modern machinery enables most of the ware to be made without hand power; plate, cup, and dish-making machines are simply worked by the moulders, behind whom are the revolving dobbins fitted with shelves for drying the green ware, which elsewhere is dried in a greenhouse. When the ware is hardened it is, as usual, packed in saggers, in which the pieces are separated by sand for the first burning, which takes about a hundred hours. When cold the kiln is drawn, and after examination the ware passes to the decorators; the blue-printing is done under the glaze, which is applied in the 
dipping-house, where precautions are taken to avoid the leadpoisoning danger. The firm, still Alfred Meakin Ltd., also produces large quantities of lithographed and gilded wares which show much variety in design and excellence in finish. Large and numerous workshops for many workers feed immense warehouses, from which there flows a continually increasing stream of semi-porcelain, ironstone china, and white granite, which is carried far and wide.

\section{Tunsta1l : Variora}

Amongst the many potters in the Tunstall district existing in I90o were William Adams \& Co., with whom a section specially deals ; Booths Ltd. ; T. Dean ; Gater, Hall \& Co. ; W. H. Grindley \& Co. ; Holdcroft \& Co. ; Hollinshead and Kirkman; Johnson Bros.; Knight and Sprotson; Lea and Boulton ; Lingard and Webster ; Alfred Meakin Ltd. ; Pitcairns Ltd. ; T. Rathbone \& Co. ; Sadler and Son ; Salt Bros. ; Shaw and Sons; The Soho Pottery Co.; and Joseph Timmins and Sons. Most of these are still engaged in the manufacture of ordinary earthenware goods; only in a few cases shall I be able to give them any special mention-they make things which are common to all districts of the Potteries, and they have had some share in securing the reputation which such earthenware enjoys.

For a similar reason it would serve no good purpose to add another list showing the names of the ordinary potters in r 876 ; a comparison of that of I900 with those which follow will show what changes occur in the proprietors of the works, and what a few firms there are in Tunstall or elsewhere which have an uninterrupted history like that of Adams, extending over a long space of time.

The Tunstall potters enumerated by Shaw in I829 are: John Mear ; T. Goodfellow ; Ralph Hall ; S. and J. Rathbone ; J. Boden ; Bourne, Nixon \& Co. ; Breeze \& Co. ; and Burrows $\&$ Co. Ward in 1843 enumerates seventeen manufactories at Tunstall; these were as under: China and earthenware, three, viz.: Hancock and Wright, Bill and Proctor, and 
Rathbone and Brummitt. Earthenware only, twelve, viz. Wood and Challinor, Thos. Goodfellow, John Meir and Son, Joseph Heath \& Co., Hall and Holland, Wm. Adams, Jun., \& Co. (Greenfields), Podmore, Walker \& Co. (two manufactories), James Beech (two), Thos. Bowley, and Mayer and Mawdesley. China toys and black ware, two, viz. Michael Tunnicliffe and John Harrison. Mr. Abraham Lowndes was also a manufacturer here. Messrs. James Beech and Abraham Lowndes had a manufactory here in I829. I call attention to this omission in the list, because Adams was also omitted by Shaw. 


\section{CHAPTER XII}

\section{WORCESTER}

Flight and Barr, Chamberlain, Grainger, Hadley

Amongst the porcelain manufactories of the world, Worcester maintains the place which it has held for a century and a half in the very front rank, not only for the superb beauty of forms, colours, and decorations, but also for the immense variety of its designs, which exceeds that of any other old English factory ; and, with the exception of one branch, that of figure-making, the unquestionable excellence of its early productions may claim the foremost place. And in the

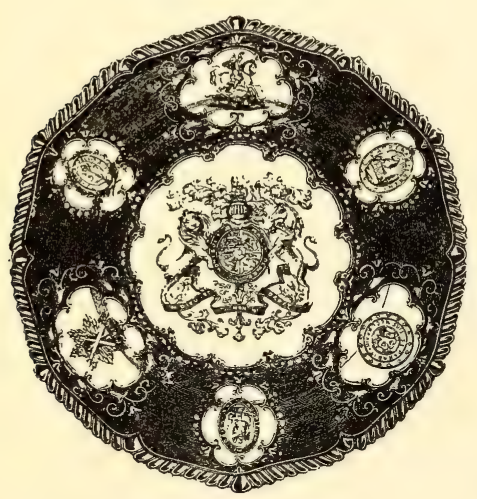

PLATE FROM A BREAKFAST SERVICE MADE FOR THE DUKE OF CUMBERLAND IN I806. modern manufacture, figures are pre-eminent, as if the management sought to supply the deficiency of the past. To-day's advertisement states this quite clearly: "The manufactures include VASES and ORNAMENTS in great variety of shapes and decorations ; FIGURES in various styles and decorations." So that now the manufactory is completely furnished to carry on the work which since 1862 has been largely extended, and Worcester china, which for a time showed signs of decadence, is enhancing the old reputation by the constant endeavours of enterprising proprietors to attain perfection. 

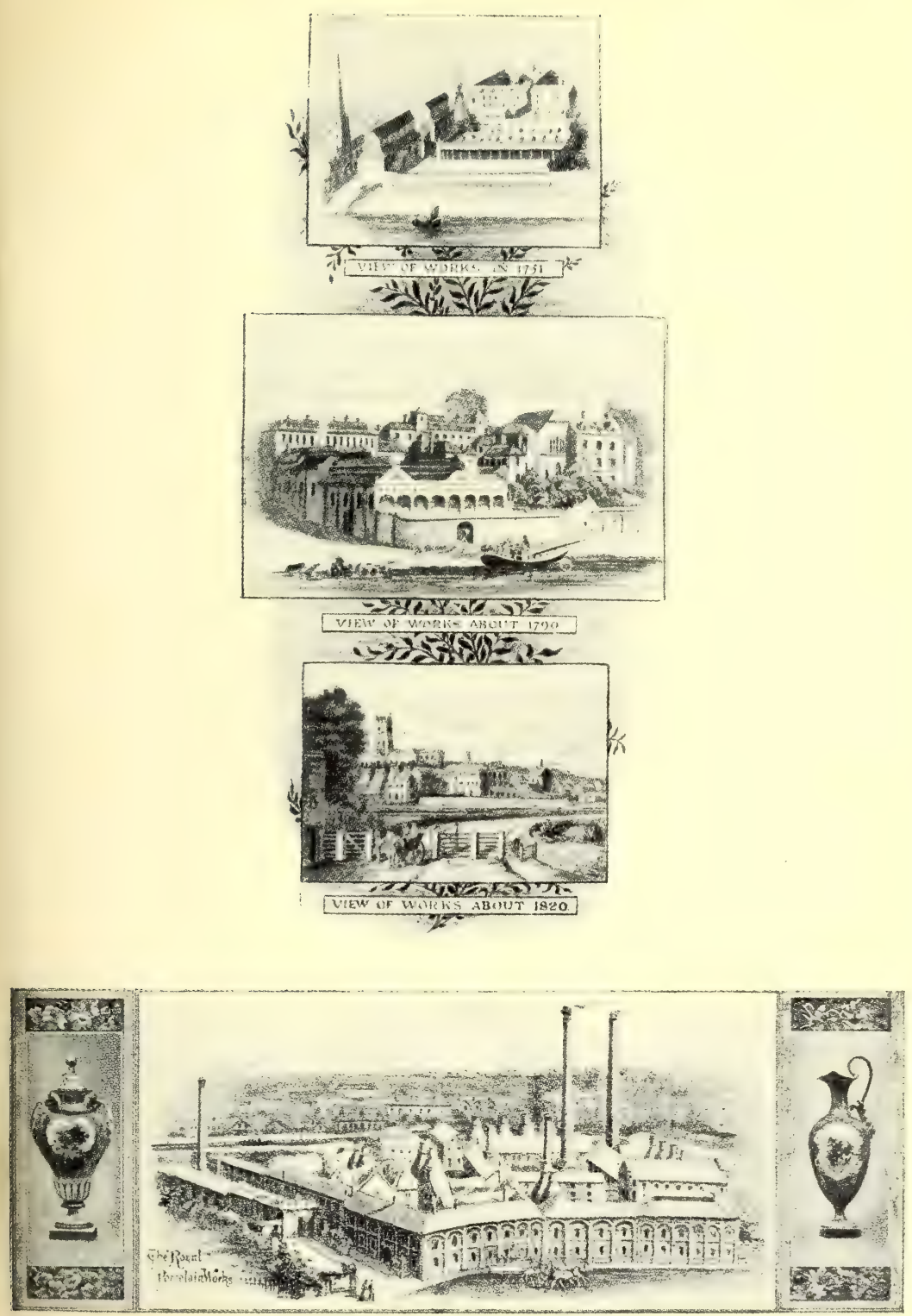

THE ROYAL WORKS AT WORCESTER IN I $9 O 0$. 



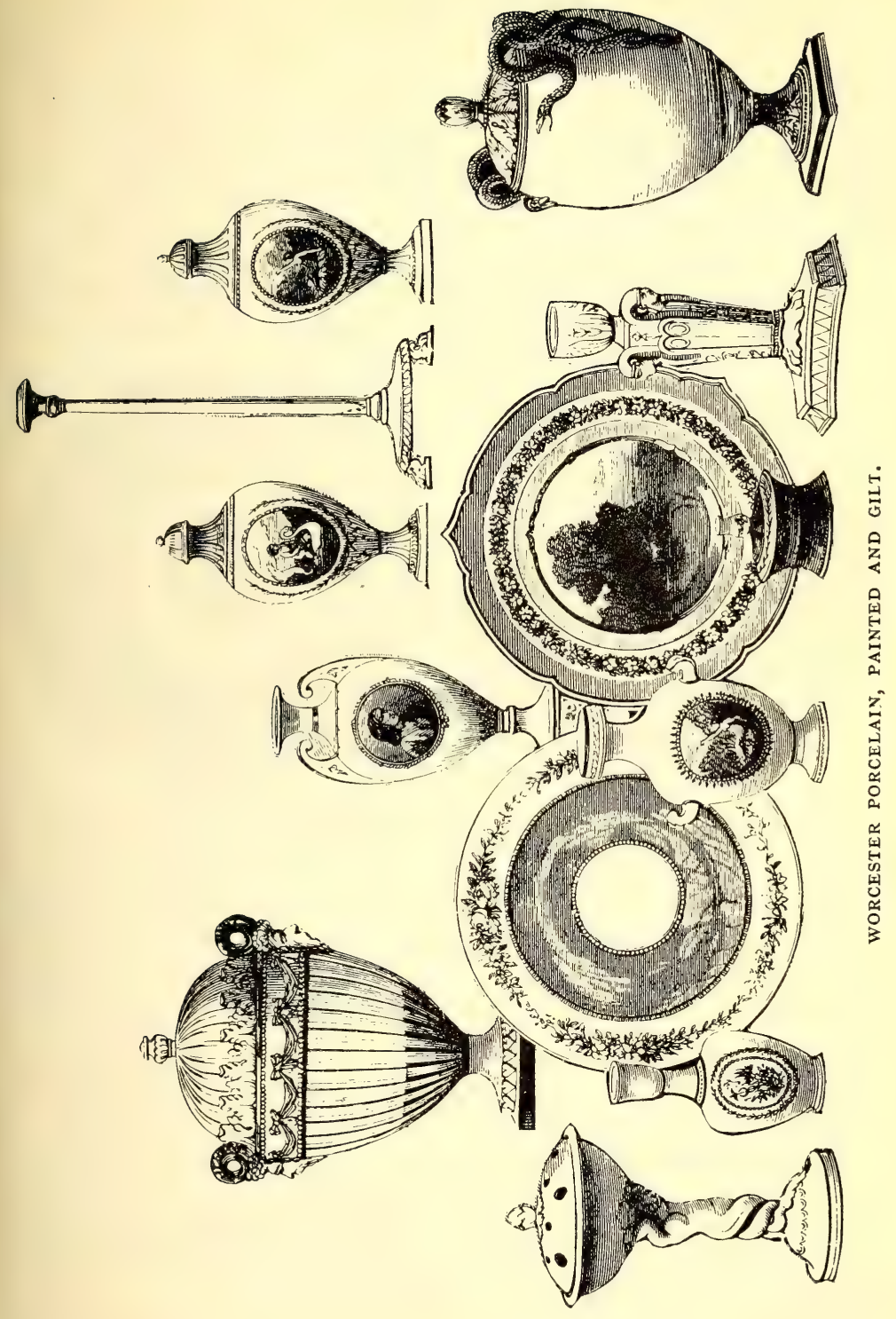


The beginning of the nineteenth century saw two manufactories at Worcester. The old works founded by Dr. Wall and his partner continued to issue beautiful products, not so desirable as those lovely specimens which are of earlier date, but very charming and very distinctive. The Diglis Works founded by Robert Chamberlain, who was the first apprentice of the old Worcester Porcelain Company, had been in existence since I786, two years before George III. and Queen Charlotte, with the Princesses, had expressed their delight with the Old Works and the stock they had examined with so much interest

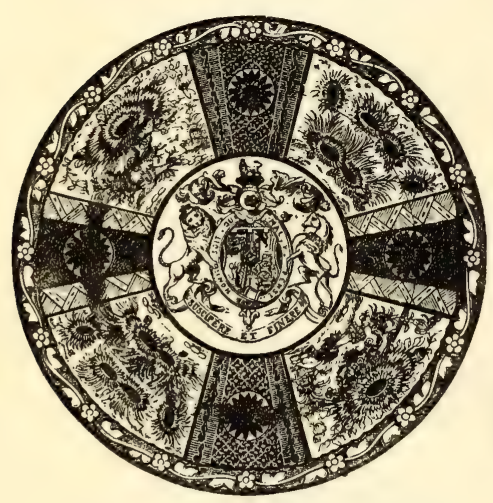

PLATE FROM A SERVICE MADE FOR WILLIAM IV. IN I83r.

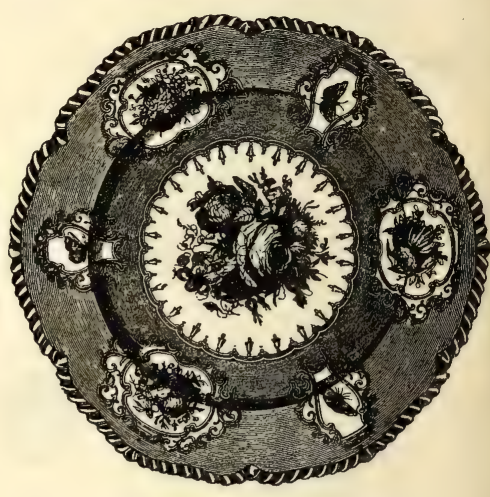

PLATE FROM A SERVICE MADE FOR PRINCESS CHARLOTTE IN I8I6.

that the King made the works " Royal," and suggested that a London warehouse should be opened. The suggestion resulted in the opening of the London house in Coventry Street, which, with other addresses, will be found in the marks. Royal patronage, fashionable support, on the one hand, and rivalry on the other. From I793 to I807 Barr was Flight's partner, then Flight and Barr became Barr, Flight, and Barr. Billingsley, and Walker his son-in-law, were engaged by this firm in I8II, but broke their engagement when they went off to Nantgarw in $18 \mathrm{I} 3$; and Baxter, the clever figure painter, when he left Dillwyn at Swansea, joined these Worcester works, but subsequently moved to Chamberlain's.

Robert Chamberlain took leave of his works in I798, leaving 

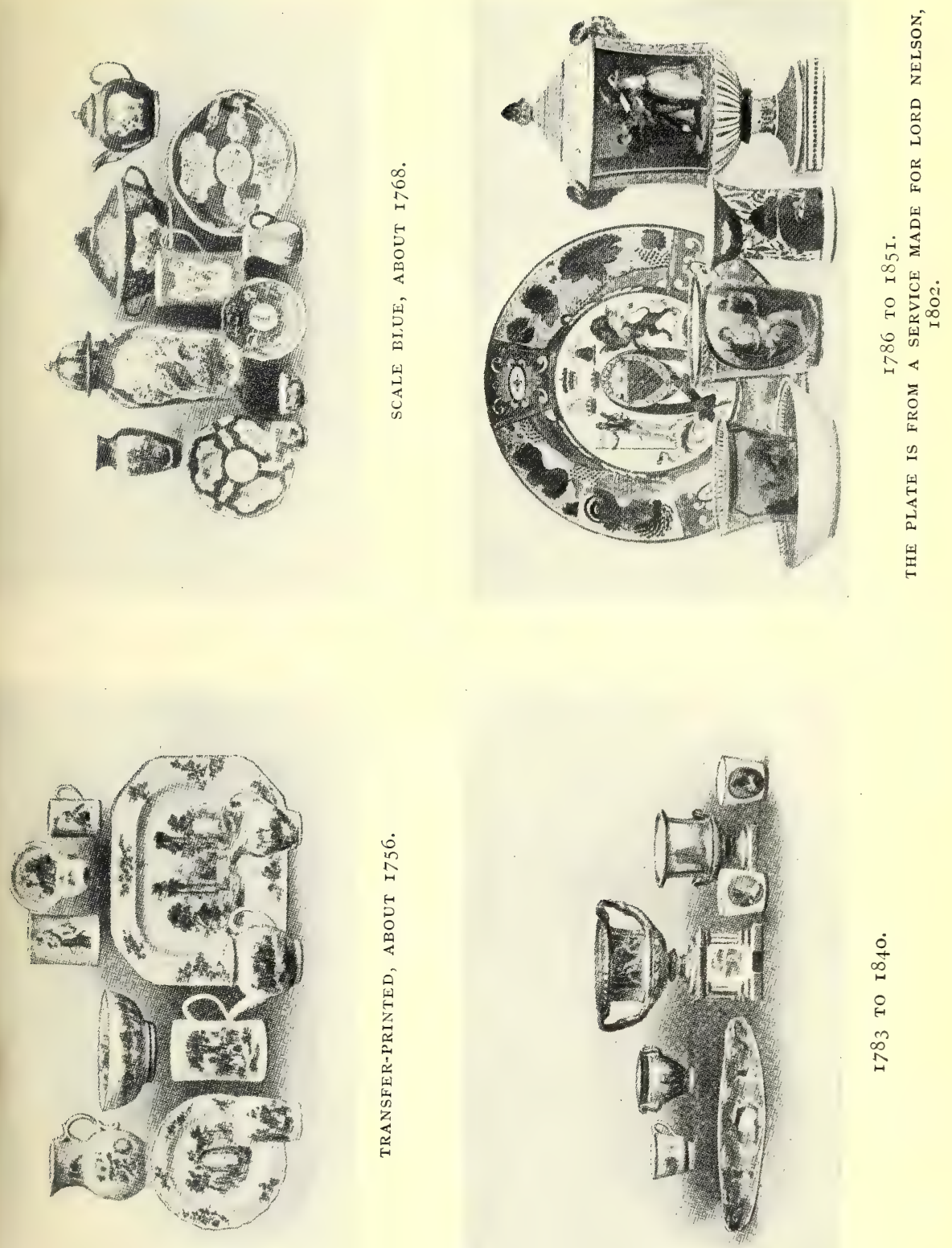



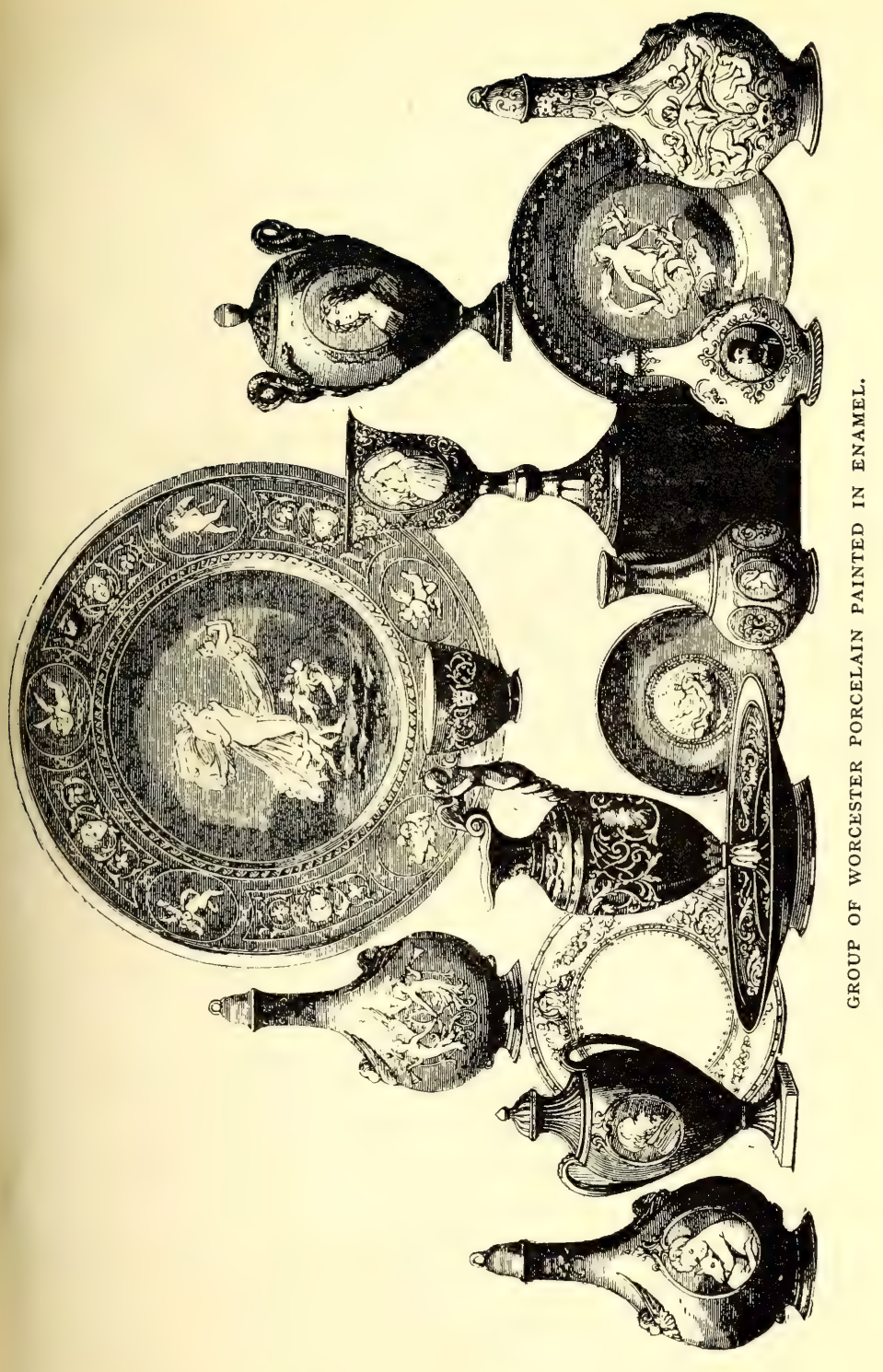




\section{I9TH-CENTURY ENGLISH CERAMIC ART}

his sons Humphry and Robert in charge, with Boulton for a time as sleeping partner. About I8II a costly, homogeneous, translucent porcelain-the Regent body-was introduced, but it was too expensive for any but the most highly decorated ware.

In I8or, still another factory was founded by Thomas Grainger, nephew of Humphry Chamberlain, to whom he had been apprenticed as a painter. With him was associated Wood, another china-painter, till in I8I2 his brother-in-law

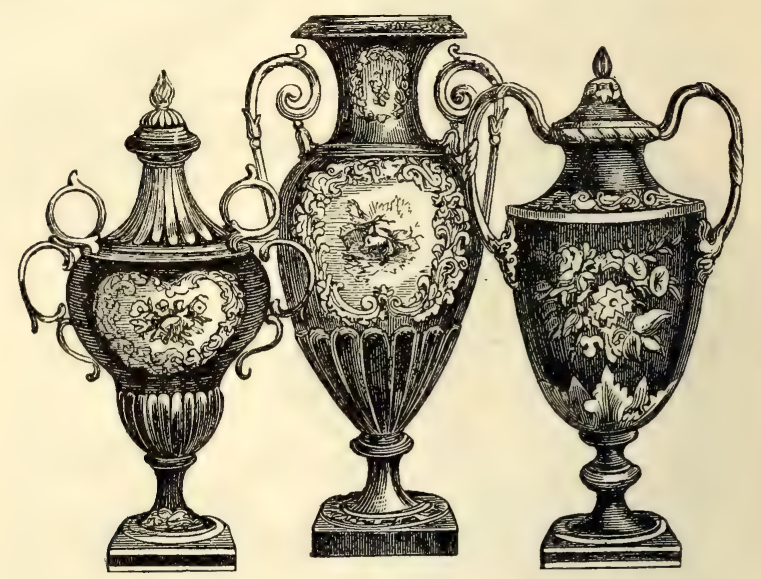

CHAMBERLAIN'S WORCESTER, I85I.

Lee joined the firm, which changed its title from Grainger and Wood to Grainger, Lee \& Co.

In a few short paragraphs I have given an account of the Worcester factories in the early years of the nineteenth century, and in tabular form the changes from the beginnings of each are traced. For this I am indebted to the Worcester Royal Porcelain Co., whose letter to me follows :

"Two of your circular-letters have reached us addressed to G. Grainger \& Co., and J. Hadley \& Sons respectively. We think it well to inform you that the business of both these firms is now amalgamated with ours, as you will see upon reference to the little book sent herewith. We shall be pleased 


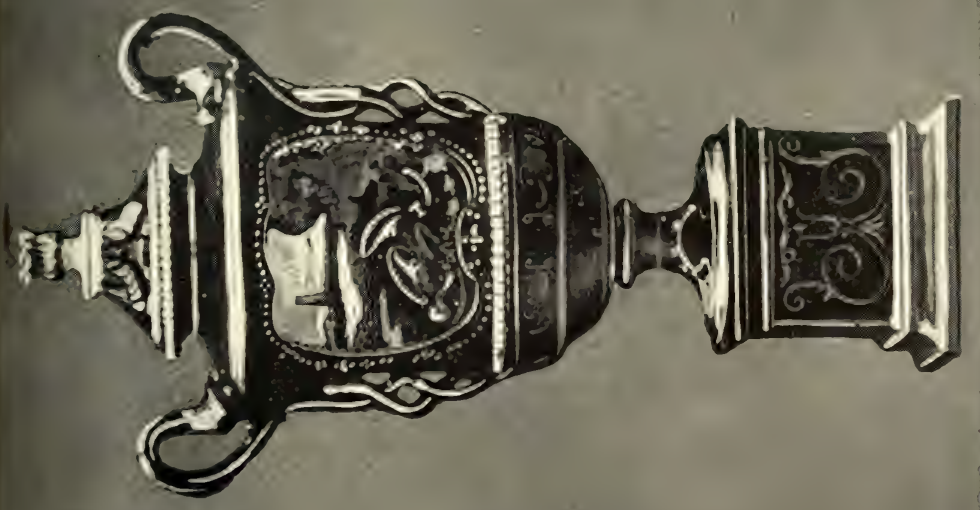

 

to furnish you with any information we can regarding our productions if you do not find all you want in the book."

I quote this as an example of many courteous replies to requests for nineteenth-century notes.

And here it may be said that Worcester and other factories

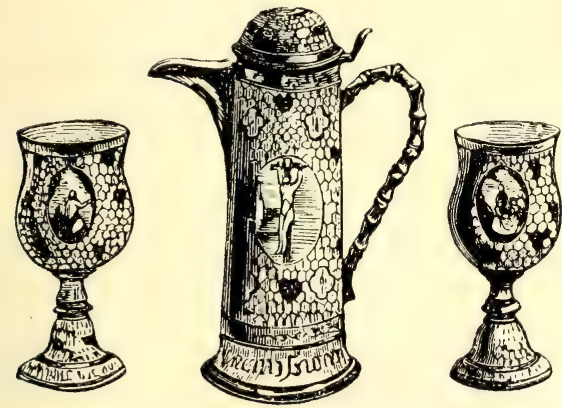

CHAMBERLAIN'S WORCESTER, I85I.

imitated the Chinese and Japanese styles, and the beautiful Sèvres and Dresden porcelains were studied with extreme care. Whatever was reproduced at this factory acquired a
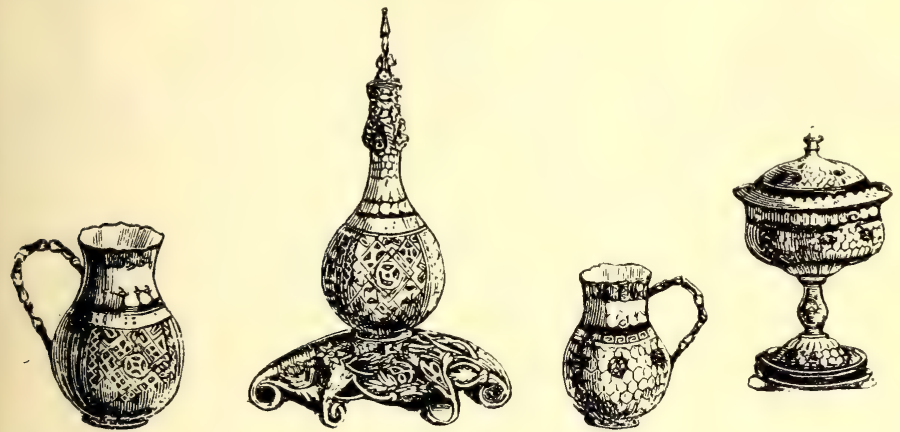

CHAMBERLAIN'S WORCESTER, I85I.

certain character unmistakably Worcester. I have seen a pair of Worcester vases of Oriental design in the finest quality which were valued at $£ \mathrm{I}, 000$, and $\mathrm{I}$ have seen the most perfect attempts to forge Worcester, square mark and all; but if the collector trusts to trained sight and touch there is 


\section{I9TH-CENTURY ENGLISH CERAMIC ART}

not much fear of error. All of the designs showing indications of foreign origin were used by the three factories, though, as I shall show, evidences proved that other influences were at work to produce pieces that were purely English.

Resuming the fortunes of the rival manufactories, we find that in I840 "Flight, Barr, and Barr " and "Chamberlain \& Co." amalgamated, and that all the business, blocks, stock, etc., were transferred to Chamberlain's china-works which were then under the control of Walter Chamberlain and John Lily, to whom Martin and George Barr, with F. St. John, were joined
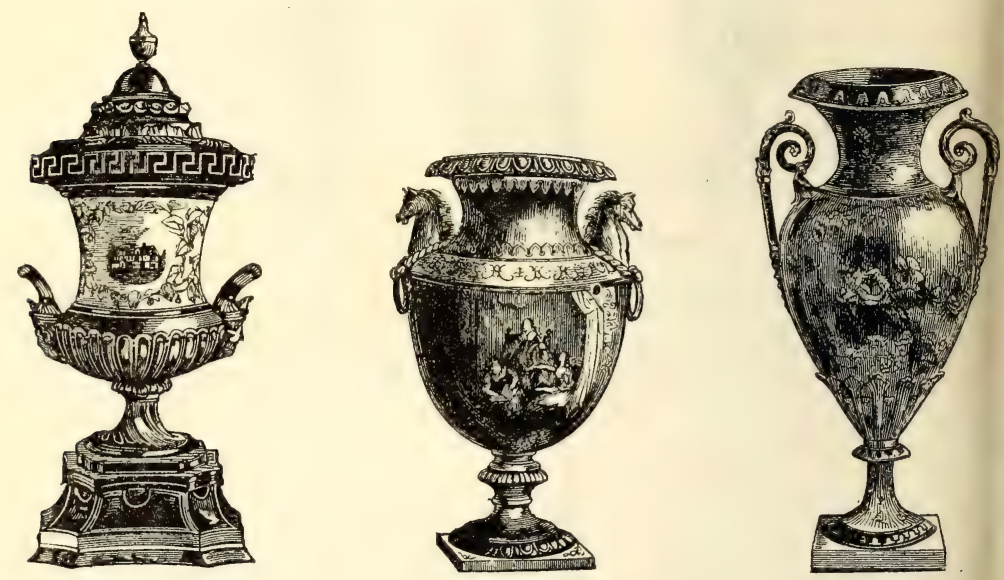

CHAMBERLAIN'S WORCESTER, I85I.

till I847, when they left, and the partners were the same as before for another three years. Walter Chamberlain, E. Lily, and W. H. Kerr formed the next group of proprietors in 1850 and to them the Exhibition of I85I owed its fine exhibits, which were duly and deservedly praised.

"The china-works of Messrs. Chamberlain," says the Art Journal, "will uphold the reputation of the long-established 'Royal Porcelain Works '-an industrial foundation which belongs to the history of English ceramic manufacture, and which has flourished for more than' a century in 'the faithful city ' of its location. It would be difficult, in the present day, for new manufacturers to obtain the same amount of éclat 
which attached itself to some of 'the old houses' in bygone times ; a fact which may be accounted for in the quality of the competition everywhere around them. Achieving a celebrity so long since, Messrs. Chamberlain have retained it in the specimens they now contribute to our Exhibition, inasmuch as they are elegant in form, and beautiful in decoration. Our cuts will give faithful ideas of their contours, although they can but hint at the colours which enrich them. The vases are generally of good form, and present much variety, the communion cups and flagon are of antique simplicity, appropriately decorated with scriptural scenes, their general surface being entirely covered with an open honeycomb pattern, giving them great delicacy and richness. The same style of enrichment has been adopted in the articles forming another group ; the scent-bottle being an exceedingly graceful and elegant adjunct to the boudoir. The honeycomb pattern is, we believe, peculiar to this establishment; we are not aware that

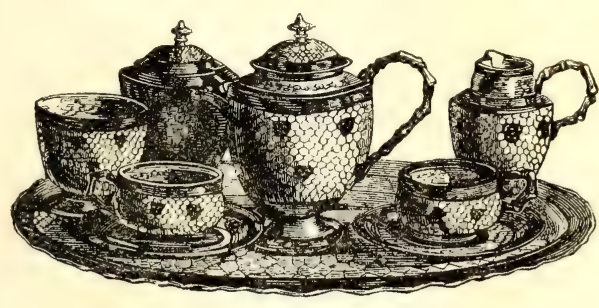

CHAMBERLAIN'S WORCESTER, I85 I.

examples of its peculiar character have been produced elsewhere. The observer will not fail to note the excellence of the painting in many of the articles contributed by this firm. They have, indeed, always aimed at superiority in this department. Altogether, we can award the praise of substantial excellence to the productions of Messrs. Chamberlain, and are glad to see our elder fabricants still vigorous in the field, and still upholding the honour of our native trade."

The year after the Exhibition, Chamberlain and Lily retired, and R. W. Binns joined Kerr, and in the same year extensive alterations and improvements were made in the premises, which then ranked as amongst the finest works in the kingdom. In 1862 Kerr retired, and the Worcester Royal Porcelain Company was formed, with Binns as the managing director. Under his skilful guidance, and that of his successors, Royal Worcester fine porcelains, ornamental 


\section{0}

and useful, have steadily and successfully kept in the van of progress, until scarcely anything remains to be done, such is the high quality of the finished product. Let us mark the successive stages and developments of the different periods. From the early blue-painted Chinese subjects, also transferprinted, from the copies of foreign style with original English designs, from the rich and careful productions which marked the last half of the eighteenth century, we move onwards to the ornate though often more severe work at the beginning of the nineteenth century, to the many improvements later,
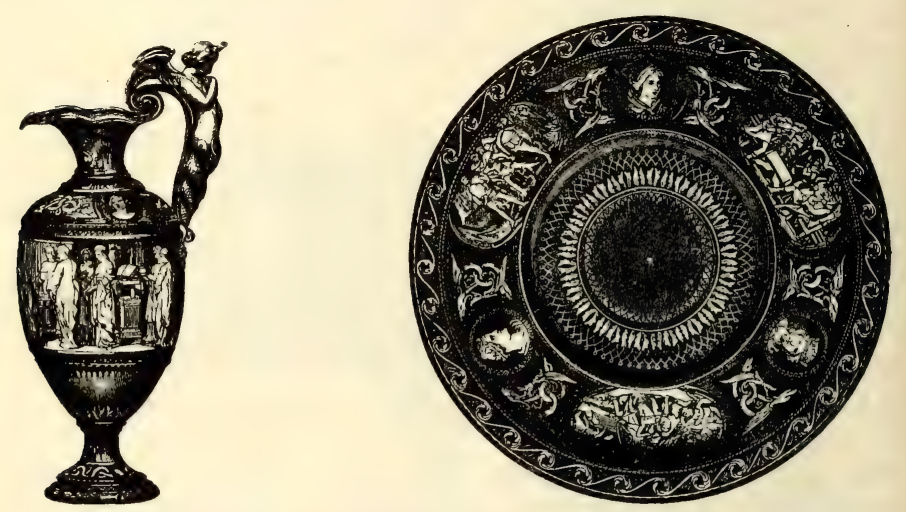

EWER AND STAND, PAINTED by botT.

when fruit and flower, birds and cattle, landscape and fish, were the objects of the painters' skill, finally, to the close of the century which was distinguished by wondrous examples of Italian, French, Indian, Japanese, and other styles.

Mr. Binns developed enamel-painting to an extent before unknown in England. His pupil, Bott, was specially gifted, and at the works specially honoured, for in the Kerr and Binns mark, a shield with $\mathrm{K}$ and $\mathrm{B}$, and, on a ribbon, WORCESTER, is a white space on the left-hand corner in which were placed his initials as the painter of the exquisite enamels. Such specimens are costly. Vases worth $£ I$,000 the pair, a ewer and basin about $f .400$, these are prices which rival the best pieces of what might be termed classical Worcester. 


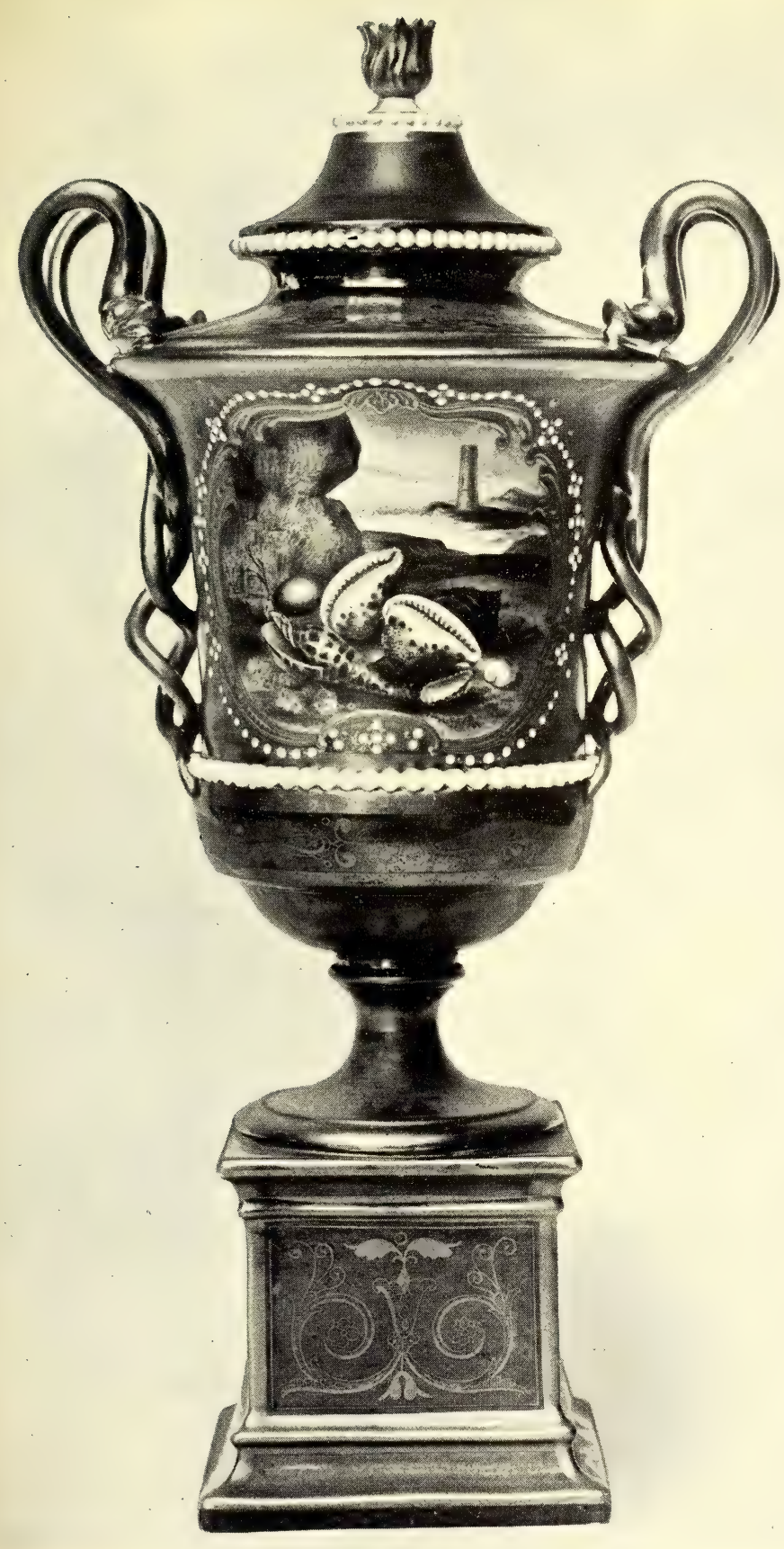

WORCESTER VASE. FLIGHT, BARR AND BARR. Lent by Mr. George Stoner, 

lence of the forms; the sharpness of the modelling; the artistic character of the designs ; the beauty of the coloured gold and bronzes used in the work, and the perfect harmony of the colouring ; the quality of the raised gold.

"A number of figures of considerable beauty and fine modelling are also exhibited.

"The vitreous ware also is specially worthy of notice. It has a fine hard body, is well glazed, and calculated to wear well in use."

Not long before, in I889, the Grainger Works were acquired by the Porcelain Company, and in I902 the manufacture was transferred to the Royal Works. The beginnings of Grainger's business have been already noted, and a short account of the products of his factory only remains to be added. In I8Io, two years before Lee became a partner, the works were burnt down and new buildings were erected upon the opposite side of the same street. Following the retirement of Lee, and, in I830, the death of his father, then sole proprietor,
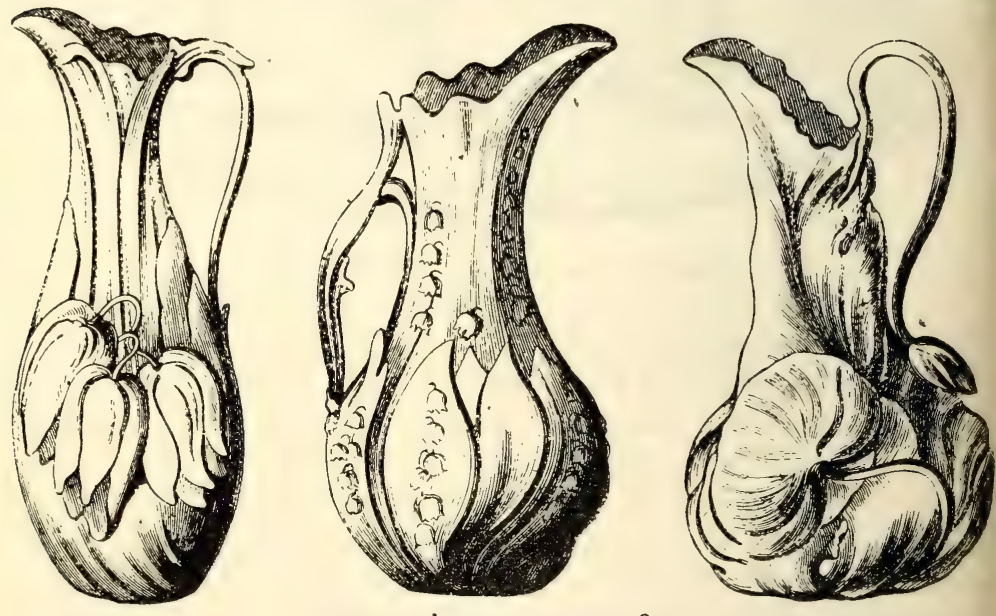

GRAINGER'S WORCESTER, I85I.

George Grainger, the son, carried on the works for many years as "G. Grainger \& Co." China was made till I850, in which year a new body of semi-porcelain was invented by the proprietor, whose exhibit in $185 \mathrm{I}$ attracted considerable 

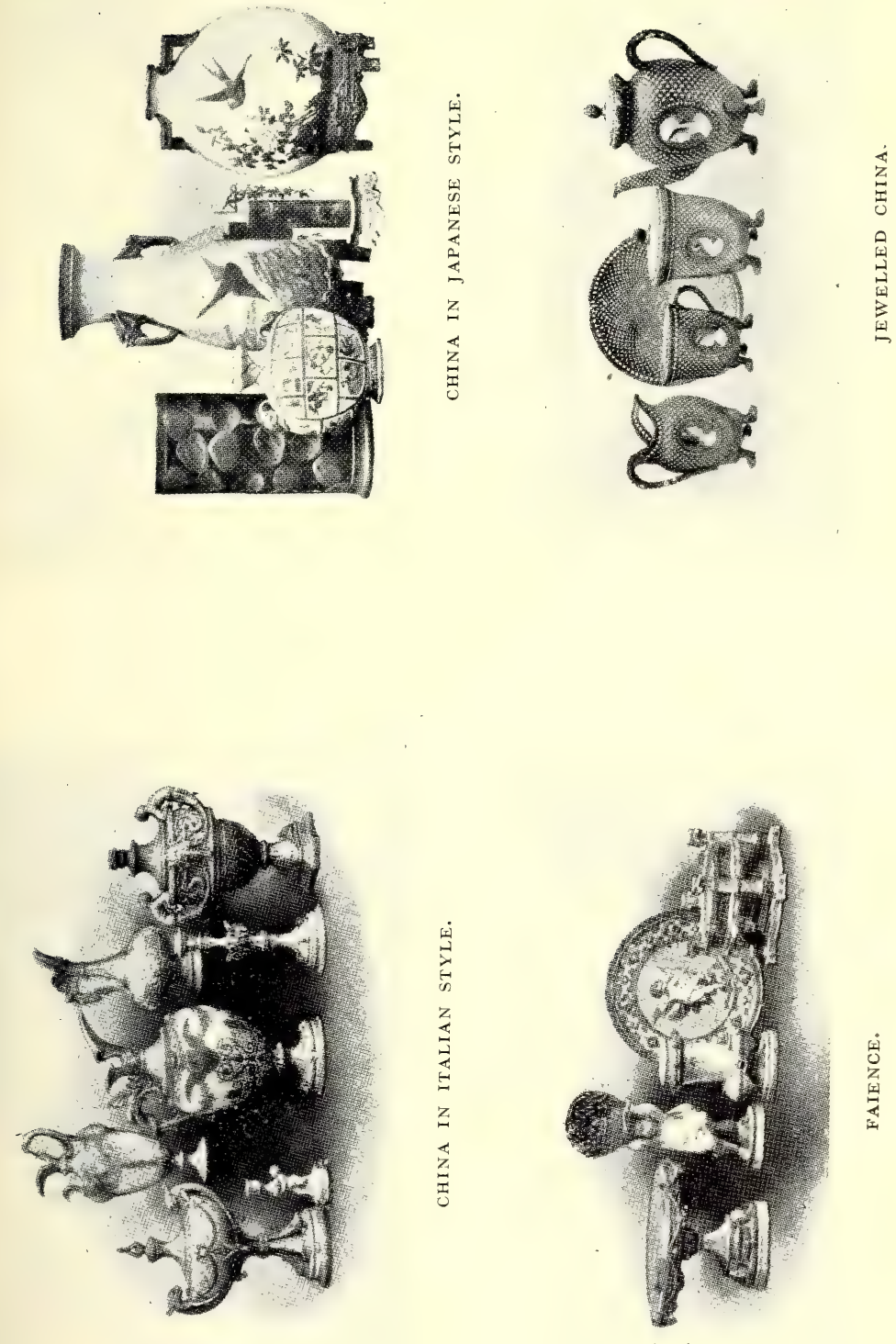

attention. His collection, some of the pieces of which we engrave, was executed in this semi-porcelain in forms which showed what I referred to before as English design. The jug with a tulip, the other with lilies-of-the-valley, and the

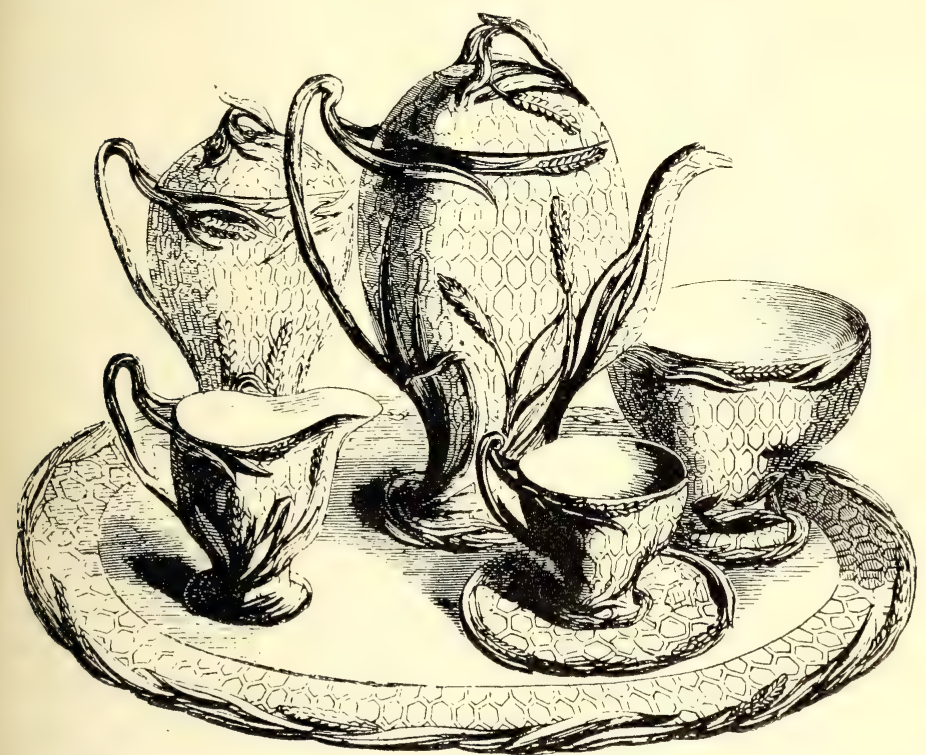

GRAINGER'S WORCESTER, I 85 I.

third with the poppy, are marked as being of this class, which is perhaps more peculiar than beautiful, though the firm had a great reputation for it. At one time such jugs, covered with leaves and flowers in hard semi-porcelain, were very popular, and the more so because the ware was very strong-it only chipped when china broke. A ewer and basin is much more pleasing except the handle, the decoration of leaves in relief is not obtrusive, and the forms are good. The coffee-service is a group of unusual design. The open honeycomb pattern shows a rich blue ground through its perforations, a style of decoration in great vogue more than half a century ago. The handles are formed of wheat-ears with their stalks and leaves. Similar wheat decoration forms the borders of 
the tray as well as the objects upon it. So the critic said in I85I, and he added:

"As a light and elegant service for the boudoir, it possesses attraction; and, though presenting the appearance of its costly prototype, it is manufactured at a comparatively small cost ; indeed, this remark will apply to the generality of works issued from the extensive manufactory of Messrs. Grainger."

At the Exhibition of I862, the last at which the firm exhibited, this semi-porcelain received the award of a medal.

The Parian figures and ornaments were made here as elsewhere, but Grainger had a speciality-he manufactured perforated Parian vases, bottles, and cups in great variety, which have been improved more recently as far as the body is concerned; the designs and the careful execution of the pierced work could scarcely be more perfect, though Mr. G. Owen's modern gems are truly masterpieces. Some pieces of the most elaborate lace drapery in ceramic art have brought great credit to the name of Grainger, with whose name is also associated a material which, as opalite, was remarkably effective as a fine vitrifiable body for embossed tiles for house decoration.

Still one more factory was absorbed, a factory in which the potting was, in the opinion of those best qualified to judge, a real triumph of the potter's art, though commercially it was not successful. In July I905 the Worcester Royal Porcelain Company acquired the business of Messrs. James Hadley and Sons, Limited, Worcester.

Mr. James Hadley (who for many years was chief modeller at the Royal Porcelain Works) opened premises in 1896 for the manufacture of the ware now known as "Hadley Ware." The leading characteristic of this ware was first obtained by means of an extensive use of coloured clays in the raised ornamentation of the vases, etc., combined with either monochrome or conventional paintings. Latterly, without losing the distinctive qualities of the ware, the severity of this early style has gradually given way to a less conventional one; and for much of the 


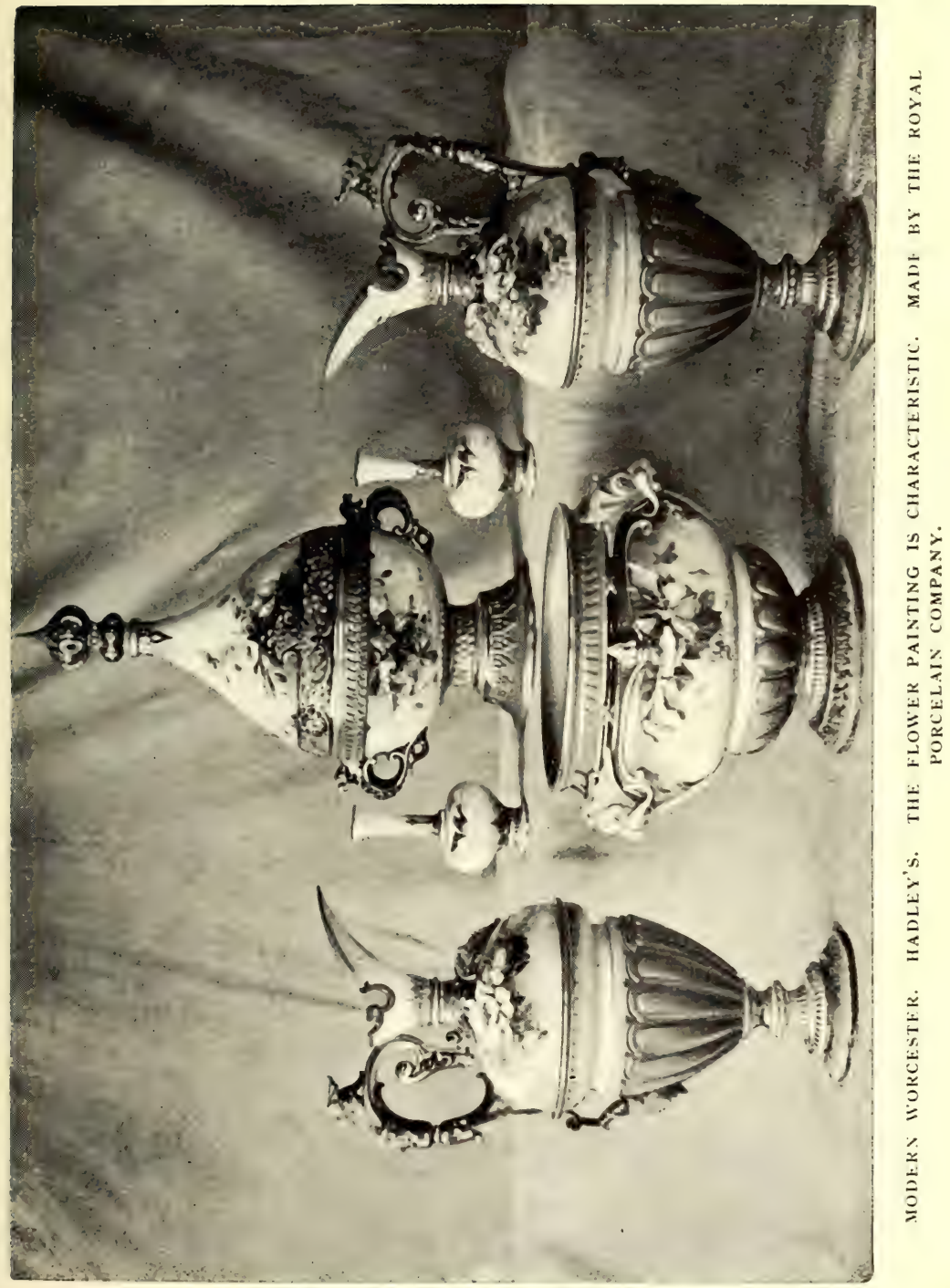



coloured clay work there is now substituted various decorative schemes in enamel colours and gold, with fully naturalistic treatment both as regards colour and composition for the subject paintings, thus supplying the artists with a much wider field of work than obtained during the earlier periods of this ware.

Possibly you may have come to the conclusion that ornamental and costly china only is produced here. This is not the case. The staple and vastly increasing production of dinner-services in china, semi-porcelain, and vitreous ware; of tea, breakfast, and dessert services; of requisites for the toilet-table; and of badged ware forms a striking feature in the trading of this great company. Its popularity is due to the purity of the ware itself, combined as it is with decoration which ranges from simple lines, etc., of gold to the most intricate and beautiful designs in colours, all alike marked with the cachet of the most refined taste.
HADLEY WARE MARKS.

The (experimental) pieces made in 1800 bear a inark either painted or stamped with rubber

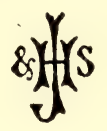

From Feb. 1897 to June, 1900 , a printed mark

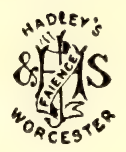

From June, 1900, to August, 1902:

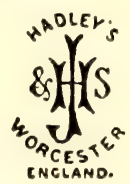

And from August, 1902, to June 30th, 1905

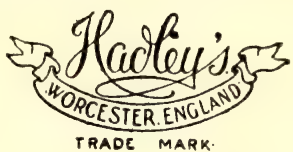

The "Hadley Ware," since J ly, 1905, has been produced by the Royal Porcelain Co., and now bears the Worcester mark

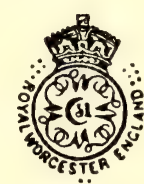




\section{2}

\section{I9TH-CENTURY ENGLISH CERAMIC ART}

A word has been said about Mr. G. Owen's masterpiece in reticulated work, and in view of its extraordinary merit it deserves further notice. Grainger's perforated Parian has fine qualities, but it was cut mechanically on a pattern applied to the unbaked clay; a man or boy without special gifts could do the piercing after some training. Not so that of $\mathrm{Mr}$. Owen; after marking off the body of the piece undergoing decoration into sections, the ground is either pierced or reserved for a delicate decoration in colour. The pierced ground, all cut by hand, is largely in a honeycomb pattern, divided by bands of reticulations of diapers in endless variety. These bands of diapers are seldom duplicated; the astonishing skill of the artist is displayed in the variety of his combinations, the sharpness and geometrical accuracy of their execution so that the walls of the vases only a fractional part of an inch thick resemble nothing so much as lace, lacework in porcelain of a beauty and delicacy beyond description.

The difference between the Grainger process and the freehand work of Mr. Owen can only be fully understood by placing the two side by side, when the superiority of the latter needs no comment, it is so evident. I visited the show-rooms of the Worcester Royal Porcelain Company not long ago, and there I was able to examine all the treasures of this wonderful process. And not only those, but the magnificent works in other styles of decoration were worthy of the highest praise. Mr. L. W. Hadley, son of the famous potter, who was in charge, showed me not only the coloured clay decoration which his father developed, but other pieces painted with a wealth of floral ornament in naturalistic style, and still again others with peacocks and pheasants. The lovely Worcester figures were not forgotten. I know of none more exquisite in their unique charm of style and colour.

In order to follow easily the various changes in the proprietary, I cannot do better than use the exact form in which they are set out in the Guide to the Worcester Royal Porcelain Works ; 


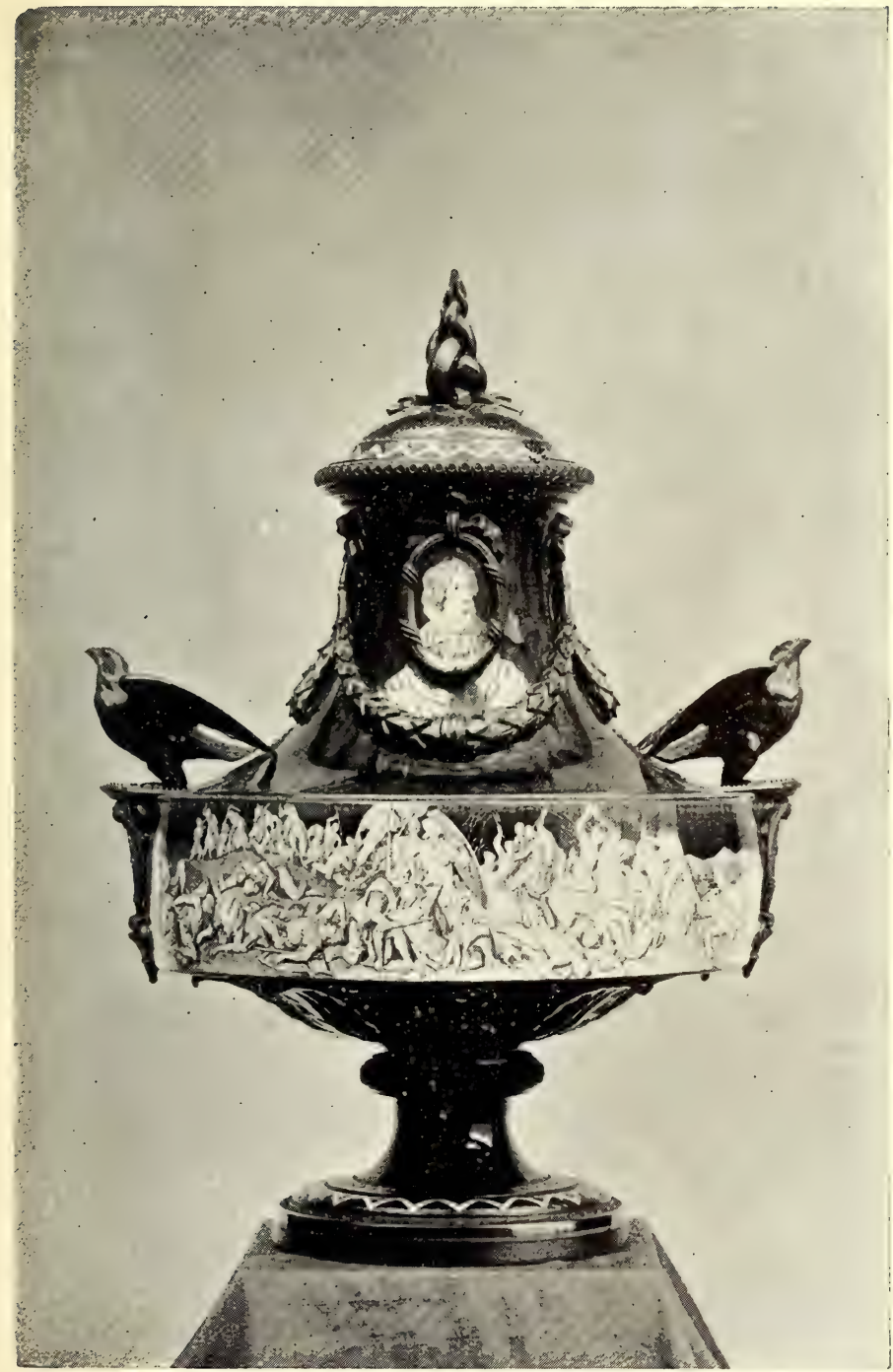

MODERN WORCESTER VASE, C. I850. SUBJECT, "THE BATTLE OF HASTINGS AND DEATH OF HAROLD." 

LIST OF PARTNERS, AND NOTES.

Works founded by Dr. Wall and partners.

Transfer-printing introduced at Worcester.

Dr. Wall died.

Mr. Flight became sole proprietor.

Robert Chamberlain left, and in I788 built a works at Diglis.

Mr. Barr joined-now Flight and Barr.

Humphrey and Robert Chamberlain, junior.

Nineteenth Century.

I801 Thomas Grainger left Chamberlain's and built works at St. Martin's.

I804 Humphrey and Robert Chamberlain and Ed. Boulton.

1807 | | Mr. Barr, junior, joined-now Barr, Flight, and Barr.

| I8II | Humphrey and Robert Chamberlain.

I8I3 | Mr. Barr, junior, joined-now Flight, Barr, and Bar until 1840.

Walter Chamberlain and John Lily.

Old Works united with Chamberlain's.

Walter Chamberlain and John Lily.

Walter Chamberlain, F. Lily, and W. H. Kerr.

W. H. Kerr and R. W. Binns.

The present Company formed.

$1862 \quad \mid$

I 889 Grainger Works acquired by Porcelain Company.

1902 - The Grainger manufacture transferred to the Royal Porcelain Works.

1902 A decision given by Mr. Justice Byrne in the High Court of Chancery that the Worcester Royal Porcelain Co., Ltd., retained their exclusive right to use the word "Worcester" as descriptive of their goods.

1905

Hadley Works (founded I896) acquired by the Porcelain Company.

The establishment has been honoured with numerous appointments from the Royal Family, among them being the following :

1789 His Majesty George III.

1807 H.R.H. The Prince of Wales.

I 808 H,R,H, The Princess of Wales, 


\section{I9TH-CENTURY ENGLISH CERAMIC ART}

I8 I4 H.R.H. The Princess Charlotte of Wales.

1830 H.R.H. The Duchess of Kent.

I834 Their Royal Highnesses the Duchess of Kent and the Princess Victoria.

I 883 Her Majesty Queen Victoria.

I90I His Majesty King Edward VII.

And also a special appointment to H.M. the Emperor of Austria and the Imperial Court of Vienna.

Not only so, but it has inspired personal interest in the minds of many Royal personages. During the nineteenth century they have paid many visits to the works, as the following list will show :

\begin{tabular}{|c|c|c|c|}
\hline 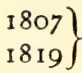 & Duke of Gloucester. & $\begin{array}{l}1870 \\
1870\end{array}$ & $\begin{array}{l}\text { Princess Christian. } \\
\text { Princess Christian. }\end{array}$ \\
\hline 832 & Princess Victoria. & I 884 & The Prince of Wales. \\
\hline 832 & Duchess of Kent. & I 884 & The Princess of Wales. \\
\hline 1845 & Queen Adelaide. & I 887 & Thakore Saheb of Morvi. \\
\hline 845 & $\begin{array}{l}\text { Ida Duchess of } \\
\text { Weimar. }\end{array}$ & $\begin{array}{l}1887 \\
1891\end{array}$ & $\begin{array}{l}\text { Thakore Saheb of Limdi. } \\
\text { Duke of Teck. }\end{array}$ \\
\hline 845 & $\begin{array}{l}\text { Anna Princess of Saxe- } \\
\text { Weimar. }\end{array}$ & $\begin{array}{l}I 89 I \\
\text { I } 89 \text { I }\end{array}$ & $\begin{array}{l}\text { Duchess of Teck. } \\
\text { Princess Victoria of Teck. }\end{array}$ \\
\hline 845 & $\begin{array}{l}\text { Amelia Princess of Saxe- } \\
\text { Weimar. }\end{array}$ & $\begin{array}{r}1894 \\
.1899\end{array}$ & $\begin{array}{l}\text { George Duke of York. } \\
\text { Arthur Duke of Connaught. }\end{array}$ \\
\hline 1857 & $\begin{array}{l}\text { George Duke of Cam- } \\
\text { bridge. }\end{array}$ & I 899 & $\begin{array}{l}\text { Louise Margaret Duchess } \\
\text { of Connaught. }\end{array}$ \\
\hline & $\begin{array}{l}\text { Queen Marie Amélie of } \\
\text { France. }\end{array}$ & I9O3 & $\begin{array}{l}\text { Princess Margaret of Con- } \\
\text { naught. }\end{array}$ \\
\hline & $\begin{array}{l}\text { Duc de Nemours. } \\
\text { The Sons of the Nawab } \\
\text { Nazim of Bengal. }\end{array}$ & 1903 & $\begin{array}{l}\text { Princess Victoria } \\
\text { of Connaught. }\end{array}$ \\
\hline
\end{tabular}

In spite of imitations often bought because they are cheap, in spite of competition, Worcester china maintains its prestige because of its excellence. No compunctions, no regrets, follow the acquisition of the best modern china. It is always beautiful, and that supreme quality commends itself to the home with a never-failing constancy; it is always pleasant to live with fine Worcester. And its value will not diminish.

The Worcester marks follow on page 279. 


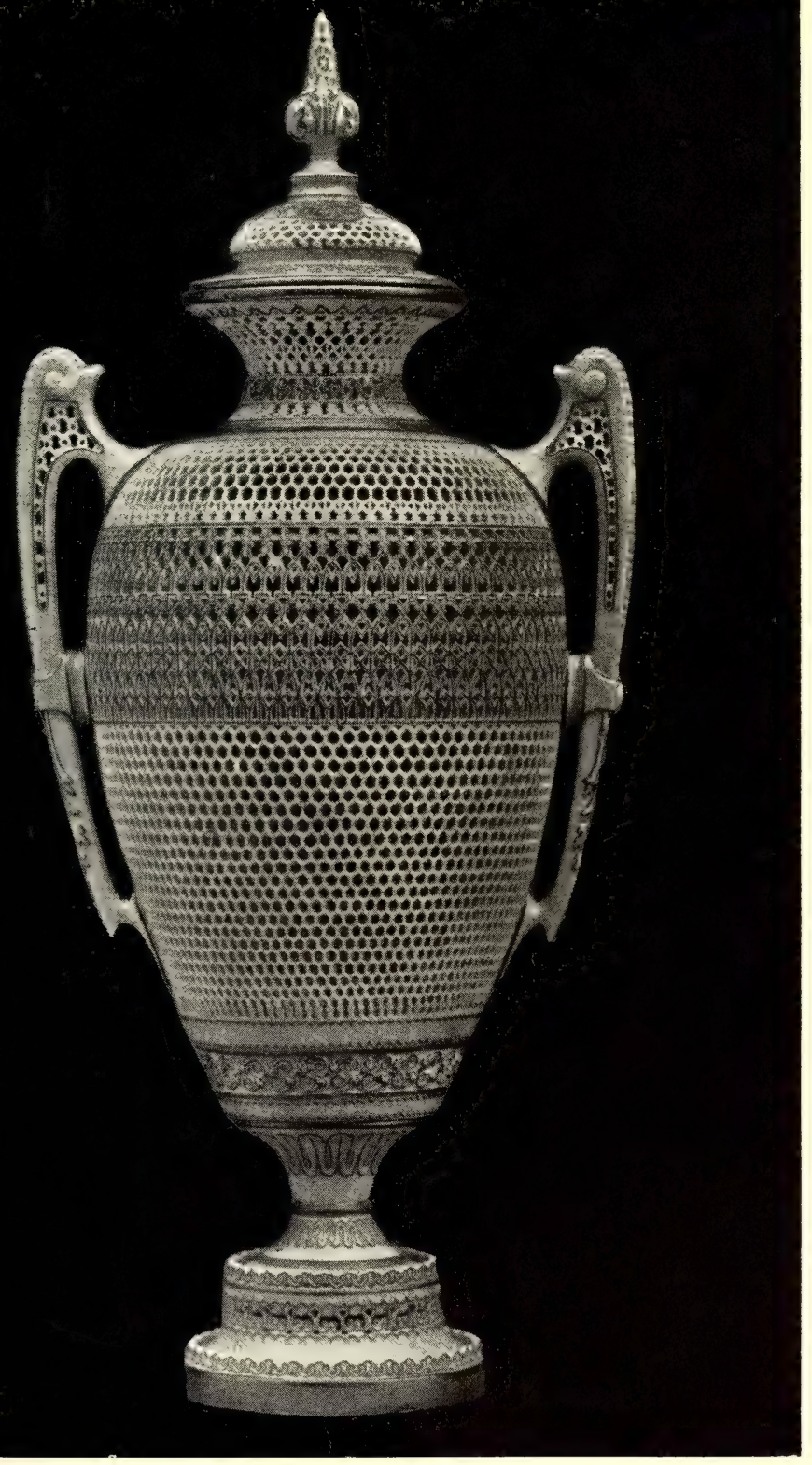

MODERN WORCESTER. PIERCED VASE BY OWEN. 



\section{WORCESTER MARKS.}

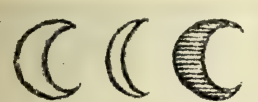

These marks appear on all kinds of Worcester China between 1751 and 1800 . The Crescent is the true Worcester mark; it was taken from one of the quarterings of the Warmstry Arms.

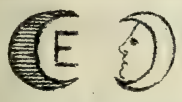

The Crescents with addition are not common; they are generally on blue ware.

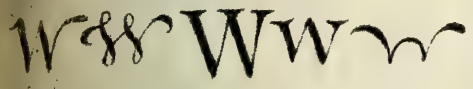

The W mark is found on a great variety of patterns of early date.

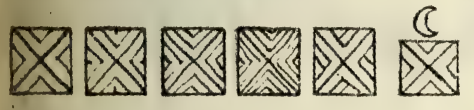

These are the square marks so much sought after, and which are frequently counterfeited.
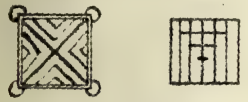

Also square marks, but not so common.

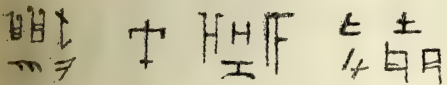

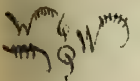

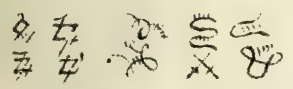

These are copies of Chinese and Japanese patterns, and generally appear on wares of that class.
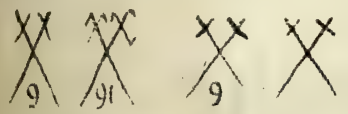

These marks appear on various styles of ware, sometimes on black prints.
R. Hancick fecit R. Horiester.

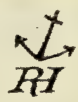

Appear on transfer prints between 1756 and 1774

\section{FLIGHTS}

Has been found impressed in the ware 1783 to 1791 .

\section{Flight}

In anderglaze blue for same period.

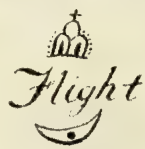

On the Royal Service made for the Duke of Clarence.

\section{$B$}

Found scratched in the clay after Mr. Barr was taken into partnership; 1793 to about 1800 .

$$
\text { Flight \& B Barr }
$$

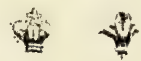

\section{Bark Flighti $\{$ BaRi?}

Roval Porrlain Wurks

WORTESTER

Londion House

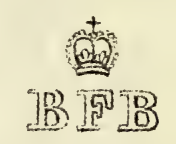

No 1, Coventry Street firom trog to 1813.

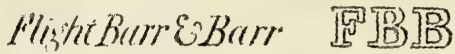

From $\$ 813$ to 1840 . 


\section{WORCESTER MARKS.}
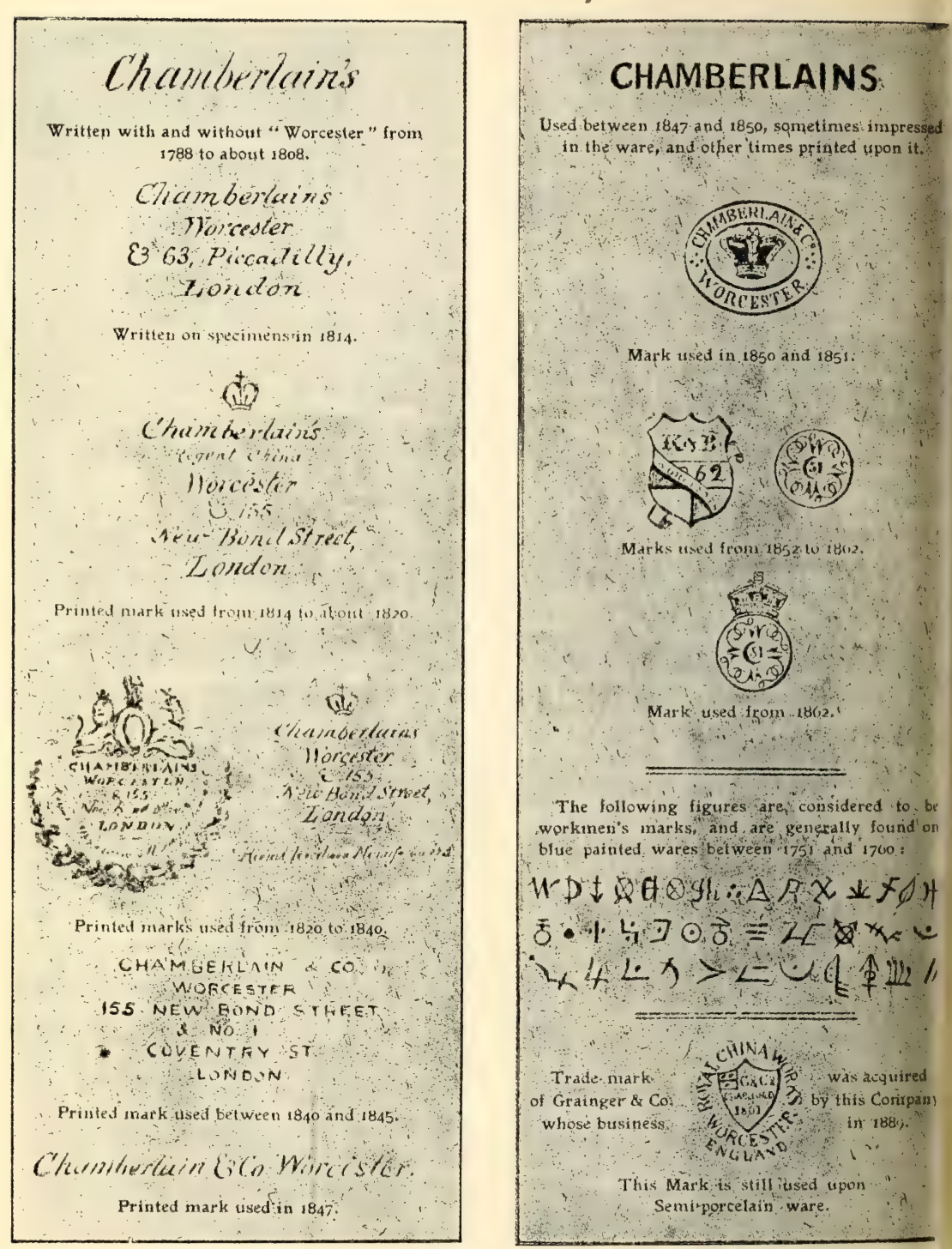


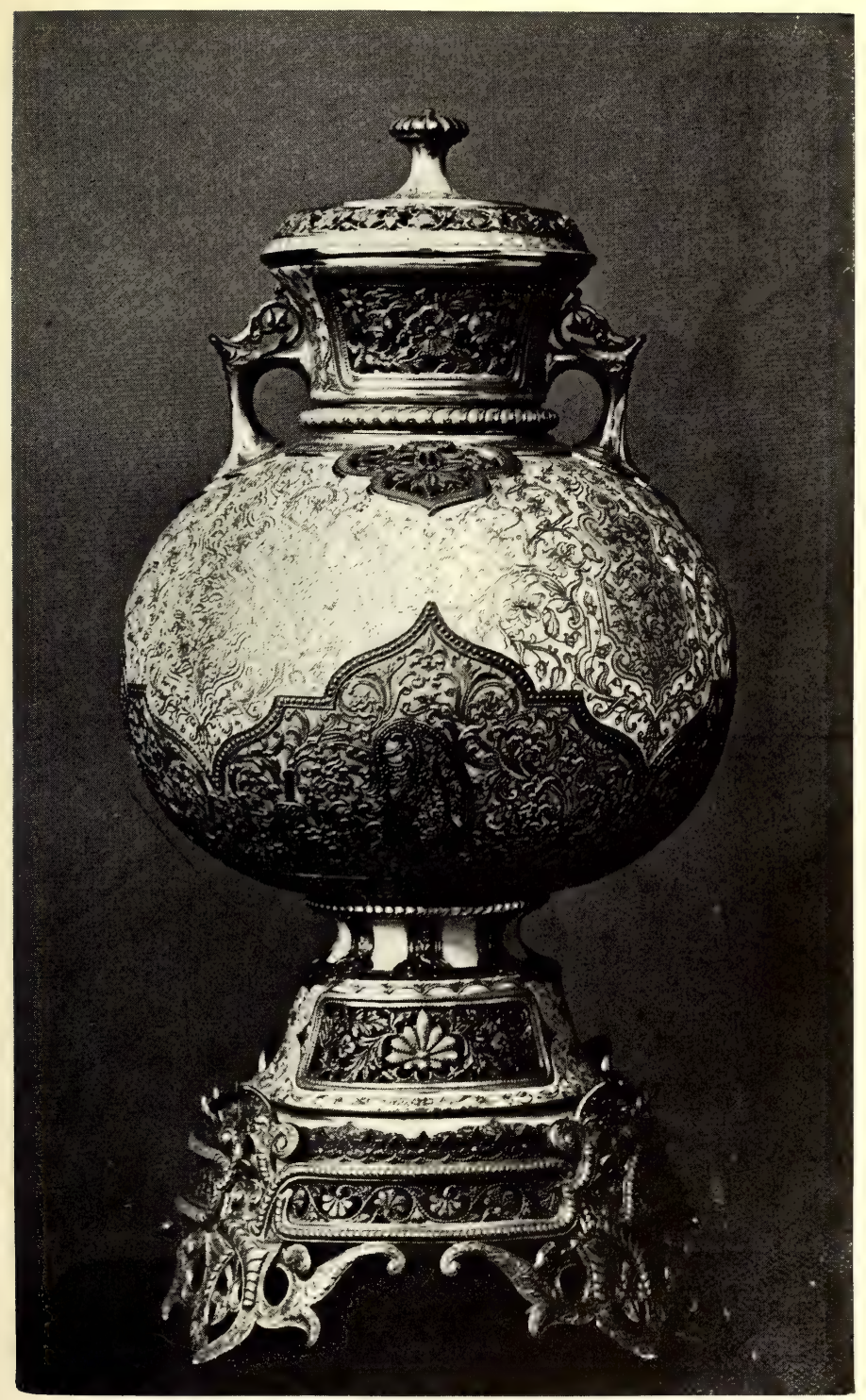

VASE AND COVER. MODERN WORCESTER OF FINE QUALITY, PIERCED WORK BY OWEN. 



\section{CHAPTER XIII \\ DERBY AND DISTRICT}

\section{Derby China}

THE marvellous growth and success of Duesbury's Derby China Works were conspicuous in the eighteenth century, when the two Williams, father and son, laboured incessantly for their advancement. From I75I ( $\mathrm{I} 756$ ?) to $\mathrm{I} 786$ the father ruled alone; for the next ten years the son, with a devotion which proved too severe, forced Derby china to the first place amongst the ceramic productions of his time. The fashionable world bought Derby, and many society ladies, with noblemen and gentlemen, made their own drawings for services, which were manufactured under Duesbury's personal supervision. When he died, the decadence commenced. In I795, a year before he passed away, Michael Kean became his partner. He was a clever miniature-painter and designer, whose skill was of much value to the factory, and whose services on behalf of the widow and her young family have been the subject of much speculation. He married Mrs. Duesbury and acted as proprietor of the establishment in the early years of the nineteenth century.

I state this with certainty because I have examined the indentures of Locker, whose name appears again later. Locker was apprenticed to Michael Kean, whose signature is appended to the document, with that of Robert Bloor as witness. Bloor will reappear upon the scene.

In 1808 the third William Duesbury married the daughter of W. E. Sheffield, and for a time the title of the business was "Duesbury and Sheffield." This Duesbury did not 
value the potter's art, did not care to follow his father's footsteps. Thus it happened that, in 1809 , he leased the premises to Robert Bloor, who had been his father's clerk, into whose hands the whole concern soon passed; but the expert interest in the actual manufacture, which had formerly been the motive power, ceased, the productions were of inferior quality, the decline led to the fall. Various causes have been assigned for the decay of the Derby factory. Some have stated that Bloor adopted an objectionable system of auction sales, but the records prove that Duesbury made money by such sales. Others have stated that the work was inferior, and there is much truth in that ; others go further, and declare that garishly decorated goods were sold by auction throughout the country. If so, that was a proof of more than ordinary enterprise.

But does not the real cause of the failure lie in the general bad state of trade due to the long struggle with Napoleon, when other potteries failed ? The benefits of the Long Peace which followed were lost to Derby because Robert Bloor's health was bad, and his brother Joseph, who had managed the mixing department, had to undertake all the duties of superintendence. When Robert Bloor died in 1845 and his brother the year after, the end of the works was not far off. Bloor's grand-daughter had married Thomas Clarke, who in $1848-9$ sold most of the models, etc., to that John Boyle, who is noticed as a partner in Wedgwoods'. The workmen had drifted to Staffordshire, the artists to Worcester, but a faithful few remained who secured premises in King Street, where, under the title of "Locker \& Co., late Bloor," they produced Derby china, which was marked with the name of the firm on a ribbon enclosing the word "Derby." After Locker's death in I859, "Stevenson \& Co.," followed by "Stevenson, Sharp \& Co.," were the styles used, and " King St." was added above "Derby." These changes were followed by others, for in I862 Sampson Hancock joined Stevenson, and for some years Stevenson and Hancock used a mark which was employed by Sampson Hancock alone when he became the sole proprietor. This mark was designed by Jewitt, and it consisted of the 


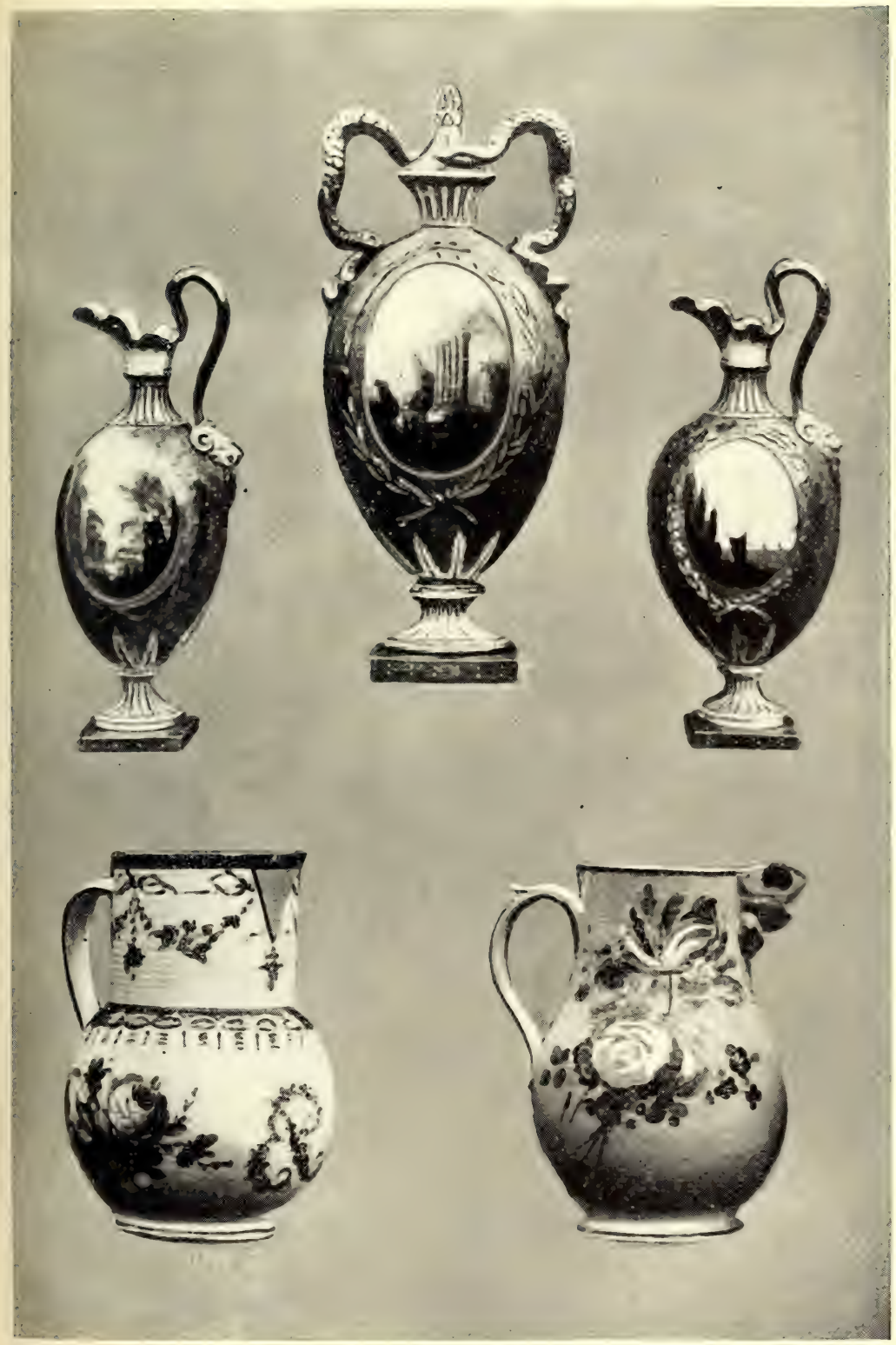

DERBY VASES AND TWO JUGS. ON THE RIGHT, THE RODNEY JUG. 

letters $\mathrm{S}$ on one side and $\mathrm{H}$ on the other, of the old Derby mark of the crown, crossed swords and dots above the script D, which fitted equally the names Stevenson and Hancock, and Sampson Hancock. When I visited the factory some years ago, the same mark was used by Hancock's relative and successor. Though this factory was a small business, which is still in existence, to it must be ascribed all the credit for maintaining unbroken the record of Derby china, and if the output was never very large it was good-in fact, the statuette of Falstaff which I bought was in modelling, colour, and gold superior to many of the late Bloor period which I have seen.

Sampson Hancock's story of the King Street Works follows in his own words :

"This is how it came about. Robert Bloor purchased the Duesbury factory from Michael Kean by disposing of a large stock of china. Bloor, although he employed capable people, allowed the quality of the ware to deteriorate. His goods, like the razors, were made to sell. As an inevitable consequence the works declined, and in I848 they were closed. I succeeded Robert Bloor, transplanting the Nottingham Road Works to my present factory in King Street. Six working men employed at the old factory put their wits together, and started my works - William Locker, James Hill, Samuel Fearn, Samuel Sharp, John Henson, and myself. We afterwards took George Stevenson into the concern."

Here we may notice that Michael Kean was the vendor, and that Locker, Stevenson, and Sharp are mentioned. These names occur on the marks before that of Hancock.

A retrospective survey of the well-marked periods of the Derby manufacture may well precede the advent of the present prosperous concern, which marks the great revival. The first recognised period dated from about I756 to $\mathrm{I} 76 \mathrm{~g}$. Mr. William Bemrose assured me that I was wrong in giving the date about I753 in my book on Old English China. It really does not matter much. The second Derby period ended in 1784 , when the entire plant from London was transferred to Nottingham Road. Then the Crown Derby period lasted 
till I8II, so that this forms the earliest distinctive style in the nineteenth century. The fourth, or Bloor, period ended with the close of the works. To these may be added a fifth for the products of the small business which in King Street continued the production of articles of the old type and character.

The workmen who made the place famous have long passed away, but such names as Billingsley, Pegg (the Quaker), James Rouse, Leonard and John Lead, Marriott, Rowland, Cutts, Wheeldon, Steele, Hopkinson, Haslem (many years art-tutor to Queen Victoria), and others, will live in the world of ceramics.

The rise and progress of the new company from the date of its commencement may be told best from information kindly furnished to me by the secretary, which I now give.

Of the starting of the new factory, it may be stated that at the very outset Mr. E. Phillips, the founder (formerly of the Worcester Works), with whom were associated the late Mr. William Litherland and Mr. John McInnes, met with considerable opposition on the part of the Litchurch Local Board and a few property owners. Very possibly-if it had not been for the aid of the Press, and the strong expression of feeling displayed at a public meeting held in Litchurch; March 22, I876, in favour of Mr. Phillips' proposal to revive the ceramic arts in a large way in Derby-the works would have been built elsewhere.

Mr. Phillips gave up a lucrative business at Hanley, and, though his friends persuaded him to retire, he took the management of the Royal Porcelain Works at Worcester about I863. Leaving Worcester in 1875, he conceived a wish to revive the fame of Derby china by means of the introduction of ample capital and the personal knowledge he possessed. Messrs. Litherland and McInnes associated themselves with this laudable desire. The consequence was, a limited liability company was formed, with a capital of $£ 67,850$. In June 1875 about an acre and a half was bought adjoining the Derby Workhouse, on the Osmaston Road, on which a mill, slip-houses, etc., were shortly erected. On December ${ }_{5} 5$ in the same year, the old Workhouse and exten- 


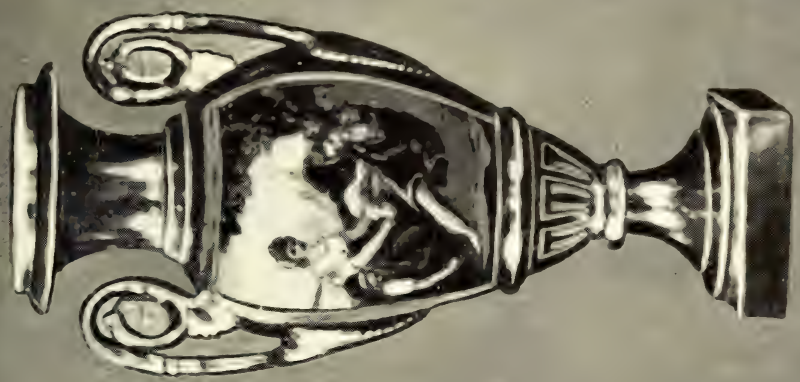

.
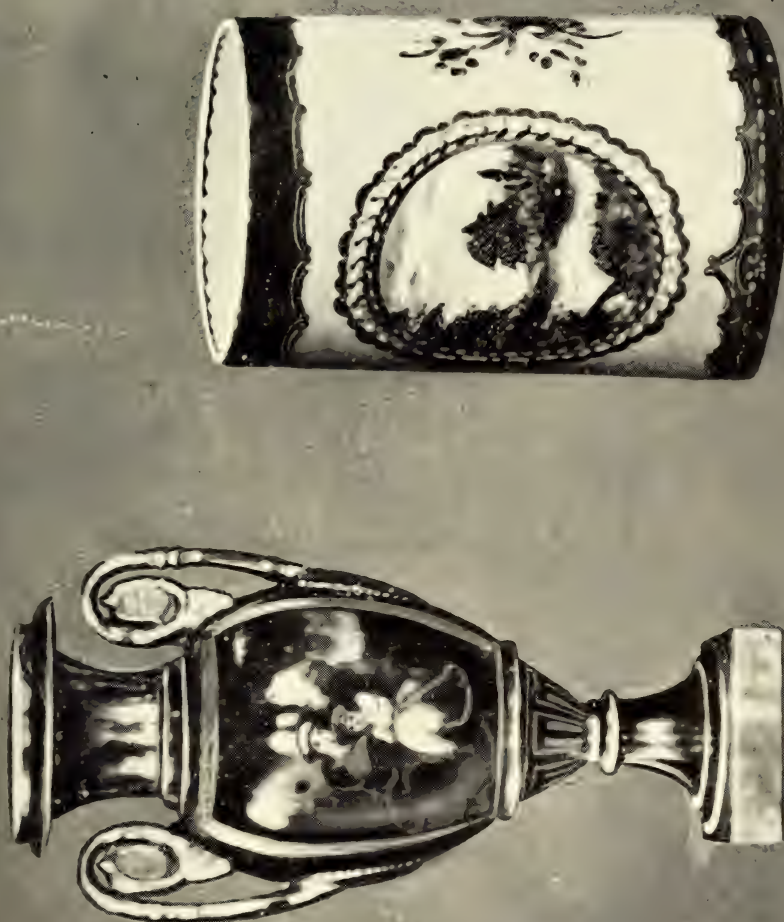



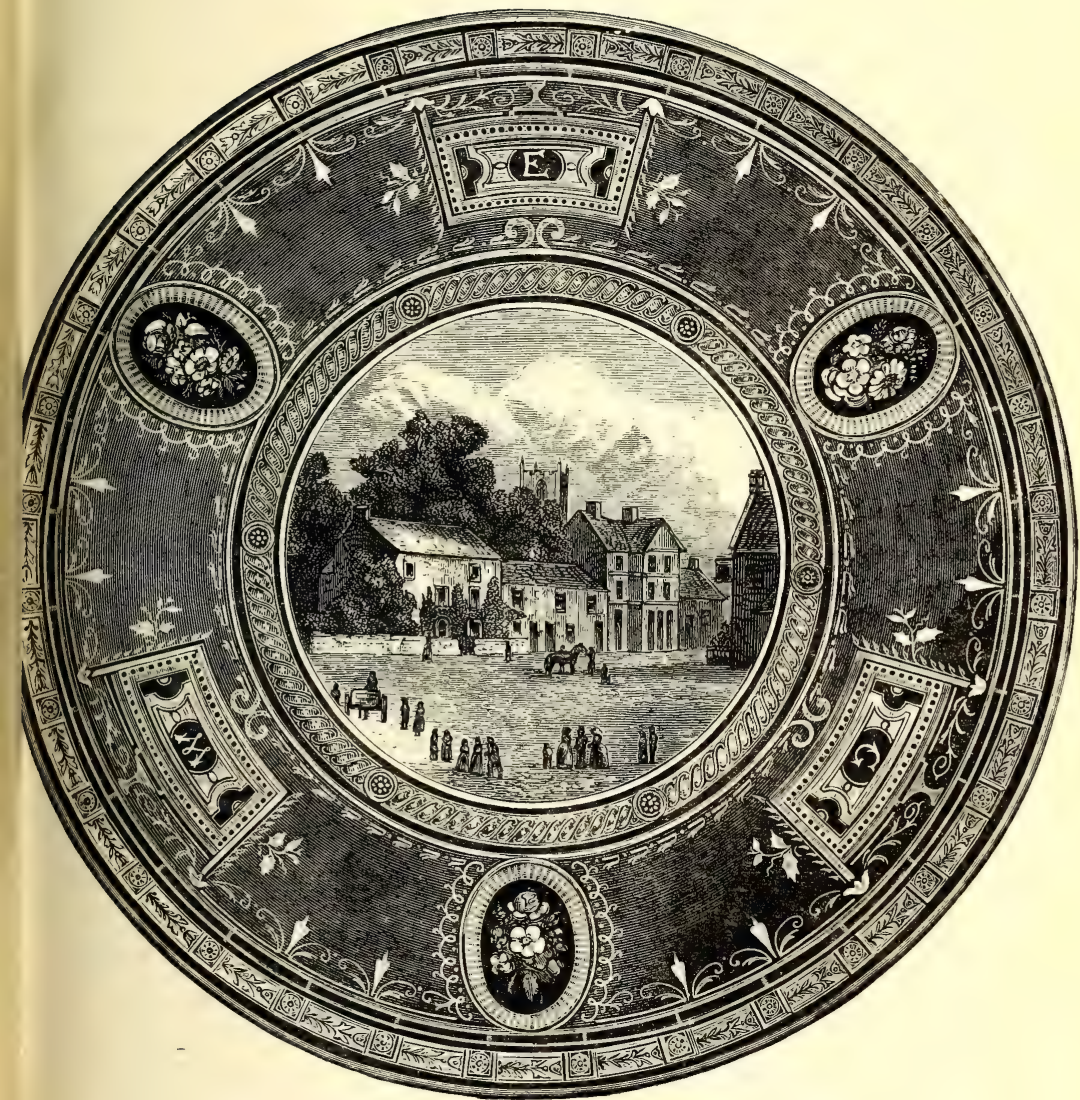

a plate from the "gladstone" presentation service. 
sive grounds were sold by auction, and purchased by the company for $£ 9, I_{50}$. The company rented premises from Messrs. Bemrose and Sons, in Chetwynd Street, in August I876. where the first modelling was done, removing to the new works in August I877. The principal modeller was $\mathrm{Mr}$. W. R. Ingram, who was assisted by a competent staff. The first apprentice was Herbert Warrington Hogg, a youth of great promise. He was admirably trained by $\mathrm{Mr}$. Ingram, and fulfilled the predictions formed of his artistic powers. His early death, in I893, was a great loss to the firm. The first directors' meeting was held at Messrs. Bemrose and Sons' offices, Midland Place, April 9, I877, the original subscribers being: William Litherland, Henry Litherland, John McInnes, John Bostock Litherland, Edward Phillips, Henry Evans, Henry H. Bemrose, W. Bemrose, and C. E. Newton, In May I879 the front of the old Workhouse was altered, and a large show-room and additional artists' rooms were built. The works, too, began to expand, and the productions quickly found favour, it is not too much to say, all over the civilised world.

Among the chefs d'œuvre which have been produced at these works, of which the company is justly proud, are the Gladstone dessert-service, of which an illustration is given, the Queen's Jubilee Presentation, and the Princess May (Queen Mary) wedding present. The Liberal working men had the fine instinct to offer for the veteran statesman's acceptance the best of their local products. Accordingly, the service was made and painted with scenes from town and country, and upon it appeared the inscription: "Designed and manufactured by the Derby Crown Porcelain Co., Limited, for presentation to the Right Honble. W. E. Gladstone, M.P., by the Liberal Working Men of Derby, I883."

In response to the address of the deputation presenting the tribute, Mr. Gladstone made a speech which was in his best vein. A few very short extracts will not be out of place :

" In the last century England took a very high place in porcelain manufacture, but in the present century certainly the relative place of England appears to me to be higher still, 


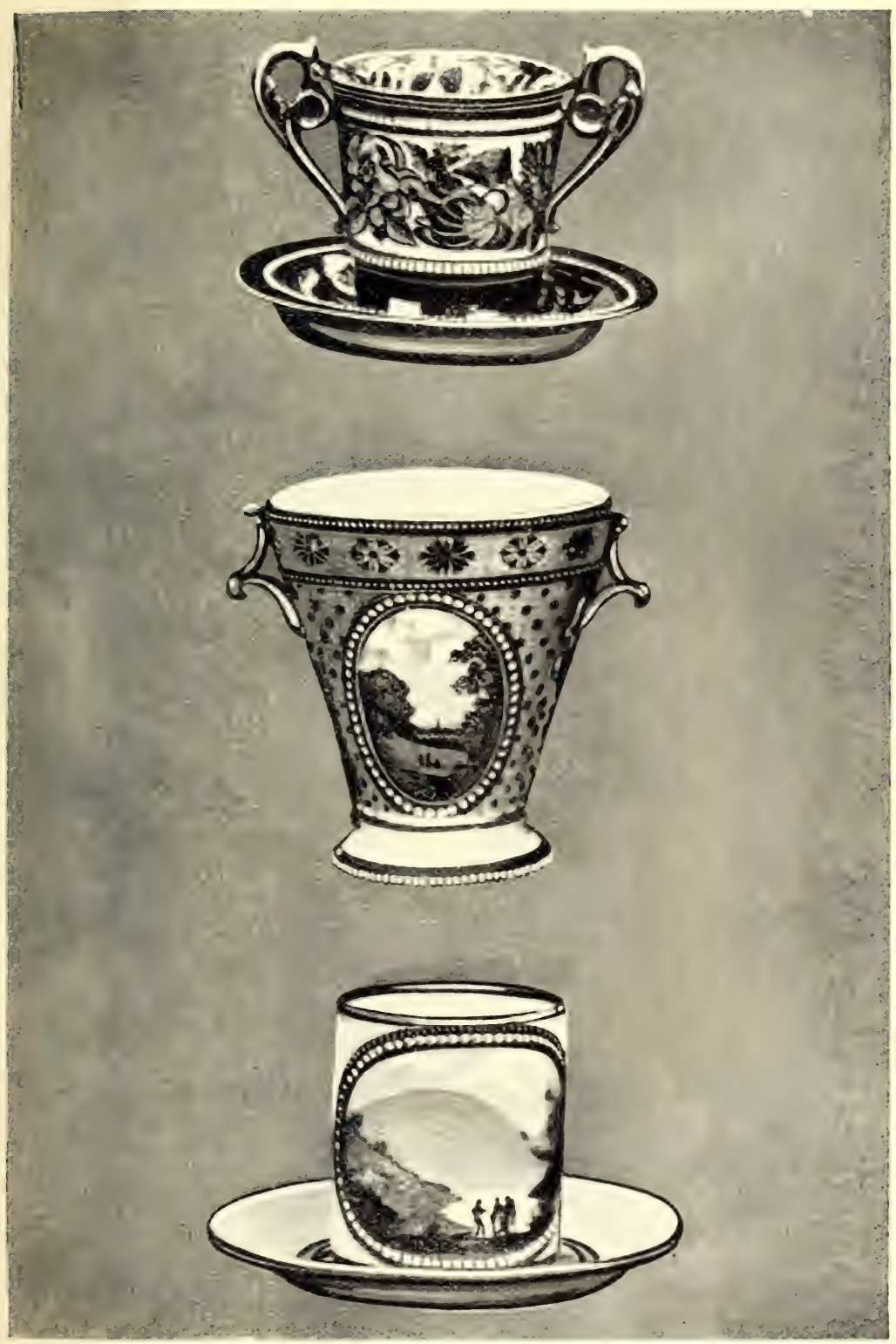

Derby porcelain, painted, JeWelled, ANd Gilt. 



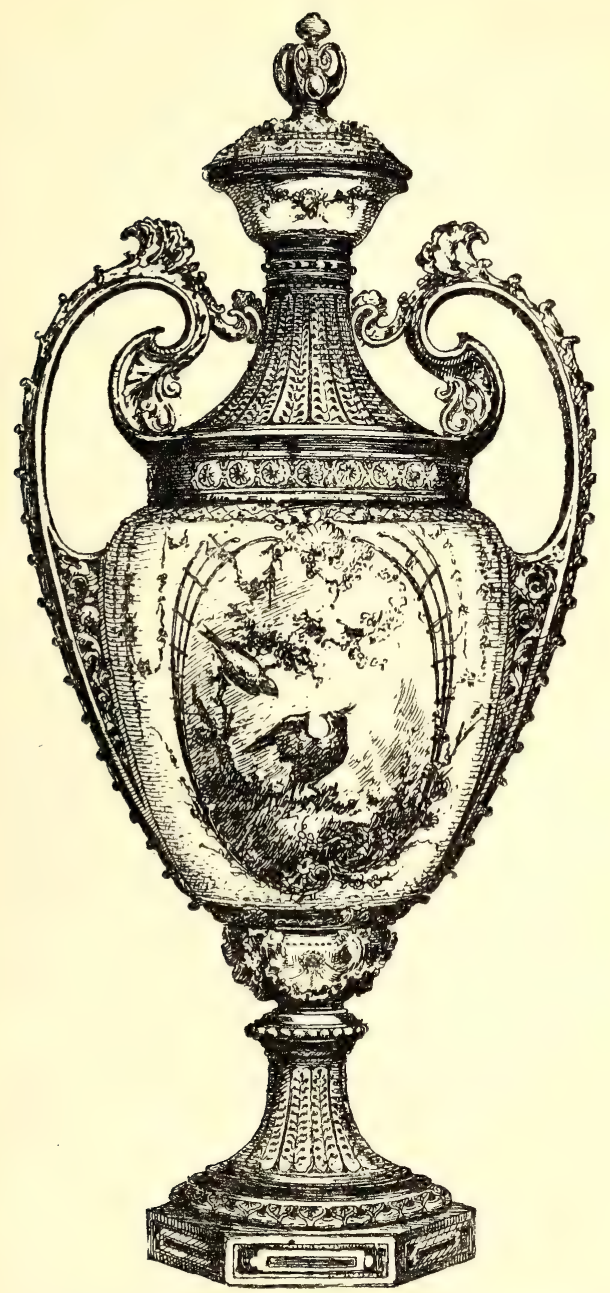

DERBY VASE PAINTED BY LEROY ON GROUNDS OF CELADON AND IVORY. RAISED AND CHASED GOLD DECORATION. 
and $\mathrm{I}$ believe it is not too much to say-I do not think I am indulging in arrogance or national vanity when I say-that at the present moment England stands at the head of the porcelain-producing countries of the world. There is one other word I will say on this subject, and it is this. I regard this manufacture with the greatest interest. For many years I have had a great love of porcelain. I think they are entirely mistaken who consider its production merely as a branch of industry, or merely as a branch of skilled industry; it is likewise a branch of art-a branch of art in which the principles of the fine arts are applied to an industrial purpose."

And he concluded :

"I knew that the greatest pains and the greatest liberality would be exhibited by you in presenting a worthy example of the Derby porcelain manufacture, but I must say that the beauty of that which you have placed on the table fairly surpasses all my expectations."

Queen Victoria's the present by women of Derby was no less happy in its inspiration. It comprised two vases and a circular plaque, which are now amongst the treasures of the Royal Family. The vases were twenty inches in height and five inches in diameter, and the decoration, upon a groundcolour of rich mazarine blue, for which Derby has been so long famous, with lighter blue used in parts, was richly embossed, perforated, painted, and gilt. The plaque was painted in the centre with a portrait of Her Majesty, enclosed by the Garter in a panel the angles of which displayed quarterings of the Royal Arms. The other decoration was rendered in gold and enamel colours, and consisted of the arms of the twenty-four colonies emblazoned in heraldic colours. Altogether it was regarded as a gift of which even Her Majesty might with reason feel proud and happy in accepting.

The wedding gift of the town of Derby to Princess May, or rather to His Royal Highness the Duke of York and Her Serene Highness the Princess Victoria May of Teck July 6, I893, now our King and Queen, was characteristic Derby china-a service of plates of gadroon shape. The embossed edge in turquoise and gold sustains exquisitely painted 
flowers with pendent medallions. Included by special desire is the heraldic badge of the House of York. In the centre is a floral monogram G. M., the first letter being in raised and chased gold, and the second delicately painted in colours. The monogram is surmounted by a crown in chased gold.

Amongst the clever artists of recent times is M. Désiré Leroy, an artist trained at Sèvres and a naturalised Englishman. He joined the company's staff in I89o, and remained with them until his death in I908. M. Leroy made a speciality of old-time Sèvres flower, bird, and trophy painting, and was also strikingly successful with white enamels. He did some very important work-among other things, this service of plates.

The Derby Crown Porcelain Co. continued under that style from the commencement of its operations in 1877 to January 3, 189o, when the works became a Royal Factory by letters patent, and from that time onwards all goods have been marked "Royal Crown Derby" over a crown surmounting two crossed D's, one reversed. The letters from the Lord Chamberlain's Office and from the Secretary of State for the Home Department are appended. Recognition of the services rendered by the Duke of Devonshire in this connection is only just ; his intervention was invaluable to the company.

$$
\begin{aligned}
& \text { “Lord Chamberlain's Office, } \\
& \text { "St. James's Palace, S.W., } \\
& \text { " 3oth Dec., I889. }
\end{aligned}
$$

"SIR,-With reference to your statement, which was forwarded by the Duke of Devonshire to Sir Henry Ponsonby on the I 7 th inst., I am desired by the Lord Chamberlain to inform you that the Queen has consented to grant to the Derby Crown Porcelain Company a warrant of appointment as manufacturers of Porcelain to Her Majesty at Derby, which will enable the Company to use the Royal Arms.

"Will you be good enough to inform me in what names the warrant of appointment should be drawn up.

"I am, Sir, your obedient Servant,

(Signed) “S. Ponsonby Fane.

"The Manager of

“The Derby Crown Porcelain Co." 
" Whitehall, " $3^{\text {rd J January, } 1890 .}$

"Gentlemen,-With reference to your letter of the $24^{\text {th }}$ ultimo, applying for permission to make use of the title 'Royal' in connection with the 'Derby Crown Porcelain Company (Limited),' I am directed by the Secretary of State to acquaint you that he has had the honour to lay your application before the Queen, and that Her Majesty has been graciously pleased to accede to your request, and to command that the Derby Crown Porcelain Company (I.imited) shall be called the 'Royal Crown Derby Porcelain Company (Limited).'

"I am, Gentlemen, your obedient Servant, (Signed) “E. Leigh Pemberton.

\section{"The Royal Crown Derby Porcelain Company (Limited), Derby."}

In I90I, on his accession to the throne, His Majesty King Edward VII. granted the company a similar warrant of appointment as manufacturers of porcelain to His Majesty at Derby.

The Osmaston Road Works produce the most delicate, the most sumptuous, and the most ornamental china, beautiful examples in old Sèvres styles, many of the finest specimens being decorated by Monsieur Leroy formerly at Sèvres, whose fine painting in white enamels on cobalt grounds much resembles pâte-sur-pâte. But it does more-it manufactures immense quantities and varieties of tea, breakfast, dessert, and dinner services, etc., for the home and export markets, and it specialises in Japan patterns, and in reproductions of the Old Crown Derby designs. Old-time traditions may have but little weight even with lovers of the beautiful, but where usefulness is combined with beauty, as it is in the objects produced at Derby, we can understand why the Emperor of Morocco, after dinner to the English Mission in 


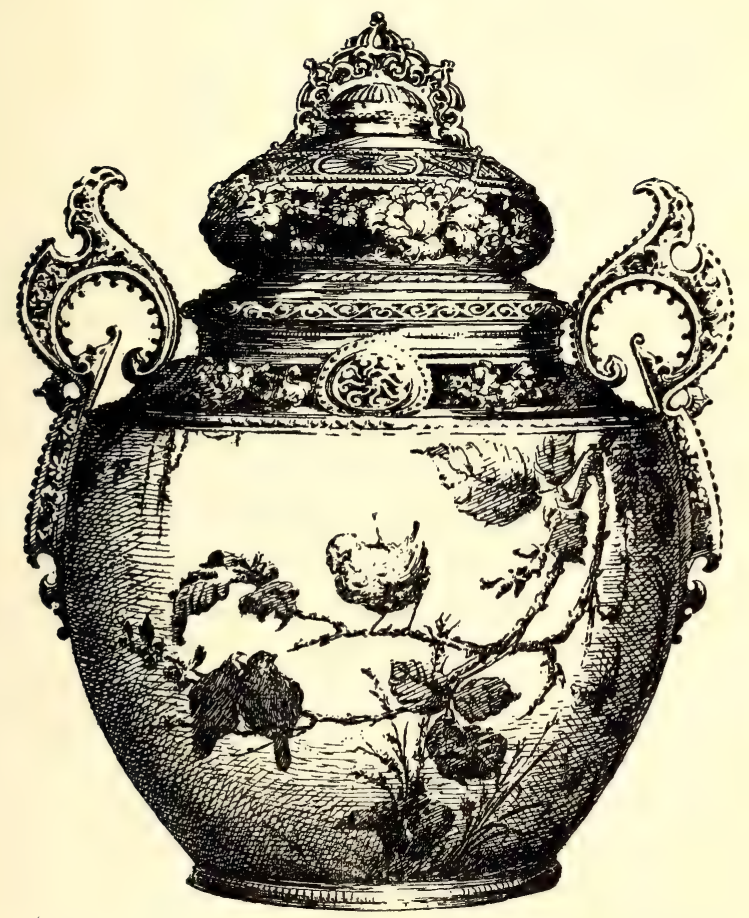

DERBY JAR PAINTED WITH BIRDS, ETC., BY LEROY ON A MAZARINE BLUE GROUND. MOUNTS RICHLY GILT AND CHASED. 
I887, served tea and coffee in charming little cups of Crown Derby, and why a tea-set of Royal Crown Derby Japan is a wedding-gift that pleases any bride.

Even with all this, the modern Derby firm has not been content-it has advanced far into new realms, where in decoration their artists have surpassed in many respects the work done by their predecessors. The original figures, such as "Tribulation," "Supplication," "Resignation," and "Adoration," are larger and finer than "Dr. Syntax" and the "Mansion House Dwarfs," though these are again produced. Then another successful and new decoration is the rich Persian, which entirely covers the surface of the piece with intricate designs in colours and gold, raised and sometimes jewelled. Raised gold work has a large place in those schemes where it is combined with the most delightful ground-colours, and with gem-like enamelling, in a lavish use of its two forms, burnished gold and mat gold of the finest quality.

Egg-shell china is made of wonderfully delicate porcelain, yet so tough as to withstand the highest temperature of liquids better than the thicker china-dainty, fairy-like cups and saucers richly gilt and enamelled. The ivory china is a close imitation of the real ivory in its soft tones, and a whole series of perforated patterns is achieved with encouraging results. These indicate a few of the new departures, which may show something of the spirit of the proprietors, who have also discovered the secret of making porcelain with stained bodies of tender greens and mauves which form a speciality of unusual interest.

So great is the distinction of the Derby work, that the Government entrusted the firm with the task of reproducing the Rhodian and Persian specimens at the Victoria and Albert Museum, so that the reproductions might be forwarded for exhibition at the provincial galleries and museums without endangering the more valuable originals. In spite of the competition of France and Germany in this direction, Derby has succeeded not only with the wares mentioned, but with 


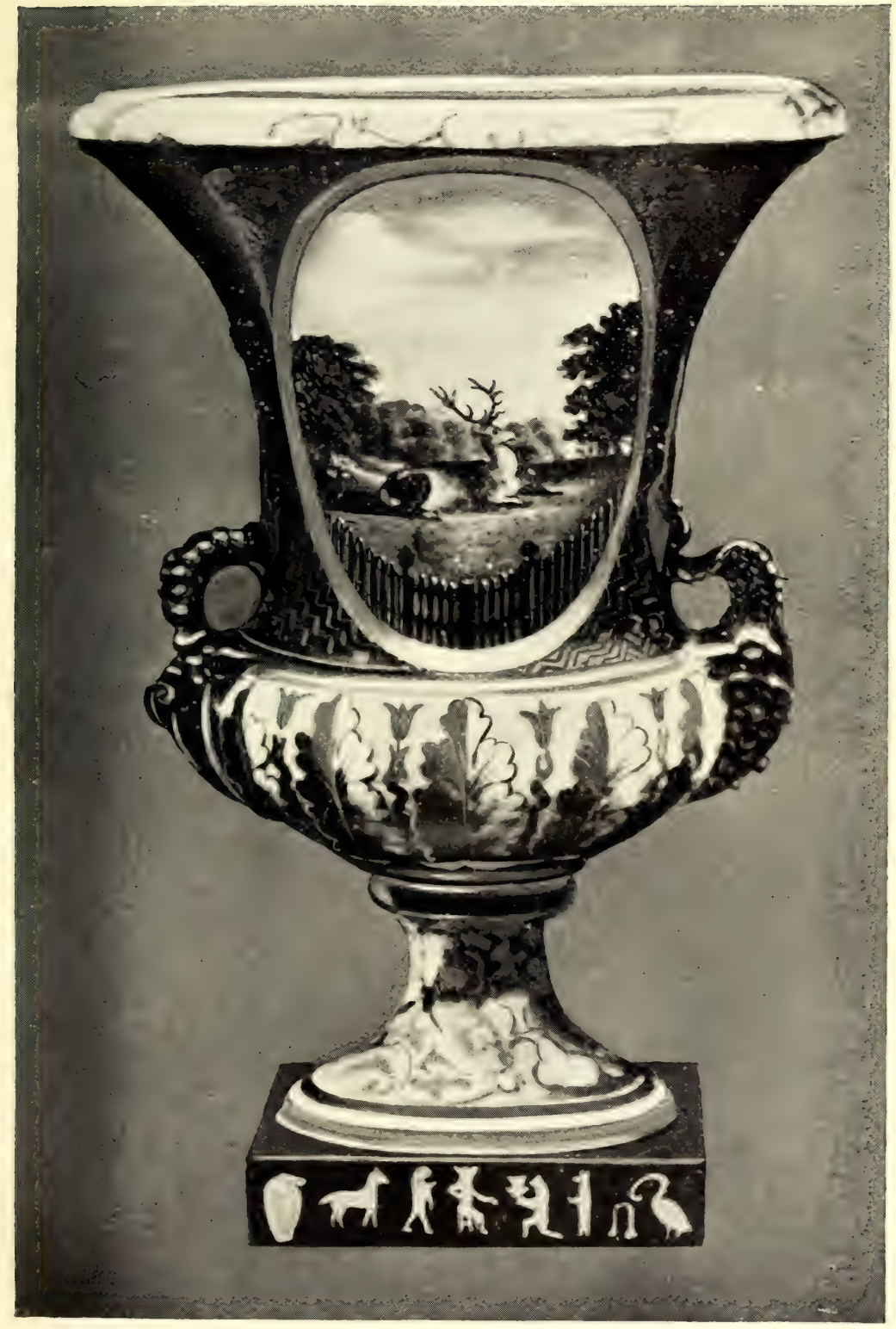

DERBY VASE.

jOI 

others, such as the Imari ware. It seems fitting that the factory which excelled in the Old " Japanes " should replicate such vases as the one which cost the authorities $£$ roo, and for which the Japanese have offered $£^{I}, 000$. The skill shown

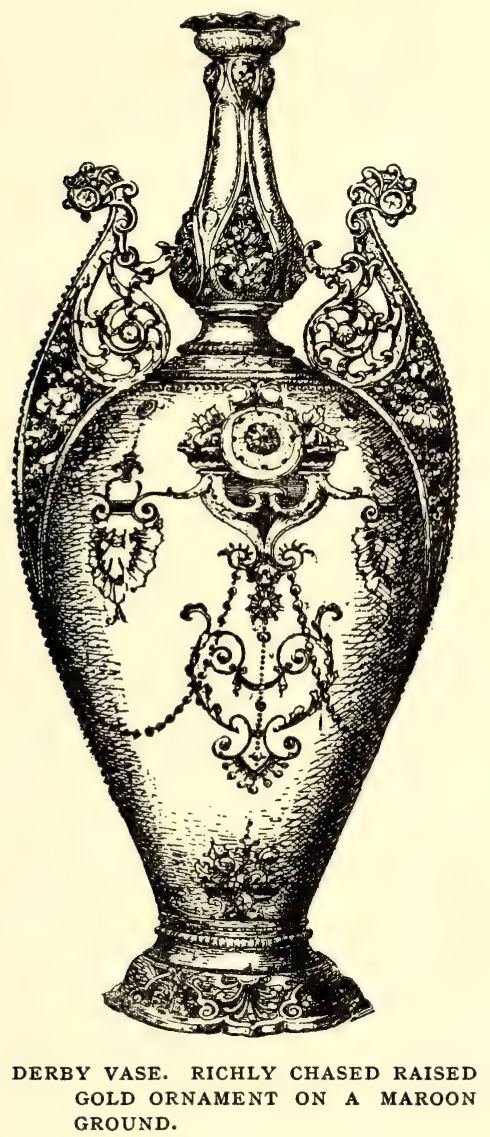

in this work has met with the warmest commendation of the best judges, and much praise is due to Mr. R. Lunn, the Art Director of the company, under whose supervision such triumphs were accomplished. Derby china can satisfy the 
most refined taste, for beauty of form, purity of body, excellence of gilding, and delicacy of painting are its distinguishing features.

\section{Derby Marks (See page 307.)}

I, 2, 3. Earliest Derby marks, generally in blue. (Some examples are known where the crown and D are used separately-probably an oversight by the workmen.)

4. Crossed swords, crown, and D, and six dots, carefully painted in blue, later in puce, used from about $\mathbf{1 7 8 2}$. 5, 6. Ditto, less carefully painted in red.

7, 8, 9, ro. Later Duesbury marks, generally in red.

II. Duesbury and Kean, seldom used, circa I795 to I809. I2, I3, I4, I5. Bloor marks, I8II to I849.

I6, I7, I8, I9. Quasi Oriental marks, used on several occasions in matching, and to use up seconds stock by Bloor. No. I7 is an imitation of the Sèvres mark.

20. Quasi Dresden mark, often used on figures.

2I. Derby Mark, supposed to have been used by Holdship when at Derby, about I766. Rare.

22. Stephenson and Hancock, King Street Factory, I862; same mark used afterwards by Sampson Hancock.

23. Mark used by the Derby Crown Porcelain Co., Osmaston Road, from its establishment in 1877 to Dec. 1889 .

24. This mark adopted by the above company when her Majesty granted the use of the prefix "Royal" on Jan. 3, I8go.

N.B.-Marks Nos. 5 and 6 were often scratched in the clay on Derby biscuit figures, in addition to a scratched number by which the figure was known to the trade and factory.

\section{Denby : J. Bourne and Son}

In I900 Joseph Bourne and Son were manufacturers of stoneware at Denby Pottery, near Derby, using the title of the firm and the name of the works as the mark upon some of the 


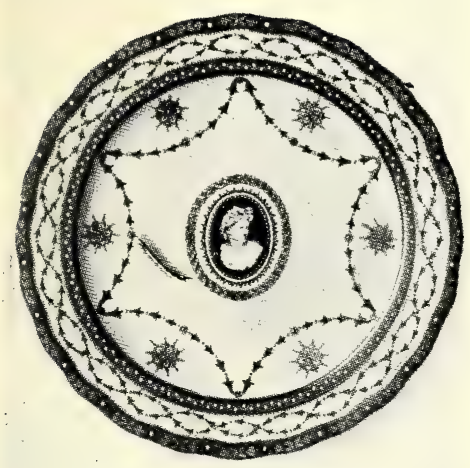

OLD CHELSEA STYLE IN COLOURS, GOLD, AND ENAMELS.

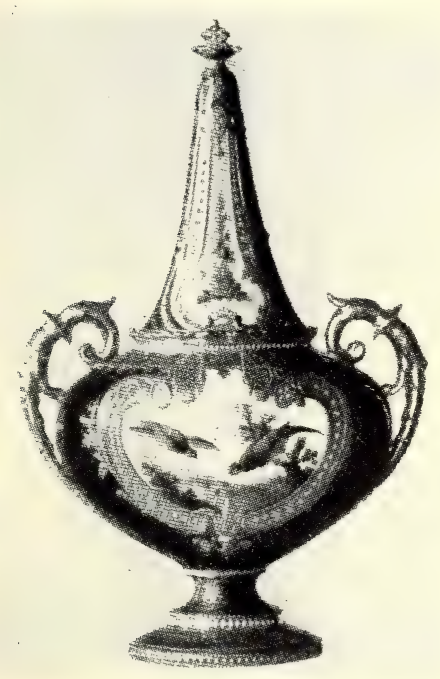

MAZARINE BLUE GROUND, PANELS PAINTED BY LEROY IN SÈVRES STYLE.

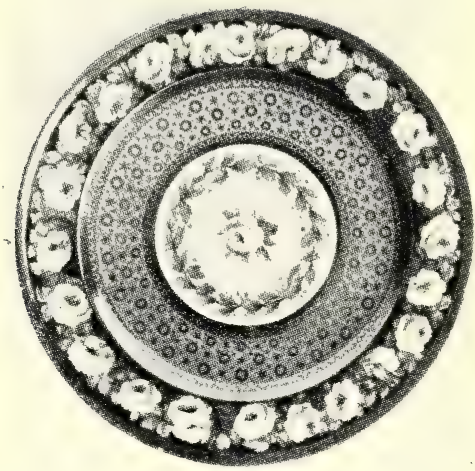

MAZARINE BLUE GROUND, BORDER OF ROSES ON BLACK GROUND PAINTED BY GREGORY IN OLD DERBY STYLE.

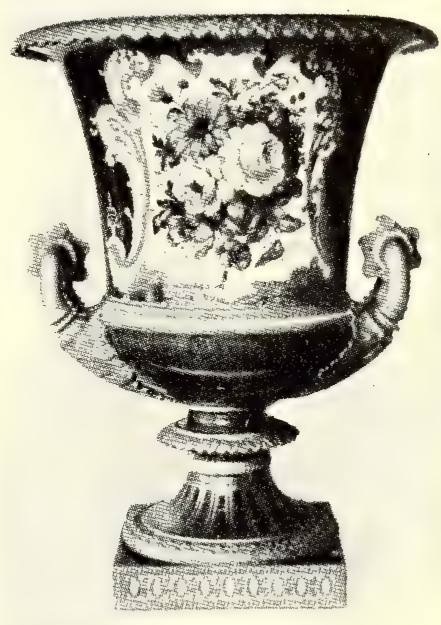

MAZARINE BLUE GROUND, PANELS PAINTED BY GREGORY IN OLD DERBY STYLE.

ROYAL CROWN DERBY. MODERN. 

DERBY MARKS

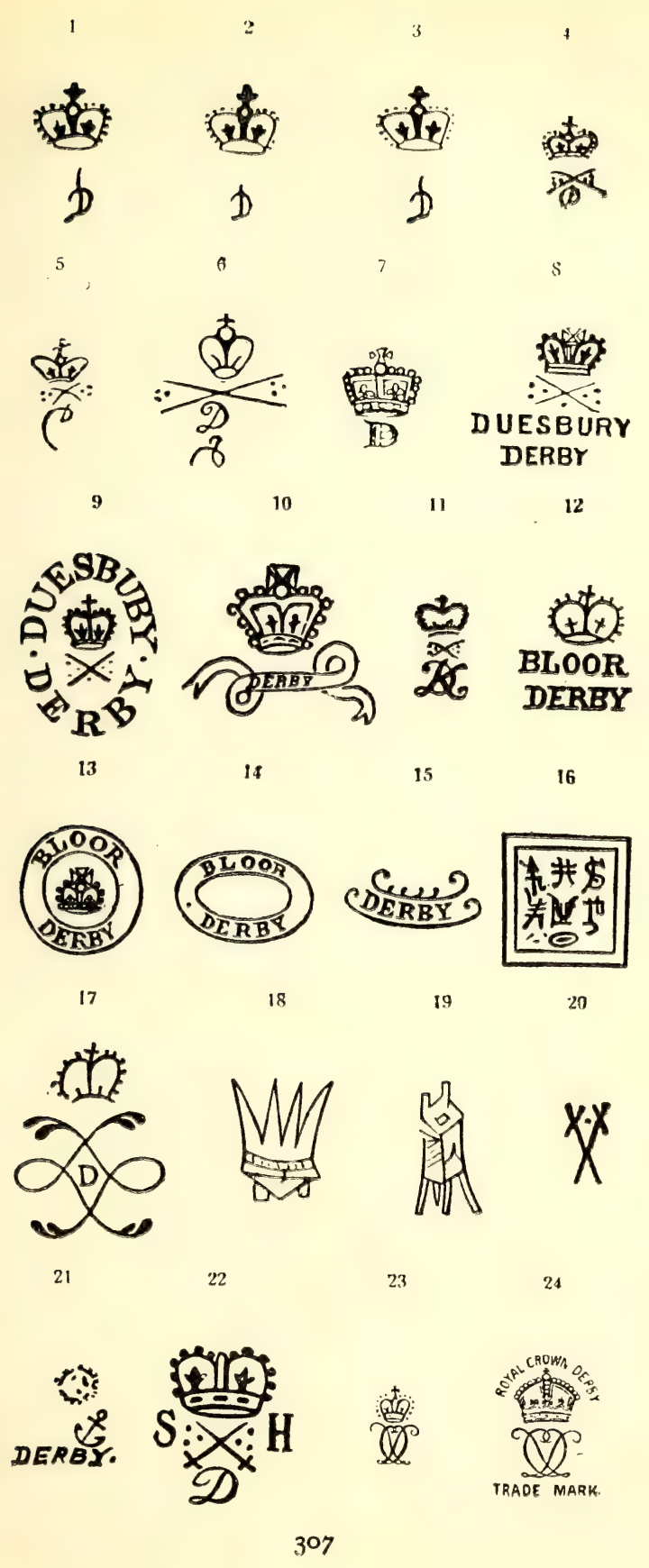


goods. The works commenced in 1809 by Jäger as the Belper Pottery, a name sometimes associated with Denby in the mark. Three years later Joseph Bourne succeeded Jäger and carried on the two works until 1834 , when those at Belper were relinquished, and the extended establishment at Denby received the plant and employés. A year before that the Codnor Park Pottery passed into Bourne's hands. This was removed to Denby in I86I, when the manufactory was much extended. The ware made at Codnor Park by W. Burton from I82I to I833 was marked by either the name of the place or the person, and consisted of pots and pans, bowls, bottles, and jugs, including puzzle-jugs in stoneware or buff-coloured terra-cotta. Household ware was discontinued here by Bourne, who made only bottles at this pottery. At Denby the great bulk of the stoneware is salt-glazed bottles-for which a medal was awarded in $185 \mathrm{I}$ - such as those used to hold ink, ginger-beer, etc., and jars of all kinds. But Bourne's hunting-jugs with raised ornaments, a stag or fox chased by horsemen and dogs, or with trees, bee-hives, windmills, and men seated smoking or drinking, are amongst the best of this class of ware for hardness, durability, and glaze-salt-glaze. White glazed ware is made, and terra-cotta which has a warm buff colour allied to a fine light body, eminently suitable for flower-vases of various designs, lotusvases, garden and other vases, with many other articles both useful and ornamental.

Joseph Bourne died in I860, and his son, who was his partner, in 1869. The style of the firm, which was carried on by his descendants, remains Joseph Bourne and Son.

\section{Brampton}

Brampton brown-ware posset-pots, puzzle jugs and mugs, jugs, and other vessels having greyhound handles, were made long before the nineteenth century, but they are still produced in forms which differ but slightly from the early ones. In the first part of the present century six potteries existed here ; in 1878 there were eight which made brownware of a very 

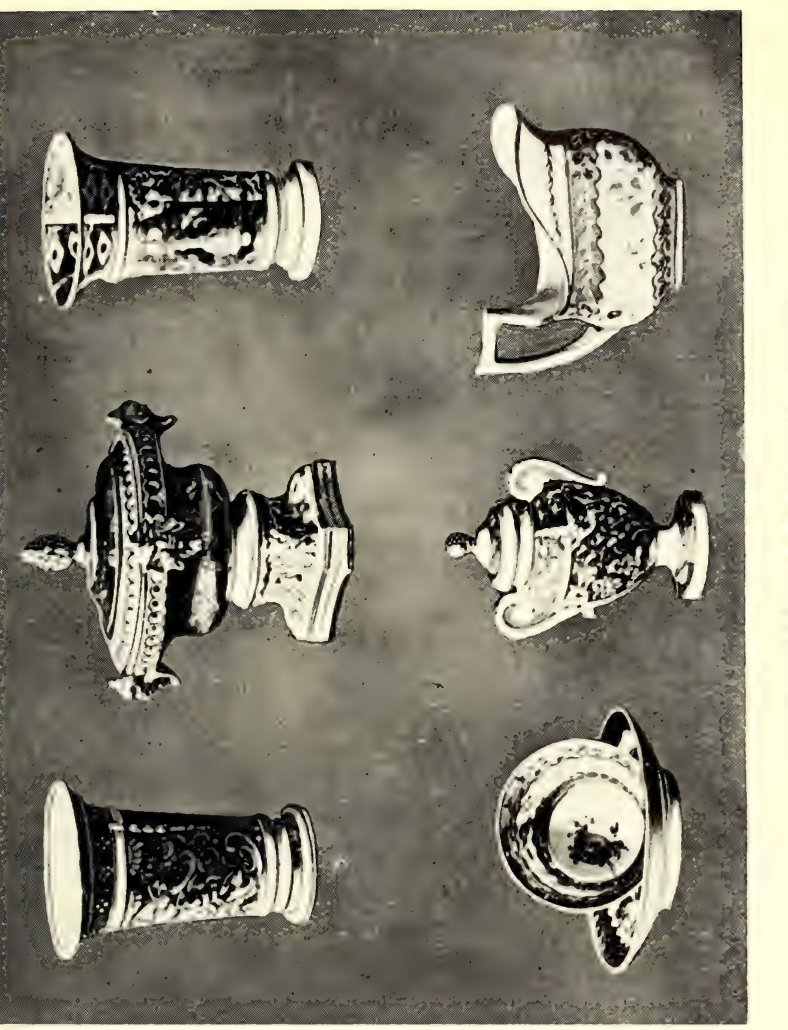

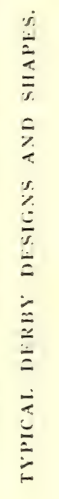
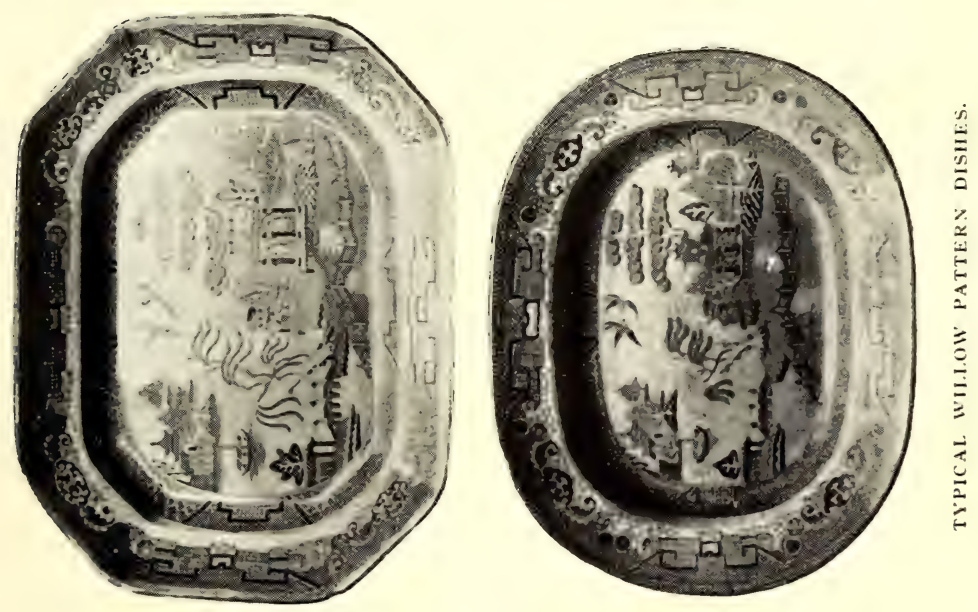



\section{DERBY AND DISTRICT}

hard quality, and stoneware which often receives the generic name of Chesterfield ware, or New Brampton ware-sometimes, and wrongly, Nottingham ware. The best salt-glazed brown ware comprises a variety of articles- " Punch," hunting,

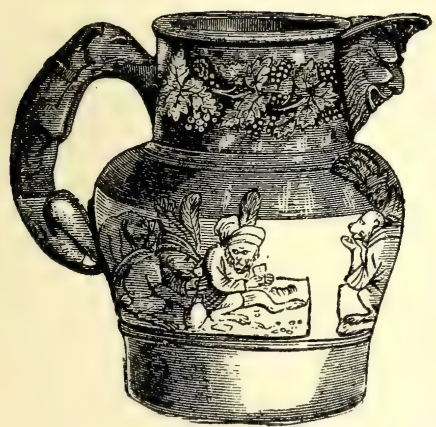

BRAMPTON JUG.

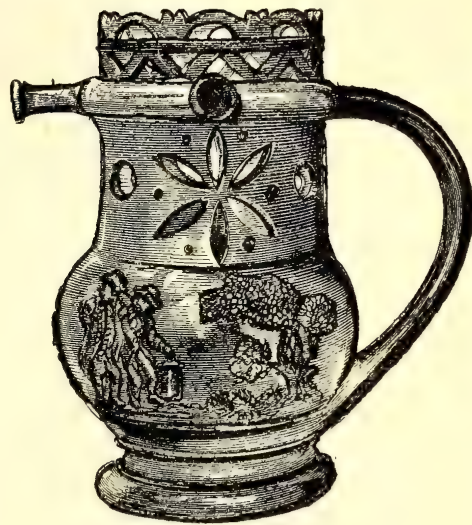

BRAMPTON PUZZLE-JUG.

and game jugs, tea-kettles, and the like; whilst the stoneware includes spirit bottles and kegs, small figures of stags, dogs, etc., and sanitary goods of various kinds. The works are now included under Chesterfield, and amongst them may be mentioned those of Messrs. Oldfield, Madin, Wright, Hewitt \& Co., established I8Io, and continued till 1826 , when John Oldfield became sole proprietor. The products from this factory were marked J. OLDFIELD; OLDFIELD \& Co., with the addition of CHESTERFIELD or Makers. The other

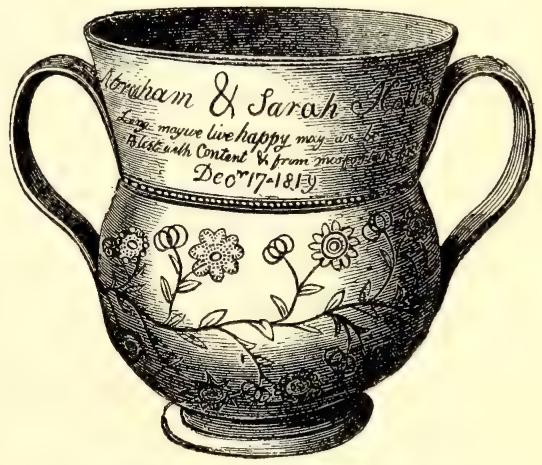

BRAMPTON DOUBLE-HANDLED CUP. makers apparently mark but seldom, if at all, and in quality there appears but little difference between the output of the Brampton manufactories. 
The following are amongst the potters who were working in I900: Barker Pottery Co., stone and brown ware; New Brampton; Beehive Pottery Co., stone and brown ware; Chatsworth Road; Clark and Mottishaw, black ware; Newbold Pottery ; T. W. Green, black ware; New Whittington; M. Knowles and Son, stone bottles and brown earthenware; Brampton Moor; S. M. Lancaster, Whittington Moor; S. Lowe and Sons, Brampton ; Pearson \& Co.; Whittington Moor; James Pearson, Oldfield and London Potteries; Plowright Bros. ; Walton Pottery Co.; E. Wright \& Co., Ltd. - the last three of New Brampton. As will be seen, brown and stone ware are the chief products of these factories.

\section{Pinxton: Coke and Billingsley}

When Billingsley left Duesbury at Derby in I796 after serving him for twenty-two years, to join Mr. Coke in starting the small factory at Pinxton, near Alfreton, he commenced his wanderings, which only ceased when he was engaged by Rose of Coalport in I820, and he died in obscurity at Coalport about eight years later. He was the most famous of all the china-painters, and his powers were fully developed, when he accepted Coke's offer and removed to Pinxton with his wife, two daughters, and mother-in-law. Here he began that search after the beautiful granular body which later brought so much fame to Swansea and Nantgarw. What china he made at Pinxton was elementary compared with his later work, but, all the same, it was good, though it lost so much owing to the demands made upon his time by the practical potting. Whilst employed by Duesbury his painting exhibited the highest talent; his roses and the harmonious grouping of his flowers had provoked special inquiries for objects " painted with Billingsley's flowers."

At Pinxton his attention was diverted from art in painting to art in modelling the body, which he had produced into forms of much beauty. But the management of the works and the supervision of the workmen and artists which he brought from Derby absorbed him. His skill and splendid colouring 


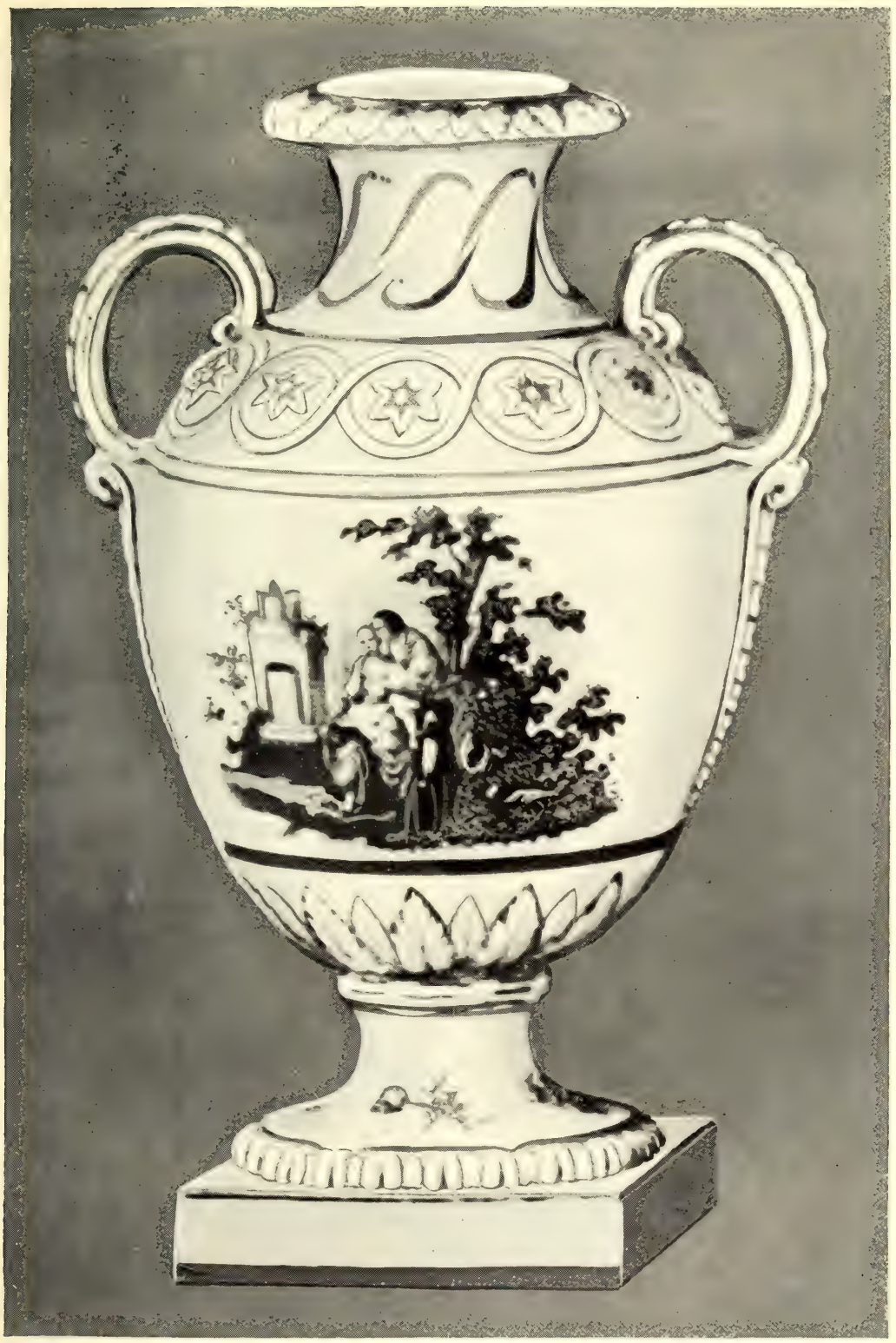

PINXTON VASE. 

seldom appear to enhance the charms of Pinxton china, so the fears of his former employer at Derby "that his going into another factory will put them in the way of doing flowers in the same way " were not realised. The granular body of the Pinxton china is very soft, and its fracture has much the appearance of loaf-sugar, and, though it was not perfect, it possessed qualities which no other porcelain had at that time.

Why Billingsley left Coke and Pinxton we do not know,

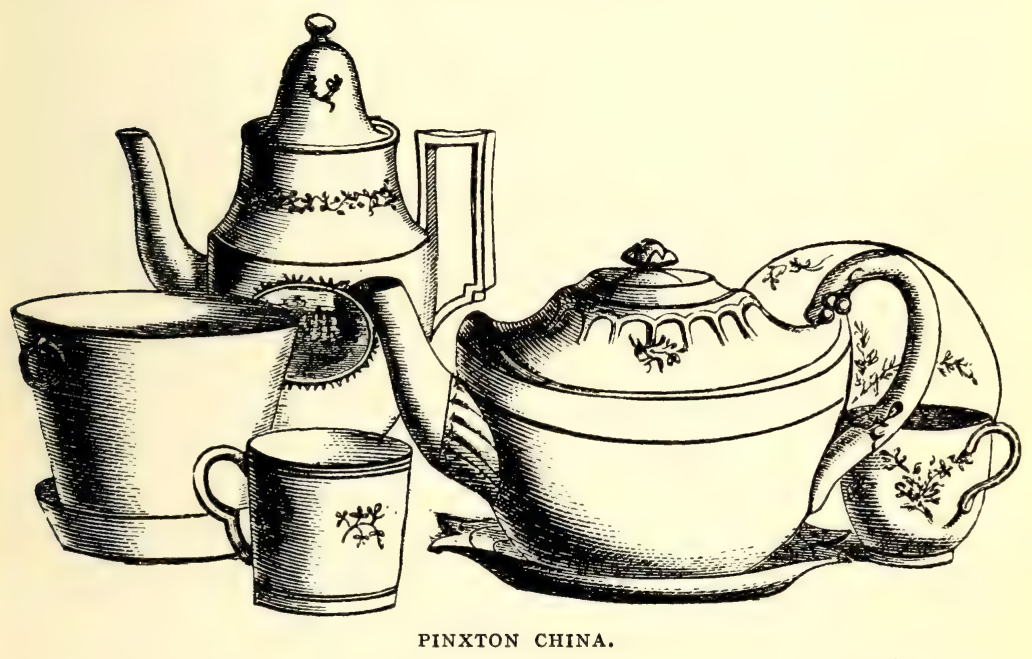

but in 1800 he removed to Mansfield, where he appears to have had a small factory at which, it is said, he continued his experiments and otherwise occupied his time in decorating china which he bought in its biscuit state in Staffordshire. But, returning to the Pinxton works, we find that Coke carried on the manufacture for some time, with the aid of managers -first Banks, then John Cutts, who in the later years of the factory, which was closed about I8I8, had the sole management. He afterwards removed to Lane End, Staffordshire.

The character of Pinxton china deteriorated when Billingsley took the secret with him, and the goods produced after I 800 , that is, the products of that factory in the nineteenth 
century, were just like the ordinary bone-china of the period, with a trifling modification in the glaze, which was slightly bluish. The decoration suffered also from the want of supervision. Some of the painters from Derby left shortly after, Alvey died in I803. No record has been kept of the individual work of these painters. We know that J. Hadfield, E. Rowland, and Morrell painted landscapes, and the last, flowers too, and we know that, amongst the workmen, Moore and Ash were clever throwers-and that is all. Davies states in I8II: "There is a considerable porcelain manufactory at Pinxton, which finds employment for several hands."

The best china produced there was remarkable for its body and glaze, both of superior quality, some notable for its excellent gilding. The decoration, as might be expected from the number of landscape painters, consisted to a considerable extent of views of places in Derbyshire and elsewhere, the best of which are credited to James Hadfield. But flowers and, specially, conventional arabesques or scroll designs were common, though the Derby or Tournay sprig was usually applied to the less expensive ware. Perhaps the most distinctive tone employed is best realised in the landscapes, which have a peculiar soft brown effect. The ice-pail at the Victoria and Albert Museum shows the special and unusual ground for which Pinxton was noted-a canary-yellow or Dresden canary-colour of much merit.

To identify Pinxton china from the mark is difficult because no mark was in general use. The number of the pattern was sometimes, given together with a workman's mark; other marks may be found, such as the script and Roman capital P, and very seldom indeed the word Pinxton in gold.

\section{Swadlincote : Ault}

The early history of a man gives many indications of those qualities which either make or mar his career. This was exactly the case with Mr. William Ault, who began as a packing-house boy at the Foley Works, near Longton, then carried on by W. Wileman. In I863 he was promoted to a more 


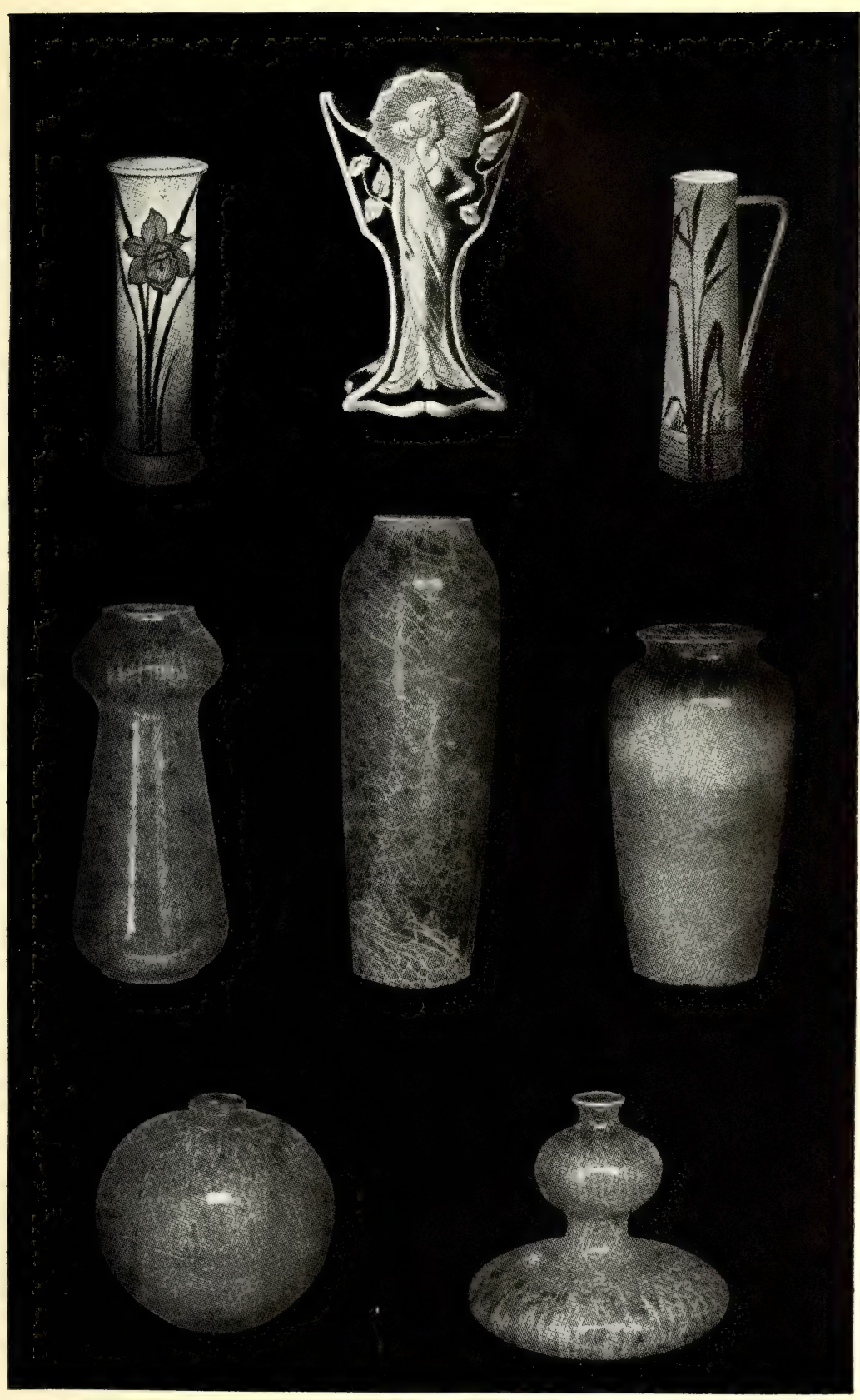

AULT FAIENCE. 



\section{DERBY AND DISTRICT}

responsible position at the other works of the same proprietor at Church Gresley, who, however, died in the next year ; when the business was bought by the late T. G. Green, with whom he worked till 1867 . He then left, but returned to the new works which had been erected for the manufacture of general white earthenware, where he acquired useful experience in the conduct of a pottery, which fitted him for the next step which he took in 1882 .

Then it was that he ventured to start a new business in conjunction with Mr. Henry Tooth for the manufacture of art pottery at Church Gresley. After four years the partnership was dissolved, and Mr. Ault built new premises for himself at Swadlincote, near Burton-on-Trent, where he installed a complete equipment, which led to such success that several extensions had to be made. A short time since, I had a talk with him and I found that he was an enthusiastic potter, though fast approaching three score years and ten, for he was born in I84I. Though he does not personally undertake the manipulation of plastic clay, he has a keen and quick perception of the artistic merit of the work of his capable modellers and other artists, and the beauty of many of the colour schemes and glaze effects is due largely to his own experiments, the glazes and colours being made and ground at the works from his own

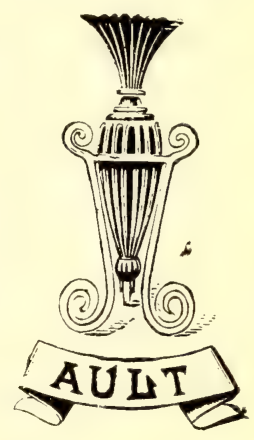
formulæ and under his personal supervision. Many of the splashed, striated, and broken colour results are unique, and exact reproductions are impossible. His productions include vases, pedestals, fine pots for flowers, Toby-jugs, grotesque forms amongst much ornamental ware; in addition, a great variety of useful articles, all showing much skill and good taste, thoroughly deserving the medals which have been awarded to Mr. Ault.

Amongst them the vases painted with butterflies and plants which are marked on the base with the script initials C. J. A. are worthy of commendation. They are decorated 
by Miss Clarissa J. Ault, daughter of the worthy proprietor of the works.

\section{Swadlincote: Sharpe Brothers \& Co.}

From I82I to I838 Thomas Sharpe carried on the works he had erected. When he died in the latter year, they were continued by his brothers as Sharpe Brothers \& Co. ; in 1878 Edmund Sharpe, the surviving brother, kept the same style, which was maintained in I900. Like most of the potteries in the district, ironstone cane, or yellow ware is a speciality, but many others are made-buff drab, fire-proof, Rockingham, mottled, and black lustre. In Derbyshire ironstone every description of household vessel is made, and the same remark applies to the other wares; every description of tea and coffee pots is made, with pressed and plain jugs and mugs of good designs, and many other articles. Blue-printed earthenware goods are also produced. Amongst the more ornamental items are Toby-jugs on the same model as the old Rockingham jugs-the Snuff-taker, for example. Sanitary ware produced here in cane-colour, white, and blue-printed varieties has a large sale at home and abroad. This firm resembles so many others, who on a small or extensive scale, produce necessary articles for household and sanitary use. Examples might be multiplied, but one or two here and there must suffice. The mark of $T$. Sharpe was his name impressed; later, a monogram of S. B. \& Co. within a wreath had the words SHARPE's Patent above.

Amongst the potters in this Burton-on-Trent district, in addition to this firm and William Ault and Tooth \& Co., which have separate notices, the following occur in I900: T. Betteridge, Cross Bros., T. G. Green \& Co., F. Heath, A. Jones, Mansfield Bros., W. Mason \& Co., T. Nadin, C. W. Outram \& Co., B. Robinson, S. H. Rowley, Smith Bros., Staley Bros. \& Co, Tunnicliffe, and J. Woodward. Yellow ware, Rockingham, jet, earthenware, and sanitary ware are by these firms produced in quantities. 

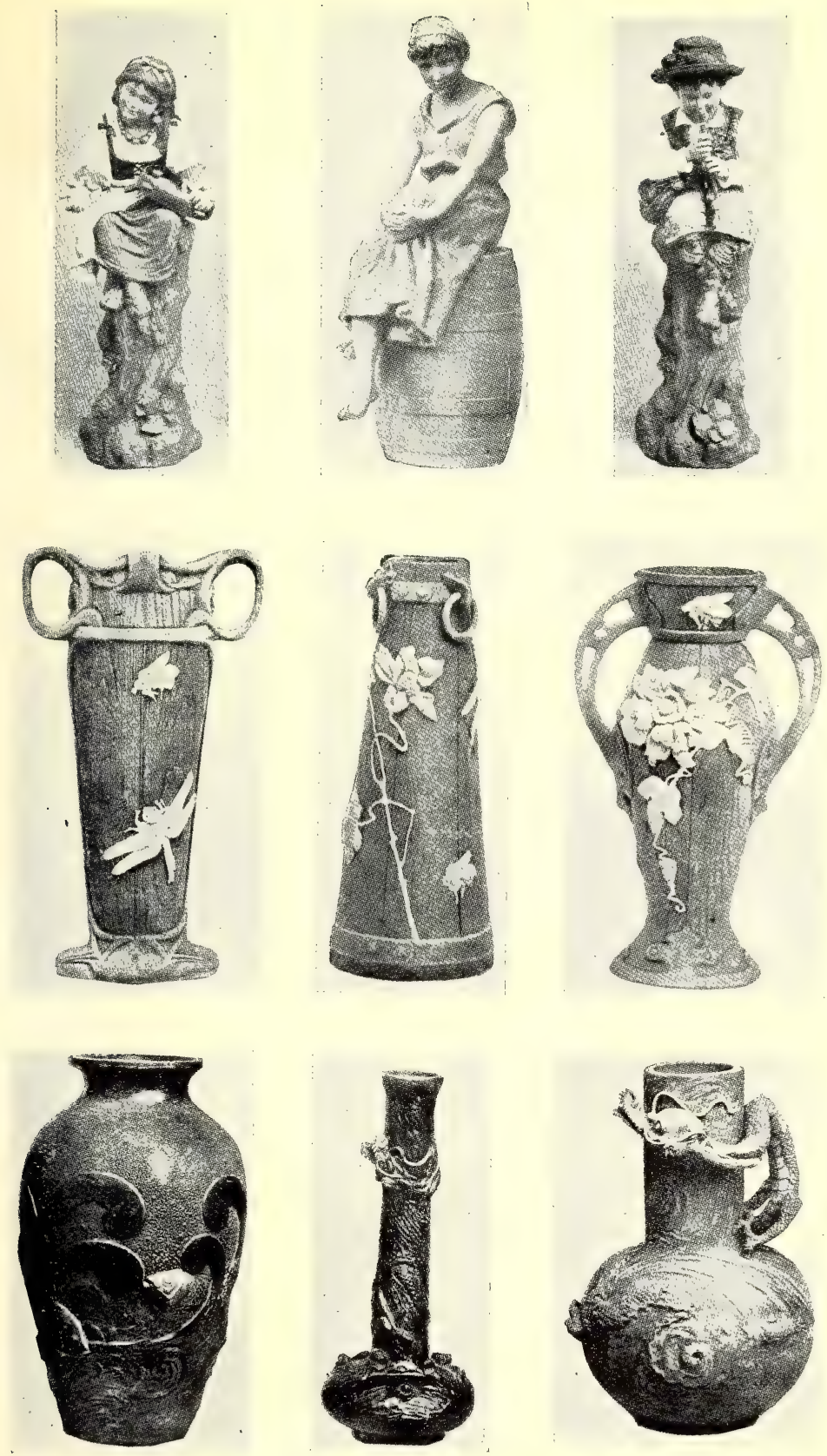

TOOTH'S BRETBY ART WARE. 



\section{Woodville : Bretby Pottery-Tooth}

Mr. Henry Tooth of the Bretby Art Pottery, Woodville, near Burton-on-Trent, gave me some valuable information on Linthorpe which I was able to use in my book * on Old English Pottery-not because it was old pottery, but because it has ceased to be. Other information and illustrations from the same kind source will interest many who have still the memory of the results which were obtained by the use of an ordinary red brick clay, sundry fine colours, and a clear, hard, firm glaze, and brains; for although the pottery starting about I 880 only existed some few years, it won great public favour. Mr. Tooth's Bretby ware is quite different in character from that which he made at Linthorpe. $\mathrm{He}$, or rather the firm Tooth \& Co., has taken a special line in manufacturing pedestals and pots, umbrella-stands, vases, jardinières, hanging pots, ash and pin trays, and other articles which have a distinction which deserves appreciation. The forms are wonderfully good, the colours delightful, and Bretby ware, though so recent, has qualities which make for success.

In addition to the Bretby ware proper there are varieties no less charming in "copperette" ware, which resembles hammered copper. Another variety imitates bronze, whilst a third comprises bronze and jewelled ware in forms which may also be obtained in glaze and metallic effects in combination. Again, "carved bamboo" ware supplies a number of Oriental designs of uncommon merit which are also made in combination with bronze. Floral ornament imitations of wood with imitation metal-mounts, glazes in plain or shaded colours, are amongst the schemes of decoration employed. A special mention must be made of the cloisonné ware and of those quaint ash-trays and tobacco-boxes which have become so popular. The ash-trays, in the form of a leaf, upon which rest walnuts and nut-cracker or biscuits or fruit, and others of various shapes holding reels of cotton, a thimble and scissors, or a corkscrew in the cork by the side of a lemon, etc., are most attractive.

\section{* The A BC of Collecting Old English Pottery.}




\section{I9TH-CENTURY ENGLISH CERAMIC ART}

Space only allows one page of illustrations from the admirable catalogue issued by the firm, which has shown remarkable development since its foundation, nearly thirty years ago, by Mr. Tooth when he left Linthorpe.

In conjunction with Mr. William Ault he started a business at Church Gresley. This was in I882, and for four years the firm continued. At the end of I $886 \mathrm{Mr}$. Ault purchased land at Swadlincote, where he erected the works he now operates. Art pottery was made at Linthorpe, at Bretby, and at Church Gresley. The man who was the pioneer in these special productions had received no training as a practical potter. Speaking about Linthorpe, he said: "I never saw a pot made until I undertook the management of this venture; during the experimental period I made, burned, and finished the ware entirely myself." This notice of Mr. Tooth and Bretby may be an introduction quite suitable to Linthorpe, and the more so because Mr. Tooth supplied the information (see Linthorpe). 


\section{CHAPTER XIV \\ COALPORT AND DISTRICT}

THE Salopian wares were manufactured in a district full of historical interest, where the Severn winds its way seawards not far from Shrewsbury and Ludlow, in the Coalbrookdale. There Caughley in the eighteenth century rivalled Worcester in the production of china, especially the blue-printed, and there, on the other side of the river, stands Coalport, with which this chapter chiefly deals, whilst near by are Horsehay, which had its pot-works in the olden times; Benthall, where in I900 Messrs. Maw's works were in active operation ; Ironbridge, noted for its one-span iron bridge over the river; Madeley, where Randall made his celebrated soft paste from I825 to I840; Jackfield, whose name is familiar to all collectors of old English pottery; and Broseley-who does not know Broseley pipes?

It is quite interesting to note how, through the ages, the manufacture of pottery has steadily clung to certain districts just like this in Shropshire. Broseley still has manufactures of Rockingham and cane ware at one works, and tessellated tiles at another, whilst the Salopian Art Pottery Company has higher aims. In the Jackfield works the manufacture of tiles has taken the place of the old black ware which was made of the local red clay, covered with a glaze, and often decorated with raised vine-leaf and other ornament, and with oil gilding. Maurice Thursfield's teapots with the covers surmounted by a bird with outspread wings take their place in the cabinets of collectors with Caughley and Coalport, whose history begins with that of Worcester ; for Coalport may be reckoned as a continuation of Caughley-a newer factory, but 


\section{I9TH-CENTURY ENGLISH CERAMIC ART}

one which absorbed the older one completely, whilst carrying on its work, using its marks, and in every way making it difficult to draw the line between the productions of the two factories.

\section{Coalport: The Roses and After}

Mr. Charles Bruff was good enough to send me the following as a reply to my inquiry for information. I have accepted it in a grateful spirit.

"On the western borderland, where the Midlands and the Marches meet and the Severn winds its silvern way through
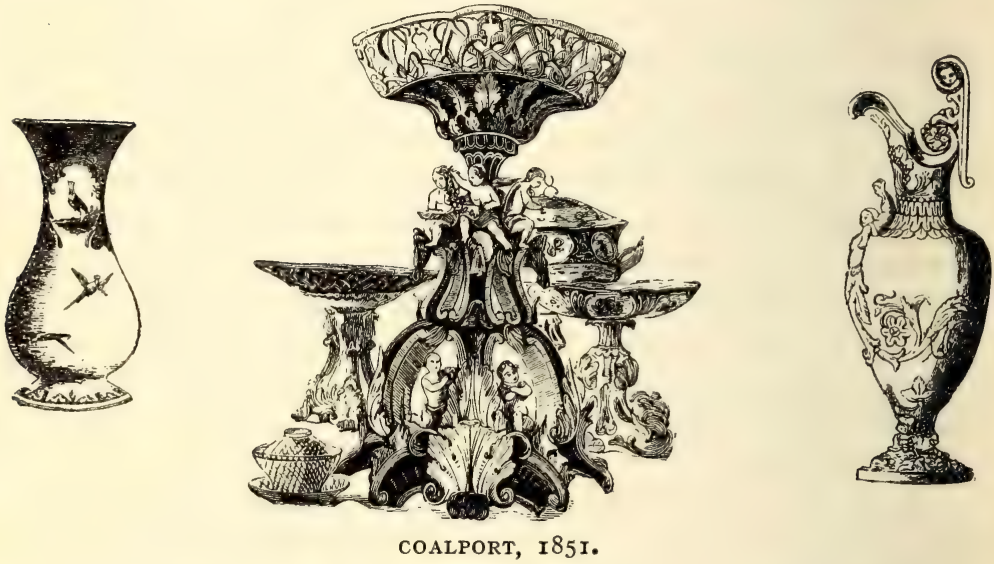

a luxuriantly wooded country, stands a tiny village whose name has won world-wide renown though itself be little known. A few cottages scattered here and there, some larger houses bowered in the trees, some smoking kilns beside the river's brink-and that is all to be casually observed of Coalport. But those big, bulging red brick kilns have for generations been firing into delicate beauty some of the most daintily wrought productions in the world of ceramics, and one at least among these kilns is probably the oldest of its kind in continuous operation in all Britain. One does not need the knowledge of a connoisseur of ceramics to appreciate the position which this outwardly insignificant village away in the wilds of Shropshire has gained in one of the foremost art 


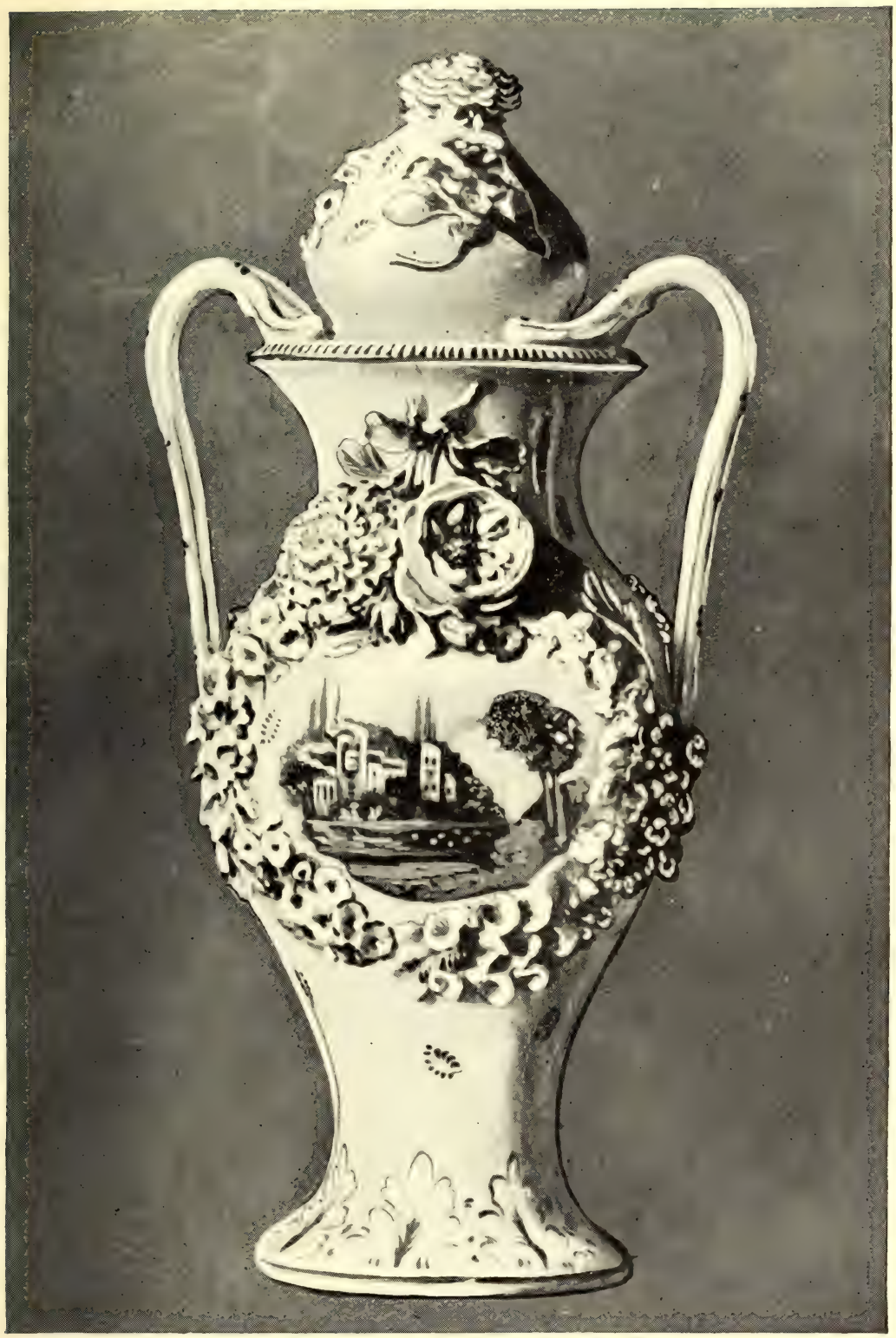

COALPORT VASE. 

industries of the world. But the history of this ancient Salopian industry is probably all too little known, and the story is of such entrancing interest in its way as to claim considerable prominence in a survey of commercial life and leadership in the Midland shires. Coalport has a history coeval with that of all the great art enterprises of this country, and like others of the number it has had its periods of prosperity and depression which threatened to lead to absolute decay but for the regenerative influence of one or two strong men inspired with a great love of their work and a great sense of their responsibilities. And Coalport is now rejoicing in a
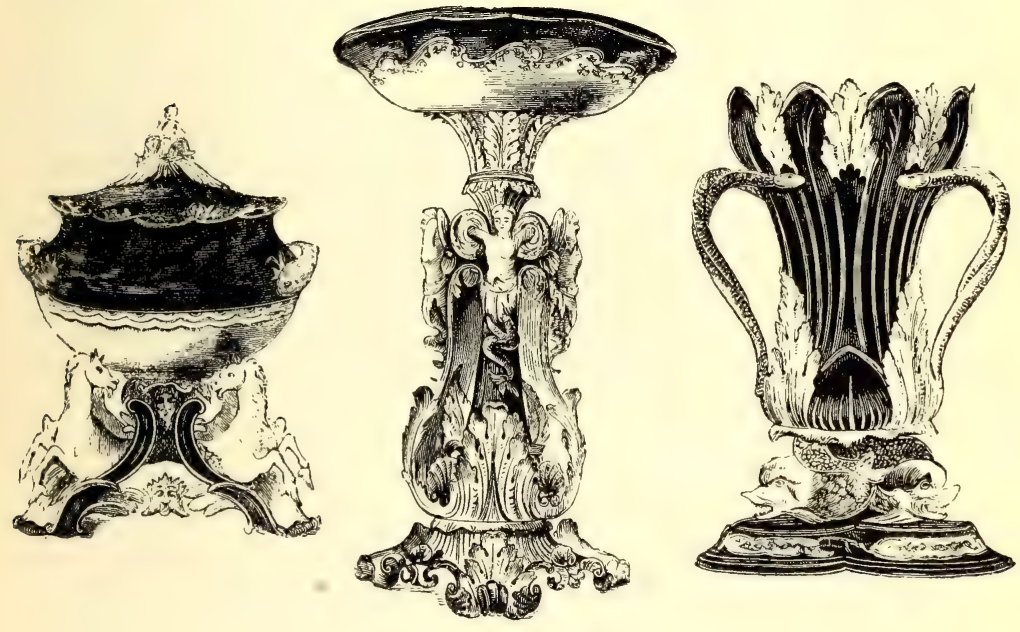

COALPORT, I85I.

renaissance primarily traceable to the vigorous personality, the courageous perseverance, and the dominating energy of Mr. Charles C. Bruff, who in less than twenty years has doubled the producing capacity of the works and re-established the business on a basis of commercial as well as of artistic success.

"Somewhere about I750 a small pottery was set up at Caughley, on the southern bank of the Severn, and here an ingenious worker named Brown began the manufacture of china and earthenware. At his death the works passed into the hands of one Gallimore, who was experimenting with some success on porcelain-printing about the same time that Dr. 
Wall was working on similar lines and laying the foundation of the fame of Worcester china. Now, Gallimore had a daughter, who all unconsciously exercised a wonderful influence on the destiny of this little corner of Shropshire. Her charms attracted to her the affections, and to Caughley the interests, of a youth named Thomas Turner, whose share in the shaping of the future of the industry proved of the highest importance. Turner was a parson's son, and had been trained as a silversmith in the city of Worcester. His marriage with Gallimore's daughter, however, engaged his enthusiasm in a far different, and at that time little understood, pursuit, and led to his acquiring control of the business in I772. After a few years' quiet, steady labour, Thomas Turner resolved on a visit to France, with the intent to enlarge his art knowledge and to gather new ideas. That he was successful in his mission is demonstrated by the developments that followed. Turner came home with several skilled craftsmen to recruit the little community of potters, and many notable patterns were presently introduced. Of these the most famous, without doubt, was the universally popular 'Blue Willow,' so highly prized nowadays, as Andrew Lang recalls in a familiar ballade, by every lover of 'china that is ancient and blue.' The original engravings of this design are, by the way, still to be seen at the works.

"Among the young Salopians who learned the processes of china-making during Thomas Turner's regime at Caughley was a farmer's son named John Rose, who after awhile left the works to found a small business of a like character. As if there were not enough china-making for one country district, a third establishment sprang up, partly organised by another member of the Rose family. But John Rose had learned his craft too well to be easily ousted, and in the end he was able, not only to buy up his new rivals, but also to take over the Caughley works of his old master, and with Turner's retirement in I798 the whole trade passed into the hands of John Rose. With this transaction the industry entered on a new era. To the artistic sensibilities by which Thomas Turner had been able to lift the business to a high level, John Rose added a commercial shrewdness which had its natural effect in the developments to come. Realising the material advantages of Coalport as a centre-in pre-railway days this little village was the port of the Shropshire coalfield, the proximity of the Severn and of a now disused canal providing 
ready facilities for water transit-he concentrated his manufacturing equipment there, demolished the Caughley works, and used its building materials anew. Thus was the actual continuity of history preserved. In I820 another important step was taken by the acquisition of the famous Nantgarw and Swansea works, the factories being abandoned and the moulds removed to Coalport. Not a few of the Welsh potters followed their work to Shropshire, and for some time Messrs. John Rose \& Company carried on a flourishing trade.

"Coalport at this time won the award of the Society of Arts for the best leadless glaze used in china-making, and while one improved process followed another, equal activity was maintained in the production of new designs. The
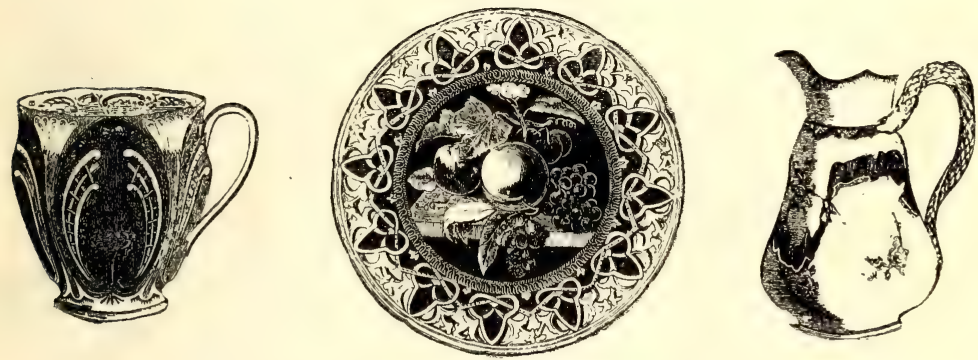

COALPORT. MESSRS. J. ROSE \& CO., I $85 \mathrm{I}$.

' Green Dragon ' and the 'Indian Tree' are names sufficient to awaken enthusiasm among china-collectors all the world over. John Rose died in I84I, and was followed by his nephew William, who did much to uphold the glory of Coalport ware, and who in $185^{\circ}$ was successful in reproducing the exquisite rose-du-Barry colouring of the famous Sèvres ware, that rich tint which had pleased Madame de Pompadour long before the beautiful Du Barry became the King's mistress and spent the King's money on porcelain extravagances. The rose-duBarry effect was applied to a superb dessert-service which attracted much attention at the Exhibition of $\mathrm{I} 85 \mathrm{I}$, and was ultimately bought by Lord Ashburton. With the retirement of William Rose a dozen years later, the business languished. The second great period of Coalport's history was in its decadent days, and there was no strong individuality to vitalise the work. Artistic expression and commercial stability alike were weakening when the industry passed into the 


\section{2}

\section{I9TH-CENTURY ENGLISH CERAMIC ART}

control of the Bruff family, and it was not till late in the eighties, and by an accident of circumstance, that the remarkable revival now to be recorded was set in hand.

"It is a curious fact that the reorganisation of a business is often most successfully carried through by those men who may be supposed to know the least about its technicalities. Perhaps the very want of a too intimate acquaintance with the internal workings makes for a clearheaded apprehension of actual necessities and a resourceful readiness to initiate sweeping reforms. An inherent love of art, a quick

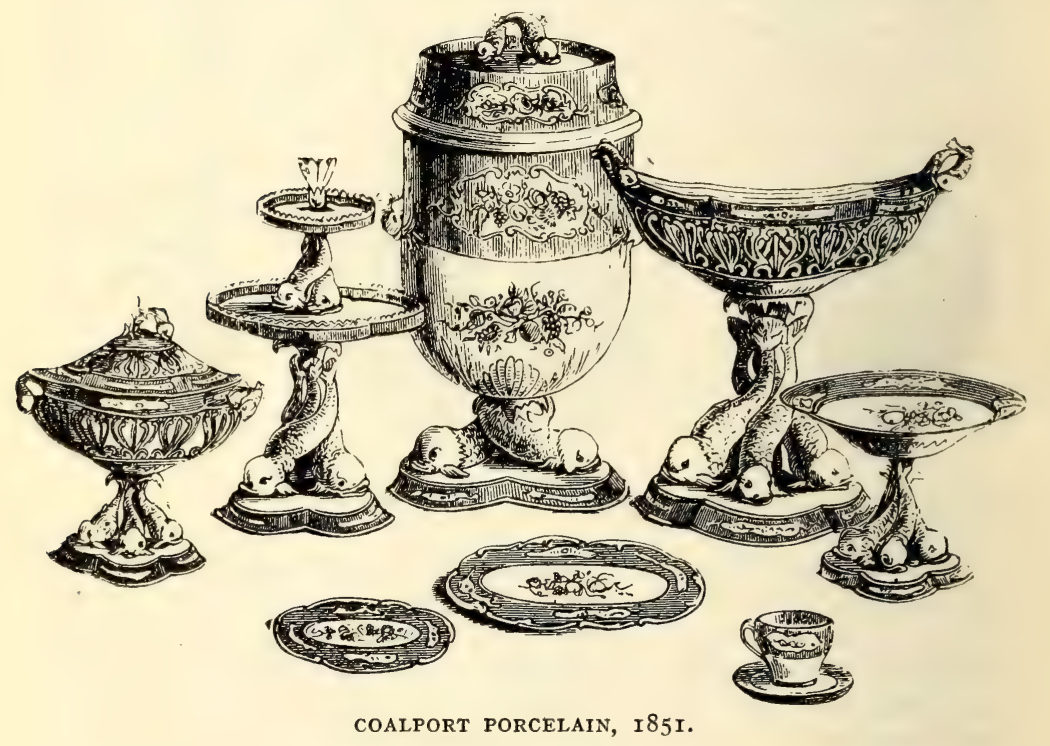

eye for the beautiful, and a keen business instinct formed the only apparent equipment which Mr. Charles Bruff possessed for his task when, in I889, he undertook to reorganise his father's business. The Coalport works had been bought some years previously by Mr. Peter Schuyler Bruff, an eminent engineer, whose home was at Ipswich, and whose interests scarcely lay in the china industry. His son, Charles Clarke Bruff, elected to follow the same profession, and, after serving his articles with a prominent Manchester firm went out to India, where Government work occupied his energies for some time. While home on leave Mr. Charles Bruff happened to 


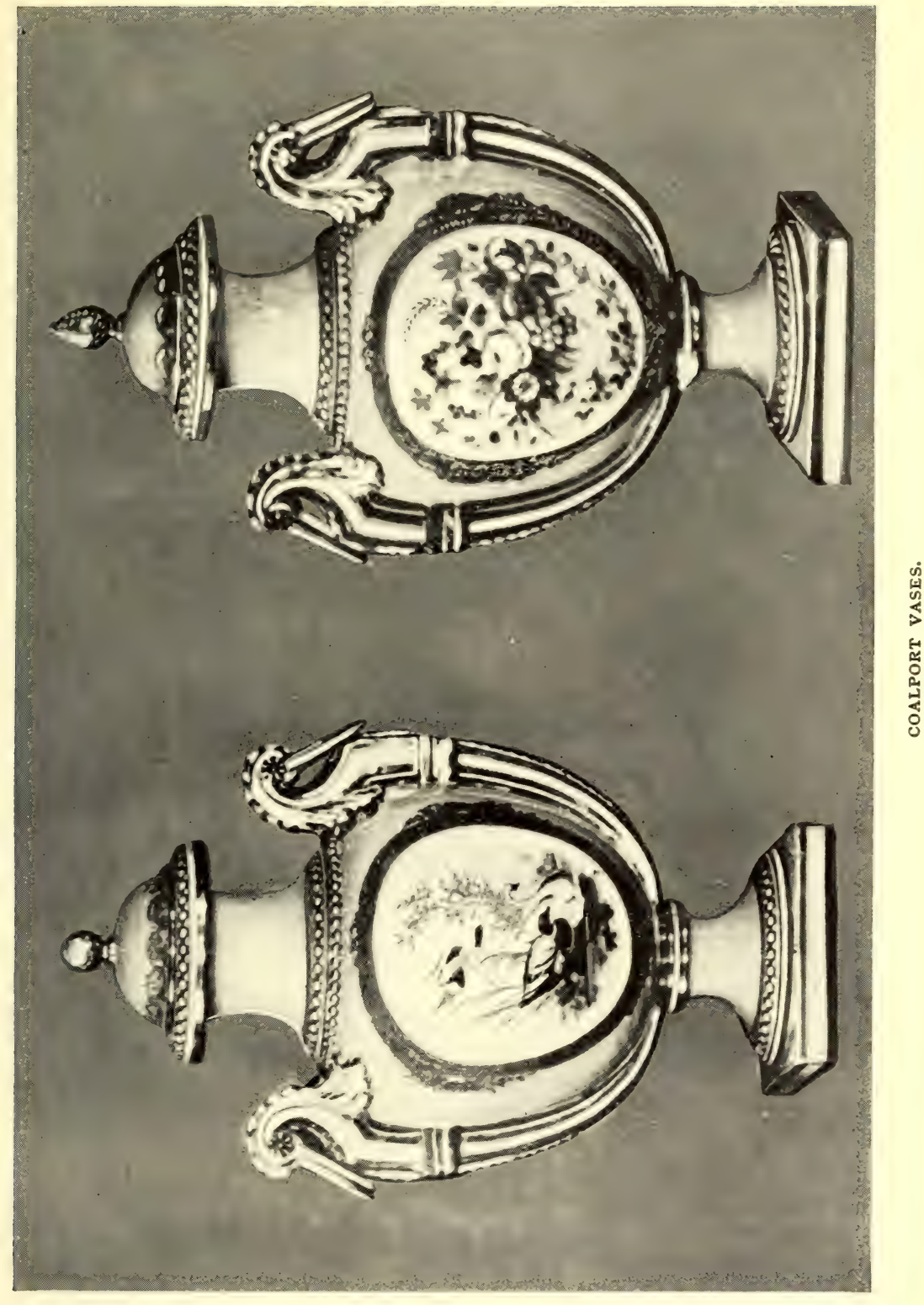



visit his father's property at Coalport, and interested himself in the china-works. His alert mind fastened on the fact that opportunities were not being turned to the best account at the moment, that the little village in the valley contained great possibilities if developments were made on the right lines, and, in short, Mr. Bruff took a great resolution-he threw up his own career, and turned his face to the lonely dales of Shropshire. An East Anglian by birth, he has become a Salopian by adoption, and he is as proud of the shire as any one around the Wrekin.

"That vacation trip from India was a fortunate circumstance for Coalport. Mr. Charles Bruff is a man of great nervous force and energy. He has the faculty of concentration in a marked degree ; he is quick and responsive in his sympathies; he is not only full of enthusiasm himself, but he has the somewhat rare gift of transmitting his enthusias m to a 11

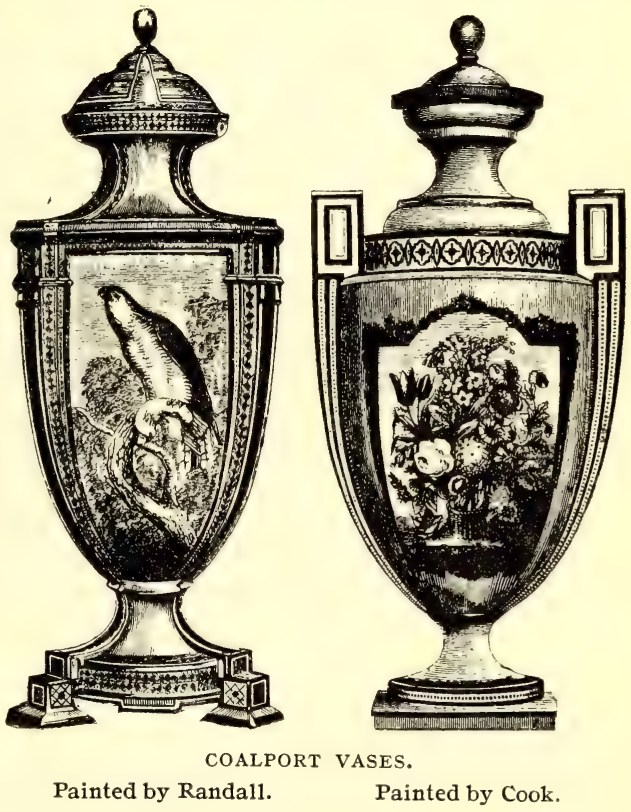
around him. The effect of such a leadership was soon observable on the historic Coalport industry. Mr. Bruff gathered round him talented artists, including Mr. T. J. Bott, skilled craftsmen, capable men of business, and a new vitality was breathed into both the art and the commercial sides of the undertaking. In a few years Mr. Bruff had completed his reorganisation and had practically regenerated the trade. Old designs were revived with all the old beauty and grace ; new designs and patterns were introduced. Imitations were studiously avoided, originality was encouraged, and with this 
spirit of fostering care the highest results possible were once more achieved. In I893 Coalport ware was exhibited with signal success at the Chicago Exhibition, and every exhibit was bought up. In Igoo the works were visited by the Princess of Wales, then Duchess of York, who drove over from Patshull with Lord and Lady Dartmouth, and expressed Royal delight with the productions-a delight which was shared by Queen Victoria and other Royal personages, who count Coalport ware among their treasures.

"The works have been extended and, in part, rebuilt, and now give employment to five hundred workpeople-a considerable community in a rural district. With the conversion of the concern into a private limited company Mr. Charles Bruff became chairman and managing director, and in the control of operations he has the co-operation of his brother-in law, Mr. A. N. Bruff Garrett, and the loyal assistance of an enthusiastic staff, from Mr. J. C. Cheadle, the secretary, at headquarters, to the representatives of the firm in foreign lands. A unanimity of pride in Coalport ware and its Shropshire home pervades the establishment, and is the natural outcome of Mr. Bruff's own forceful inspiration. He has just undertaken the managing directorship of Messrs. Craven, Dunhill \& Co., Ltd., a well-known firm of encaustic tile and ceramic mosaic manufacturers, having works on the farther side of the river. A busy man in every sense, Mr. Bruff has made Coalport the centre of an interest which pulses with the love of Art in some of its daintiest forms."

Thus ends Mr. Bruff's communicated information, which was published in a Staffordshire paper to which I cannot properly make acknowledgment, because I do not know its name. However, to the unknown I tender my thanks, and perhaps I may be able to thank the writer some day. The history begins long before the nineteenth century at which our work commences, but the story is so well told that it must stand. The beginnings of Coalport were small; the extensions came by the absorption of Caughley in I798-9, of Anstice, Horton, and Rose about I803, of Jackfield about I780, of Nantgarw I8I9, and of the Swansea Porcelain Works about the same time, probably I820. The only distinctive impression left by Billingsley upon Coalport, in addition to the 
flowers which he painted there until his death in $I 828$, was the adoption of the peculiar maroon-coloured ground which was, it is said, introduced at Nantgarw by Walker, Billingsley's son-in-law and constant companion. It is only fair to say
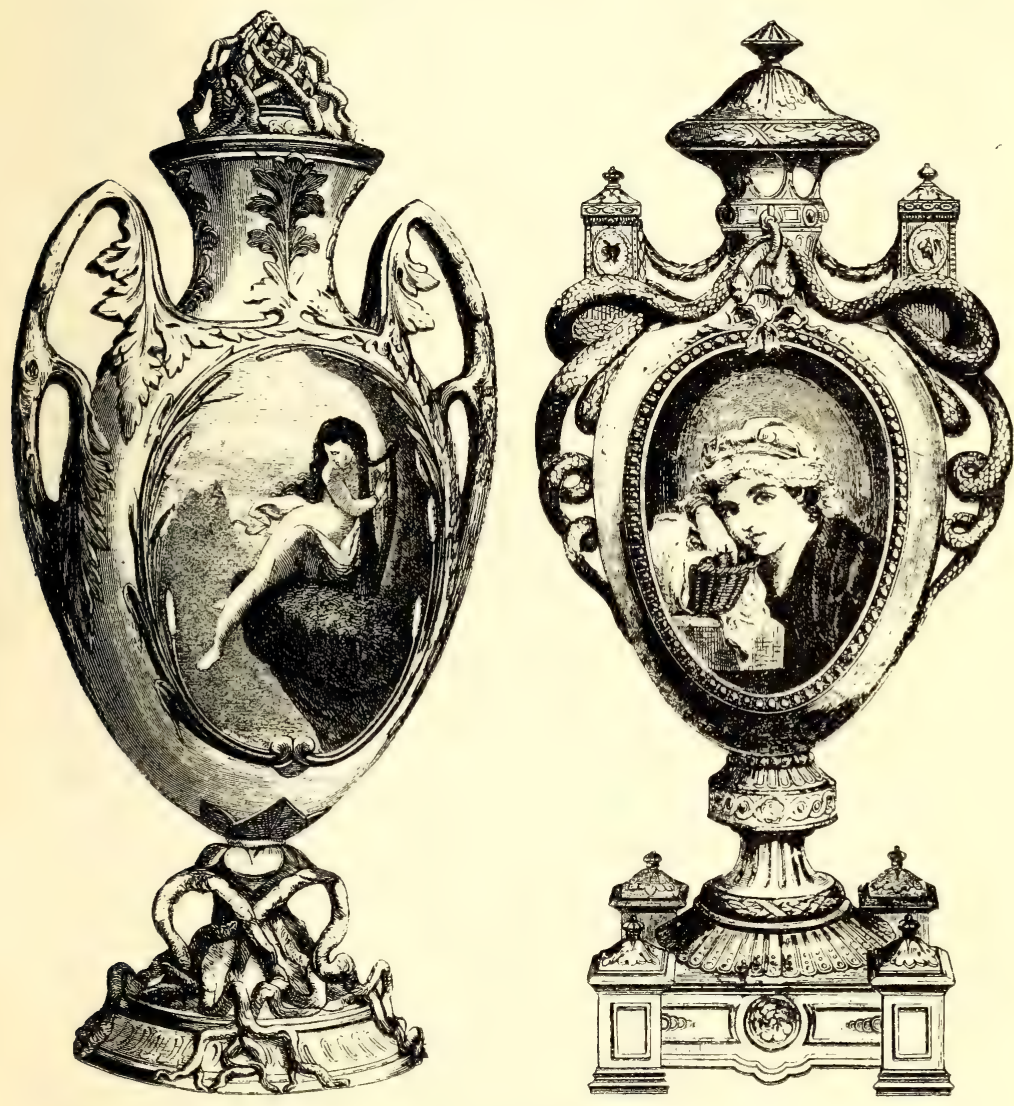

COALPORT VASES.

that many marked improvements were made in Coalport china from I82I onwards.

The Coalport works attained considerable eminence, and the exhibits of Messrs. J. Rose \& Co. in I85I could compare with advantage with the best productions of the pottery 


\section{I9TH-CENTURY ENGLISH CERAMIC ART}

districts of Staffordshire. Some idea of the great variety and originality of the designs may be gathered from the illustrations. There is a dessert-service which was shown by Daniell of London, a firm of much distinction, whose constant support of Coalport has been extended over a great many years. The service has a grace and elegance of design which may be recognised in the engraving, but it embodies that triumphant attempt to restore to fictile art the famous rosecolour named after the favourite of Louis Quatorze-Du Barry, or Barri. " It may be regarded as one of the triumphs of the Exhibition," is the remark in the catalogue. But the other specimens are scarcely less desirable-the dessert-plate painted with fruit, the characteristic vase with handles, plateau or fruit-dish, and a group of similar articles, with a sample jug and cup, are justly entitled to praise; but the numerous vases with their magnificent shapes and decoration must be placed above all.

With the exception of Madeley no factory made finer imitations of Sèvres porcelain, and when these imitations were marked with the Sèvres mark it is difficult to discover the forgery. The British Museum guide says: "Marks of other factories, such as Sèvres and Chelsea, were not uncommonly used on careful copies of the wares of these factories made at Coalport." Randall painted many of these fine copies with birds, Cook was famous for his flowers, and Hartshorne for his animal paintings. Many of the vases were simply magnificent, though Church is quite right in criticising others of inferior quality when he says :

"The vases are often coarse imitations of Chelsea porcelain, and sometimes bear what must be looked upon as the forged mark of an anchor in gold. Cups and saucers are also found having two L's crossed, in imitation of Sèvres ; marks of other factories, English and foreign, are also found upon pieces of Coalport porcelain and earthenware."

The commercial style of the firm was maintained through numerous changes in the proprietors. John Rose died in I84I ; he was followed in the business by his nephew, W, F, Rose. 


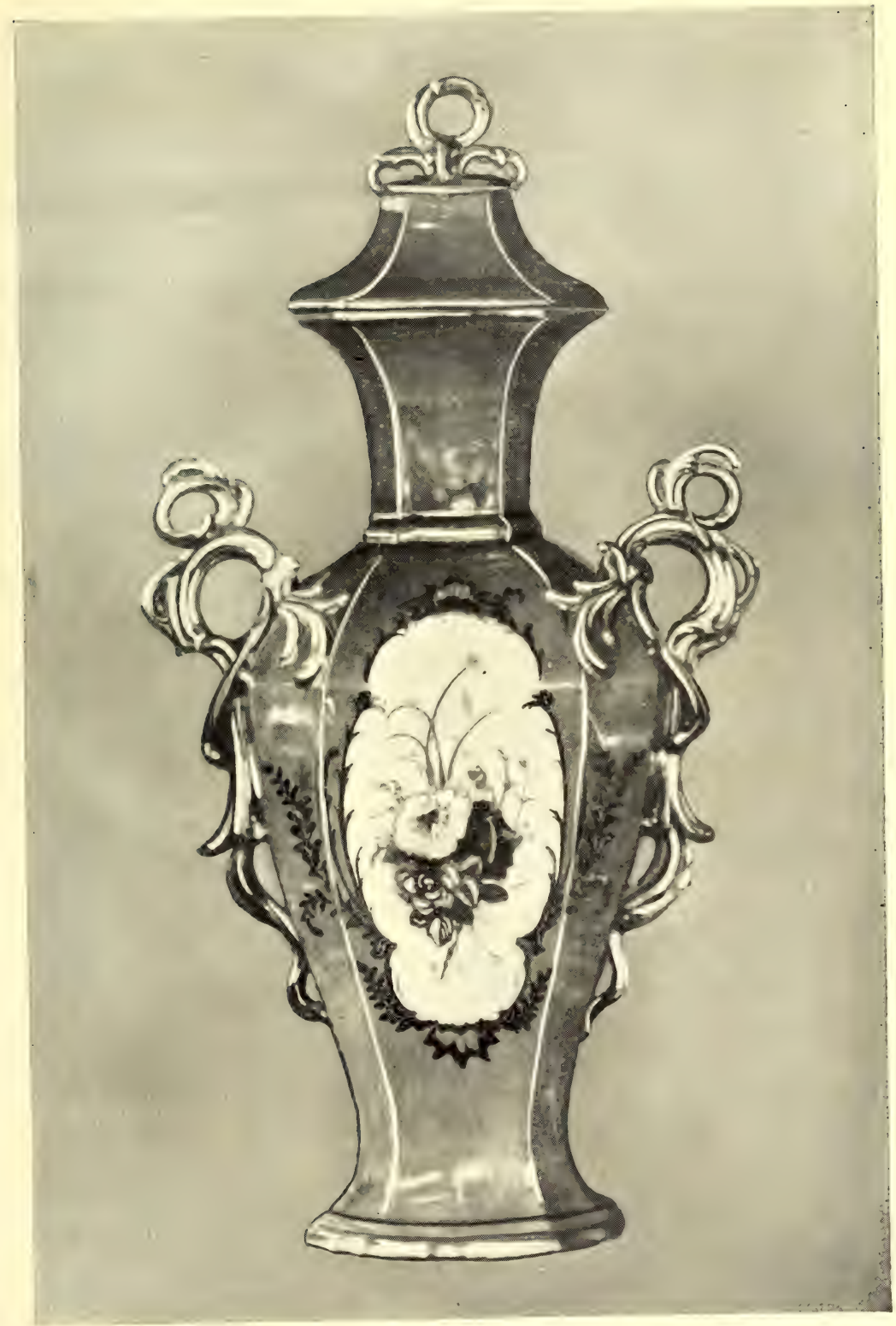

COALPORT VASE. 

It is not necessary to trace a succession of partners, but I may mention that the sole proprietor in 1878 was William Pugh, who used the old title "John Rose \& Co." This has been changed to "Coalport China Co (John Rose \& Co.)," and the modern mark is a crown having, above, ENGLAND, and, below, COALPORT.

The modern work is marked by the qualities which brought

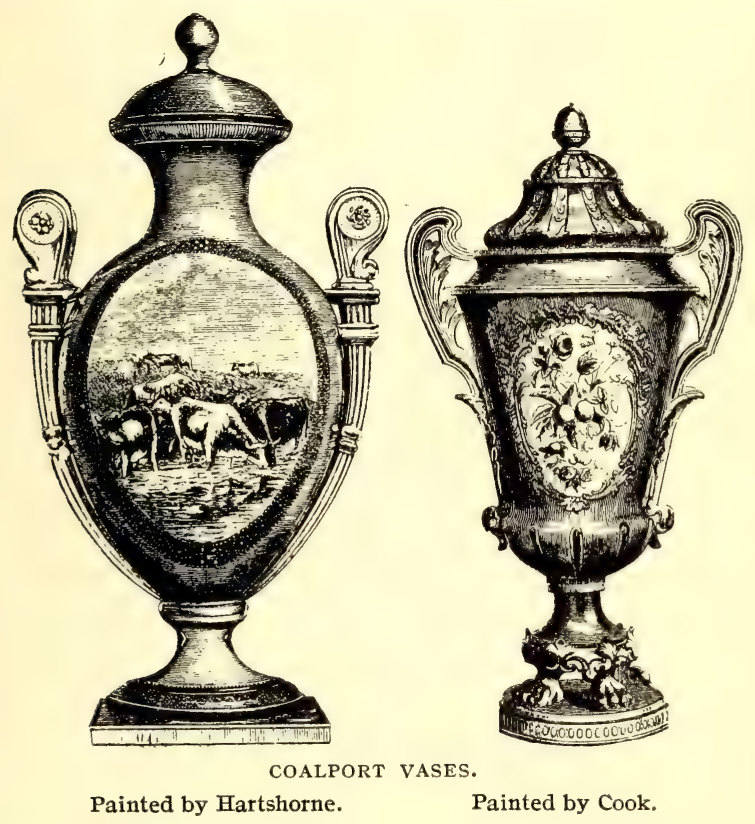

such success to the Roses. In the nineteenth century for the most part its excellence was beyond doubt - the only decadence appears towards the end of that period. The ability and energy of the new proprietors will go far and we hope for Coalport that the new era will eclipse the brightness of all previous brilliancy. Especially will collectors be interested in the statements which occur in the account of Mr. Bruff, showing that "imitations were studiously avoided," whilst "old designs were revived with all the old beauty and grace," and "new designs and patterns were introduced." 


\section{I9TH-CENTURY ENGLISH CERAMIC ART}

Amongst those old designs, the most famous were the Chinese patterns, blue-painted and printed, the well-remembered willow pattern, and the Broseley blue dragon. If you selected the one pattern which the public esteemed more highly than any other, it would be the willow, which, from the date of its first production at Caughley, must have appeared upon millions of plates and dishes, cups and saucers, which have been distributed all over the world. I saw a collection of willow-pattern dishes a short time since, which had been picked up in the towns and villages of the Straits Settlements. Probably it would be difficult to find any inhabited spot on the earth's surface, where an Englishman had lived, without some evidences of the willow-pattern plate. Many factories have produced it, and successfully. It is not misplaced upon the tables of the rich; it is welcomed by the poor. Whether the suggestion of a love-story is responsible for its popularity, or some other quality which cannot be defined, I am not sure ; but I think it owes something to its exact suitability to its surface, which, by it, is so wholly covered. The dragon is also a successful pattern, and the cabbage-leaf jug with a special shape. Both of these were imitated at many other potteries. Then Coalport adopted the various sprig patterns with tiny flowers distributed over the surface of the article; the "Tournay" and the "worm" sprigs were also common to many factories, and they have been produced here and elsewhere throughout the nineteenth century.

I have already mentioned some of the artists whose paintings formed such a delightful feature of the best Coalport vases. In addition to these three-Jabez Aston, A. Bowdler, Birbeck-C. Palmere shared, with R. F. Abraham, the merit of much of the remarkable decoration. The last mentioned was afterwards the Art Director of Copeland's establishment, and his figure painting at Coalport may be recognised by its resemblance to the style of Etty. It is a matter for regret that the names of the modellers do not appear, the excellence of their work is apparent in all the higher-class productions of the establishment, and I am sure that in the years to come, 

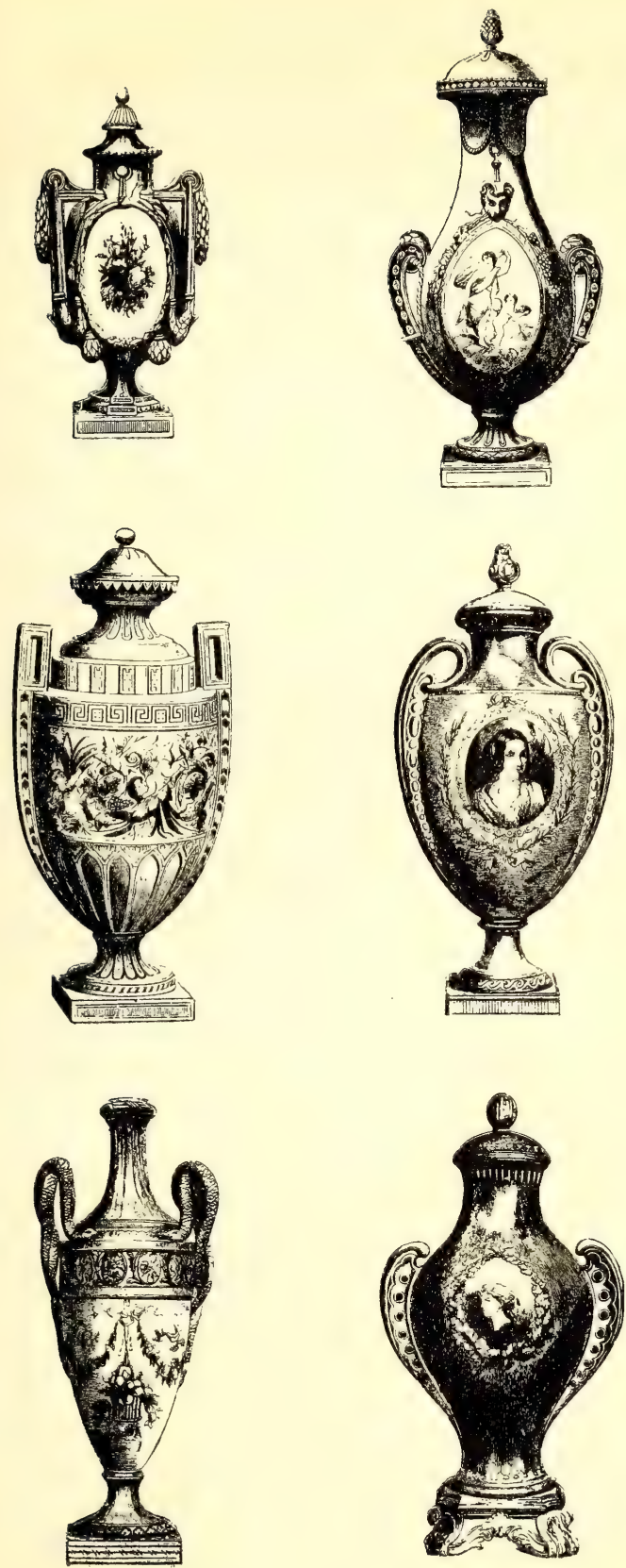

COALPORT VASES. 


\section{4}

I9TH-CENTURY ENGLISH CERAMIC ART

manufacturers would confer a boon upon the collectors yet unborn if they would publish some record and insert some mark which should indicate the artist whose talents helped to secure lasting fame for his employer, and for the factory where his trivial round and common task found adequate expression.

COALPORT MARKS.

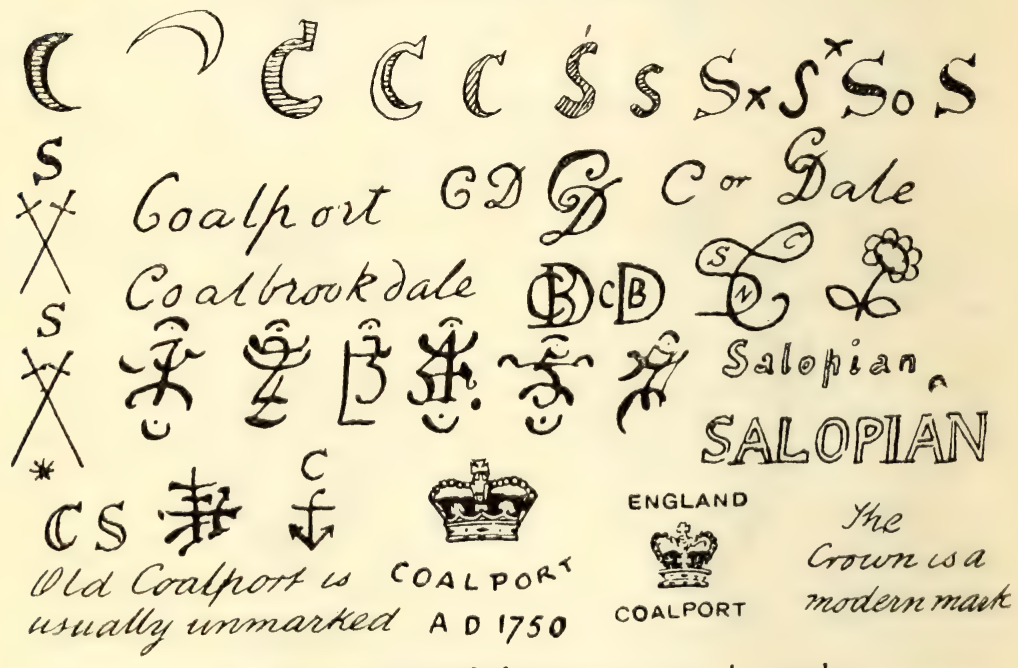

It is to be regretted that at one time the marks of other manufactories were umitated at Coalport.

\section{Broseley-Jackfield (Salop): Maw \& Co.}

In I87 I Messrs. Maw \& Co. presented an extensive series of tiles and modern majolica to the Museum of Practical Geology, illustrating the successful results of long-continued experiments, which began at Worcester in 1850 in the premises which had been used for the china manufacture of Flight and Barr. Fleming St. John had before that time tried to produce encaustic tiles there, and in buying the moulds, etc., from him, Messrs. Maw decided to remove to the Benthall works near Jackfield, Broseley, and Ironbridge, where coal and clay were available. This was accomplished 
in 1852 , and followed by seven years of experimental work, during which, in 1857 , so much progress having been made, the goods were offered to the public with such a measure of success that many additions to the buildings were to meet the demand. Plain tiles and others with geometrical patterns, and simple encaustic tiles of two colours, were followed by the making of very small tesseræ, for mosaic designs in tessellated pavements, friezes, etc. Then came the production of coloured enamels, the manufacture of majolica, and its application to architectural work. All of these have met with very great success.

Other processes have also produced brilliant results, as shown in the various exhibitions, where they have been displayed. Embossed tiles, sgraffito decoration, slip painting, applied ornament in clay of one colour upon a ground of another, mixed colour glazes, and enamels for the surface of pottery-these indicate some of the varieties of decoration. And the designs of Wyatt, Goldie, Seddon, Street, Burgess, and others have given full scope for the display of the potter's art in all its branches. The colours have much beauty, and cover a wide range-canary yellow, mottled green or purple and green, mottled red, variegated dark and light blue, are a few, but transparent céleste or turquoise blue must be mentioned. The mark used is Maw \& Co., often with the address of the firm, Benthall, Broseley.

\section{Madeley : Randall}

Martin Randall, the celebrated enamel-painter, was born at Broseley in $\mathrm{I} 786$, and was buried at Shallowford in 1859 . He served his apprenticeship with Rose at Coalport, and about I808 went to Derby, where he worked for Duesbury for a short time, migrating from there to Pinxton, which was closed in I8I2. About this time he went to London, where, becoming a partner in the firm of Robins and Randall, he set up an enamel-kiln in Spa Fields, which was kept very fully at work by Mortlock of Oxford Street, who regularly purchased large quantities of ware in the white, that is biscuit 


\section{I9TH-CENTURY ENGLISH CERAMIC ART}

china, which he had painted in London by Randall, Webster, and other artists. When we consider that Mortlock was a large purchaser of Coalport, and of Swansea, in biscuit china, we can appreciate the difficulties which surround the identification of this period of Randall's work, the period during which he painted on the various wares which were sent to him-the Coalport made in imitation of Sèvres, for instance. Not only were these English porcelains so decorated, but another firm, Baldock and Garman, bought all the soft-paste French china they could secure, and sent it to Randall to be painted.

About 1825, the partnership with Robins being ended, Randall went home, and at Madeley he set up an enamel-kiln, which enabled him to continue his painting business, which extended so much, that his nephew Gray was joined by another nephew, John Randall, both working as painters; the latter, an apprentice, became famous as a painter of birds at Coalport later. More muffle-kilns were erected for firing the enamel paintings, but Randall had been experimenting with a paste or body for china, and, having attained some success, he erected a biscuit-kiln for hard firing, and engaged a thrower and turner, a modeller and a presser, a fireman, and other assistants to do the painting. This introduces the Madeley china proper, which was a soft-paste, artificial porcelain, the closest imitation ever made of Sèvres, having a mellow, clear, transparent tone-not snow-white like Nantgarw, but specially fitted to receive those coloured grounds which are so beautifully laid upon the Sèvres china. At the Sèvres factory hard-paste china was made in I768, so that Randall's body differed from that; being soft, it was like the products of the French factory in the early period from about I753, when turquoise blue was discovered, and followed in I757 by the famous rose du Barry or rose Pompadour. Still, after I768 till about I802, soft paste appears to have been manufactured at Sèvres, side by side with hard paste. In the latter year it ceased, but was revived in I854, possibly owing to the striking success of Randall's imitations.

The illustration shows Sèvres vases such as were copied by Randall. 

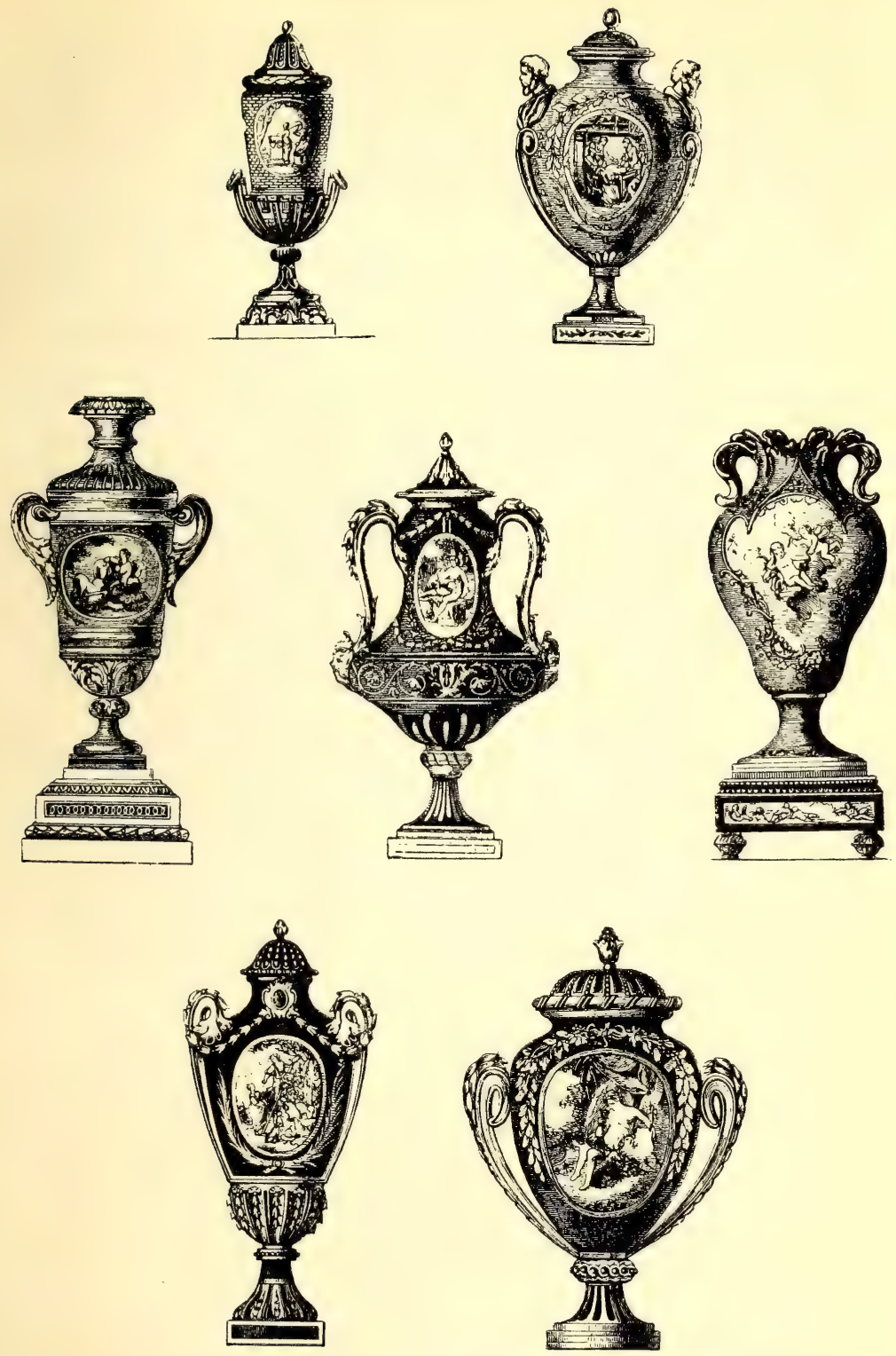

SÈVRES VASES SUCH AS WERE COPIED BY RANDAIL.

347 


\section{I9TH-CENTURY ENGLISH CERAMIC ART}

$\mathrm{He}$, however, found that his manufacture involved so much expense as to be unprofitable, so in I840 the Madeley works were closed, and he went to Shelton, in the Potteries, where he continued his enamel-painting till 1856 . He painted the Cupids and amorous scenes which Boucher and Watteau drew so effectively, but he also painted birds, flowers, and figures. So did Gray; and another artist, Ballard, was very skilful in depicting Boucher and Watteau subjects. Randall used no mark upon his own Madeley china, and whatever marks might have been upon the pieces sent to him for decoration, they remained untouched. Apart, then, from the characteristics of his own soft-paste porcelain, there are many difficulties in identifying Randall's work, which time and further research may solve. As a product of the nineteenth century his Madeley china was the nearest approach ever made to the lovely old soft-paste Sèvres, and with it the manufacture of English soft-paste artificial porcelain ceased. 


\section{CHAPTER XV}

\section{SOUTH ENGLAND POTTERIES}

\section{Lambeth and Burslem: Royal Doulton}

Doulton ware, now so celebrated, was non-existent in the early years of the nineteenth century; the stoneware works established by John Doulton at Vauxhall in I8I5, afterwards carried on by Doulton and Watts, were some years later transferred to High Street, Lambeth. At the Exhibition in I85I, the firm of Doulton and Watts exhibited a series of vases in white terra-cotta, and we are told that-

"Attention has only recently been directed to objects of an artistic character; those we have engraved may be regarded as a prelude to further success, which increased experience must ensure. The use of terra-cotta, or of artificial stone, as applied to objects of art and of decoration, is by no means new in this country, although such application has been of late very limited. Half a century since it was carried on, to a great extent, by Messrs. Coade, of Lambeth."

The quotation is from the catalogue, whose pages also contain illustrations of chimney-pots in the Tudor style manufactured by Messrs. H. Doulton \& Co. of Lambeth, who also contributed the terra-cotta vases. From that first medal awarded in I85I came a number of similar rewards, too numerous to mention, from exhibitions all over the world. The progress made has been simply marvellous.

The appointment of John Sparkes as head of the Lambeth School of Art in 1856 had far-reaching results upon the productions of the firm, which exhibited at Paris in I867 a collection of ware showing that the highest practical excel- 
lence had been attained, and the wide recognition which Doulton received stimulated him to further production. Then in I87I the report of the judge gave expression to his pleasure in calling attention to the case containing the new ware. With the full recognition of its colour and peculiar character came the adoption of sgraffito, or scratched patterns. These were made upon the body of the ordinary brown stoneware, and the scratched lines were filled in with colour. One general name was adopted for sgraffito designs, as well as
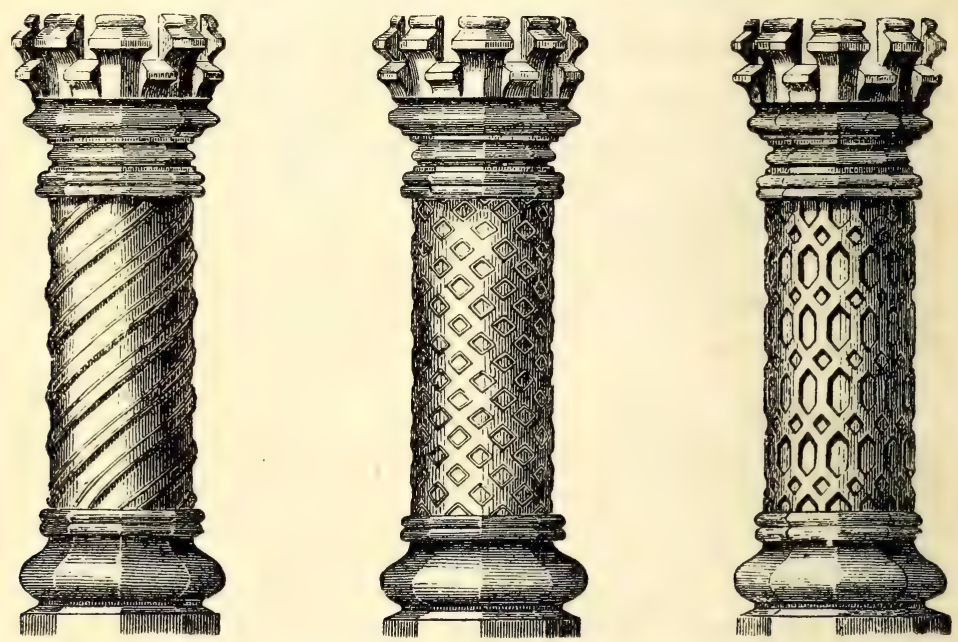

FIRST EXHIBITS IN I85 I. DOULTON.

for those ornamented by applied forms-all became Doulton ware; even the faience and impasto ware with many people are simply Doulton ware, though they should be classified apart as earthenware which is not white.

There are many methods used in the schemes of decoration for which Doulton ware has become famous. There are many bodies to which such decoration is successfully applied; bronze, green, brown, blue, chocolate, grey, white, and black bodies are all adapted to bear the heat of the salt-glaze kiln, or to be used as dry bodies as well. But I will adopt the grouping as set out in the Doulton notes on the manufactures, 
which Doulton \& Co. were good enough to send me, with a copy of John Sparkes' notes, the substance of two lectures delivered before the Society of Arts on April 29, I874, and March Io, I880. I shall reproduce the latter notes as far as they give the initials of the artists. Looking forward I can imagine some collector of Doulton who might be glad to learn who the artist was who used certain initials as a mark. The traditions of Doulton are not very old, but they are distinctly gracious, for every artist who was responsible for the decoration of a piece of the ware was permitted to use an identifying mark. Indeed I know of no factory where the work is so distinctly marked with the initials of those who decorated it. Before me is a pair of vases, with the firm's
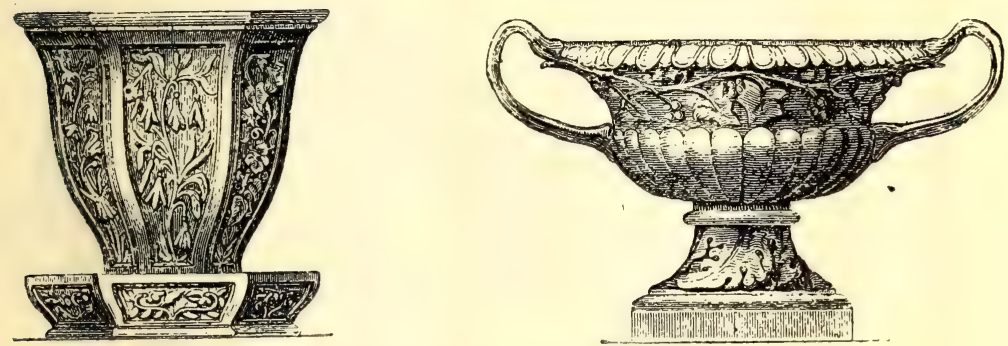

SOME OTHER EXHIBITS IN I85I. DOULTON.

mark, "Doulton, Lambeth," separated by " Carrara" on shield. This is printed, and there are other marks impressed, then " $\mathrm{K}$ 84 " with + in a small circle under it, and three other separate groups of initials : "A. T.," "F.S.," "W." I shall not attempt to interpret these, but the initials which accompany the short descriptions of the artists and their work, must limit my extracts, though Sparkes' notes are worthy of fuller quotation.

A year before his first lecture, in I873, the underglaze painting of faience was commenced, and Lambeth faience soon became as well-known as Doulton ware, though, as I have remarked, some people will confound the two products, which are entirely different in body and decoration. Passing the Exhibitions of Philadelphia I876, and Paris I878 (Grand Prix), we come to the International Health Exhibition in 


\section{I9TH-CENTURY ENGLISH CERAMIC ART}

I884, which drew attention to the immense variety of Doulton's productions. The official award of eleven gold medals, fifteen silver ones, and five bronze, showed how highly the jurors esteemed them. Messrs. Doulton had the additional gratification of knowing that seventeen of their artists received medals for works exhibited in their own names, apart from the main exhibit. The award on this occasion of the "John Stock" medal for "sanitary architectural construction" tells the tale of a department, vast in the extent of its operations, not confined to High Street, Lambeth. For the Albert Embankment showrooms are also works; still others are distributed over the country, at Rowley Regis, Dorset; Dudley,
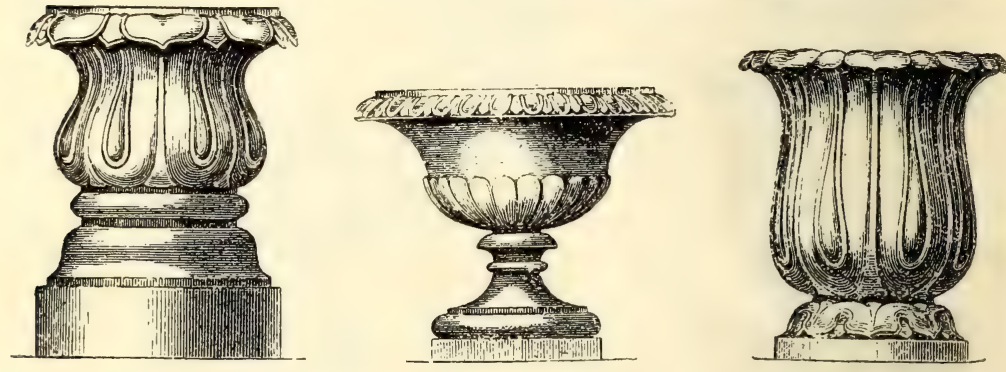

DOULTON'S EXHIBITS IN I 85 I.

Staffordshire ; St. Helens, Lancashire; Smethwick, near Birmingham and at Paisley there are Doulton's establishments, occupied with some of the special productions, and in my Igoo record, Doulton \& Co., Burslem, appear as manufacturers of high-class china and earthenware, of every description. I had the pleasure, a short time since, of meeting their Australasian agent, Mr. John Shorter, of Sydney, who is obsessed with the wonders of Doulton.

The Society of Arts, in I885, awarded the Albert Medal to Mr. Henry Doulton, "in recognition of the impulse given by him to the production of artistic pottery in this country." The technical education of women was one of the points referred to by the Society in making the award. When you read Mr. Sparkes' appreciation of the women artists, you will agree that no reward was better bestowed than that which 

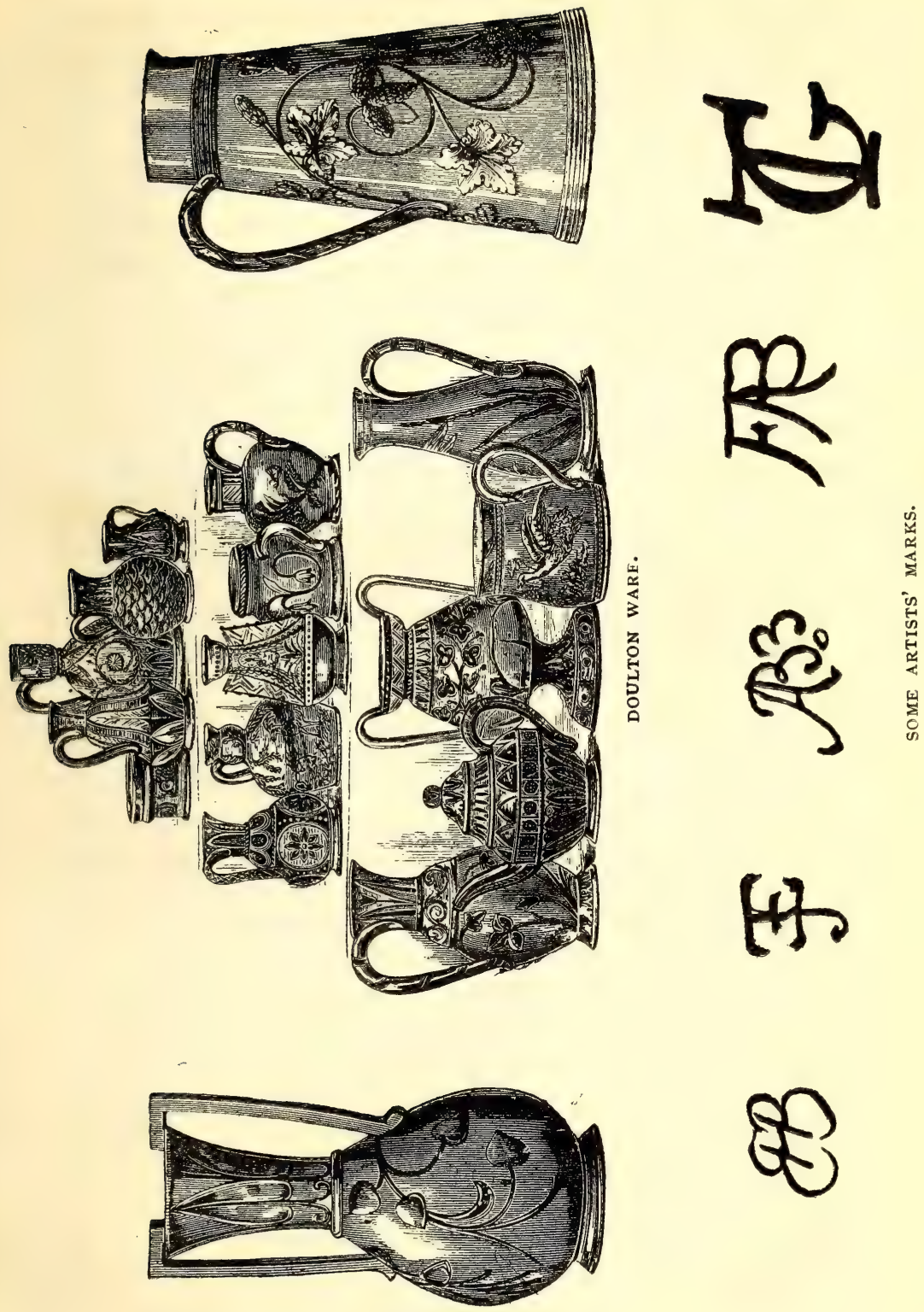

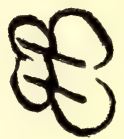


was presented to Doulton on December 2I, I885, by H.R.H. the Prince of Wales, yet that reward paled before the knighthood conferred in I887. Sir Henry Doulton deserved all honour, but he will be Doulton, and his ware will be Doulton, for all time, though made at the Royal Doulton Potteries.

More than two hundred medals, diplomas, and other awards have been won, though this is but a comparative indication of the success of the manufacture. When public support is unstinting, and the business thriving, because of that necessary feature in all businesses, when writers interested in ceramics are universal in their applause, and when the final crown to the work is given, as it was, in I9or, by the appointment as Potters to H.M. the King, surely all of it points to a long period of prosperity in the future; the enterprising spirit as the management never sleeps.

The consideration of the pottery, as grouped under various headings, will for a few paragraphs occupy your attention. First comes Doulton ware, or salt-glazed stoneware. Numerous as are the methods of decoration in this ware, they are all alike in this respect, that all are carried out while the pieces are still plastic or unbaked, and that the ware is completed in one burning - a method very little used in the present day by other potters, but at one time almost universal.

The process of salt-glazing is not applicable to any other kind of ware than stoneware, as the glaze is really formed by the partial fusion of the ware itself. During the last stage of firing, when the ware is just on the point of vitrification, common salt is thrown into the kiln. The decomposition of the salt fills the kiln with fumes of salt-vapour, producing on the wares a thin glaze or glass of silicate of soda, exceedingly hard and thin, exactly even over all parts of the surface, and hiding not the least touch left by the etching or modelling tool. This method of glazing is used for the greater part of Messrs. Doulton's ordinary manufactures, as well as for their Doulton ware.

The next class is fine stoneware, also saltgla-zed. This class includes the numerous patterns with moulded ornament such as "Toby Fillpot," or " Hunting," jugs, " Greybeards," 


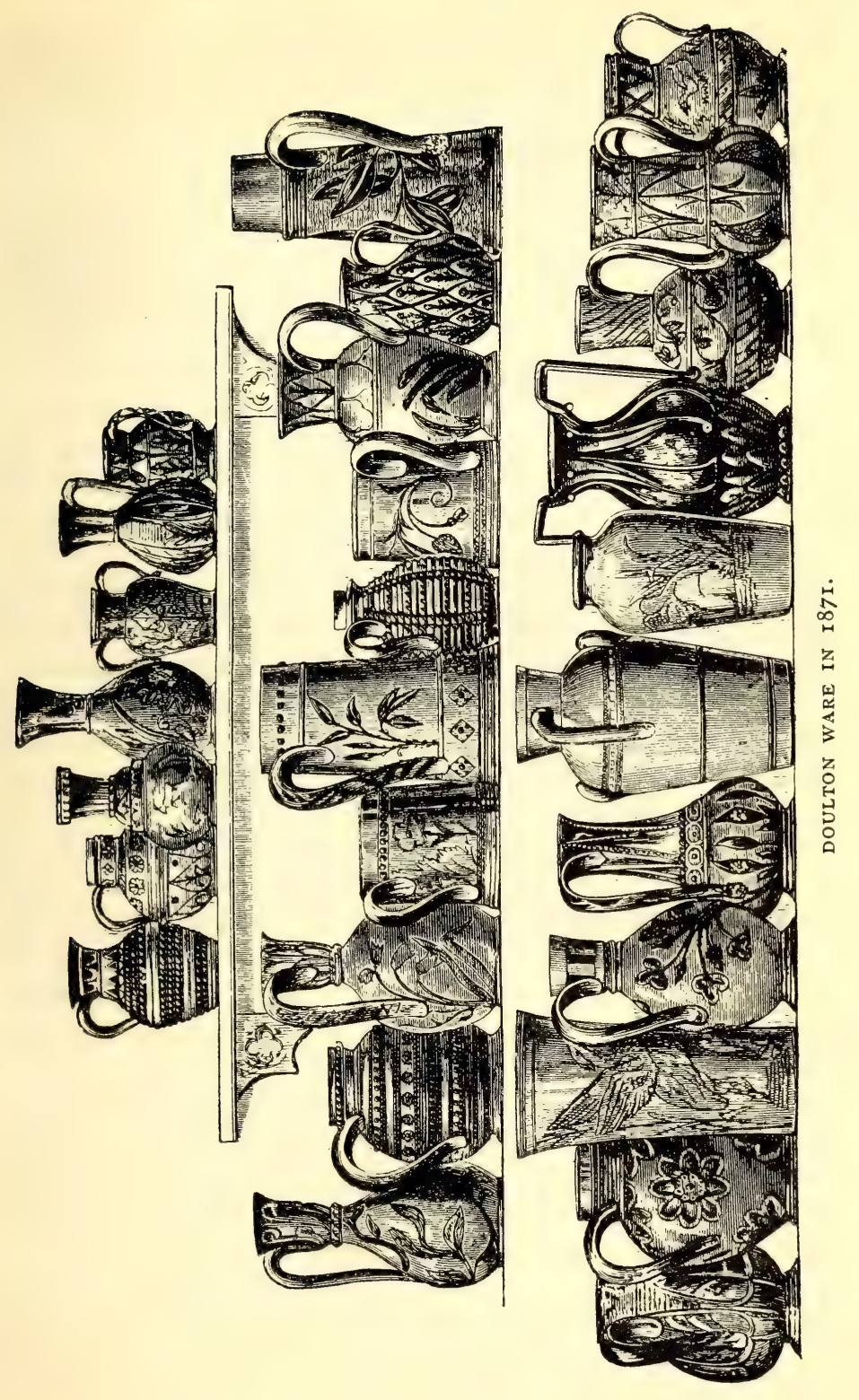




\section{I9TH-CENTURY ENGLISH CERAMIC ART}

or "Bellarmines," "Egyptian" tankards, Motto and Puzzle jugs. The colourings are restricted to the tints of the clays used for the ornament, with, in most cases, a broad band at the top or foot, of rich brown.

Then comes chiné ware, which may be salt-glazed or faience. This class is formed by a subsidiary group of patterns, adopted for repetition, in which use is made of the effects

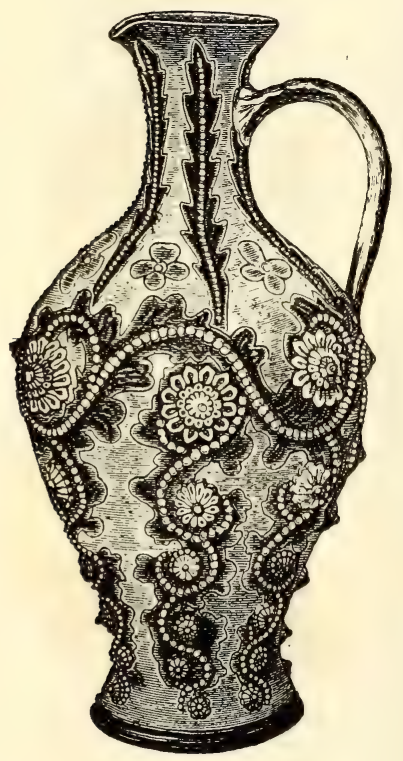

APPLIED ORNAMENT. obtained by impressing certain suitable fabrics on the surface of the ware while still soft.

Fourth, silicon ware, a stoneware with a vitrified body, but fired without a salt-glaze, the colour effects being obtained by coloured clays.

Carrara ware forms the fifth class. This is a stoneware in which the body is generally modelled while in the plastic state, and is then covered with a slightly translucent crystalline enamel. In many cases the decoration is completed in colours, and gold as it is on my much-marked vases. The method is now more frequently used in the production of architectural work in designs when

a dull-surfaced glaze is required.

Next is marqueterie ware, a recent introduction of considerable technical interest. Marbled clays in chequer-work, obtained by cutting and compressing in various ways, are used for moulding the forms, the pieces being afterwards glazed, and perhaps finished in gold.

Seventh is Lambeth faience, a terra-cotta or biscuit body, decorated by paintings, which are fired under the glaze. The method is used not only for vases, but for tile panels of all sizes. 


\section{SOUTH ENGLAND POTTERIES}

Glazed faience is mostly used for the larger forms of pedestals, vases, flower-pots, as well as for moulded tiles, and architectural decoration. The ware, having been decorated while plastic, or, for patterns which must be repeated, pressed in moulds, is first biscuited, and then pencilled or dipped with coloured glazes.

Most of the art wares are, of course, unique, each piece, or pair of pieces, not being afterwards reproduced. Now comes the note to which reference has been made: "Every piece of art ware bears the name, monogram, or mark of the artist."

Which brings us to the consideration of the notes by John C. L. Sparkes, whose efforts to develop Doulton ware deserve warm commendation.

"The artist who has given to the new Doulton ware one of its strongest characters is Miss Hannah B. Barlow. Miss Barlow's quick sketches of animals show an intense feeling for the spirit of the beasts and birds represented.

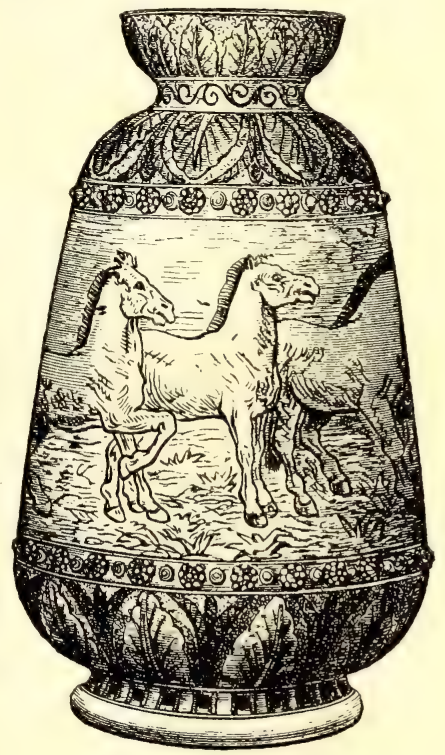

SGRAFFITO, BY MISS HANNAH B. BARLOW.

These etched-out figures are, so to speak, instantaneous photographs of the creatures. She possesses a certain Japanese faculty of representing the largest amount of fact in the fewest lines, all correct, and all embodying in a high degree the essential character of her subject. Yet there is little tendency to run into a picturesque treatment, but the fitness of her work for the manufacture, the recognition of the limitations under which the designs are made, are eminently kept in view in all her work. Her mark is shown on page 353 .

"Her sister, Miss Florence Barlow, covers a more 
extended field, as she takes both ornaments and animals, and has recently executed some very charming paintings in coloured clays-of birds especially, which give a conventional light and shape and colour treatment to her designs, very helpful on the score of variety.

"Another lady artist was Miss Emily J. Edwards. Her work is ornament made up of an ingenious mixture of classical or conventional forms with natural growths. There is usually

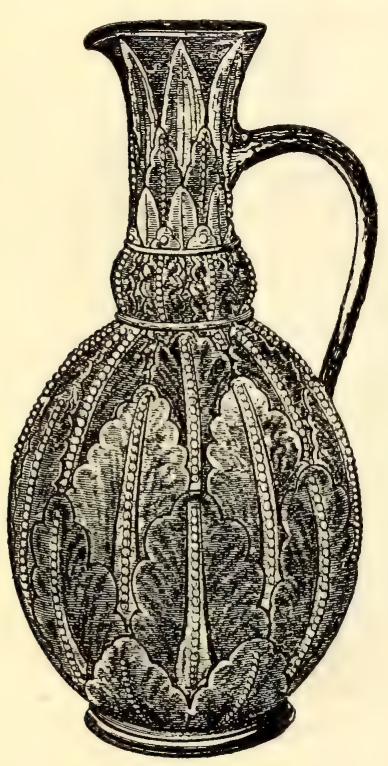

CARVED IN THE MOIST CLAY. great flatness of treatment in her work, with which elaborately diapered backgrounds in nowise interfere. The colour clings to the small stamped patterns on these backgrounds, and flows into the deeper depressions, to the manifest enrichment of the piece. She often gave indication of close study of antique methods of decoration. Her mark is figured on page 353 .

"Another artist, whose skill has done very much for the ware I am describing, was Mr. Arthur B. BARLOW. He took an entirely different line from that followed by his sisters. His ornament is original-a flowing, tumbling wealth of vegetable-form wreaths around the jug, now and then fixed by a boss, or pinned down by a point of modelled form. His education in the Art School as a modeller was of vast assistance to him, and gave him many methods of dealing with the plastic form that came under his hands. The occasional use of a gouge, or carver's chisel, or other carving-tool, gives frequent evidence of his resources. $\mathrm{He}$, too, has carried the system of bossing, or stamping with points, dots, and discs to its fullest development. His good taste and perfect mechanical ingenuity have carried his art into fields of decoration of unexpected beauty. His work is marked as shown on page 353 .

"Another artist who has made his mark on the ware by the originality of his forms is Frank A. Butler. He is 


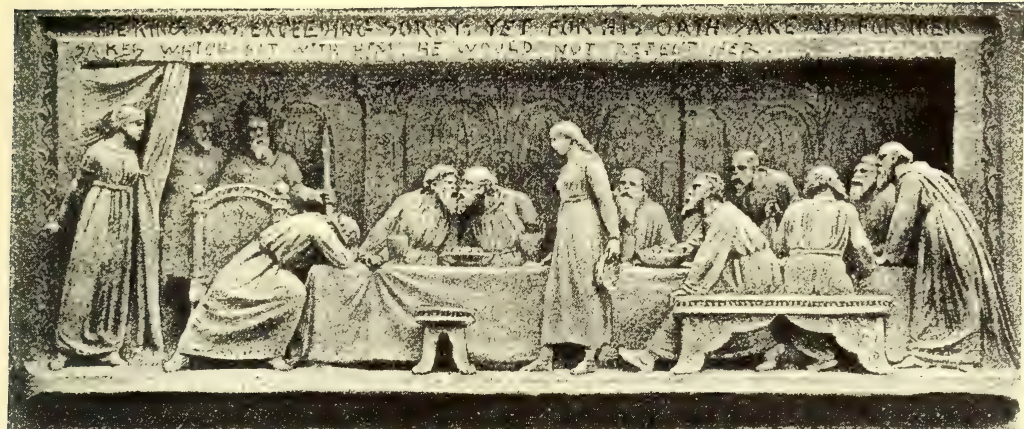

"KING HEROD WAS EXCEEDING SORRY."

Terra Cotta plaques by George Tinworth, the celebrated modeller at Doulton's Lambeth Works. From the large reredos over the church altar to the small laughing figure of a boy playing an instrument in a band of musicians, Mr. Tinworth has proved himself a master in Plastic Art.

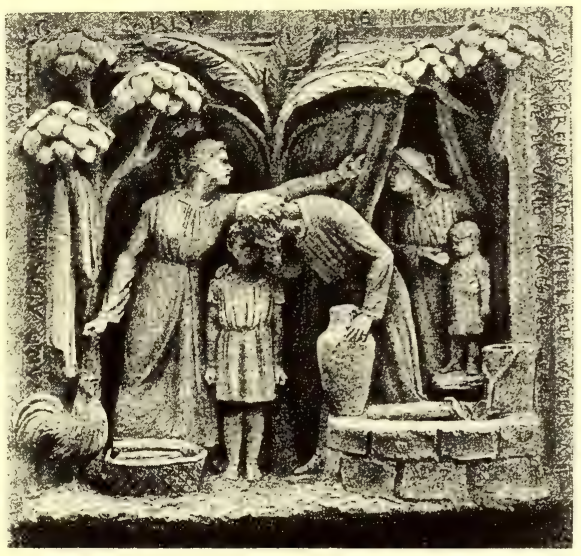

HAGAR AND ISHMAEL ARE CAST OUT.

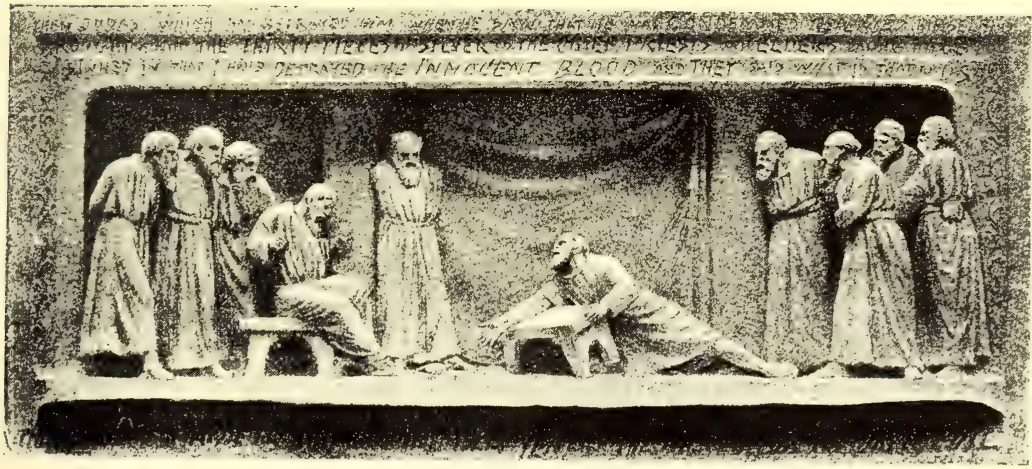

JUDAS CASTETH DOWN THE PIECES OF SILVER. 

quite deaf and almost dumb. He is one of many thus heavily afflicted who have passed through the school. He began his artistic life as a designer of stained glass, but his invention was not needed, nor, I dare say, discovered in the practice of an art which is almost traditional. I introduced him to the new work, and in a few months he brought out many new thoughts from the silent seclusion of his mind. A bold originality of treatment and the gift of invention, are characteristic of his work. $\mathrm{He}$ has struck out many new paths. A certain massing together of floral forms, and ingenious treatment of discs, dots, and interlacing lines indicate his hand. He not only produces designs for himself, but keeps three or four assistants busy, by designing forms and patterns for them to carry out. His best work, perhaps, is that where the ground is carved, leaving the pattern in relief, and he is facile princeps in the treatment of the wet-clay vessel, by squeezing it into shapes other than circular. His mark is shown on page 353 .

"The artist who has done greatest service to the arts of all kinds in Lambeth is GEORGE Tinworth. He was originally brought up as a wheelwright under his father's mastership. $\mathrm{He}$ had early inclinations to be a sculptor. These were shown

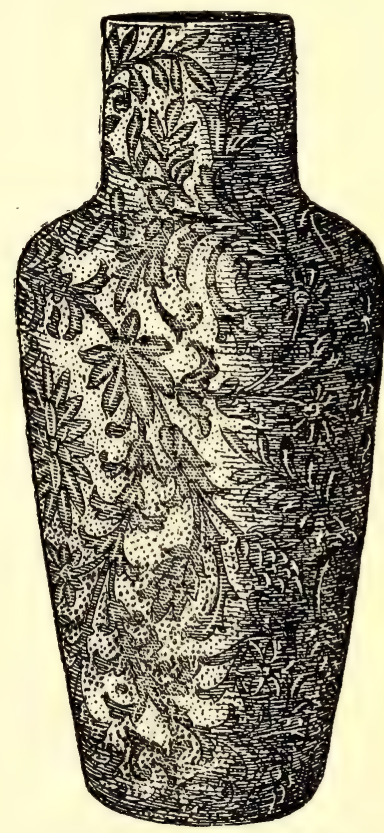

BROWN CLAY DIPPED AND SCRAPED ; SLIP GROUND. by his untutored carvings of Garibaldi and other heroes of the time. The cutting of these things formed the occupation of his midnight leisure. His father deeming these works of art dangerous, as likely to prove a bar to the proper attention his son ought to give to his business as a wheelwright, broke them to pieces whenever he found them. An arduous childhood has educated in him a deep patience, which has borne wonderful fruit. After his father's death, he tried to carry on business single-handed, but he was unsuited to the work, 


\section{I9TH-CENTURY ENGLISH CERAMIC ART}

mentally and physically. He had entered the Art School some time before this, and I was happy in being able to introduce him to Mr. Doulton as a modeller suited to his needs. His first works were some large medallions, modelled from some Syracusan and Terina coins. These were done with astonishing spirit. When the demand for artistic stoneware came, his general grasp of the intention enabled him to do works that were more than equal to the occasion; and since that time he has done some of the best pieces the factory has produced. He prefers the clay soft from the thrower's wheel, so soft as to be too tender to handle. His delight is a spiral band or ornamental ribbon, sometimes deeply interdigitated, or elaborately frilled. The ornament usually covers as much surface as the ground, and creeps or flies over the surface in wild luxuriance; bosses, belts, or bands of plain or carved moulding keep this wild growth to its work, put it in its place, and subject it to its use. No two pots are alike, and, although he has done many thousands. all different, he will still produce them in endless variety out of the same materials. Of course no one could produce such ever-new combinations unless he had invention. In his art as a modeller he has achieved marked success; and the exhibitions of the Royal Academy, year after year, prove his right to recognition as an exponent of religious art, such as seldom rises in any community in the present day.

"In I874 he exhibited a large jug, in which he worked a kind of gallery round the shoulder, and placed alternate groups from the history of the Passion of our Lord, and small niches of single figures from the Old Testament, which have a bearing on the groups they separate. The earnestness of the actors in these little scenes, and the expression of their faces and hands, will repay close examination. Apart from the detailed richness of the high art work on this jug, the vessel, as a whole, is perhaps the finest piece of decorated stoneware that has ever been produced in the modern age. If it has a rival, it is in a similar one, but somewhat smaller, that was exhibited in Vienna in 1875, and is now in the Museum of Arts and Manufactures in Edinburgh. His mark is given on page 353 .

"He has also executed a relief for the reredos for York Minster, and some excellent reliefs for the Guards' Chapel in St. James' Park, which quite realise the favourable expecta- 


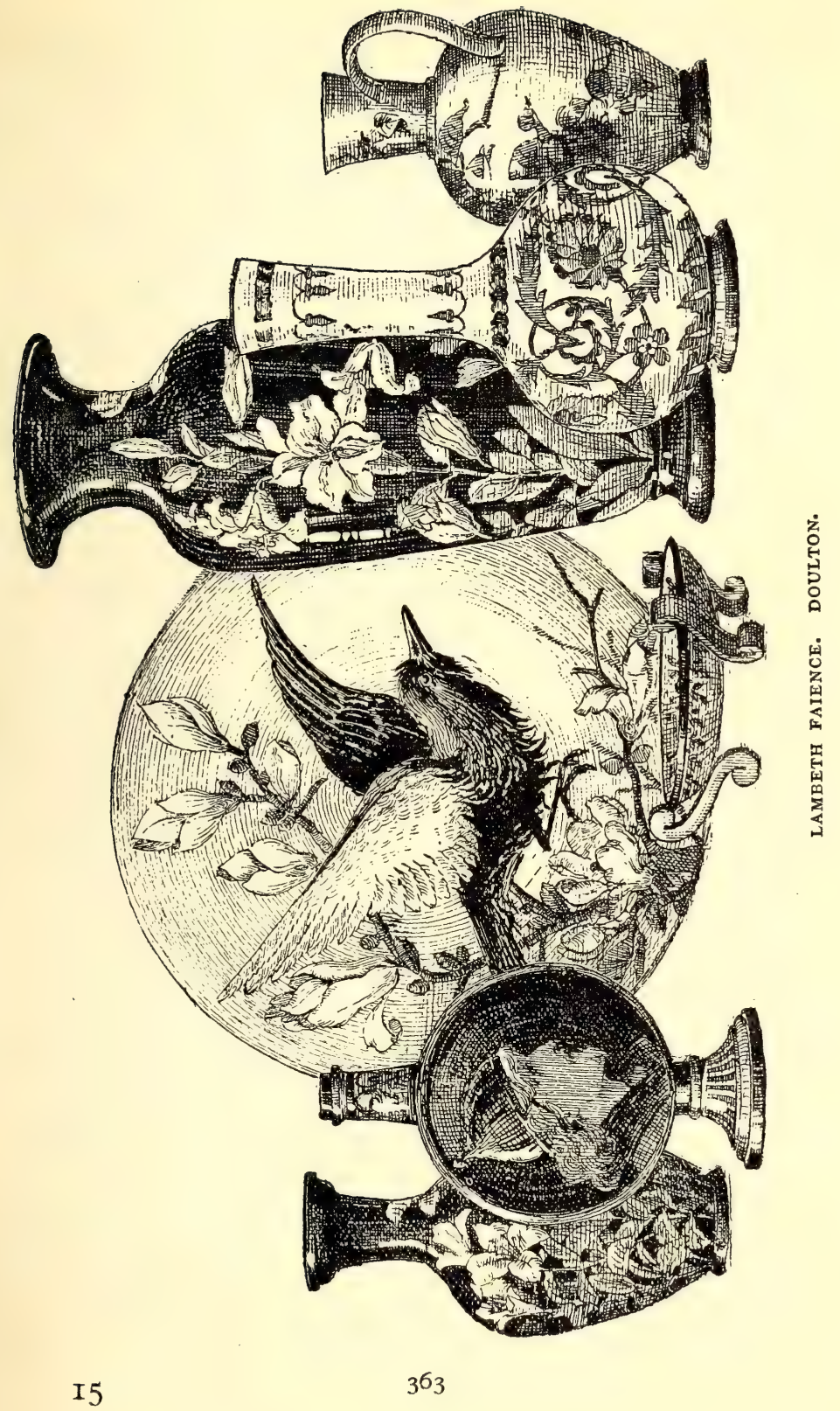




\section{I9TH-CENTURY ENGLISH CERAMIC ART}

tions of his many critics. He has added numerous conceits in the way of handles, ornaments, and small objects.

"First among those who have thrown their whole energy into their work is Miss Eliza Simmance. Her work is not only designing with the stylus, but especially she excels in painting the patte-sur-pâte patterns. There are examples of her work, which are so eminently graceful, and well-drawn, as to emulate the same qualities in the work of the Italian ornamentists. She, too, has so many ideas to spare-more than she can work out by herself-that she keeps a staff of rising artists occupied in carrying out her instructions. An example of her work is partly painted, partly incised, and the main body of the ornament is carved out of the solid clay.

"Another lady, Mrs. Eliza S. Banks, has taken up the painting on stoneware by the pâte-sur-pâte method, and has invented, and executed some excellent designs on a larger and more picturesquely ornamental scale than any one else. Her work is recognisable by a certain freedom of brushwork, which, perhaps, occasionally verges on the natural side of the line that is conventionally held to divide nature from ornament.

"Then, Miss Louisa E. Edwards may be taken as representing a style of decoration taken remotely from the Indian and Persian conventional flowers, but drawn with clear lines of perfect construction, and distributed with judicious thought, taste, and skill. Associated, to a certain extent, with her is Miss Louisa J. DAvis, who has had considerable influence in a certain direction in enlarging the plan of treatment of the same Persian or Indian motives in their stoneware translation, and has treated certain natural plants-notably, reeds, sedges, and grasses-with a masculine vigour and power of drawing that remind one of old Gerard's woodcuts.

"Also, Miss Edith D. Lupton has worked out some very characteristic half-natural forms, that in their distribution and grace leave nothing to be wished.

"Miss Frances E. LEe has taken almost all sections under her care, and it is a little difficult to say in which of them she especially excels. She has taken up the method of pressing form in to the wetclay, and has hit upon some fortunate combinations of this with surface ornament. Some of her simply incised surface decorations, also, are very good in their flatness.

"Miss Mary Mitchell has begun to add outline incisions 

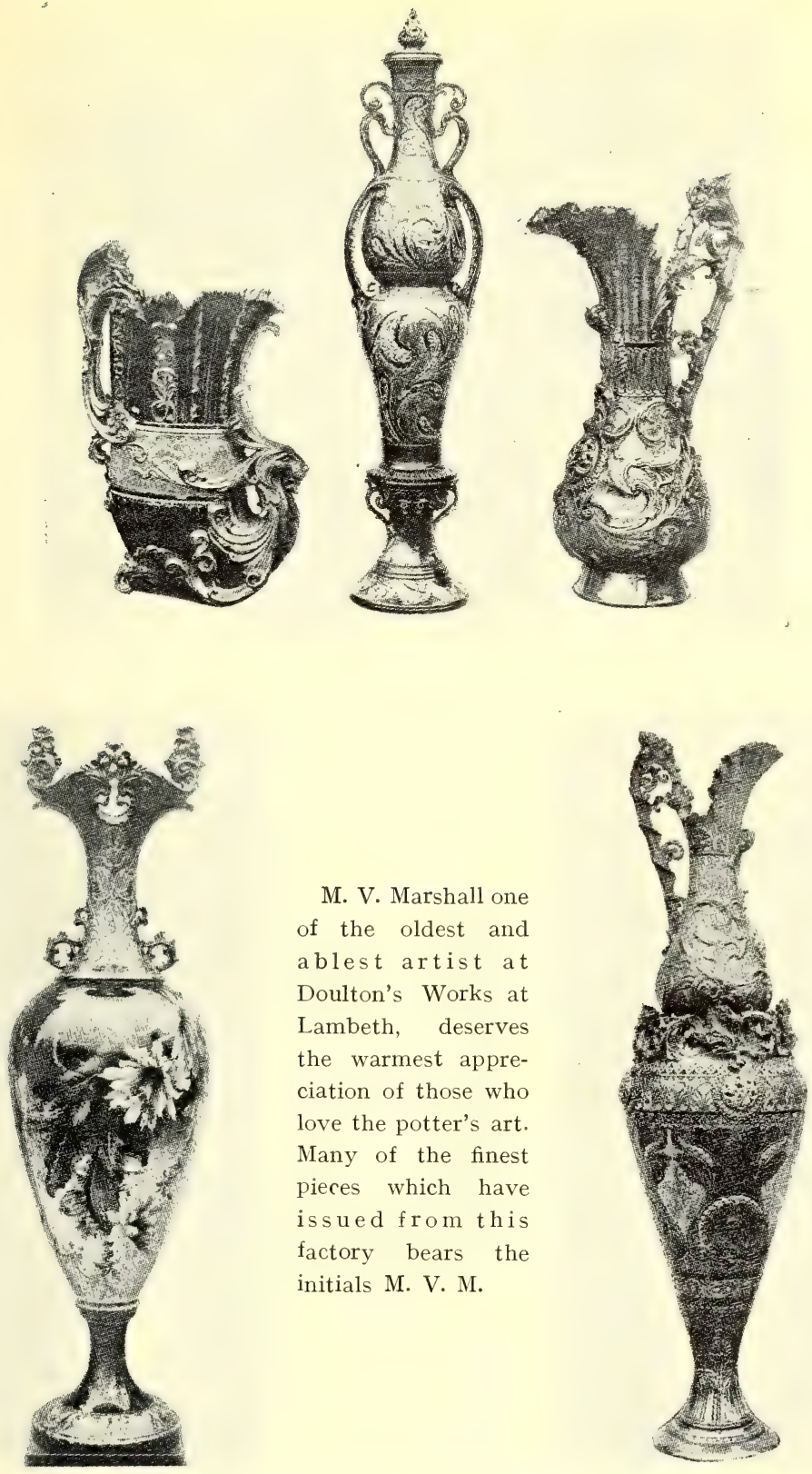

DOULTON WARE AND GLAZED FAIENCE. FOUR PIECES BY Mr. M. V. MARSHALL, AND ONE WITH FLOWERS BY MISS F. LEWIS. 

of rustic figures, treated with a pleasant semi-classical simplicity that promises well in the future.

"Two other artists, also, should be named, Mr. JoHN BROAD and Mr. BEERE; they model well, and several of their works of art are graceful and well composed, with much simple and classical feeling for beauty.

"A pilgrim bottle, with the head of Lysimachus, is one production of Mr. BROAD. It is obvious that modellers of figures must submit to the moulding of their productions, as a human figure cannot be supplied with the readiness with which a purely ornamental form can be modelled. Hence these forms are repeated occasionally.

"There are several others who are not at present quite yet so developed as to demand especial notice, but who will make their names known in connection with the new art manufacture in the future.

"Thus, so far as relates to the stoneware manufacture, I have given a short epitome of the new lines that have been entered on. These lines are new, in the sense that they have never before been applied to the decoration of stoneware, and some of them are absolutely new. All the work I have spoken of is literal hand-work; no machine, other than the potter's wheel, has anything to do with it; no mechanical reproduction or pressing from moulds; no stamping out hundreds of similar shapes; nothing but what the eye and hand of the thrower, and the taste and good drawing of the artist, can manage between them, to which is added the colour that heightens all.

"I have said that the utmost care and the greatest artistic skill would be simply valueless if the actual details of manufacture were not equally cared for. This, however, has been done in a remarkable manner by those by whom Mr. DoulTon has surrounded himself ; Mr. BRYON, the foreman, who selects and mixes the clay for the bodies, has worked with most zealous spirit. All that has been accomplished in colour is due to Mr. Rix, who, by incessant experiments and cautious intelligence has produced blues and browns which equal the ancient ware, and are in some senses superior to them. $\mathrm{He}$ has also introduced several new tints, which have the rare merit of withstanding the intense heat of stoneware kilns, and the decomposing vapours of the salt. $\mathrm{He}$, too, has organised the studios of young girls who do the subordinate part of the work, such as the sealing on of dots and bosses, 
and has thus rendered it possible to produce these highly finished handworks at reasonable prices.

"I personally feel under deep obligation to him for the zeal and interest he has shown at all times when new experiments were to be made, either in the body of the ware, the decoration, or the colouring of it.

"The forms on which all this elaboration and decoration is placed, are first 'thrown' on the potter's wheel. The art of throwing is in danger of becoming extinct in Staffordshire and was in use in Lambeth principally for the purpose of producing only the simplest wares, such as ink-bottles, blacking-bottles, jars, etc. The demand for beauty and accuracy of form found its supply in the works of THOMAS Ellis. His most skilful handicraft has done not a little to help on the fame of the new ware.

"Many of these forms are thrown roughly on the wheel, and then when green hard are shaved, that is, are turned in a lathe; this gives them a fine, true, highly polished surface. In this part of the process accuracy of hand and eye are both demanded. The earlier forms were shaved by Robert Atkins, who unfortunately died. His successor, GEORGE MARTIN, who has put the final surface on a large number of the pieces made, has done his work in the spirit of an artist.

\section{Faience}

"Faience is practically any sort of earthenware which is not white, having a decoration of painting upon the ordinary natural clay body. The ware that is, on the whole, most capable of receiving artistic impressions is that which is called impasto ware. It is so named from the special treatment it receives at the hand of the artist who decorates it. The colour is applied to the raw clay; it is, further, so thickened by the vehicle by which it is incorporated, that it models the form as well as paints it. The small amount of relief that is thus given to the ornament-coloured, as it is-adds to the apparent reality of the thing depicted, and is no doubt, an additional power in the hands of the artist ; it is also a snare, inasmuch as the treatment of this principle involves a knowledge of modelling, to some extent at least. And, without some acquaintance with practice of light and shade, it is quite possible to produce a design devoid of effect, too 
evenly distributed all over the piece. But, with taste and judicious use of the raised parts, this new material may add very considerably to the pottery painter's means of producing good work.

"The command over the texture as well as the tint of the background is also a point to be noted, as the application of paint, which has considerable opacity of substance, gives a quality that is never reached by half-transparent films.

"The whole system is, to a certain extent, analogous to painting with opaque colour in oil, while the average pottery underglaze painting is very like the water-colour painting, where the reflection from the ground passes through the coloured tints and films of pigment that cover it. Impasto painting, therefore, has all the advantages that opaque tempera, or oil-painting, possesses, inasmuch as it reflects light from its surface. The opportunity this raised or impasto work gives for a second colouring, with underglaze colours, is to be remarked as rendering the work of art capable of taking a refinement of finish in detail on the surface prepared for it in relief. The power and beauty of the material are developed to a considerable extent. The background is often a very interesting effort as decoration, by using two pigments of different fusibility, but of well-chosen harmony, so that, when they run together, the effect of each is heightened. "Various applications of this method have yet to be made."

In 1874 , the large and important art section of painting upon faience was in its infancy, and Mr. Sparkes speaks of its progress in 1880 :

"It is now a pleasant duty to record the names of some who have done well by their taste, good painting, and designing, and who have impressed their individuality on the work.

"Miss Florence Lewis has a remarkable power of design and skill in painting that is seldom surpassed. Her designs are of foliage, flowers, and birds ; and, whether she is working out a large design or a small tile, her energy and power are equally shown.

" Her sister, Miss Isabel Lewis, also gives great evidence of taste, although her original design suffers a little by the close comparison with her sister's, 
"Miss M. L. Crawley has made an important section her own. She early studied the Persian and Rhodian ornament, and now produces beautiful examples of similar style to the great originals just mentioned, with clear drawing and excellent colour and distribution.

"Miss Mary Capes has done everything; she is an inventive artist who experiments, and follows up the results thus obtained in a truly scientific spirit. Natural or conventional forms, geometrical or conventional ornament, seem to be equally familiar to this lady's experience.

"Miss CAPEs has developed an excellent section, that of painting with enamel colours on stoneware already finished with a dip of single or mixed colours, and fired in the saltkiln. Certain examples rival some of the best qualities of Japanese art. The combination of textures and colours is often singularly happy.

"Miss Katherine Sturgeon has taken the section of figure design, with considerable results. The heads she is able to arrange out of studies from the model have a very great sense of beauty and good colour and effect.

"Miss Mary ARmstrong has translated original figure designs, by Mr. MARKs, and other designers, with much delicate sense of beauty and good taste.

"Miss Fanny Stable has taken as her model the treatment of large surfaces by the Japanese, and, by the study of these great teachers, has succeeded in producing paintings of excellent interpretation of nature.

"Miss Mary Butterton, too, has done very much in original design, mainly treatments of natural forms, often circumscribed by geometrical limits, that are quite suitable to the form of the vase to be decorated. A firm decision of drawing is quite observable in her work.

"Miss Alice Shelly has done some excellent treatments of natural flowers and foliage.

"Miss Euphemia A. Thatcher has taken a similar style, in obedience to the constant demand for natural forms.

"Miss Alberta Green, Miss Matilda Adams, Miss Margaret Challis, Miss Helen A. Arding, and Miss M. M. ARding, may be mentioned as having done much that is graceful and good in various styles.

"Miss Esther Lewis has done several landscapes from nature, from sketches in Wales, Switzerland, and other picturesque countries; they are entirely satisfactory, as 

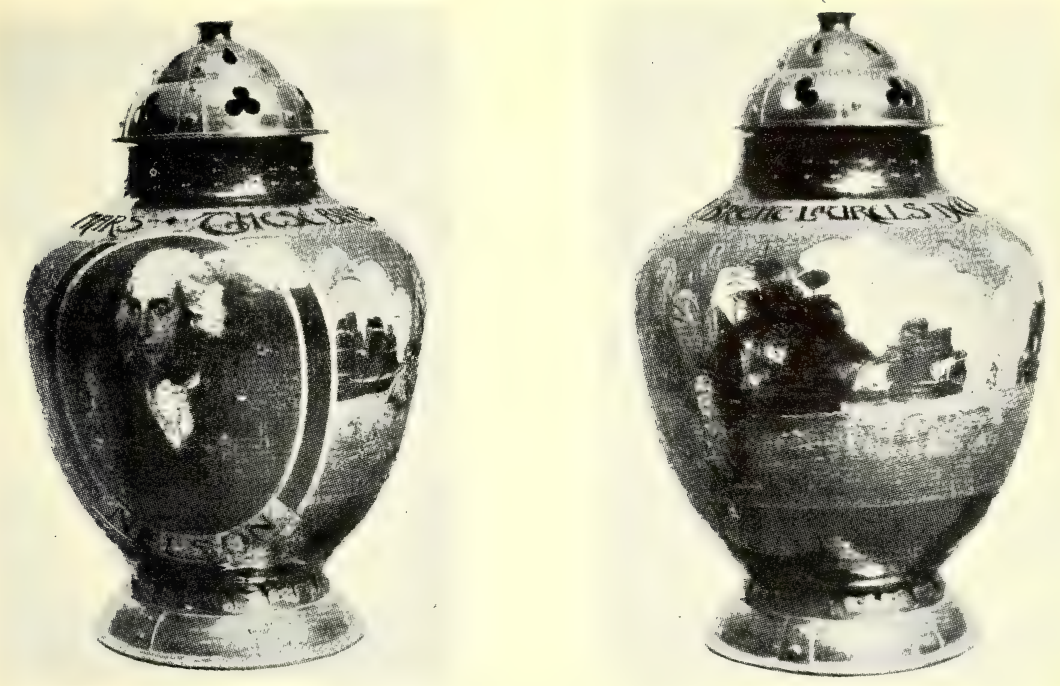

THE NELSON VASE : TWO VIEWS.
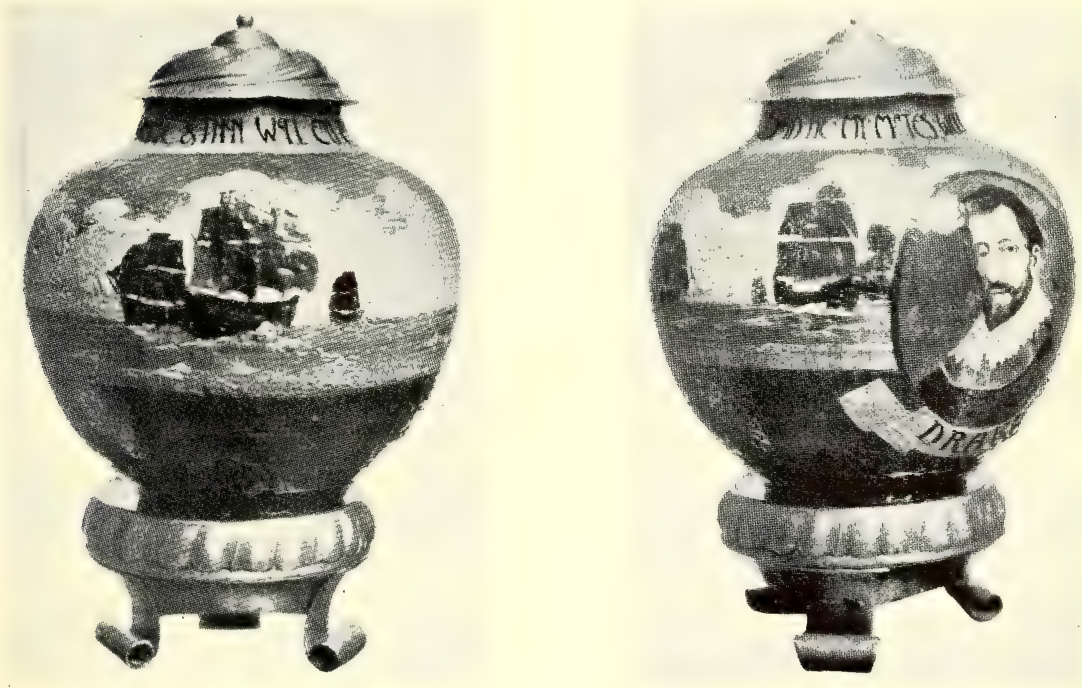

THE DRAKE VASE : TWO VIEWS.

DOULTON WARE. 

broad, breezy representations of nature in quiet grey and warm tones. From any point of view they are equally good decoration and good art.

"Miss Linnie Watr has a most distinguished gift for conveying the impression of a picturesque scene with rustic figures, in excellent colour and with artistic breadth of effect, quite admirable in its truth. Her works will speak for themselves to every artist who sees them.

"The impasto painting was primarily developed by a very talented artist, Miss F. M. Collins (afterwards Mrs. VALE). Her mark will sufficiently indicate her productions. She too, we regret to say, has passed away from this world's activities, but not before she had made her gifts appreciated, and her great intelligence valued at Lambeth, in the care she took in the working out of a new and untried section of pottery decoration.

"Her successor is Miss Linnell, whose work is the fine vase to which I have already called attention. Her treatments are in the largest style, and seldom run into trivial details."

Most of these artists used a monogram consisting of their initials as the mark of their work, similar to those which have been reproduced earlier in this chapter (see page 353).

From Mr. J. C. Bailey, the Managing Director of the Burslem Royal Doulton Potteries, the leading and guiding hand in Lambeth too, I have received a booklet, " The Royal Doulton Artists," written by William Owen, who began his career as a potter with Messrs. Pinder, Bourne and Hope fifty years ago. The last thirty years, which cover the period when Henry Doulton's influence was paramount from the time he joined Pinder's, have seen an immense development in the fictile art of these works. Mr. Bailey's efforts exerted in the same direction have been equally successful, if not more so, judging by the lovely specimens which he very generously presented to me, pieces of rouge flambé, peach blow and other mottled reds, and a crystalline blue and grey incomparable; vases of fine shape and delightful texture. The artists employed during the régime of Doulton, and later, were ably led by Mr. John Slater, the Art Director from 
Pinder's days, who in these later years has received the invaluable assistance of Mr. C. J. Noke.

John Slater, a native of Derby, trained at the Stoke-uponTrent School of Design under Silas Price, was apprenticed with Minton's when M. Arnoux was their Art Director. He won in open competition the first prize for two years in succession at the Hanley Exhibition. Coming to Pinder's, he improved his position by his talents under Doulton, eventually reaching the top as the Art Director, where his work has long been appreciated and his influence valued.

Charles J. Noke, twenty years ago, joined Doulton's at Burslem as a modeller, and his experience gained at Worcester was devoted to the improvement of shape and line, a special field which he made his own, placing form and modelling on a par with decoration, for which the factory had long been noted. Holbein ware was one of his products ; fine decorative panels painted in collaboration with Hodkinson were others. But especially must he be credited with the coloured glazes which have been mentioned, and with a raised, chased gold decoration which, I believe, is superior to any ever produced. Mr. Noke is a keen student and an artist of great power. His versatility is equal to his ability, and both are fascinating.

Edward Raby, also trained at Worcester, is a great painter of flowers upon pottery. Rich combinations of colour and a fine finish show him to be an adept at nature-study, a master indeed, one of the first flower painters of his times. His rare skill and knowledge, the beautiful colour-blending of lovely forms, and the excellence of each individual bloom are alike remarkable.

Robert Allen was apprenticed under Slater at Doulton's, Burslem, in the beginning. Like other of the artists he has been awarded medals and diplomas at the exhibitions, and with those artists he works as the designer of patterns in raised gold, beautifying the finest landscapes and flowers with fine taste and style. This form of decoration is applied to the most expensive productions.

David Dewsberry was trained under the Alcocks at the 

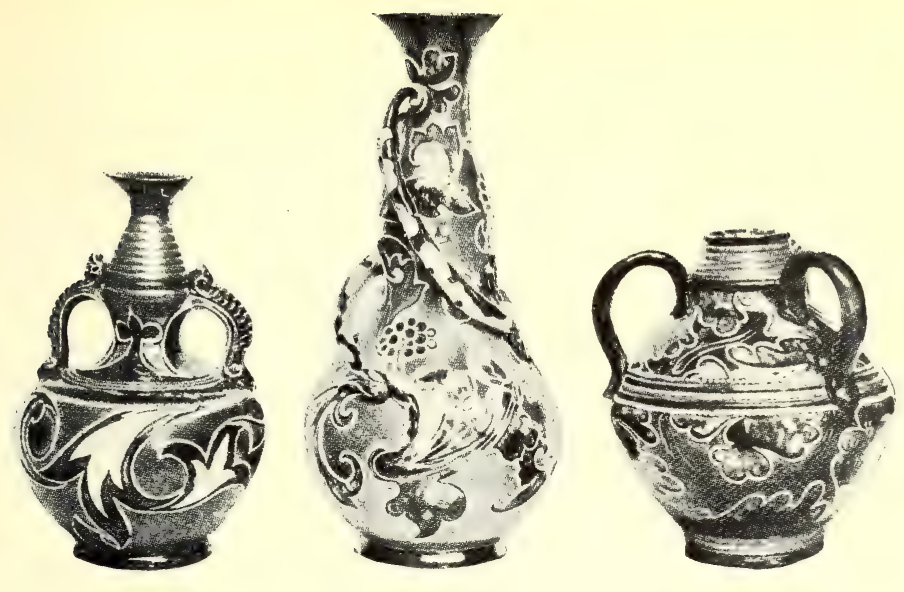

DOULTON WARE.
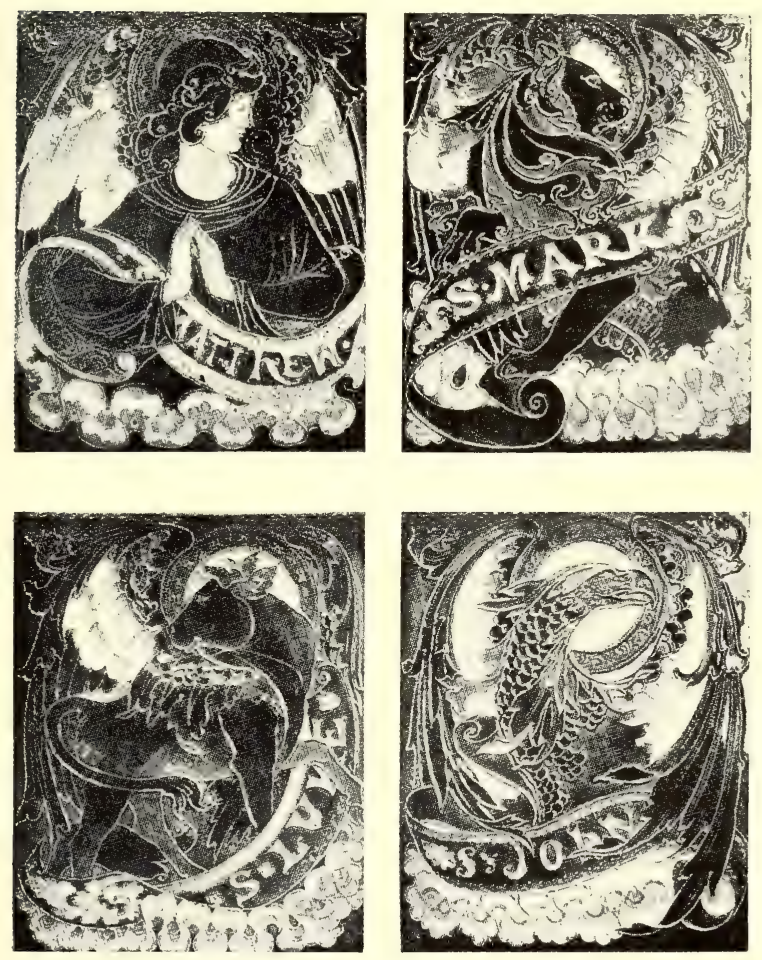

TILES. DOULTON FAIENCE GLAZED,

THE FOUR EVANGELISTS. 

Hill Pottery, Burslem. Medals and prizes have come to him, but his rarest distinction is the title "The Painter of Orchids." When you see a plate like the one in the frontispiece, or a vase painted with these ravishing flowers by the master's hand, it would be worth your while to get it and keep it. Nobody ever had such fidelity, such grouping, such boldness, and yet such delicacy in painting orchids as Dewsberry.

John H. Plant was trained at Cauldon and Coalport. When he came to Doulton's he developed the powers of a landscape painter which have reached a rich maturity. Amongst his work the Scenes of Venice take a high place. Old-world buildings, soft Italian skies in perfect blue or rosy red, these are scenes in which Plant delights.

George White was trained at South Kensington and Lambeth Art Schools, and at Doulton's he is the chief figure painter. Not only does he depict " the human form divine" with beauty, grace, and delicacy, but he has the unusual power of fixing the personality of his subject; as a portrait painter he "catches the likeness," which is more than can be said of many who profess to paint portraits.

William Hodkinson followed Slater's footsteps, being a native of Derby and an apprentice of Minton's under M. Leon Arnoux. As a decorative artist he has shown at Doulton's for more than twenty years his ability as an enamel painter and gilder, his work being of the best quality. In connection with the coloured glazes, his past has been both creditable and prominent. Diplomas and prizes have rewarded his labours.

Herbert Betteley, another decorative artist, has charge of one of the chief departments of Doulton's productions. His position was the outcome of his skill in his art and his power to guide and control others. Delicacy, taste, and harmony characterise his ornament. His training was local.

Percy Curnock, another artist of local growth, is an artist of no mean ability, whose pleasing style and thorough painting are very attractive. Flowers and figures by him show a high standard which gives them much value. 


\section{I9TH-CENTURY ENGLISH CERAMIC ART}

Leonard Langley; William Johnson, designer; William Skinner, gilder; Richard Ridgway, gilder; Wilmot Brown, landscape painter; Joseph Hancock, who specialises in painting animals, birds, and fishes; William Allen, and Charles Vyse, engravers; Charles Hart, another painter of game and fishes; Alfred Baker, modeller; Lewis Swettenham, etcher; and Arthur Eaton, decorative artist-all these are men who, by their devotion to ceramic art, have helped to bring fame to Doulton's. They live yet, and my short sketch does less than justice to their work. Yet it must suffice, because I wish to note some that have passed out of the activities into the Beyond.

Henry Mitchell excelled in painting animals. One who knew his work has left a record, "There were few things more beautiful in ceramics than Mitchell's silver greys in landscape middle distances." Indeed his delicate touch enabled him to produce atmospheric effects of uncommon beauty.

Sam Wilson painted landscapes, and nature in ever-varying moods; hill and dale with deer or cattle were not depicted more successfully, however, than fish and game. In all he did, his excellence was manifested, so that signed pieces painted by him are certain to increase in value.

Walter Nunn illustrated very ably the scenes and characters from Shakespeare's plays. Historically accurate, finely executed, his works are highly estimated.

Enoch and Harry Piper, father and son, both worked at Doulton's. Enoch was the heraldic artist, painting, amongst other services, one for King Edward VII., which was decorated with the King's crest. Harry was specially skilful in depicting the rose- "The Doulton Rose."

Amongst the coming men are several giving signs of great promise; Harry Tittensor, a young figure painter, and Harry Allen, Robert's son, a painter of Eastern scenes, for instance.

Speaking generally, the prospects of the firm are excellent. It has adopted a good policy. Commercially, it manufactures only what is of good repute. Artistically, it employs only 
good artists, and these love it and support it all they can. The pre-eminence of Doulton ware is assured. But why is it that in every town many shops sell only the cheap goods, mostly of foreign origin, when English artisans, artists, and manufacturers deserve the patronage of every Briton? Whether for the rich man's table or the poor man's home, English china and pottery can satisfy every requirement, and Royal Doulton is amongst the most desirable.

Sir Henry Doulton died on November I8, I897, and was succeeded by his son, Mr. Henry Lewis Doulton. To the Directors of Doulton \& Co. Ltd., especially to Mr. J. C. Bailey, my warmest thanks are due, and also to Mr. Mott, Art Director at Lambeth, Mr. Noke, Assistant Art Director at Burslem, and Mr. Shorter.

Summing up in a few words; the progress made at Doulton's works has been very wonderful. An enlightened policy has been ardently pursued with unceasing vigour. The artists received great encouragement from Sir Henry Doulton. The firm can reflect with just pride upon that perfection which in its admirable productions has brought fame and success, not only to Lambeth, but also, with china, to Burslem.

\section{Lambeth : Stiff and Sons}

In 1840 the London Pottery in High Street, Lambeth, came into the hands of James Stiff, and the firm became, in due time, James Stiff and Sons, which is its present title. The growth of the works has been great and gradual, necessitating new buildings in I86o. In 1878 they manufactured four principal kinds of pottery: brown salt-glazed stoneware, white stoneware, buff terra-cotta, and porous ware. The white stoneware has to a large extent superseded the old brown, being superior in its appearance. In addition to the four classes into which the productions at the present time may be divided, I must mention the Lambeth jugs in stoneware, 
because they are excellent in shape, design, and make, though the same qualities characterise the whole of the productions which come from these works, to be distributed at home and to almost all parts of the world. The useful qualities of the hard stoneware, covered with an excellent salt-glaze so necessary for sanitation, of the porous cells, and plates for the electrician, who also needs stoneware for his battery jars, and of the terra-cotta which is thoroughly vitrified for the architect, are not surpassed by any other house. Sanitary and electrical pottery have an immense sale; the following
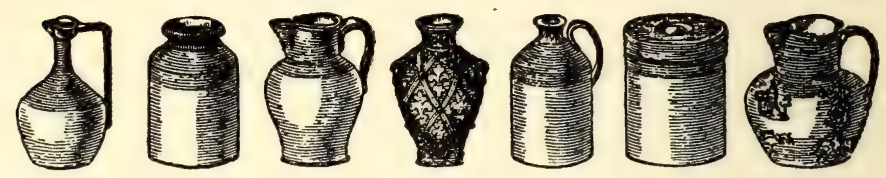

list, from an advertisement in I900, indicates the chief classes of goods which the firm now makes: stoneware bottles, jars, jugs, pans, barrels, ginger-beer bottles, cream-jugs, etc., chemical apparatus in vitrified stoneware, battery jars, insulators, porous cells and plates, etc., drain-pipes, sewer-air traps, and sanitary stoneware generally; architectural terra-cotta, chimney-pots, garden-vases, etc., water-filters, etc. Attention might well be given to the effective water-filters by those who must filter their potable water. For about fifty years these have been largely used. They are supplied with filtering materials, which retain their efficiency for some eight years without any trouble, and their cost is quite moderate.

\section{Fulham: De Morgan}

The best imitation of the fine old lustre, the marvellous creation of the old makers of majolica, is produced by the firm of Messrs. De Morgan \& Co. Since I87o William de Morgan's work in this direction has resulted in much success. After I888, when distinct improvements marked the products 
of the Fulham works, the comparative hard and distinct colours yielded in favour of those which, as it were, tone into the background, forming a haze of colour. The pottery at Fulham is decorated after designs by the founder of the factory, though much of the actual painting is done in Florence and brought to England to be fired. The differences in the painting of the Italian and English schools are evident, in the superior freedom of the former. In addition to the majolica, Persian pottery is produced, most delightful in its colour, rivalling in its intense blues those tones for which the old Persian potters of whom we know so little were famous. Amongst the many commissions which this firm has executed was a frieze of tiles for the Woburn dairy for the Duke of Bedford. The frieze, with a design of quaint parrots, surmounts a wall covered with tiles in pale blue.

In view of the many failures to produce ware decorated in these old styles by potters generally, and remembering, too, that there is more uncertainty with such decoration, even in skilled hands, than perhaps any other, it is pleasing to record the success of this firm. The pieces which reach the standard of excellence which satisfies the artist producer are amongst the highest products of modern ceramic art. The mark employed is D. M., over a tulip with two leaves.

\section{Southall : Martin}

The history of the Martin brothers has much of human interest : it tells of struggles against many difficulties, before success was in sight, and it records a heart co-operation which alone made that success possible. The brothers, Robert Wallace, Charles, Walter and Edwin, who under the title of R. W. and Bros. Martin, founded the Southall Pottery, Southall Green, started in a very small way in Pomona House, King's Road, Fulham, where they began to learn the trade. Robert was a sculptor's assistant, skilled in modelling and carving; Charles had received some art training, and the other two had been employed at Doulton's in the mechanical part of the decoration of the ware; they filled in with colour 


\section{I9TH-CENTURY ENGLISH CERAMIC ART}

the designs, which the artists scratched upon the ware, termed from this sgraffito. Both of them were students at the

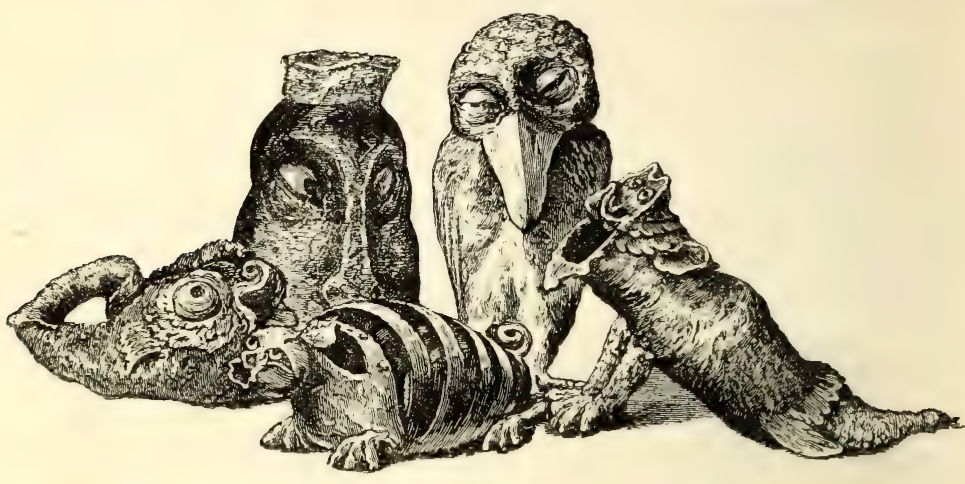

MARTIN WARE.

Lambeth School of Art, which Sparkes ruled admirably as head master.

These two acquired the art of the thrower, and all of the

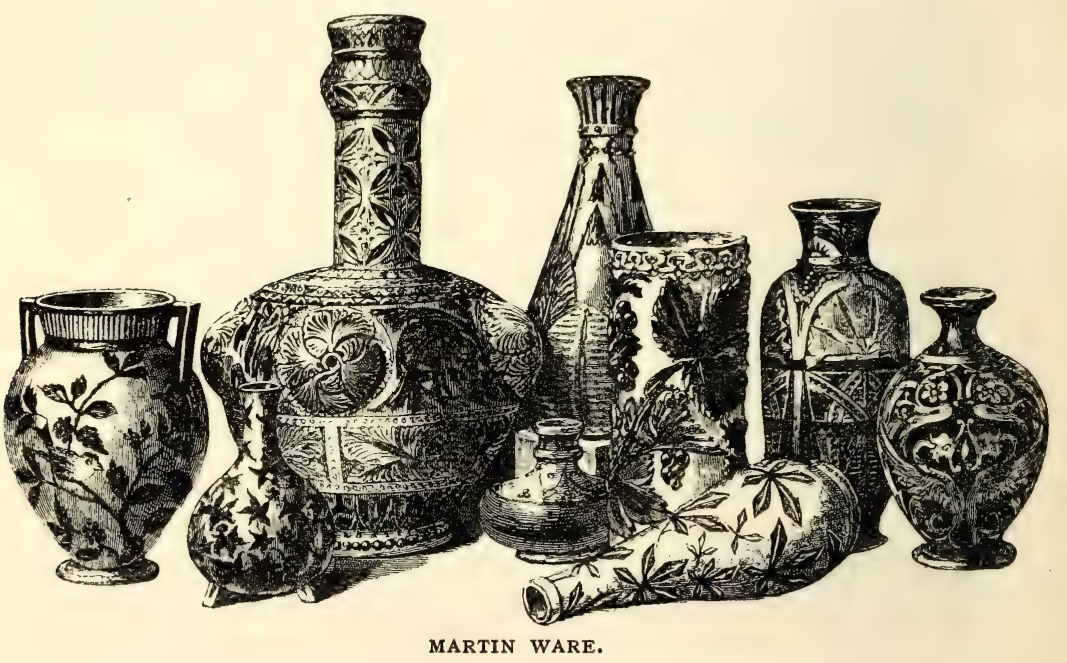

brothers were able to take part in the decoration of the stoneware, which was afterwards glazed with salt. The produc- 
tions of the firm were many forms of vases, bottles, bowls, grotesque figures, etc. The ornament consisted of conventional and natural forms, raised modellings and sgraffito, which was painted with various colours. All of these processes were executed upon the clay, before it was burnt, and they exhibit much cleverness and fertility of resource. Martin

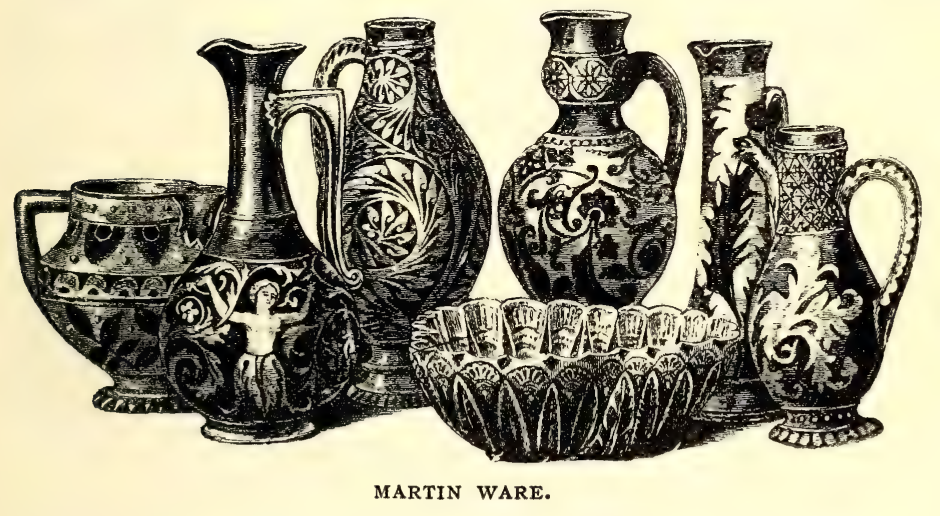

ware is distinctly original: "In character sculpturesque, architectural, and naturalistic in turns." When we consider that about 1875 the brothers, with no practical training as potters, had mastered the difficulties of grinding and mixing the clays, of throwing and decorating the ware, and of burning it in a salt glaze kiln, we may reflect that it is a fine example of determination overcoming obstacles, and of energy directed and dominated by co-operation. The address of the firm in Igoo was I6, Brownlow Street, High Holborn.

\section{Blackfriars Road, London: Blanchard}

In I839, M. H. Blanchard established terra-cotta works at Blackfriars Road. He had been an apprentice to Coade and Sealey at Lambeth, where artificial stone vases, statues and architectural ornaments were made. About I840, after Coade's had changed ownership several times, the works there were closed, and the model moulds, etc., sold by auction. Many of them were purchased by Blanchard, who exhibited 
some of his productions in $\mathrm{I} 85 \mathrm{I}$ and $\mathrm{I} 86 \mathrm{z}$, when he was awarded medals for his terra-cotta. The quality of the material and the designs are both above the average, so that a considerable trade at home and abroad is not surprising. Those who are familiar with the Brighton Aquarium will remember its terracotta decoration by this firm, which was also employed in conjunction with Blashfield, of the Stamford Terra Cotta Co., to supply the panels used on the exterior of the Burslem Institute.

Blanchard executed twelve panels large and nearly square, each one representing one of the months-no slight task when we consider that each panel contained one figure, with the attributes of the month in alto-relievo. Blashfield's twelve panels illustrated the processes of potting. These were designed and modelled by W. J. Morris at South Kensington in clay, sent from the Stamford Docks, to which they were afterwards returned, cut up into suitable pieces for firing, carefully dried and burned, issuing from the kiln in a perfect state. In coupling these two names, credit must be given to each. Both produce faultless work, having the details clearly moulded, with a finish which cannot easily be surpassed in a body of fine quality. Vases and architectural details are produced by both firms in great variety, together with statues and busts of much merit; many of them are copied from the antique. The marks used by Blashfield were the impressed name, with STAMFord or STAMFord TERRA-COtTA Co., LtD.

Amongst the London potters whose names appear in the Igoo list are the following: J. H. Bale, art potter, Westbourne Grove ; J. Bourne and Son, Euston Road ; F. Brayne \& Co., Bow Pottery; E. G. Cole, Tottenham; Cooper Bros., tiles and mosaic, Kensal Green ; Doulton \& Co., Lambeth Pottery ; Fulham Pottery and Cheavin Filter Co.; H. Goddard, Peckham ; G. Jennings, Clapham; Martin Bros., Brownlow Street, High Holborn; J. Mundy, Upper Kennington Lane; T. Pascall and Son, South Norwood; C. G. Picking, New Southgate; J. H. Sankey and Son, sanitary, Canning Town; 

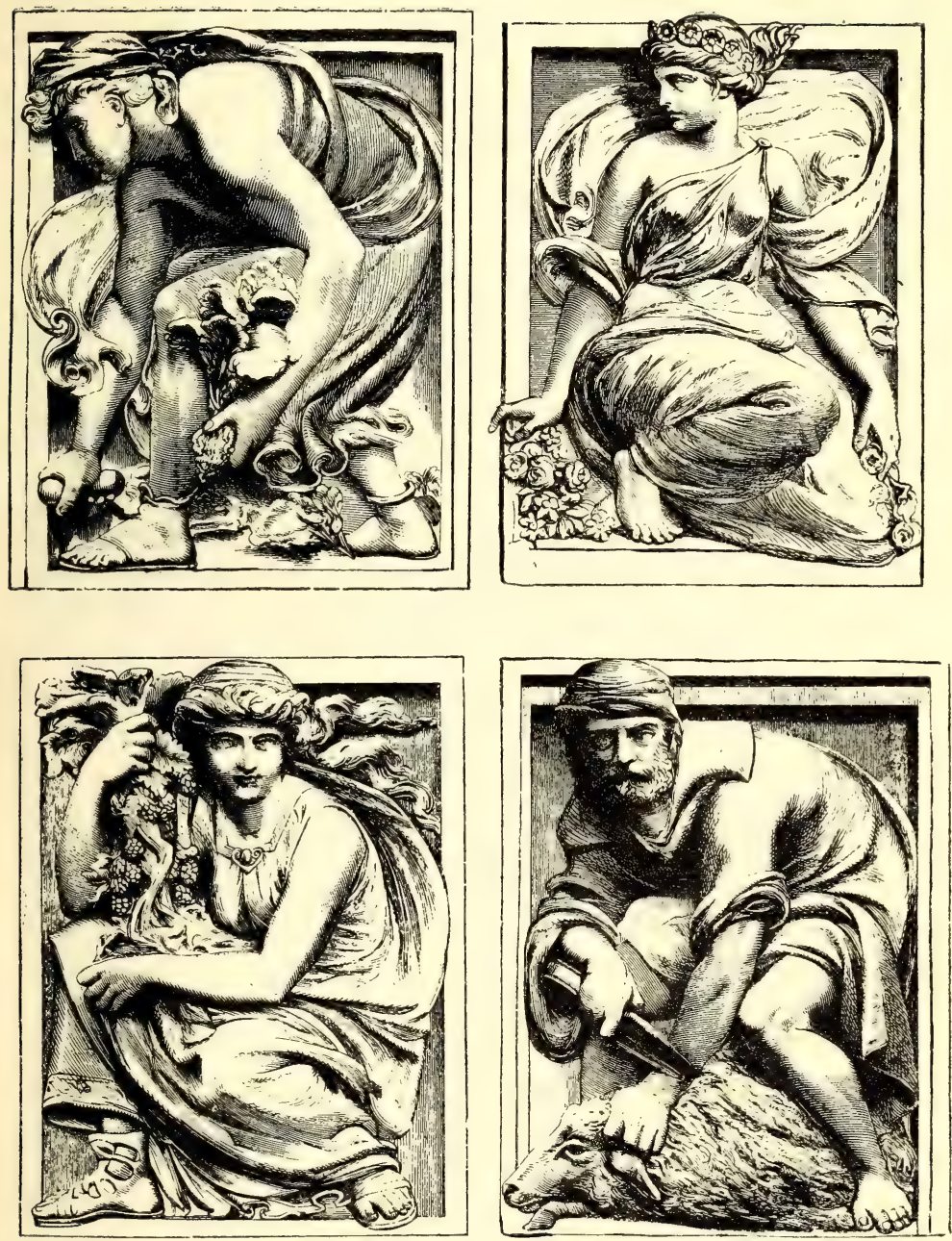

BLANCHARD'S PLAQUES IN TERRA-COTTA. 
Simpson and Rattenbury, Norwood Pottery; S. South and Sons, Tottenham ; J. Stiff and Sons, London Pottery, Lambeth and Tugby, Hosea \& Co., Old Kent Road. A few of these, such as Doulton, Martin Bros., and Stiff and Sons, have been dealt with, but where only architectural tiles, terminals, etc., are made no necessity exists for treating of work which is common to a large number of the potteries distributed over the country.

\section{Sussex Rustic Ware: Mitchell}

The Sussex Art and Ruskin Ware manufacturer, at the Belle Vue Pottery, Rye, is Frederick Mitchell, and the works have been established for half a century in the quaint old town which has been for generations the home of the family of Mitchell, potters, under whose successor came the evolution of an ancient art, in which the ordinary domestic ware has disappeared and given place to an artistic industry. Ordinarily, Sussex is ignored as an art-producing centre of pottery, common tiles and better red ware for house decoration being the industries chiefly named in this connection, and Rye, if mentioned, is described as a place where pottery, at one time, was made, though the continuity of the work has never been broken, and the secret of the mixture of the local clays has been carefully guarded, though a cream-coloured clay is also used.

From the local clays, brown-ware of a peculiarly pleasing character is made in a large variety of flower-baskets, candlesticks, jugs, pilgrim-bottles, vases, etc., which are decorated with modelled foliage, flowers and branches, and especially with the clinging hopbine. The clay is unusually light, and, though not of very close texture, it can easily be worked into any form. The peculiar brown, rich in tone, is of exceedingly good quality, and has a pleasing effect when associated with the mottling or splashing, which so often occurs, where the brown and exquisite shades of green sometimes inclining to yellow cover the modelled surface. In the cream ware, wicker-work or plaited work-baskets are made; cleverly manipulated strips of clay are treated most effectively in 


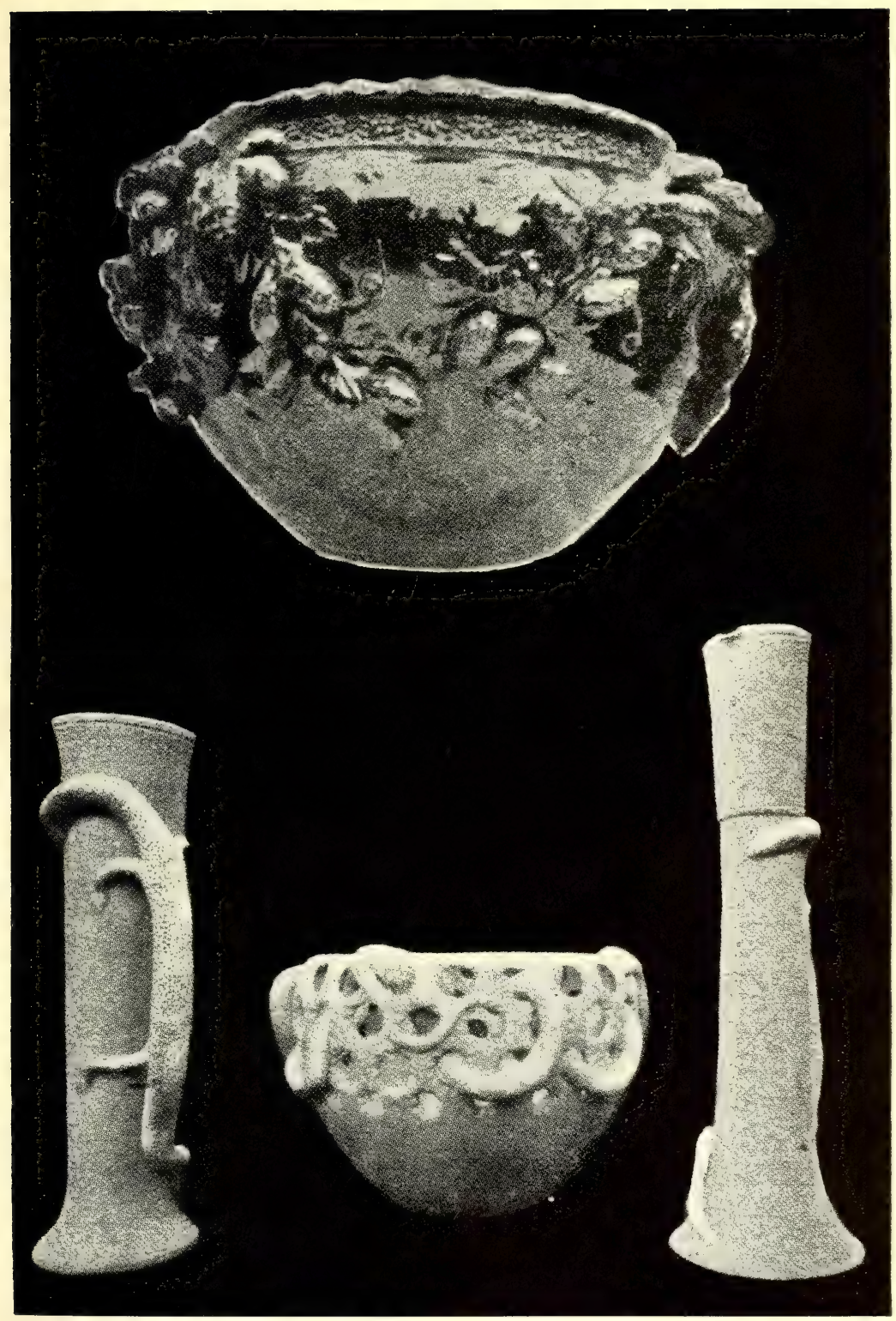

MITCHELL'S SUSSEX RUSTIC WARE. 

bowls and vases, which show precision and delicacy in this style of design. One product, which was also made at Cadborough, near by, is the Sussex pig, a drinking-vessel, resembling in its general character the "bears" which were made at Nottingham and Brampton. The body, when filled with ale, stands on end, and the head lifts off, to be used as a drinking cup, exactly in the same way as with the "bears." In rural Sussex these "pigs," when filled, are carried round to the guests at wedding feasts, so that they may drink a hogshead of beer to the health of the happy pair. The

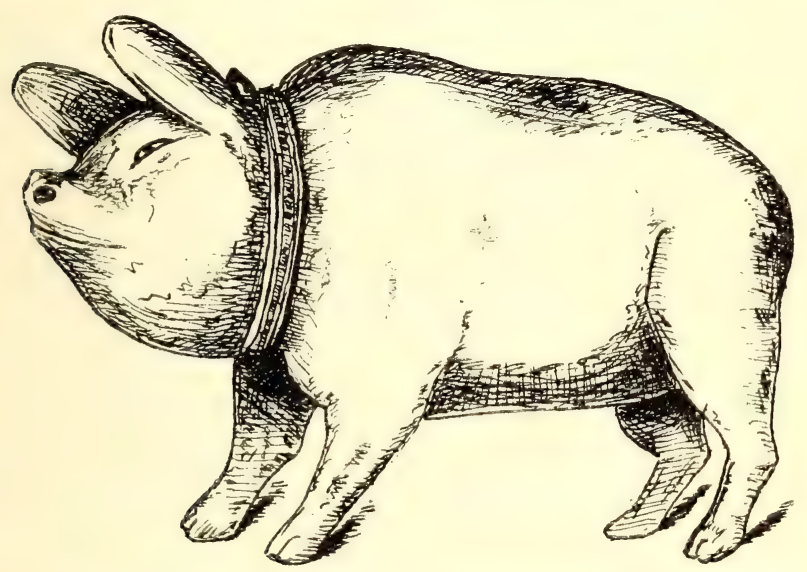

A "SUSSEX PIG" IN BROWN GLAZED EARTHENWARE-A VESSEL WiTh MOVABLE HEAD, SERVING AS A DRINKING-CUP.

same practice used to prevail at various social and convivial gatherings.

The Bellevue Pottery was founded in I869, but the same family of potters, the Mitchells, had in I840 acquired the Cadborough Pottery close by, where the ordinary common brown wares, glazed and unglazed, were made with the pitchers, crocks, and pans so widely produced all over the country. The Cadborough works were founded in 1807 by James Smith. They need no further comment, except that from them the fancy department-if we may so term it, the creation of F. Mitchell-developed, the modern Sussex 
art pottery, which cannot be described by any better word than " rustic," being the practical embodiment for the most part of nature-study.

The Crowhurst Pottery at Battle; the manufacture of brown ware, flower-pots, etc., by R. and N. Norman at Burgess Hill, and at the Chailey Potteries, the East Grinstead Pottery of $\mathrm{H}$. Foster, the Pottery works at Hellingly owned by B. W. H. Bridges and by U. Clark, are examples of those in Sussex, similar to others in many parts of England. Here and there occur isolated art potteries which have owed their origin and growth to the inclination or inspiration of some individual, who felt within himself the desire to better what was done. These art potteries are very interesting studies, though they have but a slight bearing upon the amount of the manufacture, many being small and mainly local in their distribution. 


\section{CHAPTER XVI}

\section{NEWCASTLE， SUNDERLAND AND DISTRICT}

\section{Newcastle-on-Tyne: Maling and Sons}

THE business carried on by Messrs. C. T. Maling and Sons at the immense Ford potteries is the oldest of its kind on Tyneside. Many have departed, this remains as one of the most noted in the kingdom. John Maling and his brother Christopher Thompson started a pottery near Sunderland at North Hylton, where ordinary white and rockingham (brown) earthenware were produced, in I762, just after George III. ascended the throne. Enamel and Sunderland lustre wares followed, and became a successful part of the manufacture. Then, in $18 \mathrm{I} 7$, Robert Maling succeeded his father, and soon transferred the business to Newcastle, where it has since remained. In I855 his son, another C. T. Maling, developed a small pottery, with only two kilns, into the great works, which have required repeated additions, owing to the growth of business. Into the Ford potteries, which took the place of the Ouseburn Bridge pottery, were brought all the best machinery, and all the newest processes, which produced earthenware so excellent, so much in demand, that another pottery was built. The first, known as the Old or "A," converts over eighty tons of clay into articles of earthenware in a week. The new one, or " $\mathrm{B}$," erected in 1879 , was the largest and best equipped works then existing in England.

The notable articles, manufactured by the aid of a thousand men and girls, are mugs, jugs, jam-pots, jars, and bottles. The mugs and jugs are mostly in the " $\mathrm{A}$ " department; in the "B," about a million and a half pots and jars of all shapes form the staple product. But C. T. Maling and Sons are I6 
makers of far more attractive objects than these, a wonderful variety of table, toilet, and household ware, distinguished by exceptional artistic designs, may be highly commended for decoration, which is distinctly good ; a large staff of artists, designers, engravers, modellers and lithographers is employed on the premises, which gives this firm great advantages over others, whose decorative designs are procured from sources outside their works, because the whole of the work done in these factories is exclusive: new shapes, new patterns, and novelties of many kinds. The flint mill is another instance; some firms buy their ground flint, but at the Ford potteries there is an immense mill, capable of dealing with a hundred tons of flint and Cornwall stone per week. Just as the output is varied and enormous, so the quality of the ware is all that could be desired, the finish is perfect, the colouring of the finer goods delightful, bearing evidences of considerable originality and taste.

In I889, C. T. Maling took his three sons John Ford, C. T. Junior, and F. T. into partnership, and in $\mathrm{I} 899$ he retired. The title of the firm has been continued. Before either of these events took place the father prepared an account of the earthenware works of Newcastle for the British Association in 1865 , which follows this paragraph. It only remains to add that the firm possess a reputation and a trade which are world-wide. In their specialties they have received, during many long years, the custom of other manufacturers of other commodities, which must be preserved in pots, jars, and bottles. When, in days of keen competition, such conditions of mutual satisfaction prevail, the result must be gratifying to all concerned. I should like to remark that, during the last ten years or so, Messrs. Maling have substituted, for raw lead used in the glaze, a remarkably successful "fritted" lead, which has had the effect of preventing lead poisoning. During that period they have not had a single case in which a worker has been seriously affected. These masters show special and careful consideration for their work-people.

Omitting the potteries just described, Mr. Maling's account shows that the manufacture of white ware was introduced 


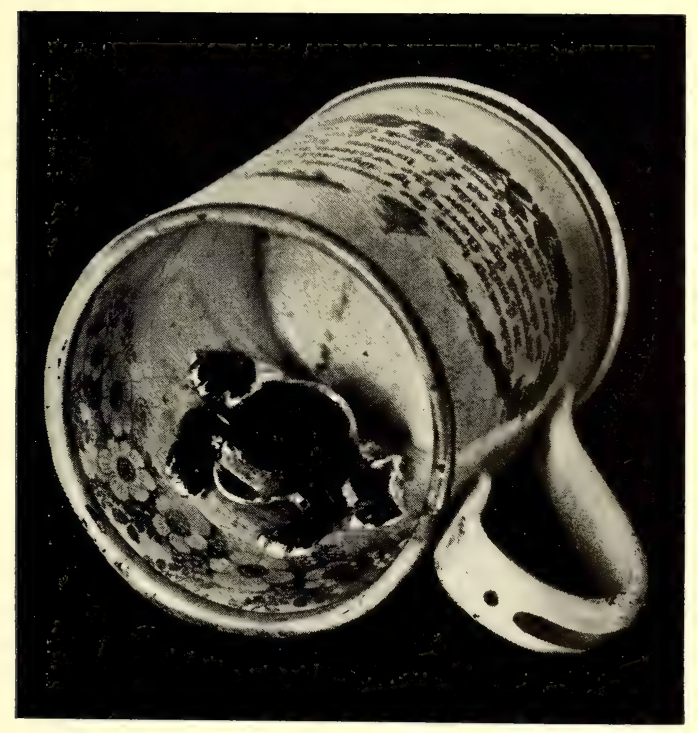

SUNDERLAND LUSTRE WARE. A FROG MUG. From Miss Edith Feilden's Collection.

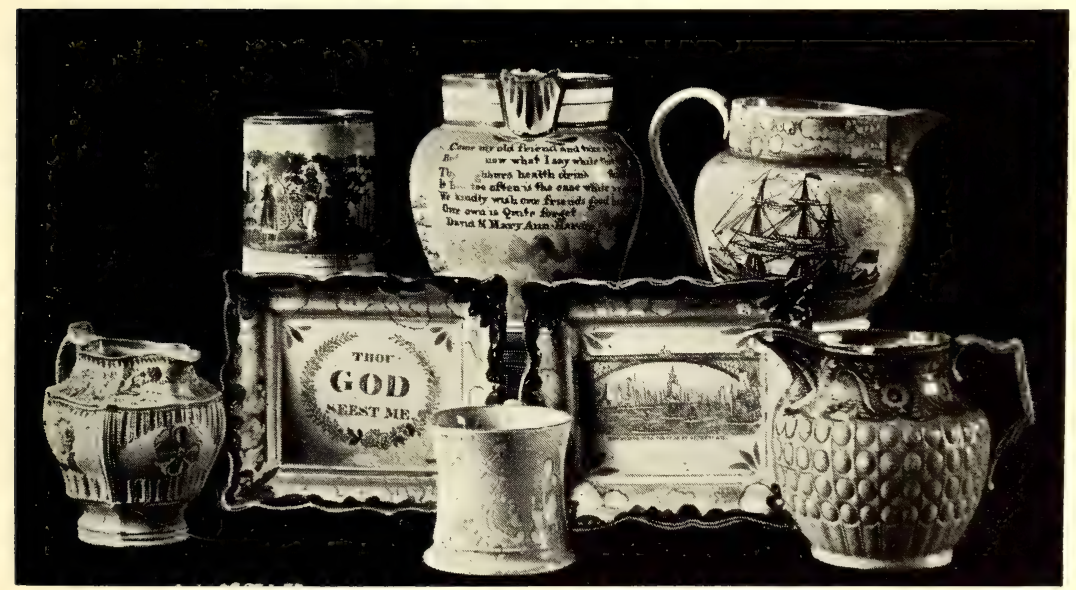

TYPICAL SUNDERLAND WARE. 

into this district by Warburton at Carr's Hill pottery, near Gateshead, about I735. After a successful existence for some years they declined, and were closed in $18 \mathrm{I} 7$, though some part of the building is still used for a brown-ware works. The next establishment was started at Newbottle, in the county of Durham, about I755; in it brown and white ware are still made. St. Anthony's; Stepney Bank ; and Ouseburn commenced some twenty-five years later. We noted that Ouseburn became the site of Maling's "A " factory. Messrs. A. Scott \& Co., and Messrs. Samuel Moore \& Co., erected potteries at Southwick, near Sunderland in $\mathbf{I} 789$ and 1803 respectively. The pottery carried on by Messrs. John Dawson \& Co. at South Hylton was built by them in I 800 .

Many of these potters manufactured lustre ware, which was usually white earthenware, decorated with black transfer printing in pictures, rhymes, songs and texts, and with pink or purplish lustred metallic colours. One further reference will be made to the Iron Bridge over the Wear, which was opened in 1796 , and depicted so often on jugs and mugs, which are found now and then, with a frog modelled inside. Such pieces were great favourites with the sailors, who liked the ships in full sail, the farewell scenes, and the verses; and the vogue for collecting them has arisen, though the artistic value of daubs of pink lustre upon a glazed white jug or bowl is small. Some pieces show evidences of careful marbling in lustre, others are painted with lustre designs, and these are much more acceptable. The lustre ware made no pretentious claim to be regarded in any way as art work; it was suitable for the requirements of those who bought it, and its verseswell, they too were typical, as those following will show.

On a frog-mug, printed in black with monument and trophies in memory of Lord Nelson, inscribed "Newcastle pottery," is the following :

" Remember whilst his mortal part has rest Th' immortal lives in every Briton's breast ; Tho' short his Span of Life, recording fame Inscribes a deathless Volume to his Name; 
Mourn not for me, 'tis vain, chase grief away,

Compleat (sic) my work and crown the glorious day;

Behold! 'tis done, his parting spirit flew,

And lighting rests, brave Collingwood, with you."

The next verse is found on a pint mug, printed in black, with "An East View of the Iron Bridge Over the Wear, near Sunderland; foundation stone laid by R. Burdon, M.P., Sept. 24th, '93"; inscribed "Edwd. Barker" :

" Glide on my bark, the summer's tide Is gently flowing by thy side ;

Around thy prow the waters bright, In circling rounds of broken light,

Are glit'ring as if Ocean gave,

Her countless gems to deck the wave."

On an earthenware bowl, ornamented with nautical subjects, transfer-printed, coloured, and bedaubed with purple metallic lustre, appears :

\section{"THE SAILOR'S TEAR.}

" He leap'd into the boat, As it lay upon the strand,

But, oh! his heart was far away

With friends upon the land;

He thought of those he lov'd the best,

A wife and infant dear;

And feeling fill'd the sailor's breast,

The sailor's eye-a tear."

The illustrations show various mugs, jugs and plaques which were made in this district; one of the plaques has a print of the bridge, just described. The purple and pink lustre, the views, ships, and verses decorated the white ware, which must be distinguished from "Sunderland ware," the brown earthenware, resembling what is known in the trade as "rockingham." Generally speaking, these factories in the north, which produced the old ware, failed to equal the lustre ware of Staffordshire, Leeds, Swansea, etc., but the characteristic nautical decoration of the mugs and jugs is quaint, as I have shown, and the feelings expressed, though 


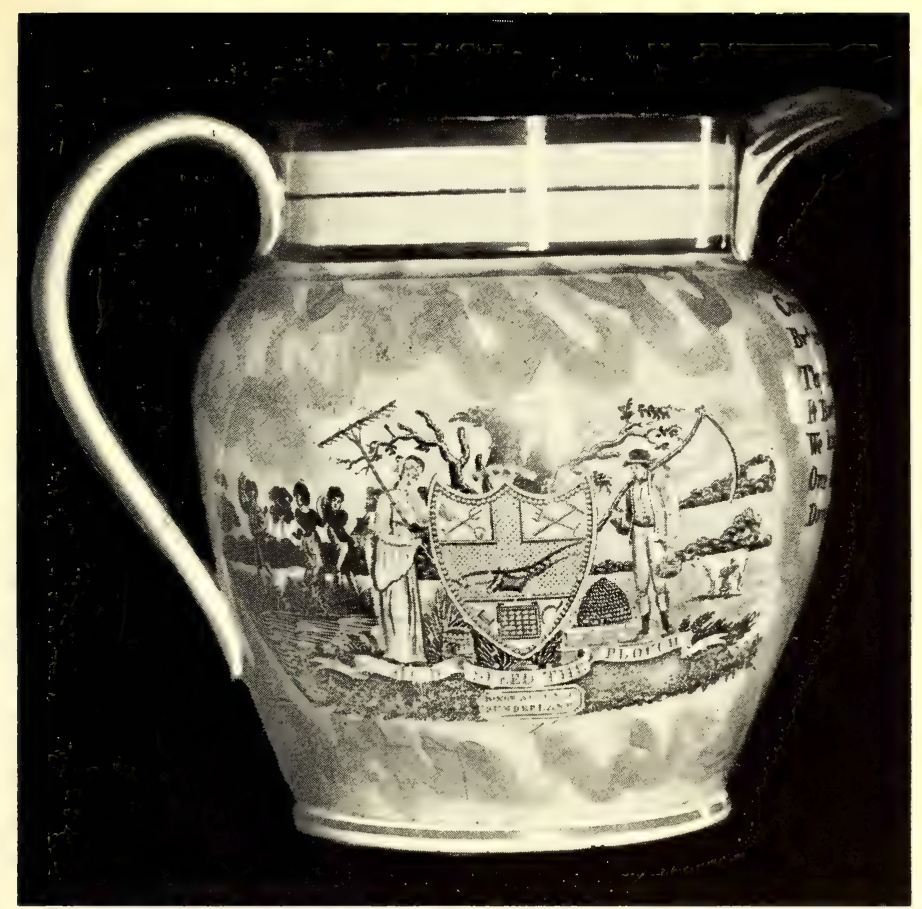

SUNDERLAND JUG MARKED "DIXON, AUSTIN \& CO., SUNDERLAND."

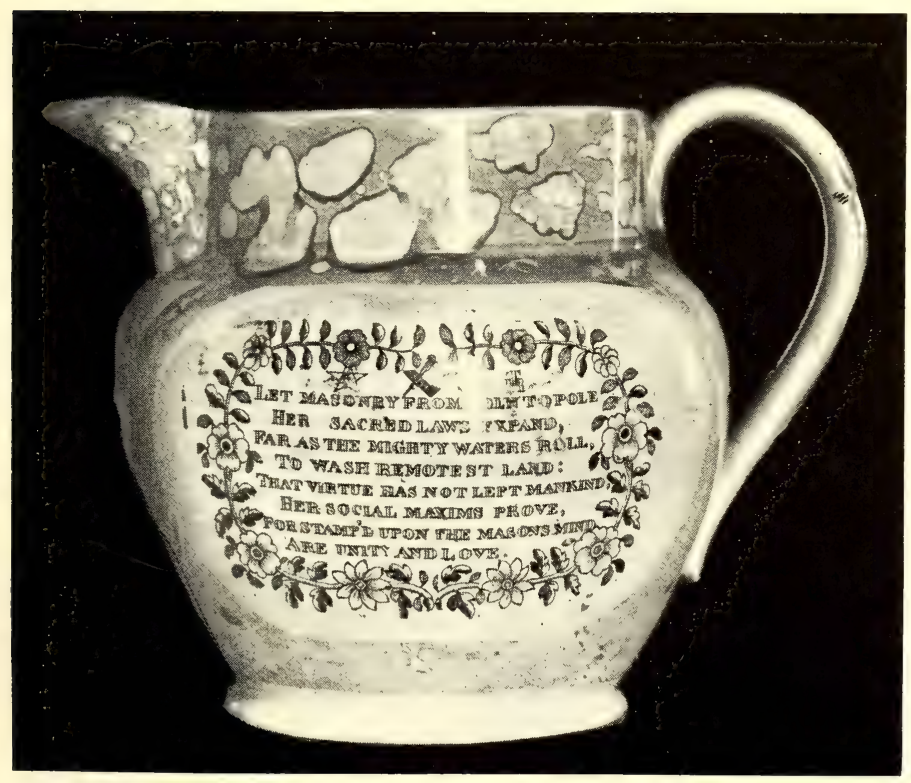

SUNDERLAND LUSTRE JUG (MASONIC). 

in doggerel verse, breathe with love for home and country and often express considerable shrewdness too, as here :

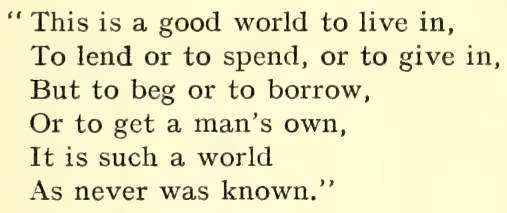

Then, again, amongst expressions such as "Jack on a cruise. 'Avast there! Back your maintopsail!'” we find verses which compare favourably with some of the hymns used in places of worship. I give one example :

\footnotetext{
"There is an hour of peaceful rest

To mourning wanderers given;

There's a tear for souls distrest,

A balm for every wounded breast-

'Tis found above in Heaven."
}

In I866 there were about twenty-five potteries on the Tyne, the Wear, and the Tees, producing earthenware of the annual value of $f_{1} 190,000$. In 1876 the Newcastle potteries were the Forth Banks, or Newcastle; the Stepney Bank; St. Anthony's, one of the oldest, noted for the mark Sewell and Donkin; the Ouseburn and the Ouseburn Bridge, and, of course, the Ford "A." In I90o the names given include Burnside Bros., Lime Street, Ouseburn; Patterson \& Co., Pottery Bank, St. Anthony's; Wallace \& Co., Foundry Lane, Ouseburn; J. Wood \& Co., Stepney, and C. T. Maling and Sons-Ford "A " and "B."

St. Anthony's may be taken as a type of the best of the old potteries in this district for the manufacture of ordinary earthenware. The information about it occurs in a letter to Jewitt, from the old manager, just such a letter as many I have received from the proprietors of existing works. Here is the letter :

"I cannot go back to say when first begun as a Small White and Common Brown Ware Works, but about I803 or I804 it was taken by the Sewells, and gradually extended by 
them for Home trade until I8I4 or I8I5, when a considerable addition was made to manufacture entirely for exportation, chiefly C.C. or Cream Coloured, Painted, and Blue Printed, and when I came to the Works in I8I9, the description of ware then produced, say about five Gloss Ovens, and two or three Enamel Kilns per week, say C.C., and best Cream Colour to imitate Wedgwood's Table Ware, then made in considerable quantities for Holland and other Continental markets, all kinds of biscuit painted, printed very dark engraved patterns, also stamping with glue, and printing on the glaze from wood engravings, also with glue, I believe the first that was done in this way, gold and silver lustre, etc. So it has been continued up to the present period by the Sewell family; but latterly not doing so much business, owing to a change of partnership, and is at present in the market for sale, since the death of Mr. Henry Sewell, the natural son of the late Joseph Sewell, who was the potter for nearly sixty years, and was a noble specimen of a good master and the old English gentleman."

Many interesting items of information are here given, the stamping and printing with glue, and from wood engravings, being amongst them. Bat-printing was the process of decorating glazed earthenware or porcelain, by means of a gelatin or glue pad. The lines of the pattern were transferred in linseed-oil from the incised plate or block to the pad, and thence to the ware, and this oil-impression was then dusted with colour-a metallic pigment-which was fixed by firing. Much of the early nineteenth-century work was decorated by this process, and it can be easily distinguished from other methods, being upon the surface of the glaze, "Sewell," or "Sewells and Donkin," is only one of the names from this district, which appear on similar ware to that described in Stevenson's letter.

About the beginning of the nineteenth century Messrs. Dixon, Austin \& Co. owned or leased the potteries at Monkwearmouth, Sunderland. Pieces of ware, printed, coloured and lustred, have been found with the mark "W. Dixon, I8II," andothers with "Dixon \& Co., Sunderland Pottery," or the full title of the firm. Curiously enough, "Phillips \& 

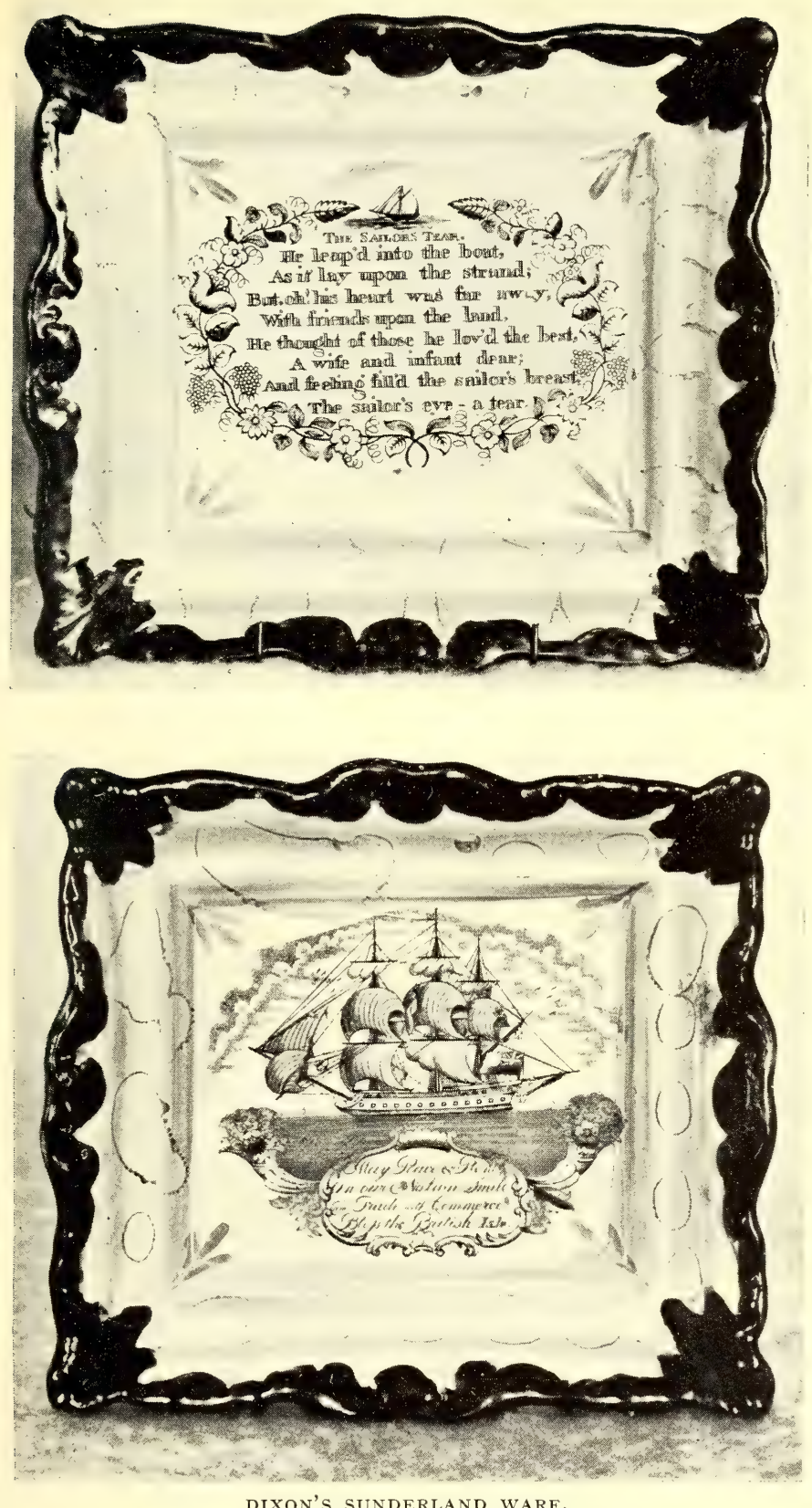

DIXON'S SUNDERLAND WARE。 

Co., Sunderland, I8I3," or simply “Phillips \& Co.," with or without "SUNDERLAND PotTERy," were the marks upon exactly the same kind of ware. When, in $\mathrm{I} 8 \mathrm{I}$, Robert Maling removed from North Hylton, Dixon, Austin, Phillips \& Co. acquired the works, from which came pieces, with the mark "J. Phillips, Hylton Pottery." So large was the output from these factories that it is a habit with collectors to ascribe all unmarked pink and purple lustre to Sunderland, with the addition of Dixon \& Co., though Dawson, also of Sunderland, Sewell and Donkin of Newcastle, the Sheriff Hill pottery, and Fell \& Co. of the same place, produced large quantities, only some of which was marked.

Then, again, the Low Lights pottery at North Shields, established in I8I4 by N. Bird, after making brown and black in addition to the ordinary ware; in 1856 , when the various changes in ownership had for some time placed John Carr as sole proprietor, the output was for a time confined to white earthenware, cream-coloured, printed, painted, and lustred. The mark at this factory, a stag's head, is seldom found, but the firm, under its old title "J. Carr \& Sons," appears on the list of earthenware manufacturers at the same premises in I90o, though many other names of active potters, who were busy in 1876 , have disappeared.

At Stockton-on-Tees the list of I90o names three firms: Ainsworth Brothers, Stockton pottery, as earthenware manufacturers; the Clarence Potteries Co., Norton, brown and rockingham; and Codling and Bainbridge, Wolveston, brown Sunderland ware. Yet, in the history of English ceramics of the nineteenth century, it would be impossible to avoid allusion to the Stafford Pottery, established by W. Smith in I825, and carried on as W. Smith \& Co. for some years. In $\mathrm{I} 848$, the firm which then consisted of W. Smith and Messrs. Whalley, Skinner, and Cowap got into trouble because they had imitated or counterfeited the name "Wedgwood or Wedgewood," and stamped, engraved, or otherwise marked, the same upon their ware. A perpetual injunction was granted against them, and they had to pay the costs of the plaintiffs, Francis Wedgwood and Robert Brown, 
trading as Josiah Wedgwood and Sons. The actual marks unlawfully used were WEDGwOoD \& Co. and WFDGwOoD. George Skinner, who was one of the defendants, afterwards purchased the interest of the other partners, except Whalley, the firm became Skinner \& Co., then in I870, Skinner and Walker, and the mark, which had been W. S. \& Co., was changed to S. \& W., which might also apply to Skinner and Whalley. The goods manufactured were Queen's ware in large quantities and brown ware.

The North Shore pottery, founded about I 840 by James Smith, brother of the W. Smith of the Stafford works, whose son afterwards carried them on, continued in the family, and another W. Smith in time succeeded as proprietor of the concern, who used W. S. Stockton, or simply W. S., as his marks. Two of the potteries given at the beginning of this paragraph appeared in I876, Ainsworth at North Stockton, and the Clarence Potteries Co., formerly Harwood's Norton pottery.

Amongst other earthenware, opaque china, cream-coloured ware, and lustre enamelled ware, will be found some with the marks in initials, M. P. \& Co. for Middlesbrough Pottery Company, and I. W. \& Co., for Isaac Wilson \& Co. These indicate the first pottery established at Middlesbrough in I83I, which, in I852, traded under the name of the proprietors as given. There have been many other works in the district of the Tyne, Tees, and Wear, which are now discontinued, and there are others which have built, upon sound foundations, a good business in the ordinary descriptions of earthenware, which need no special mention. The lustre ware of the early half of the nineteenth century, Newcastle and Sunderland, may be regarded as the speciality of the district, yet much lustre ware was made by the Staffordshire potters, notably Robert and David Wilson of Hanley, Horobin of Tunstall and Lane End, and Aynsley, also of Lane End. Some of the very finest was manufactured at Leeds. I notice this here because, though the end of the eighteenth century saw the beginnings of such decoration for earthenware, the first fifty years of the next century were notable as 

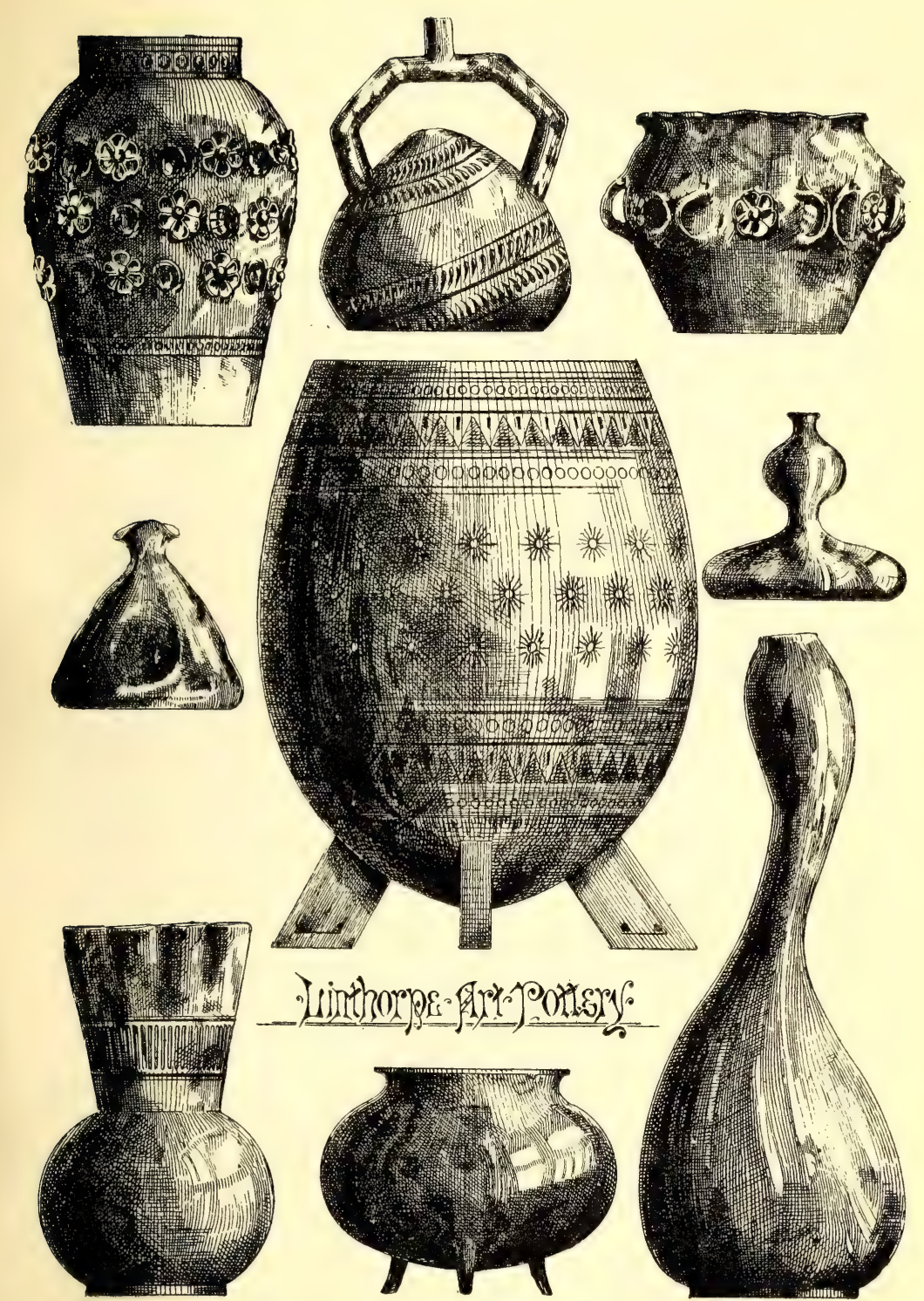
the period of its great popularity; everywhere there was a demand for it. Wedgwoods produced some of the finest, and each district acquired a distinct style, though, as I have shown in this section, comparatively little was marked, still less dated.

The last section in this chapter deals with Linthorpe pottery, a product which was distinguished by uncommon merit. Every lover of ceramic art will appreciate the delightful forms, which are shown in the illustrations, and these forms were decorated with wonderful colour effects. Mr. Henry Tooth, see Bretby Art Pottery, Woodville, was good enough to supply the illustrations and the information for the section which follows.

\section{Middlesbrough : Linthorpe}

"Linthorpe, a suburb of Middlesbrough, sprang into notoriety through the introduction there of the manufacture of a pottery ware of novel character and great artistic excellence.

"Dr. Dresser-the well-known architect and ornamentist -when in Middlesbrough some time ago, was struck with the misery then prevailing in the district through the temporary slackness of the iron trade, and, upon seeing clay on the Linthorpe estate, suggested to Mr. John Harrison, the owner of the ground, the starting of a Pottery, with the view of giving labour to idle hands, and of alleviating to some extent the misery which prevailed in the district. Mr. Harrison at once consented to act on the suggestion, raised the necessary buildings, called to his aid a most efficient managerMr. Henry Tooth, to whom I owe these notes-and surrounded himself with an excellent and skilled staff of potters; and he also arranged with Dr. Dresser that he should become the permanent Art Director of the works.

"The material of which the Linthorpe ware was made was common brick-clay, and, while it was Dr. Dresser who suggested that this common material be fashioned into beautiful objects, the working out of the idea was due to the energy and skill of Mr. Tooth.

"The production of wares of an artistic character from coarse and rude materials was, however, by no means in itself a novelty. The coarser clays have for ages been shaped into vessels of elegant form in India, Morocco, Egypt, and 

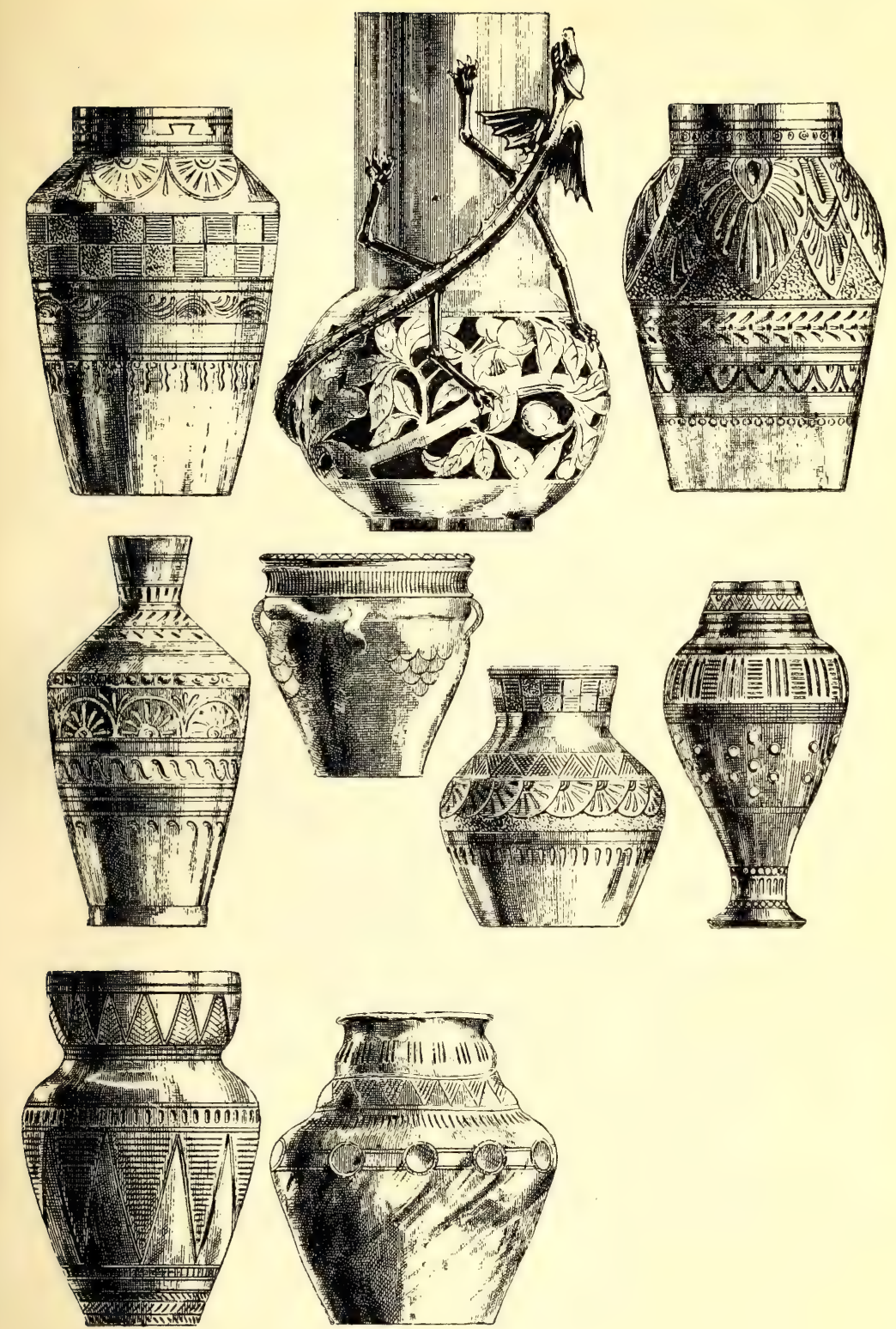

LINTHORPE ART POTTERY. 
many other countries, as common cow-hair has been fabricated into carpets of exquisite design and colours.

"In England the arts appear to have flourished, chiefly when comparatively expensive materials were employed; yet such materials, though of great value under certain conditions, are by no means of the highest importance to the production of artistic objects.

"It may be truthfully said that art was never so supreme as when it fashioned things of the greatest beauty from the commonest materials. A first principle of true art is economy, and, bearing this in mind, it is strange that modern artists, who have devoted their talent to the production of the beautiful in pottery, should so persistently have overlooked that which is so ready at hand, and so well adapted to their purpose-common brick clay. To Dr. Dresser much honour is due for the elevation of this common material into the production of a thoroughly artistic ware.

" The Linthorpe Pottery has in a marked degree a specialty which has hitherto failed to claim its due share of prominence in modern Ceramic productions, that of varied and beautiful coloured glazes. All artists are aware that richness of colour is due, in a great measure, to variety of tone, and tint, and depth. Old stained glass has a richness which we for a long time failed to imitate, and it was only when we perceived that our modern glass was of homogeneous colour, while the old was varied in tint, that we were enabled to give richness to our modern windows. If an Eastern carpet is carefully examined, it will be seen to consist of yarns which are not dyed with the evenness of tint that we give to our worsteds, and for this very reason our productions are less rich in colour than similar works from India and Persia.

"Amongst the much-prized ancient Chinese Ceramic wares, the most beautiful of all are those which depend solely for their artistic effect upon the use of parti-coloured glazes. The well-known 'Sang de Bœeuf,' the production of which was due to a family who lived about one hundred and fifty years since, and who carried the secret of its production with them to the grave, is one of the most valued effects in the 'colour wares' of China, while the apple green, the old turquoise blue, and certain mingled, or 'splashed ' effects of glaze, are hardly less famous.

"It is not simply because the secret of their production is lost to the world that causes lovers of the beautiful to 

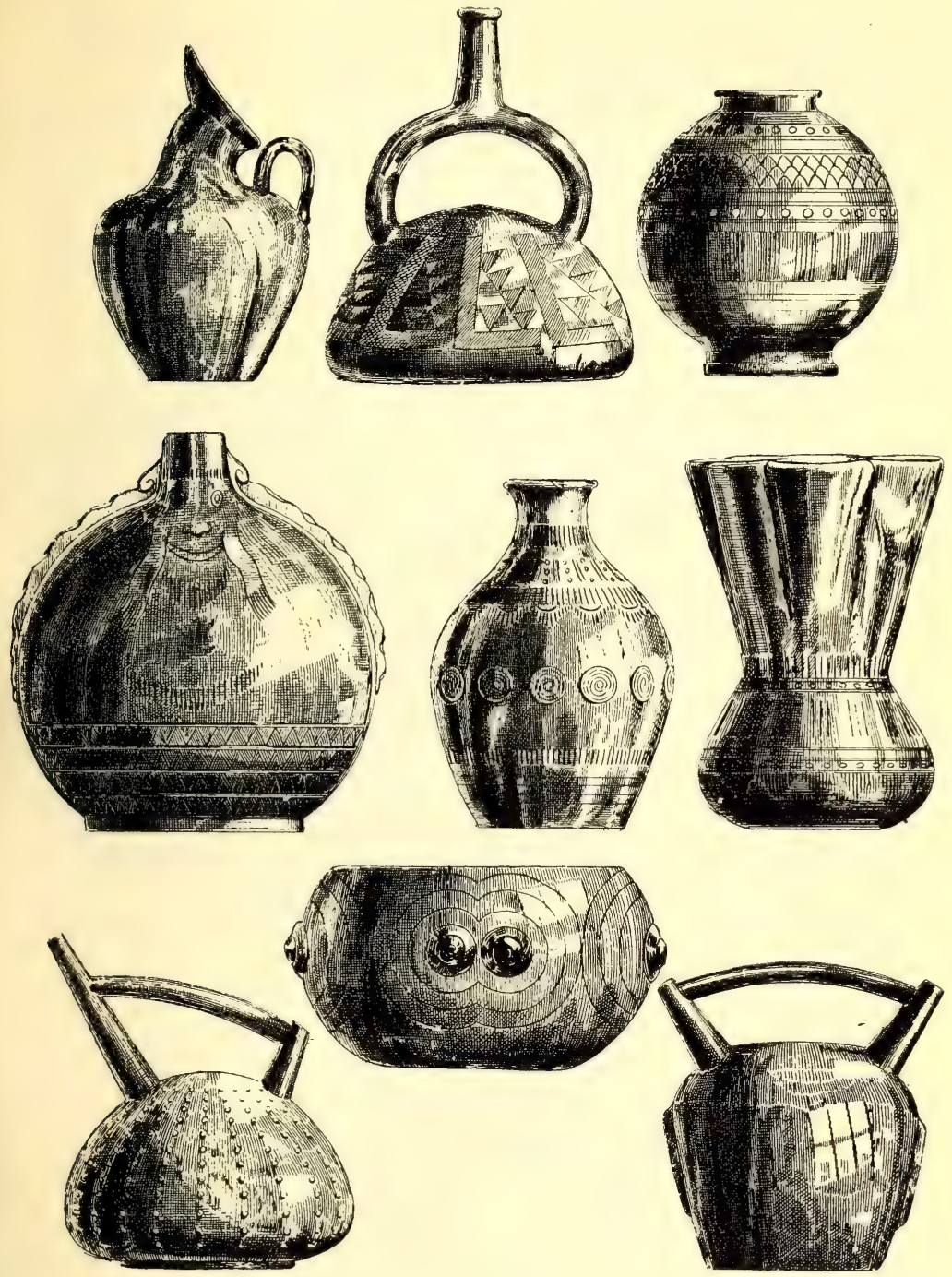

LINTHORPE ART POTTERY. 
seek out and pay high prices for these particular effects, but because all these valued 'colour wares' of China have a richness which is due to variety in their tints.

"The wares of Linthorpe present us with all the variety and mingled richness of hue which we perceive in old Chinese wares, and which we value in agate, in onyx, and other beautiful stones; and while no attempt has been made at reproducing the effects of Chinese wares, new beauties have been achieved by similar means. Low-toned reds, mottled olives, browns, and yellows of great variety of tone, and rich mingled 'juicy' effects of colour, are found in the new wares of Linthorpe.

" But, besides the glaze effects, Linthorpe made a specialty of incised and perforated wares, both of which are equally artistic. Plaques, both large and small, for the decoration of sideboards ; card-trays, tazzas, 'spill' vases (up to two feet six inches in height), and many other objects of a decorated character were made, all of which are enriched with carefully executed and tenderly drawn 'sgraffito' ornament.

"As to the shapes of the decorative objects produced at Linthorpe, they were legion in number. Some of the forms had been designed with a view to the production of what was in a high degree graceful and beautiful, while others have been created to give quaintness of effect; and, while many vessels were of original shapes, some few were derived from Egyptian, Greek, Roman, Moorish, Indian, Chinese, Japanese, Peruvian, Mexican and Celtic examples, while some were in the Mediæval and others in the Queen Anne spirit.

"Makers of such English pottery as is intended for the decoration of our houses have hitherto erred, to a great extent, in the effort to obtain excellence by introducing too much detail and excessive finish into their works. It must ever be borne in mind that whatever is intended to play a part in the decoration of a room should be so bold in effect, or so "broad" in treatment, that it can be seen together with the furniture, and other objects, when the room is viewed as a whole. It may be pleasant, when we are close to an object, to see in it both detail and a high degree of finish, but both of these are not only lost when the work is seen from a distance, but they also destroy the distant effect of the work, and prevent its playing a part in making the room beautiful as a whole.

"It is also noticeable that all authorities agree in con- 

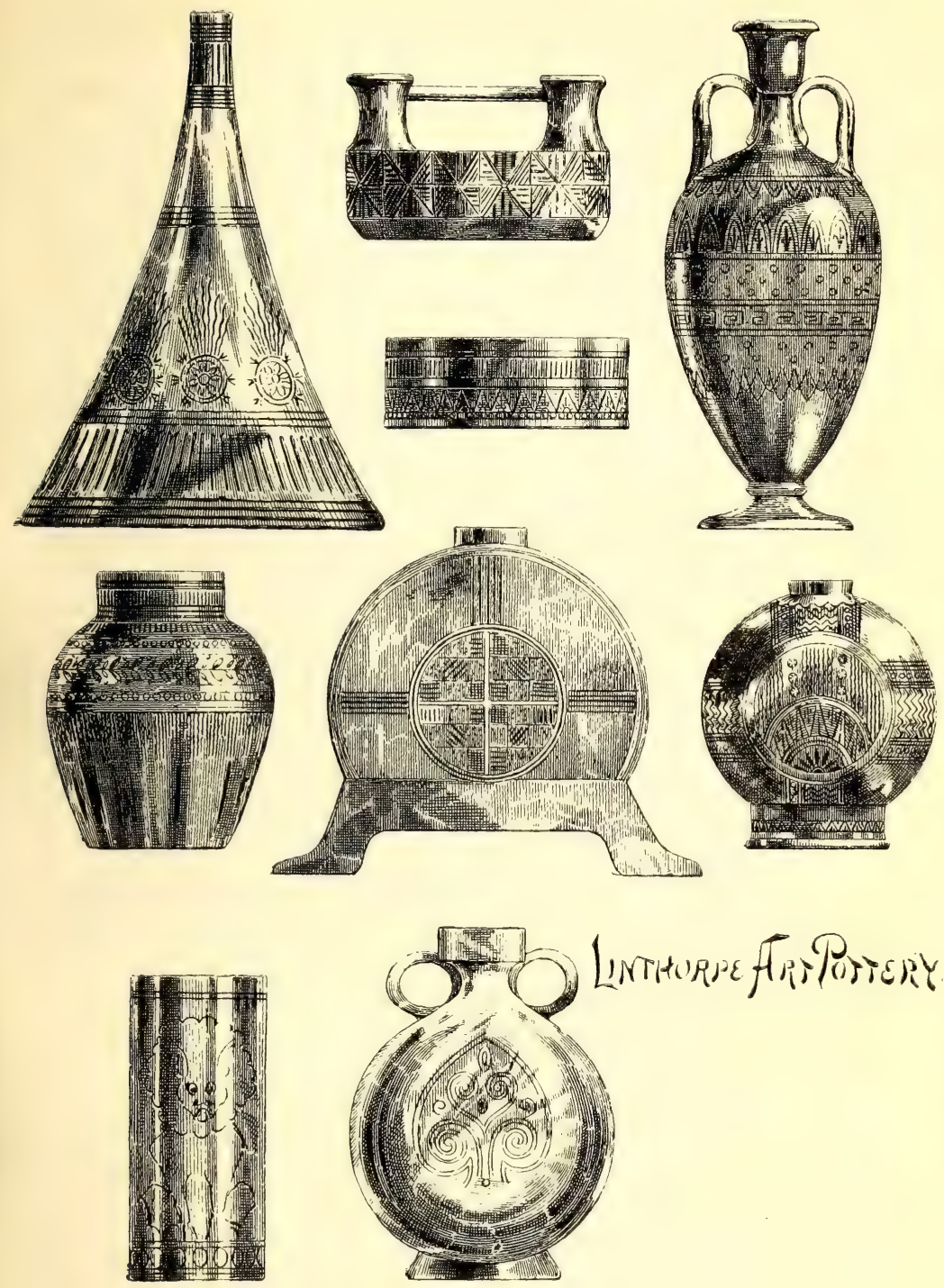
demning vases which bear strongly coloured decorations, be they landscapes, flowers, figure-subjects, or birds-whether on white, blue, or any conspicuous background.

"The Bohemian glass, with its crude tints and obtrusive decorations, was valued only so long as the 'wholeness' of effect which we now look for in all well-furnished rooms was disregarded ; but, as art-knowledge advanced, it became more and more unsaleable, till now it is almost valueless.

"The Linthorpe ware was designed to meet a growing want of the present day ; it will be found, in its varied effects, to accord with all forms of art decoration, and to take its part in adding richness and beauty to an apartment without disturbing that general repose which we now seek to achieve in our rooms. The days of white and gold backgrounds are, happily, gone, for whatever is seen against a wall thus treated must look crude and vulgar, be it ever so beautiful; and with such decorations no room can present that amount of 'snugness' and comfort which it should possess. Repose results from all the parts of the whole producing concord or harmony: hence no Linthorpe pottery, nor any other ceramic ware, can look well in certain conditions; but, whenever the wall is so decorated that it would serve as a fitting background for a picture, the wares of Linthorpe will be found to be unrivalled by any other kind of pottery now produced in England for beauty and richness of effect. In short, Linthorpe is an artistic ware which seeks its home in artistic houses."

To Mr. Booth I am also indebted for the following notice from The Graphic of June Io, I882, which shows how fully the Linthorpe Art Pottery was then appreciated by that journal. The long, unbroken paragraph is worthy of careful attention.

"The Modern English Pottery which the Society of Arts are now privately displaying in their Gallery at Adam Street, Adelphi, forms one of the most beautiful and interesting sights to be seen in London during the present season. There is the familiar Wedgwood ware from Etruria, and of course Minton makes a good show. There is Doulton ware of all sorts, shapes, and sizes-stone-ware and modelled terra-cotta panels, with designs in high relief, and, in particular, the beautiful underglazed painted work, with celadon bodies, 


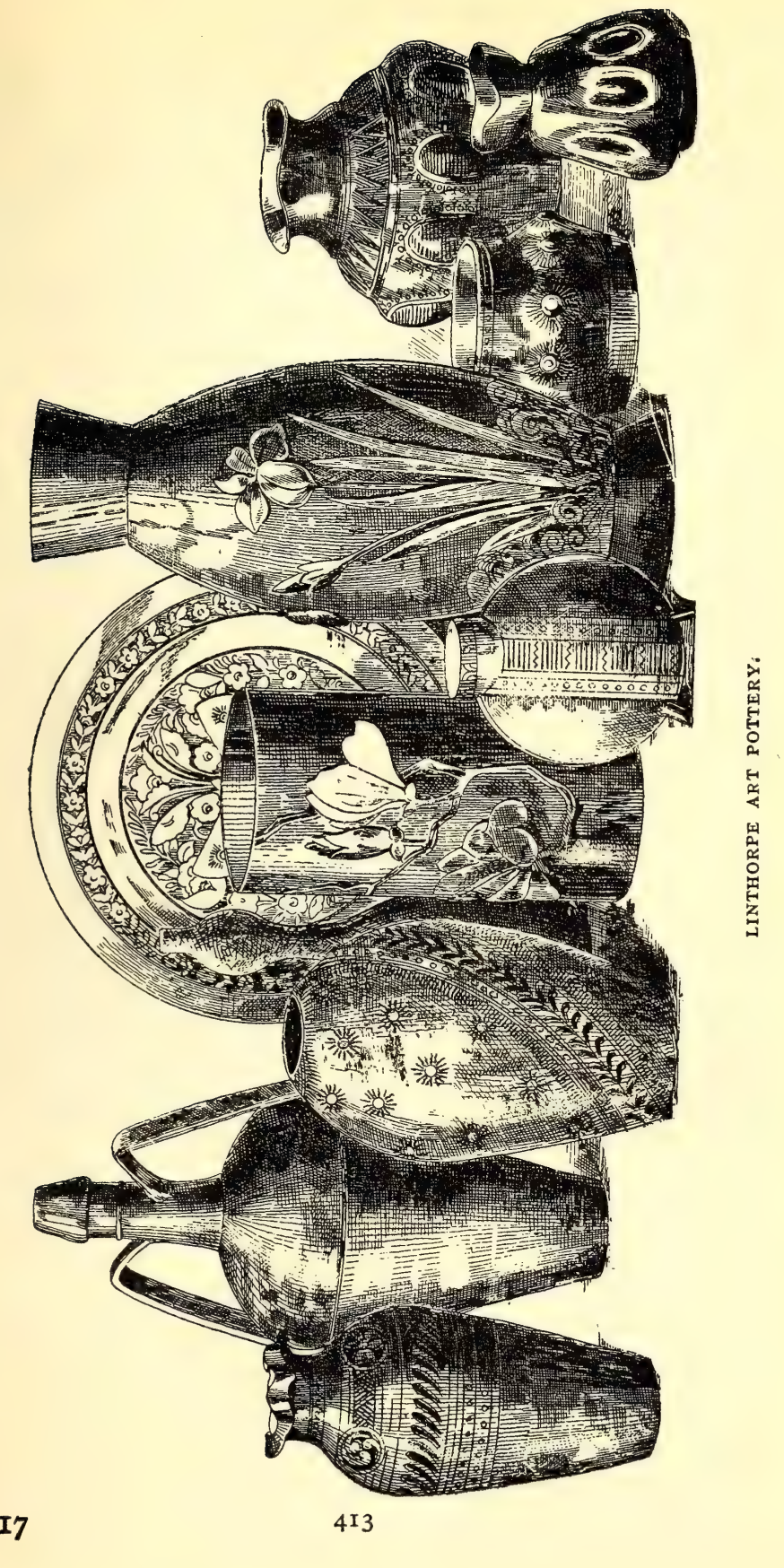


and bronze, silver, gold, and what are called 'clouded' backgrounds. From the same potteries comes also a fine show of Lambeth faience and impasto, particularly good in colour; some painted tiles and tile-panels from Broseley will attract attention by their boldness of design and decorative delicacy of tone; and a variety of infinitely pretty and glittering tea-services from the Worcester Royal Porcelain Works will make many a female heart beat with covetous desire.

"But the great feature of the Exhibition is a magnificent collection of the New Linthorpe Art Pottery, which, more than any or even all the rest, emphasises the great advance which we Britishers have made in these matters during recent years. The collection consists of specimens of nearly every possible useful and ornamental object, from a flower-pot to a tazza, from the humble water-bottle to the stately vase. But its interest consists not so much in its variety, though that is noteworthy enough, as in the extraordinary beauty of its colour and the brilliance of its glazes. It is not too much to say that this Linthorpe ware is quite a new feature in European pottery; for in depth, richness, variety, and glorious beauty of colour it is only matched by the splendid wares of the East. For purely decorative purposes it must be invaluable; its varied tones and richnesses render it suitable to any conceivable artistic conditions. It is alike capable of softness and delicate quietude, of the glory of precious stones and of the iridescent qualities of the plumage of birds. The most surprising thing about it is that so beautiful and so truly original a material can be made from 'ordinary red clay found at Middlesbrough-on-Tees.' Yet it is so, and, since there is plenty of clay, these sincerely artistic productions may be brought within the reach of all, and it will be odd if, by sheer force of competition, they do not seriously reduce the present pecuniary value of the magnificent pottery, which is imported from Eastern lands."

The Linthorpe works, established in I880, existed for about twenty years. 


\section{CHAPTER XVII}

\section{LEEDS DISTRICT AND LIVERPOOL}

\section{Leeds Ware}

As late as 1796 much of the Poole clay was sent to Selby for the use of the Leeds potteries. In I9oo only about half a dozen potteries existed in the city, one of which, Burmantofts, will receive notice. In $I 800$ the Leeds pot works were on the decline; the old Hartley, Greens \& Co. suffered from many
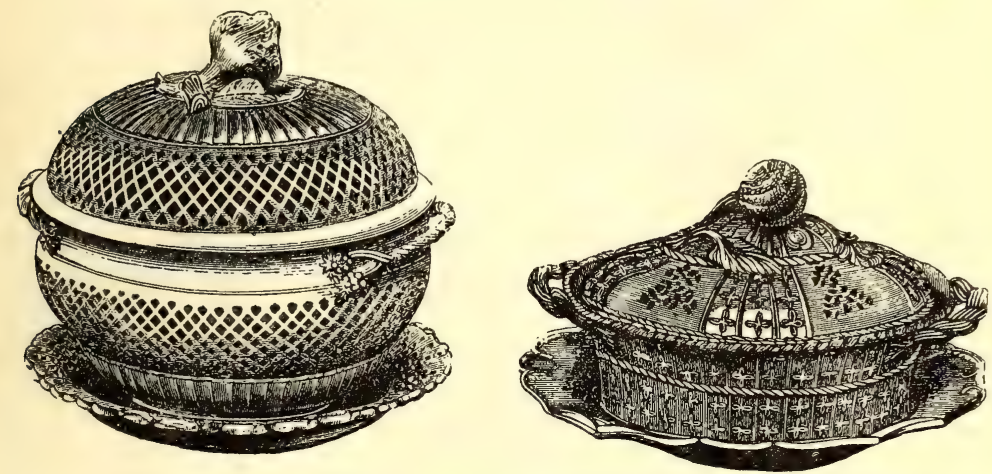

LEEDS WARE.

changes in the proprietorship, becoming Greens, Hartley \& Co. just before I825, when the concern was thrown into Chancery. In that year, when Samuel Wainwright bought out the other partners and became sole owner, there was a strike amongst the potters, whose wages had been reduced. When Wainwright died in 1832 the firm of "Samuel Wainwright \& Co." was continued by his trustees under the title of the "Leeds Pottery Company." In I840 other changes 
took place, and many more followed till, in I872, Richard Britton acquired the works, being joined by his two eldest sons, as "Richard Britton \& Sons," until 1878, when the factory was closed.

This nineteenth-century period witnessed the production of ware, far inferior to the old Leeds cream-ware with its fine potting, and its colour ever so slightly tinged with green. The decoration suffered too. The under-glaze blue printing,
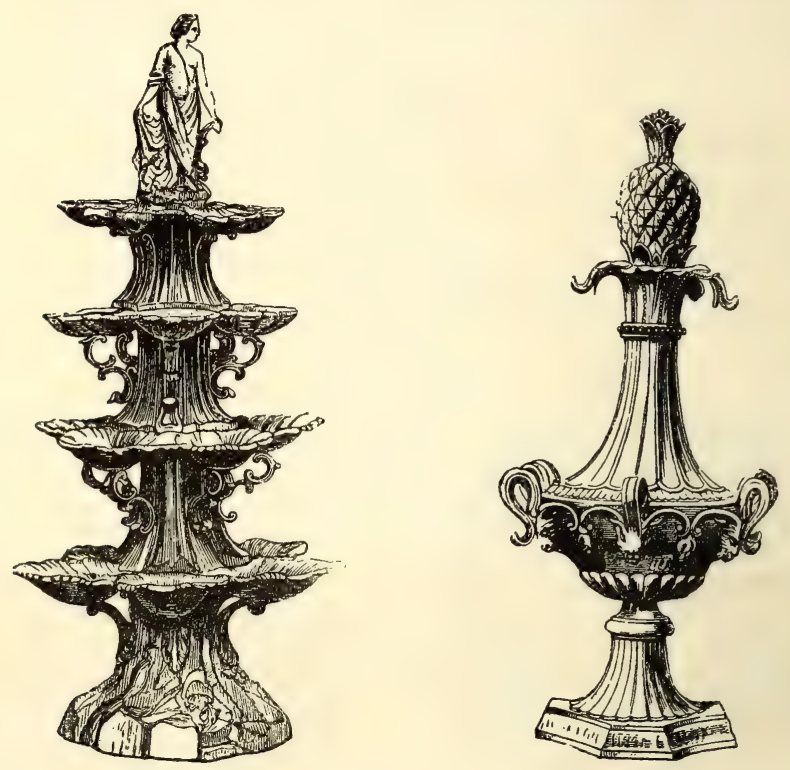

LEEDS WARE.

mainly of Oriental scenes, and the over-glaze black printing, may appear on specimens which are comparatively modern; indeed the Leeds ware has been imitated by foreign factories, who have forged the mark LeEds Potrery. This also applies to the Leeds figures, to the drinking-cups in the form of a fox's head, and to busts such as those of Wesley. The chief points which distinguish the old ware from these forgeries are these: it was particularly light, the colour a clear rich cream, and the glaze slightly greenish. Much of the best 


\section{LEEDS DISTRICT AND LIVERPOOL}

Leeds had no mark at all, and has been ascribed to other factories. Cream was a common variety of English earthenware, which Wedgwood perfected, in which Liverpool and other towns rivalled the Potteries.
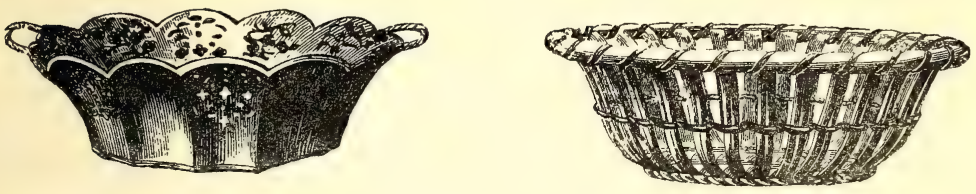

LEEDS WARE.

\section{Leeds : Burmantofts}

The Burmantofts works, a branch of the Leeds Fireclay Co., Ltd., has become noted for its faience. Though of recent growth, not appearing in Jewitt in 1878 , the development of the manufacture of vases, flower-pots, and pedestals, and, above all, of tiles, has advanced with great rapidity and success, and in addition some attention has been given to figures. Having both clay and coal quite close, attention has centred upon this local clay, which produces brown and buff ware of excellent quality, with the only admixture of the powder derived from pots burned and ground. The clay is

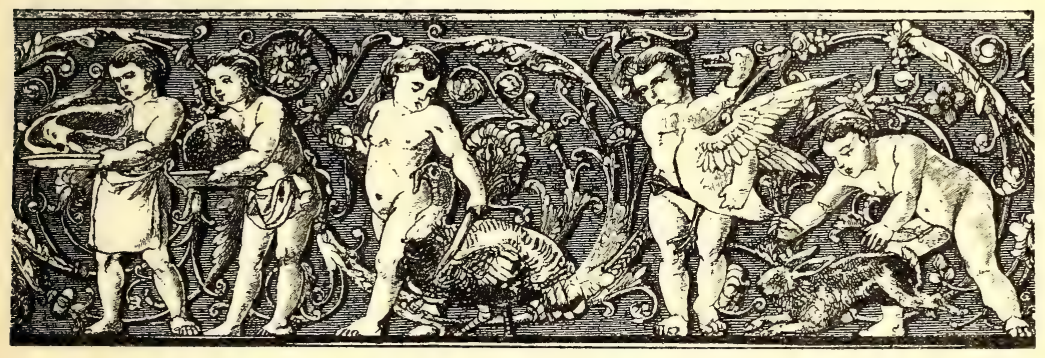

BURMANTOFTS.

mined in a solid state, and has to be crushed and sifted, giving a body of great tenacity, which is covered with a glaze largely composed of felspar, with very little lead. The body and the glaze are admirably adapted for the coloured decoration, which, especially in the tiles with figures, etc., modelled 


\section{I8 I9TH-CENTURY ENGLISH CERAMIC ART}

in relief, with floriated ornament, has attained an unusual position in schemes of architectural design. The beauty and utility of tiles are receiving constantly increasing attention, the scale of their manufacture at these works moves forward at a rapid pace, and both exteriors and interiors of some of the finest new buildings in the country exhibit

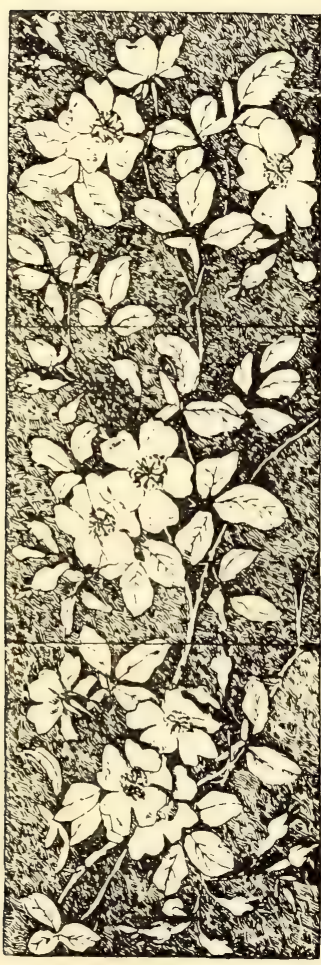

BURMANTOFTS TILES. Burmantofts tiles in rich and harmonious effects.

One name stands forth in the midst of so much progress and success. Mr. Holroyd converted a strictly utilitarian business into an art pottery, where designers are busily employed, where painters are engaged upon vases of much merit, where girls are applying coloured glazes to the small bits which form part of some great pattern, and where no profitable part of pottery production is neglected. Painted tiles and panels in barbotine - thin clay paste-stamped tiles, etc., share attention with a wide assortment of vases, jars, bottles, etc., in all of which charming variety is allied to many forms of ornamentation, requiring the exercise of considerable originality, which in this factory is specially encouraged.

\section{Castleford: Dunderdale}

About twelve miles from Leeds the Castleford pottery was founded by David Dunderdale for the manufacture of cream-coloured ware, plain and in relief, transfer-printed, painted, and enamelled. His marks were D. D. \& Co., CAstleford, to which Pottery was sometimes added. This " \& Co." was first used in I803, when Plowes became partner for a short time before going to Ferrybridge, and leaving Dunder- 


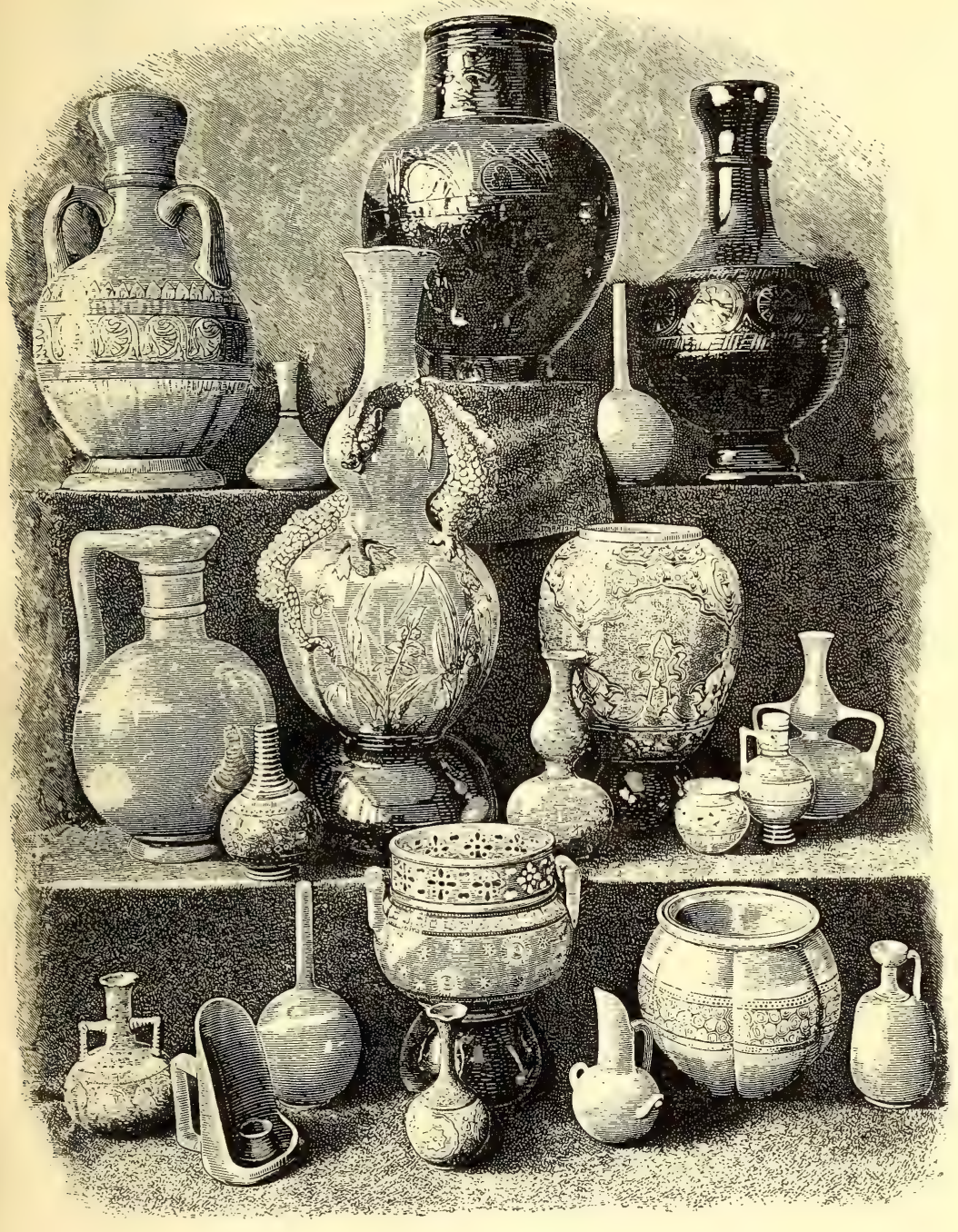

BURMANTOFTS_ART POTTERY. 
dale in sole control again. Another change occurred within a year or so, when the proprietors were Dunderdale, who owned one-half of the business, Russell, a relative, one-quarter, and Upton and Bramley one-eighth each. Dinner, dessert, and other table-ware vases, baskets, etc., were made in creamcolour ware or in white earthenware and black Egyptian ware, all of which possessed high qualities of paste and manipulation. The open-work baskets, stands, plates, and dishes differed very slightly from those of Leeds, Swinton, and other potteries, many of which, it should be remembered, were engaged upon similar work. Castleford used painted designs on the dinner and other ware, which were just like the Wedgwoods', and others resembled those employed at Herculaneum.

In I900 Robinson Brothers appear as manufacturers of stoneware, etc., at Castleford and Allerton potteries. From I8zo, when the original factory was closed and partly reopened next year by five of the workmen, there have been many changes in the proprietors. In I87I Clokie and Masterman were manufacturing all the ordinary kinds of printed earthenware, and this firm, in I90o, as Clokie and Sons at the Castleford Potteries, was still carrying on this business. The later proprietors, when trading from about $I 825$ to $I 87 \mathrm{I}$ as $\mathrm{T}$. Nicholson \& Co., used the initials T. N. \& Co. The present firm marks its productions with its initials within a border. In 1878 C. \& M. were in use.

\section{Swinton : Don Pottery}

John Green, one of the Greens of Leeds, and a proprietor of Swinton, erected a pottery close by the canal at Swinton about I80o. He was joined by other members of his family, in I807, and by Clarke, the firm trading as Greens, Clarke \& Co. Then in I83I, Green was sole proprietor till I834, when the Don pottery was sold to Samuel Barker, the owner of the Mexborough works, which he closed in I844, and seven years later Samuel Barker and Son were the proprietors. In I876 H. and E. Barker were still in possession, keeping the 


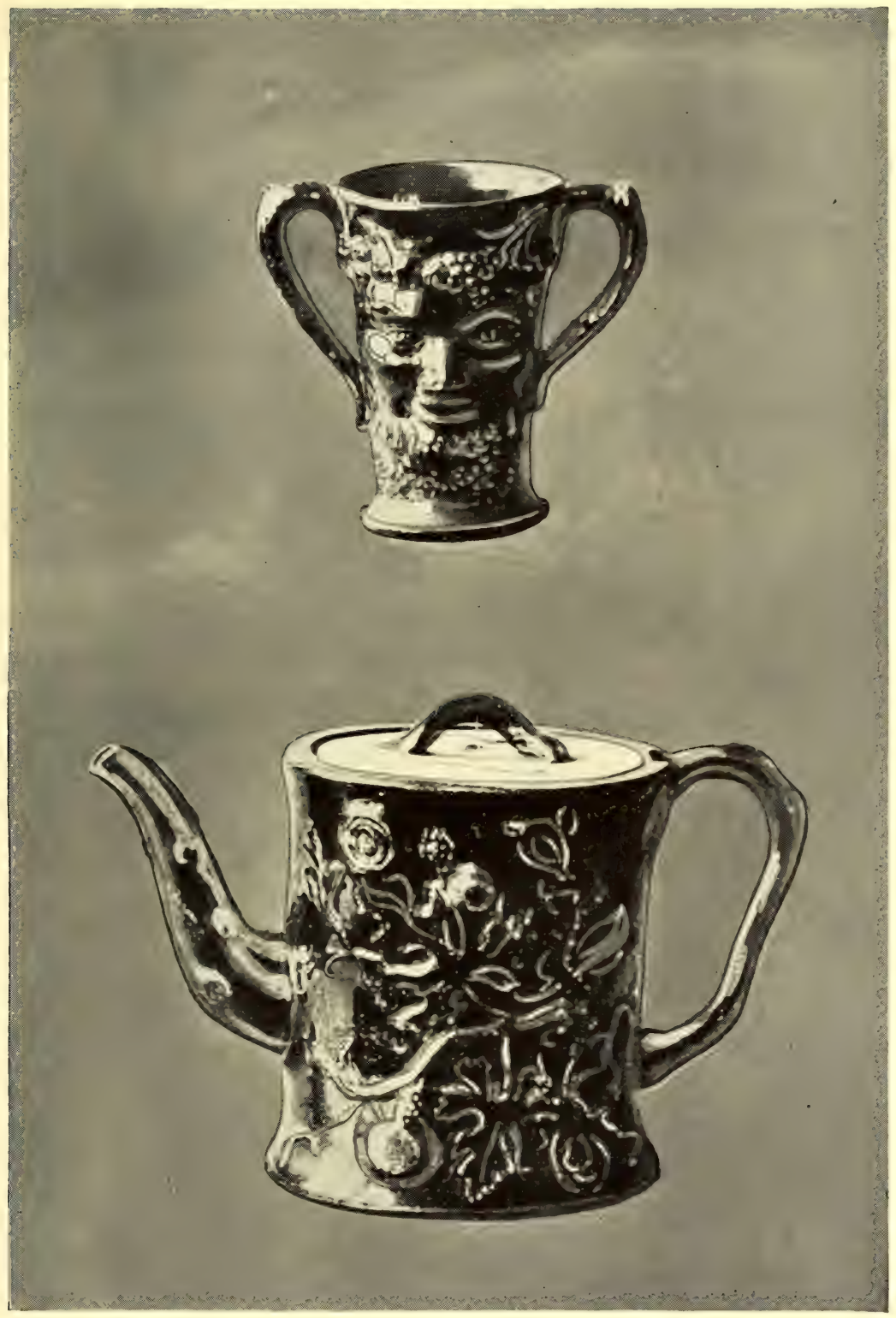

ROCKINGHAM WARE. 

same title which was retained until the works closed. The firm does not appear in the list of I90o.

Greens, Clarke \& Co. made all the usual and various kinds of earthenware-cream-colour or cane-colour, brown, blue, and green shell, Nankin blue, printed, painted, and enamelled, Egyptian black or basaltes, brown china, etc. Also, like Swinton and Leeds, they produced services with borders, landscapes, coats-of-arms, etc., ornamented with gold and silver. Naturally, the neighbouring potteries, being under similar, though not identical management, produced the earthenware and lustre-ware for which there was a demand. The engraved pattern-books of the Don pottery contained many designs in perforated, open-work, and embossed baskets and stands, which were like those in the Leeds book, so that when the pottery is unmarked with Leeds Pottery or Don PotTery it is very difficult to distinguish between them. Messrs. Barker made the usual varieties of the common classes of earthenware, which, when decorated, were enamelled, gilt, and lustred. Their mark was a demi-lion rampant, holding in his paws a pennon, with either the words DoN Pottery or S. B. and S. Sometimes a displayed eagle, rising from a coronet, may be found printed on a shield.

\section{Swinton : Rockingham-Brameld}

It was on a part of the estate of the Marquis of Rockingham that the old pottery in Swinton was built, hence the name Rockingham ware, which was given to the earthenware, which was the sole product till I8zo, when the manufacture of porcelain was introduced. From about I787 to I800 the firm traded under the title of "Greens, Bingley \& Co.," some of the Greens of Leeds taking an active part in the management, especially John Green, who founded the Don Pottery. The connection of this business with the Leeds Pottery was very close during the period, the price-lists of the latter being used with the heading removed, whilst "Greens, Bingley \& Co." was written in its place. Later we find "Greens, Hartley \& Co." printed on the price-lists. In I806, at a 
meeting held at Swinton pottery in January, W. Hartley, E. Green, G. Hanson, T. Bingley, J. and W. Brameld being present, it was resolved to close down the works, but at the dissolution of partnership which followed, J. and W. Brameld took them over, and started upon a career of considerable prosperity, under the title "Brameld \& Co.," who continued the various manufactures.

The products of the old firm were the kinds of earthenware which were produced by so many of the potters in the last half of the eighteenth and early nineteenth centuries: cream-coloured or Queen's, Nankin blue-printed, tortoise-shell, black basaltes, etc., and what was termed brown china, which

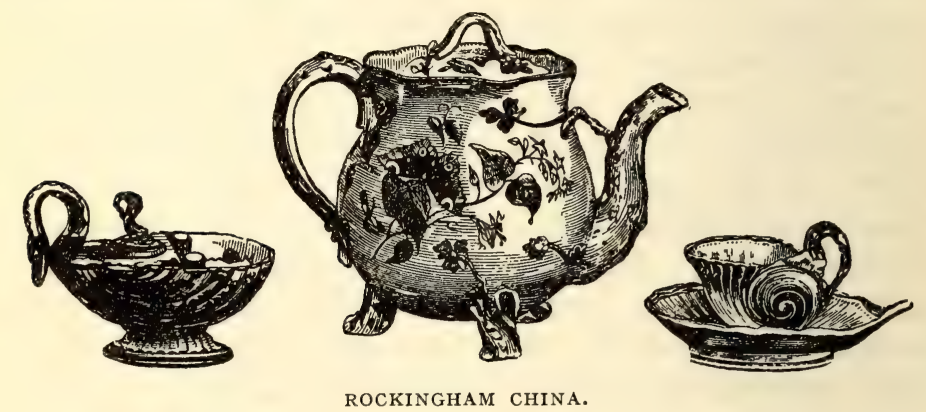

became famous. It was not china, but a hard earthenware, with a white body covered by the well-known rich brown glaze, which is copied to-day by many potters, whose specialties are jet and rockingham, without the capital R. Mortlock of Oxford Street, who deserves more than passing notice, took full advantage of the popularity of Rockingham ware, which followed a visit of the Prince Regent, afterwards George IV., to Wentworth House, where Earl Fitzwilliam had these brown wares in use. The teapots became all the rage, and Mortlock supplied the market, having his name stamped on them, instead of Rockingham. They were quite a new design, with no lid, only a hole at the bottom, the end of a spiral tube. Through this the teapot was filled, and when in its proper position there was no spilling when the tea was poured out. The device was adopted from the old Chinese wine-pots. 

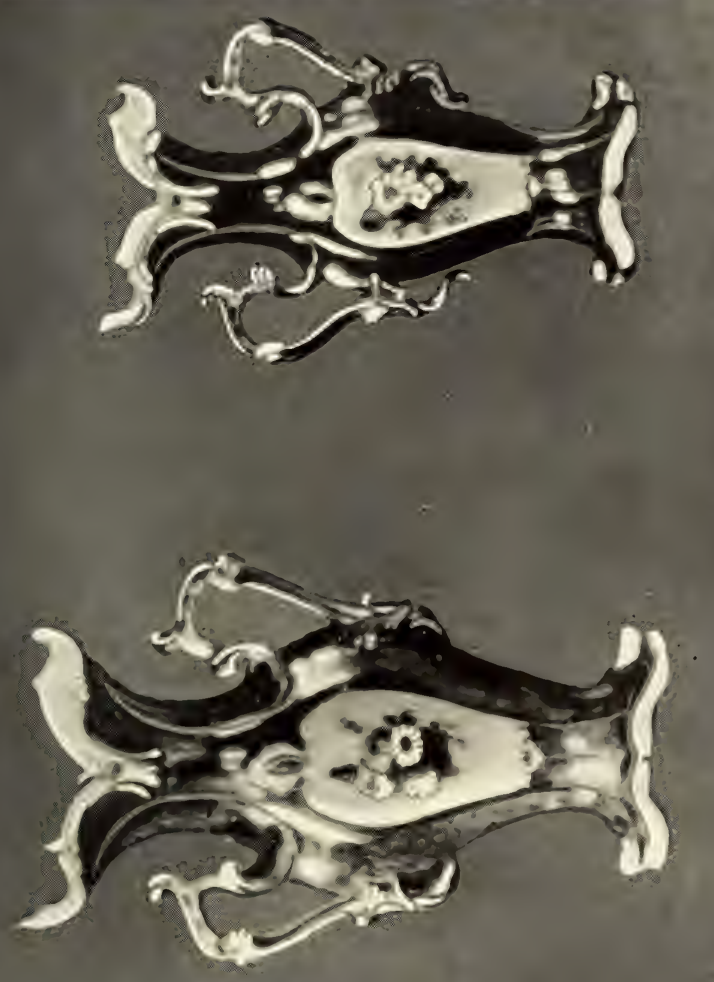

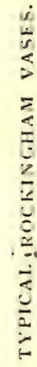

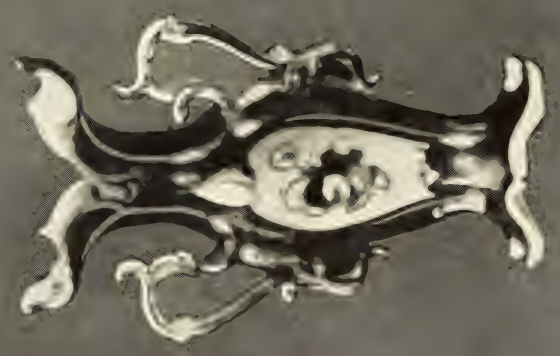



About I8I3 the sons of the old proprietors, on the death of W. Brameld, succeeded to the ownership. Thomas was the eldest; to him most of the after-success of the manufacture was due, although G. F. and J. W. Brameld were members of the firm, which in $18 z 0$ undertook china as well as earthenware. This china was technically excellent, like that of many other factories, and not only were the glazing, enamelling, and gilding of high quality, but the designs of J. W. B. - that is J. W. Brameld-gave much satisfaction. Services were made for the Duchess of Cumberland in I830,
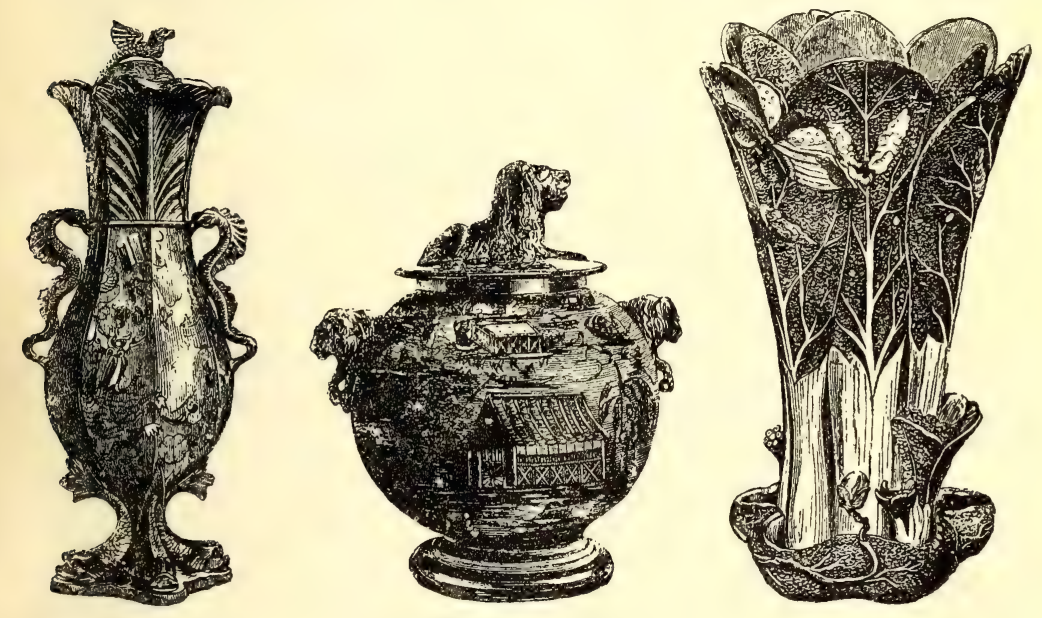

ROCKINGHAM VASES.

for the Duke of Sussex in I833, and a gorgeous one for William IV. again in 1830 , which cost $£ 5,000$ and consisted of a hundred and forty-four plates and fifty-six large pieces.

Notwithstanding these and other considerable orders for the products of the factory, it was closed in 1842 , a financial failure. The vases, sometimes very large, the plates, cups and saucers, busts, spell-vases, and flower-baskets, with the biscuit figures, are sought for, though opinions are divided as to their artistic qualities, which some decry whilst others admire ; but only admiration is expressed for the earthenware dishes and plates, with a spray of some flower painted in 
enamel colours in the centre, having its botanical name written in red on the back. Collinson painted these. The marks used were the griffin crest with RockINGHAM Works, BRAMELD, or BRAMELd \& Co. The name Baguley sometimes is found. This marks the maker at a small factory in the old works, who lasted for about ten years.

\section{Liverpool : Herculaneum}

In 1796 the Herculaneum pottery was opened by Worthington in Liverpool, and produced the usual cream-coloured ware then so much in demand, also blue-printed ware. The cream-ware was slightly darker than Wedgwood's, and not quite so yellow as Leeds; but, in the absence of marks, it is somewhat difficult to separate some Leeds and Staffordshire cream-ware from that of Herculaneum, which also produced jugs with a fine hard body which rivalled Turner's, and services with openwork rims similar to Davenport's. But the impressed and printed name Herculaneum is usually found, or the bird called the Liver impressed, or again LIvERPOOL impressed over an anchor, upon painted and printed wares.
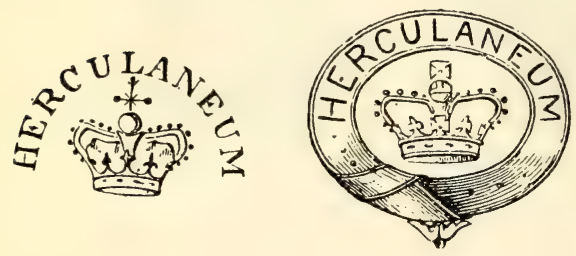

HERCULANEUM

POTTERY.

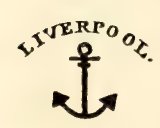

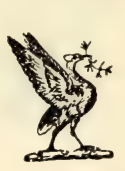
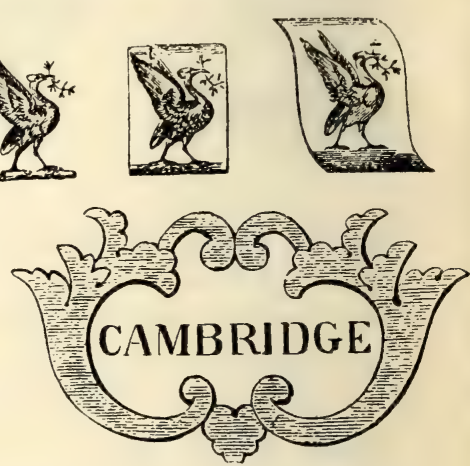

The progress made by this pottery was such that, in 1800 and $I 806$, considerable additions had to be made, for in those early years china was added to the manufacture, and the number of proprietors was increased to provide further capital. These, at a meeting in $182 z$, resolved that " to give 


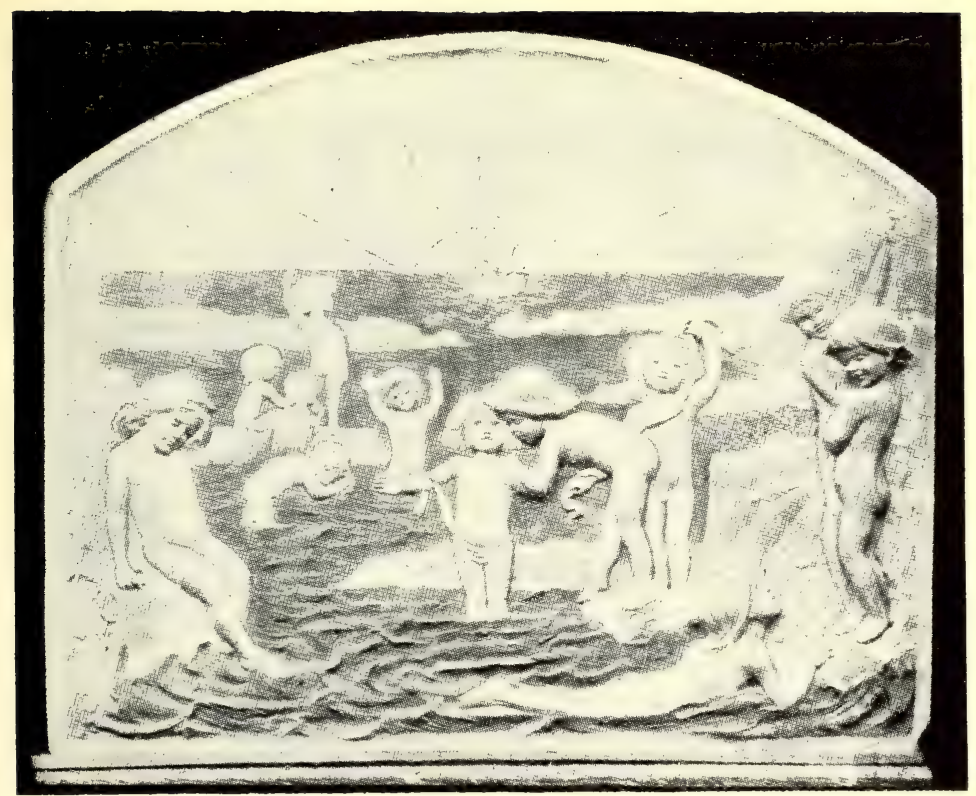

DELLA ROBBIA WARE EXECUTED BY MISS E. M. ROPE.

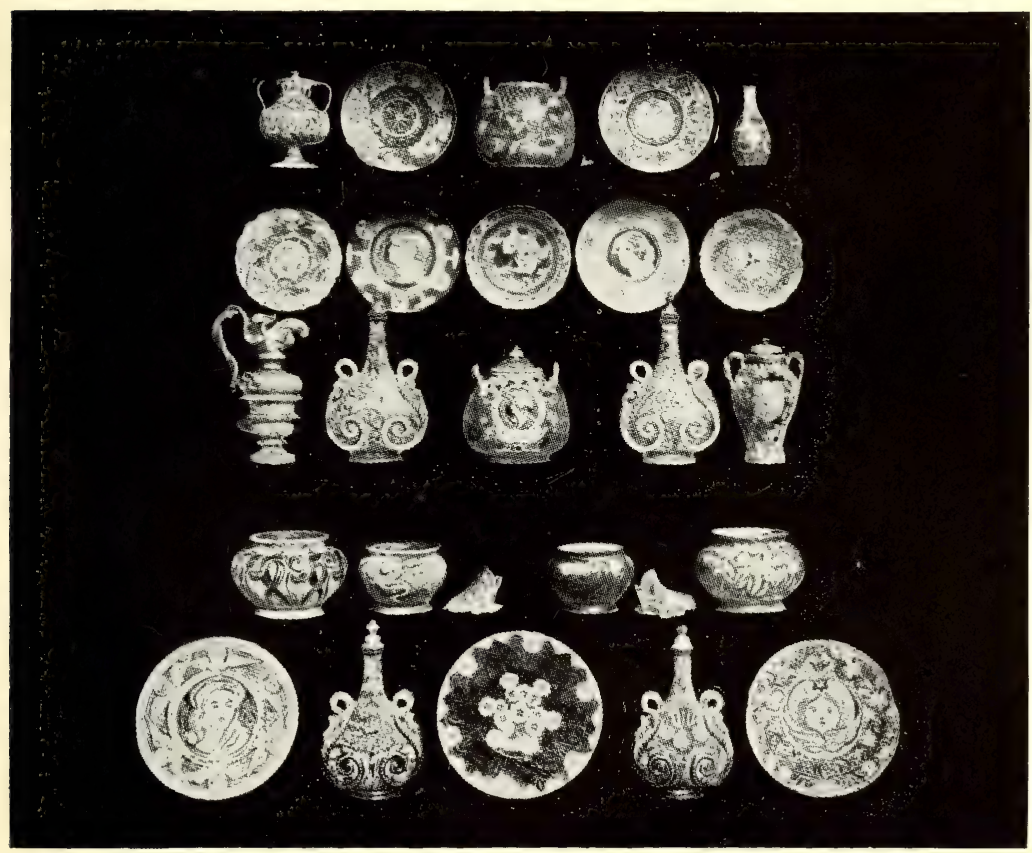

DELLA ROBBIA WARE MADE BY THE DELLA ROBBIA POTTERY COMPANY. 

publicity and identity to the china and earthenware manufactured by the Herculaneum Pottery Company, the words 'Herculaneum Pottery' be stamped or marked on some conspicuous part of all china and earthenware made." In I833, when the company was dissolved, the property was sold for $£ 25,000$ to Ambrose Lace, who leased it to T. Case and J. Mort, who during their short term of three years introduced the Liver mark. Case, Mort \& Co. were succeeded in the lesseeship in 1836 by Mort and Simpson, who continued the factory until it was closed in I84I.

The eighteenth-century products of Sadler and Green, of Shaw, Chaffers and Pennington, with others, are outside our review, but it should be noted that in addition to the painted and printed earthenware, and the painted china, Herculaneum produced black and reddish-black terra-cotta vases of good design, marked with the name impressed.

\section{Birkenhead: Rathbone}

Though this factory at Birkenhead did but little in the nineteenth century, being founded in I894, the production of its "Della Robbia" ware has excited so much attention that Mr. Harold Rathbone's work at the Birkenhead Pottery deserves favourable mention. Like all individual potters, he had his experimental period; like many, he overcame great obstacles; and, with them, he too is advancing in public favour. Again, like them, he has secured Royal patronage: Queen Victoria, King Edward VII., and King George, when Duke of York, all purchased examples of "Della Robbia" ware, now manufactured by the Della Robbia Pottery, Ltd.

The productions may be divided into two classes, domestic and architectural. In both the great object is to obtain originality in design and richness of colour. This aim is indicated by the name of the ware, and in connection with it one must commend a feature of the work adopted with marked success by Mr. Rathbone, that is his criticism and advice, given to those who under him are trained to decorate vases and other articles, in an effort " to restore to the worker the 


\section{I9TH-CENTURY ENGLISH CERAMIC ART}

individual interest and pleasure in daily work and creation " : such are his words. The results fully justify the effort, yet at the same time he has been specially favoured by the active assistance of distinguished artists, such as Mr. Anning-Bell, who modelled some beautiful panels, which were skilfully reproduced. Other designs by Dressler and Miss E. M. Rope, must be recognised together with those by Rathbone himself. The fountain in the courtyard of the Savoy Hotel is an example which reflects much credit upon the founder of the pottery.

Finely modelled vases, bottles, jars, plates and dishes, with the most charming decoration, represent the domestic class which also includes bowls and jugs in many quaint and simple shapes, with a few which are almost grotesque. Developing and improving, this pottery should go far. 


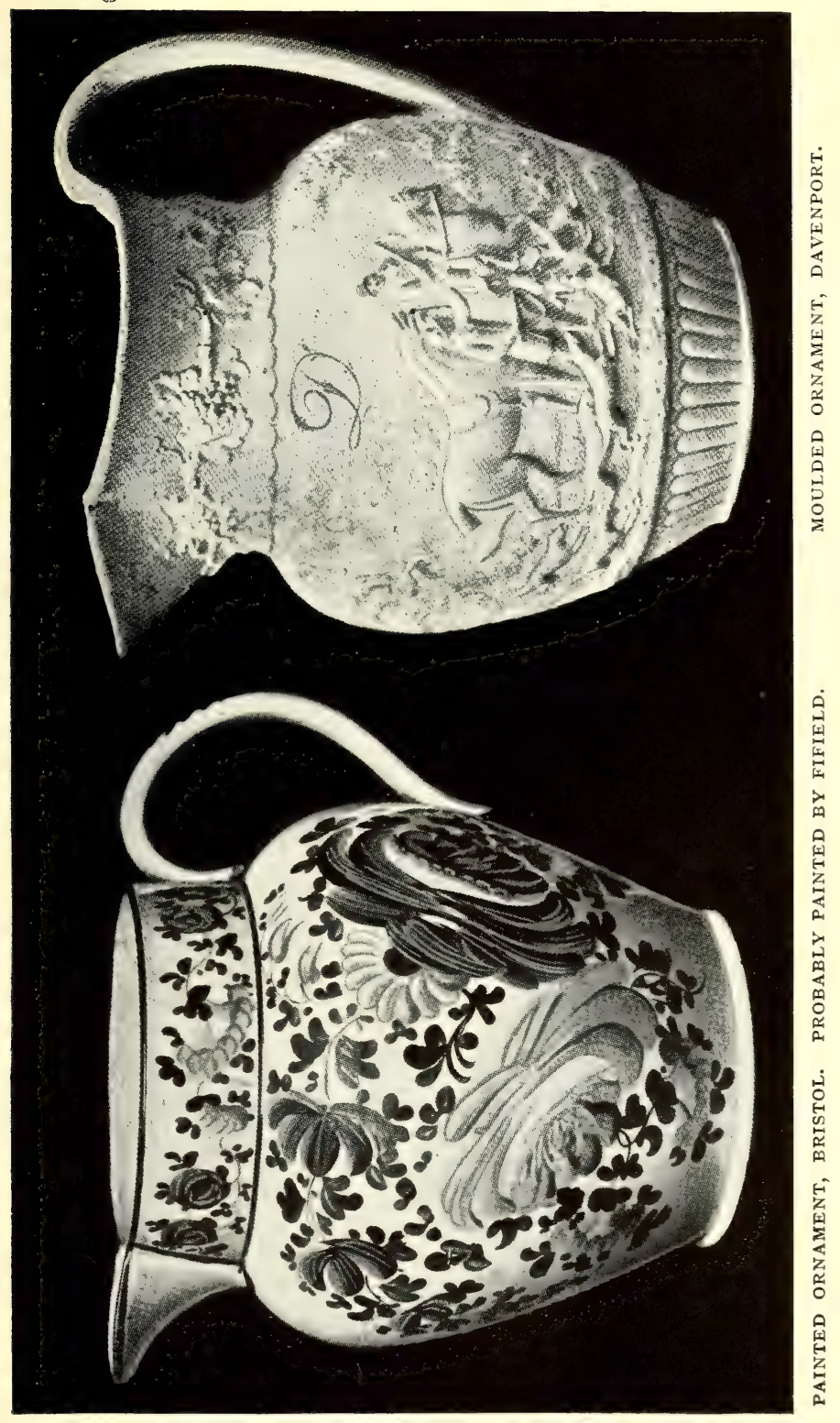





\section{CHAPTER XVIII}

\section{POTTERIES IN THE WEST OF ENGLAND}

\section{Bristol : Fifield}

THough Brislington lustre ceased to be produced after I 789 , and Ring's Delft ware came to an end in I788, Bristol stoneware, Queen's, and other ware continued at the works in Water Lane to occupy the attention of Ring, Taylor, and Carter. On the accidental death of Ring in that year his widow took his place as one of the partners. In I797 printing was introduced, and J. Doe, one of the enamel painters, became so despondent at the advent of this mechanical decoration that he took his own life.

An agreement for a new partnership at the Bristol pottery was drawn up, dated April 5, I8I3, between Henry Carter, John D. Pountney, and Joseph Ring, son of the late partner. Mr. Ring, however, died at the age of twenty-eight, on the day the deed is dated, without having executed it; and Mr. Carter only continued in the firm until I8I6, when he retired, and was succeeded by Mr. Edward Allies. The business was then carried on under the firm of Pountney and Allies until March 28, I835, when Mr. Allies retired and Mr. Pountney remained the sole proprietor. Finding the business beyond his powers, he took Mr. Gabriel Goldney into partnership, for seven years, from October I8, I836. At the expiration of this limited agreement it was renewed for a like period.

Mr. Goldney retired at the expiration of his second agreement, in September I850, and Mr. Pountney was again alone. $\mathrm{He}$ died at Clifton, in October I852. The manufacture of earthenware was carried on at the old premises, under the superintendence of Mr. Clowes, till I872, when Mr. Cobden became 
the proprietor. He owned the Victoria Pottery, and in I9oo the Bristol Victoria Pottery-Pountney \& Co., Ltd., was manufacturing the usual jet and earthenware, whilst Hawley \& Co., W. Powell and Sons, Price, Sons \& Co., were amongst the stoneware potters, with the Albert Pottery Co., and W. Hutchings \& Co., who made red ware.

William Fifield, the well-known enamel painter, was born at Bath in the year I777. He worked at the enamelling of Water Lane pottery for fifty years. He died in I857. Fifield has been described as "one of the best of the Bristol china painters, who survived many years the extinction of the manufacture." If the "manufacture" indicated is Champion's, a collation of the dates will show that Fifield was but three years old when the porcelain works became extinct. Several pieces of Fifield work will be found in the collection at South Kensington.

Henry Clark, an artist of considerable ability, was originally apprenticed at the Water Lane pottery, and continued in the employ for nearly fifty years. He died about I862. His best pieces were flowers and landscapes. Another artist, Richard Peake, a flower-painter, worked at Water Lane from about I 850 to 1856 , so did one of the old Staffordshire family of potters, named Toft, who was engaged for a short period about 1867 .

Thomas Pardoe, whose name will be found on some plates well painted with flowers, was a glass stainer and enameller, who lived from I809 to about I8I5 in Bristol, and painted on his own account china purchased in the white from the Staffordshire works. Then he went to Swansea, and from thence he followed Billingsley to Nantgarw in I8I7, and stayed there.

\section{Devon: Watcombe}

The Watcombe Pottery Co., owned by Evans \& Co., fine art potters, near Torquay, has been established for more than a quarter of a century. Watcombe terra-cotta brightly decorated in oil-colour, is widely distributed by those who take 

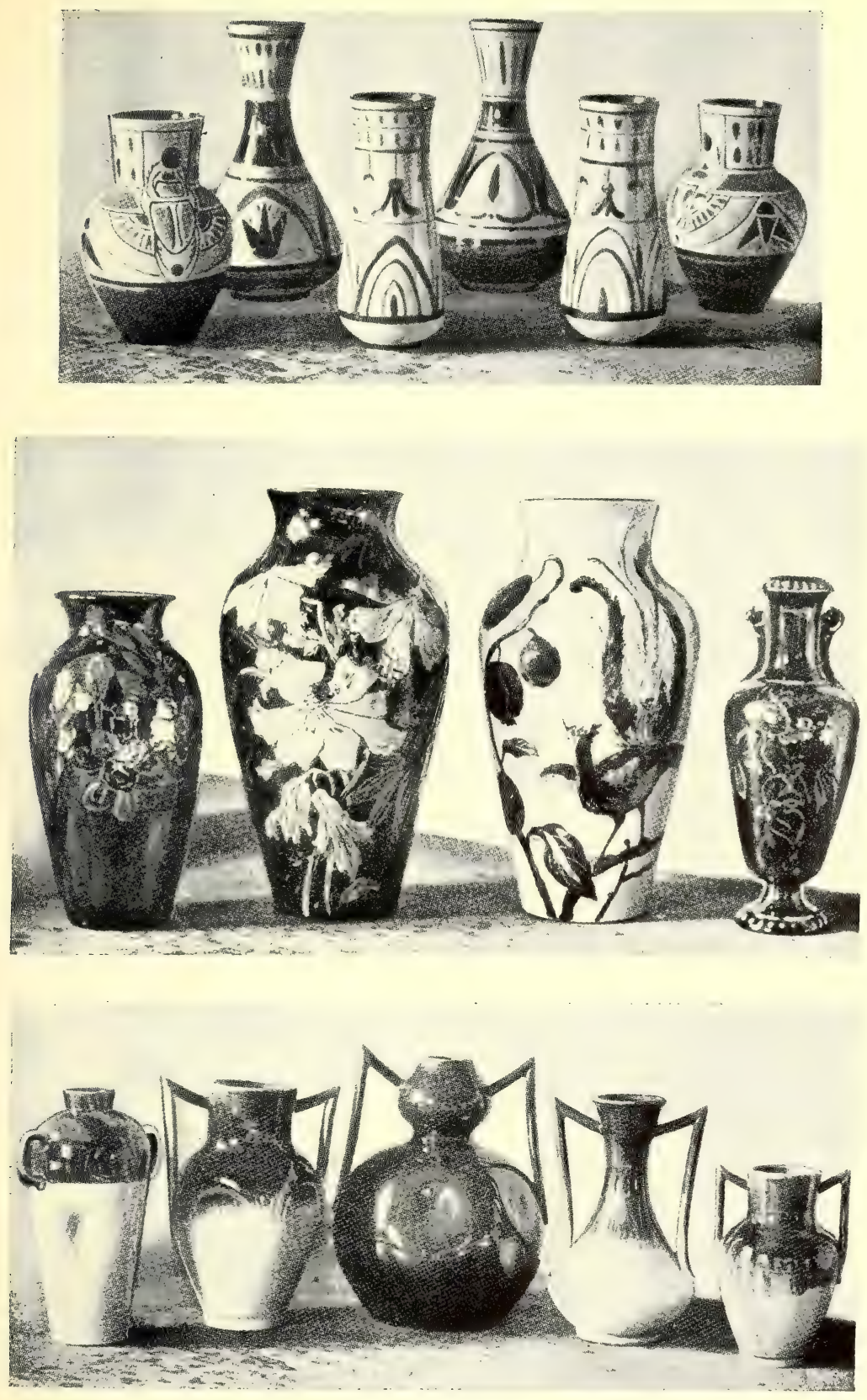

WATCOMBE WARE. 

their holiday in this delightful seaside town. As handpainted souvenirs, small pieces are very popular, and the larger plaques, with decoration of brilliant flowers, receive almost equal attention. Some of the pieces of good form and delicate decoration are desirable, but preference must be given to the "green and straw " coloured ware, to the Egyptian ware, and to the class painted with under-glaze decoration. Mere oil-painting on terra-cotta is outside the art of the potter.

Terra-cotta was for some time, however, the only product of the Watcombe works; but art-school inspiration, classical figures, and busts with those of modern men, were not likely to lead to success, therefore the scope of the work was extended to include decorative pottery, which had received public support at Aller Vale, Newton Abbott, near by. So the general resemblance between Watcombe and Aller Vale ware is scarcely confined to the clay body-both used the same clays, unless one is familiar with the special shapes and designs of each pottery, mistakes might easily be made.

Watcombe had to employ throwers and decorators from the Potteries, and the variety in shape and style is thus accounted for. The best articles are those decorated with barbotine paintings of fishes and seaweed and the like, though amongst the recent introductions the wares mentioned above are very effective in form and colour. The large ornamental vases are in a class apart, having the qualities of fine ware similarly decorated elsewhere with birds and flowers very skilfully painted upon a white or dark ground. These need fear no comparison with the work of other factories, but they are above the ordinary products, the pottery popular as Watcombe ware.

\section{Devon : Aller Vale}

Two mugs of Aller Vale ware, with a yellow glaze on a dark red body, glazed inside with brown, are before me. They are decorated with barbotine in brown and green, under the glaze which also covers the scratched mottoes, "If you can't be aisy, Be as aisy as you can," and "Thrift and wealth are I8 
near neighbours." These are examples of the " motto " ware which in bowls, jugs, and mugs is very popular. Brown inside and yellow outside, the latter with bold conventional designs in dark greens and browns; such, too, is the decoration of the A. K. ware named "Abbots Kerswell," after the home of the youths who lived close at hand and worked with but little outside assistance in the development of the ware, in what is now the Aller Vale Art Potteries (John Phillips).

About a quarter of a century ago Dr. Symons opened an evening school where young men engaged upon the farms might learn to draw, and this became a local school of art which was encouraged, amongst others, by Mr. John Phillips, maker of tiles and drain-pipes. When, in I88I, his place was rebuilt after a fire, he made it an art pottery and gave employment to some of the students, who had lessons in throwing from a gipsy. Now about sixty persons are employed, nearly every one being a native of the district, and most of them starting as boys. The whole of the processes of the manufacture, and all the decoration, are carried out with, results that reflect credit on all concerned. The "Sandringham " ware has been purchased by several members of the Royal family, and its simple, effective decoration, allied as it is to graceful forms, merits the popularity which it has secured. The "crocus" design is uncommon; the flower, stem, bulb and leaves of the crocus, in creams and greens, are extended vertically on a dark-blue ground upon vases of many forms. I have indicated typical products, but there are others which belong to a series of well-marked shapes, and of distinctive styles of decoration, which are the products of the Aller Vale folk.

\section{Devon : Barnstaple (Barum)-Brannam}

The list of the Royal patrons of this art pottery is a long one, which includes Queen Victoria and Queen Mary (Princess May). This of itself is a testimony to the merits of Barum ware, which is made at Barnstaple, North Devon, by Charles H. Brannam, who, from the small beginnings of an ordinary 

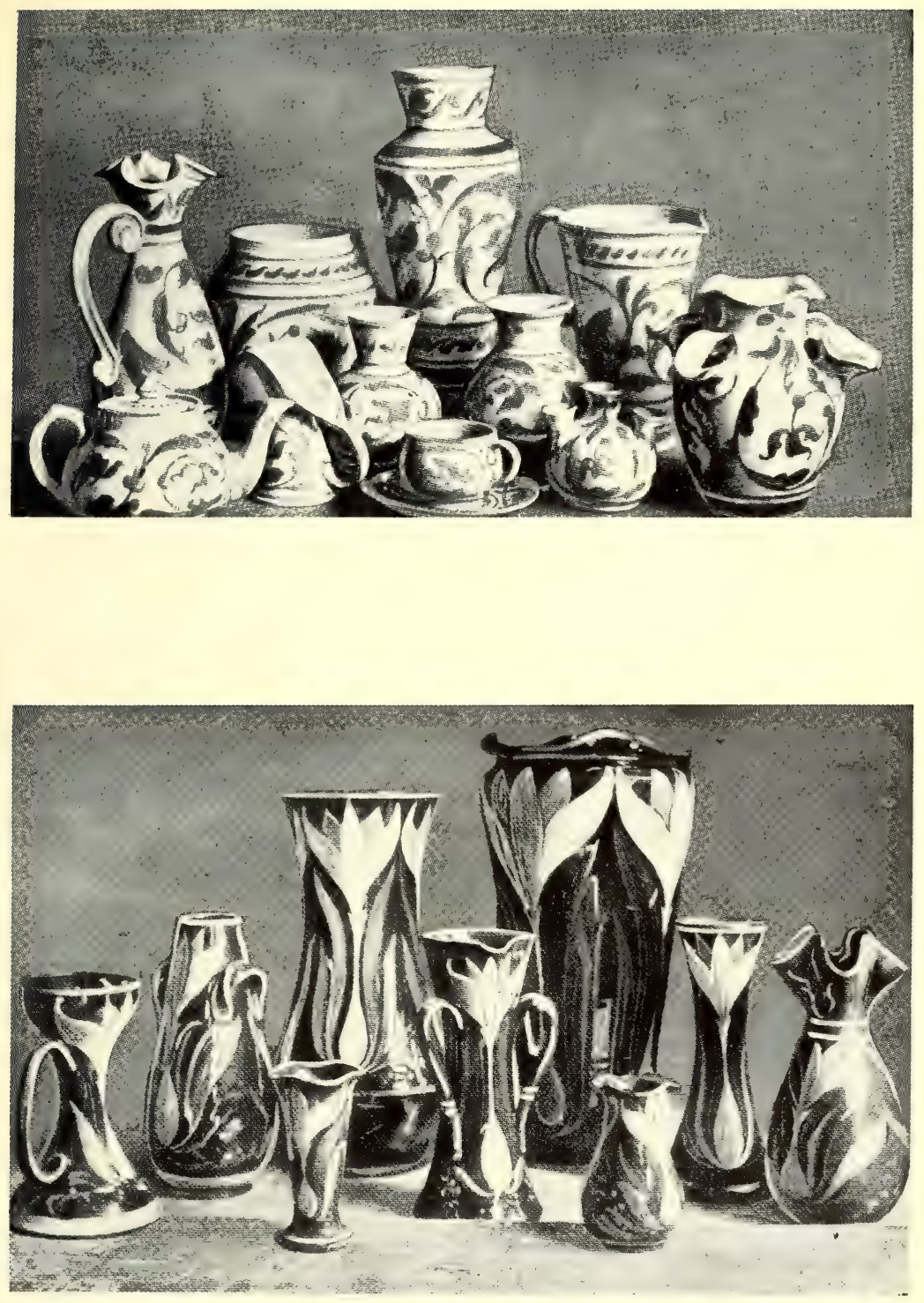

ALLER VALE WARE. 


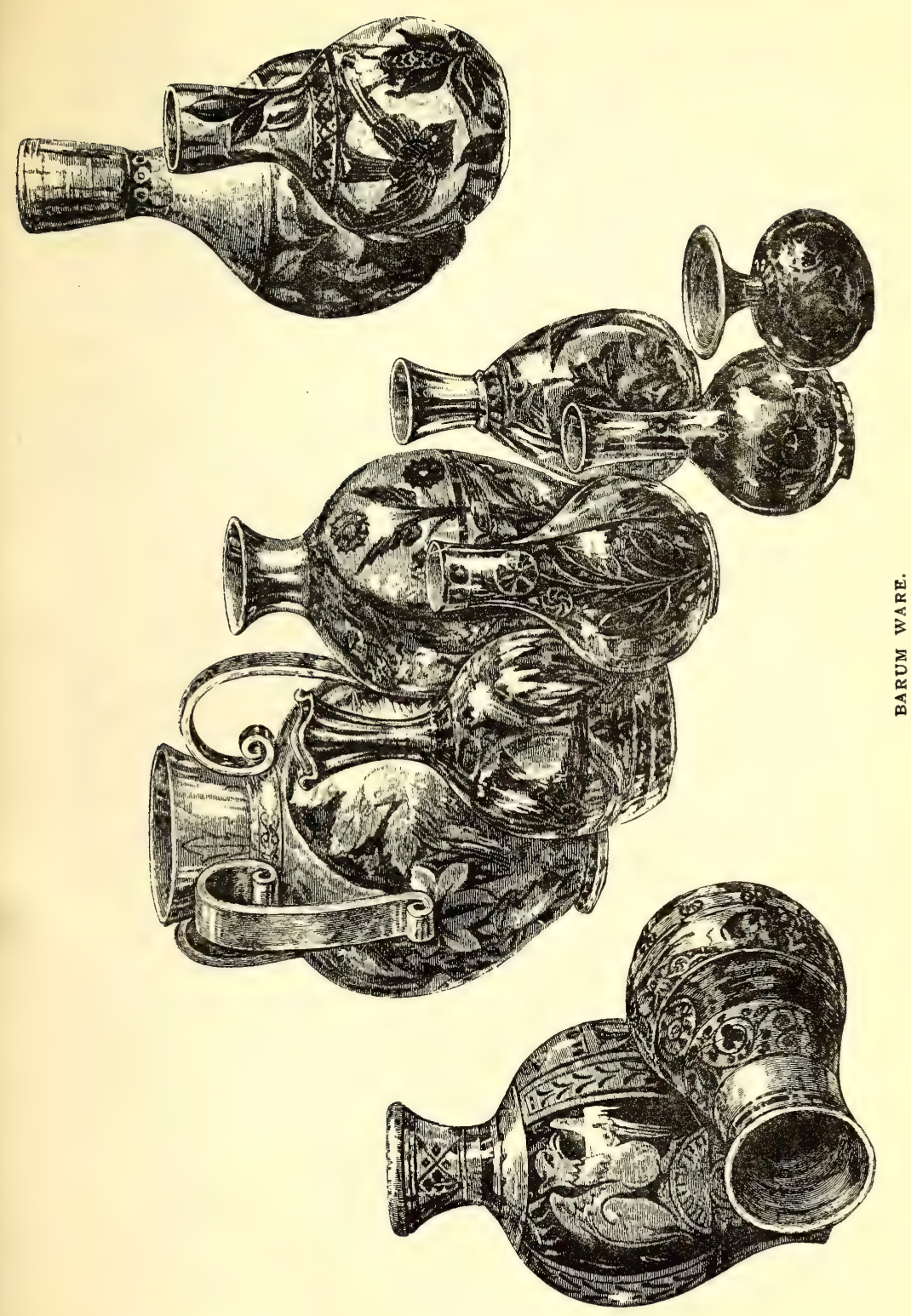


\section{4}

pottery, where pots and pans were made, has created a business and a reputation which are both enviable. From drain-pipes and roofing-tiles to the honour of praise from Sir A. H. Church at the rooms of the Society of Arts indicates much of labour, study, and progress. Seldom do we find the results of the schools of art better exemplified. What wonderful creation sprang from the influence of Sparkes in the Doulton works! and Sparkes had an intuitive perception of possibilities which were largely realised by the pupils of the Lambeth School of Art. Mr. Brannam profited by his work in the local school so that, when the pottery by inheritance became his own, he began his upward career by scratched work, the simple sgraffito on white slip, which covered the ordinary brown clay. His first productions were small jugs and vases neatly incised. Some of these came under the notice of the London firm of Howell and James, who, liking the rough but decorative ware, took steps to assist in the development of the business with such effect that, in I885, Queen Victoria bought some of it.

From this time Mr. Brannam's work has increased in quality and quantity. The designs of foliated and bird ornament, of conventional scrolls, flowers, fishes, etc., are as distinctive as the colours are good. From the white and red of his first efforts he has advanced into the richest combinations, in which delicate tones of blue, yellow, and green are associated with many others in most effective fashion.

Mr. Brannam's ware is only the ordinary earthenware, glorified with a wealth of design, expressed by coloured slip and glazed with lead, and the beautiful effects are secured upon shapes which are but slightly altered after the thrower has formed them upon the wheel. There may be some slight modelling, but the plastic clay is not bent and twisted and cut, the surface remains flat, and to that surface the slips are applied in original designs, so that one colour is placed upon another so aptly as to reveal the beauties of both design and colour in truly artistic union. The same remarks apply to the form when modelled ornament is attached. Here is a vase around the neck of which a dragon is enrolled. It stands 

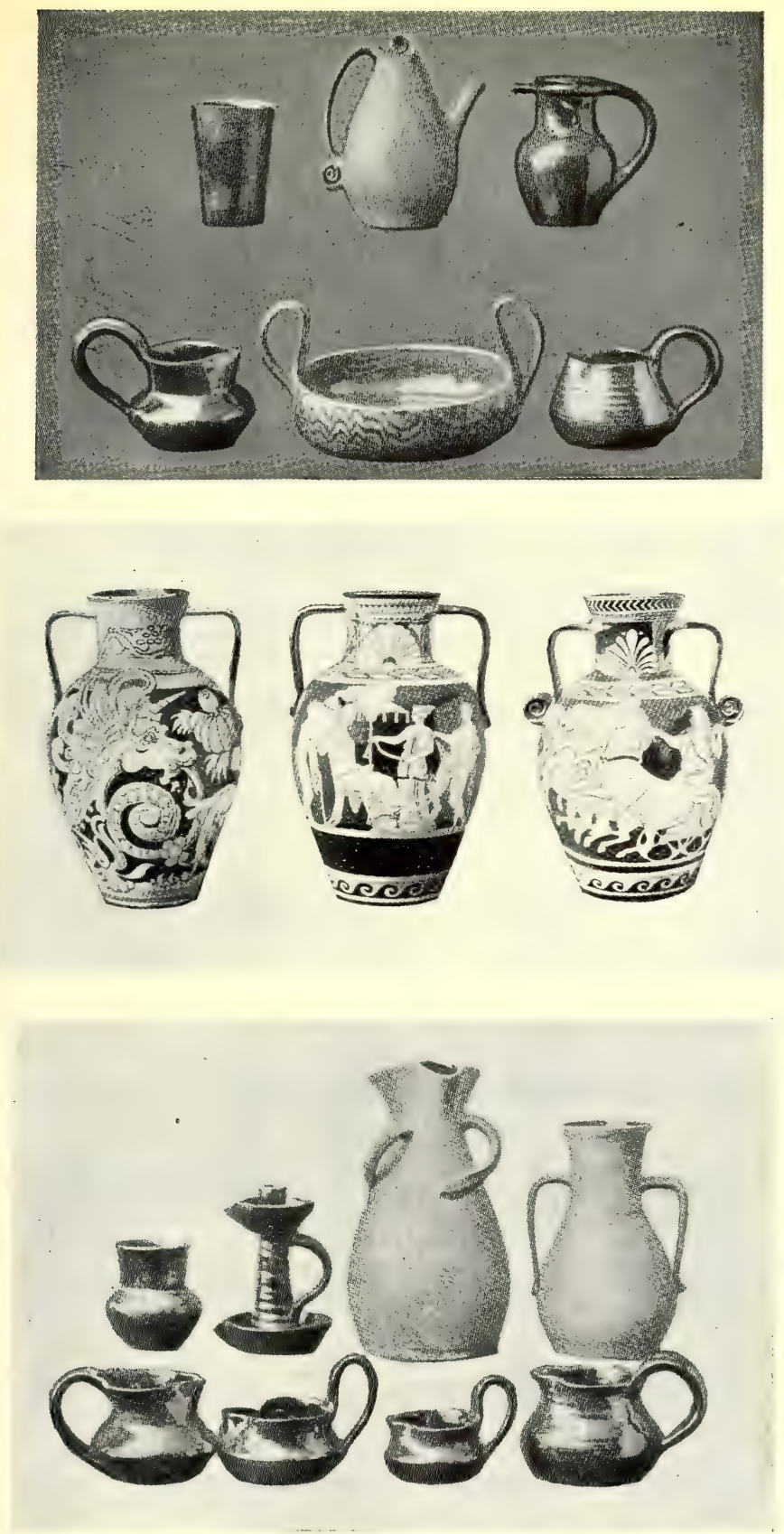

FREMINGTON ART POTTERY. 

out in high relief upon the surface of the vase. There is another with crustaceans and seaweed applied to the perfect surface, and so on. The ornament does not interfere with the shape of the vases, some of which are of considerable size, all of much merit.

This factory, again, is one of the small ones, founded independently by men who discovered within themselves a talent for the decoration of pottery. Our great English firms, Copeland, Minton, Doulton, and Wedgwood, the Royal works at Worcester and Derby, produce porcelain and pottery perfect in its composition, decorated with all the resources of the ablest artists, whose distinguished merits are well known. Yet to these small factories the credit must be given that they have created such interest in their own productions that their names have spread far beyond the localities for which at the first they laboured, and that they have incited others to imitate their examples, though sometimes, from the want of sufficient capital, they have not met with the success they deserved.

\section{Devon: Fremington-Fishley}

Mr. Fishley's forefathers were potters who made the ordinary red and brown pots and pans at Fremington, near Barnstaple, North Devon, where a suitable bed of clay exists from which the neighbouring Royal Barum ware is madefor Barum was the ancient name of Barnstaple. The owner of the small pottery at Fremington, the inventor of the ware, had to deal with the ordinary brown clay and to beautify it. By his discovery of a glaze eminently fitted for his purpose he has been able to cover the clay with all colours, perhaps the best being a rich dark green, not of uniform tone, but splashed and mottled with other tints. The glaze is iridescent.

The sgraffito vases made here in Etruscan designs are of good form and quality Upon the brown ware, whilst unburnt, a layer of slip is appiied by dipping, which while still moist is cut and etched with a tool leaving the design in white upon the brown ground. The reverse process may leave the design in brown with white as the ground. At Doulton's 


\section{I9TH-CENTURY ENGLISH CERAMIC ART}

sgraffito has been practised with much success for some years, but I do not remember any classical decoration, such as appears so effectively upon the Fremington ware. The process lends itself to continual combinations of ground and glaze.

Puzzle-jugs, quaint "Cadogan" pots, fruit-dishes, candlesticks, and vases are amongst the most charming products of this potter, whose smaller pots in coloured ware are in demand in various parts of the country, but the chief market is found at Barnstaple. To this he resorts during the summer season, with a stock for disposal to visitors, who purchase it freely. It should be mentioned that medals were awarded to the sgraffito ware at Newton Abbot, and for the general exhibit at Plymouth.

\section{Clevedon (Somerset) : Elton}

The art ware of E. H. Elton, of the Sunflower Pottery at Clevedon, is quite original. Like other individual potters, he has utilised the local clay and made it into earthenware, which he has covered with a coloured slip and glazed with a lead glaze. In the lead-glazed decoration a fine film of colourless glass is over all. Where the colour is applied in the glaze the firing fixes the colours and the glaze. Mr. Elton was not a potter, and unusual difficulties had to be surmounted before he secured what he wanted, which was to make and decorate pottery with slip, or with applied ornament, or both ; that is, ornament applied on a coloured-slip ground, the said ornament being itself coloured, and to glaze it.

He began his experiments three years before success was obtained in I882, and when we learn that his kiln, his slip, his glaze were his own productions, we may well wonder when the beautiful ware, Elton ware, attracts our notice. Not only are the shapes of the bowls and jars, vases and jugs, simple and effective, but the decoration displays much ingenuity in its conventionalised natural forms, boldly adapted to the surface which they are intended to ornament. These designs were no less his own than the coloured slips which he has brought to such excellence in reds and blues, purples and 

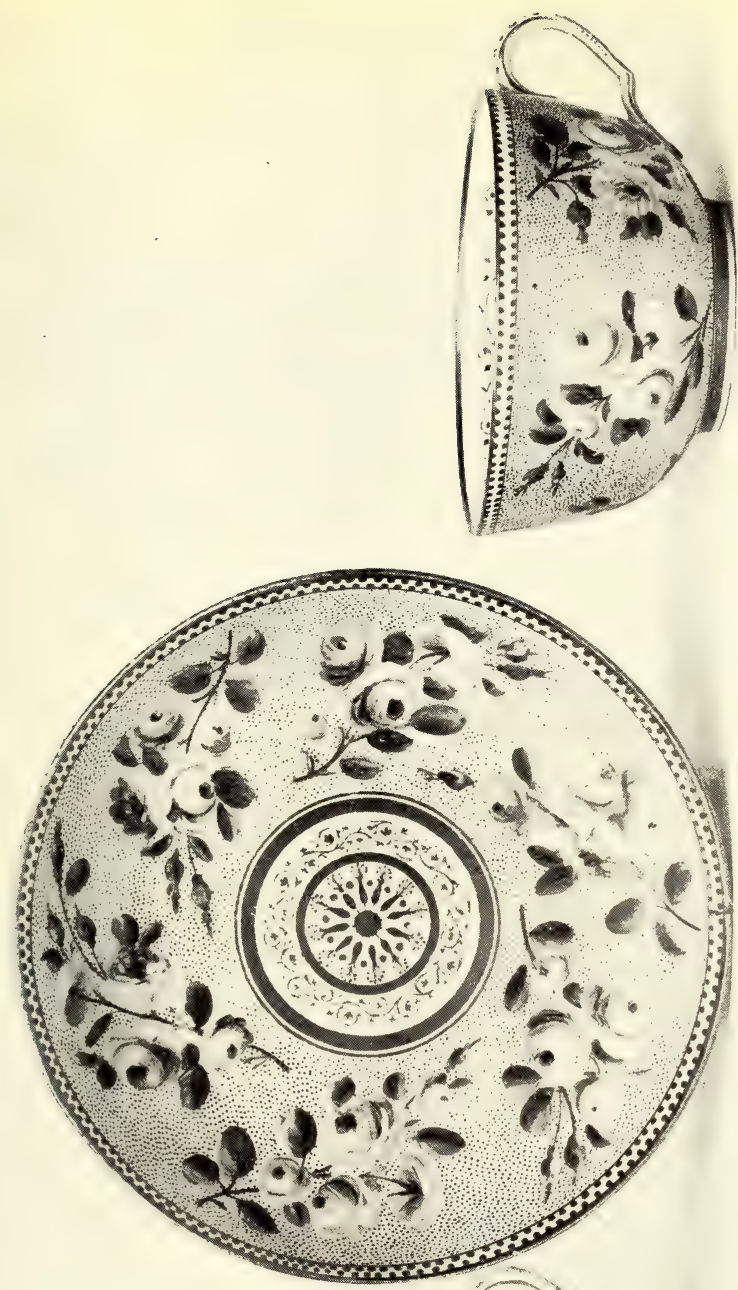

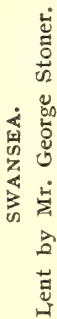

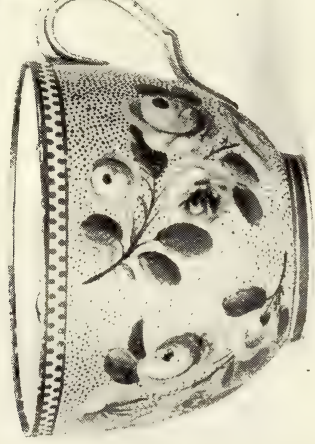





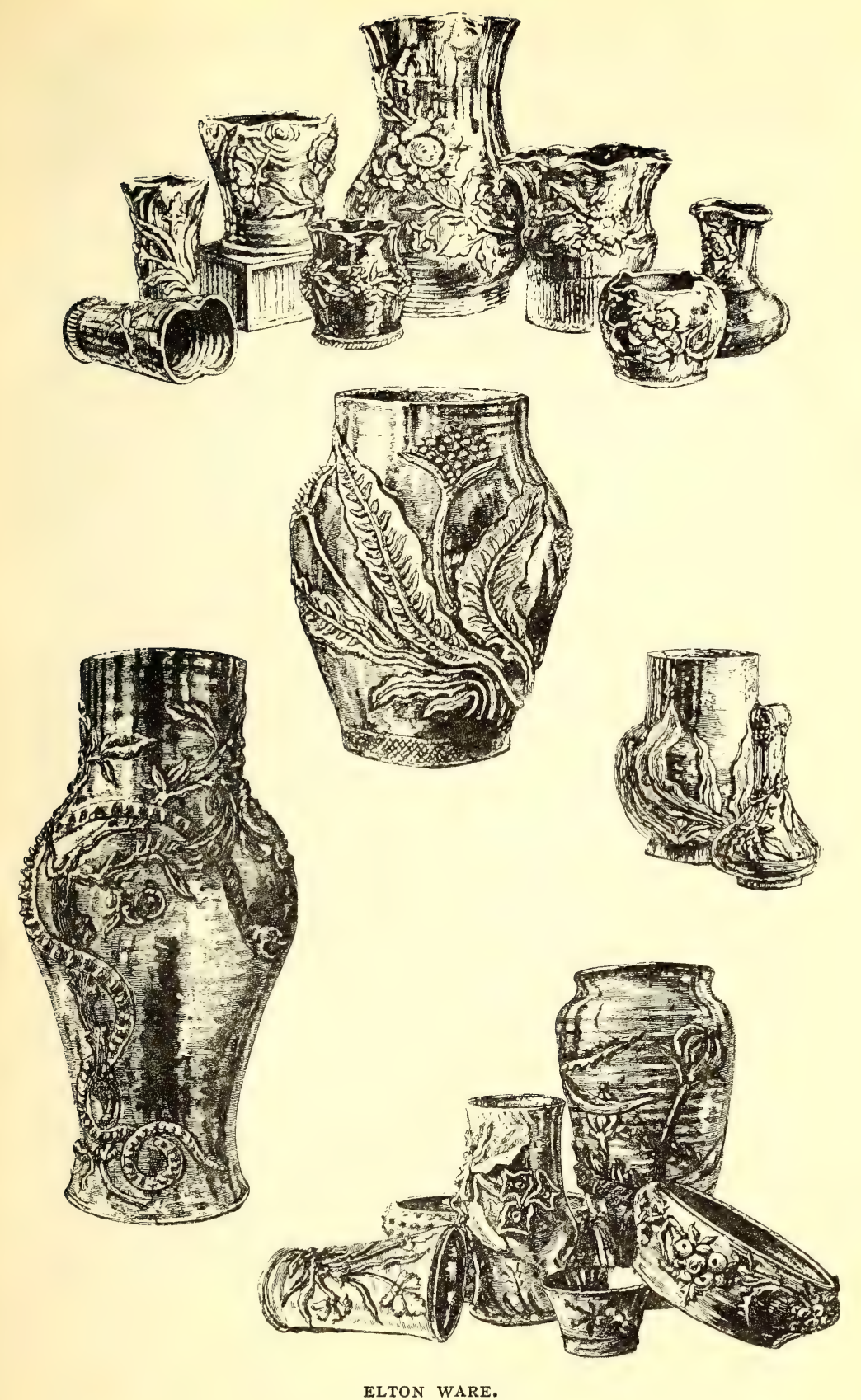


greys, which, when splashed, combine into wonderful tones; sometimes limited to two colours, they are then no less effective, the harmonious contrasts of red with purple or green, and the violet with the grey, being singularly charming.

Mr. Elton's mixture of scratched work (sgraffito) and of modelled slip is distinctive in this, that the masses of coloured slip are laid on in the rough and then modelled. From the early rough moulded vessels, made with coarse clay, he has progressed into the highest regions of art pottery, where his ware maintains its position because of its very real merit. 


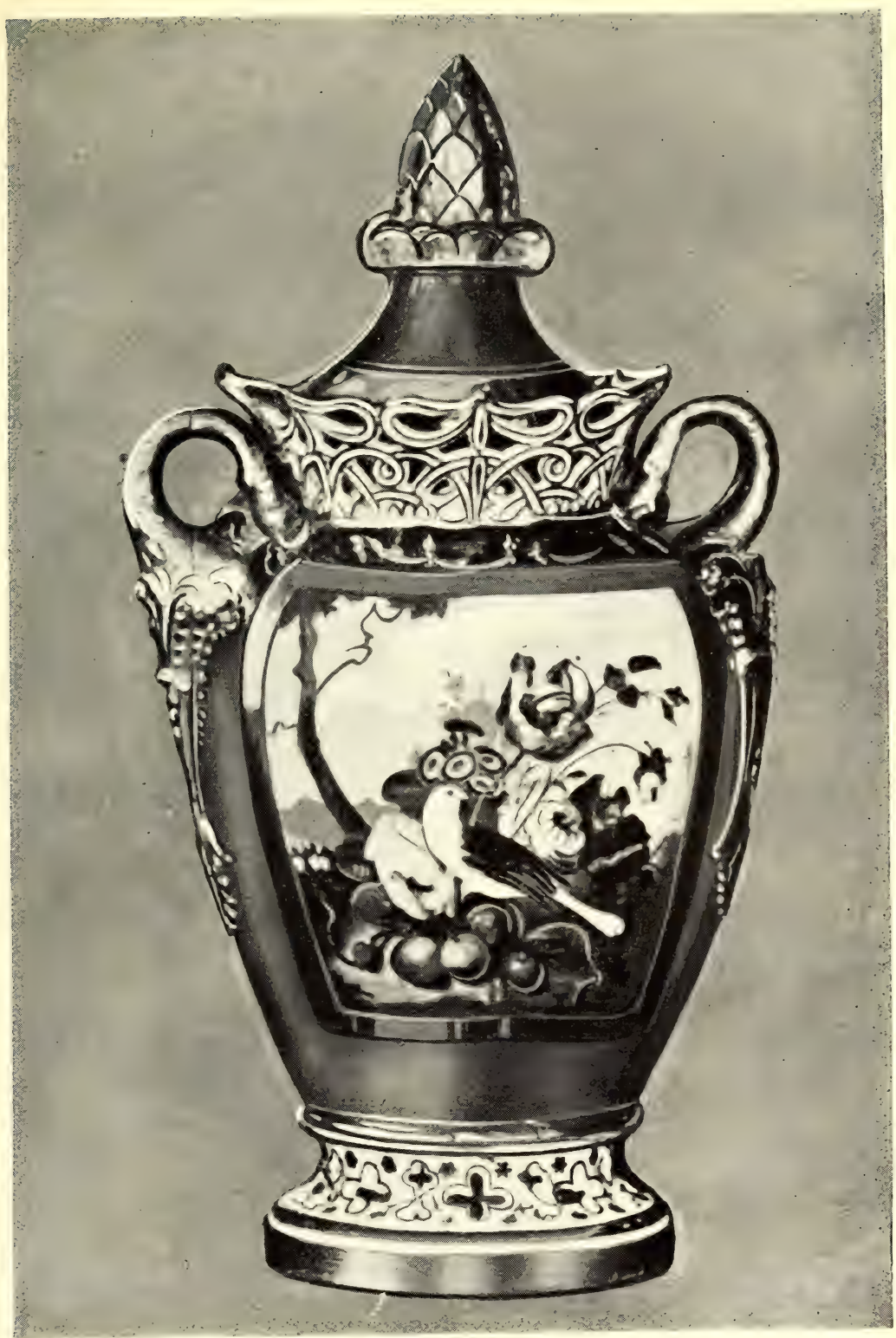

SWANSEA VASE. 



\section{CHAPTER XIX}

\section{WELSH, SCOTTISH, AND IRISH POTTERIES}

\section{Wales : Swansea-Dillwyn}

BEFORE the nineteenth century G. Haynes, at the Cambrian Pottery, made cream-coloured and white-enamelled ware similar to that of Staffordshire. This was marked CAMBrian PotTERy, sometimes in script capitals, and another mark, G. H. \& Co., was also used on the table ware, less frequently on figures like the Staffordshire ones, which are often distinguished by a brown or orange line round the square base. In I802 a new style of decoration was adopted by L. W. Dillwyn, who employed W. W. Young as a painter of shells, butterflies, and birds, first upon the opaque china, and later upon the porcelain. This white ware, with a slightly blue-tinted glaze, marked one period of the work at Swansea, when the finest productions were decorated with a marbled blue ground, enclosing panels painted by Young. Still the mark,

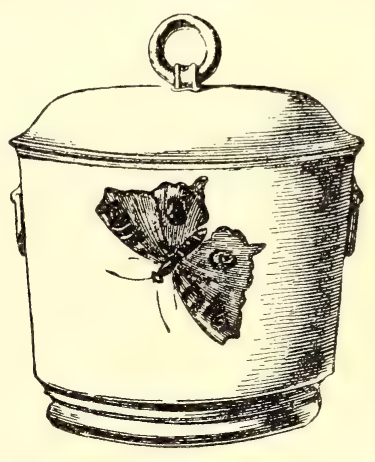

SWANSEA SUGAR-BASIN.

CAMBrian PotTery, was used in gold or brown. Other ware was painted with single flowers and birds, their names being frequently written on the back or inside. At Swansea the well-known black basalt was produced in figures and vases, with buff-ware unglazed, having figures in relief, and Etruscan ware exceedingly well decorated, in black and red, 


\section{I9TH-CENTURY ENGLISH CERAMIC ART}

was introduced by Dillwyn, and marked Dillwyn's EtrusCAN WARE. This was about I850.

Now, going back to I8I4, we find that L. W. Dillwyn received a letter from the Government asking him to examine and report upon the works which had been established about ten miles north of Cardiff at Nantgarw, in I8I3, by William Billingsley, and his son-in-law, George Walker, of whom more will be said when we treat of Nantgarw. The result of Dillwyn's visit to that place was an arrangement whereby both Billingsley and Walker came to Swansea, to the Cambrian Pottery, where, two new kilns having been erected, the

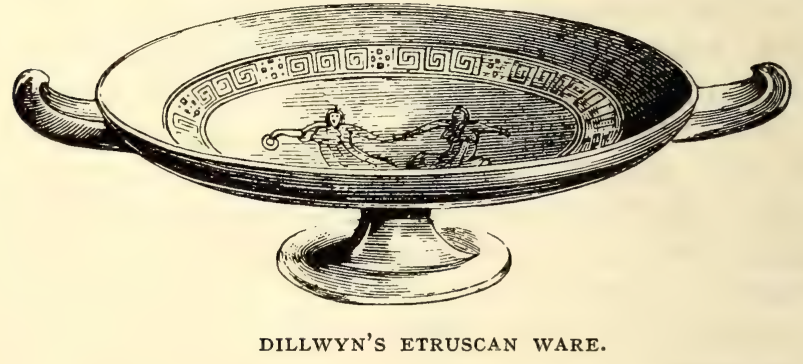

beautiful translucent porcelain was by them produced from I8I4-I7, when, to use Dillwyn's own words-

"While endeavouring to strengthen and improve this beautiful body, I was surprised at receiving a notice from Messrs. Flight and Barr, of Worcester, charging the parties calling themselves Walker and Beeley (Billingsley) with having clandestinely left an engagement at their works, and forbidding me to employ them."

They returned soon after to Nantgarw, which event closes the second period of the Swansea manufacture, when it attained its highest excellence, not only in the paste, but in the decoration of the china with flowers painted by Billingsley in his inimitable style. Dillwyn, when they left, gave up the making of porcelain to BEVINGTON \& Co., which appears with SwANSEA and I. W. as an impressed mark on china, and on biscuit figures for a short period only, I8I7-20. About the 


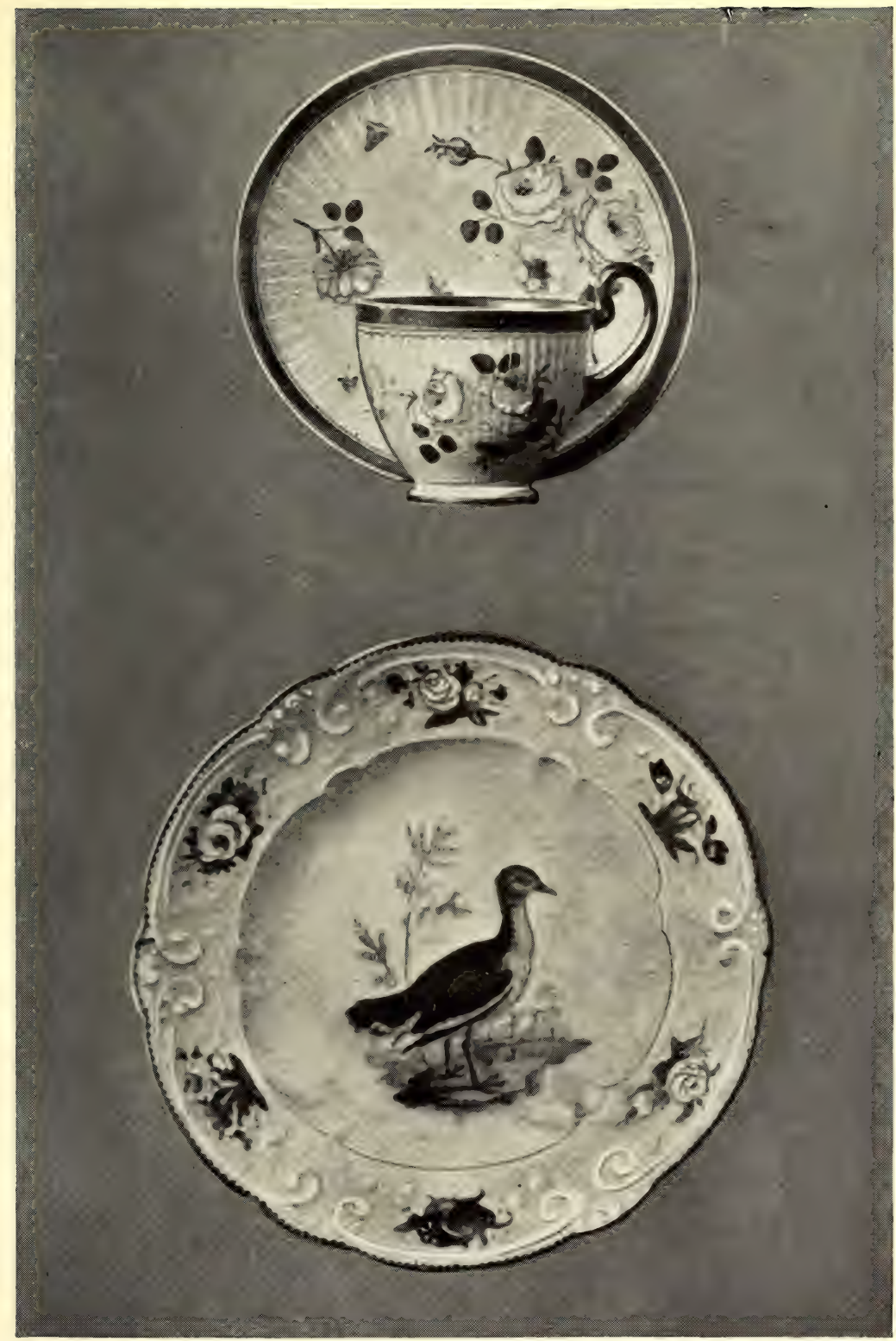

SWANSEA. PLATE ALSO NANTGARW PATTERN. 

latter year the mould, etc., were purchased by Rose, of Coalport, who at the same time bought those of Nantgarw and took Billingsley and Walker into his employment, so that no china was afterwards made at either place. This then closed the third period of Swansea : first, opaque china ; second, Billingsley's ; third, Bevington's. Transfer-printing and lustre were both used by the last-named.

The Cambrian Pottery continued, but the works were leased by L. W. Dillwyn to Bevington, and he taking a partner, the firm became successively Bevington and Roby, Bevington, Roby \& Co., and then reverted to Dillwyn, whose son, L. L. Dillwyn, after-

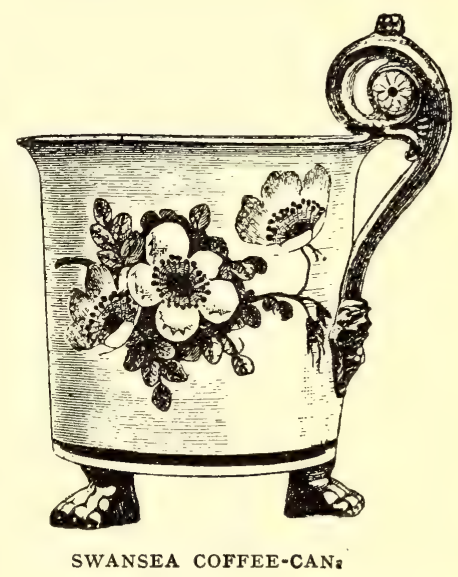
wards became the proprietor. In I840 some negotiations took place with Messrs. Brameld, of Swinton, but they fell through owing to the price being too high. When L. L. Dillwyn retired in I852, Evans, Glasson and Evans carried on the business with corresponding changes in the marks till I859, when the change to Evans \& Co. was soon followed by another to D. J. Evans \& Co., who manufactured the ordinary classes of earthenware, blue-printed and agatised. At the close of the works, about I870, the copper plates were sold to the South Wales Pottery, Llanelly, which appears in the I90o list with Guest and Dewsberry as proprietors, makers of earthenware.

No history of Swansea porcelain would be complete which did not recognise the extraordinary talents of artists other than Young and Billingsley who were employed at the works during its palmiest days. Pardoe, the flower-painter, afterwards worked with some others at or for Nantgarw, for upon some specimens of the finest Nantgarw were figures which could be painted only by Baxter, the celebrated figure-painter 


\title{
460 I9TH-CENTURY ENGLISH CERAMIC ART
}

who painted at Worcester, leaving in I8I6 for Swansea, where he worked for three years before returning to Worcester, where at first he worked for Flight and Barr, then for Chamberlain's. Bevington, whose name has been mentioned as proprietor or

\author{
SWANSEA MARKS. \\ Gumbricun Pottery. \\ CAMBRIAN \\ POTTERY.
}

On the porcelain made by Billingsley and Walker for Mr. Dillwyn, the mark appears to have simply been the name SWANSEA printed in red; or, as on the subsequent make of china, the name sometimes occurs simply impressed,

SWANSEA SWANSEA, or SIVANSEA, or Swansea.

CAMBRISAS

DILLWYN \& COMPANY

누

OPAQUE CHINA, SWANSEA.

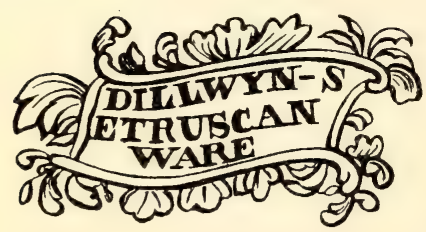

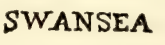
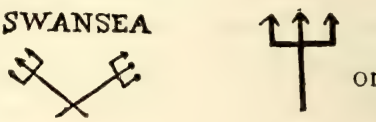

SWANSEA

DILLWYN \& CO.

CAMBRIAN POTTERY

HAYNES, DILLWYN \& CO. CAMBRIAN POTTERY. SWANSEA.

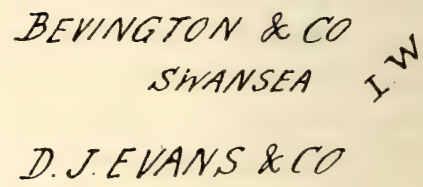

lessee of both the china works and the pottery, was a flower painter; Reed and Hood were the chief modellers; Morris painted fruit; Colclough flowers, and Beddoes the coats-ofarms. During its short life the works at Swansea were dis- 


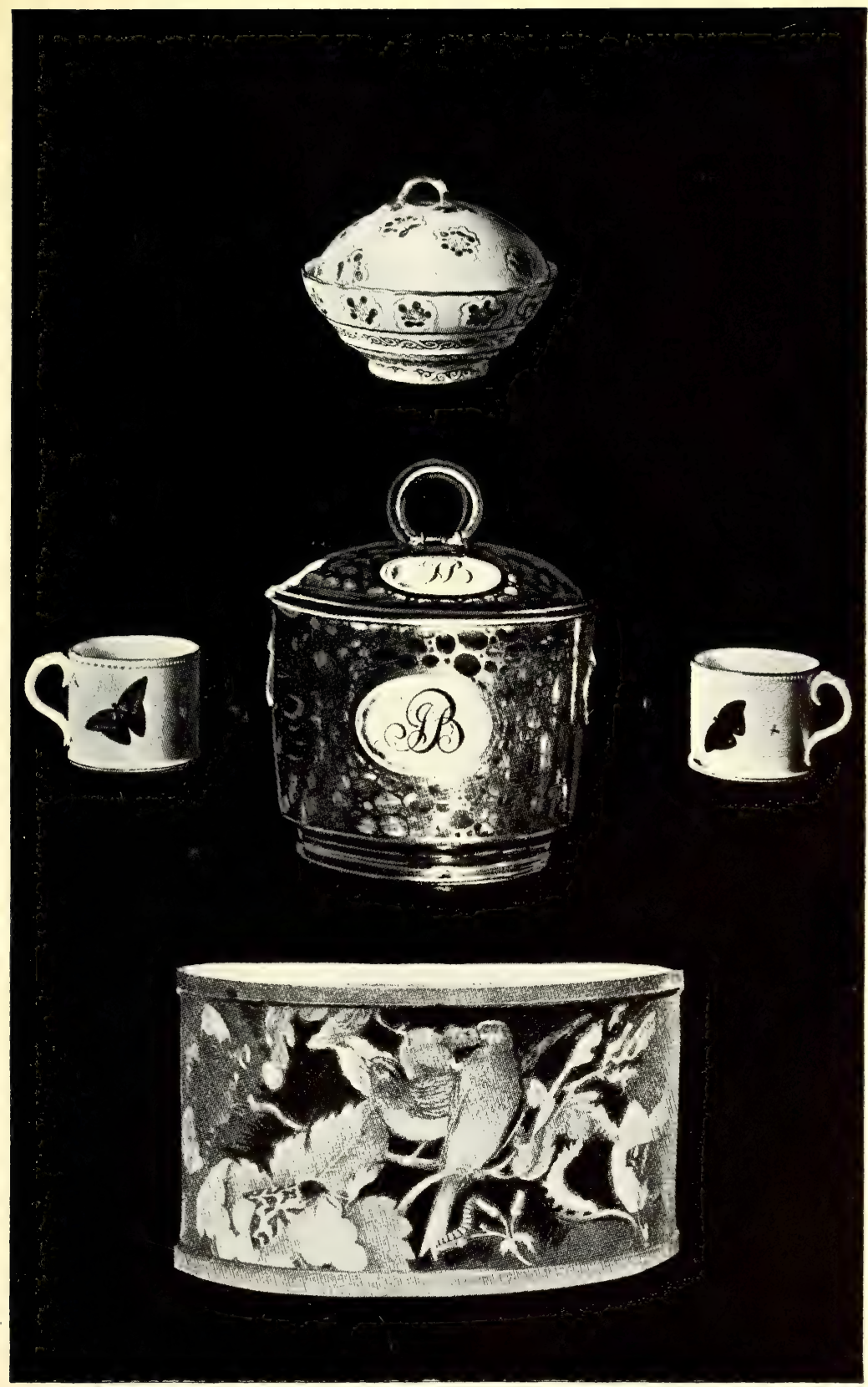

SWANSEA. 



\section{WELSH, SCOTTISH, AND IRISH POTTERIES 463}

tinguished by its excellent artists. Whether we consider the opaque china painted by W. W. Young with shells, butterflies, or with birds, such as the hen-harrier (Falco cyanicus), the merlin (Falco asalon), or the golden eagle (Falco chrysatos), or the beautiful porcelain, with embossed border and delicate painting, by other of the artists named, we must conclude that, during its short history, if Dillwyn did not achieve pecuniary success, he left an enviable record of artistic effort which deserves warm approbation and which receives from collectors its due meed of admiration.

\section{Nantgarw : Billingsley}

William Billingsley worked at Derby for twenty-two years, being apprenticed to Duesbury in I774. Then he went to Pinxton, where his previous experiments in china bodies were successfully continued till I80o, when he started a small place of his own at Mansfield, which was given up about four years later, when he removed to another small factory at Torksey, staying there for a short time before proceeding to Wirksworth. Of these small concerns, and his work in them, but little is known, nor of the cause of his migrations. However, in I8II he and his son-in-law, George Walker, were engaged by Flight and Barr at Worcester, where Walker erected a reverberating enamel kiln, but where Billingsley was not encouraged in the use of his special body, or paste. So they broke their engagement in $18 \mathrm{I} 3$, and, under thename of Beeley, Billingsley and Walker, wandered to Nantgarw, near Pontypridd, where they set up a small kiln and started making china.

Next year they went to Swansea at the invitation of Dillwyn, who built a small factory, where for three years they produced the celebrated translucent porcelain, which for beauty of body and elegance of decoration was only surpassed by what they themselves made on their return to Nantgarw, about two years later. The years $\mathrm{I} 8 \mathrm{I} 7$ to $\mathrm{I} 82 \mathrm{z}$ were notable for the expenditure of about $f 8,000$ in the experiments and trials and in the alteration of buildings, the purchasing of materials, 
etc.; but those years were more distinguished by the complete success which attended these efforts, which gave to the

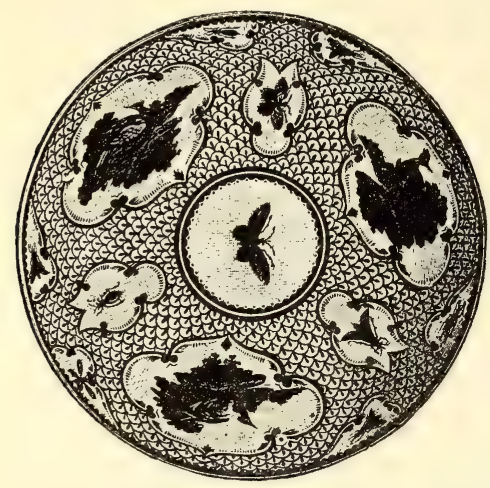

NANTGARW SAUCER WITH LILAC AND GILT SCALE GROUND. world an exquisite porcelain, decorated by W. W. Young, by Pardoe and Baxter, as well as by Billingsley, now at the height of his fame, which reached London and brought Mortlock as a supporter of the china, and a large buyer; and it brought besides a crowd of fashionable folk, who visited Nantgarw in such numbers that forty gentlemen's carriages came there in one day.

Mortlock bought white china, which was enamelled in London by Randall of Madeley, later by Webster from Derby amongst others. The popularity of Nantgarw seriously affected the Coalport output, so Rose, its proprietor, who had absorbed the trade of Jackfield and Caughley, entered into an arrangement by which Billingsley and Walker accepted a permanent engagement at Coalport, to which place, in I8zo, they moved with their moulds. It is said that $\mathrm{W}$. W. Young carried on a factory at Nantgarw after I $8 z 0$, but records are wanting. In I8z3 Pardoe died, and in the same year much of the china works was pulled down, yet nine years later

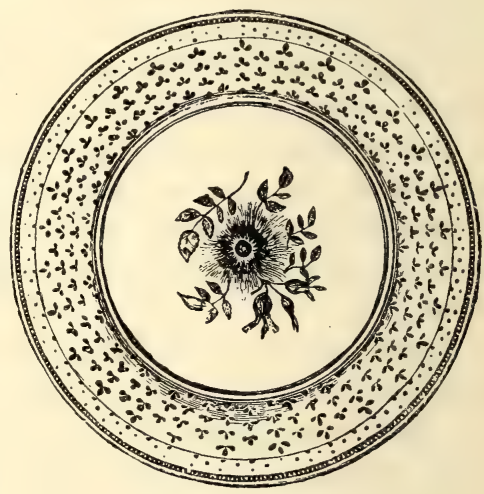

NANTGARW PLATE. W. H. Pardoe commenced a factory there, and though at first he made red ware only and tobacco-pipes, rockingham and 

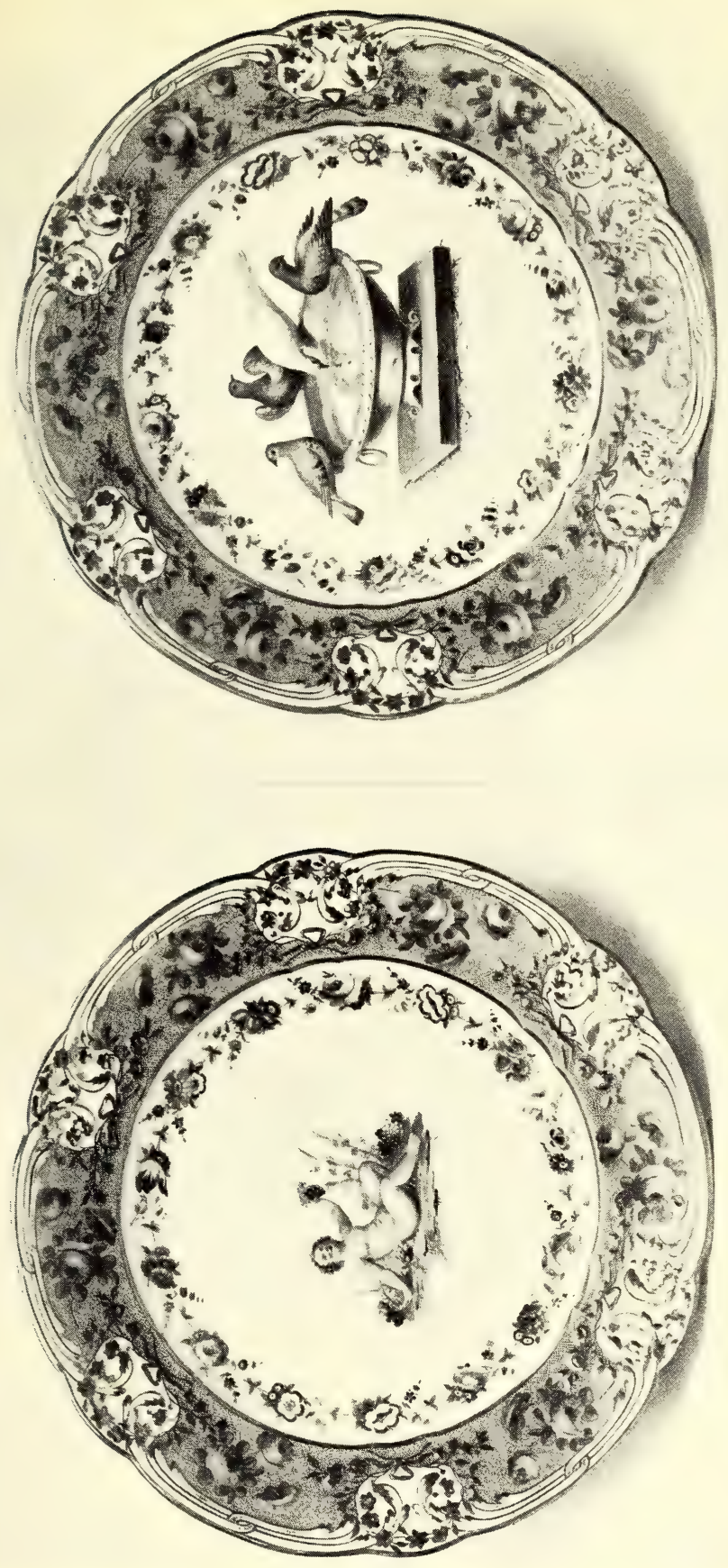

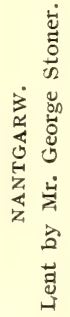





\section{WELSH, SCOTTISH, AND IRISH POTTERIES 467}

stonewares were soon amongst the ordinary productions. In I878 stoneware bottles of every kind, hunting-jugs, and mugs find a place in an extensive list. W. H. Pardoe died in I867, and the works were then carried on by his widow and her family. In I9oo the title of the firm was "Pardoe Bros., Manufacturers of Earthenware, Nantgarw."

The exquisite paste and the delicate flower-painting which made Swansea famous were possibly excelled by the second Billingsley period of Nantgarw. Nothing quite of the same quality has ever been produced: soft, milky, and almost transparent, remarkable translucent porcelain of very fine texture, are words which feebly express some of the character of the paste, or body, whilst in the decoration of figures, flowers, and landscapes, in delicacy and dexterity reveal the highest skill of the master painters.

The mark was NANTGARW impressed or in colour, sometimes with G. W. added.

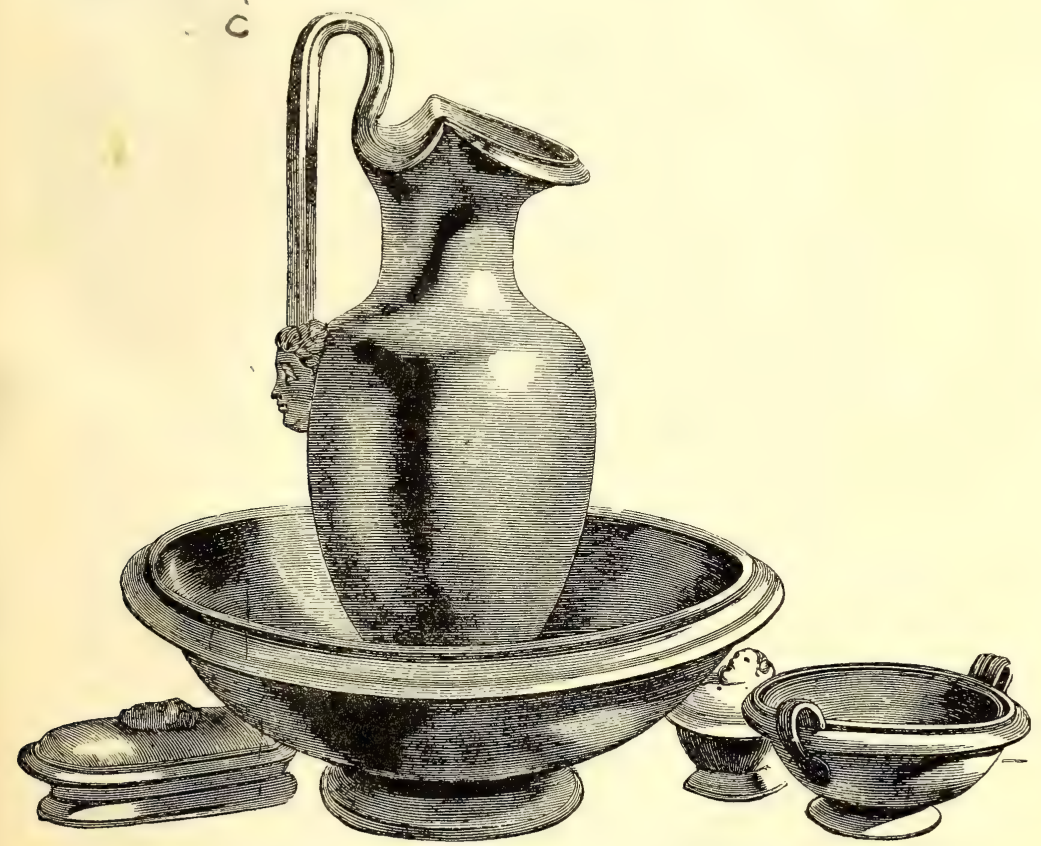

J. AND M. P. BELL \& CO., GLASGOW, I85I. 


\section{Scotland : Glasgow-J. and M. P. Bell \& Co.}

The Glasgow Pottery, under the same title which was adopted in 1842 , when it was established, produces white and printed earthenware, just as it did then. It ranks amongst the first factories in Scotland. From the beginning particular attention was paid to the constitution of the body, or paste, and improvements in form and decoration soon followed.

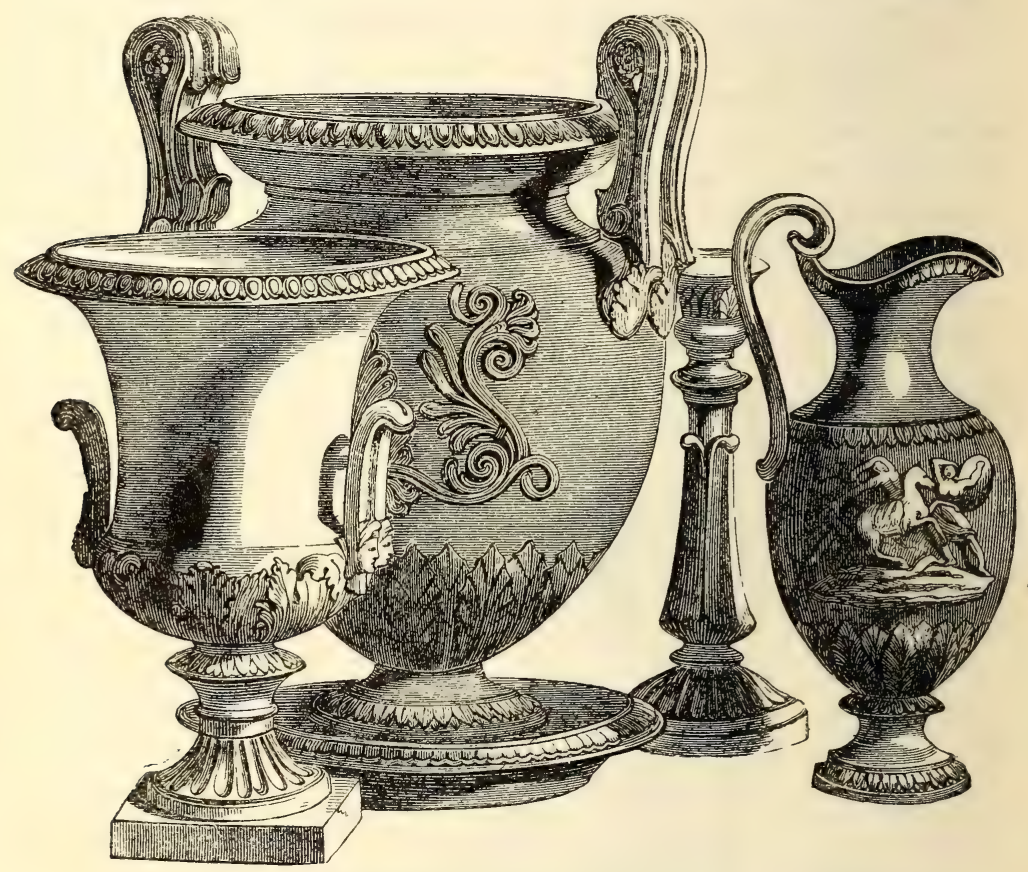

J. AND M. P. BELL, GLASGOW, I85T.

The toilet-set received particular commendation in $185 \mathrm{I}$ as being " especially elegant." "The other forms in Parian and terra-cotta are evidently designed after the antique. Their decoration is quite suitable."

Later the works, which are of considerablesize, manufactured large quantities of table-ware in fine white and pearl porcelain granite, and in china. The general earthenware goods have a 


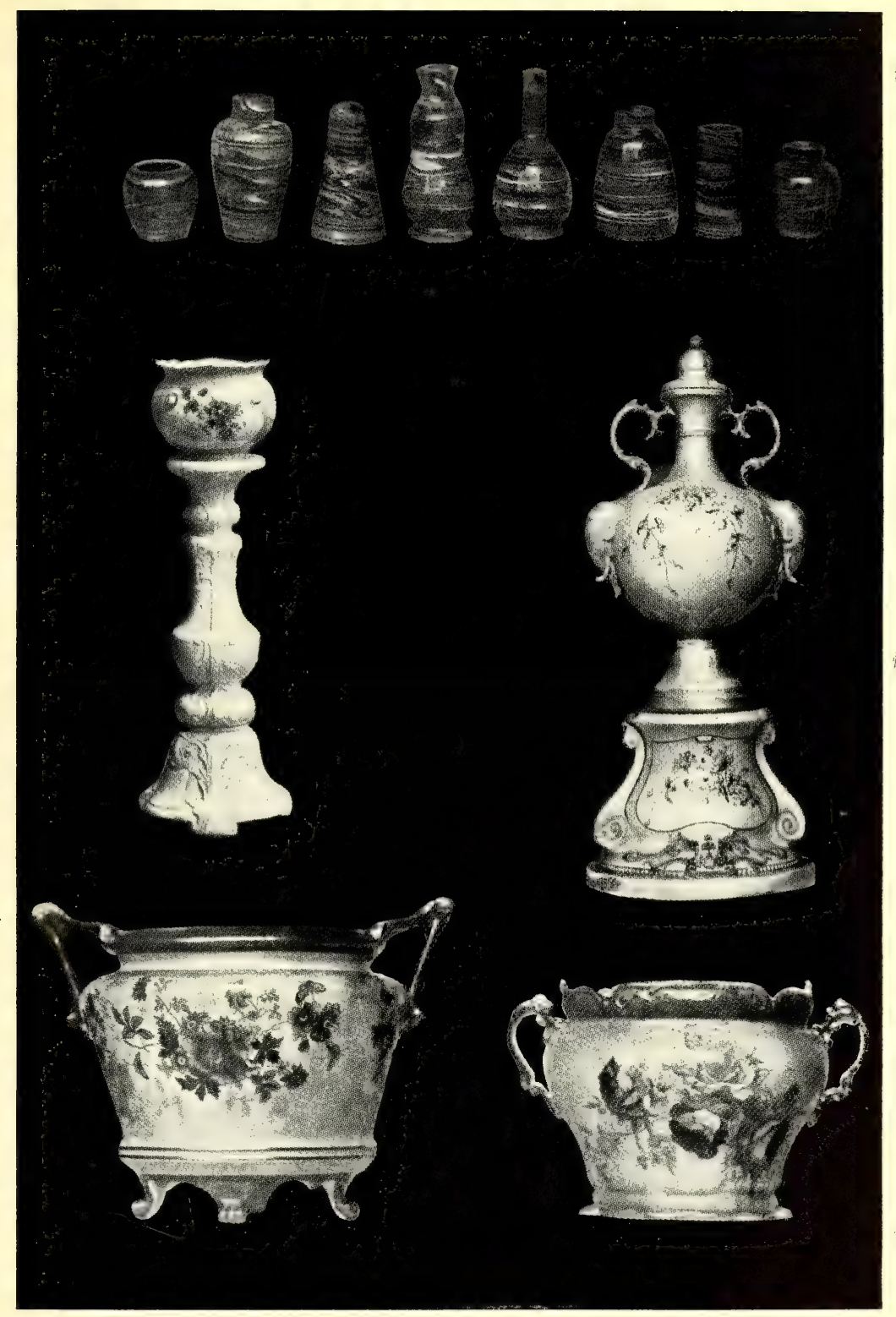

COCHRAN AND FLEMING'S WARES. 



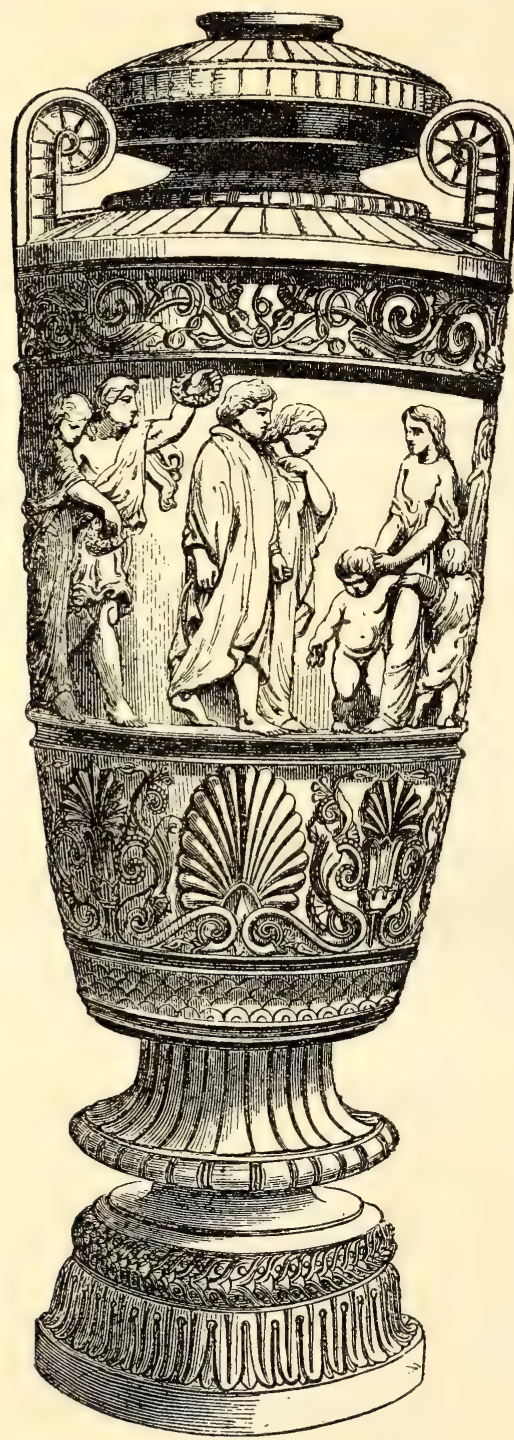

FERGUSON, MILLER \& CO., GLASGOW, I85I. tion" because, in 1862 , the works passed into the hands of Messrs. Young, who carried on their business of plain and ornamental brickmakers, etc., both at Heathfield from this date and at the Cardowan Works, which were established ten years earlier. The moulds became the property of the Garnkirk Fireclay Company.

This Garnkirk Works produced articles in fireclay, but they were noted more especially for their terra-cotta : garden vases in great variety, fountains with several tiers supported by dolphins and cranes of extraordinary size, and busts, figures, and groups of much merit. Amongst these were reproductions of Bailey's beautiful "Eve at the Fountain," the "Gleaner," " Minerva," "Bacchus,", "Atlas," and the like. These productions were simply marked GARNKIRK, and, with every other variety of such ornamental goods, they found a ready market, not only in Europe but in the East and West Indies. 


\section{WELSH, SCOTTISH, AND IRISH POTTERIES}

We have not seen designs more admirable than these vases from any of the terracotta potteries in England, hence it is a pleasure to recognise Glasgow work of such merit, dating from the middle of the nineteenth century.

\section{Grangemouth}

In $\mathrm{I} 85 \mathrm{I}$ the proprietors of the Grangemouth Coal and Fireclay Works in Scotland received honourable mention for an exhibit of a large number of useful articles, constructed in their improved material, which contains a large amount of silica and alumina, both of the most essential use in the production of an infu-

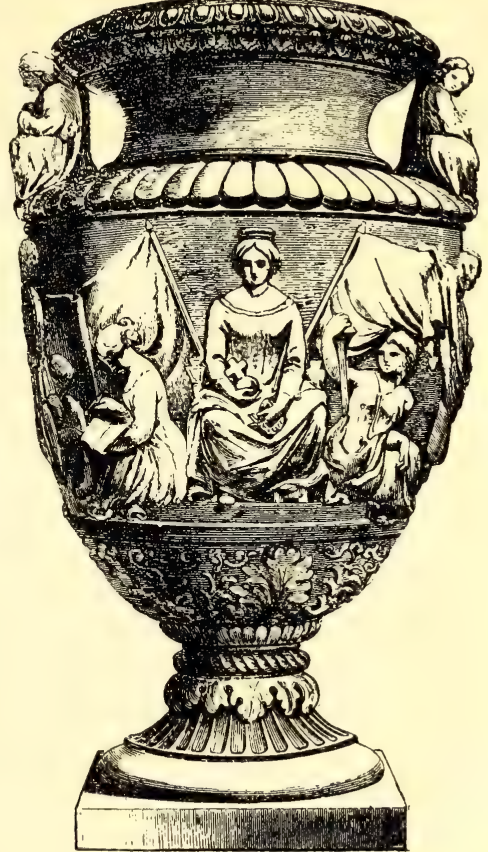

TERRA-COTTA. FERGUSON, MILLER \& CO., GLASGOW, I85I. sible fireclay. The vases which are shown illustrate the forms which were made in the material. Similar vases, well
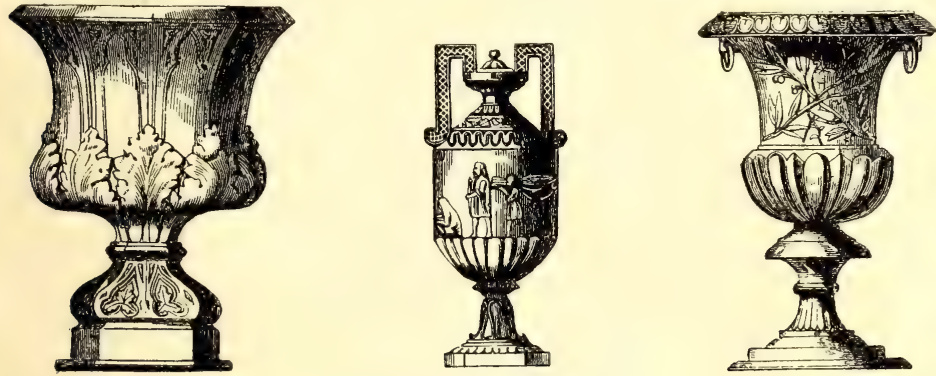

GRANGEMOUTH VASES,

adapted for gardens, and figures received a medal at the Hamburg Exhibition in I866. 
In I900 there were many potteries in Scotland engaged in making terra-cotta vases, ornamental garden-edgings, gothic, clustered and other chimney-tops, ridge, flooring and roofing tiles, and numerous other articles in pottery ; others

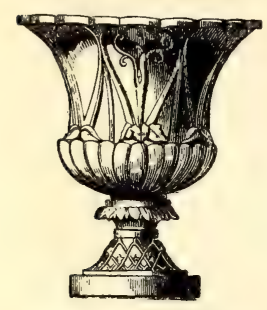

GRANGEMOUTH VASE. were engaged in the production of stoneware-filters, jars for druggists, bottles for beer and spirits, chemical vessels and apparatus, and so on. Another important manufacture was that of ordinary earthenware goods in granite and cream-coloured ware, printed, enamelled, painted and gilt. Rockingham and cane-ware in teapots and jugs have been, and still are, produced in immense quantities for the home and foreign markets, with majolica and jet-ware goods.

In $\mathrm{I} 878$, besides the two factories shortly described, there were in Glasgow the Caledonian Pottery, built about I8or, and removed to Rutherglen in I870. This is one which appears in $I 900$ in the list of Scottish potteries. In I820 earthenware was first manufactured at Verreville, where glass was also made. Now the firm at Verreville is R. Cochran \& Co., whose speciality is white earthenware. Robert Cochran acquired the works in 1846 , and was the first to make china in his own country; but after ten years he devoted his whole attention to earthenware. No marks except the initials of the firm appear to have been used. These are stamped upon the ware.

The Garnkirk Works are elsewhere dealt with. In I863 James Binnie established potteries for terra-cotta at Gartcosh, where suitable clay was abundant at from eighteen to twentyfive feet below the surface. The North British Pottery produced ordinary qualities of earthenware in 1878 ; in 1900 it specialised on sponged ware, the proprietors then being A. Balfour \& Co. The Saracen Pottery, established in 1875, does not appear in my I90o list, but the Port Dundas Pottery Co., established in I8I9, does, as manufacturing stoneware in which excellence has been reached. At Santiago, in I875, this firm was awarded a gold medal, and it is largely responsible 
for making Glasgow chief amongst stoneware producers. About I837 Hyde Park Potteries were founded by John McAdam, and later, in I855, Robert Cochran, of Verreville, established the Britannia Pottery, now Cochran and Fleming, to which reference was made a few pages earlier.
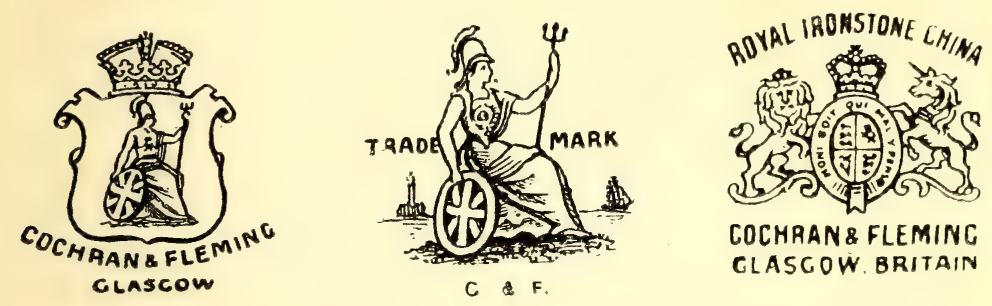

The Bridgeton Pottery is now named the Eagle Pottery. It was built in I869 by F. Grosvenor, and the present firm is "Grosvenor \& Son," who make a feature of stoneware bottles, which appear also to find favour at the Barrowfield Pottery, established by Henry Kennedy in 1866, and continued as Henry Kennedy \& Sons. Their "glass-lined" stoneware, marked with three bottles beneath a ribbon, bearing the date, supplies both home and foreign markets.

At Greenock is the Clyde Pottery Co., which in I90o produced the ordinary qualities of white earthenware, sponged, painted, printed, enamelled and gilt, and marked C. P. Co. In Portobello, near Edinburgh, exist to-day the Midlothian and Waverley (formerly Portobello) Potteries. The former, founded about I 857 by W. A. Gray, now W. A. Gray and Sons, makes stoneware; so does the latter, owned by A. W. Buchan \& Co. Kirkcaldy Pottery, belonging to David Methven and Sons in 1878 , manufactures earthenware, cream-coloured, sponged, printed, enamelled and gilded, which is of such fine quality, that it obtained a medal at Paris in I896. The Sinclairtown and Gallatown Potteries were then in existence, and appear in I900, with the addition of the Fife Pottery. The last is owned by R. Heron and Son, who at the former date are credited with the ownership of the Gallatown Pottery. Now the Rosslyn Pottery, Gallatown, belongs to Morrison and 
Crawford. The Sinclairtown productions are mainly rockingham and jet; the others make earthenware.

These may be regarded as examples of the works which are to be found in many places in Scotland and Wales, as well as in England, where rockingham or brown ware, jet or black ware, common earthenware, ordinary red pots and pans, stoneware, and fireclay goods have existed for many years. Some of the productions are mainly disposed of in the surrounding districts, others have a wider market at home, whilst some have extended their trade much more widely, and help to supply the needs of the world at large. Just as an example, I may cite Jewitt upon the Alloa Pottery, founded as far back as I790, and acquired in $\mathrm{I} 855$ by W. and J. Bailey, who appear as the proprietors in 1900.

"The productions of the Alloa Pottery, besides the home trade, are exported in large quantities to Australia, New Zealand, Canada, Germany, France, America, etc., and medals have been awarded to them at the Paris and Philadelphia Exhibitions. The excellent quality of the Alloa goods arises from the nature of the clay got in the neighbourhood, and the density of colour and softness to the touch of the glaze are highly commendable."

No less than twenty-six thousand tea-pots (brown ware) could be produced per week at this single factory.

\section{Ireland: Belleek}

These works on the banks of the River Erne, near the borders of Donegal, in Ireland, were established as the result of the finding of large quantities of felspar in the neighbourhood. Prior to the Dublin Exhibition of I853 Mr. Kerr, of the china factory at Worcester, and Mr. Armstrong, of London, made a tour through Ireland for the purpose of discovering materials suited for the manufacture of pottery and porcelain. The materials thus obtained served for the production of the celebrated service designed from subjects in The Midsummer Night's Dream," and displayed in the Dublin Exhibition. In consequence of the exhibition of this 


\section{WELSH, SCOTTISH, AND IRISH POTTERIES 477}

service, attention was called to the existence at Belleek of felspar, as well adapted to the purposes of the potter as that imported from Sweden or Norway; and a manufactory was accordingly established, in 1857 , under the direction of $\mathrm{Mr}$. Armstrong. The china-clay employed was imported from Cornwall. Many of the ornamental objects produced by the factory were characterised by being carefully modelled from natural objects. A nacreous lustre was given to much of the

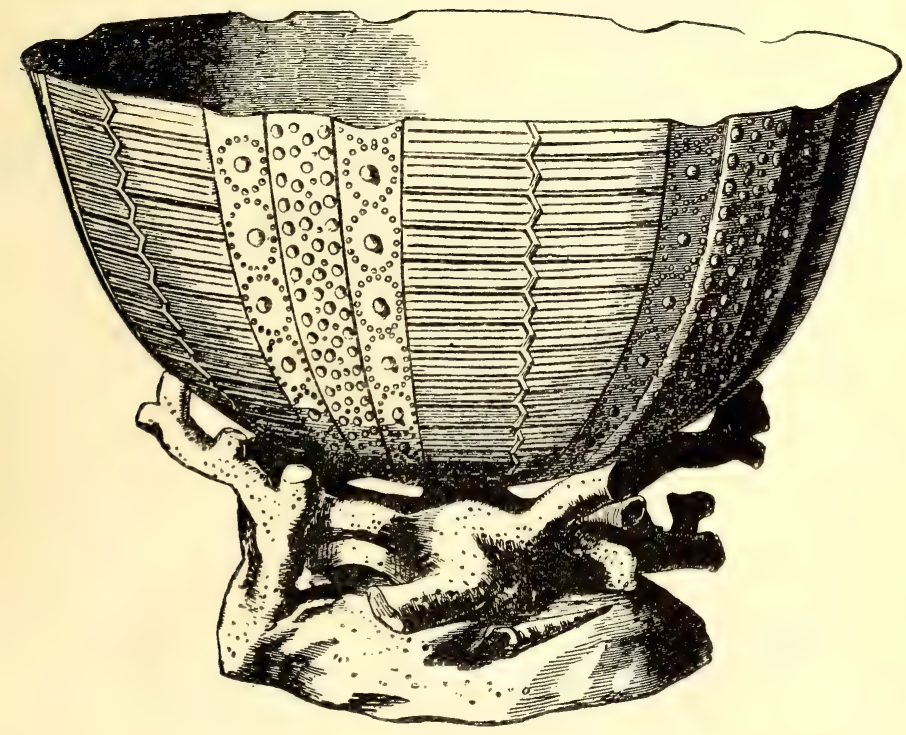

BELLEEK. FROM QUEEN VICTORIA'S SERVICE.

ware by the use of a preparation similar to that patented by Brianchon, and formed of salts of bismuth mixed with resin and oil of lavender, and coloured by certain metallic oxides.

The chief peculiarities of the ornamental ware produced at Belleek were its thinness and lightness of body, its rich cream-like lustre in ivory tones, and the iridescence of its surface. We need not consider the ordinary earth-ware, made of the local clays, the jet, red and cane-coloured wares, but we may extend our admiration to the graceful forms, so 
delicately modelled, to the egg-shell quality, so fitted to represent a delicate shell, and to the glaze which recalls highly polished mother-of-pearl. The glaze or lustre resembles no other used in this country, at least during the time when the Belleek works were in their prime. The lustres with gold

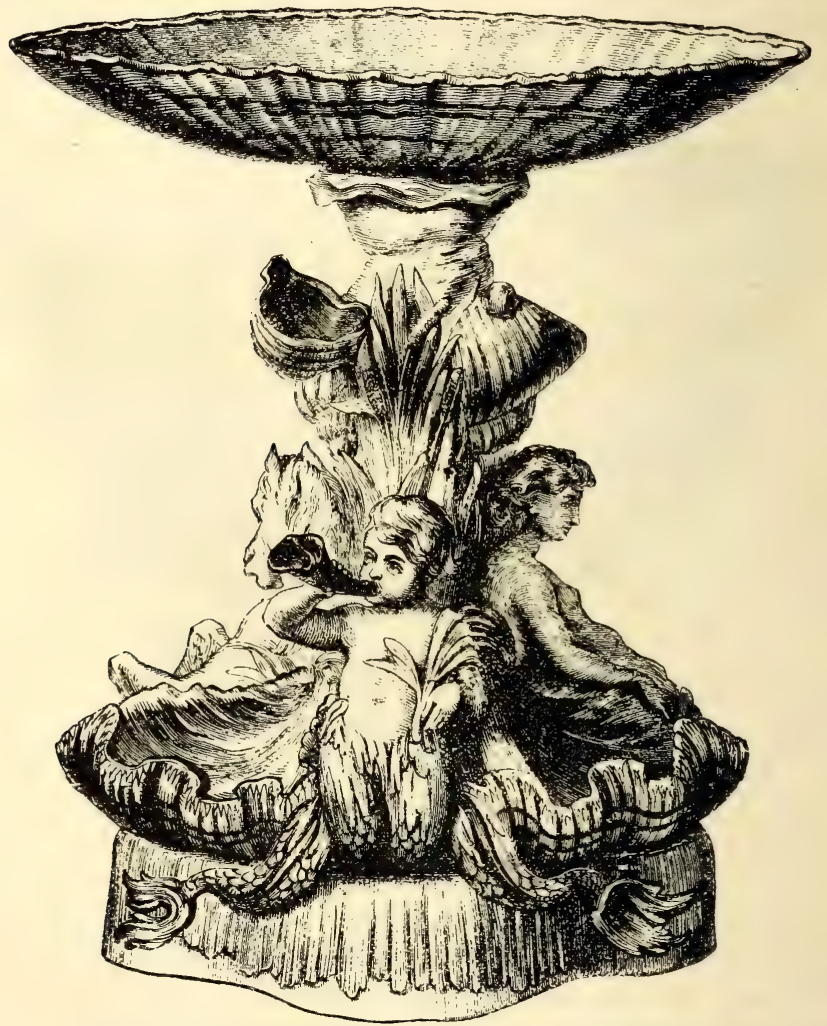

BELLEEK. EDWARD VII. (PRINCE OF WALES) SERVICE.

solution, and tin solution added to oil of turpentine and flower of sulphur, the platinum and spirits of tar, and other metallic lustres, are noticed in the chapter on the manufacture of earthenware and porcelain. But this Belleek lustre resembles neither the gold, silver, platinum, nor any other; it is unique, 
just as the modelling of the shells from nature is. These two qualities alone attract in no ordinary measure.

When we further remark the extreme delicacy which far surpasses the ordinary egg-shell china in the beautiful cabinet pieces, shells, cups and saucers, we can only wonder at the manipulative skill which treated a plastic material having but little more thickness than ordinary writing-paper. Then this delicate body may be tinted, it may be left unglazed, like Parian, it may be gilt, and, above all, glazed with the iridescent glaze. A tea-service made for Queen Victoria had the echinus, or sea-urchin, as the basis of its design, supported by

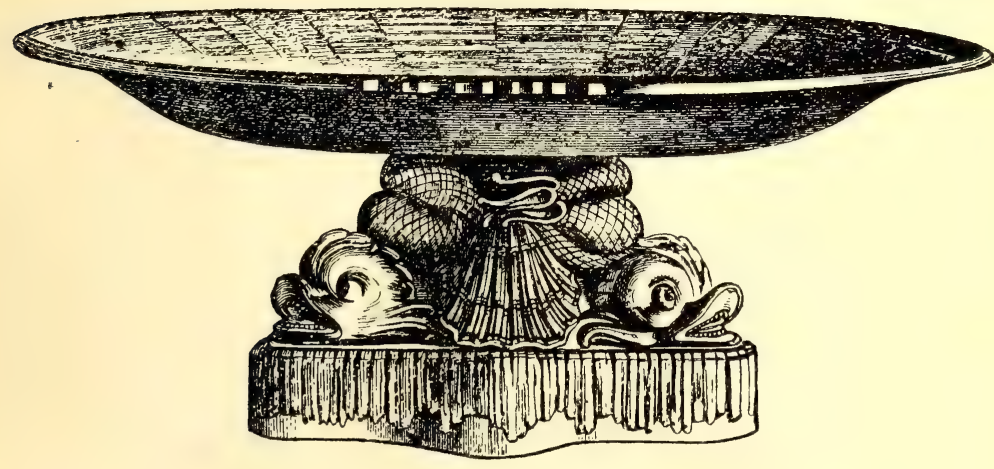

BELLEEK. EDWARD VII. (PRINCE OF WALES) SERVICE.

branches of coral. Besides this and other Royal services, a large variety of table-services in various styles of decoration were produced with figures of amorini, and animals which showed equal qualities of excellent modelling and tasteful colouring. The graceful modelling is enhanced with happy effect by the contrast between the ivory surface of the unglazed china and the sparkling sheen of the glazed portions of the same design. The illustrations show how fine some of the forms are, but they can teach nothing about colour and glaze. There is no doubt in my mind that the early Belleek china will appreciate in price very considerably at time passes on.

Mr. Armstrong, who had been joined by Mr. M'Birney in the management, died in I884, and his partner shortly after 


\section{I9TH-CENTURY ENGLISH CERAMIC ART}

him. In the words of a communication which I received on this subject, " Money was plentiful in those days." " M'Birney was rich, and all the profits were for some time spent on improvements ; skilled designers and artists were employed." After his decease these men were nearly all discharged, and, when a local company purchased the works, the nacreous lustre glaze reniained in the possession of Armstrong's sons, who

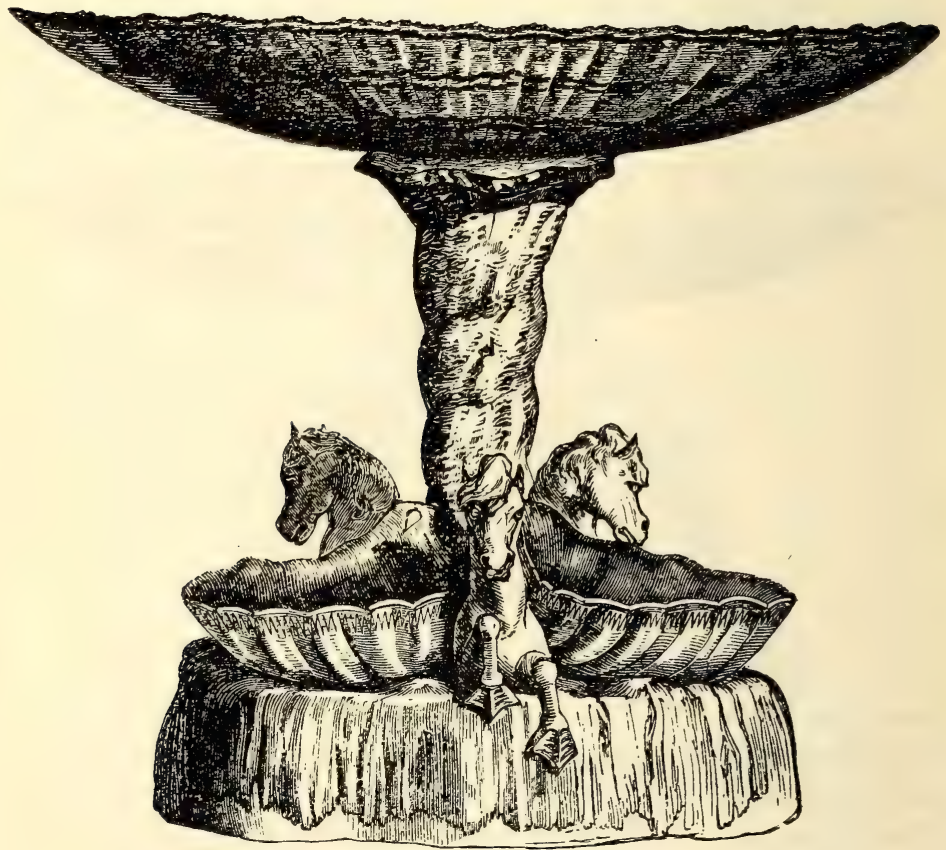

BELLEEK. EDWARD VII. (PRINCE OF WALES) SERVICE.

supplied the quantities needed and kept the secret. When one of the employés discovered a very good Parian glaze no more was bought, and the secret was offered to some English potteries, with what result I cannot say. Perhaps some of them may make ware like Belleek, yet the faint creamy or yellowy tint of the earlier ware will be difficult to reproduce. The later productions of the factory, which is still in exist- 


\section{WELSH, SCOTTISH, AND IRISH POTTERIES 48I}

ence, have but little of that excellence, that delightful delicacy, and that beautiful lustre which have been described. Pretty Parian ware is made in wicker designs and good afternoon tea-sets. The mark used is an Irish harp, hound, and tower over Belleek, in a ribbon from the ends of which rises the shamrock, or the other, which is the harp surmounted by the Royal crown.
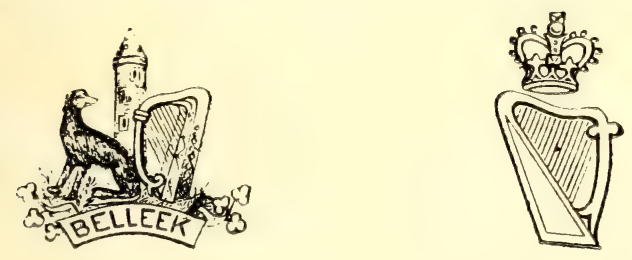


\section{CHAPTER XX}

\section{ESSENTIALS TO THE POTTER'S ART}

THE potter's wheel, like many other inventions, came from China, where it was used long ages before it came to England; but the time when it was brought into this country is as indefinite as the actual date of its invention. Knowledge of its value as a means of making earthen pots travelled, in an ever-widening circle, from China until it reached lands the most remote, and as it went it left an art behind, which in some countries took the most refined forms of beauty, even before the Christian era.

What is a potter's wheel ? In its primitive form it consisted of a horizontal disc, or small round table, mounted on a spindle. This was called the potter's wheel, and it was made to rotate by foot power, or by another wheel turned by a second person, who laboured at the crank. In either case the potter's two hands were free to manipulate and mould the lump of prepared clay placed before him on his wheel. By the use of water, into which he dipped his fingers, he could mould the clay into almost any rounded form. Nowadays the potter's wheel may be driven by steam instead of handpower, but the thrower, as he is called, still begins his magical work by throwing a ball of clay upon his revolving wheel, and still from his fingers arise any circular shape which he may desire.

In all countries, whether civilised or not, the same general idea prevails-horizontal revolution to produce articles of daily use from clay, pots and pans of varied form and size. Whatever else that follows in the direction of finish, by the turner, and handler, or the figurer, who applies decoration to 

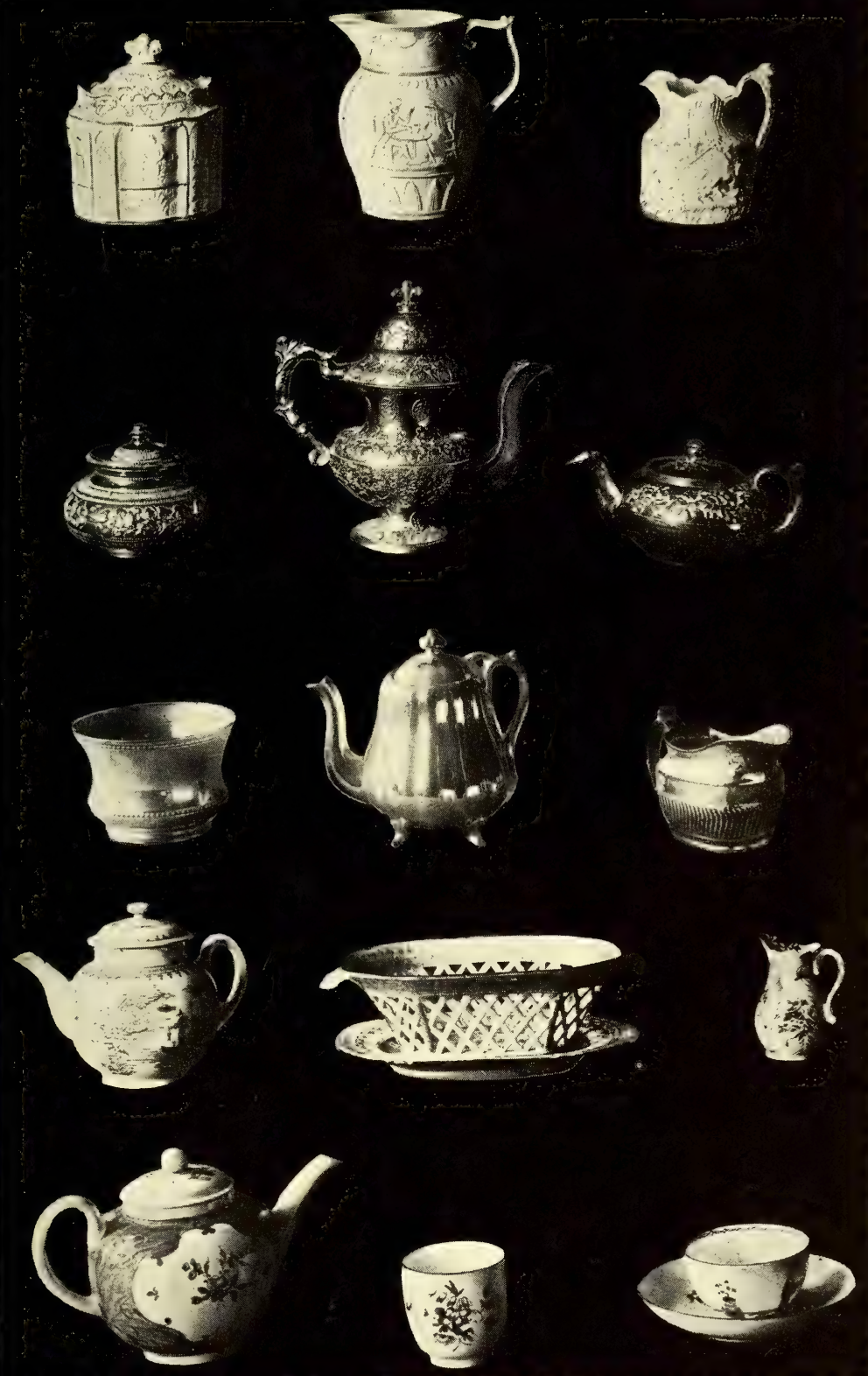

EARLY I9TH-CENTURY WARES. CASTLEFORD, WHITE; STAFFORDSHIRE, BLACK ; SILVER LUSTRE; TRANSFER-PRINTED WORCESTER AND SPODE; AND LEEDS AND BRISTOL PAINTED.

From Mr. A. M. Broadley's Collection. 

the surface, whatever other methods are used by flat-pressers or hollow-ware pressers, by casters and figure-makers, or by machinery processes, we come back to the fons et origo of ceramic art, to the simple, wonder-working, ancient potter's wheel.

To one name a tribute must be paid in connection with the great progress of the earthenware and porcelain manufactures in this country-to William Cookworthy, who discovered the china-clay of Cornwall about I755, and in I768 took out his celebrated patent for using this clay and moorstone, or china stone, in the manufacture of porcelain at Plymouth ; shortly afterwards joining Richard Champion, of Bristol, to whom in I773 the patent rights were sold. Then, in I78 $\mathrm{I}$, Champion closed his factory and transferred his rights to a Staffordshire company of potters, who afterwards made hard-paste porcelain at New Hall works, which in 1825 were closed.

Kaolin, or china-clay, is now chiefly prepared in Cornwall from the granite in the neighbourhood of St. Austell and St. Stephens, from the north side of Tregoning Hill, near Breage, at Towednack, near St. Ives, and at St. Day, near Redruth; while in Devon it is worked at Lee Moor, and at Meavy, on the south side of Dartmoor. Although the method of preparing kaolin is sufficiently simple, much care is at the same time required to obtain the substance in as pure a condition as possible. The presence of iron has particularly to be avoided, as many of its compounds would tend to colour the paste of the porcelain, or the earthenware, into the composition of which they might enter.

In preparing kaolin, those localities are selected where water can be readily procured, and where the rock is in a very friable state owing to the decomposition of its felspar, The exact natural conditions under which this disintegration has been brought about are not well understood. The less of foreign minerals the rock may contain, and the harder, the heavier, and the less decomposed these may be, the better. The disintegrated rock, usually containing much quartz, is generally exposed on an inclined plane to a fall of a few feet of water, which washes it down to a trench, whence it is 
conducted to catch-pits. The quartz, and the schorl, mica, or other minerals which may be present, are in great measure retained in the first catch-pit ; but there is usually a second, or even third pit, in which the coarser portions are collected before the water charged with the finer particles of the decomposed felspar, in a state of mechanical suspension, is allowed to come to rest in the tanks or ponds prepared for the purpose. In these the kaolin is permitted to subside, the supernatant liquid flowing off in another direction ; and, by a repetition of this process, the tanks become nearly filled with kaolin in the state of a soft clay. Formerly this clay was dried by simple exposure to air, at the ordinary temperature; but artificial heat is now usually employed. Thus, at the Lee Moor Works, the semi-fluid clay is removed to a series of clay-pans heated by hot-water pipes, and, when sufficiently dry, is cut into rectangular blocks, which are then transferred to a building artificially heated, where they become properly dried for sale. When sufficiently dry, the outsides of the lumps are carefully scraped, and the pieces of kaolin sent to the potteries.

China-stone, or Cornwall stone, is largely used in the Potteries, though some firms also import felspar from Sweden. It is usually a mixture of quartz and decomposed felspar. The amount of decomposition varies materially in different varieties of china-stone, but the felspar always retains more or less of its alkaline silicate, which thus renders the rock fusible. It is generally assumed that china-stone represents the disintegrated granitic rock which, in a more advanced state of decomposition, furnishes kaolin; but the relation between the china-stone and china-clay is still somewhat obscure. The china-stone is quarried chiefly from the granite of St. Stephens, in Cornwall, which furnishes also some of the best kaolin. In quarrying the stone, those parts should be avoided in which it becomes intermixed with schorl, or black tourmaline, a mineral somewhat common in the granite of which the china-stone forms a portion. The stone requires no preparation before being sent to the potteries, but when quarried is merely broken into pieces of a size convenient for carriage. This stone is employed in the making of the paste, 
or body, and also in the glazes for both earthenware and porcelain. Though it has the appearance of granite, when exposed to the weather it becomes soft, and will come away in flakes. Upon examination, particles of clay and quartz will be found mixed closely together. The china-stone, like all other component parts of the paste, is ground to powder.

Natural clays are extensively employed for British pottery ; such, for example, as the Devon or Bovey clays, and the Dorset, or Poole clays, refined and sifted, and they are usually mixed with a certain proportion of the Cornish and Devon artificial kaolins, the proportion varying according to the kind of earthenware or porcelain required. Grains of silica are always mingled with them, these commonly now obtained from flints, finely pounded, and mechanically mingled in the general paste, or body. The flints are obtained from the chalk districts, from which there is the cheapest carriage, and usually by sea and canals. Those which are black are preferred. They are first calcined or burnt in a kiln, to render them easily broken. They are then stamped or crushed, and afterwards mixed with water and reduced to the consistence of cream by grinding in circular pans, the bottoms of which are commonly paved by some hard stone, not uncommonly chert, over which heavy stones of the like kind are driven round by machinery, the flints being thus ground in water between them. When taken out of these pans the creamy-looking mixture is placed in a reservoir, often termed an ark, where the pounded flint settles and the water is drawn off.

The manufacture of earthenware and porcelain is such an immense business that it would be difficult to dilate upon all the materials, which are used in accordance with the practice of the individual factories, but a general idea of them may be useful, as well as of the processes usually employed. I need not dwell upon the increased employment of machinery, which in some factories has superseded hand-labour to a marvellous extent. First, we will trace the manufacture of common earthenware, which formed the bulk of the products of the nineteenth century. The information was compiled 
by Mr. G. Maw, F.S.A., for the Museum of Practical Geology in 1876 .

"The common body is generally composed of Dorset or Poole clay, Cornish or Devon kaolin, and flint.

"The best body is formed of Dorset or Poole clay, Cornish or Devon kaolin, Cornish china-stone, and flint.

"The Dorset, or Poole clay, which may be regarded as the base or chief ingredient in the manufacture of English earthenware, is mixed with water and reduced to a state in which it can be passed through sieves of various sizes in order to free it from lumps and to render it of a fine uniform consistency. The kaolin requires no preparatory cleaning, and the flints are used as they come, finely comminuted from their deposit in water after passing the grinding-mills. The china-stone requires to be crushed and reduced to a fine powder in mills, its treatment being indeed similar to that of the flints, with the exception of its not requiring calcination or burning in kilns.

"All the materials being thus ready for use, the proportions of each considered requisite for the kind of ware about to be made are mixed with water, and with each other, and the mixture taken to the slip-kiln, a long brick trough, heated by means of flues from a furnace. Here it is kept simmering until it acquires somewhat the consistency of dough. In this state it is ready for use, and is placed, until required, in cold dark cellars. If coloured bodies or pastes are required, so as to give a general tint to the ware, certain metallic oxides, or coloured clays or marls, are added to the prepared mixture.

"The body or paste of mixed materials being now prepared, it is either 'thrown,' as it is termed, by means of the potter's wheel - that is, raised into circular forms of different kinds by means of the rotary motion of the wheel, and by the action of the fingers-or it is moulded into forms, in the latter case the paste being first rolled into flattened pieces, which can be easily squeezed into a mould, commonly of plaster of Paris. When thought desirable, the 'thrown' forms are finished by placing them on a lathe and turning them into more accurate shapes.

"The various forms having been completed, the pieces are taken to be carefully dried in rooms prepared for the purpose, in order to deprive them as much as possible of moisture. Indeed the water is to be regarded only as a tool 

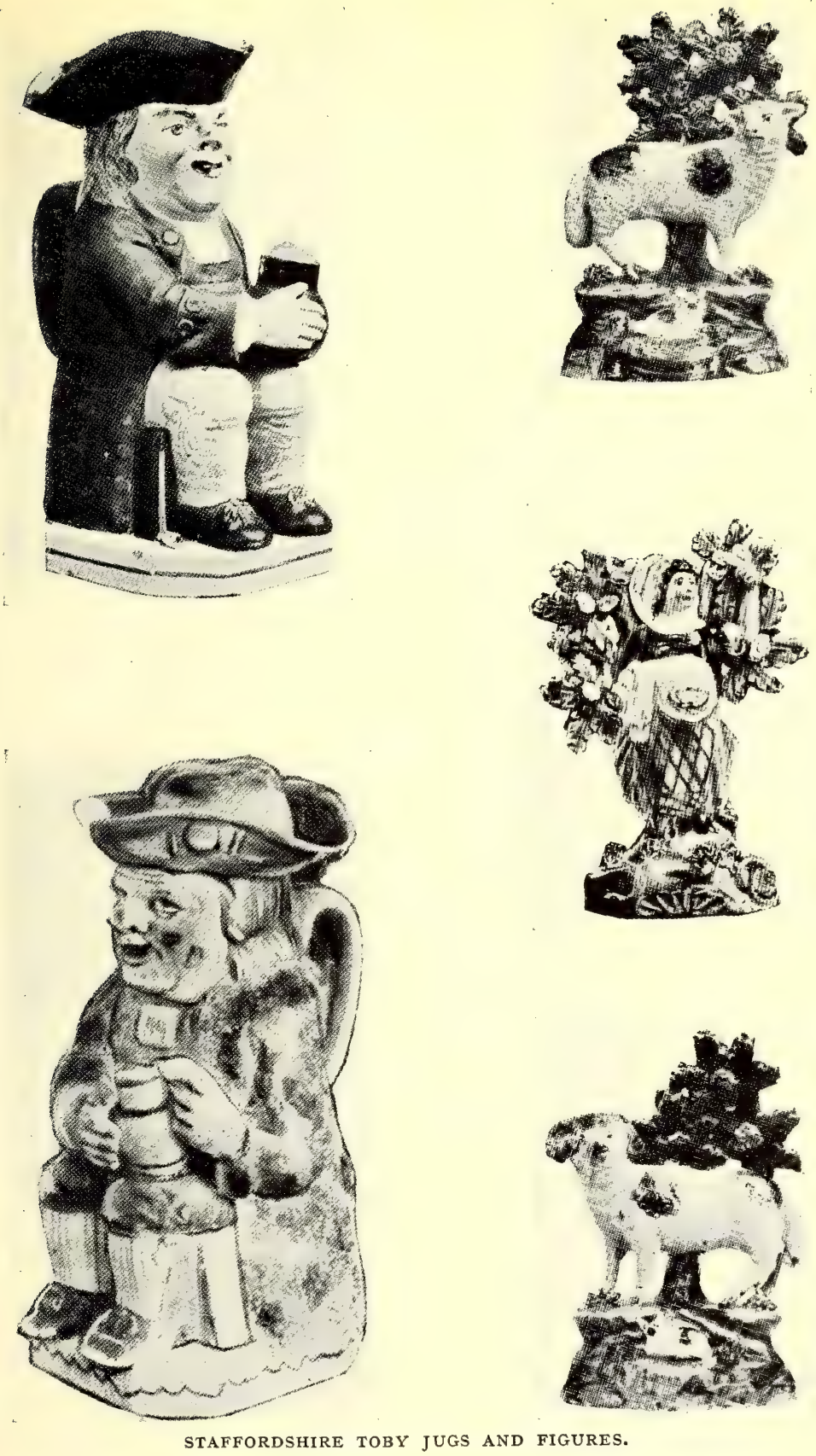

in the manufacture, a vehicle of plasticity to be laid aside when no longer required.

" Having been thus sufficiently dried, the pieces of earthenware are placed in large flat-bottomed pans, oval or round, as may be considered desirable, with vertical sides of sufficient height ; these cases are termed 'seggars,' or 'saggers,' and are made of refractory materials, such as fireclays, broken pieces of earthenware after the first firing, and also of broken saggers themselves, pounded up and often mixed with a small portion of damaged Dorset, Devon, or Cornish clays. In these saggers the dried pieces are so placed as to allow as many as possible to be packed without injury to one another. The saggers are then arranged in a kiln, termed the 'biscuit kiln,' one above another, so that an upper covers a lower sagger. The kiln is then 'fired'-that is, the proper heat is communicated to it-and the fire is continued for about three days ; for instance, a kiln fired on Monday evening will be ready to be 'drawn,' or the saggers and their contents removed, on Friday morning. The ware is then in the condition of 'biscuit,' being white and porous, and readily absorbing water.

"This biscuit may now be painted with certain colours, which can be used 'under the glaze' - that is, before it is covered with a preparation which in another ' firing' forms a coating of glass-or it may receive transfers from engravings, thus producing printed ware. The colours which can be advantageously used under the glaze, are few as compared with those employed above it. In the latter case the paints used are enamel colours-that is, glasses of different kindsmixed with metallic oxides which give the required colour. The printing is but the employment of the colours that can be advantageously used under the glaze, mixed with oil, and worked as ordinary printing-ink for engravings. Care is required in manipulating the paper from which the print is transferred to the biscuit, and in dexterously removing the paper after its application, so that the impression be not injured. To drive off the oil used as a vehicle for the colours the ware, after printing, is exposed to a low heat in a kiln, termed the hardening kiln, after which it is ready to be glazed. The materials of the glaze, which may and do vary according to the practice at different potteries, are mixed with water, so as to form a substance of about the consistency of cream. Into this liquid the earthenware, either painted with colours 
which will not suffer by the heat of the kiln, into which it is next placed, or printed with colours of the like kind, is dipped. Upon removal all traces of the colouring are lost under a thin coating of the glaze, the moisture of which is readily absorbed by the porous biscuit ware. It is now placed in saggers, and exposed for about a day in a gloss or glost-kiln, where it is subjected to a lower temperature than in the biscuit-kiln, but at the same time the temperature is sufficiently high to fuse the coating upon the ware, and so form a glass or glaze which by its transparency discloses the painting or printing beneath, whilst it is impervious to water. The earthenware is then warehoused for sale, unless it has to be further decorated by gilding, which is referred to later on. Of course any printed ware which is painted with colours receives this treatment, with its consequent firings, before the gold amalgam is applied.

"Common pottery is often decorated with a brilliant lustre, an extremely thin film of metal in liquid form, generally mixed with balsam of sulphur and oil of turpentine. This having been applied to the piece by means of a brush, it is then fired, and the reduced metal, in a state of extreme tenuity, exhibits its characteristic lustre without burnishing. To the gold, silver, platinum, copper, and bronze lustres may be added the pink or purple, which is obtained from a mixture of tin chlorides with gold chloride, which forms a precipitate known as purple of Cassius, which is painted over the glaze.

"The chemical composition of plastic strata varies as much as their mechanical condition. They may be generally described as an association of silicate of alumina, alumina, free silica, and magnesia, with more or less water of combination. Clays and marls scarcely ever occur entirely free from iron, to which their colour is mainly due ; it exists in various states of combination, further referred to below. Carbonaceous matter, especially in the tertiary and carboniferous clays, is frequently associated in a fine state of subdivision, and the alkalies are generally present in variable proportions, both as silicates and carbonates.

"CONTRACTION IN BURNing.- This character is of so much importance in all branches of ceramic manufacture that it may be of interest to notice one or two features that the experiments exhibit.

"The amount of contraction in burning, due partly to the loss of water of combination and of the carbonic acid in the carbonates, when present, and to the ignition of any car- 
bonaceous matter contained in the clays, but more especially to the drawing together of the particles in the production of vitreous silicates, is very variable and depends both on the chemical and mechanical composition of the clays. The presence of the alkalies and iron tends to complete vitrification, which is always accompanied by a great amount of contraction and the production of a glass-like body, with a bright conchoidal fracture. On the other hand, in clays containing much free silica, or even silicate of alumina, without the accompaniment of the fluxing alkalies, a small amount of contraction takes place and an open porous 'body' is the result.

"The amount of contraction is not less due to the state of mechanical subdivision of the constituent particles. Clays in a coarse state of subdivision, and containing a large proportion of gritty matter, especially of silicious sand, invariably contract less in burning than those of smooth and fine texture, in which the constituents are in an impalpable state of subdivision; this will be at once seen by a comparison of the amount of contraction of the slabs, composed of the coarse clay in its natural state, with those moulded from the clays from which the coarse particles have been removed; and the larger the proportion of coarse matter in the native clay the greater is the difference between the amount of contraction of the clay in its natural and refined states. The average contraction of the whole of the burnt slabs composed of the native unrefined clay amounts to 6.0I per cent., and of the burnt slabs of refined clay 7.53 per cent. of the original moulded size. This appears due to two causes; firstly, that a mixture of large and small particles is, to begin with, actually more dense than a mass of particles of equal size, and therefore admits of less contraction in the drawing together of the particles in vitrification; and, secondly, that the coarser subdivision and less intimate contact seems to hinder the recombination of the constituents as vitreous silicates in the process of burning.

"Few clays produce a perfectly vitreous and unabsorbent body. Some of the burnt slabs approach to a glassy texture, whilst others are so highly silicious and coarse in grain as to be held together by very slight cohesion. These are in the burnt state open and spongy, and have undergone but little contraction in the kiln. Such clays as those of which the celebrated Stourbridge fire-bricks are made are, 
from their refractory character, eminently suitable for the manufacture.

"The great majority of the examples are intermediate in character between these two extremes, and, after the process of burning, form a compact but slightly porous body, subject to a moderate amount of contraction, and are available for general pottery purposes.

"The Colouring Matter of Clays.-No native clay is entirely free from the presence of iron, which occurs in aluminous earths in various proportions and states of combination. Those most free from iron are the white lower tertiary clays of Devon and Dorset, largely exported from Teignmouth and Poole for the manufacture of white earthenware ; for this purpose the absence of iron is a matter of great importance, as it imparts to the ware a yellowish tint, to obviate which it is found necessary to cloak and neutralise the natural cream colour of the burnt clay by the admixture of very small proportions of cobalt blue.

"Iron in the white and grey tertiary clays occurs principally in the form of grey carbonate of protoxide, generally in association with finely divided carbonaceous matter, in proportions varying from a mere trace up to 4 or 5 per cent.

"Iron, which is so prejudicial in clays employed for white pottery, is an essential colouring matter in those used in the manufacture of terra-cotta, encaustic tiles, bricks, and all common pottery. Grey clays containing less than I or $I_{2}^{\frac{1}{2}}$ per cent. of iron change in the kiln to various shades of cream colour and buff, whilst those containing from 2 to Io or I2 per cent. range in colour from yellowish-fawn to dark reds; from 3 to 4 per cent. of iron produces in the kiln the bright red bodies used in the manufacture of red terra-cotta, encaustic tiles, red building bricks, etc. There seems to be no essential difference in the colouring matter of the clays that burn buff and those that burn red in the kiln, the depth of colour depending merely on the amount of iron present, the buff shades regularly graduating into the deeper shades of red."

In view of the modern practice of covering earthenware with slip by means of dipping, various methods of treatment have been successfully adopted. It is evident that if a white slip is applied to a brown body a series of designs could be applied by treating the vessel whilst moist before firing. The 


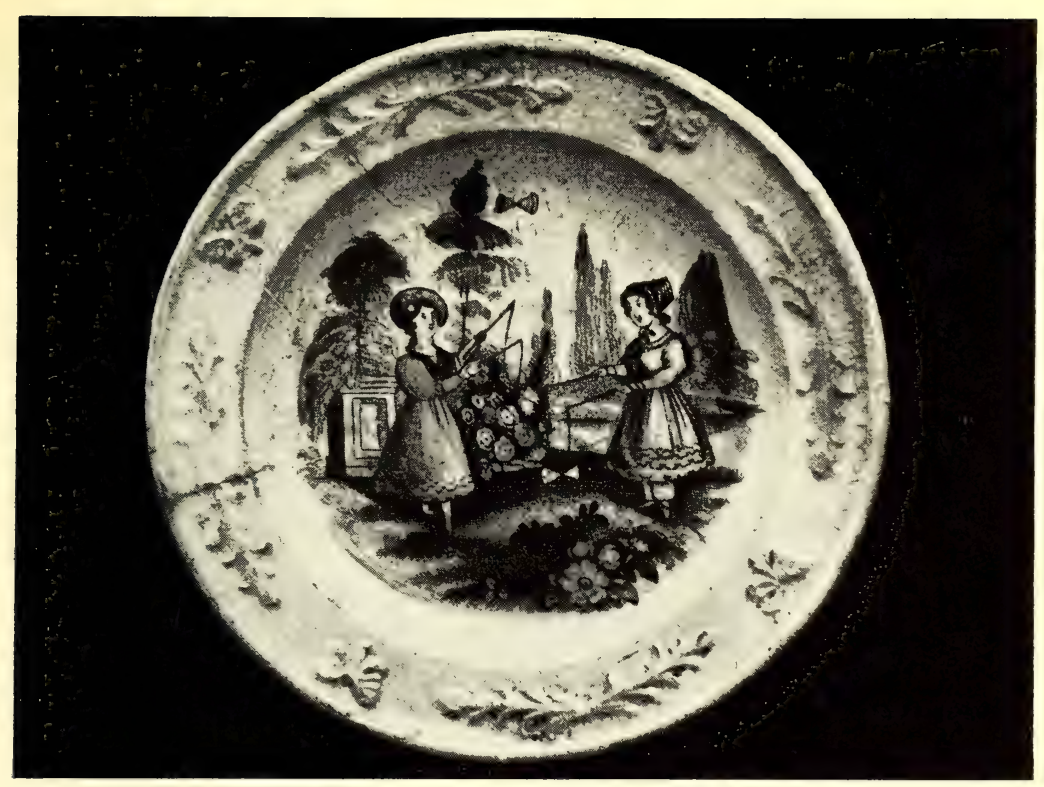

TRANSFER-PRINT, " DIABOLO.”

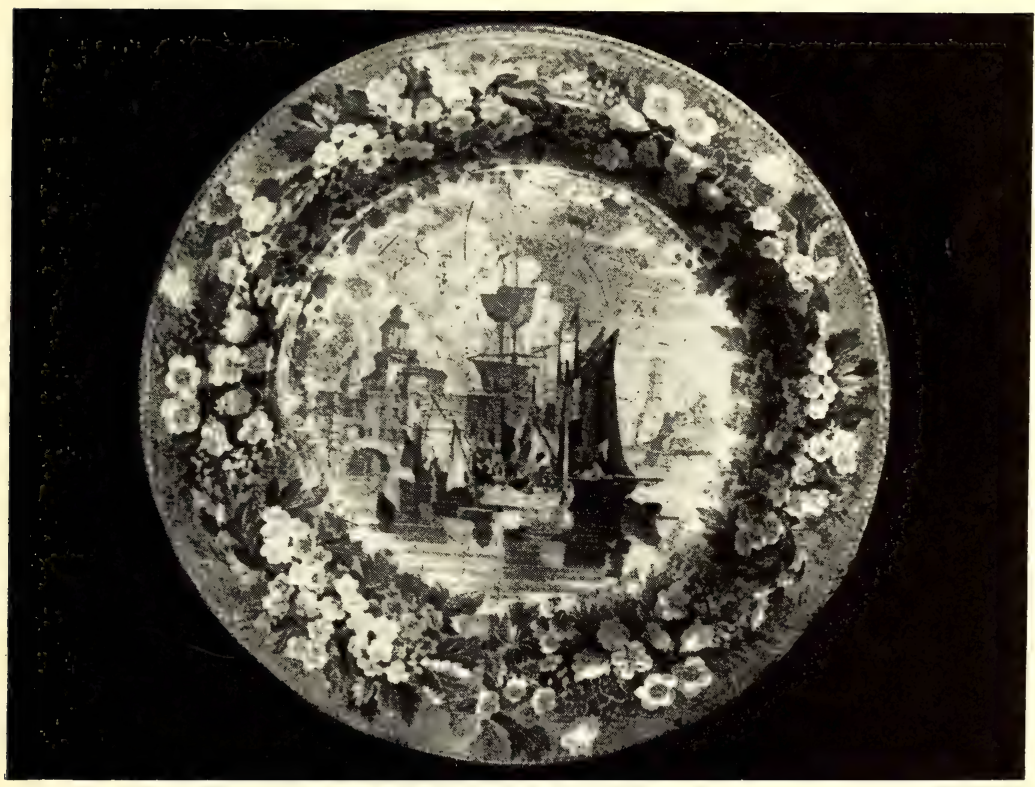

TRANSFER-PRINT, SHIPPING WITH FLOWER BORDER. STAFFORDSHIRE. 

slip could be cut into all sorts of patterns with the body as the ground, or the reverse process could be adopted, in which the design would be left upon the body by removing all of the slip except what was necessary to form the ground. Doulton ware is often decorated by this process, which is practised also with success by some of the individual and independent potters upon their productions. There appears to be scarcely a limit to the patterns and colours which may be effectively employed, especially when the lathe is employed by the dipturner after the piece has been thrown as usual. Rings of coloured clay can be deposited on the revolving piece of ware, and, by dexterously dropping portions of the creamy clays, patterns of different kinds and of different colours may be produced, great variety of design being thus obtainable. The arborescent or dendritic forms are also usually produced by the " dip-turner," who, after covering the turned piece of the original paste, or body, with an evenly spread coating of his " dip" compound in its creamy condition, drops upon it, before it becomes dry, another kind of "dip " compound, having a greater density than the first, and thus, by holding the piece so that the heavier compound or colour can descend amid the moist first-spread " dip," he permits it to disseminate its particles in an arborescent form. The pieces thus prepared are then merely fired in the biscuit-kiln, and glazed in the gloss-kiln for the market.

The manufacture of porcelain bears a general resemblance to that of earthenware, the difference relating chiefly to the composition of the pastes, or bodies, and of the glazes, to the arrangement of kilns by which the more refractory materials are exposed to higher temperatures, and to muffles or kilns for firing the various enamel colours employed upon the different forms given to the porcelain. The ingredients employed are commonly Cornish or Devon clay, Cornish china-stone, and flint with prepared bones. The following was the ordinary composition of Staffordshire porcelain about I840 : Cornish clay 3I per cent., Cornish china-stone 26 per cent., flint $2 \cdot 5$, and prepared bones $40^{\circ} 5$ per cent. M. Arnoux, of Minton's, was perfectly correct in stating that the English 
porcelain differed only from that known as hard paste by the presence of the tricalcic phosphate of lime contained in the bones. This bone porcelain was first introduced by Josiah Spode in I8oo.

The composition of glazes must be such that they can unite with the paste, or body, without crazing or cracking on cooling, and they must cover smoothly and evenly the whole surface, effecting a complete union. The glazes, or glassy coatings, are variously composed of quartz, flint, felspar, gypsum, borax, boracic acid, common salt, potash, soda, and red oxide of lead. It is important to bear in mind that some glazes are first fritted, or melted into a glassy body, before being used, and this frit is powdered. Coloured glazes are made by the addition of certain metallic oxides from manganese, cobalt, copper, iron, chromium, etc. Glazes containing lead20 or 2 I per cent. of carbonate of lead-are used for some of the English porcelains, but formerly lead was much more employed than it is at present. John Rose, of Coalport, gained the gold medal of the Society of Arts, in I8zo, for a glaze containing neither lead nor arsenic, composed of felspar 27 parts, borax I8, Lynn sand 4, Cornish clay 3, nitre 3, soda 3. This was fritted and three parts of calcined borax added. Felspathic glazes appear to have been largely used at Meissen (Dresden), Berlin, Sèvres, etc.

Salt glazes are still used by manufacturers of stoneware drain-pipes and sanitary ware; but, though Staffordshire potters do not glaze with salt, as they did for about a hundred years, commencing with I680, the famous Doulton ware is largely salt-glazed, fired, and glazed in one operation. The glazing is effected by throwing common salt into a kiln containing the ware, towards the end of the firing, through apertures constructed for the purpose. The salt is vaporised by the heat of the kiln, the vapour filling it, and surrounding the various vessels. The vapour and the silica of the surface of the ware act on each other, through the medium of the watery vapour always present in the furnace, the oxygen of the water producing soda with the sodium of the salt, and thus a thin gloss of silicate of soda is formed over the ware. 
But Doulton uses no seggars (or saggers), so that the contents of the kiln are fully exposed to the open fire, and not protected in any way. Glazing with salt upon colours produces many effects which may be termed accidental, but they are none the less charming. In the chapter on Doulton ware we have noted that other methods are employed with other ware. The stoneware is salt-glazed.

Tin-glazes, or enamels, formed an important coating for the early pottery, the majolica, the wares of Persia and Arabia, and for the more modern Delft including that made in England, which has been reintroduced during the latter part of the nineteenth century by those potters who specialise in imitations of such ware. The particles of tin give a white opaque character to the glaze, and form a surface well adapted to receiving decoration by painting. The stanniferous glazes display an endless variety of treatment, from the richest colour and lustre decoration of the old Italian majolica to the crude Dutch and English tiles painted in blue.

For painting on pottery and porcelain, the colouring matter is usually mixed with some substance, a flux, which vitrifies on fusion, and this causes the colours to adhere to the surface, whilst at the same time it protects them by becoming the glaze where applied over that surface. In some cases the colours are simply minute particles of some"metallic oxide in mechanical suspension in the flux, as in the greens from oxide of chromium, and the reds and browns from peroxide of iron. In others a chemical combination is set up by heat, and silicates are formed. This is the case with the blues from cobalt oxide, and the reds and blues from copper oxide. The most durable decoration is that applied in colour upon the clay, then glazed, and the whole fired in the biscuit-kiln in one operation. Most of that is what we term blue and white, with the blue under the glaze. But the number of colours which can withstand the fierce heat of the biscuit-oven unchanged is very limited. Hence, whilst other colours are applied to biscuit-ware, which is then glazed in the glostoven, the temperature is much lower, though the flux with the metallic oxides must expand and contract in the same 
degree as the glaze, and both must adhere equally to the biscuit body. Here, again, but a comparatively few colours can be employed : cobalt blue, chrome green, copper red, and iron red may be used under the glaze, though in England the eminent skill of the Chinese in dealing with these two reds under the glaze has not yet been attained. But none of these are altered by the heat of the glost or glazing kiln, though I have noted that the reds are not used in this country under the glaze.

Then we come to decoration over the glaze, where the fluxes, or enamel colours, though more easily fusible than the glaze employed in the glost-kiln, can unite with it, and cover it by the application of a lower temperature in the heat of the muffle-kiln, which is also termed the enamelling oven. It needs many visits to this kiln before some of the pieces with elaborate decoration are completed; but, to secure the difference between painting and enamelling, fire must be invoked. Even with the greatest care examples of peeling are sometimes found in work of the highest type.

In addition to the blues, greys, and black from cobalt, and the greens from chromium, peroxide of iron furnishes reds, browns, and violets, oxide of antimony shades of yellow, oxides of copper reds and blues, peroxide of manganese violets and blacks, etc. Oxide of zinc modifies and improves other colours, with which it may be mixed-the blues from cobalt, for example-and these colours may also be affected by the nature of the flux employed. By the most laborious and extended experiments, some English potters have during the nineteenth century won back the secrets that were lost, or they have discovered how to produce those marvellous tints for which the old Chinese potters were famous. I have seen some of these, and they are astonishing revelations. But I must say a few words about the gilding. An amalgam of gold and mercury is mixed with a flux, and the powder worked up with turpentine and oil and then painted on the surface, being afterwards placed in the muffle-oven and fired. The gold left on the design by the evaporation of the vehicle is dead, or mat; but, under the hands of the burnisher, in a 


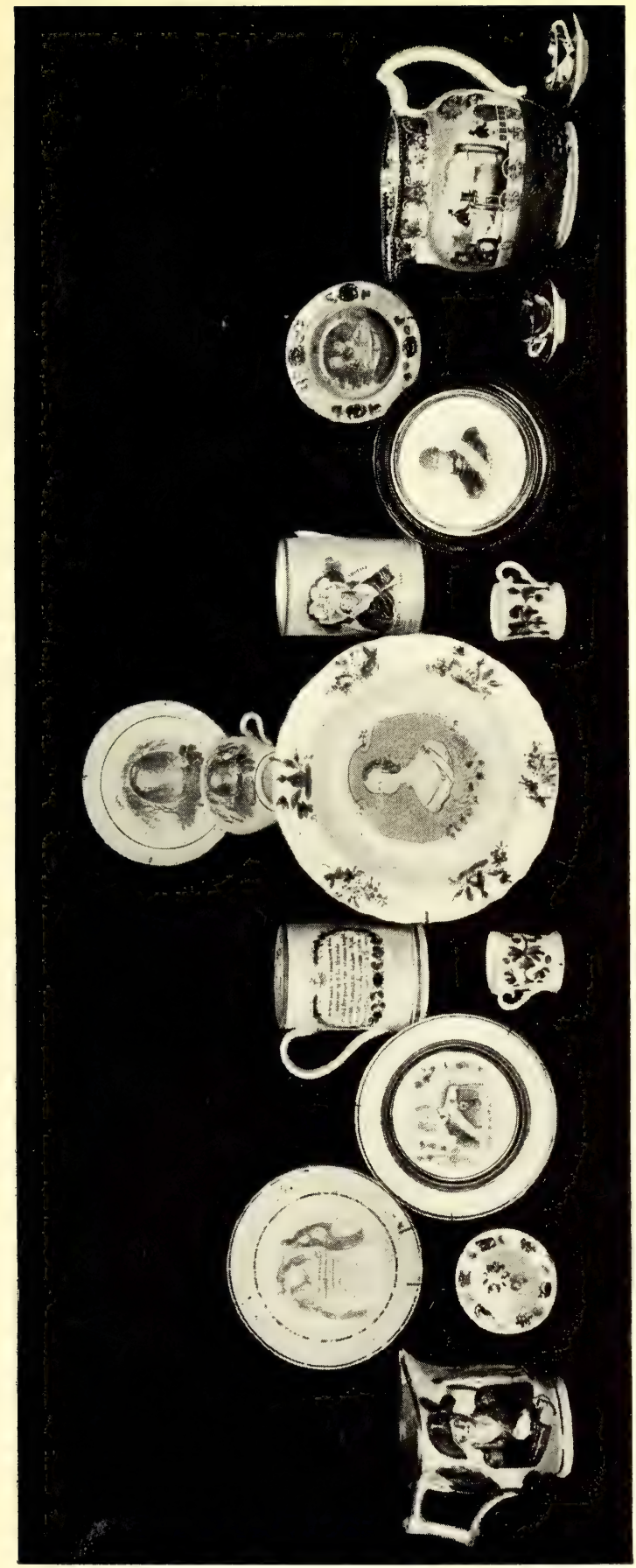

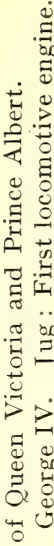

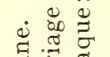

表焉

उั.

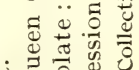

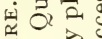

出㟔它

푤

苋芯

ด

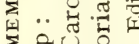

₹

卌

명며

…尹巳寸

㲾

击步。

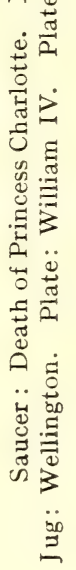





\section{ESSENTIALS TO THE POTTER'S ART 503}

few moments its lustre appears by the friction of a polished agate or other hard stone. The rich effect of raised gold is obtained by the tracing of the design with thick yellow enamel in the first instance before gilding. After the burnishing is completed the china enters the show-room ready for sale. 


\section{CHAPTER XXI}

\section{A FEW LETTERS FROM MODERN POTTERS}

In reply to my inquiries, extended to nearly the whole of the firms of importance whose names appeared on the list for I90o, I received much valuable assistance; but some had no information to give, and others did not care to give any. This chapter will give those replies which I have been unable to use elsewhere; not all of them, but a selection which may not be without some interest as actual quotations.

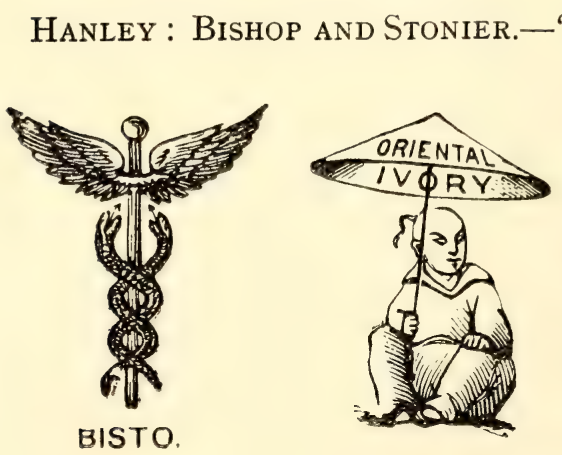

"We enclose illustration of our two trade-marks in present use. The caduceus is sometimes used without the word 'Bisto,' sometimes with the initials B. and S. The Chinaman under the umbrella is only used on our 'Oriental Ivory' ware, which is of a specially rich, somewhat yellowish tint."

Hanley: Dudson Brothers Successors to James T. Dudson.- "This business was established in I800 and has descended in a direct line since. Trade-marks are DuDson, England; Dudson Brothers, ENGLAND; and Dudson Brothers, Hanley, England. Previous to I86o a large proportion of the ware was unstamped. Our speciality is "stoneware.",

Hanley : J. H. Weatherby and Sons.- "We have been in 


\section{A FEW LETTERS FROM MODERN POTTERS 505}

occupation of these works for the past seventeen years, making general goods, such as tea-sets, toilet-sets, dinner-sets, teapots, cheese-stands, vases, etc. Our trade-mark is the Union Jack with the word 'Durability' across it as per imprint on this page."

LONGTON: JAMES KENT (manufacturer of useful and ornamental earthenware for

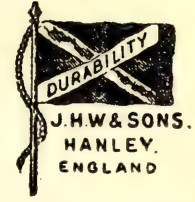
all markets).- " It ('The Old Foley') is the oldest works about here. Wesley used to make the house on these works

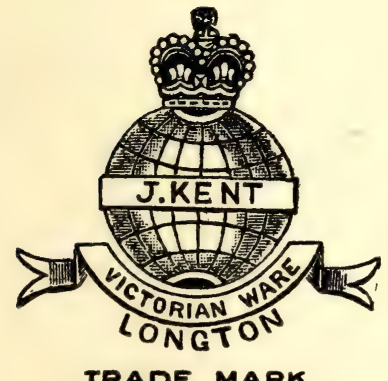
his centre. Mr. Mayer was the owner and potter at that date. I am also told Wedgwood commenced here, and old moulds, etc., on the works now go to prove that he was here. We have very ancient things in moulds, and, being called 'The Old Foley Pottery at Wedgwood's,' time rather proves the place goes back a long way."

Glasgow: The Nautilus PorceLAIN Co._.." It is now about thirteen years since this company started the manufacture of Fine Art Ivory Porcelain in a small pottery at Barrowfield, Glasgow. From a very small beginning they now make a large variety of figures, centrepieces, vases, dessert-sets, tea-sets, trinket-sets, and other articles suitable for a high-class trade. These are all artistically painted by hand, and have found a ready sale in this country, and also in the Colonies, America, and on the Continent. About ten years ago they removed their works to larger and more commodious premises at Possil Pottery, situated in the north part of Glasgow. Here they have extended their business very considerably, adding to their manufacture wicker baskets and crest-china. These wicker baskets, with their embossed flower work, are all made by hand, and embrace a great variety of shapes of the most artistic description. The crest-china department has grown to an enormous extent. The endless variety of shapes and the innumerable crests and coats of arms which they have reproduced go to show that they have supplied this class of ware all over the country. The shapes are well modelled, and the beautiful ivory tint of the ware makes it much sought after." 
The Pottery, Langley Mill, near Nottingham.-"We are afraid our marks would not be of very great interest, as we are only manufacturers of the commoner kind of stoneware. However, we send you impressions of one or two marks which we use, which may be of some slight use to you." The firm, it should be mentioned, is LovatT and LovatT.
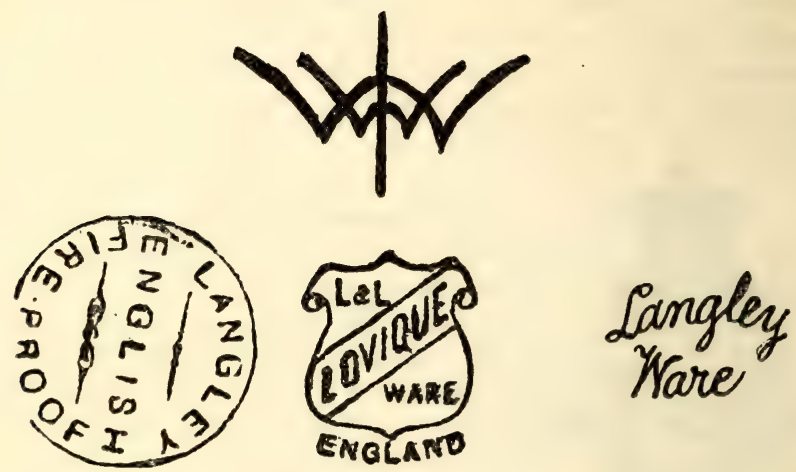

Hanley: Geo. L. Ashworth and Bros.-"We beg to say that we are the sole reproducers of Mason's Real Ironstone China, and all his decoration and shapes, all the existing moulds and engravings being in our possession, and were purchased from the Mason firm by us when his business was closed. We enclose herewith a circular giving a few particulars, also a few illustrations, which may be of interest to you."

Much of the information sent by this firm has been embodied in the chapter "In the Potteries at Hanley."

The following is an extract from a letter the writer of which does not wish his name to appear, which I publish because it clears away much misapprehension regarding the old master potters.

"The late Mr. Hulme, of Burslem, who presented to the Burslem Museum (in the Wedgwood Institute) one of the finest collections of Whieldon, Old Wedgwood, Turner, Adams, and the products of other famous Staffordshire potters, always spoke of, and labelled, the jasper, fine stoneware of the eighteenth century Turner, Adams, etc., as 'contemporaries' 


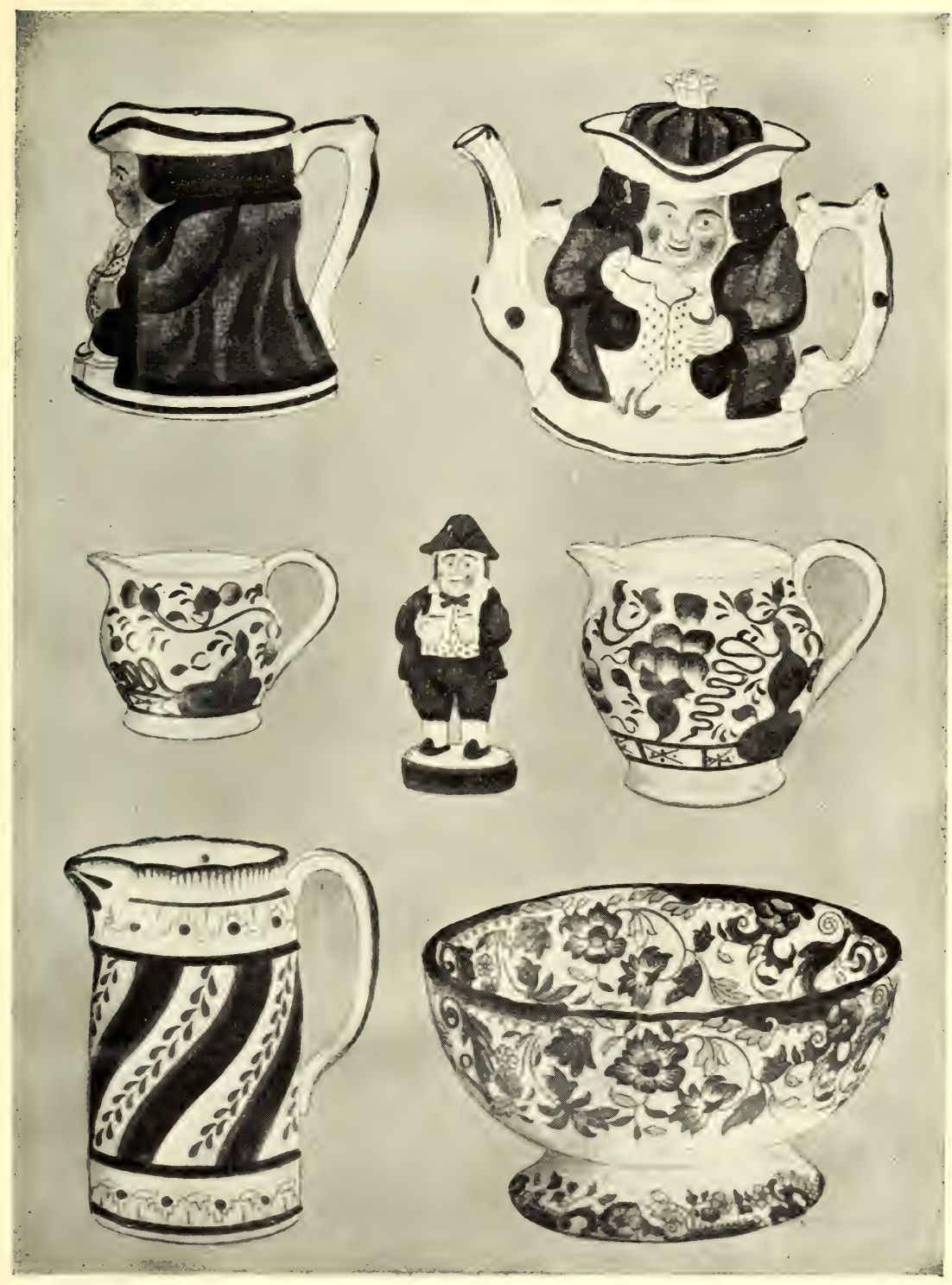

ALLERTON'S LUSTRE WARE. 



\section{A FEW LETTERS FROM MODERN POTTERS 509}

of Wedgwood, never as 'imitators.' He was Honorary Curator of the Burslem Museum for many years, and one of our greatest authorities."

In my book, The $A B C$ of Collecting Old English Pottery, the chapter on "Wedgwood and his Rivals" has the subheading "The Rivals of Wedgwood, or his imitators-which?" and the letter printed above is a conclusive answer to that question, though there appears to be but little doubt that Palmer deliberately set himself to reproduce Wedgwood's designs, and that his partner Neale did the same. With these exceptions, and perhaps Voyez as another, the other firms were honourable competitors, not imitators.

Longton: Chas. Allerton and Sons.-The following letter from the firm of Chas. Allerton and Sons, manufacturers of earthenware, semi-porcelain, bone-china and gold, and silver lustre, as well as resist lustre, contains much useful matter :

"We enclose two separate slips, on which are some of our trade-marks, although they are not of much service in
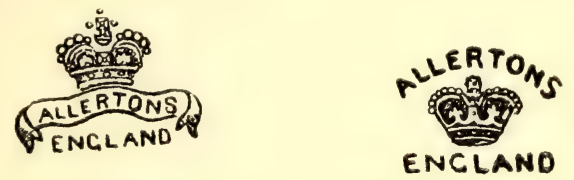

CHASALLERTON \&SONS

ENOLARO
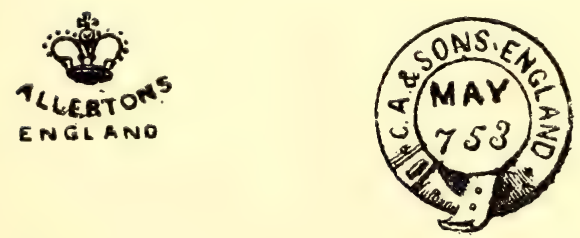

tracing the earlier productions of this firm-which, we may say, was founded by the late Mr. Chas. Allerton in I83I, of whom the present proprietors are grandsons. 
"We believe that this is the only firm (with the exception of MEssRs. Josiah WEdGwood and Sons) in the Staffordshire potteries carried on by the third direct generation. Incidentally, we may add that we have a fourth generation almost ready to take up the reins when called upon to do so.

"We enclose an illustrated sheet of lustre goods-the items marked with a cross have been made by this firm soon after the commmencement of the business in I83I. The original proprietor of this business also introduced a genuine Silver Lustre Ware, of which there are a good few specimens in various parts of the world. Unfortunately, these pieces were not stamped or impressed with the firm's name, but we can usually tell when we come across some of the pieces made between $\mathrm{I} 83 \mathrm{I}$ and $\mathrm{I} 870$. We have all along continued to make some of the old shapes in Silver Lustre, using the original receipt, and also the original method of applying the Lustre to the ware.

"At the present time there is a cheap kind of Liquid Silver Lustre on the market, and this should not be confused with the original. In regard to the present cost of our Silver Lustre, we may say that one of the principal materials used in its manufacture has advanced in price about seven hundred (700) per cent. during the last fifteen years. We refer to platinum.

"Gold Lustre (or Copper Lustre, as it is sometimes called) is a much cheaper article to produce, and we have usually a good number of orders on our books for this class of goods, both for the home and foreign markets, although the heavy duties imposed by most foreign countries have been a great drawback to the volume of business, which could have been done had there been a reasonable duty to be paid.

"Collectors of Antique Silver Lustre Ware send us pieces to be resilvered, which we do only on the understanding that they take all risks attending such pieces while under our care, including the refiring of such pieces.

"We do not know of much more information that we can give you-excepting to say that of recent years the demand for new shapes and decorations has almost reached bewildering point. About twenty-five years ago a matter of half a dozen shapes of cups and saucers was sufficient to bring full work to our China Works. To-day we must have about fifty shapes, or we should get left behind-and, as we intend to 


\section{A FEW LETTERS FROM MODERN POTTERS 5II}

keep in the running, we are continually adding new shapes and decorations."

Fenton: E. Brain \& Co., Foley China Works.- "The principal item of interest with regard to this firm's productions is that we were the originators of the simple style of design and decoration as applicable to Pottery; that, since we introduced it a few years ago, it has been so universally appreciated and admired, that the style has been copied and imitated by practically every firm in the Potteries and also very largely by the continental pottery manufacturers.

"The pottery, when introduced, was branded THE PEACOCK POTTERY, and if the copies of this mark and examples, as per enclosed, are of any value to you, we shall be pleased to give you our permission to use the same."

For such permission from so many firms; for much information, for books and illustrations from others who rendered me that assistance, which has enabled me to undertake, however feebly, this task, my grateful thanks are heartily tendered. The general feeling is well expressed in Messrs. Doulton's letter- "We shall be pleased to send any other particulars that may be required "- and in one from the Royal Crown Derby Porcelain Co., Ltd., enclosing two booklets: "These may be of some assistance to you. If you should require further information on any point, we shall be pleased to furnish it, if possible."

And so with others, whose contributions have been valuable. On the other hand, some were not so gracious; hence, though it would have been difficult to compress the history of so many different works more than I have done to meet the requirements of space, some firms may be wanting, some again may be treated very shortly; but frankly recognising, as I do, 


\section{I2 I9TH-CENTURY ENGLISH CERAMIC ART}

that my requests for information and for illustrations would not commend themselves to everybody, I am only too grateful that the general response has been so generous, and in some cases so extremely kind, even to the revision of the written matter. 

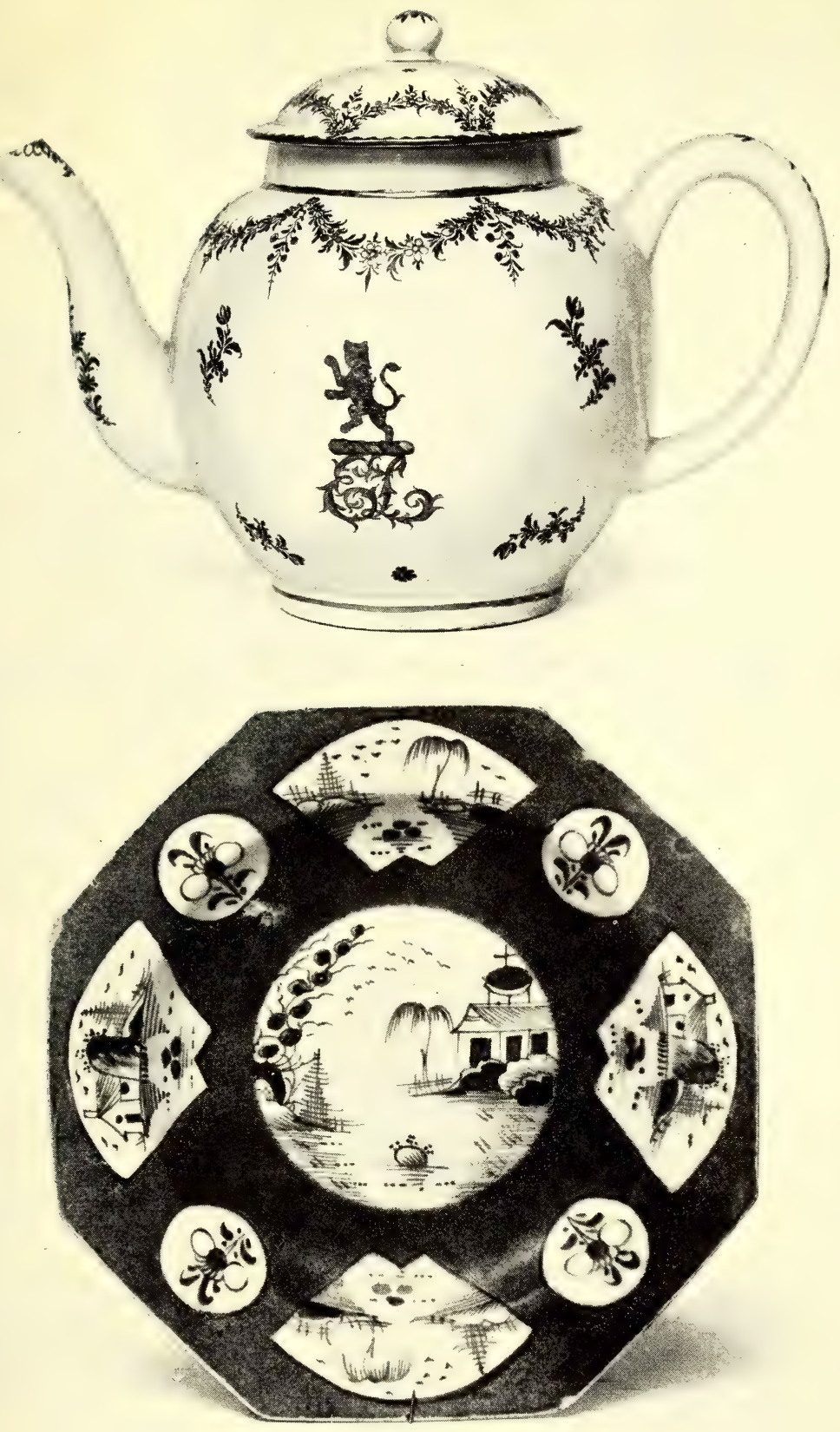

LOWESTOFT.

Lent by Mr. George Stoner. 



\section{CHAPTER XXII}

\section{NOTES ON LOWESTOFT}

\section{Hedingham. Conclusion}

THE Lowestoft factory was founded about I755, and in I770 the proprietors were Robert Brown \& Co. In I790 Gillingwater, in his History of Lowestoft, notes that:

"The only manufactory carried on at Lowestoft is that of making porcelain or china-ware, where the proprietors have brought this ingenious art to a great degree of perfection, and, from the prospect it affords, promises to be attended with much success."

Although a London warehouse was opened, early in the nineteenth century the manufacture was ended. The competition of the Staffordshire potteries was one cause of the failure, another was the losses of the company, especially at Rotterdam, where, when Napoleon captured the city, some thousands of pounds were lost by the destruction of Lowestoft china. So it is stated, and his enmity towards England, who made an abortive attempt, in I799, to drive the French out of Holland, was shown in the Berlin Decrees, which were referred to in the introduction.

It was in $\mathrm{I} 80 \mathrm{z}$ that the Lowestoft factory was closed. All kinds of Oriental armorial porcelain, in addition to many unmarked pieces of other English china, have been ascribed to this factory, and "Chinese Lowestoft," whatever that may be, is a term often used. Most of the genuine specimens which I have seen were of coarse quality, painted with borders and flowers in blue and with names or initials. Some of it resembles blue and white Plymouth china in its decoration, 


\section{I6 I9TH-CENTURY ENGLISH CERAMIC ART}

which is not surprising when we consider that the coasting trade was easy between the two towns. Indeed, I am not sure that, amongst the specimens which are regarded as early Lowestoft, some of Cookworthy's could not be found. The authenticated ware is an artificial porcelain, soft paste like Chelsea and Bow, but many pieces with the inscribed names are hard paste. I am not speaking of the forgeries which abound, but of undoubted old china. The discovery of the moulds at the site of the old works, to my mind, was better evidence than that of the fragments of finished ware, because Chinese porcelain, delft-ware, and English earthenware are also found.

The true Lowestoft is somewhat opaque and yellowish in tinge; when viewed by transmitted light the glaze is, again, like Plymouth, often speckled. The moulds which were found prove that sauce-boats and cups, ribbed and fluted, like Worcester, were made, and teapots with embossed patterns like Bow. The painted blue decoration under the glaze, whether of Chinese landscapes or flowers in the Chinese style, resembles that of Bow, Worcester, and Plymouth, which all used the same kind of scenes and the same type of flowers. Then Lowestoft applied blue as a powder blue ground, having panels reserved in white, and painted with such subjects as have been mentioned, or in some cases, as in a specimen at the British Museum, with local views. The saucer-dish at the Museum shows Lowestoft Church in the centre, and in the six small panels round it are small seascapes, etc. The common blue painted Lowestoft mug has but little worthy of commendation; nevertheless, it is prized if inscribed with a name and date.

As may be gathered from the foregoing remarks, very little of this china was made during the nineteenth century. It is well to guard against many of the ideas which have been formulated without proof regarding this factory, which left comparatively few records of its history and its work. Some say that much Chinese porcelain was decorated there, but this is extremely doubtful. Painted Chinese porcelain could be imported much more cheaply than Lowestoft could 

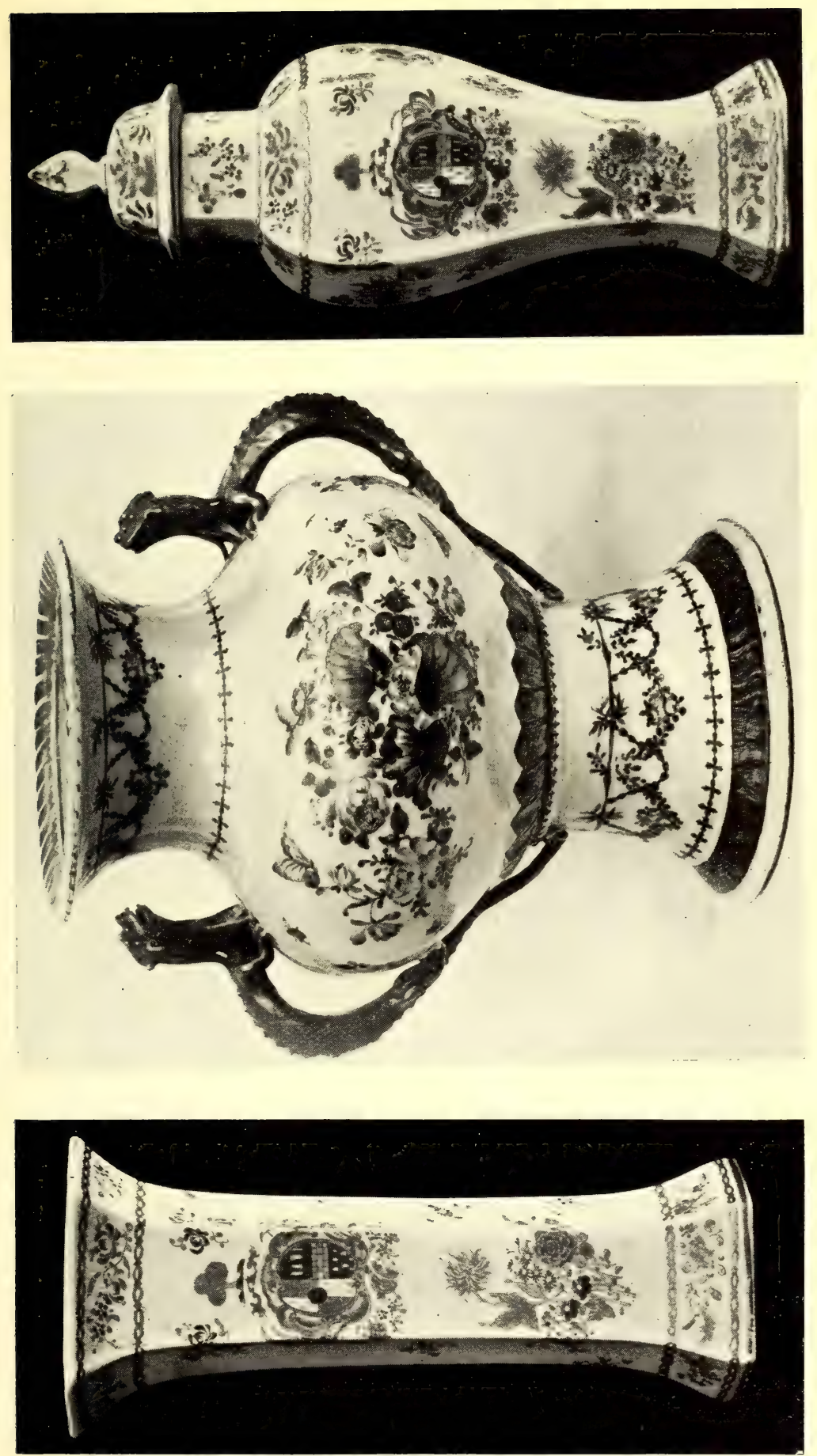

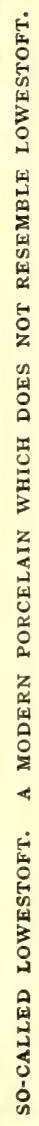



decorate it, and the difficulty of fixing soft, easily fusible, enamel colours to the intensely hard glaze of Oriental china would be great. No heat of an enamel or muffle kiln would affect that glaze, though the vitrifiable enamels might melt and stick to it upon the surface in a design raised above that surface.

The difficulties connected with the identification of Lowestoft china are increased by the absence of a factory mark, and by the use of marks such as the crescent and some Oriental marks usually associated with Worcester. But the glaze, the colour, and the weight are all different from that factory. If I were asked what special quality distinguished the Lowestoft productions I should say, at once, its weight. I have seen and handled many pieces of this ware, and in almost every one the weight was greater than would be the case in a similar specimen from any other English factory, where artificial porcelain was made. A comparison between the chief constituents of unglazed or biscuit porcelain made at Bow and at Lowestoft shows great differences: Bow, analysed, gives 40 per cent. silica, I6 alumina, 24 lime, and just over I7 phosphoric acid, whilst Lowestoft gives 42 per cent. silica, $6 \frac{1}{2}$ alumina, $26 \frac{1}{2}$ lime, and just over $2 z$ phosphoric acid. It must, however, be said that the compositions of the artificial pastes do not appear to have been constant in the same factory. We must not degrade Lowestoft to the lowly position of simply making mugs, and little else-the moulds tell a story of better work; but, on the other hand, we cannot place this factory upon the same level with the Bow, Chelsea, Worcester and other celebrated works, whose ornamental ware ranks with the finest ever produced. The subject of Lowestoft china is attractive because of the theories which have surrounded it; but much remains to be done before the whole truth is revealed.

You will have noticed that many of the most famous factories of the eighteenth century were closed before the dawn of the nineteenth, and only passing reference has been made to them; Lowestoft disappears with that dawn, leaving behind a number of dated pieces, which cover the period 
between $I_{7} 62$ and $I 789$. In addition to the date, the initials or full name of the person for whom they were made often appear, especially ABRM. MOORE, I765, a name which is common on forgeries, which are numerous.

The Hedingham Ware Art Pottery Works in Essex were in existence in I900, but when my inquiries were addressed to Mr. Edward Bingham, in I903 the circular letter was returned by the Post Office marked "Gone away." The Essex Archæological Society held a meeting at Castle Hedingham on May 25, I892, and afterwards visited these potteries, where the actual operations were described by Mr. Bingham. Some of the articles shown were very beautiful in design, notably an elaborate vase bearing the arms of the Essex boroughs, and of some old county families. Although quite modern, the style of decoration, as well as the forms of the objects, resembles the antique very closely, but a safeguard is found in the mark, which is a castle rising above a ribbon on which is the name E. Bingham. It is well to remember that when this mark is applied in white slip to the brown ground the letters are sometimes illegible. They puzzled me for a long time, and others who with me examined a marked piece.

Here, then, after a survey of the great ceramic art of the nineteenth century, we conclude with an appreciation of the potters of that age. They were men of liberal attainments, worthy successors who have fully maintained the high standard which was set for them, combined with equal sound judgment, and an honourable pride in their descent and in their work. We have seen them in the prosecution of their researches, devoting years of labour, and much money, to the recovery of the secrets of the past, with such success that nearly all of the fine old colours are again at their service-powder blue, famille rose, and the like. We have seen them, undismayed, attack new schemes of decoration, and attain eminence in wares which were given by them to the world for the first time-original creations, which have been accepted with warm approval throughout the civilised world. Perhaps no other single manufacture gives so much positive enjoyment, such a vast sum of gratification and pleasure. From the tea- 


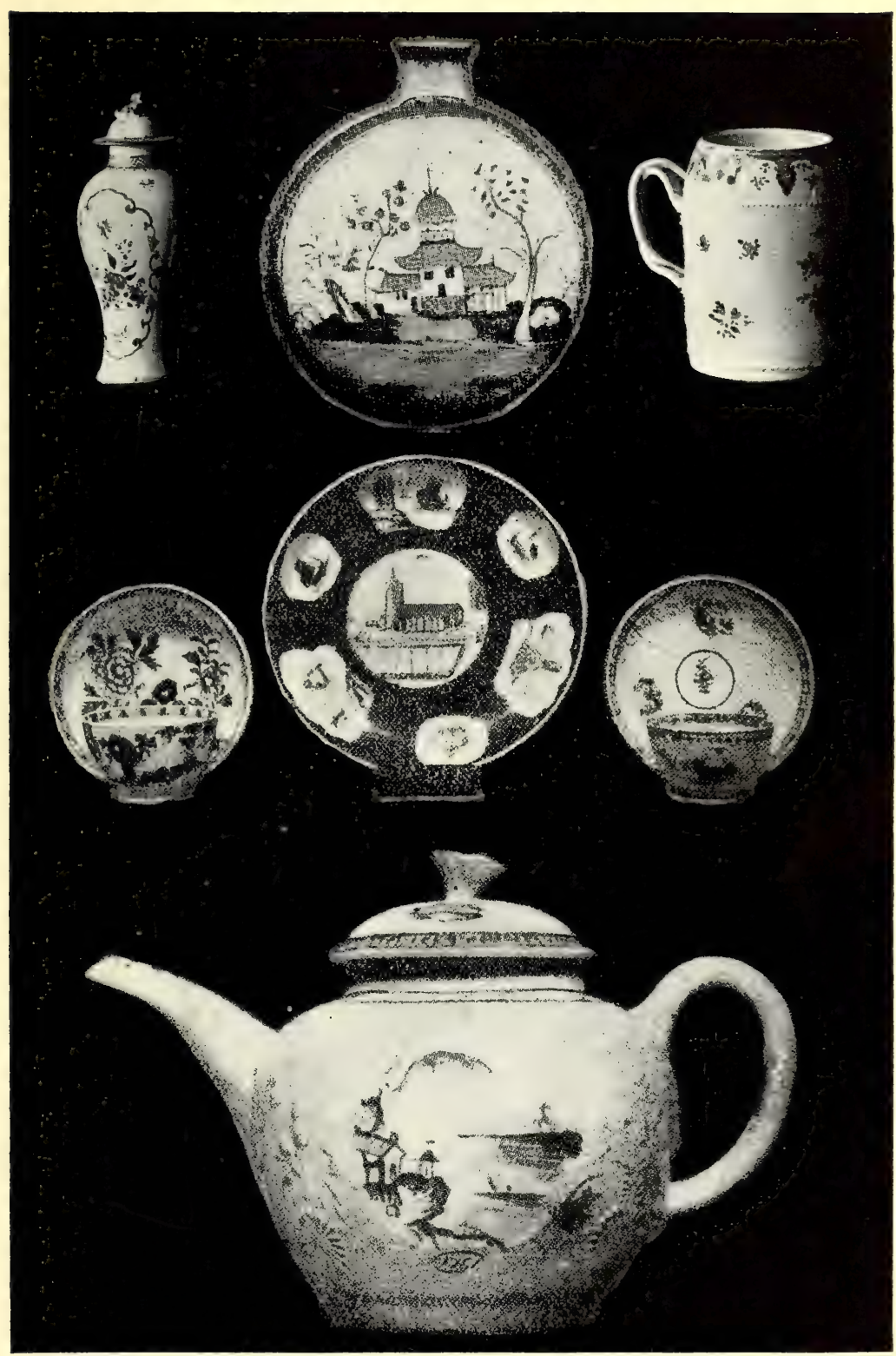

LOWESTOFT. THE MUG AND COVERED VASE ARE DOUBTFUL. 

service, with its harmonious decoration, to the magnificent vase, brilliant with the best efforts of man's skill in modelling, painting, and gilding, we derive some satisfaction, even if we are not interested in the actual collection of the treasures of the days that are gone, but, if we are collectors, how much more is our delight in tracing the history of that service or vase, in knowing how they were evolved from the crude products of earlier times!

We may judge of the estimation in which the ceramic art is held by the collections which the nations have formed, at great cost, to meet the needs and gratify the tastes of those students and enthusiasts whose perception leads them to an ever-increasing devotion to that art, and in this connection I venture to make a suggestion that our Museum authorities should acquire specimens of the later nineteenth-century productions of the excellent factories whose proprietors have done so much to maintain the national reputation of English earthenware and china. In the course of years such pieces which we now call modern, would take their due place in a series, and they would have one great advantage over the existing collections-they could be made thoroughly representative. The Minton masterpieces of Solon's pâte-sur-pâte, Wedgwood's vases painted by Lessore, Tinworth's Doulton ware, and the like, are somewhat expensive, but by and by they will be much more costly, and surely they ought to be represented in the Museums. I feel sure that the manufacturers would welcome such a proposition, and such a recognition of their art would be to them no less gratifying than stimulating.

I said we may judge of the estimation of ceramic art by the Museums, and, whilst that is true, it is not all. There are thousands of people who have their own collections; sometimes very valuable and complete; at others, not so valuable, but specialised; at others, again, small but eminently pleasurable. There are thousands more who treasure the old earthenware and china, which have been kept in the family from generation to generation. And there are other thousands whose good taste attracts them to old china, as part of the 


\section{I9TH-CENTURY ENGLISH CERAMIC ART}

decoration of the home; a part, too, which never palls, owing to its charms of quiet and repose. During the stress and turmoil of a busy or tempestuous life, what recreation can give more enjoyment than collecting ? What is more likely to counteract the effects of excessive devotion to business and its worries than the pursuit of a collection of old china, in which other sensations, other hopes and fears, temporarily displace those of the daily task which in these days tear the life from the stoutest hearts ? Recreation is needed, and you can find it and use it, and go back to the work saner and sounder, because of the intervals of change, of repose, and quiet enjoyment. You can exchange your ordinary profession, with mental and physical advantage, for that of a collector.

Elsewhere I have said how valuable the fine old china of the eighteenth century has become, how difficult it is to get even at a high price, and I know that the early productions of the nineteenth century are scarcely less costly, scarcely less rare. But there is a later period which awaits you-the Victorian era, which in this book is illustrated with examples from the Exhibitions of $185 \mathrm{I}$ and $\mathrm{I} 862$, and in such pieces as are shown in the products of the potters of the last century lies a whole world of interest and of value. The value must increase because the supply cannot, and collectors can. Hence, whilst positive gratification is mine in sending this book into the world, it is vastly augmented by the thought that it may give some pleasure to those who read it, and that it may influence those who feel within themselves the need for recreation, to adopt one form of it which, reasonably enjoyed, leaves no room for vain regrets, for heartburnings and strife, but which leads on to that which in the end is more than compensation for them all-the perception of ease.

Though there is food for reflection in the following lines by Longfellow, there is also much of that pessimism to which the diversion of collecting can act as the surest antidote, brightening even those dreary lives

"Toiling on and on and on,

With breaking heart and tearful eyes, 
And silent lips, and in the soul

The secret longings that arise,

Which this world never satisfies!

Some more, some less, but of the whole

Not one quite happy, no, not one !"

These sentiments express a condition in sharp contrast to that happiness which the collector enjoys when living in a

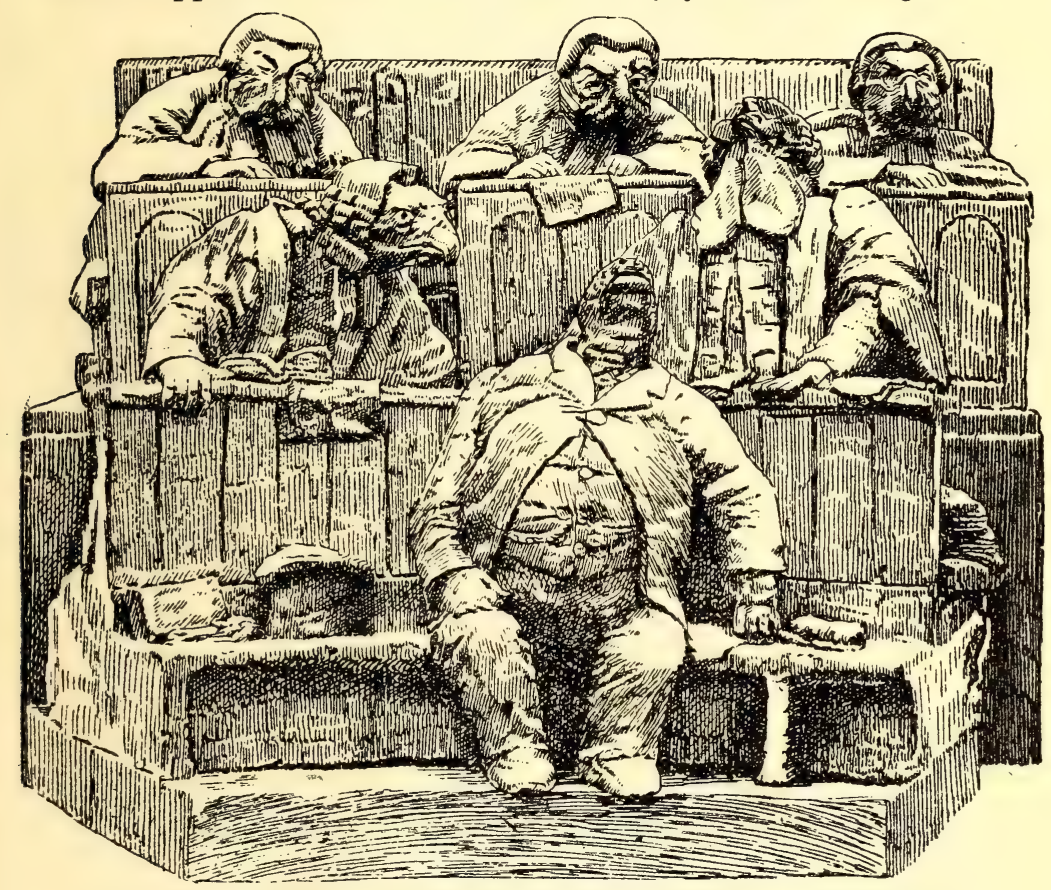

JUSTICE MELLOR. LORD CHIEF JUSTICE COCKBURN. JUSTICE LUSH. MR. HAWKINS.

DR. KENEALY.

THE CLAIMANT.

MODERN GROUP DESIGNED BY RANDOLPH CALDECOTT.

THE TICHBORNE TRIAL, I873-4.

world amongst his treasures, or when seeking them, apart from his ordinary business. One's own experience and the knowledge of the enjoyment of other people bear evidence to the passing of worry and the coming of ease. Besides, as M. Hale remarked in I682, " in all ages, as well old as young 


\section{6}

I9TH-CENTURY ENGLISH CERAMIC ART

almost every person hath some Hobby-horse or other, wherein he prides himself." Men and women must have relaxation, and what form can that take better than the collection of objects for the home beautiful, for, after all, home is life enjoyable or otherwise. In Dryden's words :

"'Tis not for nothing that we life pursue;

It pays our hopes with something still that's new;

Each day's a mistress unenjoyed before;

Like travellers, we're pleased with seeing more.

Did you but know what joys your way attend

You would not hurry to your journey's end."

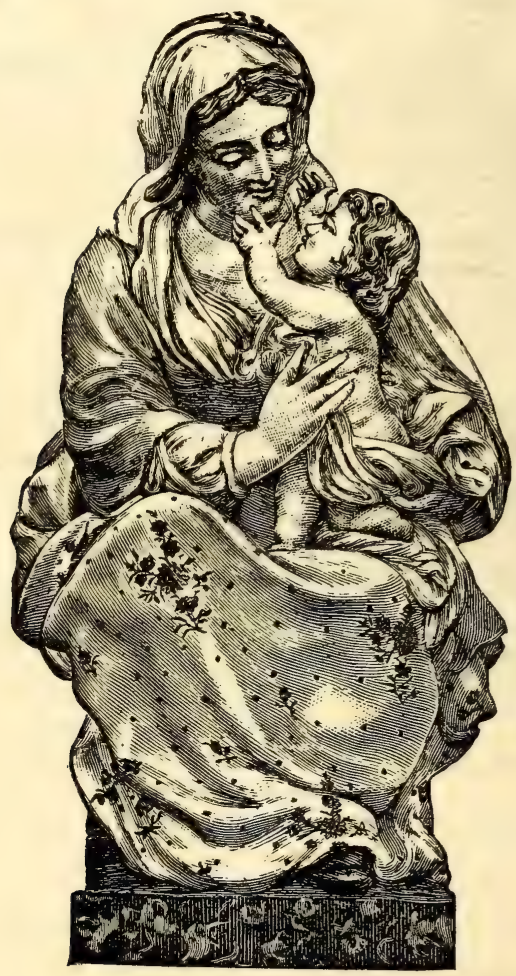

A FINE OLD STAFFORDSHIRE GROUP. ENOCH WOOD 


\section{N D E X}

A

Abrahams, the figure painters, 82, 88,342

Adams \& Co., 53

— \& Sons, 50

- John, 50

- marks, 56, 62, 63

- the, master potters, II, 24, 49 et seq., 96

- ware, American views, 54, 59

- William, of Burslem, 49

- - of Stoke-upon-Trent, 49

- - of Tunstall, 49, 53, 54

Alcock, S., \& Co., potters, Burslem, 23, I68

Aller Vale pottery, 439, 440

Allerton, Chas., \& Sons, Longton, 509,510

_ _ - - lustre ware, 5 IO

American market, the, 2I4, 216

- views on Adams ware, 47, 54, 59

Arnoux, M., Director of Mintons, 3I, IO2, IO7, 497-8

Art Journal, the reports in the, I6 et seq., 70

Ashworth, G. L., \& Bros., Hanley, 4I et seq., I94, 506

Astbury, potter, II, 60

Ault Clarissa J., painter, 320

- W., potter, Swadlincote, 316-20

Aynsley, John, potter, I73

\section{B}

Baddeley, potter, Shelton, 28, 50

Ballard, figure painter, Madeley, 348

Bancroft, flower and fruit painter. Mintons, $\mathrm{IO} 2$

B. and L., Burgess \& Leigh, I68

Barker, S., \& Sons, Don Pottery, $42 \mathrm{O}, 423$

- Sutton \& Till, potters, 27
Barlow, T., potter, Longton, 222

Baron Marochetti, sculptor, Mintons, 107

Barum ware, Barnstaple, 440-7

Basaltes ware, 54,60, I 28

Battam, T., Copelands, 70

Beardmore, F., \& Co., Fenton, I 82-6

Bell, J. and M. P., \& Co., Glasgow, $23,468-7$ I

Belleek china, Irish, 476 et set.

Belleuse, M. Carrier de, Mintons, IO 7,235

Benthall works, Maw \& Co., 325 , 344

Berlin decrees of Napoleon, 28

Billingsley, potter and painter, 40 , I 8I, 3I 2, 3I 5, 456, 463 et seq.

Bingham, E., Hedingham pottery, 520

Birkenhead factory, Rathbone, 43 I

Bische, figure, etc., painter, Copelands, 82,88

Bishop \& Stonier, Hanley, 504

Black basaltes ware, 54,60 , I 28

Blanchard, M. H., Blackfriars Road, London, 383

Blashfield, potter, Stamford, 384

Blue printing, 53, 6I, 64, 66, 67, I 45

Bone, constituent of china, 67

Boote, Messrs., potters, Burslem, 23, I 54-8

Booth, E., potter, 60

Booths Ltd., Tunstall, 236 et seq.

Bott \& Co., potters, I 73

Bourne, S., enamel painter, Mintons, $\mathrm{IO} 2$

Bowers, C., chemist and potter, Booths', 236 et seq.

Boyle \& Son, potters, Stoke-uponTrent, 50

Brameld \& Co., Swinton, Rockingham ware, 28,423 et seq.

— initials, J.W.B., 427 
Brampton ware, 308, 3 I I-I 2

Brannam, H., Barum ware, Barnstaple, 440

Bretby Art Pottery, H. Tooth, 323-4.

Bristol, 27, 39, 435-6

Broseley pottery and tiles, 325 , 344-5

Brown, potter, Caughley, 329

Brownfields, the, potters, Cobridge, I 74

Brownlow Street, High Holborn, Martin Bros., 38I-3

Brown-Westhead, Moore \& Co., Ridgway's, 198

Burgess \& Leigh, potters, I68

Burslem potters in I 829 , I 7 I

- - in 1843,172

-. - in 1900,172

Burton, W., expert, on Moore's flambés, 227

B.W.M. and B.W.M.\&Co., marks, 2 I I

\section{C}

Cambrian pottery, Swansea, 455

Campbell Co., the tiles of the, i 6

Cane-colour ware, I3I

Castleford pottery, Dunderdale, $418-20$

Caughley, 6I, 325, 329

- Turner of, 330

- with Coalport marks, 344

Cauldon Place, J. \& W. Ridgway, I 98-2 I I

C.B., mark of C. Bowers, Booths', 236

Champion, Bristol, 36,485

China clay and rock, 35,485 et seq.

Church, Sir A. H., expert on Wedgwood, I4I-5

Clays, colouring matter of, 494

- contraction in burning, 492-3

- for pottery and porcelain, 35, I 28,48 5-8

Clementson, potter, I 73

Clevedon, Elton ware, 448-52

Clews, J., potter, I73

Close \& Co., potters, 59

Coalbrookdale, 23, 40. See Coalport

Coalport absorbs Caughley, 336 ; Jackfield, 336 ; Nantgarw and Swansea, 331, 336

— artists who worked for, 338, 342
Coalport, Billingsley at, 336,337

- Bruff, C., Director of, 326 et seq.

- China Co. (John Rose \& Co.), $34 \mathrm{I}$

- Chinese patterns, 342

- Cook, flower painter at, 338

— forged marks, 338

- Hartshorne, animal painter at, 338

— imitations of Sèvres, 338

- its history, 326 et seq.

- marks, 344

- Randall, bird and figure painter for, 338,345 et seq.

- Roses, the, 23, 330, 338, 34I

Cobridge, 24, I 74 et seq.

Cochran \& Fleming, Glasgow, 47 I, 474-5

Coke, Pinxton, 40, 3I2, 3I 5-I6

Cook, china painter, 35,338

Cookworthy's discoveries in Cornwall, 36,485

Copeland and Garrett, 68

- - his artists, $80,82,88$

- Stoke-upon-Trent, 20, 24, 40, 64 et seq.

- W. J., \& Sons, 70

- - late Spode, 69

Cornish china clay and rock, 35 , I $28,485-8$

Cornwall, Staffordshire and, 3 I et seq.

- stone, $42,45,486$

Cream-colour ware, 4I, 60, I02, I 26, I 36

Cumberworth, sculptor, Copelands, 74,76

D

Dale Hall, a Burslem pottery, I63-6

- marks, B. G. and W., J. G., and K. \& Co., I65-6

Daniel, H. and R., potters, 50, 235

Davenport, John, Longport, 2 I 7 et seq.

- marks, 22 I

Della Robbia ware, II3; Rathbone, 43I-2

De Morgan, Fulham, 380-1

Derby and district, 283 et seq.

- artists, 288, 297

- Bloor, 283-4

- Bourne, J., \& Son, Denby, 304. 308 
Derby, Brampton, 308, 3I I-I 2

- crown period, 287-8

- Duesburys, the potters of, 283-4

- egg-shell china, 300

- Gladstone's service of, 292-6

- Hancock, Sampson, 284, 287

- Kean, Michael, painter, 283,287

- King Street works, 284, 287 , 288

- Japan patterns, 298, 303

- Leroy, M. Désiré, painter, 297

- Locker apprenticed to M. Kean, 283

- - of the King Street Co., 284-7

- Nottingham Road works, 287

- Osmaston Road works, 288

- periods, the four, $287-8$

- reproductions for the Government, 300

- Royal letters-patent, 297-8

- Stevenson \& Co., 284, 287

- $\&$ Hancock, 284, 287

Devon, Aller Vale ware, 439

- Barum (Barnstaple) ware, 440

- Fremington ware, 447

- Watcombe ware, 436

Dickens illustrations on Adams ware, 59

Dillwyn, Swansea works, 455 et seq.

Dimmock, potter, Shelton, 23

"Dr. Syntax's Tour" on Adams ware, 59

Don Pottery, Swinton, 420

Doulton and Watts, I6, 349

Doulton's a Royal factory, 349-79

- Allen R., designer for gilding, 374

- artists at Burslem, 373-8

- at Lambeth, 357-73

- awards, 35 I, 352, 354

- Barlow, A. B., Lambeth, 358

- Miss H. B., Lambeth, 357

- Betterley, H., decorator, 377

- Carrara ware, 356

- Chiné ware, 356

- Curnock, P., flower and figure painter, 377

- Dewsberry, David, flower painter, 374,377

- faience, $350,356,368$

- Hodkinson, W., 374, 377

- impasto, 350, 368-9

- marqueterie ware, 356

- Marshall, M. V., modeller, 365
Doulton, Mitchell, H., animal painter, 378

- Mott, J. H., Director at Lambeth, 379

- Noke, C. J., artist modeller, etc., 374

- Plant, landscape painter, 377

- Raby, E., flower painter, 374

- salt-glaze ware, 350, 354

- salt-glazing process, 354, 498-9

- sgraffito ornament, 350,357

- silicon ware, 356

- Slater, J., Director at Burslem, 373-4

- Sparkes's lectures on, 357-73

- - work for, 349

- Tinworth, G., modeller, 36I-2, 364

- White, G., figure painter, 377

- Wilson, S., landscape painter, 378

Dudson Bros., Hanley, 504

Duke, Sir J., \& Nephews, Hill-Top Pottery, i 68

Dunderdale, Castleford pottery, 4 I 8

Durham, J., R.A., sculptor, Copelands, 80

\section{$\mathrm{E}$}

Early ware, the, 60

Earthenware, brown, 24

- cream-colour, 4I-2, 60, IO2, I 26,136

- jet, 24, 46

- red, 3I, 60

- Rockingham, 24

Eastwood, mark used by Baddeley, 28

Elers, the, potters, 3I, 60

Elton ware, Clevedon, 448, 452

Essentials to the potter's art, 482 et seq.

Etruria, Wedgwoods, I 2 I et seq.

Etruscan ware, 54, I 28, 455-6

Exhibition, the, of $\mathrm{I} 85 \mathrm{I}$ and before, I I et seq.

Extract, poetical, on a Staffordshire teapot, 46

$$
\mathrm{F}
$$

Felspar in the composition of china, 67

Fenton, 24, 4I, I 78 et seq.

- Crown Staffordshire Co., I 78

- Green Bros., I 78 
Ferguson \& Miller, Glasgow, 47 I Fifield, W., painter, Bristol, 436

Figures, Staffordshire, 27, I 7 1, I 73

Fishley, potter, Fremington, 447

Flaxman, sculptor, Wedgwoods, I $36,140,145$

Flight \& Barr, Worcester, 40, 250 et seq.

Foley china works, Brain, 5 I I

Ford potteries, Newcastle-onTyne, 39I et seq.

Forgeries and imitations, I2, I 5

Forrester, potter, 50

Fremington pottery, Fishley, 447

Frit and fritting before glazing, 498

Fulham lustre, De Morgan, 380-I

Furnivals Ltd., Cobridge, I 77

\section{G}

Gallimore from Belleek at Goss's, 232

G. \& Co., Grainger's mark, Worcester, 280

Garnkirk works, Scottish, 472

G. J., initials of George Jones, 234

Glasgow, Bell \& Co., 23, 468

- Cochran \& Fleming, 47 I, 475

- Ferguson \& Miller, 47 I

- Nautilus Porcelain Co., 505

Glazes, lead, leadless, salt, tin, 498-9

- salt-glaze ware, 60, 350, 354, 498

Goss, W. H., potter, Stoke-uponTrent, 232-4

Grainger, G., \& Co., mark on Worcester, 264

Graingers, potters, Worcester, I2, $23,254,264-8$

Grangemouth potteries, 473

Green Bros., Fenton, I 78

Greens, Bingley \& Co., 423

- Clarke \& Co., 420-3

- Hartley \& Co., 423

\section{$\mathrm{H}$}

Hackwood, potter, I 73

Hadley, J., \& Sons, potters, Worcester, 254, 268, $27 \mathrm{I}$

Hancock, flower and fruit painter, Mintons, $\mathrm{IO}_{2}$

Hanley, 24, I 89 et seq.

- Ashworth's, I89-97, 506

- Cauldon Place, I98-2 I I

— Old Hall and the Meighs, 2 I I-I 2
Hard and soft pastes displaced, 68 - paste, Minton's success in, $\mathrm{IO}_{2}$ Hartshorne, animal painter, Coalport, 35,338

Hedingham pottery,Bingham,520

Herculaneum pottery, 428, 43 I

Hill-Top pottery, Burslem, I 68

Hollins, New Hall works, 96 ; Shelton, I 73

Hughes, S., \& Co., potters, I 77

Hürten, flower painter, Copelands, 80,82

\section{I}

Imitations not deceptive, I 5

Irish pottery, Belleek, 476 et seq.

Ironstone china, Ashworth's, 4I, I94, 506

- C. J. Mason \& Co., 4I, I93,

- Hicks, Meigh \& Johnson, 193

- Spode, 64, 67,68

" Isabella," a poem, extract upon a teapot, 46

I. W. \& Co., initials of Wilson, 404

$$
\mathrm{J}
$$

Jackfield works, 325,344

Japan patterns on English china, $67,98,298,303$

Jasper ware, Adams, 53, 54 ; Wedgwood, I 28 et seq.

- solid, Adams, 53 ; Wedgwood, I 28 , I 3 I

— dip, Adams, 53 ; Wedgwood, I 28, I 3 I

Jeannest, M. Emile, sculptor, Mintons, IO7

Jones, G., \& Sons, Stoke-uponTrent, 235

J.W.B., initials of Brameld, 427

K

Kaolin or china clay, 485

Kent, J., potter, Longton, 505

\section{I.}

Lakin and Poole, potters, 173

Lambeth, Doulton, 349 et seq.

- Stiff \& Sons, 379-80

Lane Delph works, 4I

Langley Mill, Lovatt \& Lovatt, potters, 506

Lead glazes, 498

Leadless glaze, Rose's, Coalport, 331,498 


\section{INDEX}

Leeds, 6I, 396, 404, 4I 5 et seq.

- Burmantofts, 4I 7-8

- District and Liverpool, 4I 5 et seq.

- ware, 4I 5-7

Lessore, painter, Mintons, 35 ; Wedgwoods, I 39, 523

Letters, a few, from modern potters, 504

Linthorpe art pottery, I I, I2, 406-I 4

Lists of potters at Burslem, I 7 I-3

- - - Cobridge, I 78

- - - Hanley, 2 I I

- - Longport, 22 I

- - Longton, 227-3I $---\frac{-}{235-6}$ Stoke-upon-Trent, 50,

- - - the Exhibition in $185 \mathrm{I}$, 27

- - - Tunstall, 244-5

Liver, bird used as a mark, 428

Liverpool, 27, 428

- Herculaneum pottery, 428, 43 I

- marks, 428

Lockett, potter, I 73

London potters, 349-86

Longport, 24, 2 I 7 et seq

- Davenport at, 2 I 7-2I

- List of potters at, 22 I

Longton, 24, 222 et seq

- Allerton, C., \& Sons, 509

- Barlow, 222

- List of potters at, 227-3I

- Kent, J., 505

- Moore, B., 222, 224, 227

Lowestoft, 5 I 5 et seq.

- compared with other china, 516,519

Low Lights pottery, N. Shields, 403

Lustre ware, Allerton's, 5 Io

- how made, 492

- Leeds, 396, 404

- - Staffordshire, 396, 404

- Sunderland and Newcastle, 395-6, 400

- - Swansea, 396

— widely distributed, 27

\section{M}

Madeley, 35, 39, 325, 338, 345 et seq.

- imitations of soft paste Sèvres, 346,348
Madeley, painters at, 348

Makers of Staffordshire figures, I 7 I , 173

Maling, C. T., \& Sons, potters, Newcastle-on-Tyne, 39 I et seq.

Manufacture of pottery and porcelain, 487

Marochetti, Baron, sculptor, Mintons, 107

Martin Bros., potters, 38I-3

Mason, C. J. and G. M., ironstone china, 4I, I67, I89

- marks, 197

- Miles, 4I, I 73

Master potters : Adams, 49 et seq.

- Copelands, 64 et seq.

- Mintons, 96 et seq.

- Wedgwoods, I 2 I et seq.

Maw \& Co., Benthall Broseley, 344

- G., on the potting industry, 488 et seq.

Mayer \& Newbold, potters, I73

- E., potter, I73

- Thomas, potter, 50

- T., J., and J., potters, I63-6

Meighs, the, potters, Old Hall, 2 I I - I 2

Meir, potter, I 73

Mellor, Crown Staffordshire Co., I 82

Memorandum by E. Wood on cream ware, 42

"Midsummer Night's Dream" service, 25,86

Milès, M. L. S. See Solon

Mineral substances used in the potteries, $32,485,488$

Minerva Works, Fenton, Green Bros., 167, I 78 et seq.

Minton, I I, I 2, 24, 40, 50, 61, 96 et seq.

- artists, I I 4

- Della Robbia ware, I I 3, 43 I

- Hollis \& Co. tiles, I I 3 , I I 5

- journeys to Cornwall, 45

- Lessore, painter for, I I4

- marks, I 15

- Palissy ware, I I 3

- Parian ware, I07, Io9-10

- pâte-sur-pâte, Solon's work, I 2 , IO7-IO

- Solon's great work for, I2, IO7-10

- Thomas, 45, 96, 98 
Misapprehension on jasper ware removed, 506, 509

Mitchell, Sussex rustic ware, 386 , 389

Mohr \& Smith, potters, I 73

Moore, B., potter, 222-7

- S., \& Co., Southwick, Sunderland, 395

- W., Brown-Westhead and Hanley, 207

Morgan, de, potter, Fulham, 380-I

Morley, F., successor to Masons, 193

Moseley, potter, I 73

M. P. \& Co., initials of Middlesbrough Pottery Co., 404

Museums should buy modern ware, 523

N

Nantgarw, 27, 39, 40, 456, 463 et seq.

- Baxter, figure painter, 459, 464

- Billingsley, 40, I8 I, 456, 463 et seq.

- china decorated by Randall \& Webster, 464

- mark, 467

- painters at, 464

- Pardoe, flower painter, 459, 464

- sold to Rose of Coalport, 33I, 336

- Walker, G., at, 463

- Young, flower, bird, and butterfly painter, $455,459,464$

Napoleon's Berlin decrees, 28

Neale, potter, 54, 509

Newcastle, Sunderland and District, 39 I et seq.

- ware, 395

New Hall china works, 39, 96, 485

Newport pottery, Burslem, I 58

Notes on Lowestoft and Hedingham, 5 I 5

O

Old Hall and the Meighs, 2 I I-I 2

Old master potters made similar wares, 508-9

Opaque porcelain,ironstone, Spode, 67

Owen, G., artist in pierced work, Worcester, 268, 272

\section{$\mathrm{P}$}

Painting on glazed pottery and porcelain, 499, 500

- under the glaze, 49 I, 499, 500

Palmer \& Neale, potters, 54

Parian, statuary porcelain, 50, $74,76,88$, I07, I 35

Pâte-sur-pâte, Solon's, for Minton, I07-9

Phillips, potter, 28, I 73

Pinxton, Coke \& Billingsley, 3 I 2, 316

- painters at, 3 I 6

Poole, Stanway \& Wood, potters, 235

Porcelain gilding, 500, 503

- manufacture, 497

- painting, 499, 500

Potteries in the West of England, 435 et seq.

- Staffordshire, the, and Cornwall, 3 I et seq.

- South England, 349 et seq.

Potter's art, essentials to the, 482 et seq.

Potters, at Hanley, I 89

- at Tunstall, 49, 236

- Longport and Longton, 217

- more at Stoke-upon-Trent, 232

- others at Cobridge and Fenton, I 74

- some at Burslem, I 54

- the master, Adams, Tunstall, 49

- - Copelands, Stoke-uponTrent, 64

- - Mintons, Stoke-uponTrent, 96

- - - Wedgwoods, Etruria, I2 I

Potteries, the, I6-349

Pottery towns form a county. borough, 50

Pratt, F. \& R., potters, Burslem, I 66

Processes of manufacture, mixing, throwing, drying, biscuit firing, decorating under and over the glaze, printing, lustring, gilding, 488 et seq.

Protât, M., scuptor, Mintons, 107

Q

Queen's ware, 42, I 26

$\mathrm{R}$

Randall, china, painter for Coal- 


\section{INDEX}

port, $33^{8}, 345$; and Nantgarw, 464

Randall, maker and painter at Madeley, 35, 39, 345 et seq.

Rathbone, potter, Birkenhead, $43 \mathrm{I}-2$

Red ware, I 3 I

Regent body, the, Worcester, 40

Ridgway \& Co., 23, I98 et seq.

Riley, potter, 24

Rogers, potter, 28, I 73

Rose \& Co., Coalport, Coalbrookdale, $23,40,330-1$

- John, 330-I ; buys Caughley, Jackfield, Nantgarw, and Swansea, 330, 33 I, 336

- - gained a gold medal for leadless glaze, 498

Royal Crown Derby. See Derby

- Doulton. See Doulton

- Worcester. See Worcester

\section{$\mathrm{S}$}

Salt glaze, 6o, 350, 354, 498

Salt, Ralph, potter, 27, I 73

S. B. \& Co., initials of Sharpe Bros., 320

S. B. \& S., initials of S. Barker \& Son, 423

Scale blue, Booths', 240

Scottish potteries, 468 et seq.

Service, "Midsummer Night's Dream," 25, 86

Sharpe Bros., Swadlincote, 320

Shaw, historian, 27, 3I, 50, I 7 I, I 72,2 I I , 235, 24.4

Shelton, Dimmock, potter, 23

Silicon china, Booths', 236-43

- ware, Doulton's, 356

Simpson, J., figure painter, Mintons, $\mathrm{IO}_{2}$

Smith, W. \& Co., Stafford pottery, Stockton-on-Tees, 403, 404

_ - imitated Wedgwood, 403

Sneyd, potter, I 73

Solid agate ware, 53, I 28, I 3 I

Solon, M. L., painter and expert, Mintons, 35, 107-9, 523

South England potteries, $349 \mathrm{et} \mathrm{seq}$. Spode, 39, 40, 50, 61 , 64 et seq., 498

- Josiahs, three, 64-8, 498

- marks, 95

Staffordshire and Cornwall, 3 I et seq

- a poem on a teapot, 46
Staffordshire, figures, 27, I 7 I, I 73

- potteries, 23, 27, 40, 49-245

Steel, potter, 28, I 73

Steele, fruit and flower painter, Mintons, $\mathrm{IO}_{2}$

Stevenson, W., potter, 28, I 73

Stiff \& Sons, potters, Lambeth, 379-80

Stoke-upon-Trent, 24, 3I, 64, 96, 232

- - Copelands, 20, 24, 40, 64 et seq.

- - Mintons, I I, I 2, 24, 40, 50, 6r, 96 et seq.

- - more potters at, 232

Sunderland, Dixon, Austin \& Co., potters, 400,403

- Fell \& Co., potters, 403

- Phillips \& Co., potters, 402-3

- Phillips, J., potter, 403

- Sewells, 400

- Sewells \& Donkin, 400

- Sheriff Hill pottery, 403

Sussex potteries, 386,390

- rustic ware, Mitchell, 386-9

Swadlincote, Ault, potter, 3 I6, 3 I9

- Sharpe Bros., potters, 320

Swansea, Baxter, figure painter, $459-60,464$

- Beddoes, painter of coats-ofarms, 460

- Bevington \& Co., 456

- Billingsley, 456 et seq.

- Dillwyn, 40, 455 et seq.

- Evans, D. J., \& Co., 459

- Evans, Glasson and, 459

- Haynes, G., 453

- Haynes, Dillwyn \& Co. (mark) 460

- Pardoe, flower painter, 436 459,464

- sold to Rose of Coalport, 33 I 336

- Young, W. W., flower, bird, and butterfly painter, 455, $459,463-4$

Swinton, Don pottery, 420-3

- Rockingham, Brameld, 423-8

$\mathrm{T}$

T. G. G. \& Co., initials of T. G. Green, I 82

Theed, sculptor, Copelands, 74

Thursfield, M., potter, Jackfield 325 
Tiles, Burmantofts, 4 I 8

- Boote, T. \& R., I 54-8

- Campbell Co., I I6

- Minton, I IO, I I 5

- Minton \& Hollins, I I 3, i I 5-6

- Minton, Hollins \& Wright, I 16

Tin glazes for pottery, 499

Tinworth, G., modeller, Doultons, I $2,36 \mathrm{I}-4,523$

Toft, C., figure modeller, Wedgwoods, I 39

Tooth, H., potter, Lindthorpe, I 2 , 406, 412

- - - Woodville, Bretby art pottery, I 2, 323-4

Tournay sprig pattern, Coalport, 342

Transfer printing, 50, 60-I, 64, 66, 67,145

Tunstall, 24, 49

- Adams, potter, 49 et seq.

- Booths, 236-43

- Meakin, 243-4

Turner, John, potter, 6I, 98

- Thomas, Caughley, 330

Turner's jasper ware, 54, I65, 506

Twyford, potter, 3I, 60

$\mathrm{U}$

Underglaze decoration, 49 I

V

Value of the output from the potteries, 32

Voyez, imitator of Wedgwood, 54, 509

W

Walton, potter, 27-8, I 73

Warburton, potter, 28, 60, I73

Ward, historian, I 72, I 78, 235 , 244-5

Wares not now made, 46

- common to many factories, 46

Watcombe pottery, Devon, 436-9

Waterloo potteries, Burslem, I 54

W. B., W. \& B., W. B. \& S., initials of Brownfield, I 74

Weatherby, J. H. \& Sons, Hanley, 504

Weaver, bird painter, Copelands, 82

Wedgwood \& Bentley, 42, I 22

- and Brown, I 2 I-2

- and Etruria, I I, I2, I9, 20, 24, $39,40,42,54,96$, I 2 I et seq.
Wedgwood, and his contemporaries, 54, 60, 506, 509

- china, 4I, I46

- cream ware (Queen's ware), 42, I 26

— inlaid ware, I 36

- Jacquemart on, I 26

- jasper ware, solid and dip, I 28 , I 3 I

- marks, I 2 I-2, I 49-50

- modellers employed by, I 36

- modern ware, I 32, I46

- Parian, I 35

- ware and Sir A. H. Church, I $4 \mathrm{I}-5$

Welsh potteries, 453 et seq.

West of England potteries, 435 et seq.

Whieldon ware, a class name, 60

Whitehead, a potter, 60

Willow pattern widely used, 64 , 342

Wilson, potter, 28, I 73

Wood \& Caldwell, potters, 27, I 7 I

Wood, Enoch, 27, 28, 42, 61, 168

- — \& Sons, I 7 I

Woodville, Bretby art pottery, $H$. Tooth, 324-5

Worcester, 40, 98, 246 et seq.

- Bott, enamel painter, 260

- Chamberlain, 250-8

- Flight, 40

- Flight \& Barr, 250-8

- Grainger, 1 2, 23, 254, 264-8

- Hadley, J., \& Sons, 254, 268-7I

- Japan patterns, 98, 257

- Kerr \& Binns, 258-60

- list of firms, partners, and dates, with notes, 275

- Owen's perforated ware, 268, 272

- Royal, Porcelain Co., I I, I2, 275-6 ; appointments, 275-6

Wornum's "Essay on the Exhibition, I 85 I," I9-24

W. S. \& Co., initials of Whalley \& Smith, 403-4

W. S. and W. S. S., W. Smith, Stockton, 404

\section{Y}

Young, W. W., flower, bird, and butterfly painter, $455,459$. 464

Printed by Hazell, Watson \& Viney, Ld., London and Ayles bury. 




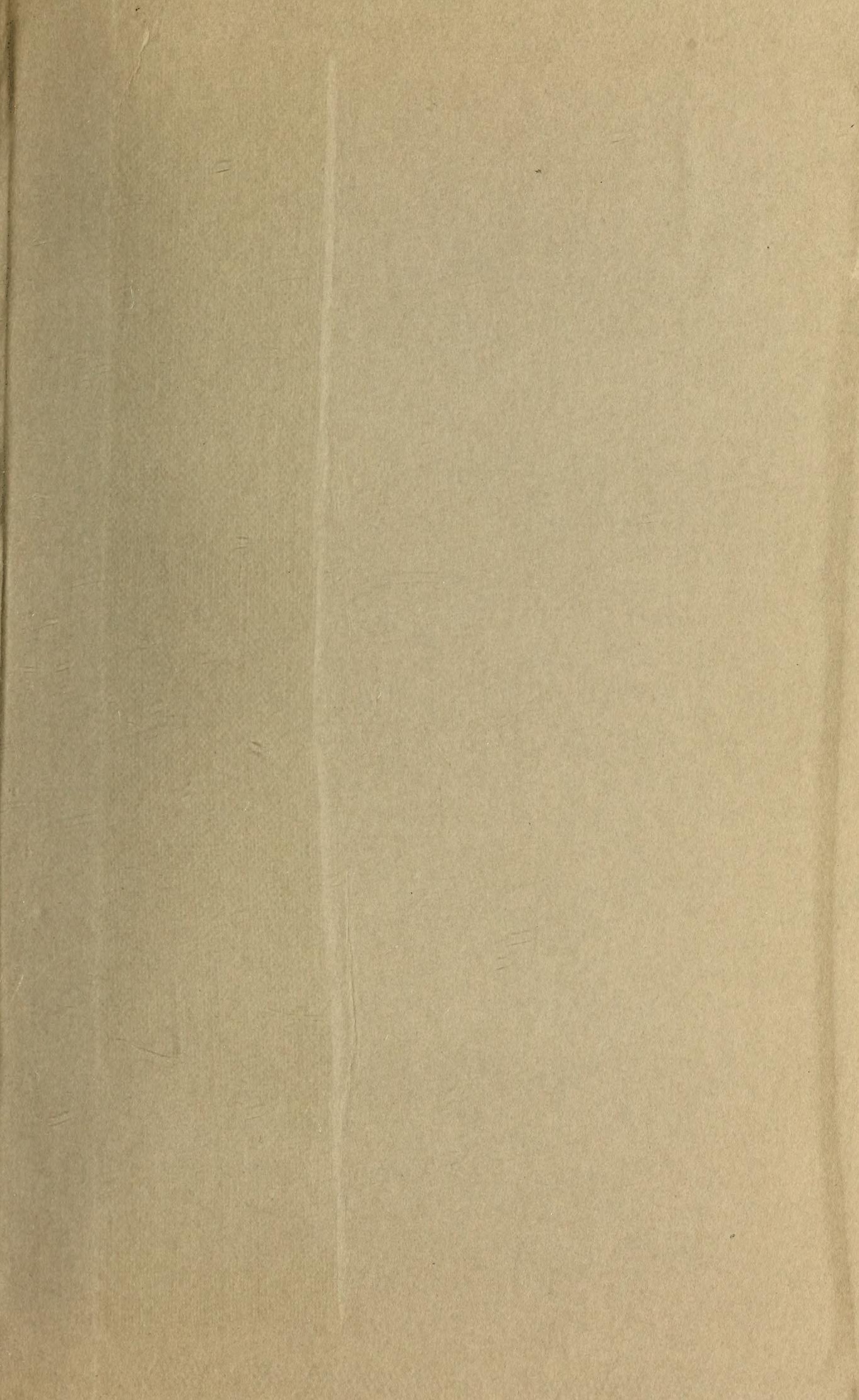


SMITHSONIAN INSTITUTION LIBRARIES 